\title{
COLOURED VIEWS: IMAGES OF THE NEW ZEALAND CITY AND TOWN, 1880 - 1930
}

\author{
by \\ Dominic Alessio
}

\author{
A thesis \\ submitted to the Victoria University of Wellington \\ in fulfilment of the \\ requirements for the degree of \\ Doctor of Philosophy \\ in History
}

Victoria University of Wellington 1992 


\section{ABSTRACT}

"Coloured Views" is a comparative and multidisciplinary examination of the motives and methods of New Zealand's urban boosters between 1880 and 1930. It looks at the positive image of the country's cities and towns rendered in the literature and art of the period, and compares it with other British Dominions as well as with America. Such optimistic images were considered vital to urban growth by promoters who were intent on inducing increased immigration, tourism and investment to their cities and towns. In addition to economic motivation, it will also be argued that the boosters in New Zealand were imbued to an unusual degree by dreams of creating an urban utopia in their New World, one that was free from the influences of vices typically associated with the Old World.

In examining perceptions of urban New Zealand, this thesis also attempts to revert the imbalance in New Zealand historiography which has generally ignored cities and towns or which has assumed that all debate about them was negative. It undertakes a study of a wide array of promotional sources, including material which has never before been examined, such as motion pictures and foreign language texts. "Coloured Views" attempts to show that cities and towns had their ardent defenders in New Zealand as well as their critics. The study concludes with an examination of modern booster techniques in order to emphasise the topicality of the subject matter. 


\section{TABLE OF CONTENTS}

ABSTRACT

ILLUSTRATIONS . iii

PREFACE AND ACKNOWLEDGEMENTS viii

INTRODUCTION 1

CHAPTER 1: THE BOOSTERS 13

CHAPTER 2: THE CIVILISED CITY 45

CHAPTER 3: THE VOCABULARY OF DESCRIPTION 68

CHAPTER 4: PICTURES AND PAINTINGS $\ldots \ldots \ldots \ldots \ldots \ldots \ldots . \ldots 9$

CHAPTER 5: PHOTOGRAPHY AND FILM $\ldots \ldots \ldots \ldots \ldots \ldots \ldots \ldots$

CHAPTER 6: COLONIAL COMPARISONS $\ldots \ldots \ldots \ldots \ldots \ldots \ldots \ldots$

CHAPTER 7: A CHRISTCHURCH CASE-STUDY $\ldots \ldots \ldots \ldots \ldots \ldots$

CHAPTER 8: THE BAD AND THE UGLY $\ldots \ldots \ldots \ldots \ldots \ldots \ldots \ldots \ldots$

CHAPTER 9: BACK TO THE LAND $\ldots \ldots \ldots \ldots \ldots \ldots \ldots \ldots \ldots \ldots$

CHAPTER 10: 'AN ATLANTIS OF THE ANTIPODES':

THE INFLUENCE OF UTOPIA

CONCLUSION 248

BIBLIOGRAPHY 259 


\section{ILLUSTRATIONS}

1. Table showing increase in the New Zealand urban population, 1881-1956. (Ross, An Introductory Study of the Origins and Evolution of Town Planning in New Zealand: 1840-1926), p.196.

2. Government tourist display at the New Zealand High Commissioner's Office in London, 1928. (TO 1, 28/22 National Archives, Wellington)

3. New Zealand Tourist and Publicity Department agency in Melbourne, 1906. (TO 1, 1906/310 National Archives, Wellington)

4. The free theatre of the 1925 Dunedin Exhibition. From the Special pictorial history, New Zealand and South Seas Exhibition 1925-6, p.36. (C 16300 Alexander Turnbull Library)

5. Mount Langton from near Tinakori Rd., Wellington, watercolour by Henry Atcherly, 1893. (F 1243891/2 Private owner c/- Alexander Turnbull Library)

6. Copy of the letter from G.M. Fowlds suggesting possible comparisons for New Zealand's attractions, May 6, 1930. (TO 1, 53/3 National Archives, Wellington)

7. The deserted square, etching by James Fitzgerald, 1925. (JF20 J.S. Fitzgerald Collection, Canterbury Museum)

8. Ferry buildings, Auckland, watercolour by Cranleigh Harper Barton, ca.1930. (C 16428 Alexander Turnbull Library)

9. The Dunedin tramway system starting Princes St. From The Australasian Sketcher, 1881. (Alexander Turnbull Library)

10. The octagon, Dunedin. From the Album of Christchurch and Dunedin N.Z., ca.1885, p.9. (C 16294 Alexander Turnbull Library)

11. The square, Palmerston North. From Beattie, From City to city; Views of the North Island main trunk railway, ca.1910, p.33. (C 16296 Alexander Turnbull Library)

12. Sir Robert Anderson's residence, near Invercargill. From Hall-Jones, Souvenir of Invercargill and Southland (scenic and historical), 1949. (C 16312 Alexander Turnbull Library)

13. 87 years of progress, New Zealand, 1840-1927. From Wedderspoon, The Dominion of New Zealand..., 1927. (C16286 Alexander Turnbull Library)

14. The growth of New Zealand's industries and commerce, 1800-1924. From the Special pictorial history, New Zealand and South Seas Exhibition 1925-6, ca.1925. (C 16299 Alexander Turnbull Library) 
15. Auckland public library in 1880 and 1922. From Barr, Municipal and Official handbook of the city of Auckland..., 1922, p.40. (C 16293 Alexander Turnbull Library)

16. Auckland in 1850. From Unity Press, Auckland, 1850-1929, (C 16305 Alexander Turnbull Library)

17. Auckland in 1929. (Ibid., C 16306)

18. Postcard of Strange's drapery company, Christchurch. From the Postcard Collection, ca.1900-1920. (New Zealand Room, Canterbury Public Library)

19. Designs of R.A. Lawson, watercolour by George O'Brien, late 1860s. (Collins and Entwisle, Pavilioned in Splendour, 1986), p.79.

20. Wood-nymphs in Wellington. From Wellington the capital city of New Zealand, ca.1901, p.11. (C 16282 Alexander Turnbull Library)

21. A spur to action! From the Dunedin Expansion League, An appeal to loyal citizens..., 1911. (C 16289 Alexander Turnbull Library)

22. Dunedin's women at the seaside. From the Souvenir of the visit to Dunedin, "The city beautiful", by the American Fleet, August, 1925, 1925. (c/n E 4747/13 Hocken Library, Dunedin)

23. A pensive (and naked) Maori maid. From Peterson and Guy, New Zealand the wonderland of the Pacific, 1930?, p.39. (C 16302 Alexander Turnbull Library)

24. Queen Street, Auckland (detail), oil on canvas by Jacques Carabain, 1889. (Brown, Visions of New Zealand, 1988), p.104.

25. Auckland from the wharf, oil on canvas by Edward Augustus Gifford, 1887. (Docking, Two Hundred Years of New Zealand Painting, 1971), p.92.

26. Auckland harbour, New Zealand, lithograph by Archibald Duddington Willis, 1889. From Wakefield, New Zealand Illustrated, 1889. (F 932001/2 Alexander Turnbull Library)

27. Dunedin 1888, chromolithograph by George O'Brien, 1888? (F 1130991/2 Alexander Turnbull Library)

28. The Christchurch meat company's "Smithfield" freezing works. From the Caroline Bay Association, Official guide; Timaru and surrounding districts, 1912. (C 16290 Alexander Turnbull Library)

29. Bird's eye view map of Dunedin, 1875. (Dunedin Early Settler's Museum)

30. Invercargill. From The New Zealand Graphic, 1890. (Alexander Turnbull Library) 
31. Zealandia. From The Cyclopedia of New Zealand, 5 (1906), title page. (C 16309 Alexander Turnbull Library)

32. Zealandia. From the Auckland Industrial, Agricultural \& Mining Exhibition, official catalogue and guide, 1913, cover. (Special Collections, Victoria University of Wellington Library)

33. The Leviathon hotel. From the New Zealand and South Seas Exhibition, 1889-90, Official catalogue of the exhibits, 1889, p.2. (C 16297 Alexander Turnbull Library)

34. Illustration of the Roslyn Woollen Mills. From The Cyclopedia of New Zealand, IV, 1905, p.336. (C 16310 Alexander Turnbull Library)

35. Photograph of the Roslyn Woollen Mills. (Ibid., C 16311), p.337.

36. Illustration of the H.E. Shacklock foundry, Dunedin, ca.1898. (Angus, The Ironmasters)

37. Photograph of H.E. Shacklock's "shop block", Dunedin, ca.1882. (Ibid.)

38. The Kaiapoi Woollen Mills, Kaiapoi. From Davie, Tourists' guide to Canterbury, 1902. (C 16292 Alexander Turnbull Library)

39. St. Patrick's Cathedral, Melbourne, hand coloured photograph with drawing by W.C. Fitler, 1887? (National Library of Australia)

40. Dunedin, watercolour by John Kinder, 1890. (1937/15/97 Auckland City Art Gallery)

41. Dunedin from north east valley above Chingford homestead gardens, watercolour by artist unknown, ca.1890s. (F 854181/2 Private owner c/- Alexander Turnbull Library)

42. Auckland from Albert Park, by Christopher Aubrey, 1902. (Alexander Turnbull Library)

43. Blenheim in flood. From The Cyclopedia of New Zealand, V, 1902, p.318. (C 16308 Alexander Turnbull Library)

44. Diamond Lake, Wakatipu. From Scenes in New Zealand, ca.1905. (C 16307 Alexander Turnbull Library)

45. A youthful canoeist along the Wanganui River. From Beautiful New Zealand; cities, townships and beauty spots, ca.1905. (C 16285 Alexander Turnbull Library)

46. Business and beauty thrive side by side. From Auckland from the air, 1930. (C 16303 Alexander Turnbull Library)

47. Lambton Quay, Wellington. From Adlam, Emerald hours in New Zealand, 1907, p.50. (C 16283 Alexander Turnbull Library) 
48. The square in Palmerston North. From Green, New Zealand tourist and commercial guide, 1930. (C 16521 Alexander Turnbull Library)

49. Picnickers along the River Avon, Christchurch. From Kelly, Christchurch, the garden city of New Zealand, 1925, p.49. (C 16287 Alexander Turnbull Library)

50. Une baignade, oil on canvas by Georges Seurat, 1883-84. (Department of Art History, Victoria University of Wellington)

51. La grande jette, oil on canvas by Georges Seurat, 1884-86. (Ibid.)

52. The Henderson factory, watercolour by Samuel T. Gill, 1876. (State Library of Victoria, Melbourne)

53. The Trans-Australian Railway, colour lithograph by Percy Trompf, ca.1935. (Butler, Australian Travel Posters, 1990), p.13.

54. Bird's eye view map of Sydney, chromolithograph by M.S. Hill, 1888. (National Library of Australia, Canberra)

55. Aims and objects of the Canterbury Progress League. From the Canterbury Progress League Minutes, 1918-24, p.11. (Canterbury Public Library)

56. Postcard of tudor homes along the River Avon, Christchurch. From the Postcard Collection, ca.1900-1920. (New Zealand Room, Canterbury Public Library)

57. Postcard album of the New Zealand International Exhibition, 1906-7. Ibid.

58. The Suckling Brothers, Christchurch. From Fanning, New Zealand today, 1925. (C 16560 Alexander Turnbull Library)

59. Rotherfield hotel letterhead, Christchurch. From the Christchurch City Council Archives, June 1909-July 1909. (Z Arch.53/52 Canterbury Public Library)

60. Lyttelton Times and Star building photograph, Christchurch. From the 'Star' Jubilee Number, May 1918. (12607 Canterbury Museum)

61. Lyttelton Times company letterhead, Christchurch. From the New Brighton Borough Council Archives, 1921-25. (Z Arch 41/14 National Archives, Christchurch)

62. Heywood and co. letterhead, Christchurch. From the Christchurch City Council Archives, 1908. (Z Arch 53/21 National Archives. Christchurch)

63. Heywood's building photograph, by Joan Woodward, 1982. (4345 Canterbury Museum)

64. An open air school. From the Christchurch Beautifying Association, The City Beautiful, I, No.3 (December 1, 1924), p.17. (C 16284 Alexander Turnbull Library) 
65. Old Custom House St., Wellington, by Sydney Hamlet Higgs, ca.1930. (Alexander Turnbull Library)

66. Farish St., Wellington, by Sydney Hamlet Higgs, 192-. (Ibid.)

67. At typical day in a British manufacturing town! From Reade, The revelation of Britain, 1909, inset. (Special Collections, Victoria University of Wellington).

68. Arcadia in Australia: the Glen Aplin estate advertisement. The Sydney Mail (January 14, 1920), p.7. (State Library of Victoria, Melbourne)

69. Broaden the base. From Alley, Back to the Land, 1930. (Alexander Turnbull Library)

70. Town planning and housing model. From Thompson, Official record of the New Zealand and South Seas International Exhibition, Dunedin, 1925-26, 1926, p.80. (C 16298 Alexander Turnbull Library)

71. An Atlantis of the Antipodes: Massias's vision of a new capital. From Courte, $L a$ Nouvelle Zélande, 1904, p.121. (C 16288 Alexander Turnbull Library)

72. The railway station, Invercargill, engraving by William Beverell,1895. (Alexander Turnbull Library)

73. Relaying the tram track, High St., Christchurch, etching by James Fitzgerald. (JF17 J.S. Fitzgerald Collection, Canterbury Museum)

74. The electric city of the future. From the Auckland Electric-Power Board, A city of light \& power, 1930, p.1. (C 16291 Alexander Turnbull Library)

75. Postcard of Wellington's City Centre, ca.1990. (Pictorial Publications Limited, Hastings) 


\section{PREFACE AND ACKNOWLEDGEMENTS}

Since coming to New Zealand in late 1989 to undertake research on my Ph.D., the first question that people inevitably ask me is: "Why New Zealand?" My standard reply consists of a list of logical reasons: I was given funding; there was a wealth of untapped literature awaiting analysis; my supervisor had just completed similar work on the same subject; and I had never been to the South Pacific before and this provided me with the perfect opportunity to see a bit of the world which I might not otherwise visit. However, when repeating these endless motives for coming to the country, I must always remind myself of the reason I was particularly attracted to New Zealand in the first place: its image. I was attracted to the country by a certain utopian and/or arcadian vision of the country.

This idealised image first made itself apparent in the international news, when New Zealand made its firm stand against French nuclear testing in the Pacific and against visits by nuclear powered ships. The positive image of a people concerned for their environment was subsequently reinforced by further ideal images which were passed by word of mouth from friends or distant acquaintances. I was constantly subjected to a barrage of typical travellers' tales about a clean and green country full of lovely beaches, fine tropical weather, stunning scenery, sophisticated metropolises and beautiful women. This antipodean paradise myth was of course further promoted in the glossy tourist brochures which came in the post following my inquiries. The story of how I came to New Zealand is important for it not only provides a good introduction to "Coloured Views", but it also stresses the topicality of the subject matter (something which will be examined in the Conclusion). The positive image of New Zealand rendered overseas today, combined with my interest in urban history (particularly the promoters of towns and cities), provided me with a unique opportunity to examine for myself the origins of the New Zealand paradise myth.

During my stay in New Zealand and the course of my studies, I have accumulated many debts. First and foremost I wish to thank my supervisor Professor David Hamer, not only for his ample support and propitious advice, but also for his untiring enthusiasm. I am also very grateful for an extremely generous 1990 Commonwealth Scholarship; I owe a special debt to Maureen Penning (Victoria University's Scholarships Officer) and to Cathe Carpenter (the New Zealand Vice-Chancellors' Committee Scholarships Officer) in this capacity. 
I also want to thank the many libraries and institutions which assisted me in my research, especially the librarians and support staff of the Alexander Turnbull Library, who went out of their way to make me feel at home and to introduce me to scholars who were working in similar fields. I would also like to record the kindness and assistance given to me by the reference and reserve librarians at the Victoria University of Wellington Library. Separate mention should be made here for the valuable help provided to me by the librarians in Special Collections. Other institutions whose help I can not stress enough, include: the Auckland City Art Gallery; the Auckland City Library; the General Library, University of Auckland; the Auckland Institute and Museum Library; the Canterbury Public Library; the Canterbury Museum Library; the University of Canterbury Main Library; the Christchurch Civic Offices; the Hocken Library, Dunedin; the Dunedin Public Library; the Hamilton Public Library (New Zealand); the National Library of New Zealand; the National Archives of New Zealand; the New Zealand Film Archive; the Wellington Public Library; the General Assembly Library; the National Library of Australia, Canberra; the State Library of Victoria, Melbourne; the Mitchell Library, Sydney; the Australian National Gallery; the Hamilton Public Library (Canada) and Pictorial Publications Limited, Hastings.

I am very grateful for the patience shown to me by a number of individuals, particularly during my first few years of research in New Zealand when my knowledge of the country's historiography was meagre. I would like to thank everyone in the Department of History at Victoria University, in particular those other graduate students who shared an interest in colonial and urban New Zealand: Caroline Dailey, Malcolm MacClean, Ben Schraeder, Michael Biggs and Michael Eyes. I owe a tremendous debt of gratitude also to Tony Bellette in the Art History Department of Victoria University, who kindly let me sit in on his New Zealand courses. I would also like to thank Charles Williams of the New Zealand Tourism Board, Alison Corich of the Wellington City Council and Mike Gilbert of the Wellington Chamber of Commerce, for agreeing to be interviewed. I owe a great deal of gratitude to Adelle Kenny in Christchurch and to Lea and Andrew Giles-Peters in Melbourne for their warm hospitality. Many thanks also to Mary Turner and the Sutton family for the welcome shown to me during my stay in Sydney, and to Gil Stelter, John Weaver, Ezio Cappadocia, Thomas Hoey, Nelson Wattie, Harvey McQueen, Lyman Tower Sargent and Miles Fairburn for their interest and advice. Nor can I forget the very kind assistance offered by Brett Robertson in the 
photographic studios of Victoria University and Jim Baltaxe of the Computing Services Centre, also at Victoria University.

At this point I would like to stress the debt which I owe to all my friends. A special thanks goes to I'u Tuagalu for reading over my drafts and for giving me much needed moral support. I would also like to thank my flatmates over the years: Rebekah Bell, Rachel Crawford, Sophie Crichton, Shannon Hyman, Stephen Reid and all those in 321 Karori Road. I want to thank everyone at Helen Lowry Hall, particularly the Wardens Janis and Peter Lind. And most of all I want to thank Sarah Williams, my grandparents Mary and William, and my parents Antonio and Maria, for all their love and support. This thesis is dedicated to them and to all the people in New Zealand who made my stay in the country so enjoyable. 


\section{INTRODUCTION}

A small number of illustrated souvenir booklets depicting New Zealand scenes at the turn-of-the-century advertised on their jacket covers the fact that their photographs had been "coloured". ${ }^{1}$ It is important to note that these photographs were not colour negatives; rather, the original black and white image had been painted-in to a certain extent by a trained artist. Trees and grassy areas were typically coloured green, while the sky was painted blue, the buildings grey and distant mountains were sometimes topped with white to give a picturesque impression of freshly fallen snow. The intention of the publishers was to provide the viewer with a prettier picture of the view concerned than that which a stark monochrome still could portray and, at the same time, to attain the competitive edge over similar illustrated publications which only portrayed black and white scenes.

Yet unlike the technical meaning suggested by the promotional titles, the word coloured can also have other connotations - of being exaggerated, tainted, or deliberately altered. The latter definition implies the coloured souvenir illustrations had been consciously changed by the artists, acting under the guidance of the publishers who had commissioned the works, so as to deliberately enhance the subject-matter; not only then were colours added to a few places, but it seems that other more considerable modifications were made which might greatly affect the perception of the scene. Grey skies became sky blue, weather beaten clapboards turned the colour of stone and brick, poor roads and ugly buildings were tidied up, and muddy fields blossomed a pretty green. Such romantic scenes would prove much more delightful to the naked eye than the original coarser photographs. Consequently, tourists visiting New Zealand, or overseas readers examining these illustrations, would obtain a much more favourable picture in their minds of what New Zealand was like.

The double meaning suggested by the phrase "coloured views" provides an introduction to a study of the image of New Zealand cities and towns between 1880 and 1930 as portrayed by their promoters or, to use the American term which will be

\footnotetext{
${ }^{1}$ See: Souvenir album of 36 artistic postcards, each one different; coloured views of Wellington \& district and West Coast of New Zealand, faithfully reproduced from original photographs (London: G.D. \& D. Co., ca.1910) or Beautiful New Zealand; cities, townships and beauty spots; the scenic paradise of the world, the home of the Maori (Wellington: C.B. \& Co. Ltd., ca.1905).
} 
adopted for the duration of this study, boosters. ${ }^{2}$ This thesis proposes to examine those positive images which New Zealanders constructed to advertise their country's towns and cities overseas and at home so as to attract settlement, tourism and investment, while at the same time deterring people from moving away. It will also look at the image which foreigners manufactured for New Zealand and the political and personal reasons why they chose to fashion such a picture. Such an examination inevitably touches upon a number of other significant urban-related themes which contributed to fashioning the New Zealand booster image, namely: an exploration of the debate on town life in the country and an investigation of the influence of utopian ideas. Both these latter themes greatly affected the New Zealander's perception of the urban environment and they will be discussed in the second part of this work. The prevalence of utopian literature deserves special mention in a study of boosterism as it contributed directly to fostering that element of the booster image which subscribed to an optimistic belief in the future prosperity and harmony of the town and city.

The material will be approached thematically rather than chronologically since the same promotional meanis were used relatively constantly throughout the fifty year period chosen for the examination. The truthfulness of the material and the reality of the contemporary state of urban New Zealand is not what is of importance here; rather, the emphasis must be on the perception - what the promoters believed was the situation, or would be the situation, or might be the situation, and why. Other historians and critics of New Zealand literature have pursued a similar tactic for examining such sources. Peter Gibbons, for instance, in his study of early New Zealand non-fiction, ignores the veracity of the information and looks instead at the evidence for its cultural significance. ${ }^{3}$ David Hamer in his work on nineteenth century frontier societies, is not concerned with, "what 'really' happened but what people thought was happening or

\footnotetext{
${ }^{2}$ Although the term booster is in origin an American word, it has been used before to describe the promotional tactics of Australasia; see David Hamer, New Towns in the New World: Images and Perceptions of the Nineteenth-Century Urban Frontier (New York: Columbia University Press, 1990). Boosters employed other means to promote their cities and towns than just fashioning specific images; these included offering financial inducements like lower taxes, free land and cheap rates. Such economic allurements, however, do not come into the ambit of this study as they do not constitute images.
}

${ }^{3}$ Peter Gibbons, "Non-fiction," in Terry Sturm, ed., The Oxford History of New Zealand Literature (Auckland: Oxford University Press, 1991), p.27. 
should happen." ${ }^{4}$ Scholars of American and Australian art history have also emphasized the importance of perception and myth over that of reality and fact. Elizabeth Broun, for example, in her 'Foreword' to The West As America, says that the various authors included in the book did not examine the numerous paintings, drawings and photographs of frontier America in the exhibition for their aesthetic value, but rather in order to understand "the intentions of the artists and their patrons." ${ }^{5}$ And Leigh Astbury, in discussing the impact of the rural myth on the Heidelberg artists in Australia, contends that it is the "psychological veracity of the myth" which is of importance in a discussion of late nineteenth century rural images, not "the accuracy of its depiction of rural life at the time."

My motives for examining the New Zealand city and town during this Victorian and Edwardian time frame are as many and varied as the motives of the boosters themselves. Firstly, there exists a wealth of untapped information not only on New Zealand ${ }^{7}$, but also on the country's cities and towns. According to David Hamer, this "metropolitan bias" in urban literature was due to the fact that travellers tended to visit centres which were easily reached; therefore, only relatively large urban areas on welltravelled routes with easy access to rail, water or road transportation seemed to get mention in diaries and travel journals at the expense of the smaller and more isolated rural places. ${ }^{8}$ The same held true for booster pamphlets and tourist tracts promoting

${ }^{4}$ Hamer, New Towns in the New World, p.2.

${ }^{5}$ Elizabeth Broun, "Foreward," in William H. Truettner, ed., The West As America (Washington: Smithsonian Institute Press, 1991), p.vii.

${ }^{6}$ Leigh Astbury, City Bushmen: The Heidelberg School and the Rural Mythology (Melbourne: Oxford University Press, 1986), p.4.

${ }^{7}$ Miles Fairburn in The Ideal Society and Its Enemies (Auckland: University of Auckland Press, 1989), makes mention of how popular New Zealand was as subjectmatter in literature of the period by referring to T.M. Hocken's Bibliography of New Zealand Literature(1909) that listed circa 2000 titles between 1840 and 1909 (p.20). Even contemporaries writing about New Zealand recognized it as a popular theme. Guy Scholefield writing on the industrial and political state of the country in the first decade of the twentieth century calls New Zealand, "...comparatively the best-described country in the world." See: Guy Hardy Scholefield, New Zealand in evolution, industrial, economic and political...With an introduction by the Hon. W. Pember reeves" (London: T.Fisher Unwin, 1909), p.xi.

${ }^{8}$ Hamer, New Towns in the New World, p.44. 
New Zealand's larger urban centres, which unlike the smaller and more isolated rural communities in the country, had the necessary funding needed for a great deal of selfpromotion. $^{9}$

A second reason for studying the New Zealand city and town during this time frame, is that the country's urban centres were entering a new phase in their development. This new phase gave rise to a distinct urban form, one which tended to be characterized by neo-Gothic and neo-Classical architectural styles, as well as by the increased use of materials such as stone, brick, glass and steel. Many of the edifices from this period remain standing to this day, and examples of these various architectural styles can be found in cities and towns throughout the Anglo-American industrialised world. This new phase of urban development owed its origins to unprecedented technological change and was characterized by the appearance of a more permanent urban infrastructure that left the old pioneer stage behind. In New Zealand the new phase was initiated during the 1870s, financed by the Prime Minister Sir Julius Vogel and his 20 million pound borrowing scheme. By 1911 the country's new urban infrastructure would support a population which had surpassed its rural one (ILLUSTRATION 1). This development can be evidenced in a number of areas. More solid building materials such as brick and stone were replacing older timber structures. Public buildings and bridges were being constructed. To design these new edifices professional architects and engineers began to appear. Communication and transportation facilities flourished with the construction of railways, telegraph lines and roads. Steamship services to America, Australia and Britain fueled demographic growth; an underwater cable to Australia improved communication with the other Australasian colonies. Schools and universities were erected, a result of advances in education such as the provision of free primary education to European children in 1877 and the creation of the University of New Zealand from the constituent Colleges of Otago and Canterbury. There were also improvements in health, with the laying of sewers and the purification of water. Moreover, the first shipment of frozen meat to Great Britain in

${ }^{9}$ Records of the Canterbury Progress League (an association set up to promote the Canterbury area), reveal that the city of Christchurch was more often than not the subject of promotional material rather than the smaller rural communities in the province. Some of these same records also reveal that these frequently ignored rural communities often complained of their lack of representation in the League. See Chapter 7. 
Table Showing Percentage of Populatior Living in Rura ${ }^{X}$ and Urban ${ }^{\prime}$ Areas from 1881 to 1956 (Excluding Maoris) 87

\begin{tabular}{|c|c|c|c|}
\hline & Counties & Boroughs & Migratory \\
\hline $\begin{array}{l}1881 \\
1886 \\
1891 \\
1896\end{array}$ & $\begin{array}{l}59 \cdot \frac{44}{56} \cdot 58 \\
56 \cdot 18 \\
55.69\end{array}$ & $\begin{array}{l}39 \cdot 80 \\
42 \cdot 46 \\
43 \cdot 14 \\
43.69\end{array}$ & $\begin{array}{l}0.76 \\
0.96 \\
0.68 \\
0.62\end{array}$ \\
\hline 1901 & $54 \cdot 04$ & $45 \cdot 32$ & 0.64 \\
\hline 1906 & $51 \cdot 63$ & $47 \cdot 79$ & $0 \cdot 58$ \\
\hline 1911 & $49 \cdot 26$ & $50 \cdot 14$ & 0.60 \\
\hline 1916 & $45 \cdot 59$ & $53 \cdot 24$ & $1 \cdot 17$ \\
\hline 1921 & 43.55 & $55 \cdot 95$ & 0.50 \\
\hline 1926 & $41 \cdot 02$ & $58 \cdot 39$ & 0.59 \\
\hline $\begin{array}{l}1936 \\
1945 \\
1951 \\
1956 .\end{array}$ & $\begin{array}{l}40 \cdot 32 \\
36 \cdot 91 \\
35 \cdot 91 \\
34 \cdot 59\end{array}$ & $\begin{array}{l}59.29 \\
62.89 \\
63.77 \\
65.20\end{array}$ & $\begin{array}{l}0.39 \\
0.20 \\
0.32 \\
0.21\end{array}$ \\
\hline
\end{tabular}

$x$ Rural population covers counties, all town districts and extra-county islands.

y Urban population means population in cities and bor oughs. 
1882 supplied the country with an important export industry that would sustain the growth of this modern New Zealand.

This new phase in urban development was not unique to New Zealand. John C. Weaver, in a discussion on the development of the modern Canadian urban infrastructure, also visualizes the period from the 1870 s through to the 1920 s as being formative in that country's evolution: "Many structures stand today as an inheritance of these remarkable years of urban growth." ${ }^{10}$ Lewis Mumford in The Culture of Cities (1938), argued somewhat pessimistically that from the period 1820-1900 a new type of city emerged throughout the Western world, one that could be likened to Charles Dickens' Coketown because of its subservience to industry and the new technology which made the factory system possible. ${ }^{11}$ And the cultural historian Edward Timms states that around 1900 the city became the predominant theme in European painting and writing of the period as a result of technological advances. ${ }^{12}$ Robert Hughes, in The Shock of the New, lists some of these technological advances which contributed to the new era of the industrial metropolis:

[1875] Thomas A. Edison invented the phonograph... Pablo Picasso... was born in $1881 \ldots$ the recoil-operated machine gun (1882), the first synthetic fibre (1883)... the Kodak box camera and the Dunlop pneumatic tyre (1888)... the Diesel engine (1892), the Ford car (1893), the cinematograph and the gramaphone disc (1894). In 1895, Roentgen discovered x-rays, Marconi invented radio telegraphy, the Lumiere brothers developed the movie camera, the Russian Konstantin Tsiolkovsky first enunciated the principle of rocket drive, and Freud published his fundamental studies on hysteria. And so it went: the discovery of radium... the first voice radio transmissions, the Wright brothers' first powered flight (1903) and the annus mirabilis of theoretical physics, 1905, in which Albert Einstein formulated the Special Theory of Relativity... and ushered in the nuclear age with the climactic formula... $\mathrm{E}=\mathrm{mc} 2$. $^{13}$

${ }^{10}$ John C. Weaver, Hamilton: An Illustrated History (Toronto: James Lorimer \& Co., 1982), p.125.

${ }^{11}$ Lewis Mumford, The Culture of Cities (London: Secker and Warburg, 1938), pp.143-144.

${ }^{12}$ Edward Timms, "Unreal City - Theme and Variations," in Edward Timms and David Kelley, eds., Unreal City (New York: St. Martin's Press, 1985), p.1.

${ }^{13}$ Robert Hughes, The Shock of the New (London: BBC P्म blications, 1981), p.15. 
Advances such as these, most notably the building of roads and railways and the creation of an industrial infrastructure, make it impossible to separate elements in the description of the industrial or transportation field from the urban image. For trains, automobiles and factories tend to embody the new urban age as much as the images of the various cities and towns themselves. Railroads were in fact a powerful force in "altering the urban landscape. ${ }^{14}$ Where there is no strictly urban description in the literature or depiction in the visual material, the appearance of railways or manufacturers serves as a constant reminder that the urban presence is not far off. Also, images of industry and transport can not be ignored in an examination of urban booster material as these images frequently relied upon the same promotional and optimistic conventions as their city and town counterparts.

A third motive for an analysis of New Zealand's urban image at this time is that it affords the historian and student of urban studies an opportunity to explain the urban imagery in one country (New Zealand in this case) and then compare it to other new societies (as with Canada and Australia in Chapter 6). What results may be a theory of the processes of urbanization and the development of national myths that is potentially valid for the English-speaking world if not for the rest of the globe, for certainly this rapid urban growth and the resulting debate which it engendered and that was mentioned above, was not endemic to New Zealand alone. A comparative approach including British and American contemporary sources, in addition to the Australian and Canadian ones (as well as modern academic criticism from all four nations), is used throughout this study to examine a history of urban perceptions while keeping such a correlative context in mind.

A final reason for studying the city and town from 1880-1930 is that much of the debate surrounding the metropolis, the fast pace of technological change and the promotion of a certain vision of New Zealand, is as valid today as it was then; an examination of the booster literature and art of the period affords some sort of perspective on present-day problems and reactions to the urban environment in the country, as well as helping to explain some modern New Zealand promotional

${ }^{14}$ Lionel Frost, The New Urban Frontier: Urbanisation and City-Building in Australasia and the American West (Kensington: New South Wales University Press, 1991), p.8. 
techniques. ${ }^{15}$ Anselm Strauss emphasizes this point with regard to American urban imagery in particular:

...there persists a remarkable stability of urban images. Indeed...Olmsted writing about parks in the 1870's, early city planners bemoaning the apathy or greed of citizens, and turn-ofthe-century businessmen boasting their particular cities all seem quite up to date. ${ }^{16}$

Before moving on to a discussion of the ensuing chapters to show the direction which the argument is going to take, an explanation of the source materials used for the study is required. All facets of visual material have been examined, from the "high" art of the more famous New Zealand painters such as George O'Brien and James Fitzgerald, to the more common and everyday graphic advertisements found in newspapers and on letterheads. Newspapers, advertisements, booster pamphlets, municipal histories, private correspondence, speeches, parliamentary debates, travel histories, almanacs, tourist brochures, etc... have all been looked at; however, images of the city in the New Zealand novel have not been included. The reasons for such an omission include: (a)the fact that similar work has been done or is already being done in this area and in this time-period; ${ }^{17}$ (b) such an examination would be too great an undertaking to add to the present study; and most importantly, (c) although novels reflect aspects of a society they tend to reflect the author's personality more. Leo Marx in his essay "The Puzzle of AntiUrbanism in Classic American Literature" (1980) echoes this last point, arguing that the city for authors is merely an "abstract receptacle for displaced feelings about other things." 18

Although ignoring the New Zealand novel in this analysis, utopian works of fiction have been included for three important reasons. Firstly, they provided the boosters with

${ }^{15}$ Modern New Zealand promotional techniques will be discussed in the Conclusion.

${ }^{16}$ Anselm L.Strauss, ed., The American City: A Sourcebook of Urban Imagery (London: Penguin Press, 1968), p.xii.

${ }^{17}$ Nelson Wattie is presently doing a survey of "The Image of New Zealand in Fiction" up to the 1920's.

${ }^{18}$ Leo Marx, "The Puzzle of Anti-Urbanism in Classic American Literature," in Michael C.Jaye and Ann Chalmers Watts, eds.,Literature and the Urban Experience: Essays on the City and Literature (New Brunswick: Rutgers University Press, 1980), p.64. 
a ready-made source of effective propaganda. Utopian works were not only popular amongst the general reading public, ${ }^{19}$ but they were also milked repeatedly for their images by the boosters, evidence of which can be seen consequently in some form or another throughout the promotional material. Secondly, utopian works have also been included in this study as many were like the booster literature in intent and method, having been written for purposes of advertising some aspect of New Zealand. Geo W.Bell's Mr. Oseba's Last Discovery (1904), for instance, publicized New Zealand's advances in social welfare and the country's rich resources as a way of attracting settlers. In a thinly disguised parallel to the processes of colonisation from England, the fictional country of Cavitorus, that is located somewhere at the centre of the Earth, sends out an expedition to find "a land to which, if possible, we may desire to send a colony of our surplus population..." ${ }^{20}$ New Zealand of course is that land, since its inhabitants are:

...the best fed, best clothed, best housed, best educated and best satisfied, most progressive, healthy, happy and free people, that ever loafed about on the surface of this planet... ${ }^{21}$

A third reason for including utopian works in a study of boosterism, is that much of the intent of this kind of work was designed to introduce reform of some nature or another, which leads to the question of motivation. It shows that utopianism was not necessarily just another effective promotional gimmick in a battery of booster propaganda; but rather, for some perhaps, it reveals that the desire to build a better world in New Zealand was a heartfelt and genuine conviction, one which many boosters may have shared. John Torren's A Trip to Mars (1901) for example, created a vision of a future Auckland replete with low density housing and vast transportation networks. Another instance of this reformist preoccupation is Alexander Joyce's Land Ho(1881); the story is set over fifty years into the future - in the New Zealand of 1933 - and shows

${ }^{19}$ According to Kenneth M. Roemer, between 1888 and 1900 more than 160 utopian works may have been published in America alone. Roemer goes on to quote a critic who stated that utopian literature as a whole "was perhaps the most widely read type of literature in America." See The Obsolete Necessity: America in Utopian Writings, 18881900 (Kent State University Press, 1976), p.3.

${ }^{20}$ George W.Bell, Mr. Oseba's last discovery (Wellington: The New Zealand Times Co. Ltd., 1904), p.47.

${ }^{21}$ Ibid., p.163. 
the prosperity brought to the country as a direct result of the nationalisation of the land. ${ }^{22}$ Graeme Davison reiterates this latter argument while discussing similar "prophetic histories" in Australia, such as the 1889 story about a killer plague in Melbourne. Davison states that such works were:

On the simplest level... political pamphlets in fancy dress, their concerns as mundane as a voluntary militia and sanitary pans. But, at a deeper level, they express and exploit an underlying unease with the vapid prochecies of the boomers... ${ }^{23}$

The first chapter of the thesis, rather than focusing strictly on urban images of New Zealand, deals with the promoters themselves and the reasons why they boosted the country's cities and towns. Was it simply for material gain by attracting capital, settlement and tourism? Or were there more altruistic motives involved such as a sincere love of country and a strong sense of pride? Included in the discussion are debates on the accuracy of booster material, its popularity, why the opinions of visitors could sometimes vary, and why there was so little opposition to boosterism in general.

Chapters 2 and 3 are straightforward depictions of the most typical means by which boosters championed their cities and towns in the written medium. Chapter 2 is an in depth look at the various means by which boosters tried revealing the country's towns and cities as civilised places. The two most common techniques were to compare New Zealand's urban areas to those in Europe and England and then to argue that New Zealand's cities were in fact superior in nearly every way to their Old World counterparts. Chapter 3 , on the other hand, analyses various other tactics used by boosters to promote their towns and cities, including: prophesying great and glorious futures; advertising the romantic or fairy-like quality of the townscape; emphasizing the healthiness of the environment; and underlining the solidity of the economic potential, to name just a few examples.

Chapters 4 and 5 offer an analysis of the urban visual image and the procedures by which artists and photographers might exaggerate the aesthetic qualities of a city.

${ }^{22}$ As a result of my own research and of conversations with Nelson Wattie and others doing research on the New Zealand novel, it appears that there were no other works of fiction (apart from the utopian novels), which were written explicitly for the purposes of promoting New Zealand.

${ }^{23}$ Graeme Davison, The Rise and Fall of Marvelous Melbourne (Melbourne: Melbourne University Press, 1978), p.246. 
According to Elizabeth Broun, an examination of visual material like the one being conducted in this study, provides an extremely valuable historical tool as it allows the historian to discover "the hidden agendas and ambitions that demanded some mediation, some gloss, before they could be shown to the world."24 Chapter 4 looks particularly at painting and illustration (including bird's eye view maps), while Chapter 5 examines photography and film. Notable booster techniques included: altering the scale of the subject matter to make it appear bigger or more grandiose; ignoring the bad aspects and focusing instead on what was ordered, efficient and beautiful; and carefully posing the scenes to give an impression of prosperity and civilization thereby countering any notions of New Zealand as being a backwoods and an untamed environment where prospective settlers might become lost in the woods or the quarry of hungry cannibals.

Chapter 6 is a comparative analysis of the ways in which towns and cities in Australia and Canada were boosted. It offers an opportunity for us to compare the urban image in other colonial cities to that found in the New Zealand examples. It will be seen that Canadian and Australian cities followed a course similar to that of New Zealand and for the same reasons. Chapter 7 is a case-study of the city of Christchurch and one of its neighbouring boroughs, New Brighton. It presents a detailed analysis of the means by which boosters in Christchurch promoted that city's potential; the formation of various Progress Leagues and Improvement Societies receive much attention, as do the reasons for boosting. It will be seen that those promoters in Canterbury were desirous of making Christchurch more attractive not only to advance her trade and tourism, but also because they had been greatly influenced by the utopian promises of both the City Beautiful Movement and new ideas about Town Planning.

The latter section of Chapter 7 introduces two further urban themes: the urban/rural debate and the impact of utopian thought. It also opens the way for an analysis of various kinds of other urban commentators, namely town planning professionals, local and national politicians, and civic officials. These other debates and assorted urban commentators require evaluation if one is to fully understand the influences on the boosters, and it is these aspects of the urban image which will be examined during the second half of this study.

Chapter 8 looks at the negative attitudes expressed towards New Zealand cities and towns by visitors and inhabitants alike. It explores the emergence of the very evils in

\footnotetext{
${ }^{24}$ Broun, p.vii.
} 
New Zealand which, according to booster propaganda, were not supposed to exist and were intended to have been avoided by planning ahead. This chapter has been included not to reveal the truth or falsity of the promotional material, but rather to offer some explanation as to why New Zealanders held such potent anti-urban and arcadian attitudes and a subsequent reformist/utopian vision of the future which developed as a result of these same attitudes. It also helps to explain the obvious necessity of urban promotional material in order to attract settlement and tourism to New Zealand by countering any negative imagery.

Chapter 9 deals with what I have termed the 'Back to the Land' movement. It proceeds with an examination of the reasons why this particular reaction came about, placing emphasis on the negative images of the city and town as discussed in Chapter 8. It then follows with an examination of the ways in which people were induced to settle in the countryside rather than in the cities and towns, in the vain hope that such a solution would prove a panacea to all or most of the country's urban problems. Chapter 9 is important as it reveals the prevalent anti-urban bias that existed in New Zealand; it shows the booster's perceived need to improve the image of the city before it was effectively tarnished forever, thereby condemning future urban growth in the minds of the nation's promoters.

The final chapter of this thesis looks at the idealistic and philanthropic influences on the boosters. It argues that given the emergence of old world problems and a realization after 1911 (the year that the country's urban population exceeded the rural one), that New Zealand might no longer be the progressive nation that its booster propaganda was making out to be the case, then it was time for the country to improve its urban environment before it became too late. It will be shown that New Zealanders turned to Europe and America for solutions, which included: City Beautiful and Garden City schemes, suburbs, and the introduction of town planning legislation. This last chapter will argue that the nation's boosters were not entirely motivated by thoughts of attaining profit; rather, there existed a sincere belief amongst certain members of the community that it was not too late to create an ideal society in New Zealand, the very same one which had been advertised in the booster rhetoric. It will be argued that some people living in New Zealand were eventually as much victims of their own booster propaganda and the overseas utopian idealism which fostered it, as the settlers and tourists who were convinced to emigrate or visit in the first place. Technology in 
particular was seen as offering New Zealanders a means to achieve such a utopian vision by offering previously unthought of benefits such as improved transportation and building techniques. Emphasis is put on the fact that after 1911 the New Zealand reaction to city or town life changed from being generally pro-rural to exhibiting a firm belief that a fantastic and futuristic metropolis could become reality - should New Zealand only plan ahead and take warning again from European and American examples. However, before concluding the chapter, the argument will take into consideration the very real possibility that urban improvement and beautification schemes were not entirely influenced by a genuine desire to build a new Jerusalem in the England of the Antipodes. For City Beautiful and town planning propaganda was also good promotional material, and as mentioned previously, was necessary to counter bad urban publicity. Such urban improvement schemes were also likely to have been fueled to a certain extent by other material ambitions, such as desire to increase property values or to secure a stable workforce for the manufacturing sector of the community in order to ensure increased investment. 


\title{
CHAPTER 1: THE BOOSTERS
}

The intent of this chapter is to provide the reader with an understanding of boosterism and it is for this reason that it is necessary to devote a great deal of space to promotionalism in New Zealand in general, rather than purely concentrating on the image of the city and town. The first part of Chapter 1 will deal with the motives of the boosters themselves. Their primary aim throughout the fifty year time period of this study, was to induce settlement, investment and tourism in the country. At the same time the boosters had the added incentive throughout the 1880 s and early 1890 s, of convincing those immigrants who had already chosen to come to New Zealand not to leave, despite the economic downturn which had resulted in the Long Depression and many New Zealanders emigrating to Australia in search of work. This discussion on the incentives of the New Zealand booster will also reveal the fact that the majority of those people who promoted the country for material gain, at the same time felt some sort of loyalty for the Dominion and the Empire, as well as a degree of pride in what the colonists had accomplished while settling the new land.

The second part of the chapter will focus on who the boosters were, namely: the New Zealand Government, local town and city councils, shipping companies, foreign visitors and individual New Zealanders. The wide variety of their methods and motives will be examined in relation to the first section of this chapter. The remaining part of the chapter will focus on the dubious nature of much of the advertising, as well as giving the reasons, both public and private, why reactions to New Zealand were so diverse.

\begin{abstract}
$* * *$
...you might encounter someone in England whose brother had an intimate friend - he having emigrated many years back - (the latter person's name had quite escaped the memory of the party addressing you) but the said brother's friend "went to Australia or was it Auckland?" - some years ago; and when you met him, as no doubt you did... he would be sure to entertain you with accounts of his latest epistolary tidings of his friends... in Great Britain.
\end{abstract}


On your...confessing to your loss of the pleasure [to] a meeting with your friend's brother's un-named friend...you are probably relegated - in spirit - to the category of imbecility. ${ }^{1}$

When Charles S. Mackie returned Home to England in 1900, after having lived in New Zealand and South Africa for a considerable period of time, he found the British public very badly educated about the condition of their overseas colonies. Various and numerous instances of this state of ignorance abounded at the time, exemplified most especially in the postal addresses reading, "New Zealand, South Pacific Ocean; New Zealand, near England; New Zealand, Alaska" or "Australia, New Zealand."'2 Mark Twain while on a lecture tour of the Australasian Colonies in the 1890s, was also aware of the utter lack of geographical awareness that people revealed while discussing New Zealand; he said that there were perhaps five people in the world who knew something about the colony, like where it was located on the map! ${ }^{3}$ Yet Twain was also careful to point out that there was a great deal of information about the colony available to those interested in the subject.

This geographical ignorance revealed by people at "Home"4 is but one reason why New Zealand boosters felt that they had to promote their colony if they were to attract settlement and investment. ${ }^{5}$ But lack of knowledge about the country was not the sole

1 Charles Strickland Mackie, A half-century's personal reminiscences of New Zealand, and garden of South Africa (London: Gould \& Co., 1901), p.3.

2 The first three examples are from a Canterbury promoter's work: Richard Wedderspoon, Pictorial South Canterbury: being a description of the four counties of South Canterbury, the port of Timaru and other principal towns (Christchurch: Simpson and Williams, 1925), p.9. The last illustration is from an Australian journalist: Charles Grattan Grey Australasia, old and new(London: Hodder and Houghton, 1901), p.ix.

${ }^{3}$ Samuel Longhorne Clemens, Following the equator: a journey round the world by Mark Twain (New York: Harper and Brothers, 1899), no page.

4 "Home" was an affectionate expression of the time meaning the British Isles. As the majority of people who had come to settle in New Zealand had been born in Britain, the phrase was universally accepted and is evident throughout the booster literature examined for the purposes of this thesis.

${ }^{5}$ New Zealand was not the only colony about which Europeans expressed a startling ignorance. At the 1878 Paris International Exhibition, many Frenchmen believed "that Canada was a tropical country (as maple sugar was mistaken for sugar cane) or that its inhabitants were identical with the Canaques, a rebellious tribe in New Caledonia". See: Eva-Marie Kröller, Canadian Travellers in Europe 1851-1900 (Vancouver: University of British Columbia Press, 1987), p.158. 
motive for boosting New Zealand. There were other difficulties to overcome, such as a vast amount of misinformation regarding the climate, the Maori, the wildlife, and the physical geography of the nation, all of which might adversely affect their country's overseas image. In fact, as a direct result of the Maori Wars in the 1860s, New Zealand's boosters until well into the first few decades of the twentieth century, were particularly concerned with demonstrating that the native threat had been eradicated. There was also a great deal of uncertainty abroad about the country's economic potential as a field of investment for the capitalist and as a place to find employment for the emigrant. These latter rumours were of specific distress to the boosters during the years of the Long Depression.

The only items of news in the past which have reminded people of our existence, has [sic] been some sensational report of a sea serpent - an earthquake - eruption, or flood, items which probably don't favourable [sic] impress the British public. ${ }^{6}$

W.B. Perceval, New Zealand's Agent-General in London from 1891 - 1896, accurately summarizes the fears of many New Zealand promoters about the nature of the country's unfavourable publicity overseas. Even thirty years after Perceval's remarks, sensationalist newspaper reports and unfounded gossip were still causing much debate and contention in New Zealand. Thomas Wilford, MP and Leader of the Opposition was worried about stories of earthquakes in the country:

...it was reported in the San Francisco papers that sixty people had lost their lives in the Taupo earthquakes. New Zealanders might smile at these statements, because they know that the reports were untrue. And, although scare headlines were quite common in San Francisco papers... it was still a fact that we had no one at that end of the world who could put the facts in the Press, and prevent harm being done to this country. ${ }^{7}$

Coupled with this paucity of reliable information and knowledge was the realization that other countries such as Canada, the United States, South Africa and Australia (as well as their respective provinces, states, cities and towns), were all competing amongst themselves (and against New Zealand), as spheres of investment and

${ }^{6}$ Letter from W.B. Perceval to New Zealand Prime Minister John Ballance (February 20, 1892), in Raewyn M. Dalziel, The Origins of New Zealand Diplomacy (Wellington: Victoria University Press, 1975), p.153.

${ }^{7}$ Thomas Wilford, NZPD (August 3 - September 13, 1922), p.138. 
potential destination points for the migrant population. Combine this too with the fact that New Zealand was off the beaten track, then the reasons for boosting become obvious. If New Zealand was to vie with other colonies for a share of the rewards offered by foreign investment and settlement, the country was going to have to undertake a massive promotional campaign. A.H. Messenger summarizes the situation nicely; as a New Zealand Government Tourist and Publicity Officer, he was only too aware of this predicament when trying to induce greater advertising on the part of New Zealanders:

...this is an age of advertising and competition between the various countries for a share of the world's tourist traffic and trade, is extraordinarily keen...

Advertising from a Government standpoint means bringing forward in an attractive manner the beauties and advantages of a country from the point of view of the settler, the investor who seeks new fields for his capital, the trader, and the tourist. ${ }^{8}$

One way of offsetting these injurious accounts was for cities like Dunedin and Christchurch to hold International Exhibitions proclaiming their colony's affluence and material advances. In 1905, at the laying of the foundation stone for the Christchurch exhibition, New Zealand's premier R.J. Seddon prophesied that:

...the New Zealand International Exhibition would be an outward and visible sign to the world of the colony's progress...It would mark its advancement in science, art, industries, education, and an improved and higher civilisation. ${ }^{9}$

According to R.C. McDonald, the advertisement of a city or country with an International Exhibition was a common practice in times of adversity. McDonald claims that each time Dunedin promoted itself with an Exhibition, the city was in a state of crisis:

The New Zealand and South Seas International Exhibition of 1925-26 was in some degree Dunedin's gesture of defiance against the conception that the city had lost its vigour. It is

${ }^{8}$ Auckland Advertising Club, Handbook and Programme of the New Zealand Advertising Exhibition inaugurated...under the direction of the Auckland Advertising Club to be opened...on Tuesday, June 28, at 2 p.m., Town Hall, Auckland... (Auckland: 1927), p.11.

${ }^{9}$ James Cowan, Official Record of the New Zealand International Exhibition of Arts and Industries, held at Christchurch, 1906-1907. A descriptive and historical account (Wellington: Government Print, 1910),pp.25-26. 
perhaps significant that each of the two previous projects of this kind had been launched in times of adversity: that of 1865 in the period of the decline of the goldfields, the 1889-90 Exhibition in a time of deep commercial depression. In 1925 Dunedin similarly felt a need of reassurance... ${ }^{10}$

John C. Weaver affirms McDonald's assertion when discussing the reason why Hamiltonians in 1860s Canada erected their own Crystal Palace at Victoria Park: "[it] was constructed to help arrest Hamilton's sliding economic fortunes..."11

Another means of countering inauspicious data about the poor financial state of the colony was to publish overseas reports affirming the opposite. One British captain William Ashby - after a "careful investigation" of New Zealand, concluded that the colony "was well to the fore as a great commercial outlet from the mother-country."12 Yet despite Ashby telling the reader that he is unbiased in his conclusions and that he has not been commissioned to undertake such an inquiry, one cannot help but wonder about his analysis as Ashby is a London Shipping Agent and consequently is bound to profit by increased passage bookings; so it comes as no surprise that his work exudes all the qualities of a typical emigration tract.

Thus far we have witnessed New Zealand boosters deliberately trying to promote an image of the colony overseas as a civilised, safe and economically sound place. Such promotional material could also be used to convince those people already settled in the country to remain in New Zealand and not to go and seek work abroad in times of adversity as many were inclined to do, and did, during the late 1880 s and early 90 s. $^{13}$ Yet despite the profit-orientated incentives of the boosters, the evidence suggests that there were other reasons for promoting the urban areas of New Zealand, and the country in general, which are reflective of a genuine sense of pride. This pride is manifest both p.322.

${ }^{10}$ R.C. McDonald, City of Dunedin (Dunedin: Dunedin City Corporation, 1965),

${ }^{11}$ Weaver, Hamilton: An Illustrated History, p.66.

${ }^{12}$ William Ashby, New Zealand the Land of Health, Wealth and Prosperity. Its present position and future prospects (1889), p.6.

${ }^{13}$ According to W.B. Sutch, 125,000 people left New Zealand between 1885 and 1892 as a direct result of the adverse effects of the Long Depression. See: W.B. Sutch, Poverty and Progress in New Zealand; a reassessment (Wellington: A.H.\& A.W. Reed, 1969), chronological table following at end of book. 
in the praise shown at what New Zealanders accomplished in such a short period of settlement and in their celebration of the greatness of the British Empire and her people.

The magnificence of Empire and its seeming triumphs was a common theme permeating the literature of the period. It was frequently the practice, as with Sir Arthur Percy Douglas's All Red Series, to write about Britain's Dominions, not only to inform intending settlers and tourists about the colonies, but most importantly to stimulate the patriotism of Englishmen at home and abroad. Such patriotism can be seen in the author's prefatorial remarks, where the supposed idealistic virtues of empire come before pragmatic considerations of colonisation:

The All Red Series is designed at once to quicken the interest of Englishmen in the extension and maintenance of the Empire... They are intended alike for the immediately practical use of emigrants or visitors, and for the study of those who stay at home. $^{14}$

Empire permeated everywhere; there were calls for English settlers overseas never to forget their heritage by creating little pockets of England wherever they settled. ${ }^{15}$ Flags, flagpoles and military parades were given a great deal of attention, as were the visits by royalty at the beginning of the century. ${ }^{16}$ David Hamer says that "Much of the early celebration of cities in Australia, New Zealand, and Canada was a celebration of British enterprise. ${ }^{17}$ A great deal was also made of the superiority of the Anglo-Saxon race and its achievements:

These sturdy Britons...have done more to elevate, to educate, to emancipate, to civilise and to unite humanity; to free the brain from superstition, the limbs from fetters, and the world from

${ }^{14}$ Sir Arthur Percy Douglas, The Dominion of New Zealand (London: Sir Isaac Pitman \& Sons, 1909), p. inset.

\footnotetext{
${ }^{15}$ R. Acton, Our Colonial Empire (London: Cassel, Petter, Galpin and Co., 1881), p.iv.
}

${ }^{16}$ One reason advocated by Raewyn Dalziel for Julius Vogel's strong loyalty to the crown, and which can perhaps be extended to other English migrants, is that patriotism was a means of overcoming "feelings of alienation" and remoteness. See Julius Vogel (Auckland: Auckland University Press, 1986), p.178.

${ }^{17}$ Hamer, New Towns in the New World, p.225. 
bondage, than any other nation or race that ever inscribed its achievements on the pages of human history. ${ }^{18}$

Allied to this heartfelt patriotism was a strong sense of civic self-esteem. New Zealanders felt pride in their achievements of having built what they perceived of as great municipal centres by the 1880 s and 1890 s; this rapid urban development was seen by New Zealand's boosters as being in stark contrast to the centuries it took European cities to reach their apex. New Zealanders boasted about their handsome public buildings, their transportation networks, their beautiful public gardens and their prosperous inhabitants. Michael Katz, in discussing the mindset of the entrepeneurial class in 1850 s Hamilton, Canada, says that pride was a prominent factor amongst that group: "...pride was felt in the public buildings made of abundant local stone and in the magnificent mansions, such as Dundurn Castle..."19 William Pember Reeves, New Zealand's Agent-General in London after 1895, paid tribute to the cities and towns of New Zealand as symbols of the colony's advanced state of civilisation:

To the European visitor a colonial town...is just a third-rate town and nothing more. To the pioneer who has seen it grow...the prosperous streets, roomy villas and comfortable cottages represent victory - the triumph of his race in their battle with emptiness and desolation. ${ }^{20}$

This heartfelt sense of pride was a factor that sometimes blinded contemporary boosters to their own over-zealousness. One booster of New Zealand could ridicule a

${ }^{18}$ George Bell, pp.72-73. Bell was a former United States Consul in Sydney who appeared sincerely taken with New Zealand because of both the country's social reforms as well as its natural beauty. In the "Introduction" to his work, Bell argues that he has no clandestine reasons for praising the colony and his only interest is in the greatness of the Anglo-Saxon race; in New Zealand he visualizes the race as achieving its full potential. Yet despite Bell's supposed pride in the race, his thoroughly optimistic description of New Zealand closely resembles the American Progressive literature that was being published during the early twentieth century and which praised Antipodean society to the extreme. The intention of such literature was partisan, however, as it was aimed at getting the United States to emulate aspects of Australasian social legislation. See Peter J. Coleman, Progressivism and the World of Reform. New Zealand and the Origins of the American Welfare State (Lawrence: University Press of Kansas, 1987).

${ }^{19}$ Michael B. Katz, The Peoples of Hamilton, Canada West (Cambridge: Harvard University Press, 1975), p.5.

${ }^{20}$ William Pember Reeves, "New Zealand Today" in Charles Sydney Goldman, ed., The Empire and the century; a series of essays on imperial problems and possibilities by various writers (London: John Murray, 1905), p.463. 
Glaswegian gentleman, "who believed...that Glasgow, city of smoke and turmoil and grey skies, is the most beautiful city in the world", ${ }^{21}$ but could not see this same fault in his own descriptions of New Zealand and those of his contemporaries. Others could, however, as testified to by the comments of the English traveller Percy Podmore:

New Zealand has been over-advertised and ridiculously exaggerated... The scenery is decidedly beautiful, but when compared with other parts of the world, it is insignificant. ${ }^{22}$

New Zealand's International Exhibitions were yet another manifestation of civic and national pride. James Cowan attests to this when commenting on the 1905 Christchurch Exhibition: "The beauty of the site and the buildings...gave colonists good cause for satisfaction..."23 Graeme Davison in his work on Melbourne, also envisions that city's 1880 Exhibition as a powerful emblem of all that had been accomplished by the city's pioneers. ${ }^{24}$

Certainly imperialism and civic pride were also excellent tools by which to advertise New Zealand overseas for the purposes of benefitting materially. Richard White in Inventing Australia (1981) discusses the uses of patriotism in advertising: "None was more enthusiastic in the celebration of Australiana than local companies advertising their products...Patriotism protected local manufactures...from outside competition. ${ }^{125}$ Even if civic and national virtues were being manipulated for political ends, this in no way invalidates their legitimacy; in fact, it only goes to show that advertisers were aware of the potency of these beliefs. Yet as the evidence given by the boosters and by Davison attests, the celebration of the Dominion's cities and towns was based on more than just motives of financial gain. Nick Rider in his review of a series of essays relating to the 1888 Barcelona Exhibition, makes the point that although

${ }^{21}$ Edward Ellis Morris, Pictorial New Zealand With Preface by Sir W.B. Perceval (London: Cassell \& Co. Ltd., 1895), p.109.

${ }^{22}$ Percy St. Michael Podmore, Rambles and adventures in Australasia, Canada, India, etc... (London: L. Upcott Gill, 1909), p.231. The New Zealander's love of "blowing" will be discussed in greater detail in Chapter 3.

${ }^{23}$ James Cowan, p.80.

${ }^{24}$ Davison, The Rise and Fall of Marvelbus Melbourne, p.5.

${ }^{25}$ Richard White, Inventing Australia: Images and Identity, 1688-1980 (Sydney: Allen \& Unwin, 1981), p.114. 
Catalans were using the Exhibition as a means of attracting investment and development, a greater motive was a variant of civic pride reflecting a need to impress foreign visitors that bordered on what can only be called "a collective neurosis." ${ }^{26}$ John Richardson reiterates Rider's comments about the Catalonian's municipal self-esteem:

In the 1890 s Barcelona was a city of opportunity... its avant garde looked ahead to the twentieth century with an optimism that was positively utopian... They [the city's politicians and architects] were determined to create a great new modern capital - a rival to Madrid... [the] Universal Exhibition [was] the apotheosis of this dream. ${ }^{27}$

Other modern historians emphasize the same points - that boosters strongly believed in what they were advertising. David Hamer admits that while some boosters were out to exploit, others were influenced by "a strong vein of utopianism." 28 Michael Katz, while discussing the merchants of mid-nineteenth century Hamilton, concludes: "The expectations of the merchants who wagered on the future... were not irrational. The future of the city... did appear unlimited." ${ }^{29}$ Raewyn Dalziel states that Julius Vogel, first Prime Minister of the country, then Agent General (and also author of a number of celebratory New Zealand tracts), was so overcome with a feeling of optimism in the colony that he believed "[New Zealand] had to have a great future in front of it." ${ }^{30}$ Paul Voisey too makes this same suggestion when debating the nature of small-town boosterism in Western Canada:

But did the boosters believe their own propaganda? Certainly in the towns' first bustling years optimism did not seem misplaced... ${ }^{31}$

${ }^{26}$ Nick Rider reviewing Pere Hereu i Payed, ed. Arquitectura i Ciutat a L'Exposicio Universal de Barcelona de 1888 in Urban History Yearbook (Leicester: Leicester University Press, 1990), p.230.

27 John Richardson, A Life of Picasso Volume 1 (1881-1906) (New York: Random House, 1991), pp.14 and 62.

${ }^{28}$ Hamer, New Towns in the New World, p.61.

${ }^{29}$ Katz, p.2.

${ }^{30}$ Julius Vogel New Zealand, its past, present and future. A paper read at the Imperial Institute on December 4, 1893, in Dalziel, Julius Vogel , p.306.

${ }^{31}$ Paul Voisey, "Boosting the Small Prairie Town, 1904-1931: An Example from Southern Alberta," in Alan F.J. Artibise, ed., Town and City: Aspects of Western 
Having looked at the reasons for boosting New Zealand, some for material or political gain, others out of a sense of pride, and for others still from a possible combination of both, one must now examine the boosters themselves. The material examined reveals that, in general, those celebrating the country were a mixed bag of groups and individuals working in not so different ways and for the same ends. Among those promoting the colony was the national Government, various shipping companies, local town and city councils, chambers of commerce, large publishing houses, and assorted promotional groups and individuals.

By far the most prominent group publicizing the country was the national government. This was done by means of various booster pamphlets and books, international exhibitions, government officers, paintings, stamps, films, and interestingly enough in 1901, a government tourist department. Debates in Parliament about how better to promote the country were a common occurrence. Special exhibitions in New Zealand were sponsored by the Government to advertise the country's products and scenic attributes to visiting foreign fleets; it was believed that sailors aboard these foreign vessels, upon returning home, would act as a "good advertising medium for possibly fifty years to come", ${ }^{32}$ should their impressions be favourable. Conversely, New Zealand servicemen who had seen action in Europe during World War One, were also seen by some government officials as an effective device for promoting the country; according to G.W. Russell, the Minister of Internal Affairs: "...many men from Great Britain, and France, and Belgium will desire to come to a country which has turned out such magnificent men." ${ }^{33}$

The Government was responsible from time to time for the display of New Zealand manufactured goods and tourist attractions at International Exhibitions overseas, such as that of Melbourne in 1880; however, representation at some of these exhibitions was at best minimal - if made at all - owing to financial restrictions and to the parsimonious natures of certain politicians. The Government did commission a number

Canadian Urban Development (Regina: University of Regina Press, 1981), p.163.

${ }^{32}$ Charles Henry Poole, MP for Auckland West on the visit of the American fleet; NZPD (June 29-July 29, 1908), p.78.

${ }^{33}$ The Press (Christchurch: 1919), p.49. 
of New Zealand Handbooks though, with the intention that these works would act as good advertising vehicles for the country. They were either sent to the various overseas exhibitions or Home to friends and family. Sir Julius Vogel stated that the Government should subsidize the cost of sending these works Home to ensure that they reached the widest potential audience. ${ }^{34}$

It was also the practice of government officers overseas to do as much as possible to encourage tourism and emigration to the colony. William Pember Reeves as AgentGeneral gave talks to various groups of people in England on the advances which the colony had made and on the natural wonders to be encountered there. ${ }^{35}$ The picture which he painted to his Fabian friends Sidney and Beatrice Webb for instance, about the Liberal Governments' reforms in the country, was the direct cause of their visit to New Zealand towards the end of the nineteenth century. Others followed too in the wake of such a reformist image, including the French political scientist André Siegfried in 1898 and the Scottish Labour agitator Keir Hardie in 1908. A number of other visitors most certainly also came to New Zealand for the express purpose of seeing for themselves the country's well publicised advances in social legislation. Included in this group were: "Ramsay MacDonald (1906)... trade unionist Ben Tillett, C.P. Trevelyan, and the socialist Tom Mann." ${ }^{136}$ The British were not the only ones to come and see New Zealand's highly publicised reforms. According to Peter Coleman, American progressives, social scientists, government officials, and journalists, were also interested in Australasian legislation. ${ }^{37}$ David Hamer in The New Zealand Liberals, argues that this idealized image which the country had internationally, had been deliberately cultivated by the Liberal Government at the turn-of-the-century "to make New Zealand

${ }^{34}$ Sir Julius Vogel, NZPD (Sept 25-Oct 22, 1884), p.301.

35 The Liberal Government of the 1890 s was very successful at cultivating a particular image of New Zealand as a kind of model democracy which had secured an end to labour/industrial disputes and the land issue. This situation was attributed to innovative legislation such as the 1894 Industrial Conciliation and Arbitration Act, the 1892 Lands Act and the break-up a year later of the Cheviot Estate. See David Hamer The New Zealand Liberals: The Years of Power, 1891-1912 (Auckland: Auckland University Press, 1988).

${ }^{36}$ K.R. Howe, Singer in a Songless Land: A Life of Edward Tregear (1846-1931) (Auckland: Auckland University Press, 1991), p.136.

${ }^{37}$ Coleman, pp.157, 161 and 181. 


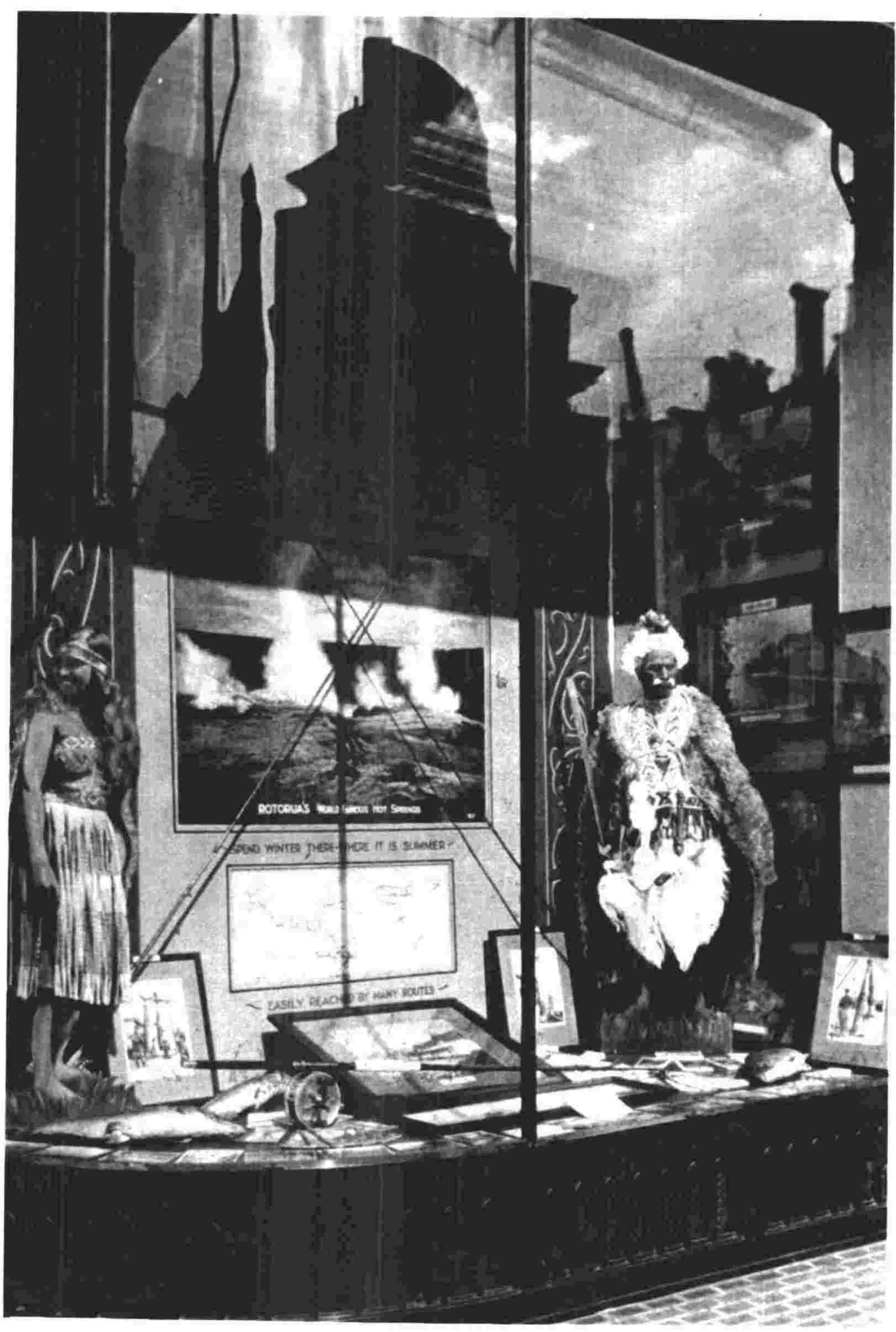

illustration 2 
known overseas and to sell New Zealand's products and attractions for the investment of capital." ${ }^{138}$

One of the foremost responsibilities of the newly formed New Zealand High Commissioner's Office, was to promote the appeal of the country. It became common practice for that office in London to present public exhibits of New Zealand attractions, such as the 1928 tourist and sporting display window in the front of the Commissioner's office (ILLUSTRATION 2).

Another method by which the Government came to advertise New Zealand was on postage stamps. By the middle and late twenties, scenes of the colony's natural wonders such as Mount Cook or Milford Sound had begun to replace portraits of heads of state. Only in 1925 does the first urban image appear - a special issue commemorating the Dunedin Exhibition and showing the main pavilion grounds. By the late twenties the New Zealand Post and Telegraph Department had tried to initiate a programme of appealing directly to individuals overseas by mail to incite interest in the colony as a holiday destination. It was believed at the time that targeting individuals with personal invitations would be more appealing to those receiving them and also that it would be a guarantee that the advertisement was seen, if not read. ${ }^{39}$ There was also talk in the 1920s about advertising the nation, and the 1925 Dunedin Exhibition in particular, with a stamp cancelling machine. According to records in the National Archives, authorities in Dunedin already had one such machine which printed the words, "Visit the big Exhibition, Dunedin, 1925-26."10

One of the most innovative ways by which the New Zealand Government promoted the country as a tourist resort as well as a good place for the investor, was through the creation of the Department of Tourism and Publicity in 1901. It was the idea of Sir Joseph Ward, then Minister of Railways, who eventually became Prime Minister in 1906. This Department was the first of its kind created anywhere in the world, and it used a host of techniques to promote New Zealand, including: the creation of a photographic and film section to show everyday scenes of New Zealand; the distribution

${ }^{38}$ Hamer, The New Zealand Liberals ,p.63.

${ }^{39}$ Auckland Advertising Club, p.23.

${ }^{40}$ Department of Tourism and Publicity Records. Letter to Minister in Charge of Publicity, August 28, 1924. (National Archives of New Zealand, Wellington). 
of posters advertising the Christchurch Exhibition; the presentation of lantern slide exhibitions with shots of cities, the Maori and New Zealand's natural wonders; taking out newspaper advertisements to influence foreign travellers to choose New Zealand as their holiday destination; and the publication of numerous pamphlets summarizing sites of interest which were sent to the leading hotels of the day.

Another technique employed by the Tourist Department was to purchase paintings of New Zealand subject matter which was deemed appropriate for boosting purposes. Works by the more famous artists of the day, like J.B. Perrett or like L.W. Wilson's "Dart Valley" (ca.1907), were then distributed throughout the colony and overseas in various Government agencies. T.E. Donne, Superintendent of the Department, in a letter to New Zealand artist Ms. Von Meyern, states the Department's position on matters pertaining to the purchase of works of art for such purposes:

If you will please send me samples of your work I shall be glad to consider whether I can give you any orders. I must say that I sometimes purchase paintings, either water, oil or pastels, for exhibition in the various Tourist Offices throughout the Colony...This of course forms an excellent advertisement for the artist as well as the Colony. ${ }^{41}$

As well as distributing material throughout numerous countries and cities, the Department of Tourism and Publicity also set up a number of offices abroad and throughout New Zealand to assist tourists and prospective investors and settlers. The aim of such agencies, according to the Australian Star of 1906, was to champion anything that would benefit New Zealand: "whether it be for the promotion of settlement on the land, for facilities of travel, or for the extension of commerce..." ${ }^{12}$ Overseas offices were eventually established as far away as Sydney, Melbourne, Brisbane, Adelaide, Perth, Vancouver, San Francisco, Durban, Johannesburg, Calcutta, Bombay, Rangoon, Tokyo and London. While agencies in New Zealand were located at all the major urban and tourist locations: Auckland, Dunedin, Wellington, Christchurch, Nelson, Wanganui,

${ }^{41}$ Department of Tourism and Publicity Records: Letter dated February 4, 1903, from T.E. Donne to Miss Von Meyern. (National Archives of New Zealand, Wellington). The artist concerned was probably Ellen Von Meyern (rather than her sister Blanche who was also an artist); according to Una Platts, Ellen was the more prolific of the two artistic sisters and was also the major breadwinner in the family. See Nineteenth Century New Zealand Artists (Christchurch: Avon, 1979), p.243.

42 Australian Star, (July 20, 1906). 
Invercargill, Te Aroha, Rotorua, the Waitomo Caves, Waikaremoana, Greymouth and at the start of the Milford Track. The setup of these offices, both in New Zealand and in other countries, was basically the same. Typical decoration included wall maps, photographs and paintings of New Zealand's natural scenery and "principal cities";"43 included also was a vast array of literature consisting of potential itineraries and places to stay. For the avid sportsman or sportswoman, the tourist offices also had the stuffed and mounted bodies of salmon, heads of wild stag, and any other assorted game to be found in New Zealand which might be of interest to the outdoor enthusiast.

Innovation was the order of the day, and any tactic helpful for the promotion of New Zealand's Tourist and Publicity Department aims was utilized. Attention-grabbing electric signs which flashed words every few seconds with coloured lights were used to draw notice to the Government's offices in Sydney and in Melbourne (ILLUSTRATION 3). The New Zealand agencies sometimes copied ideas for advertising from other tour groups like Thomas Cook and Son. And no expense was spared to portray New Zealand in the best light possible. This is clearly evident with the case of the Invercargill Tourist Office which, for purposes of government savings, was threatened by amalgamation with the District Office of the Department of Agriculture. The Agent at the Invercargill Office wrote to the Director of Commerce and Tourism opposing the move on the grounds that the office would not be aesthetically pleasing to visitors:

...it would be decidedly inadvisable to have farmers, horse owners and cattle and sheep dealers transacting business at the same counter as the tourists. To listen to a farmer asking for information regarding abortion and sterility in dairy cows etc; or to a horse owner discussing some diseases contracted by one of his horses would certainly not be pleasant for the tourists, especially the ladies... Further it must be remembered that farmers and such persons who have to visit stables and cow bires generally forget to clean their boots, and consequently do not smell very sweet when they come to town. ${ }^{44}$

The planned amalgamation was quickly rejected and the Invercargill Agency remained in its own building.

${ }^{43}$ Lyttelton Times (Lyttelton: April 19, 1907). Report on the opening of the Department of Tourism and Publicity's Christchurch Office.

${ }^{44}$ Department of Tourism and Publicity Records: August 10, 1911. (National Archives of New Zealand, Wellington). 


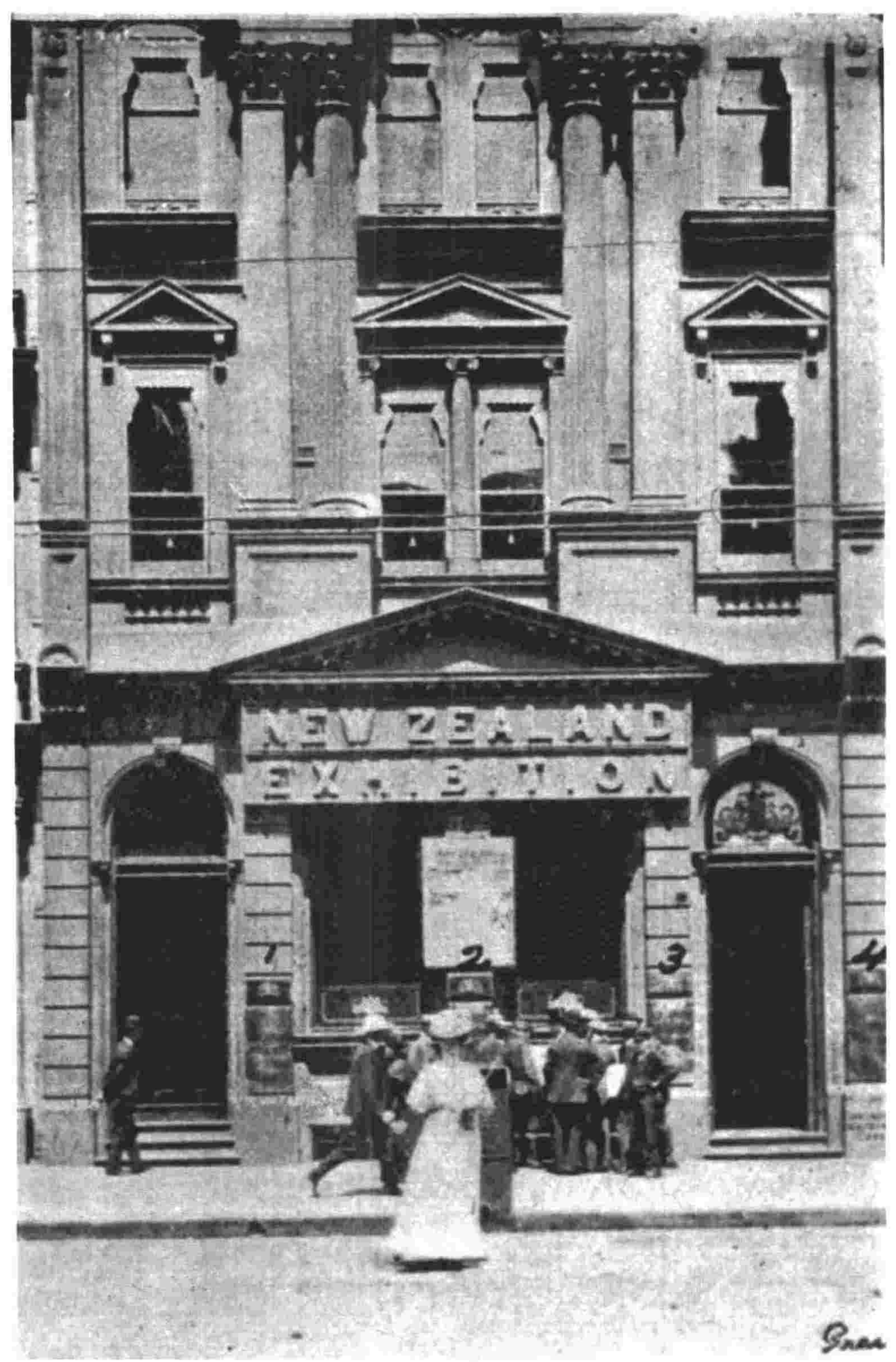

illustration 3 
Other prominent boosters were the local town and city councils with their associated progress and expansion leagues. These leagues were formed by the city or town with the express purpose of advancing the interests of their particular area. A number of them, like the Dunedin Expansion League, had the facilities for publishing their own promotional material. The objects of all these promotional groups were similar in intent and can be summarized by the manifesto of the Dunedin Expansion League:

The aim of this organization is to arouse the spirit of civic enthusiasm; to imbue the people of Dunedin and Otago with unwavering confidence... to develop individual activity and effort in making known the advantages, opportunities, and resources of City and Province alike; to secure ample publicity for our agricultural, commercial and educational interests - to work, strive, labour, and fight for the success, prosperity, and advancement of our City and Province. ${ }^{45}$

New Zealand's municiplaities were not the only ones to have become directly involved in promotionalism for the purposes of reaping economic compensation. The people in Boston, Massachusetts, for example, were eager to exploit their city's role in revolutionary America, ."not least because of the commercial rewards of historical tourism. ${ }^{446}$

The procedures employed for such boosting objectives were analogous in method to those used by the New Zealand Government of the time. Civic histories were commissioned and published which were in reality thinly disguised advertisements promoting the sponsors and nothing else. A vast array of tourist literature was prepared, which was either left in local hotels or sent overseas to be distributed on the transPacific ocean steamers; these tourist brochures and pamphlets were also sent to the leading British or Continental clubs and spas, as well as parts of the United States: "the object being to reach the wealthy tourist. ${ }^{147}$ Other strategies implemented, entailed the taking out of newspaper advertisements, the organization of exhibitions and fairs, the production of promotional stickers in the case of Wellington, and the advertisement of

${ }^{45}$ Dunedin Expansion League, An appeal to the loyal citizens of Dunedin and the residents of Otago (Dunedin: Mills, Dick \& Co., 1911), no page.

${ }^{46}$ Graeme Davison, "Cities and Ceremonies: Nationalism and Civic Ritual in Three New Lands", New Zealand Journal of History, 24, No. 2 (October 1990), 102.

47 Dunedin Expansion League, What are we doing! A short resume of work undertaken (Dunedin: The League, 1914), p.2. 
New Zealand scenes on cigarette cards with the intention that these cards be distributed abroad. $^{48}$

Lantern slide exhibitions were yet another means for promoting a particular city. By the 1880s these spectacles had become quite commonplace; according to Maren Stange's article on American urban photography, these slide exhibitions were usually accompanied by music and narrative. ${ }^{49}$ Records from the Dunedin Expansion League show that grants were made towards residents who agreed to give public talks accompanied by lantern slides about the attributes of New Zealand while touring in the United Kingdom. Surviving collections of these lantern slides reveal the promotional nature of their subject-matter. This can be seen with the few remaining published texts which had been originally designed to accompany such slides, such as T.B. Lamburn's New Zealand, North and South Islands or The Colony of New Zealand, in two parts. Part I - The North Island (which was presented in London by Sir Dillon Bell, New Zealand's Agent General). ${ }^{50}$ The promotional nature of these slides can also be evidenced by the many pictures of beautiful scenes, advanced cities and native inhabitants which are to be found in one particular collection of two hundred and fifty of these slides at the Canterbury Public Library; what shows these pictures were aimed especially at inducing settlement in the country, are the twelve slides depicting various New Zealand homes ranging from three roomed to twelve roomed dwellings. ${ }^{51}$ Such slides were meant as examples of domestic living arrangements in New Zealand which the incoming settler might choose from.

It was common for major groups of boosters - especially the Government and the Town/City Councils - to work together. Hansard recordings from the parliamentary debates and records from municipal councils and chambers of commerce, all show that

\footnotetext{
${ }^{48}$ Wellington Chamber of Commerce Records (General Minute Books, 1927), p.7. (Manuscripts, Alexander Turnbull Library).

49 Maren Stange, "Jacob Riis and Urban Visual Culture: The Lantern Slide Exhibition as Entertainment and Ideology", Journal of Urban History, 15, No.3. (May 1989), 292.

${ }^{50}$ See: The Colony of New Zealand, in two parts. Part I - the North Island (Westminster: 1882?) and T.B. Lamburn, New Zealand, North and South Islands (London: 1901?).

${ }^{51}$ Henry Thompson lantern slide collection. (Canterbury Public Library).
} 
a great deal of cooperation existed between these groups. The chambers of commerce frequently made suggestions to Parliament about ways of improving promotional methods; and town and civic councils repeatedly asked the government to help fund either their exhibitions or their published material meant for overseas readers. Letters between the Otago Expansion League and the Department of Tourism demonstrate that the Government often subsidized the League - either directly through grants or indirectly by taking out full page advertisements in the League's publications. ${ }^{52}$ Both groups also offered a free exchange of photographs and information, and in return for the Government's assistance, the League sent its pamphlets free of charge for distribution to New Zealand Government Agencies abroad and in the country. ${ }^{53}$ The degree of collaboration between these various organizations with the intent of boosting the city and nation is evident in a great deal of the promotional literature. For example, The South Island of New Zealand (1930), was a collaborative publication financed by the combined Chambers of Commerce and Progress Leagues of the South Island. ${ }^{54}$ The prefatorial remarks found in the promotional work New Zealand Today (1925), are indicative of the degree of cooperation that took place amongst the various promotional bodies:

Designed, prepared and produced by arrangement with the New Zealand Government Department of Industries and Commerce....and also under the auspices of... the New Zealand and South Seas International Exhibition, Local Bodies, Progress Leagues, Chambers of Commerce, and Manufacturers' Associations. $^{55}$

${ }^{52}$ The Otago Expansion League was formed in 1915. It was the new name given to what was formally known as the Dunedin Expansion League. The Dunedin Expansion League had itself come into being in 1911, created in turn out of the Dunedin and Suburban Reserves Conservation Society (which had been established in Dunedin in 1888).

${ }^{53}$ Department of Tourism and Publicity Records: 1912. (National Archives of New Zealand, Wellington).

${ }^{54}$ Combined Progress Leagues and Chambers of Commerce of the South Island,The South Island of New Zealand; a tourist guide (Christchurch: New Zealand Newspapers, 1929-30).

${ }^{55}$ Leo S. Fanning, New Zealand today; an authentic illustrated description of the industries \& commerce of New Zealand and the government's policy for the development of the Dominion's rich resources, scenery, sport \& other attractions of the "Brighter Britain of the south" (Dunedin: Vivian E. Page, 1925), p.inset cover. 
There were other groups and individuals advancing New Zealand than just the Government or elected municipal officers. There were the big New Zealand publishing companies such as Tanner Brothers, Duncan Frank and Co., the Howe Brothers, Muir and Moodie, Ferguson Limited and Whitcombe and Tombs, to name just a few. These firms issued large numbers of photographic albums publicizing New Zealand, either because they had been contracted to produce such works or because these albums were popular and sold well. The albums usually followed the same artistic formula: attractive engravings or photographs of civic streets, prominent buildings, monuments, and native scenery, sometimes highlighted by small captions drawing the reader's attention to some aspect of the scene. Often the pictures in these works were the same, despite differing publishers, as attempts to introduce a copyright law were only initiated in 1896. The albums were in general softcover and embroidered with flowery gold-painted lettering on the front; the variations of their titles such as Auckland the Beautiful or Beautiful Napier proved monotonously repetitive, as did their subject-matter after a time. Should the work sell well, numerous reprints and re-issues were often made.

Some of the less creative booster handbooks tended to follow a repetitive promotional formula that bordered on the extremely tedious. First came the local histories of European settlement; these were usually followed by photographs or illustrations of a contemporary town or city, with the emphasis placed upon the downtown and suburban residences (or "villas" as was the more marketable term). Following this came information on gas, water and other power utilities available in the area, as well as long-winded descriptions of hospitals, harbours, educational facilities, local government offices, churches, and the like. A quick list of the primary industries and local manufactures usually concluded these booster works. Interspersed throughout the booklets were advertisements promoting local hotels, shops, or industries. Sometimes, if an author was feeling especially creative, the reader might be surprised to see a change of order in the narrative, with churches being discussed before civil institutions or power utilities before municipal histories! ${ }^{56}$

The publishers of the booster works by the large printing houses did not appear to be unduly influenced by notions of civic loyalty, as it was not uncommon for a work

\footnotetext{
${ }^{56}$ For an example of this kind of booster work see: William Gisborne's The Colony of New Zealand, its history, vicissitudes and progress (London: E.A. Petherick \& Co., 1888).
} 
promoting a particular city to be published in another rival centre, suggesting that a publisher's loyalty verged more towards financial recompense at the expense of municipal patriotism. For instance, Wellington, the Capital City of New Zealand (1901), was published in Christchurch. What is even more ironic is that another booster work which celebrates Wellington while also criticizing Auckland, New Zealand Cities: Wellington (1919), was actually published in Auckland! This same trend can be seen in overseas material as well. For example, The Picturesque Atlas of Australasia (1886), which was published in Sydney, is generally much more favourable to New Zealand's cities (particularly Auckland) at the expense of the Australian city. ${ }^{57}$

Others championing the cause of New Zealand were philanthropic organizations or residents "blowing" (the expression of the time used to describe the inhabitant's penchant for talking up the town). The New Zealand Tourist League testified to the means and the motives of the former: a "non-profit organization"58 aimed at convincing the Government of the need to exploit the country as a tourist destination in order to capitalise on the wealth generated by sightseeing.

The reasons for individuals boosting their town, however, were somewhat more varied. Often, when strangers visited New Zealand's towns or cities, they found the residents eager to expand on the "greatness" of the place. The same occurred when New Zealanders travelled overseas and boasted about their country and what it had accomplished. Certainly some of the wealthier New Zealand residents stood to gain on increased property values should foreign investment increase. According to Raewyn Dalziel, Julius Vogel's motives for boosting and speculating were somewhat questionable. Dalziel states that:

In common with many other nineteenth-century politicians Vogel made politics work in his own as well as the country's interest... Politicians who were landowners, businessmen, and speculators did not draw rigid lines between their private and public interests. $^{59}$

${ }^{57}$ Wellington, the capital city of New Zeland (Christchurch: Christchurch Press Co. Ltd., ca.1901). Charles Wilson, New Zeland cities: Wellington (Auckland: W \& T, 1919). Andrew Garran, ed.,Picturesque Atlas of Australasia (Sydney: Picturesque Atlas Publishing Company, Limited, 1889).

${ }^{58}$ Department of Tourism and Publicity Records: Letter dated December 16, 1929. (National Archives of New Zealand, Wellington).

${ }^{59}$ Dalziel, Julius Vogel, p. 83. 
Michaal Katz echoes Dalziel's point, stating that a certain class of people in Hamilton, Canada, had a vested interest in their city:

The entrepreneurial class formed an overlapping elite, governing all the major activities within the city, whose economic prosperity they had made, through their investments, identical with their own. They invested the city's money in railroads and utilities, in which they were stockholders. They bought land which the coming of the railroad would make more valuable. These leading citizens made the public interests of Hamilton and their private economic prospects the same. ${ }^{60}$

John Weaver is equally skeptical about certain Hamiltonian's sense of civic duty: "If civic patriotism glimmered, it only did so through greasy layers of self - interest." ${ }^{\text {"61 }}$ Yet a large segment of this elite company - like many of the boosters themselves - were influenced also out of a sense of pride, the result ${ }_{n}$ of the rapidity of a city's growth which seemed to herald a great future and the simple but sincere feeling of many residents that there was no place like home.

Two other groups require attention when examining the make-up of the boosters the local newspapers and foreign visitors. The motives of the first body are quite simple; apart from a genuine loyalty to the municipalities which they served, it is important to remember that their success depended upon the success of the settlement. Should a city or town prosper then the local paper would also reap the benefit through increased advertising. Therefore, newspapers were bound to do all in their power to promote their urban centres.

Foreign visitors, on the other hand, also played a very significant role in the booster war of words; but their part is somewhat more complicated to explain as each traveller had his or her own reasons for writing about New Zealand. Pecuniary incentives remained a significant catalyst for writing about the colony. The most obvious contributors to this group were the shipping companies and their agents, such as Captain Ashby mentioned earlier, all seeking to make a profit on tourist and emigration fares. Then there were the individual writers compiling histories of their travels for financial gain. These ranged from works by relatively unknown hands and meant only for private circulation amongst a limited company of friends, to books written for a mass market

\footnotetext{
${ }^{60}$ Katz, p. 184.

${ }^{61}$ Weaver, Hamilton: An Illustrated History, p.52.
} 
by famous authors of the day such as Anthony Trollope or Mark Twain. ${ }^{62}$ Even a few American reformers, with their descriptions of successful progressive legislation in New Zealand, were as guilty as some of the travel writers in their desire to make a profit: "Henry Demarest Lloyd... expected to make money from his articles, books, and speeches about Australasian affairs... So, too, did Charles Edward Russell..." ${ }^{163}$

Foreign visitors, particularly the reformers, were not solely motivated by thoughts of securing riches and wealth. Many in this group came from England, Europe and the United States looking to New Zealand precedents, chiefly enacted under the Liberal government, to take home to use as examples in polemics about the future socio-political courses which their own nations should pursue. ${ }^{64}$ Peter Coleman suggests that many American progressives celebrated New Zealand as an ideal model "because they had a vested interest in capitalizing on the supposed success of the New Zealand experiments..." ${ }^{65}$ Examples of this type of motive abound; there are tracts praising the racially exclusionist policies of New Zealand:

...the national aim of New Zealand is to keep the Dominion for New Zealanders - to keep it free from the taint of coloured races and the influence of undesirable immigrants... ${ }^{66}$

Then there are visitors such as Dr. Edith Elmer Wood, a leading authority in Town Planning in the United States, who praises the colony's radical legislation as an example for the world to emulate:

Some of us in the United States are inclined to regard New Zealand as a model for the rest of the world in respect to the

${ }^{62}$ Mark Twain and his family were forced to go on a lecture tour of Australasia in 1895 in order to pay off their debts, as Twain had gone bankrupt in the United States. See: Miriam Jones Shillingsburg, At home abroad: Mark Twain in Australasia (University Press of Mississippi, 1988).

${ }^{63}$ Coleman, p.161.

${ }^{64}$ See the work of the American Professor Frank Parsons and his The Story of New Zealand. A history of New Zealand from the earliest times to the present with special reference to the political, industrial, and social development of the island commonwealth... (Philadelphia: C.F. Taylor, 1904).

${ }^{65}$ Coleman, p. 41 .

${ }^{66}$ William Dickson Boyce, Australia and New Zealand Illustrated (New York: Rand McNally \& Co., 1922), p.235. 
homes of the people, and the facilities for home ownership afforded by the Advances to Workers Act. ${ }^{67}$

$* * *$

From the evidence above, it becomes apparent that there was a variety of different groups all cultivating a precise vision of New Zealand and for any number of reasons. This fact in itself should be enough to secure proof that at least some of the literature publicised did not fail to reach an audience. Yet there are other factors which can be applied to measure the popularity of the booster information. Firstly, many booster works were either reprinted or had updated volumes written. The Government's New Zealand Handbook, for example, underwent a whole series of re-issues. Secondly, there is written testimony that this booster propaganda was studied. For the many letters published in newspapers by people who did emigrate to New Zealand attest either to the falsity or veracity of the promotional work which they had read before coming over. Taken In: A Sketch of New Zealand Life (1887) for instance, is one particular piece written by a settler who had gone to New Zealand only to discover that the rosy picture which the booster material had painted of the country was far from the truth. ${ }^{68}$ Thirdly, there is visual evidence, which if it can be trusted, reveals that the advertising campaigns of the government at least did not go unheeded. Taking ILLUSTRATION 2 again, one notes the crowd gathered round the New Zealand Government Tourist Office in Melbourne. Also, in ILLUSTRATION 4, one sees a packed house at the free theatre of the 1925 Dunedin Exhibition watching films by the New Zealand Publicity Office. Fourthly, the Dominion's newspapers were read overseas. It was often the case for shipping companies to have captain's reading rooms at their home port where New Zealanders living abroad and those interested in the country could catch up on domestic events. Also, it was common practice for ship's captains to exchange bundles of newspapers at each port which they visited, implying that at least a small amount of the colony's news did reach other places, however difficult to quantify. And lastly, the visits by the Webbs and others interested in the country's reform programmes confirms the

${ }^{67}$ Christchurch Beautifying Association, The City Beautiful, 2, No.2 (1925), 1.

68 'Hopeful', "Taken in;" being, A sketch of New Zealand life (London: W.H. Allen \& Co., 1887). 


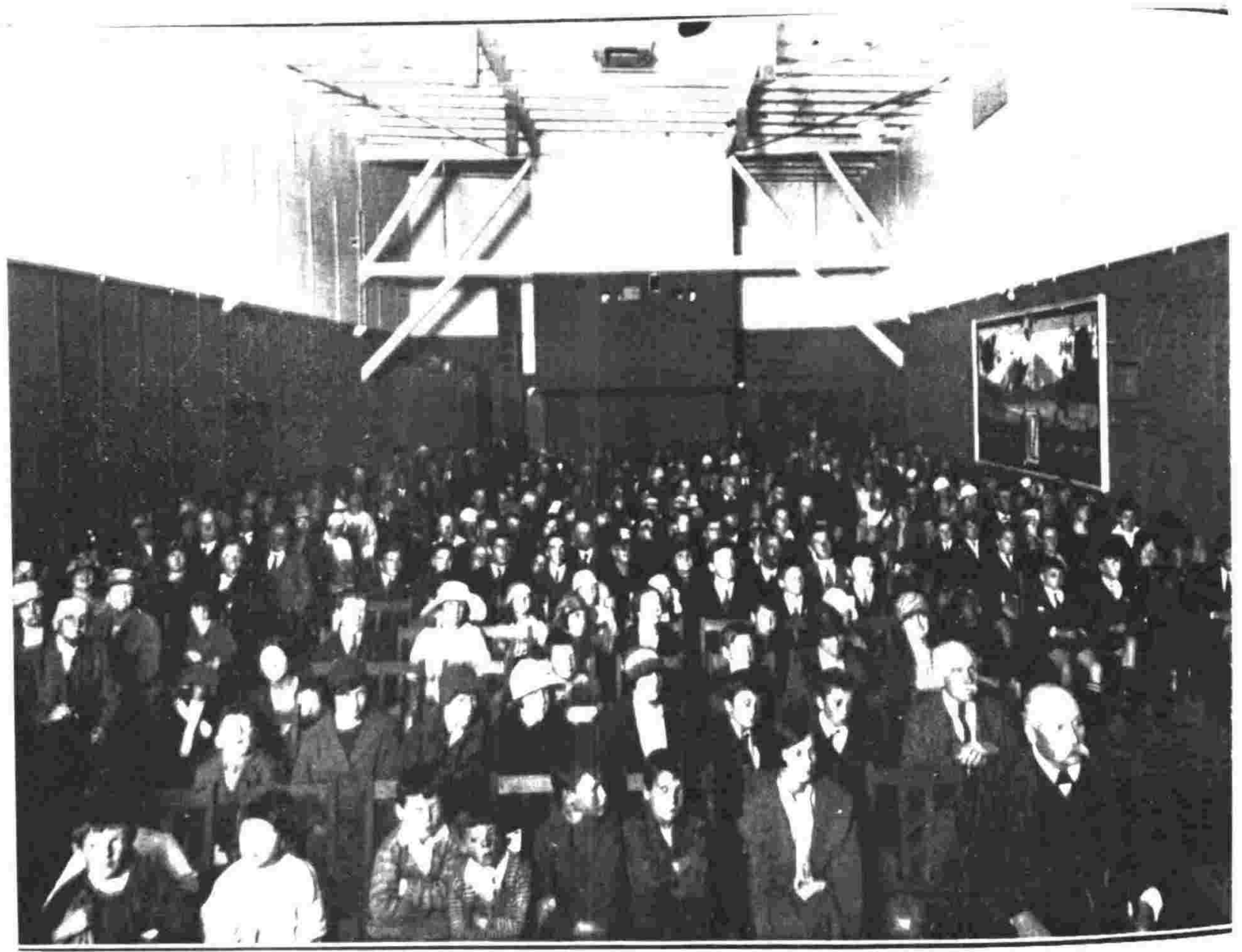

FLASHLIGHT PILTOGRAPII OF ASSEMBLY IN THE FREE CINEMA

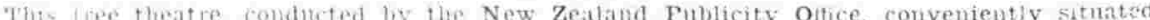

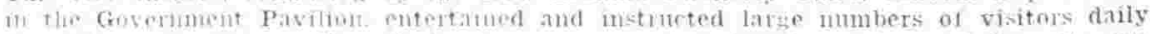

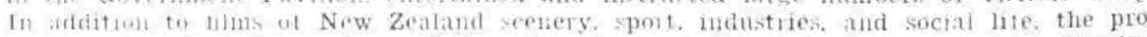
arinumes melnded recls of Great Britain, Canada. Alstralia. and othei parts of the Empire.

illustration 4 
success of people such as William Pember Reeves and of the Liberal Government with their strategy of advertising the country.

The numerous American visitors who testified to the world attention which the country was receiving, can be also used as unwitting witnesses to the effectivenss of some of the booster propaganda. Frank Parsons mentions the rumours that were going round about New Zealand: "During some years past we have been hearing strange and interesting reports from the progressive commonwealths of the South Pacific, particularly New Zealand..." ${ }^{169}$ David P. Gooding, an American travel writer in 1913, discusses the reason why New Zealand had become a focus of world attention: "Its recent world fame rests mainly on its humanities to man. New Zealand has long been singled out as a striking example of the utopian tendencies of this age."170 According to Coleman, progressive Antipodean subject matter was so prominent in the United States during the first few decades of the twentieth century, that it led one Iowa man to label the phenomenon "the New Zealand fever."71

Having shown that at least some of the promotional material was finding an audience, it is necessary to comment on the general accuracy of the information that was being divulged by these boosters. Modern historians and literary critics are only too aware that many works written during this period did not get all their facts straight. A.G. Bagnall, editor of the New Zealand National Bibliography, describes one particular piece of travel literature - Frank Tatchell's The Happy Traveller (1923) - as having, "more than the usual number of inaccuracies."172 How trustworthy can the other sources inlcuded in the National Bibliography then be? Eva-Marie Kröller, in a discussion on the exactness of travel books written by Canadians in Europe, comments on the fact that

${ }^{69}$ Frank Parsons, no page.

${ }^{70}$ David Paul Gooding, Picturesque New Zealand (New York: Houghton Mifflin Co., 1913), p.5.

${ }^{71}$ Coleman, p.78. Coleman believes that "A careful search of the pamphlet and newspaper literature... might show that much material from the South Seas reached American readers." (p.x).

${ }^{72}$ A.G. Bagnall, ed., New Zealand National Bibliography to the Year 1960 Volume 4.(Wellington: A.R. Shearer, 1969), p.280. 
many of the "authors often heightened, by satire or other means, scenes." ${ }^{73}$ It was not only literary sources that could be unreliable. R.P. Hargreaves and T.J. Hearn are alert to the fact that illustrations were not entirely honest in their depictions of incidents:

The engravings which depict news events were based on artists' impressions which in turn were based on descriptive news reports and/or recollections of participants or eye witnesses. Very often they reflect an over-enthusiastic imagination and emphasis on the dramatic. ${ }^{74}$

Michael Katz also raises queries about the dubious nature of certain primary sources:

The sources on which people have based their observations about the past also have contributed to the distortions in both popular thought and social theory. For the most part these sources have been literary, descriptions by more or less knowledgeable people - politicians, social reformers, novelists, journalists - of the times and conditions in which they lived. Unfortunately, perception is a very selective procedure, and these contemporary descriptions of social reality as often as not have proved generally unreliable, or at least only partially true. ${ }^{75}$

But we need not rely on the testimony of secondary sources alone to tell us what we can see for ourselves. The ample primary evidence attesting to the suspect disposition of some of the authors is proof in itself. Joseph Taylor's plan for a canal scheme in Nelson, for example, was entitled Nelson Harbour and City Improvements; a Ship Canal Scheme Which Would Defray its Own Cost (1901). Although a qualified engineer with an apparently reasonable but somewhat technical plan for improving Nelson harbour, one cannot but help question the man's character when he talks about his encounters with ghosts, demons and other bizarre phenomenon in Personal Psychic Experiences (1909). Likewise, how reliable can authors like James Cowan be, who attempted a serious history of New Zealand, yet who later appears somewhat commercialized after having prepared short trivial histories of notable events in the country for the back of Dominion Tobacco cards? James Belich certainly attests to the "obvious bias and obvious weakness" in Cowan's work; for according to Belich,

${ }^{73}$ Kröller, p.7.

${ }^{74}$ R.P. Hargreaves and T.J. Hearn, New Zealand in the Mid-Victorian Era (Dunedin: John McIndoe, 1977), no page. A discussion will follow in subsequent chapters about the reliability of the visual promotional material.

${ }^{75} \mathrm{Katz}$, p.8. 
Cowan's "primary objective was to rehabilitate the 'frontier period' and 'the adventureteeming life of the pioneer colonists'... He set out to show that New Zealand had a Wild West too..."17

Then there are the confessions of immigration and advertising agents themselves regarding their twisting of the truth. T.W. Whitson, who compiled promotional pieces for the Union Steamship Company, admits that when thinking up names for helping to promote New Zealand, his "enthusiasm blinded [his] sense of proportion." 77 William Courtney, Taranaki's immigration officer in Great Britain, admits too that, "he had got a little enthusiastic...in his lectures on the colony..." ${ }^{78}$ and consequently apologizes for any inconveniences caused!

Travel diaries in general could not be that accurate because their authors were always moving around and therefore might not get a true feel for the place which they were visiting. Accordingly, Edward Tregear (the first secretary of the Labour Department), took particular exception to foreign visitors "who flash in upon us for a moment, [and] instantaneously know more about us than we know about ourselves. ${ }^{179}$ For this reason, says historian K.R. Howe, Tregear proceeded to lambast J. Anthony Froude's negative portrayal of New Zealand on account of Froude's only visiting Auckland and Rotorua. Likewise, Miriam J. Shillingsburg states that Mark Twain refrained from commenting too quickly on New Zealand during his tour, as he wanted to ensure a "proper reflection" on the country, thereby avoiding "the treatment some casual 'globe-trotters'... had given to the Americans. ${ }^{180}$ John Floyd, a visiting American traveller at the end of the century, makes mention of the fact that because he did not

76 James Belich, The New Zealand Wars (Auckland: Auckland University Press, 1986), p.16.

${ }^{77}$ T.W. Whitson in a letter to A.H. Turnbull, (January 20, 1910). The letter had been inserted in a copy of Maoriland - An Illustrated Handbook to New Zealand (Melbourne: George Robertson and Co., 1884), which I examined in the Special Collections of Victoria University of Wellington.

${ }^{78}$ William Courtney quoted from a letter dated March 27, 1888, and published in Taranaki: the garden of New Zealand. Compiled by W. Courtney (London: Howard \& Jones, 1887), p.72.

${ }^{79}$ Howe, p.60.

${ }^{80}$ Shillingsburg, p. 145. 
stay long enough in a place to get a proper feel for the spot and its inhabitants, his travel notes might not be all that faithful. ${ }^{81}$

Floyd does, however, find New Zealand news personally more favourable to that found in the United States; according to him, papers in the Dominion did not publish lists of the despicable felonies which had occurred: "they do not fill their columns with the horrible details of vice in order to meet a public demand. Not all the things seen and heard in the worst police courts find expression in the daily papers." ${ }^{12}$ Yet what does that say about the reliability of New Zealand's press as the voice of truth? Paul Voisey makes considerable mention of this latter point when debating the nature of the small town press in the Canadian West; he argues that local newspapers merely became organs of the booster's propaganda, thereby "inflicting considerable injury on journalistic ideals." 83

Nor was the Government immune to accusations of falsehoods when trying to boost New Zealand. R.M. Dalziel says that one reason for Featherston not being suited to the role of New Zealand Agent General was because, "his honesty, integrity and diplomatic talents - were not qualities to ensure his effective administration of immigration." ${ }^{184}$ Even in the early 1920 s, there was much contention in Parliament about the ways in which the Government was advertising the country. Peter Fraser, Labour member for Wellington Central, objected to the false information being distributed to intending settlers:

\begin{abstract}
...it is entirely true that from the High Commissioner's Office, there has gone out a stream of publications, and that a number of these publications painted things in far rosier hues than the immigrants saw when they came to the country... What we have objected to...is the criminal folly of bringing people out here innocent people who are not cognizant of the economic and social conditions ruling in New Zealand - bringing them out under false pretenses... ${ }^{85}$
\end{abstract}

${ }^{81}$ John F. Floyd, Our tour around the world containing a description in brief letters of a tour...through America, Hawaiian Islands, New Zealand...including ten years' residence in New Zealand and Australia (Chicago: Charles H. Kerr \& Co., 1896), p.5.

${ }^{82}$ Ibid., p.45.

${ }^{83}$ Voisey, p. 154.

${ }^{84}$ Dalziel, The Origins of New Zealand Diplomacy, p.45.

${ }^{85}$ NZPD (June 30 - August 2, 1922), pp.842-843. 
As expected, the written and visual material promoting the colony had been deliberately coloured by the boosters to give a more favourable impression. Yet how does one explain the differing reactions amongst those travellers and settlers who came to New Zealand and who were not writing to advertise the country or to convince an audience at home of the benefits of reform? It seems apparent from the evidence that the response of the tourist and the settler varied according to their personal circumstances at the time.

Often, a traveller arriving in the country on an ocean steamer and after a long and rough sea voyage, would be more than happy to praise New Zealand, or any land for that matter; this was specially the case should this passenger have been suffering badly from the "mal de mer". ${ }^{86}$ Edward Payton found his first sight of the colony in the late 1880 s very pleasing: "It was a bright, sunshiny day, and that doubtless was very much in favour of first impressions, beside the fact of running ashore for six hours after a stormy voyage." ${ }^{187}$ Stuart Reid, however, arriving one early grey morning in 1883 at the Bluff, had this to say about the place: "it is about the most forsaken, dreary, and miserable place one can possibly imagine. ${ }^{188}$

The reception one received upon arrival and during one's tour in the country, also had some influence upon ones opinion of New Zealand. W.J. Frater arrived after a long voyage from Britain in 1885 and having received a warm welcome at the Good Templar Lodge, had only praise for New Zealanders. On the other hand, Conor O'Brien, a yachtsman flying the Irish Ensign in 1925, was greeted with nothing but scorn by the Auckland harbour authorities who happened to be staunch imperialists. Consequently, O'Brien's parting comment on the country, was not too favourable: "Fortunately, New Zealand is liable to earthquakes." 89

${ }^{86}$ A visitor's general health and well-being could generate a specific response to a place. According to Shillingsburg (p.144), Mark Twain's "pleasant stay" in Christchurch was due to his good health and spirits.

${ }^{87}$ Edward William Payton, Round about New Zealand being Notes from a journal of three years' wanderings in the antipodes (London: Chapman \& Hall Limited, 1888), p.3.

${ }^{88}$ Stuart Reid, Three weeks in Southland being the account of a trip to New Zealand partly for pleasure and partly for profit... (Melbourne: 1885), p.31.

${ }^{89}$ Conor O'Brien, Across three oceans; a colonial voyage in the yacht "Saorise" (London: Edward Arnold \& Co., 1926), p.143. 
There were personal reasons for reacting positively or negatively to a place. A touring American actor who specialised in productions of Shakespeare and who was very well received in Dunedin, acclaimed that city to the skies throughout his tour. Yet he showed nothing but disdain for the city of Christchurch and its people, whom he accused of being dimwitted and dull after his performance had failed to generate ticket sales in that city, or a good response from local critics. ${ }^{90}$ Similarly, rich landowners during the Depression years would extol the country and dismiss bad economic forecasts since the well-off were generally unaffected by stiff pecuniary repercussions; as W. Ringland, one of the more perceptive tourists visiting the discovered upon making the acquaintance of such an individual in Wellington: "the usurious state of interest demanded by holders of money, the universally mortgaged estates, and the monstrous state debt, were lightly received by him." ${ }^{11}$

There were other reasons for responding to the country in a particular manner. According to David Hamer's psychoanalytic interpretation, André Siegfried's positive reaction to the Dominion had more to do with his age and background than anything else: "New Zealand, a young country engaged in discovering and formulating a national identity, appealed to a young man seeking to come out from under the shadow of his father's dominating personality. ${ }^{1192}$ Religion and ethnicity could also play a part in why reactions to a city could sometimes vary. According to Kröller's studies of Canadian travellers in Europe, French-speaking Catholics and English-speaking Protestants frequently reacted positively or negatively to London, Paris or Rome, depending on their particular religious outlook. ${ }^{93}$

There could be hidden and personal motives behind an individual's reactions to New Zealand. W.M. Maskell, a critic of Wellington's stone and brick architecture, (which he envisioned as being susceptible to earthquakes), reproaches his colleague and

${ }^{90}$ D.E. Bandmann, An actor's tour or Seventy Thousand Miles with Shakespeare (Boston: Cupples, Upham and Company, 1885).

${ }^{91}$ W. Ringland, In Southern Seas. A Trip to the Antipodes (London: Simpkin, Marshall, \& Co., 1888), p.92.

92 André Siegfried, Democracy in New Zealand (1904). Translated by E.V. Burns with introductions by David Hamer and William Downie Stewart (Wellington: Victoria University Press, 1982), p.xxx.

${ }^{93}$ Kröller, pp.104-148. 
rival Thomas Turnbull: "The stupendous ugliness of the new Government Printing Office is such that perhaps even an earthquake might disdain to touch it." ${ }^{94}$ The newly arrived immigrant Herbert Sprackman, in a series of letters Home to his fiancé, does everything he can to promote New Zealand and consequently persuade her to come out and marry him:

There is very little difference between the civilisation here and at home. Indeed New Zealand is more go-ahead than many parts of England. Three daily papers here and one weekly, in a town of less than 9000 inhabitants! Telephones and telegrams all over the place. Libraries with the latest books. Philosophical and debating societies, operatic and musical societies... ${ }^{95}$

Reactions to a place or an event were subjective and vulnerable to a number of external influences. What was one person's medicine might be another's poison. Stuart Reid is aware of this when commenting upon the differing responses to seeing the Bluff for the first time: "The Bluff is somewhat disappointing to me; but that the mental condition is subjective rather than objective, is evident from the fact that Dr. M. is highly delighted with it." ${ }^{196}$ George Seddon and David Ravine are aware of this too when debating varying interpretations on the image of Perth, Australia: "the response to the portrait must depend as much on the viewer as on the view." ${ }^{197}$

Government officials, at both the civic and the national level, were only too well aware of the fact that the reactions of travellers visiting New Zealand usually depended upon the circumstances they encountered upon their arrival. For this very reason the boosters did all that they could to ensure that prestigious and influential visitors were left with a favourable impression. VIPs were usually welcomed at the city's harbour or railway station by official dignitaries; these visitors were then wined and dined, often given free rail passes valid throughout the country, and frequently given the services of a guide to facilitate their tour. Sydney E. Taylor (1887-1973), for example, a

94 W.M. Maskell in A Discussion on Earthquakes and Architecture before the Philosophical Society, Wellington (Wellington: 1889), p.5. Library).

95 Sprackman Papers 1891-1900. Volume 4. (MS Sequence, Alexander Turnbull

${ }^{96}$ Stuart Reid, p.12.

${ }^{97}$ George Seddon and David Ravine, A City and Its Setting: Images of Perth, Western Australia (Freemantle: Freemantle Arts Centre Press, 1986), p.59. 
photographer working for the Department of Tourism, had to act as a tour guide from time to time. ${ }^{98}$ While Edward Tregear, the first Secretary of the Labour Department, "often played host to... overseas visitors, conducting them through his Department of Labour offices and sometimes travelling through the country with them." 99 Such visitors were only shown those positive aspects of urban New Zealand which could be helpful as propaganda in attracting future settlement and tourism. This booster strategy was deliberately cultivated to employ these visitors as a good advertsing medium overseas, for once these people returned home, it was hoped that they would relate their pleasurable experiences to their friends, colleagues and families.

Rollo Arnold in his study of British emigration to New Zealand, gives evidence of this tactic when relating the story of the National Agricultural Labourers' Union delegate Christopher Holloway, during his visit to the colony. According to Arnold, as Holloway was in a position to advise people in England about emigration to New Zealand, civic officials in New Zealand went out of their way to court him. When he visited the country in 1874, they put Holloway "in the best hotels... [and] local worthies conducted him on visits to the various industries and public institutions." 100

The evidence reveals that municipal boosters employed this approach throughout the fifty year period of this study. In 1886 Herbert Roberts commented favourably on a tour which a town councillor in Dunedin had given him the year before: "Would a town councillor at home... escort a wandering stranger round his offices, and dilate to him of the wonders of his town? I trust not."101 Sir John Gorst, the Special Commissioner representing the Crown, after being greeted by Christchurch's mayor at the 1906 Christchurch Exhibition, remarked that the city was "...the loveliest town" he had ever seen. ${ }^{102}$ The Dunedin Expansion League in the first years of World War One, met a group of distinguished visitors at the city's railway station and then proceeded to

\footnotetext{
${ }^{98}$ E.A. Aubin, The Otago Daily Times (Dunedin: November 29, 1973), p.12.

${ }^{99}$ Howe, p. 136.

${ }^{100}$ Rollo Arnold, The Farthest Promised Land (Wellington: Victoria University Press, 1981), p.80.
}

${ }^{101}$ Herbert J. Roberts, A World Tour: Being a Year's Diary, written 1884-1885 (Liverpool: 1886), p.481.

${ }^{102}$ Quoted from Rupert Tipples, "Christchurch - The First Garden City?" Paper presented to the New Zealand Historical Conference, Christchurch. May 1991. p.12. 
lay on a luncheon for them, "with the object of adding to the interest of their visit while in Dunedin." ${ }^{103}$ Similarly in 1923 during a trip to Auckland, Lord Northcliffe was given a guided tour of the city: "Naturally, the mayor was anxious to show me the bridges, buildings, and fine suburbs and the growth of the city in the last five years." 104

In general there was little opposition to boosterism. The Organizer of the Canterbury Progress League proudly proclaimed that there had been no resistance to the formation of a society dedicated to promoting the interests of the province: "so far there has not been a hostile note." 105 The Government, the municipalities and other associated groups, did all they could to counter any pernicious publicity which might have proved detrimental to the interests of the country. They were probably helped by the fact that New Zealand was so far away from other centres that the promotional images fashioned could not be disproved easily. ${ }^{106}$ Even the newly settled migrant who had not found the promised utopia he or she was expecting, as well as people living in rural areas, did not tend to disparage the myth that was being created as they were told that their livelihood might be affected. ${ }^{107}$ For increased investment and tourism meant more jobs and more money circulating, and this was supposedly good for all classes within the country. John C. Weaver makes this point too when examining the history of Hamilton, Canada:

...the makers and shakers of Hamilton often acted with a measure of public sanction because their interest in community expansion with its promise of jobs could be embraced by all social groups. ${ }^{108}$

${ }^{103}$ Dunedin Expansion League, What Are We Doing! , p.8.

${ }^{104}$ Alfred Charles William Harmsworth Northcliffe, My journey round the world (16 July 1921 - 26 Feb. 1922 (London: The Bodley Head Ltd., 1923), p.24.

${ }^{105}$ Lyttelton Times (Lyttelton: September 26, 1918), p.13.

${ }^{106}$ Hamer, The New Zealand Liberals, p.51.

${ }^{107}$ Fairburn in The Ideal Society and Its Enemies, pp.20-22, has also forwarded similar conclusions as to why individuals tended to respond favourably to their new environment.

${ }^{108}$ Weaver, Hamilton: An Illustrated History, p.12. 
Also, those who came to visit or settle in New Zealand, and who did not like it at first, may have adjusted after a period of time and come to consider the place home. The American travel writer David Gooding was affected by this spirit of optimism which pervaded the nation: "The New Zealanders pride is justifiable, it is contagious."109 Taking the example of the Canterbury Progress League again, its organizers repeatedly argued that what benefitted the city would also benefit the country. And so with the exception of those travellers visiting the country on holiday who were repeatedly critical of the conditions they found, the only staunchly vocal opponents of the boosters were some Labour agitators; and their voice was drowned out by a flood of pro booster sympathies and by the fact that the press was a font of booster patronage:

In our opinion the best interests of Labour can be served by our standing aloof from the so-called Progress League. In view of the fact that those responsible for its formation are interested solely in commercial and landed interests, their definition of progress is not Labour's definition - theirs is financial, ours is human welfare and human happiness. ${ }^{110}$

${ }^{109}$ David Gooding, p.3.

${ }^{110}$ The Press (January 7, 1919), p.17. 


\section{CHAPTER 2: THE CIVILISED CITY}

Nature now seemed finally to have been mastered. The city, in which nature was most obviously tamed, confined in parks, tubs and pots, seemed to be the symbol of that mastery. ${ }^{1}$

Cities and towns were particularly suited to New World booster iconography. For at the turn-of-the-century they epitomised not only the ideal symbol of humanity's mastery over nature, but also the promoter's faith in the future prosperity and stability of the nation. Whereas the preceding chapter was an general introduction to the boosters: who they were, what their motives were, the agencies used to advance New Zealand's image, whether or not the information was read and whether or not it was accurate, Chapters 2 and 3 look at the urban milieu in particular and the various methods and descriptions which the boosters used to promote New Zealand's towns and cities. In Chapter 2 it will be seen that New Zealand's promoters used a variety of methods to reveal how civilised the colony was, in order to encourage settlement, tourism and investment. On the one hand, such a tactic was aimed at portraying New Zealand's cities and towns as "better than the labyrinth of disease and wrong and crime wherein they must lose their way" in Old European centres. ${ }^{2}$ Yet on the other hand, New Zealand's promoters also wanted to prove that the nation's towns and cities were culturally mature, and not the frontier or mining towns popular in Wild West mythology or romantic adventure stories. The historians George Seddon and David Ravine reiterate this concern with the city in the new world as being too little civilised, when they concentrate on the American and Australian nineteenth century urban image. They argue in fact that Henry James and Henry Adams left America for London on account of colonial backwardsness. They also see this lack of cultural maturity as the reason why many of Australia's artists, writers and musicians left that country for Europe, "looking for the cultural richness and stimulus that only a great city can offer". 3

$$
* * *
$$

${ }^{1}$ Frank Whitford, "The City in Painting," in Edward Timms and David Kelley, eds., Unreal City (New York: St. Matrin's Press, 1985), p.57.

\footnotetext{
${ }^{2}$ John Macmillan Brown, Riallaro, the archipelago of exiles, by Godfrey Sweven (London: G.P. Putnam's. 1901), p.14.

${ }^{3}$ Seddon and Ravine, p.24.
} 
Auckland city is a galaxy of emeralds set in diamonds. No tongue can sing, no painter describe one-half the glories of this beautiful city...

Auckland is ancient Corinth, with this exception: in Auckland everything is new and bursting into life; in Corinth everything is old, with decay on all sides. ${ }^{4}$

One of the most common methods by which New Zealand's boosters tried to promote their urban centres, was by likening them to contemporary European or North American cities. Boosters also liked to draw analogies with the cities of the ancient and classical world. The desired effect of such comparisons was both to attract immigrants by revealing how prosperous and how picturesque New Zealand's urban centres were, and also to give the impression that New Zealand was not so exotic and far away that conditions were terribly different from Europe or other civilised places. These latter images were deliberately cultivated to reassure the prospective immigrant that the Dominion was not the setting of a Jules Verne novel replete with cannibals, volcanoes and sea monsters, but rather a cultured and industrialised country which had much to offer the newcomer in the way of riches and a sophisticated civilisation.

All manner of comparisons to the Old World were made. Due to its climate and geography, the country was constantly being favourably equated with famous Southern European or Middle Eastern centres. Frequently, Napier was likened to Nice and San Remo, and Auckland to Naples. ${ }^{5}$ Auckland harbour was even described in Classical terms: as "the South Sea Cyclades of the Hauraki", "ancient Corinth" (see footnote 4), and Constantinople. ${ }^{7}$ Because of its hills dotted with villas and gardens, James Inglis (a New South Wales Minister of Public Education who was touring the country), likened

\footnotetext{
${ }^{4}$ The Colony of New Zealand, in two parts, p.5.
}

${ }^{5}$ For Napier examples see: Napier, a bright and prosperous city (Auckland: The Brett Ptg. and Publg. Co. Ltd., 1907?), p.2. And, Arnoldo Cipolla, Il Mio Viaggio in Oceania, Australia e Insullindia...Disegni originalli di Umberto Zimelli (Milano: Casa editrice Giacomo Agnelli, 1928), p.65. For the Auckland comparison please refer to: Maturin Murray Ballou, Foot-prints of travel; or, Journeyings in many lands (New York: Ginn \& Company, 1888?), p.93.

${ }^{6}$ Auckland Industrial, Agricultural and Mining Exhibition, 1913-14 Official Accommodation Directory (Auckland: 1913), no page.

${ }^{7}$ John Murray Moore, New Zealand for the emigrant, invalid and tourist (London: Sampson Low, Marston, Searle \& Rivington, 1890), p.62. 
Napier to Malta; ${ }^{8}$ and due to its many trees and gardens, Christchurch was compared to Damascus. ${ }^{9}$ On one occasion Auckland was even compared to Palermo, while New Zealand as a whole was described as an "antipodean Italy." 10

Even the art of the period invoked such comparisons to Mediterranean centres. This can be seen in the style of Henry Atcherly's 1893 watercolour "Mount Langton From Near Tinakori Rd., Wellington" [ILLUSTRATION 5]. Atcherly's painting, with its dappled sun, the cupola on the house in the right middleground, and the sun reflecting on the sea, resembles any number of similar panoramas which can be seen along the Ligurian coastline or the Côte d'Azur.

There were other means by which boosters used the European connection to entice would-be settlers. Contrasts were habitually being made between New Zealand cities and towns and their supposedly Old World counterparts that had reputations as holiday resorts. Napier was compared to Brighton on account of her beaches. ${ }^{11}$ Nelson, calling attention to itself as a summer holiday destination, was described as New Zealand's answer to Torquay. ${ }^{12}$ And the Caroline Bay Association, a group in Timaru purposely set up to foster tourism during the summer months, called their city "The Riviera of New Zealand" and "The Venice of the South."13 Such comparisons are endless. G.M. Fowlds, President of the New Zealand Tourist League in a letter to the Department of Tourism, suggested the creation of a booklet which might advertise the Dominion as "The World in Miniature", and where every one of New Zealand's attractions had a

${ }^{8}$ James Inglis, Our New Zealand cousins (London: Sampson Low, Marston, Searle, and Rivington, 1887), p.94.

9 John Stuart Kelly, Christchurch, the Garden City of New Zealand. Compiled from information supplied by the Christchurch City Council, the Chamber of Commerce, the Progress League, Industrial Association, Beautifying Association and the Canterbury Pilgrims' Association (Christchurch: Andrews, Baty \& Co. Ltd., 1925), p.26.

${ }^{10}$ Giuseppe Capra, La Nuova Zelanda (una Italia australe) (Rome: La Società Geografica Italiana, 1911), p.4.

${ }^{11}$ Beautiful Napier. (Hawke's Bay, N.Z.) From a visitor's point of view (Napier: 1900), p.2.

${ }^{12}$ Arthur Clayden, A Popular handbook to New Zealand, its resources and industries (London: Wyman \& Sons, 1885), p.198.

${ }^{13}$ Caroline Bay Association, Visitors' guide to Timaru and Victoria Cross records (Timaru: The Association, 1929), p.4/p.6. 


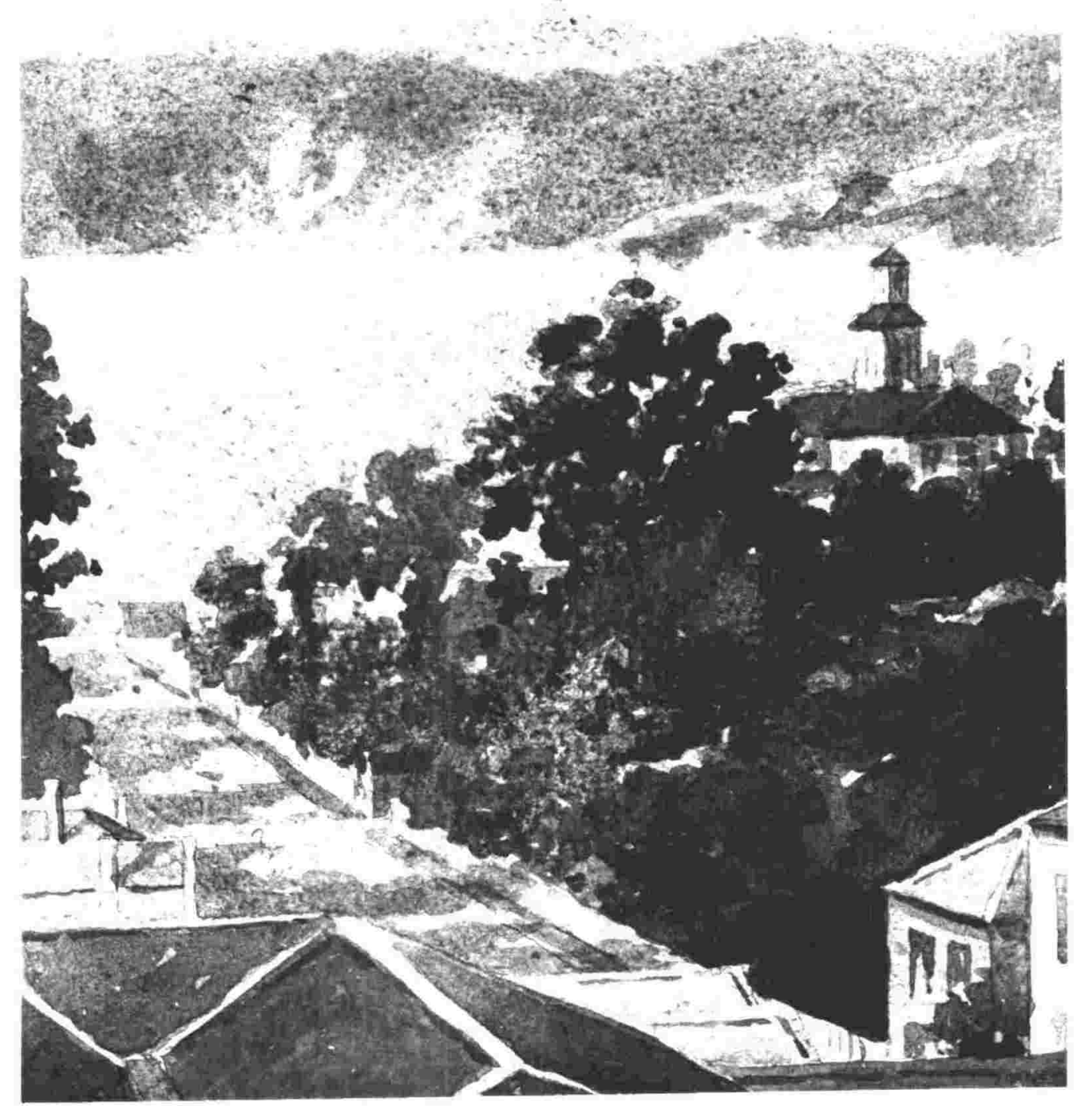

illustration 5 
parallel abroad [ILLUSTRATION 6]. ${ }^{14}$ In his eagerness to suggest overseas parallels, Fowlds went so far as to compare Auckland's museum with the Parthenon in Athens and Christchurch's cathedral with Canterbury Cathedral in England. These comparisons, which were sometimes taken to the extreme, were not rare; in fact, many authors imaginations did get carried away in their enthusiasm to advertise a particular place. One promotional piece mistakenly compared Nelson to the ancient capital of the Roman Empire on account of the fact that Nelson, "Like Rome... is situated on three hills..."! 15

In keeping with these booster tactics, New Zealand cities and towns were also praised as being centres of civilisation and learning. Dunedin, because of its impressive stone architecture, a result of the gold boom of the $1860 \mathrm{~s}$, was labelled the "Athens of the South. ${ }^{16}$ Christchurch, seeking praise for its educational institutions, was compared to North American models and called "the Boston of New Zealand"17 and "the Toronto of New Zealand." ${ }^{18}$ Similarly, Wanganui, in trying to compare its educational facilities to those in England, called itself "a little Oxford, a miniature Cambridge."19 And in 1921 the town of Otaki, the home of Maoriland Films, tried promoting itself as "the Los Angeles of New Zealand's moving picture industry." ${ }^{.20}$

These comparisons to European and American examples were not just to be found in the literature of the day, as testified to with the example of Henry Atcherly's watercolour earlier on. Many artists also employed the same techniques when they were boosting New Zealand in their paintings, photographs and lithographs. James Fitzgerald's 1925 painting entitled "The Deserted Square" [ILLUSTRATION 7], with

\footnotetext{
${ }^{14}$ Department of Tourism and Publicity Records: letter dated 6 May, 1930. (National Archives of New Zealand, Wellington).

${ }^{15}$ The Golden North of the South Island; Golden Bay, sunny Nelson, Marlborough the golden (Christchurch: H.W. Bullivant \& Co., ca.1925), p.9.

${ }^{16}$ Sir Julius Vogel, ed., The official handbook of New Zealand edited by the AgentGeneral Parts I and II (London: Edward Stanford, 1883), p.100.

${ }^{17}$ William Boyce, p.264.

${ }^{18}$ André Siegfried, p.254.

${ }^{19}$ John Ball, Wanganui, pretty, prosperous and progressive (Christchurch: 1901), p.6.
}

${ }^{20}$ Onfilm, 7, No.2 (February/March 1990), p.24. 


NEAN ZEALAND ${ }^{*}$ The World in Miniature.
Now Zealand

SCENIC

Mt Cook

Mt Ngaruhoe (volcano)

int Egmont

Rangftoto Tsland (extinct volcano)

Milford Sound

Preservation Inlet or other, bush

Sutherland Falls, 1904 foet high

Bowen Falls,

Wakatipu or Wanaka Lake

Wanganut. River

Geysers, Rotorua or Va1rake1

Karapiti blowhole?

Waitomo caves, Glow-worm

Aratiatia rapids,

Flacier, Franz Joseph,

Kaur1 treeş

Tree ferns

Bush scene

Beaches,

Christhcurch cathedral.

Cambridge or stratford, typical smal.'

The Thames river

The Avon, Christbburch

Auckland Muselum

The Cenotaph, Auckland or

Deer heads

600 ft above sea level

Trout fishing weight \& number ?

Salmon fishing (picture \& we logt)

Deep-sea fishing, aworlfish, tomalio shark

King fish or Kahawa or

Mnose or Chamols?

Yachting, launching, tennis, bowling, golf, football, cricket $\mathbb{R}$ oversea contrasts MAORI LIFE.

Maori house

Mrori canoe

liaor1 froup

Naor 1 paka

Worl pol tance
Mt Blanc, Sw1tzerland

Mt Vastrius, Italy

Mt Fujiyama, Jpenn

? Stromboli 1slani, Italy

Norweglan food

British Columbia sounds

Yosemite falls, ? High ? Germany

Jake Lucerne (or) Switze

The Rhine, Germany

Yellowistone Park, U.S.A ? Iseland

Mammoth Cave, II. S.A.

? Linden falis, Gement

?

Sw1tzer̂f.and

Redwood trees, U.S.A.

Forest, Austria or

Waikiki or Riviera

Canterbury Catheara], Eng

Cambridge or Strratford "

Thames river, Inndon

The Avon, Stratford

The Parthenon, Athens

Cenotapls, Iiondon

Deer head, England

Trout, -do-or Ireland Salmon flshing Scotland

Swordfish, Cata]. Ina

Tarpon, Flon1da? ?

Japanese house or Al.askan New guinea canoe

Soluth sag island natives

Zulu dance

Hawalian women, hula ?

illustration 6 


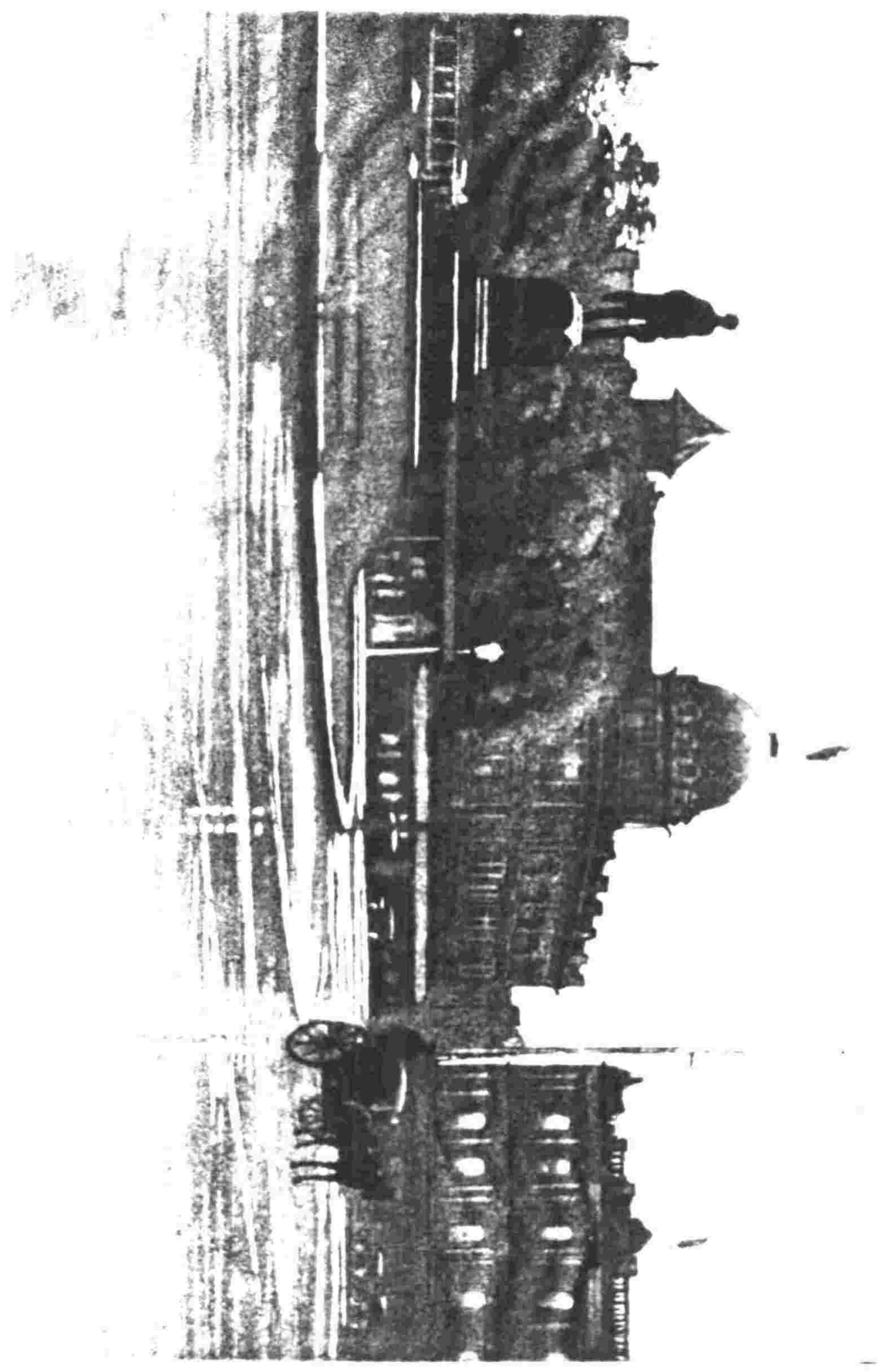

illustration 7 
its emphasis on Christchurch's stone buildings, civic monuments and the city's rainwashed streets, gives the viewer the impression of a culturally mature city similar to a Renaissance painting of Florence. Does not the dome of the Royal Exchange building in the background resemble the many pictures of London or Rome with St. Paul's or St. Peter's in the distance? In a corresponding manner, Cranleigh Harper Barton's pre-1930 watercolour of the "Ferry Buildings, Auckland" [ILLUSTRATION 8], has a misty romantic quality about it which is very Turneresque in its fashion, evoking resemblances to Turner's studies of Venice or London. George Seddon and David Ravine with their work on Perth, Australia, comment on this artistic tendency to conjure up European associations when discussing urban photographs in Australia. They conclude that a certain 1920s picture of Perth, which emphasized the city's monuments and rainy streets, was deliberately aimed to create an overall impression of "an older, more 'European' city."21

This same vision of a cultured and Europeanized metropolitan centre was evident with the newspaper lithographs of the period. The 1881 engraving of "The Dunedin Tramway System Starting Princes St." [ILLUSTRATION 9], conveys such an impression. The emphasis is on the stone Colonial bank firmly planted in the background which gives an enduring quality to the subject-matter by seeming to proclaim "I am here to stay". The engraver has also focused on the tram in the middleground - a symbol of progress, and the bustling well-dressed population thronging the streets - all of which was meant to affirm the prosperity and permanence of the city.

The resemblances between New Zealand and Europe were not merely founded upon a desire to reveal New Zealand's cities and towns as being as beautiful or as civilised as their European cousins. If the Dominion was to attract capital, as well as immigration and tourism, the country's boosters could not just base their advertisements on the fact that their urban centres were picturesque. Consequently, many promoters tried likening their cities and towns to industrial European precedents. Greymouth, because of its status as a relevantly important port on the West coast of the country, was compared to Newcastle in England. ${ }^{22}$ Auckland, also because of its busy port, was

${ }^{21}$ Seddon and Ravine, p.29.

${ }^{22}$ Edgar Sanderson, The British Empire in the nineteenth century; its progress and expansion at home and abroad, comprising a description and history of the British colonies and dependencies vol.6, (London: Blackie \& Son Ltd., 1899), p.287. 


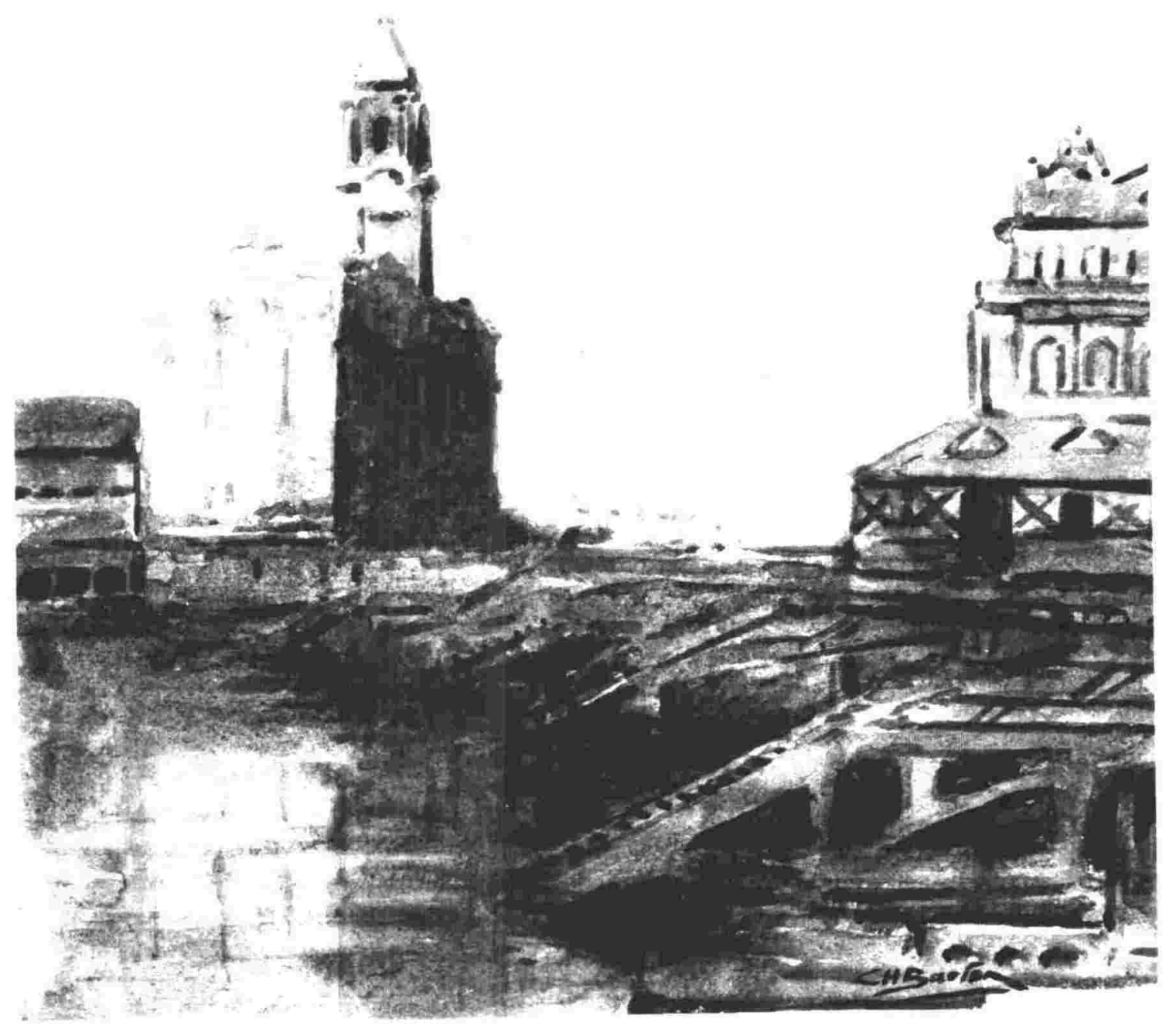

illustration 8 


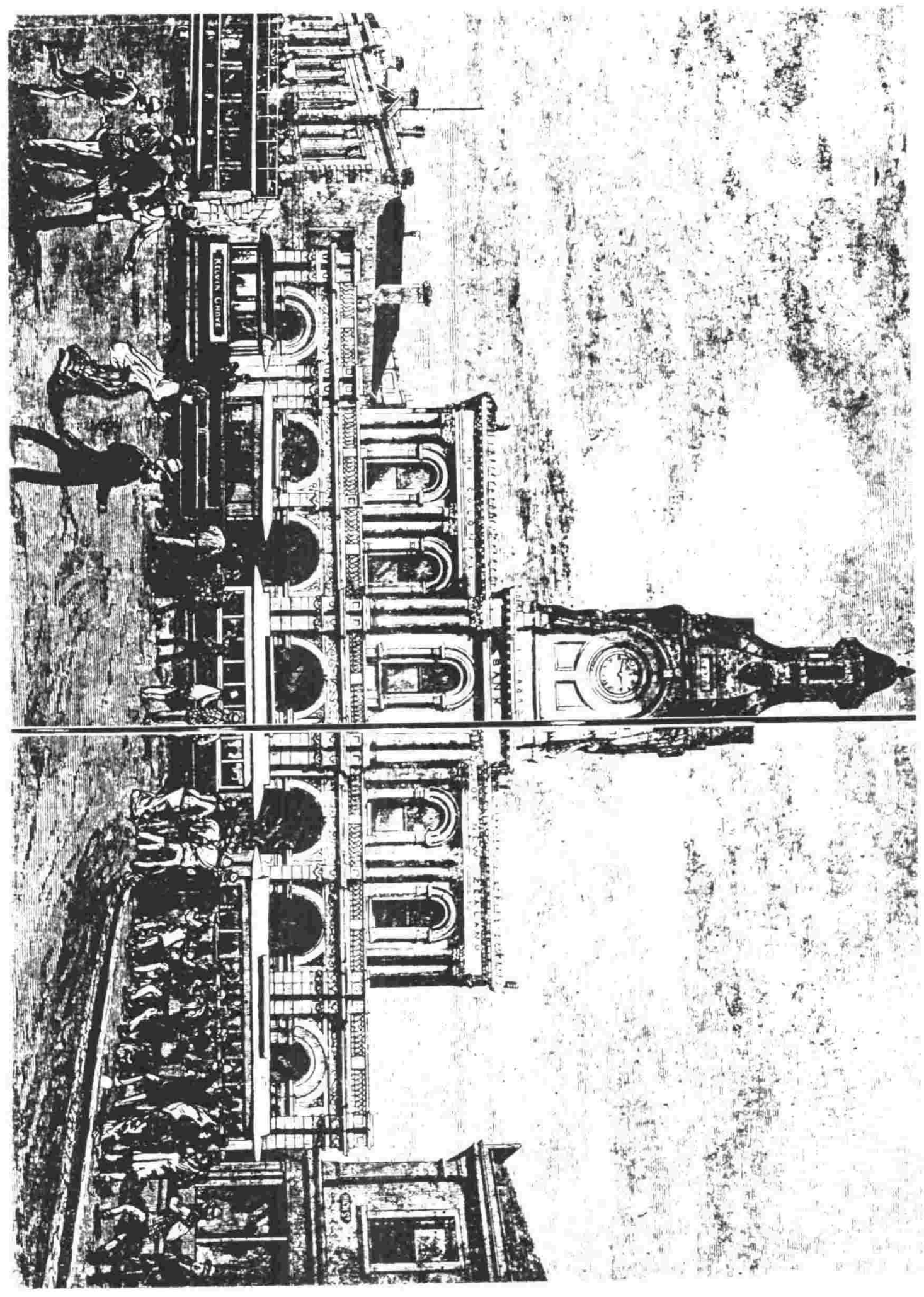


referred to as "The Liverpool of the Colony." ${ }^{13}$ All the while Dunedin, because of the industrial nature of its manufacturing base, was termed "the Birmingham of New Zealand." 24 These industrial comparisons were not mutually exclusive. If New Zealand cities and towns could promote themselves as being progressive as well as pretty, all the better. Hence descriptions of Auckland as beautiful in one work and industrial in another, did not register in the minds of the promoters as being counterproductive to their advertising strategy. So it comes as no surprise to find Auckland described in a combination of terms, as "a sort of Neapolitan Liverpool."25

In keeping with the practice of drawing parallels with European urban settlements, and just as frequent, was the penchant to depict New Zealand cities as English (as distinct from European). Since the majority of those coming to settle in the Dominion were of British origin, the tendency to depict New Zealand's urban areas along English lines might seem natural. Certainly such images could and would be used to promote the Dominion, and for the very same reasons as those European comparisons mentioned above - to reassure the settler and to lessen the threat of culture shock. So it comes as no surprise when promoters like Edward Wakefield, a journalist and public servant and son of Edward Gibbon Wakefield, talked about the English fashions to be seen being paraded along the streets of the colony's primary cities, and how "The colonists have never fallen into the habit of dressing like Robinson Crusoe..."26 Other emigration tracts tried to entice colonists by using the same techniques. One work described how English a town was, and by implication, how civilised and up to date it was at the same time:

As we walk through the streets, the shops present all the appearances of those in an English town. Handsome windows permit the display of goods... and within almost every conceivable article is for sale. Stationers', jewellers', music,

\footnotetext{
${ }^{23}$ John Moore, p.58.

${ }^{24}$ Arthur Clayden, p.193.

${ }^{25}$ Edward Morris, p.127.

${ }^{26}$ Edward Wakefield, New Zealand after fifty years (London: Cassell \& Co., 1889),
} p.40. 
grocers', drapers', bootmakers', china, ironmongers', and other shops succeed each other in quick rotation... ${ }^{27}$

Like the other European analogies, these booster procedures for comparing New Zealand to Home were not limited to the written word. James Fitzgerald's 1926 illustration of the "Old Provincial Buildings, Christchurch" has for its subject-matter a worker tidying up a garden outside an apparently old building. ${ }^{28}$ (The "old" Provincial Buildings were in fact constructed in the 1860s). The Gothic design of the structure, complete with the idyllic scene of the gardener weeding a landscaped lawn, gives an overall impression of a rustic setting which one would expect to come across in Eighteenth Century England. The Provincial Buildings might well have ivy clinging to their walls for all we know. If the spectator were not given the title of the work, the scene which the artist has created could well be imagined taking place outside any Medieval English manor.

Yet this underlining of the essentially British nature of New Zealand was not done solely for promoting the colony. The desire to recreate in a foreign, distant and new land, what Home had been like in the minds of the immigrants, must have undoubtedly been based upon a certain frame of mind. Immigrants arriving from England were bound to bring to New Zealand their "cultural baggage" as well as their personal possessions. This wish to rebuild a better England in the New World was both a conscious and an unconscious means to prevent homesickness and to allay fears of the unknown.

This Englishness, however, was also symptomatic of a genuine pride in the British Empire and its people. Beatrice Webb, describing Auckland's pedestrians with their mackintoshes, umbrellas and boots, praised the city for being "delightfully British." 29 An American traveller Edward Dawson, responded favourably to the "portraits of the Queen and royal family", which adorned the walls of Auckland's homes and which

${ }^{27}$ John Bradshaw, New Zealand as it is. (London: Simpson Low, Marston, Searle, \& Rivington, 1883), p.355.

28 A copy of Fitzgerald's illustration can be found at the Canterbury Museum's Pictorial Collection.

${ }^{29}$ Beatrice Webb in David Hamer, ed., The Webbs in New Zealand 1898: Beatrice Webb's Diary with Entries by Sydney Webb (Wellington: Price Milburn for Victoria University Press, 1974), p.17. 
testified to the colonial's loyalty to the Crown. ${ }^{30}$ Anthony Trollope while in New Zealand, wrote a kind of utopian novel set in 1980 in the land of Britannula - a fictional island near New Zealand. Is not Trollope's choice of the name Britannula with its capital Gladstonopolis indicative of his pro-British sympathies? And E.H. D'Avigdor, when talking about the English atmosphere of Christchurch, concluded that it brought up memories of England:

Here, in drawingrooms overlooking smooth lawns, you take a cup of afternoon tea; the surroundings are so homelike that it requires no imagination to fancy yourself within fifty miles of London. The "Graphic" and the latest magazines strew the tables... the ladies are dressed as only English ladies can dress; the men come in from cricket in their flannels... The whole course of life is an almost exact copy of that pursued by an English family at home. ${ }^{31}$

\section{$* * * *$}

Another of the most common techniques by which New Zealand publicized her urban centres was not merely to juxtapose them with European and British examples, but in the comparison, to ensure that the Old World standards fell far short of the apparent domestic situation. New Zealand's cities and towns were constantly being portrayed as better than anything found in the Old World, even better than anything in the other New World - America. Recalling the comparison to Corinth made earlier (footnote 4), Auckland was said to be as beautiful as the Greek original yet better; for while Corinth was sinking into decay and oblivion, Auckland was vibrant and growing everyday.

In keeping with this Old World comparative theme was the emphasis made by local boosters regarding the healthiness of the cities. Stress was put on the point that there was little or no pollution in New Zealand; consequently, children could grow up being weaned on "the pure ozone of the Pacific", rather than the toxic poisons which were circulating in the air of major European manufacturing centres such as London or

${ }^{30}$ Edward Walter Dawson, The Isles of the Sea; being an entertaining narrative of A Voyage to the Pacific and Indian Oceans... (Hartford: Betts \& Co., 1886), p.511.

${ }^{31}$ E.H. D'Avigdor, Antipodean Notes collected on a nine months' tour round the world (London: Sampson Low, Marston, Searle \& Rivington Limited, 1888), pp.60-61. 
Birmingham. ${ }^{32}$ Foreign travellers visiting New Zealand liked to make much of this point. Ernest Michel, a French lawyer on a world trip in 1883, had nothing but praise for Dunedin's spacious suburbs and gardens, which he saw as being responsible for the low death rate of the colony: "La mortalité n'est que de 12 pour mille, pendant qu'elle est de 24 à Paris et de 21 à Londres. ${ }^{133}$ Similarly, C.W. MacMurran, an American writing a booster piece on New Zealand to promote the colony's reforms and to attract American interest in the country, had this to say about New Zealand when measuring it up against New York:

I one day noticed the employees coming out of these woolen works [Christchurch] and could not help contrasting their rosy, rugged, happy, round faces and neat attire with the pale cheeks and oftentimes poorly dressed factory-workers in New York City, where... the unfortunate toilers are obliged to stow themselves away in overcrowded tenement-houses... ${ }^{34}$

MacMurran's mention of tenements brings us to another frequently used "measuring stick" which was used to calculate the level of New Zealand's progress over the rest of the world - housing. The state of housing in the Dominion as well as the level of home ownership, were considered at the time to be one of the best indicators of the colony's prosperity, and therefore, excellent bait by which to entice settlement. Boosters in Napier stressed how in that city, "Every home has its Garden...", with a capital "G", and that "Over 75 per cent [of the houses were] owned by the folk who live in them". ${ }^{35}$ Edward Wakefield commented that, "It is very unusual in the colony for more than one family to live in one house. ${ }^{136}$ A great deal was also made of the fact

${ }^{32}$ Beautiful Napier, p.1.

33 "The death rate is no greater than 12 per thousand inhabitants, while that of Paris is 24 and that of London 21." Ernest Michel, A travers l' hemisphere sud ou mon second voyage autour du monde (Paris: Librairie Victor Palme, 1888), p.327.

${ }^{34}$ C.W. MacMurran, From New York to New Zealand; or, The new century trip...Introduction by His Honour Sir Robert Stout (Wellington: Government Print, 1904), p.55.

${ }^{35}$ Horace Spence Cottrell, Napier, NZ; sunshine and sea breezes (Napier: 1920), no page.

${ }^{36}$ Edward Wakefield, New Zealand Illustrated. The story of New Zealand and Descriptions of its cities and towns (Wanganui: A.D. Willis, 1889), p.38. 
that New Zealand's homes were "neat and pretty", ${ }^{37}$ and commentators were always saying how "picturesque", "handsome", peaceful and prosperous everything looked.

Even the more honest and down-to-earth descriptive material praised the New Zealand house. While one book ridiculed the aesthetics of the New Zealand cottage by comparing it to a packing case, there was still much admiration for the standard of living and level of general comfort attained in that packing case. ${ }^{38}$ Similarly, Constance McAdam, while admitting the existence of slums in the country, had nothing but compliments for the local domestic abode:

What is much more a feature of town life is the number of cottages with gardens back and front. Spaciousness is a characteristic of the towns; "terraces" are few and tenements in the old-world sense hardly exist. ${ }^{39}$

New Zealand boosters were not the only ones to harp on the issue of the colony's homes. William Webb Wheeler, an American writer admiring New Zealand's social reforms and trying to induce American politicians to copy the colony's precedents, applauds the worker cottages in the Dominion as being superior to anything else back in the United States. ${ }^{40}$

There were many other analogies made between New Zealand and the Old World, with the former always emerging the victor in any comparison. The colony had its own Horatio Alger myth which was often a vehicle of booster propaganda. Richard Seddon perhaps symbolized such a figure. Overcoming his working class background as a miner, he rose to the ranks of international statesmanship by becoming in 1893 and maintaining that position until his death in 1906. Perhaps The Wellington Amateur Operatic and Dramatic Society's 1893 production of "The Monarch of Utopia", may well be a reflection of Seddon's meteoric rise? Is not the ordination of Artaxominous as king

${ }^{37}$ Robert Brown, The Countries of the World: Being A popular description of the various continents, islands, rivers, seas, and people of the globe (London: Cassell, Petter, Galpin \& Co., 1880), p.110.

${ }^{38}$ Robert Francis Irvine and O.J.T. Alpers, The progress of New Zealand in the century (Toronto: Linscott Publg. Co., 1902), p.384.

${ }^{39}$ Constance McAdam, New Zealand; country and people (Christchurch: W \& T, 1925), p.39.

${ }^{40}$ William Webb Wheeler, A glimpse of the isles of the Pacific (St. Joseph, Mo: Hardman Press, 1907), p.35. 
of Utopia, "an uneducated man, of obscure birth and of rowdy... proclivities"41, similar to the rise of Seddon as Prime Minister? And as it was shown in the introduction and as we shall see in later chapters, was not New Zealand often referred to as utopia? Whether Seddon (King Dick as he was affectionately called), and King Artaxominous are one and the same cannot be shown. What can be proven is that New Zealand's propaganda revealed her cities and towns as places where getting on in life was possible and where rewards were granted, not according to one's place in the social hierarchy, but for hard work. David Hamer mentions this aspect of promotionalism in his work on the New Zealand Liberals:

...New Zealand was depicted as a place where 'getting on in life' was the result not of inherited privilege or of the class into which one was born but out of the possession and exercise of certain moral qualities such as industriousness and frugality. ${ }^{42}$

Beatrice Webb showered Christchurch with praises along these lines, describing the city as a place, "without the grinding poverty or the aristocratic and ecclesiastical pretensions which disfigure our country towns." ${ }^{143}$ A great deal of importance was made with the Christchurch Exhibition and its exhibition of British sweated industries; William Pember Reeves had purposely put together such a collection in order to show how workers in New Zealand were better off than their counterparts at Home. ${ }^{44}$ Echoing this theme is one booster's praise for the attributes of the colony as a place for the aspiring migrant:

New Zealand has been justly called the poor man's paradise... A working man in New Zealand need never know what the cry of "no work" means... he need never see his wife and children crying for more bread... ${ }^{45}$

R.C. Stone in his study of the elite of Auckland devotes much attention to this promotional rags-to-riches story; however, he says that the myth was less valid than ever

\footnotetext{
${ }^{41}$ Fred W. Jones, The Monarch of Utopia (Wellington: 1893), p.2.

${ }^{42}$ Hamer, The New Zealand Liberals, p.52.

${ }^{43}$ Beatrice Webb, p.55.

${ }^{44}$ James Cowan, p.150.

${ }^{45}$ The immigrants prospects in New Zealand. Handbook of Information, Resources, Advantages and Attractions, Soil, Climate, Products, Trade \& Wages (London: F.W. Hetherington, 1883?), p.3.
} 
while it was being promoted during the $1880 \mathrm{~s} .{ }^{46}$ Perhaps this was a way of countering the bad image which the country was receiving as a result of the Long Depression, rather similar in method to the intention of city boosters when organizing International Exhibitions during economic hard times. (Refer back to chapter 1)

Another formula for promoting urban New Zealand at the expense of European and British rivals was to advertise the fact that despite being a civilised nation, the colony's larger cities were not so advanced that they threatened to reproduce old world evils. James Froude published his controversial Oceana in 1886, which was a highly critical assessment of the state of New Zealand. Not only did Froude's work lambast the colony for poor economic decisions, specifically the tremendous debt which it had accumulated, but it was also disparaging of the fact that New Zealand's towns were outpacing the growth of the countryside. According to Froude, this urban encroachment on the country threatened to reproduce those very evils which many had come to New Zealand to specifically avoid, namely: high unemployment, slums, crime, disease, tenements, and the workhouse. New Zealand's promoters, not wanting the reputation of the colony tarnished, reacted decisively. In 1888 John Bradshaw directly replied with a promotional work which included a US Government report that found the increase of population in the colony as being equally distributed amongst the urban and rural sectors. $^{47}$

New Zealand boosters tried numerous means to show that in the colony there was a perfect marriage of the urban and the rural, and that the cities were not developing into vast and ungovernable metropolises like London or New York. John Barr celebrated the small town qualities of the city of Auckland: "The sky-scraper happily does not exist - an eight-storey building being the tallest in the city. ${ }^{148}$ André Siegfried, resentful of uncontrollable urban sprawl exemplified by the electric tram and the skyscraper, praised

${ }^{46}$ R.C.J. Stone, Makers of Fortune: A Colonial Business Community and its Fall (Auckland: Auckland University Press, 1973), p.40.

47 John Bradshaw, New Zealand of to-day 1884-1887 (London: Sampson Low, Marston, Seale \& Rivington, 1888), p.9.

${ }^{48}$ John Barr, ed., Municipal and official handbook of the city of Auckland, New Zealand. Prepared by direction of the Auckland City Council (Auckland: Wilson \& Horton, 1922), p.17. 
Auckland for the quaint horse-drawn omnibuses and the city's small houses. ${ }^{49}$ Henry Bolitho argued that the colony's cities and towns, "have never developed beyond the point of being commercial centres for the farming land behind them. ${ }^{50}$ Meanwhile, the Union Steamship Company propaganda stressed how New Zealand had all the urban attributes that the civilised European could want, yet at the same time there existed the possibility of escape:

But it is different with the scenery of this new world. Society you can have if you choose, but, what is better, you can also escape it if you like. You can have solitude, you can be alone with the majesty and the mystery of Nature. ${ }^{51}$

The boosters repeatedly tried to demonstrate that the Dominion had learned from the mistakes of European and American precedents. Frank Duncan \& Co. underscored this when writing about Auckland: "With the experience of older cities to guide her, Auckland has wisely guarded her open spaces." ${ }^{52}$ The same was said about Christchurch and its tendency to plan ahead and to preserve its parkland:

Even in the city's early days, its rulers had big ideas... In consequence of the spirit that prevailed, and the belief that the city was destined for great things, it has avoided many mistakes perpetrated in other places... ${ }^{53}$

Another area where New Zealand towns were portrayed as being one up on their overseas rivals was in their physical attributes. Zelandia's urban settlements were continuously described as being more beautiful than anything in the Old World. Auckland's harbour, for instance, was always being compared to other more famous ocean ports of the day like Naples, Sydney and Rio, and Auckland was always coming out on top. James Inglis, after seeing many famous harbour-cities, concluded in his

${ }^{49}$ André Siegfried, p.246.

${ }^{50}$ Henry Hector Bolitho, The New Zealanders...illustrated by Harry Rountree (London: J.M. Dent \& Sons Ltd., 1928), p.21.

51 Union Steamship Company of New Zealand Limited, New Zealand the wonderland of the world (Dunedin: The Union Steam Ship Co. of New Zealand, Limited, 1886?), p.5.

${ }^{52}$ Auckland the Beautiful, (Auckland: Frank Duncan \& Co., 1926), no page.

${ }^{53}$ Industrial Corporation of New Zealand, Exhibition of New Zealand Industries, Christchurch 1922 (Christchurch: 1922), p.79. 
travel history that Auckland, "has a beauty of its own, which...exceeds that of any other spot of earth I have yet seen. ${ }^{154}$ Edward Wakefield, in his promotional piece which was aimed at attracting emigration to Auckland, brought-up the well-known saying of the time: "See Naples and then Die". He then mentioned that Aucklanders had their own phrase to describe their city: "It is better to die in Auckland than to live anywhere else." ${ }^{15}$ The New Brighton Publicity Committee, in association with the Canterbury Progress League, stated that its beaches were, "often referred to as the finest in the Southern Hemisphere." 56

In keeping with this sense of civic superiority which New Zealand's boosters liked to cultivate, was another image of the urban environment which declared that the country's cities and towns comprised the best of all worlds. Beatrice Webb described Christchurch as "a contented and bright English cathedral town in an Italian setting..." 57 William Pember Reeves talked about the English grasses, English roses, English oaks, English skylarks and English gardens of Christchurch, but declared that with the beautiful snowcapped mountains in the distance, the scene rendered an altogether more lovely picture than that, which similar towns in England could provide. ${ }^{58} \mathrm{~A}$ few years before Reeves, John Bradshaw had found the town of Reading, England, a possible comparison to New Zealand's towns; he based his assumption on the fact that Reading was a relatively new urban centre which was also quite prosperous. He concluded, however, that the resemblance was not that accurate as Reading lacked the picturesque beauty and the luxuriant greenery which so characterized the Dominion's settlements. ${ }^{59}$

New Zealand's cities and towns were constantly being measured against European rivals; and when the New Zealand urban centres came out looking superior, the resulting

\footnotetext{
${ }^{54}$ James Inglis, p.7.

${ }^{55}$ Edward Wakefield, New Zealand Illustrated, no page.

56 The New Brighton Publicity Committee in association with the Canterbury Progress League published a promotional booklet entitled: New Brighton, New Zealand, Canterbury's playground (Christchurch: 1923), p.13.

57 Beatrice Webb, pp.54-55.

${ }^{58}$ William Pember Reeves, The fortunate isles (picturesque New Zealand). A paper contributed to the Proceedings of the Colonial Institute, May 12, 1896 (Wellington: Government Print, 1897).
}

${ }^{59}$ John Bradshaw, New Zealand as it is, pp.354-355. 
image tended to paint the colony Their inhabitants were depicted as people who: were religious - "Sundays [were] decorously observed"; ${ }^{61}$ who seldom drank to excess, "...but few drunken people are to be seen about the streets", ${ }^{62}$ and who enjoyed good relations with all the varying religious denominations within the nation, "... protestants et catholiques vivent en bons rapports."

A great deal was also made of the point that New Zealand was a relatively crimefree place. Booster propaganda highlighted the fact that the local police did not carry guns: "...the constable's baton is all that is wanted to keep order, and not much of that." ${ }^{164}$ The same propaganda made that criminal element which did exist in the colony to look like a group of mischievous "lads" who were so harmless that they were allowed to leave jail during the day. ${ }^{65}$ Edward Wakefield even prophesied that with New Zealand's advances in education, crime would become obsolete in the country within a generation. ${ }^{66}$

New Zealand's urban boosters were using their cities as gauges of civilisation and progress. Graeme Davison asserts the same conclusion about Australian centres,

${ }^{60}$ New Zealand was not the only New World to celebrate its progressive character and superior situation. According to Kröller (p.91), Canadian propaganda also painted a picture of itself as a utopian version of the Old World: "In describing Canada's qualities to prospective immigrants, propagandists often spoke of their country as a utopian version of Britain and France where the errors committed by the mother countries had not yet been repeated, and, it was hoped, never would be." See the comparative material on Canada and Australia in Chapter 6 of this thesis for an examination of colonial feelings of superiority.

${ }^{61}$ John Moore, p.70.

${ }^{62}$ John Bradshaw, New Zealand as it is, p.356.

63 "Protestants and Catholics get on well together." Ernest Michel, p.239.

${ }^{64}$ John Houghton, Rural New Zealand, The Britain of the south (Auckland: Henry Brett, 1893), p.8.

65 John Bathgate, New Zealand its resources and prospects (London: W \& R Chambers, 1882), p.22. Bathgate was a Dunedin judge who, while living in Great Britain, went about promoting New Zealand as an emigrant destination.

${ }^{66}$ Edward Wakefield, New Zealand after fifty years, p.30. 
professing that "urbanization was an index of natural maturity." ${ }^{167}$ So it should come as no shock to discover that New Zealand's urban boosters, in drawing comparisons with the Old World, were sometimes insinuating that their colony was as civilised as its European counterparts, even its English ones. At other times the boosters were blatantly stating that such was the case. The image of New Zealand's cities and towns as being more civilised than their double in Great Britain should come as no surprise to the reader, for a population myth was being propagated at the time throughout the colony that New Zealand's settlers represented the best of British stock. This same theme of how New Zealanders believed themselves superior to people in the Old World has been discussed by Stevan Eldred-Grigg in his work on vice in the colony. Eldred-Grigg illustrates his point with a quote from Lady Stout about homosexuality in New Zealand, which was given in a 1910 interview during a tour of England: "We have no class of men who are effeminate in dress or intellect or degenerate in morals, as in old countries." 68

The boosters, however, were employing a whole host of promotional strategies other than just the ones stated above, to reveal how advanced, how civilised and how much better off their colony was, including: mentioning what cultural attractions a place had, how cosmopolitan it was, how New Zealand could provide an example to the rest of the world, how the native peoples posed no threat to settlement, and how this new land was utterly under the control of the Europeans.

The country's boosters liked to emphasize the fact that their towns and cities had much to offer the settler and visitor in terms of cultural attractions. They wanted to prove that "New Zealand's chief cities...have passed out of the raw pioneering stage..." ${ }^{169}$ Hence in the booster literature, churches, museums, hotels, schools, universities, athenaeums, public parks, art galleries, post offices, masonic halls, theatres and zoos were given a great deal of space and prominence. Herbert Roberts commented most favourably on the exhibits of indigenous birds, fish and fossils which he came

${ }^{67}$ Davison, "Cities and Ceremonies", p.112.

${ }^{68}$ Lady Stout in The Times (1910) in Stevan Eldred-Grigg, Pleasures of the Flesh (Wellington: Reed, 1984), p.169.

${ }^{69}$ James Cowan, The dominion of New Zealand, p.47. 
across while visiting the local museum in Invercargill. ${ }^{70}$ Edward Payton and his travelling companion were astounded at the impressive stone buildings which they saw in Dunedin: "What on earth can they want with such buildings as these out here..? Why, these banks, hotels, and Government offices are fit for London..." ${ }^{171}$ The Flemish promoter Émile De Harven, in trying to attract settlement and capital from Belgium to New Zealand, praised the colony's prolific literary market - specifically that of Auckland. ${ }^{72}$ The New Plymouth Tourist and Expansion League emphasized how progressive their town was, being "...well equipped with public buildings, modern hospitals, and educational facilities. ${ }^{173}$ A Dunedin Reverend J.G.S. Grant, compared the growth of his city to that of Rome, and in the process intimated that the physical position of Dunedin was superior to that of its Italian relative: "Rome is said to be built upon seven hills. Those hills are mere tumuli compared to the Dunedin hills." ${ }^{174}$ And the Christchurch promoter Montague Mosley, lavished praise on the Canterbury Museum as being the best in the Southern hemisphere and "equal with those of Frankfurt and Stutgardt..."75

Urban promoters, specifically those in Auckland, liked to make much of the fact that their city was a thriving, South Seas, cosmopolitan port in which fascinating characters straight out of a Robert Louis Stevenson novel could be seen and heard. Such a strategy was in all likelihood employed to make New Zealand's urban locales appear fascinating places, unlike the "wopwops" impression which might have adversely influenced settlement. ${ }^{76}$ Cassell's Picturesque Australasia portrayed Auckland's Queen

${ }^{70}$ Herbert Roberts, p.462.

${ }^{71}$ Edward Payton, p.133.

${ }^{72}$ Emile De Harven, La Nouvelle Zélande Histoire, géologie, climat, Gouvernement, institutions, agriculture, Etc... (Anvers: 1883), p.133.

${ }^{73}$ New Plymouth Tourist and Expansion League, New Plymouth, New Zealand (New Plymouth: 1923), p.7.

${ }^{74}$ James Gordon Stuart Grant, Twenty five years in Dunedin (Dunedin: 1880), p.2.

75 Montague Mosley, Illustrated guide to Christchuch and Neighbourhood (Christchurch: 1885), p.63.

${ }^{76}$ The "wopwops" is a derogatory New Zealand term used today for a place which enjoys few luxuries or civilised amenities. It is a primitive backwoods, which in terms of cultural attractions or forms of entertainment, is more than severely crippled. The 
Street as an exciting place where the visitor could hear "half-a-dozen different languages, from Maori to Gaelic." ${ }^{17}$ George Edward Mason, a Church of England clergyman, was amused and amazed at the range of public orators to be found in Auckland: "Almost any speaker can obtain a hearing... Lecturers, teachers, preachers, litterateurs, escaped nuns, and reformed convicts gain an audience..." ${ }^{178}$ And Henry Bolitho described Auckland's harbour as a dynamic and multicultural panorama, akin to those romantic images of San Francisco, Shanghai, Tiger Bay and other famous sea ports of the day:

Boats from every place came into the harbour, English boats...boats from China...from Japan ...from the Melanesian Islands... All the boats of the world came to Auckland - and they come there still, with passengers and cargo and fantastic sailors with knives at their belts, strutting the docks, swearing, chewing tobacco and spitting into the water. ${ }^{79}$

Auckland was not the only city to be praised in such a fashion. Promoters in Wellington bragged about the progressive nature of their city and the fact that the capital had a night club in 1920, "when Auckland people still thought even the waltz rather intimate. ${ }^{180}$ And John Moore, writing an emigration handbook, commented on the popularity which rollerskating enjoyed in the colony in general, "despite [the] bruises, fractures, dislocations, sprains and the doubtful acquaintances made in these halls by young ladies..." ${ }^{181}$

expression is derived from the Australian term "woopwoops", which according to G.A. Wilkes, A Dictionary of Australian Colloquialisms (Sydney: Sydney University Press, 1985), was "a byword for backwardness and remoteness" (p.452). I have found no evidence to suggest that the term was in use in New Zealand during the period of my study, but certainly the image and connotation of such a place would have existed and would not have been lost on the migrant. Wilkes does, however, provide an example of the idiom being used as early as 1926 in Australia, therefore it is not improbale that the phrase was in use in New Zealand during the same time period.

${ }^{77}$ Edward Ellis Morris, ed., Cassell's Picturesque Australaia (Melbourne: Cassell \& Co. Ltd., 1889-1890), p.195.

${ }^{78}$ George Edward Mason, Round the round world on a church mission (London: Society for the Promotion of Christian Knowledge, 1892), p.54.

\footnotetext{
${ }^{79}$ Henry Bolitho, p.30.

${ }^{80}$ Ibid., p. 113.

${ }^{81}$ John Moore, p.206.
} 
Another area in which New Zealand's promoters liked to compete with her Old World relatives, was in championing the technically advanced and innovative state of the Dominion to the detriment of Europe. According to Graeme Davison, this emphasis on the Dominion's newness and careful planning was only natural, considering that the new colonies "could not boast the long and illustrious histories of Athens and Rome, Paris and London. ${ }^{182}$ Consequently, Ernest Michel praises New Zealand, which unlike Europe, attempted a great deal of thoughtful planning in regards to hospital designs for convalescent recovery. He also praised the layout of the city of Dunedin, arguing that it could serve as a model for the rest of the world in regards to planning cities built on hills. $^{83}$

Examples of praise for the colony's advanced state of industry and technology are evident throughout the booster material. Ethel Vincent, the authoress of a travel book, celebrates the fact that "The telephone is in general and more frequent use here than in England. ${ }^{184}$ Henry Wigram, reflecting on Christchurch's abundance of bridges, asserted that "They are more numerous to the square mile... than with any other place which the writer is acquainted." Wigram went on to celebrate Christchurch by concluding that "there are more bridges in Christchurch than there are in London." 85 Wellington was constantly being alluded to as the location of the largest wooden building in the world. John Barr, in a handbook designed to publicise Auckland, applauds Grafton Bridge as being the biggest, best and most up to date bridge of its kind: "[it] is notable as having the longest three-hinged arch in the world, and was, at the time of its construction, the longest single span arch constructed in reinforced concrete. ${ }^{1186}$

${ }^{82}$ Davison, "Cities and Ceremonies", p.97.

${ }^{83}$ Ernest Michel, p.242 and p.328. Dunedin's layout was originally planned in Great Britain by architects and surveyors who were relatively ignorant of Otago's topography, hence the city's strict grid-iron structure despite its surrounding steep grades. Such was the case with many new world towns and cities conceived back Home.

${ }^{84}$ Ethel Gwendoline Vincent (Moffat), Fortythousand miles over Land and water The journal of a tour through the British Empire and America (London: Sampson Low, Marston, Searle \& Rivington, 1885), p.158.

${ }^{85}$ Sir Henry Francis Wigram, The story of Christchurch, New Zealand (Christchurch: Lyttelton Times Co. Ltd., 1916), p.226.

${ }^{86}$ John Barr, p.57. 
This tendency to concentrate on the progressive and the advanced could be seen in the commercial advertisements of the day as well; at the Christchurch Art and Industrial Exhibition in 1895, Adams Curties and Co. proclaimed that their bicycles were, "365 Days Ahead of Them All." ${ }^{187}$ This tactic of emphasizing the forward looking nature of New Zealand's cities (and New Zealand's commercial products), was an effective advertising vehicle and also a carryover from Liberal reforms at the turn of the century as discussed in Chapter 1; for according to David Hamer:

In writing about New Zealand by New Zealanders, there was a strong note of pride in what had been accomplished. The Liberals associated their reforms with the concept of New Zealand showing the way to the rest of the world. This notion proved very appealing to New Zealanders and it has remained an abiding feature of their understanding of their country's purpose. $^{88}$

In keeping with this theme of a "civilised" New Zealand, was the booster's insistence on either ignoring the native population or emphasizing the fact that the indigenous Maori population no longer constituted a threat to the newcomer. Throughout a great deal of the promotional and travel literature, when authors did mention the aboriginal population, they usually insisted that the Maori were a dying race and subsequently would not prove a barrier to prosperous and peaceful settlement. David Hamer echoes this last point, arguing that urbanisation was seen as a way of countering what was believed to be the uncivilising forces of bush and native. He states that in some cases, "the passing of the 'red man' or the aborigine was matter for unqualified rejoicing." 89 Where the authors of these advertisements did not celebrate the demise of the Maori, they envisioned them as becoming integrated into mainstream European life. Frequent testimonials were made praising the athletic ability of the men, the beauty of the females, or the fact that the Maori skin colour was not too diverse from that of the European - thereby implying that the Maori had certain "qualities" which were shared by the Europeans and which could lend to the Maori becoming favourably

${ }^{87}$ Christchurch Art and Industrial Exhibition, 1882, Catalogue of exhibits (Christchurch: 1895), p.30.

${ }^{88}$ David Hamer, "Centralization and Nationalism," in Keith Sinclair, ed., The Oxford Illustrated History of New Zealand (Auckland: Oxford University Press, 1990), p.146.

${ }^{89}$ Hamer, New Towns in the New World, p.213. 
assimilated. Consequently, those Maori who did become civilised, turned into symbols of New Zealand's progress; Sir Frank Fox quotes a French visitor to New Zealand applauding the civilizing of the natives as a sure sign of the Dominion's advancement: "There are Parliaments where sit, eloquent and correct, men who used to be cannibals." 90

David Hamer discusses the fear of the bush which was prevalent amongst many prospective Australian residents. He says that anxieties about being "eaten by blacks" existed amongst migrants in Sydney as late as $1880 .{ }^{91}$ As can be expected, events during the Maori Wars of the 1860 s were not the ideal propaganda tools for attracting European migration or tourism to New Zealand. Once the wars were over there was a deliberate attempt to counter any adverse image which the fighting may have caused. Ethel Vincent, while touring New Zealand in the early 1880 s, quotes a local lady who was very concerned about the barbaric image which the colony had overseas: "I believe they think at home that we are living in the midst of cannibals, and certainly in a state of rude civilization and semi-barbarism." 92 Yet surprisingly, this concern amongst New Zealanders over the image of the Dominion as a land of barbarous savages is evident as late as 1927. For Richard Wedderspoon, in trying to promote New Zealand, attempts to show "that New Zealand is no merely half-developed land peopled chiefly by coppercoloured natives and a few white settlers..."193

\section{$* * *$}

The written word was not the only medium utilised by the boosters to promote the idea of the New Zealand city and town as being civilised. As seen in the paintings and engravings used in this chapter, illustration was another method to promulgate this idea. However, according to historians like David Hamer, Marian Minson, David Ravine,

${ }^{90}$ Sir Frank Fox, Oceana...containing...illustrations in colour... (London: Adam and Charles Black, 1911), p.141.

${ }^{91}$ Hamer, New Towns in the New World, p.202. Hamer is quoting from the New South Wales Parliamentary Debates, First Series, 2:1806.

${ }^{92}$ Ethel Vincent, p.157.

${ }^{93}$ Richard Wedderspoon, The Dominion of New Zealand, Britain's El Dorado of the southern hemisphere. Produced under the auspices of the Government Tourist and Health Resorts Department (Christchurh: Simpson and Williams, 1927), p.22. 
Peter Schmitt and George Seddon, attempts were often made at showing how civilised a new land was through the use of depictions of formal gardens and parklike scenery which revealed a mastery over nature. This could be accomplished by the artist focusing on such elements as decorative shrubbery, flower beds, stone walkways, white-picket fences and carefully manicured lawns, all of which would serve to underline the presence of people in the environment and their control over it. For the bush and the forest were seen as savage and uncivilised, and images of persons cultivating the fields, cutting down the trees, clearing roads and building homes, were common symbols of the humanizing of the environment. The inclusion of green belts and public parks as subject matter in city booster material also served the added promotional bonus of showing how well planned the nation's cities were, in contrast to the brick and grey prisons of Dickens' Coketown and European centres of a similar ilk.

Such images are rampant in the booster works of the period. This is exemplified in the 1885 example of the Octagon in Dunedin [ILLUSTRATION 10], and the artist's concern with emphasizing the carefully controlled municipal park. The grassy areas are encircled by brick walkways. The trees, supposedly to protect them from wandering animals or the destructive curiosity of little boys and girls, are all surrounded by white fences. Yet the impression rendered is one of nature emasculated; all the greenery has been carefully controlled, kept within the strict confines of brick and wooden barriers. This same concern with visual order and of nature controlled is evident with the photographs of the square in Palmerston North [ILLUSTRATION 11] and of the late Sir Robert Anderson's residence near Invercargill [ILLUSTRATION 12]. In both cases, the effect of the ornamental trees and shrubs, as well as of the park-like lawns, conjures up images of model train sets and the highly idealized scenery which often accompanies such miniature locamotives. The photograph of Robert Anderson's landscaped garden is strikingly reminiscent of the neo-classical landscape popular in eighteenth century English gardens, "where nature has been improved and idealised by art."194 It is an arcadian landscape of the classical world that many settlers would have found appealing, a vision of "the uncorrupted world of piping goatherds and melancholy poets living in the bosom of nature." 195

${ }^{94}$ Hugh Honour, Neo-Classicism (Auckland: Penguin, 1987), p. 159.

${ }^{95}$ Ibid., p.163. The arcadian image and its emigrant appeal will be discussed in Chapter 9. 


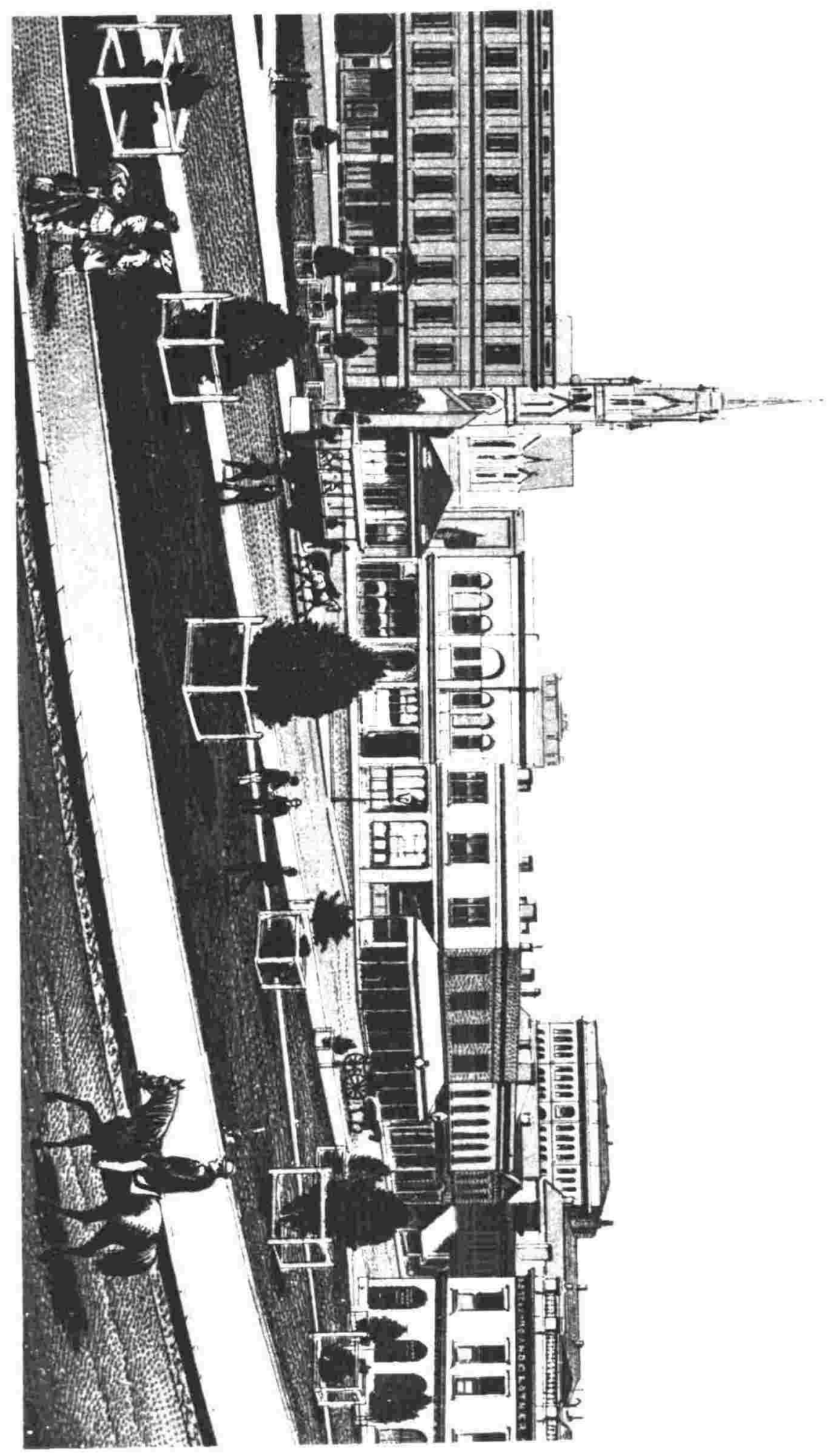




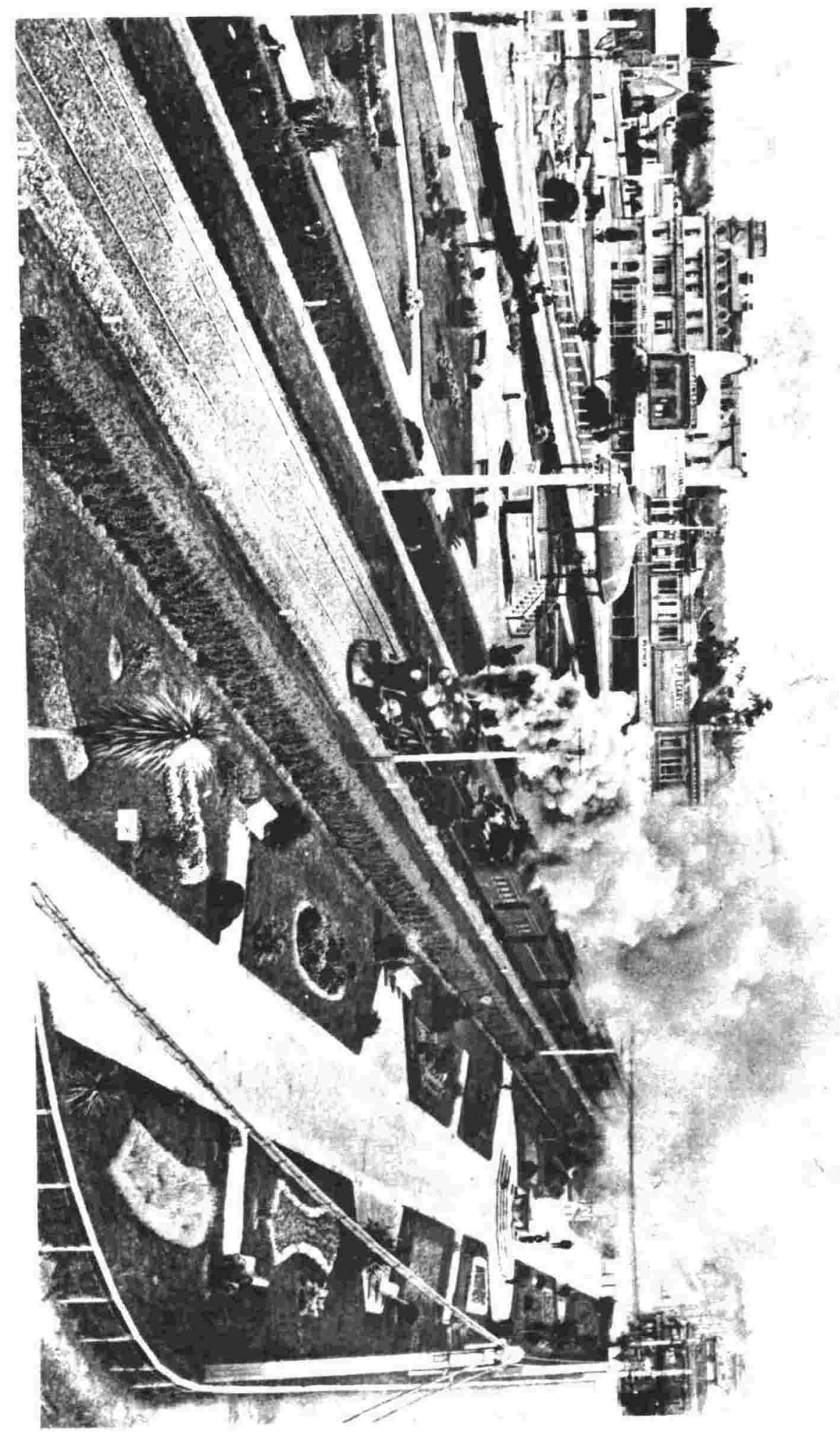

illustration 11 


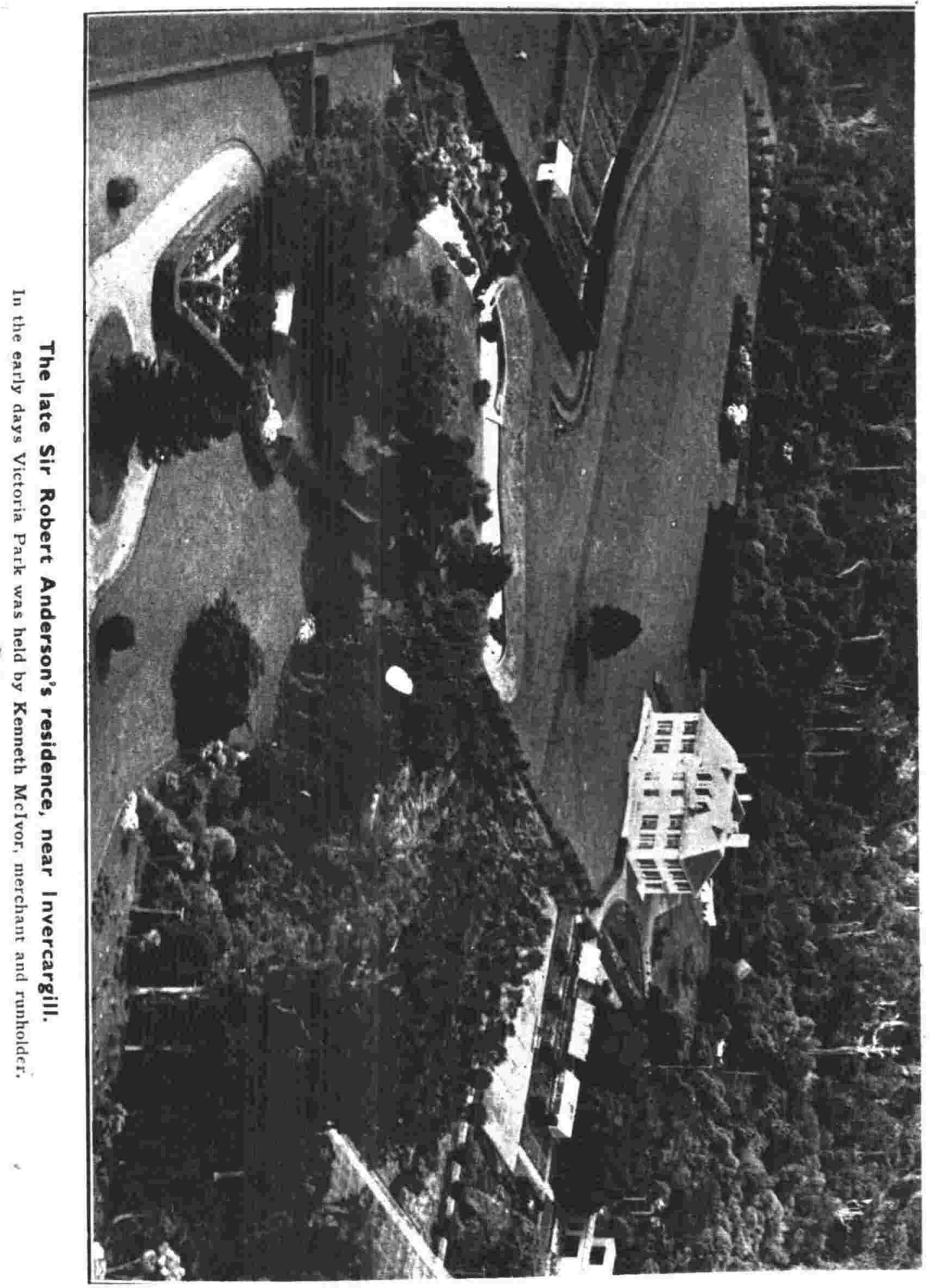

illustration 12 
One of the only areas in the urban booster works where some of the natural flora has been left untouched are the Botanic Gardens and the Town Belts. Two of the reasons why these green urban areas were originally created by the city's founding fathers to be located nearby the city or actually in the city, were in order to insure that urban growth did not go unchecked and to provide a balance to the monotonous drudgery of brick and mortar building. The immediacy of these green areas to the city also happens to imply that nature is there to be enjoyed, but only within the strict confines of the urban environment and only a few minutes walk from the centre of town. This theme of nature subject to the whims of the European settler is nowhere more apparent than in some of the illustrations which depicted children playing in gardens and local bush. Photographs and illustrations of the period frequently revealed images of little girls carelessly picking flowers, little boys tearing off branches from trees and groups of children trampling flowerbeds as they waited for a photograph to be taken, all the while their adult supervisors watched nonchalantly. Such destructive action on the part of children would not be so favourably received today, as "keep off the grass" signs are meant to ensure that plants and trees were left untouched. The fact that the children in all these pictures are dressed in their elaborate Sunday best not only indicates that New Zealanders are well-off, but it also underscores the point that the city and all the civilised amenities which it offers, is not too far away. 


\section{CHAPTER 3: THE VOCABULARY OF DESCRIPTION}

Chapter Two examined the ways in which New Zealand's boosters attempted to convince people overseas that the country's cities and towns were civilised places, and not the backwoods of popular mythology. They did this firstly and most commonly by comparing the colony's urban centres to European and English examples. Then the New Zealand promoters took these analogies a step further by arguing that their cities were in fact far superior to Old World precedents. The resulting image which the boosters created was of an ideal city composed of the best of two worlds: a sophisticated Old World metropolis replanted in the New World but without any Old World problems. To further this progressive and civilised image, the boosters utilised a number of other promotional techniques; these included emphasizing the fact that the native threat had been subjugated and that the wilderness had been tamed.

Chapter Three, however, examines a range of other techniques used by the boosters to promote New Zealand's cities and towns. These included: expressing incredulity at the quick pace of urban growth; likening New Zealand's urban growth to magic; making grand prophecies of prosperous futures awaiting a particular place; drawing romantic parallels to fairy realms to convince people of a place's natural beauty; utilizing literary conventions such as alliteration or understatement to promote an area's attractions; boosting a city or town at the expense of a rival or neighbour; celebrating the beauty of the New Zealand woman to gain the interest and attention of the rich male tourist; emphasizing Zelandia's cities as prosperous to counter negative images of economic downturn; showing the towns and cities as healthy and safe; employing statistics and quotations as proof of the good conditions to be found in the Dominion's settlements; praising the efficiency of certain cities and towns when the aesthetic could not always be highlighted favourably; the New Zealanders penchant for "blowing"; and lastly, using all sorts of extreme and bizarre tactics for attention-grabbing headlines, inluding slow trains and erupting volcanoes!

A large number of foreign travellers coming to visit New Zealand for a holiday expressed considerable amazement at the extraordinary stage of development which the colony seemed to have achieved in a remarkably short period of time. C. Cesary, a 
Roman Catholic priest visiting the South Pacific from India in the early 1880 s to regain his health, expressed his wonder at the appearance of Dunedin: "In entering the city you are surprised to see for so young a place to have such fine building." ${ }^{\text {A }}$ visiting French aristocrat, H. Gaston de Ségur, declared how he had been pleasantly astounded at the advances which he saw in New Zealand: "Dans une ville d'aussi récente origine, je ne m'attendais guère à trouver d'aussi larges rues, de si belles maisons..." ${ }^{\prime 2}$ Similarly, an English Reverend on a lecture tour, had these positive comments to make on the Dominion's growth:

In 1832 the whole white population [of Auckland] was only 100; in 1895 it [the population of the entire colony] is hard on 700 000. But the pioneers... are not yet dead... The first age of colonisation has hardly closed, yet here are cities, Invercargill, Dunedin, Christchurch, Wellington, Napier, Nelson, Wanganui, New Plymouth, Palmerston, Auckland, and many more with great stone civic buildings, town halls, P.O.'s, opera houses, Government Houses, churches and Cathedrals galore!... the framework is complete. ${ }^{3}$

Such approving comments about the rapid and tremendous growth of New Zealand were not restricted to visiting foreigners. Many New Zealanders expressed varying degrees of pride in their colony's brisk maturation. J.G.S. Grant, the Rector of Dunedin's High School of Otago, saw his hometown, "transformed from a paltry village... into a fair city." He then went on to envision such miraculous growth akin to the expansion of Rome in the first century, AD: "I feel stirring within me an emotion similar to that which animated the bosom of Augustus Caesar when he told the Senate that he found Rome built of brick and that he left it constructed of marble." ${ }^{44}$ During the fiftieth Anniversary celebrations of British settlement, a critic from the New Zealand

\footnotetext{
${ }^{1}$ Rev. C. Cesary, The beautiful countries or Travels in Australia, New Zealand and Tasmania, through Madras, Colombo and Candy (Calcutta: Cones and Co., 1884), p.234.

2 "In a city so recently founded, I was slightly astounded to find such large roads and such lovely houses..." Vicot H. Gaston de Ségur, Au Bout de Monde. Une Saison en Nouvelle Zélande (Paris: Librarie Plon, 1901), p.21.

${ }^{3}$ Hugh Reginald Haweiss, Travel and Talk; 1885-93-95. My hundred thousand miles of travel through America, Canada, Australia, New Zealand, Tasmania, Ceylon and the paradises of the Pacific, II, (London: 1897), pp.127-128.

${ }^{4}$ James Grant, p.2.
} 
Times used the demise of the Maori and the increase in Anglo Saxon numbers as a similar indicator of the Dominion's progress: "The beach where the Maori landed in his gay canoe is now thronged with people born of another race..." ${ }^{5}$ William Pember Reeves vividly accentuated this pride while defending New Zealand's cities and towns against criticisms by a few European visitors that they were aesthetically unappealing:
Europeans are apt to be impatient of colonial towns, seeing in them collections of buildings neither large enough to be imposing nor old enough to be mellowed into beauty or quaintness... Yet these towns, standing where seventy years ago nothing stood, have other features of interest besides their newness... What if...the brick and stone business edifices embody modern commercialism! The European visitor will note these features; but he will note also the spirit of cleanliness, order, and convenience everywhere active... The unconcealed pride of the colonist in material progress may sometimes jar a little on the tourist in search of the odd, barbaric, or picturesque. But the colonist, after all, is building up a civilised nation. Art, important as it is, cannot be the foundation of a young state. ${ }^{6}$

Yet the feelings of unfeigned pride manifested by many New Zealanders in their colony's rapid urban growth were also manipulated as a promotional gimmick by boosters. Such a tactic was especially suited for the prospective capitalist in search of a field for investment. For in the eyes of the boosters, the point of highlighting such quick growth was to show that the investor's capital was not only secure but also that it was guaranteed to increase. This tactic of emphasizing rapid urban growth is discussed by David Hamer in New Towns in the New World. He states that such a practice, whether intentionally promotional in nature or not, was certainly effective "proof that the town was growing and changing, that were was a process of evolution underway."7

Evidence of New Zealand boosters adopting the promotional method of highlighting swift growth abounds. Edward Wakefield compared the progress of the country to that of "a photograph of a horse at full gallop". He concluded that it was

${ }^{5}$ The New Zealand Times (January 22, 1890), in Davison, 'Cities and Ceremonies', p.112. Amongst many nineteenth century New Zealand poets the Maori were often portrayed as a race on the eve of extinction. I owe this point to Harvey McQueen.

${ }^{6}$ William Pember Reeves, New Zealand painted by F. and W. Wright, described by Hon. William Pember Reeves, High Commissioner for New Zealand (London: Adam and Charles Black, 1908), pp.19-20.

${ }^{7}$ Hamer, New Towns in the New World p.167. 
impossible to achieve an exact picture of New Zealand as "the object has undergone a change even while the process is still going on..." ${ }^{8}$ Evidence of this promotional tactic being used in New Zealand can also be seen in a booster publication from Frank Duncan and Co., in which a photograph of modern Queen Street in Auckland was juxtaposed with a written description of the city before colonisation: "Eighty years ago this locality formed the banks of a small muddy creek, devoid of any trace of civilisation." 9 Such a stratagem was employed in order to emphasize the degree of change that had occurred in the city. This change also appears to have been imaginatively heightened by the publisher (whether consciously or unconsciously), through the media chosen to stress the city's progress; for the newer medium of photography which showed a modern Auckland, contrasted symbolically with the older medium of the printed word which described a pioneer wilderness.

As the Frank Duncan \& Co. publication has revealed, these images of rapid urban development were not restricted to the written word. For photographs and illustrations underlined much of the country's evolutionary and revolutionary development. At the very beginning of Richard Wedderspoon's The Dominion of New Zealand, [ILLUSTRATION 13] there is a two page illustration depicting the progress of the country from 1840-1927. The image reads from right to left. At the far right, during the earliest years of settlement, is a portrait of a pioneer trapper in the bush replete with furs and gun. As the viewer's gaze proceeds to the left (symbolically depicting the passage of time), images of apparent progress intrude abruptly into the picture. Initially there is a farmhouse on the river bank opposite the trapper, a first tentative sign of European domestication; then, as one's eyes continue leftwards, a steaming train emerges from a tunnel. Following the train is a huge steampowered ocean liner arriving at a thriving port city. The presence of such a large and apparently prosperous city seemed to consummate that vision of Reverend Grant's new Rome in the Antipodes mentioned earlier; it represented an ultimate symbol of growth and advancement.

A discussion of this work is not complete, however, without making mention of the native elements in the colony, specifically the bush and the Maori (the latter in this illustration seem to resemble more the Mohicans of a James Fenimore Cooper novel)!

\footnotetext{
${ }^{8}$ Edward Wakefield, New Zealand after fifty years, p.v.

${ }^{9}$ Auckland the Beautiful, no page.
} 


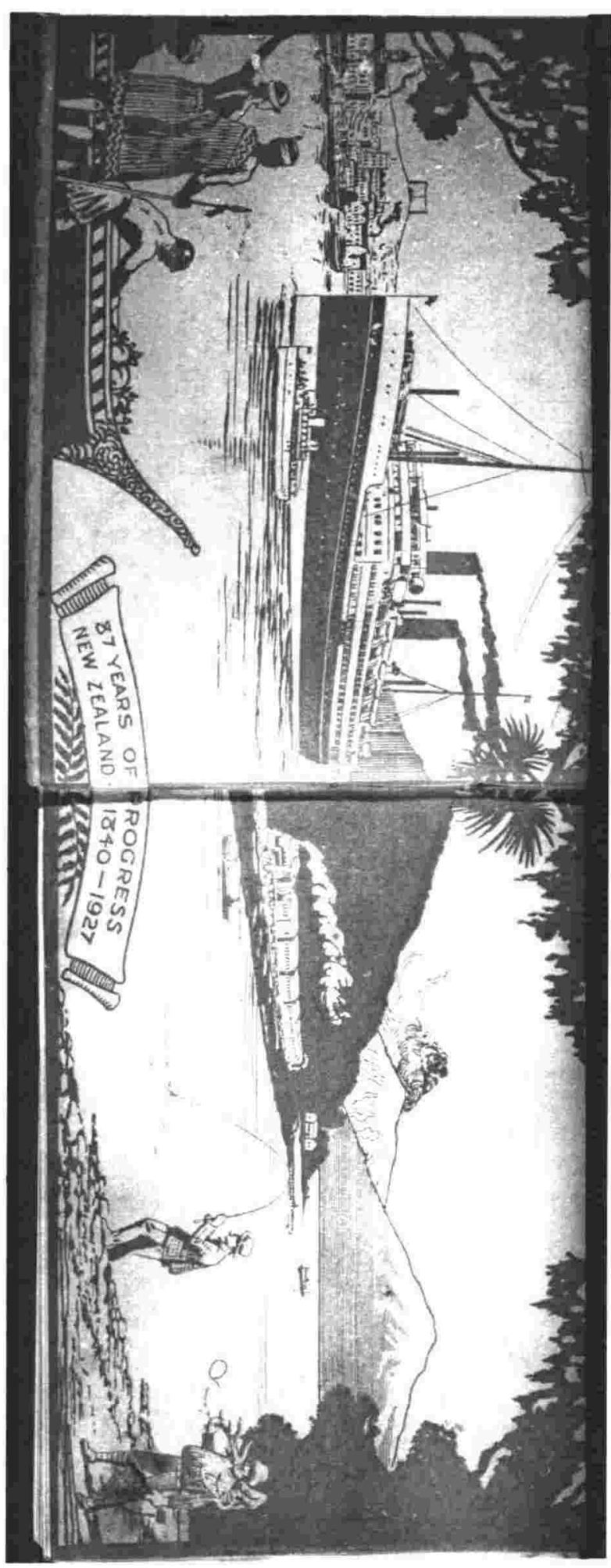

illustration 13 
Both native elements in this picture, the aboriginal peoples and the wilderness, have been obscured. They are physically separated from the images of progress by the river. Their only function appears to serve as a kind of framing or decorative element. They seem to have no place or serve no purpose in the new New Zealand. One can imagine the trapper on the right either turning his back on the panorama unfolding before him and disappearing for good into the forest; or, he can become transformed into the weekend fisherman next to him, giving up his furs for a city suit and hat. Likewise, the Maori can only pack up what few belongings they have into their canoe, and sail far away. Does the Maori sitting in the canoe lower his head in remorse for what has been lost or for what he is being denied? The fact that the artist got the look of the Maori wrong by drawing a likeness to an Amerindian tribe, is in itself an indication that, for the artist at least, the Maori had already become a thing of the past. According to David Hamer, this marginalisation of the native and pioneer elements in a new world, was done "to emphasize progress and antithesis between urban society and primitive nature, existing in harmony or the one developing out of the other and gradually replacing it." 10

A similar historical diorama to the one found in Wedderspoon's work was prepared for the New Zealand Government Pavilion at the New Zealand and South Seas Exhibition. The Exhibition itself was held at Dunedin in 1925, and the pavilion's diaroma was reproduced at the beginning of the Special Pictorial History, New Zealand and South Seas Exhibition 1925-6 [ILLUSTRATION 14]. The original painting was thirty-three feet in length and charted the growth of the Dominion's industries from 1800 to the year 1924. Like the previous illustration for Wedderspoon's work, it was meant to be read from right to left.

The emphasis on certain historical themes and civilised images in this depiction is comparable in many ways and on many levels to those booster elements found in The Dominion of New Zealand. At the far right during the $1800 \mathrm{~s}$ are symbols of a supposedly "primitive" or pioneer New Zealand: a pa, a war canoe, the virgin forest, and in the distance - the first ominous presence of the European - a whaling or settler ship. As time passes, farm houses and fences are built, and the smoke from settlers clearing bush in order to cultivate the land fills the horizon. All of a sudden, the bush disappears, and the view that emerges is one of well cultivated fields, expanses of grazing sheep,

${ }^{10}$ Hamer, New Towns in the New World, p.51. 


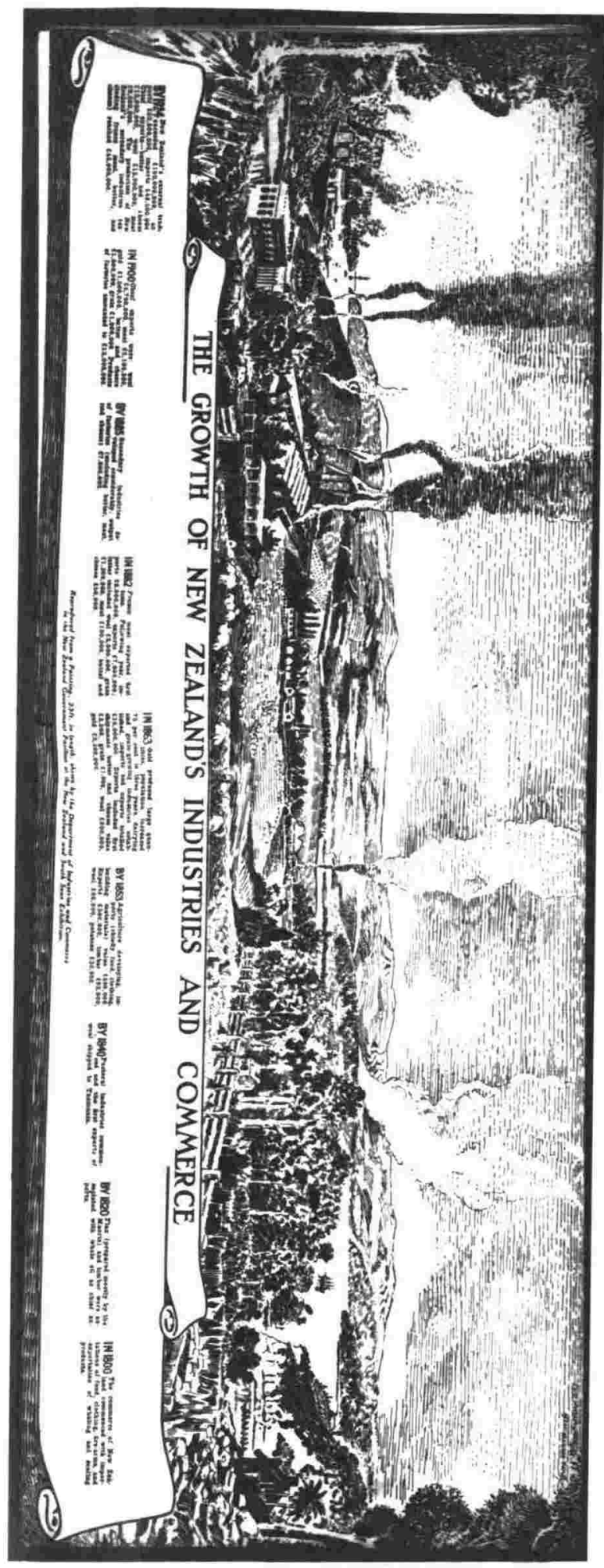

illustration 14 
and farmhouses nestled snugly amongst rolling hills. Eventually the single smoking chimney of a lone farmhouse is overtaken by at least eight factory chimney stacks, the intention of which was to underline the fact that the country had created a stable industrial and manufacturing base. The last and most powerful of all the descriptive elements in this picture which serve to reveal the progress of the colony, however, is the image at the far left of a large and cosmopolitan city complete with skyscrapers and a thriving port. Once again, the bush has been marginalised, serving only as a component for the framing of the composition. There are no Maori at all to be seen in this image. Instead, the stone and marble walls of the city's numerous multi-storied edifices, the city's dominant position in the landscape, and the fact that it represents the seat of all authority and power in the land, obliges a comparison (on the physical as well as the symbolic level), with a feudal manor or medieval castle from Europe's Middle Ages.

Photography was another medium that quite commonly utilized this before and after sequence to depict the rapidity of New Zealand's urban growth and physical evolution. John Barr's history of Auckland shows a picture of the city's public library in 1880 and in the 1920s [ILLUSTRATION 15]. In the top half of the photograph, the library appears a flimsy, ramshackle, wooden structure on the point of collapse and only reached by a small dirt path. Directly below this photograph, on the other hand, is a picture of the new public library in the early twenties which has been combined with a civic art gallery and a museum. Built of stone and in the French Renaissance or Beaux-Arts style of the late nineteenth century, the more modern building is three stories high and surrounded by landscaped lawns; it includes such elaborate architectural embellishments as dormer windows and even a tall clock tower. Barr concludes that from these pictures the reader can take such progress as being "typical of the growth of the City's institutions in general."11

Civic advances like that of Auckland's library were a favourite subject of booster photography. Another good example is that of road improvements. In a view of Auckland in 1850 , one sees a wagon almost being swallowed up by a muddy road [ILLUSTRATION 16]. Contrasted with this picture of primitive transport conditions, is another photograph on the facing page of modern Auckland in 1929. The emphasis in

${ }^{11}$ John Barr, p.40. According to Hamer (New Towns in the New World, p.173), many "so-called [civic] "histories" ended up as thinly disguised booster publications". 


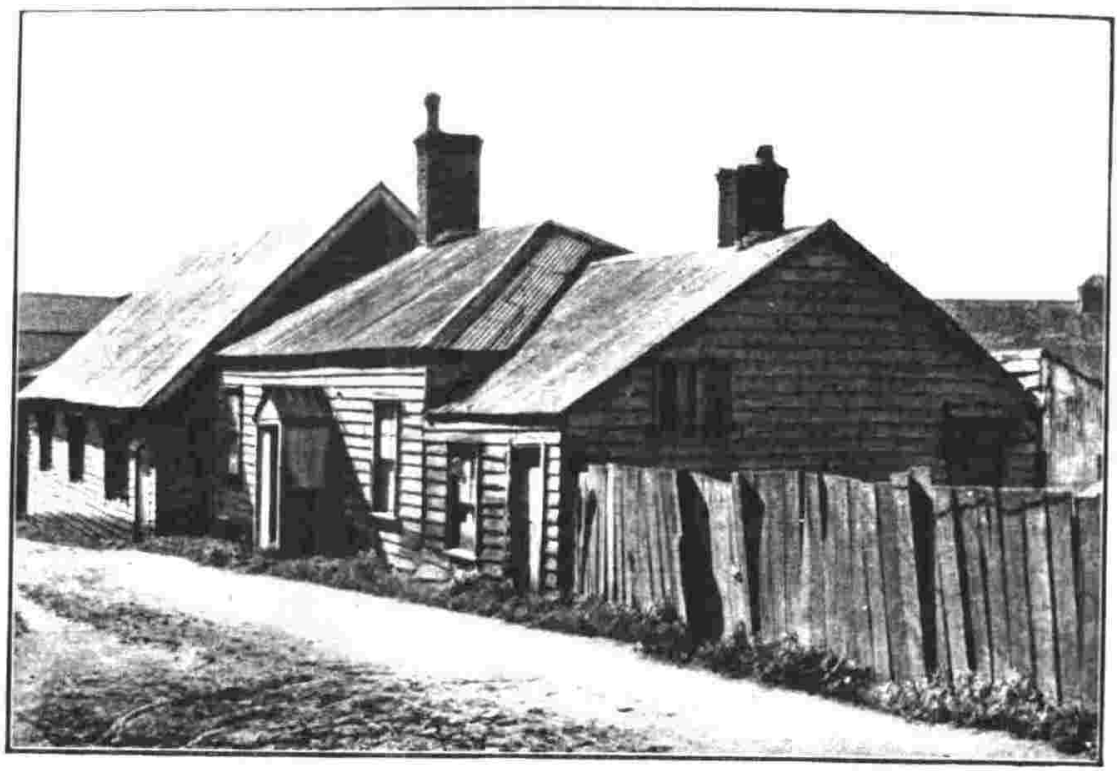

Auckland Public Library, 1880

For.aerly the Mechanics' Institute and Library, established 1842

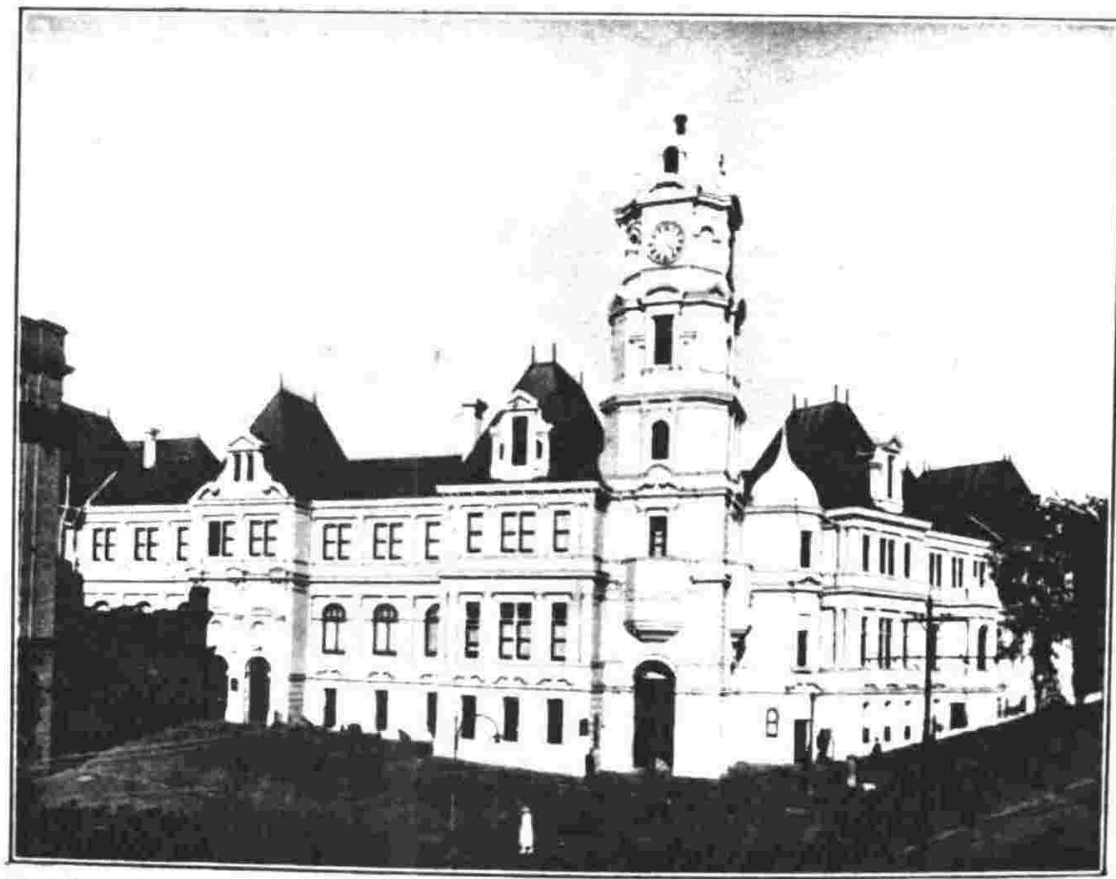

Public Library, Art Gallery and Old Colonists' Museum, to-day The progress illustrated in these pictures may be taken as typical of the growth of the City's Institutions in general 


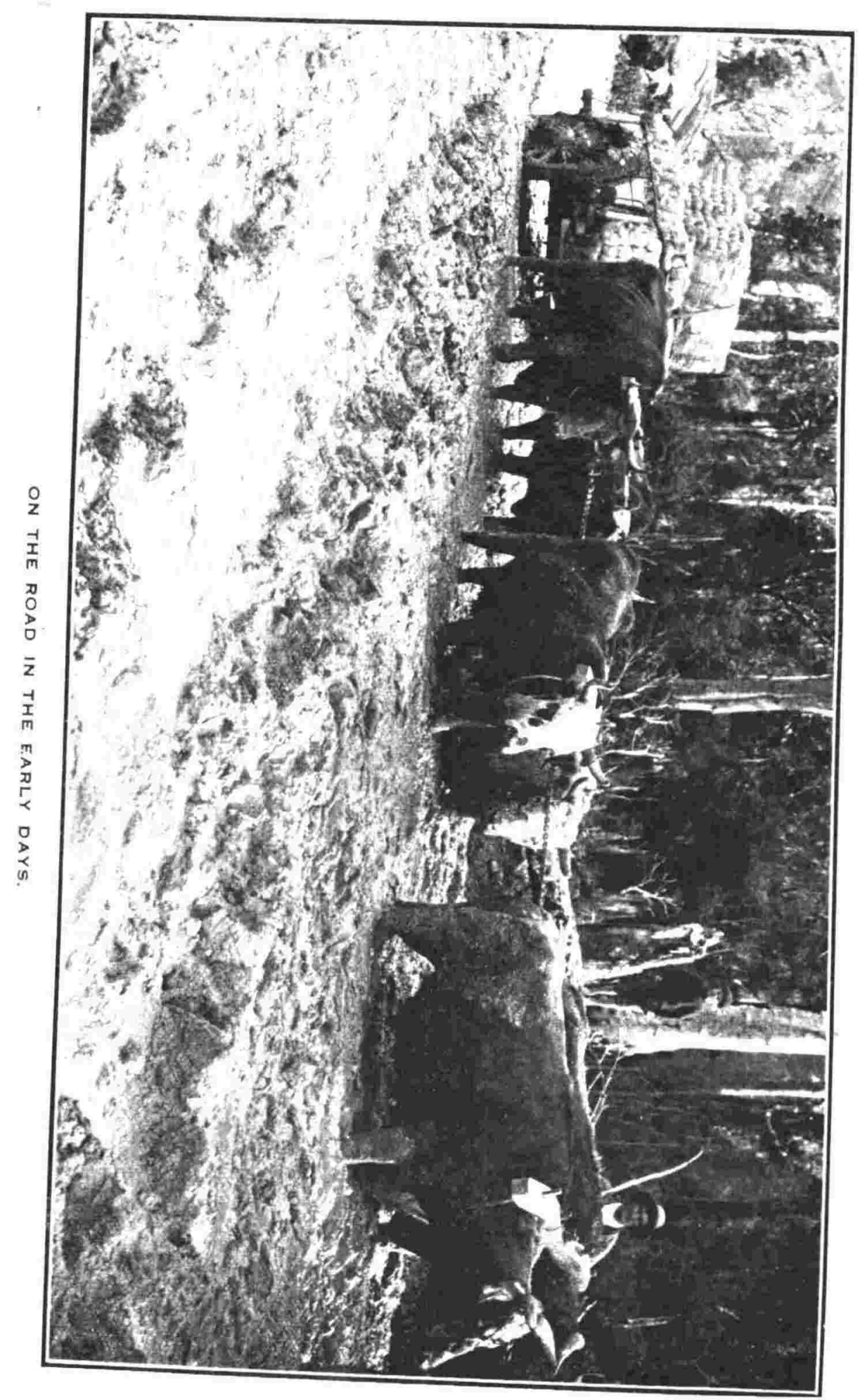

illustration 16 
this second picture is on the happy motorist driving along a beautifully graded and sealed road. [LLUSTRATION 17]

Manufacturers and businesses also liked to use this "before and after sequence" as a promotional strategy. The primarily commercial and profit-orientated intentions of such advertisements amongst this group are easily discernible. A good example of a New Zealand business utilising this strategy can be found with the postcard developed for Strange's Drapery Company in Christchurch, which was inserted with all their deliveries [ILLUSTRATION 18]. On the one side was a written message addressed to the customer and hoping that the product had arrived in good order; while on the other side of the postcard was a photograph of the firm in 1868 and below that a picture from 1910. The picture from 1868 showed a one storey wooden building while that from 1910 depicted a three storey brick building replete with decorative elements such as a balustrade and crown. The fact that the more contemporary photograph of the firm was taken from a low viewpoint and from an angle gives Strange's an illusion of being taller than it really is. This sense of added height coupled with the focus on the firm's new stone premises, when contrasted to the older one storey timber building of 1863 which was drawn from a lower angle, resulted in an apparently unmistakable sign of the company's success. This postcard was also doubly effective as a promotional strategy for it not only seemed to tell customer and investor alike that the firm was solid and reliable, but it also insinuated that the company was destined to keep growing.

$* * *$

Similar in method and intention to boosters commenting on the rapidity of New Zealand's urban growth, was their tendency to liken this development to the miraculous and the magical. John Bradshaw, while celebrating the beauty of Christchurch, conceived of the city as being magically transported: "It is as though a magician had transported some of the prettiest villas from the lakes of Cumberland, and set them down... that he had then flown to Oxford and stolen some of its Gothic architecture, to be reproduced... in the numerous public buildings which everywhere adorn the town."12 Oscar Vojnich, a tourist visiting the Christchurch Exhibition, defended it against accusations from foreigners that is was a failure and could not be compared to those exhibitions held

${ }^{12}$ John Bradshaw, p.15. 


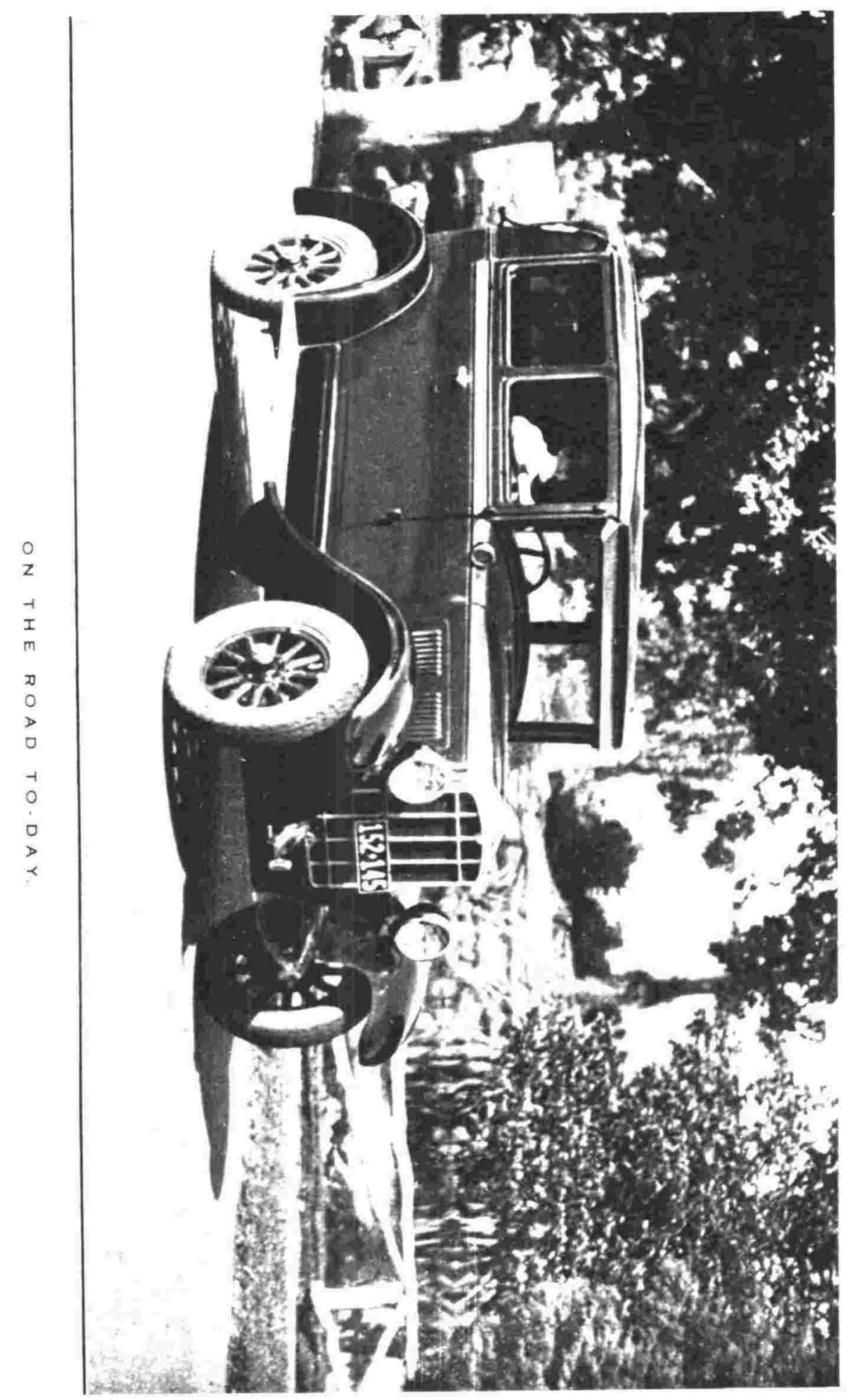

illustration 17 


\section{STRANGE'S \\ 1863.}
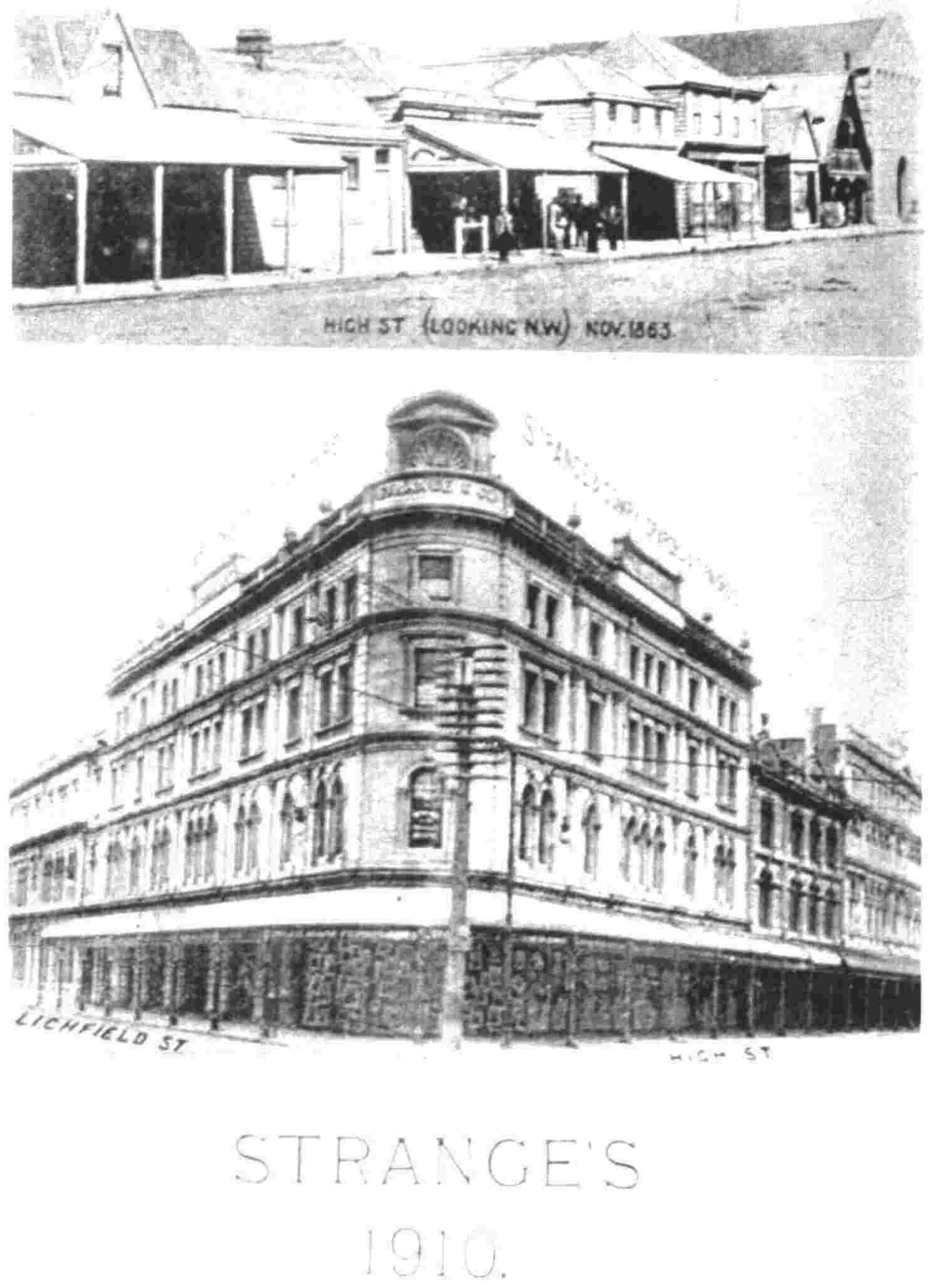
previously in Paris or Chicago. ${ }^{13}$ Vojnich, in underscoring the point that New Zealand was a small country which had only been recently settled, was implying that the fact an Exhibition was ever put together in the first place was in effect miraculous.

However, the magical element in the evolution of New Zealand's towns and cities, was tempered by reason. According to David Hamer, "The danger was that overemphasizing "magic" could breed complacency and damage a town's development by encouraging the belief that development would occur without any need for human exertion." ${ }^{14}$ In underlining the magical origins of the New Zealand city, there was also the added danger of suggesting that a town could as easily disappear as quickly as it had appeared, (as was the case with many a boom town of the gold era that had turned into a ghost town). Consequently, New Zealand's urban boosters liked to stress a settlement's solid base and rational growth rather than any magical sources. The New Plymouth Tourist and Expansion League accentuated the fact that their town "bases its faith in its future destiny on no mere chance win from the wheel of fortune."15 Palmerston North's City Council said that their city "did not appear by magic... Hard work, co-operation and the community spirit have contributed to its present-day prosperity." ${ }^{16}$ John Ball talked about the business acumen of Wanganui's inhabitants: "enterprise is stamped upon the foreheads of her people, and "progress" is the watchword of her sons."17

$* * *$

Another common procedure utilized by boosters to promote New Zealand was to foresee a great and glorious future awaiting a particular place. Onehunga's boosters advertised the fact that their home was soon to become "the chief industrial town in the Dominion", ${ }^{18}$ on account of that locale's proximity to Auckland. New Plymouth was

${ }^{13}$ Oscar Vojnich, The island-world of the Pacific; journey notes Translated from the Hungarian by Arthur B. Volland. (Budapest: Pallas Literary Publg. Co., 1909), p.86.

${ }^{14}$ Hamer, New Towns in the New World, p.133.

${ }^{15}$ New Plymouth Tourist and Expansion League, p.8.

${ }^{16}$ Palmerston North City Council, Highways, railways and seaways lead you to Palmerston North, New Zealand (Palmerston North: H.L. Young Ltd.,1925), p.6.

17 John Ball, p.4.

${ }^{18}$ Onehunga - Manukau Chamber of Commerce, Onehunga the future industrial town (Auckland: Onehunga-Manukau Chamber of Commerce, 1913), p.3. 
"on the highway to prosperity", ${ }^{19}$ because of its fertile surrounding land and fine new breakwater. Dunedin was destined to become the playground of the rich and famous because of its grand architecture and enlightened populace..$^{20}$ In a utopian tract set in the year 2076, the city of Wellington is described as "the vast and daily increasing metropolis of the populous and wealthy empire of New Zealand", as well as, "the brightest jewel in the British crown." ${ }^{21}$ For Wellington has become, in this novella at least, the new home of the British Empire since revolutionary ferment and geological upheaval in Europe apparently left London an unstable, and congruently unsuitable choice for a capital.

This practice of auguring good fortune for a town or city was done to encourage confidence in order to inspire immigrants to settle and capitalists to invest. Yet the evidence suggests that some of the authors of these works really believed their own prophecies. Certainly the rapid growth of New Zealand's towns and cities gave her inhabitants reason to believe that they were destined for even greater things to come. Edward Wakefield asks why New Zealanders "cannot but believe that the progress of the colony in the future will be as great as it has been in the past?"22 The boosters in Franklin County argue that, "great though Franklin's progress in the past, we are now approaching a new era of greater development. ${ }^{123}$ Such faith in the future of the colony is not that surprising, for the Antipodes were perceived by a number of contemporary

${ }^{19}$ The imperial album of New Zealand scenery depicting scenes, cities, industries and interesting phases of New Zealand life. Preface by Sir Robert Stout vol.2, (Wellington: McKee \& Gamble and Wheeler \& Son, 1899), p.226.

${ }^{20}$ The actor D.E. Bandmann, who had his public performances successfully received in Dunedin, tended to be very enthusiastic about the city (p.44).

${ }^{21}$ Europa's fate; or The coming struggle A history lesson in New Zealand (London: Griffith and Farran, 1875), p.31.

${ }^{22}$ Edward Wakefield, New Zealand after fifty years, p.222.

${ }^{23}$ Franklin District Advertising Court Committee, Fertile Franklin, the sunshine county; a brief description of the district, its progress and products (Pukekohe: 1929), p.1. 
utopian authors as places far removed from the upheavals and disorders of the Old World, and where a new society could begin again. ${ }^{24}$

*** $*$

Another means of promoting New Zealand's towns and cities included comparing them to the marvels and beauties to be found in imaginary fairy realms. Consequently, the New Zealand cityscape and landscape was often being described in the booster material of the period as an Eden, El Dorado, or land of "eternal spring." 25 Tourist guide books were also guilty of such romantic language; for instance, the New Plymouth Tourist and Expansion League celebrated a local park for its "haunting vistas...shaded wood...glimpses of Paradise...[and] rippling stream." ${ }^{126}$ Such comparisons owed much to the fact that romantic and arcadian themes permeated a great deal of the popular poetry, art and literature of the day. ${ }^{27}$ Nineteenth century New Zealand poems like Marie Randle's "An Arbor Day Vision", conjured up images "Of elves within... woodland shades." ${ }^{\prime 28}$ The 1912 Auckland Arts and Crafts Club's Exhibition displayed fantasy works like Richard Walliwork's "The Unbeliever" (ca.1912), a poorly executed

${ }^{24}$ For another utopian and prophetic work along these lines (other than Europa's Fate), refer to Charles John Stone, History of the Decline and fall of the British Empire by Edwarda Gibbon...Auckland, A.D. 2884 (London: Field \& Tuer, 1884). The work is set in the year $2884 \mathrm{AD}$, with the British having moved to the Australasias on account of the climate becoming cooler in Europe. This same theme of the Antipodes as being a kind of safe haven from Old World threats is evident in modern science fiction literature too, namely John Wyndham's The Chrysalids, Greg Bear's Eon, and Nevil Shute's On the Beach. Shute's antipodean haven does not last long, however, for all the world is finally affected by the radiation fallout from a global nuclear war.

${ }^{25}$ New Zealand was described as an Eden in Glimpses of New Zealand: being a collection of high class and perfectly-finished views of the "Beautiful Britain of the south" (Christchurch: New Zealand Publg. Co., 1896), intro. The Waikato was likened to El Dorado in The Descriptive Handbook of the Waikato: Its conditions and resources. To which is added A short guide to the Hot Lakes, Province of Auckland, New Zealand (Hamilton: E.M. Edgcumbe \& Co., 1880), preface. And Robert Stout, Prime Minister in 1884 , called the country a land of "eternal spring" in C. MacMurran, p.v.

${ }^{26}$ New Plymouth Tourist and Expansion League, pp.10-11.

${ }^{27}$ See Chapter 9 for a detailed discussion on the prevalence of arcadian thought and imagery in New Zealand.

${ }^{28}$ Marie R. Randle, Lilts and Lyrics of New Zealand (Dunedin: James Horsborough, 1893). I am indebted to Harvey McQueen for pointing out this poet to me. 
work expressing a young boy's wonder upon encountering a beautiful fairy. ${ }^{29}$ Charles Dickens used such imagery in his depiction of Coketown in Hard Times, when he likened the glow from iron smelters at night to a surreal and magical fairy realm. Romantic-inspired images are also apparent in the landscape architecture of the period, most especially in the numerous "rustic bridges" which adorned civic squares and gardens in Palmerston North and Queenstown, and the "fairy fountain" in Auckland's 1913-14 Exhibition. Eva-Marie Kröller reveals that Canadian visitors to London and Paris were not immune to such romantic inspiration either; she quotes tourists describing the pleasing "fairy-tale mood" evoked by the English capital and she cites favourable comparisons of the French capital to one "of the enchanted cities of the Arabian nights." ${ }^{130}$

New Zealand's urban boosters, however, also employed much of this language to deliberately promote the attractions of their cities. Palmerston North's Esplanade and square is portrayed as "a picture fairy realm." ${ }^{131}$ The town of Nelson is depicted as the realization of Samuel Johnson's Happy Valley. ${ }^{32}$ Wanganui is described as "A City of Romance." ${ }^{133}$ Thomas Bracken, journalist, Liberal politician and author of the country's national anthem, "God Defend New Zealand", when describing the view of the city of Christchurch, concluded that "it would not require much stretch of imagination to fancy oneself in Fairy-land. ${ }^{134}$ Richard Wedderspoon, one of the more prolific Canterbury and New Zealand promoters, compared Christchurch to "a veritable fairyland," ${ }^{35}$ while John G. Greenbough concluded that the view of the city of Auckland from a steamer was like that found in fairy tales:

${ }^{29}$ Auckland Arts and Crafts Club, Catalogue of the first annual exhibition held at Coburg Street, Auckland, Open Ist November 1912... (Auckland, 1912), no page.

${ }^{30}$ Kröller, pp.111 and 122.

${ }^{31}$ Palmerston North City Council, p.3.

${ }^{32}$ Andrew Garran; ed., p.618.

${ }^{33}$ J. Ilott Ltd., Wanganui, New Zealand's river city (Wanganui: Wanganui Chronicle Co. Ltd., 1924), p.1.

${ }^{34}$ Thomas Bracken, The New Zealand Tourist (Dunedin: Union Steam Ship Company of New Zealand (Limited), 1879), p.39.

${ }^{35}$ Richard Wedderspoon, The Dominion of New Zealand, p.141. 
Nearly the whole city passes before him in brilliant panorama. He is circled by spire and dome, suburban isles, gullies creeping up between miniature mountains and hilltops far away, which are sylvan and enchanting enough to be the abode of fairies. ${ }^{36}$

Such comparisons to fairy land were not restricted to the promotional literature. The New Zealand artist George O'Brien in his late 1860s work "Designs of R.A. Lawson", [ILLUSTRATION 19] shows many of architect Lawson's buildings huddled together in a strange and irregular manner creating a mysterious, uncanny and almost surreal fictional city. According to art historians Roger Collins and Peter Entwisle, this work makes allusions to "the region of fantasy" and "the fairy tale"137, the purpose of which is unknown. However, the reasons for the New Zealand Government Publicity Office dressing up some local girls in supposedly fairy-like costumes and placing them in one of Wellington's nearby woods, are not unknown [ILLUSTRATION 20]. The Office was deliberately nurturing the romantic and fairy-like quality of Wellington City's green belt and parklands as an innovative means to attract tourists to the capital.

Booster authors were usually applying a certain literary vocabulary when promoting a particular city or town. Words like "picturesque", "pretty", "romantic" or "handsome" were constantly being repeated in all the material. Emphasis was always made regarding the number of hours of sunshine a particular place had, how its "villas" and "cottages" provided a relaxed and healthy lifestyle, and how a place's ample beaches or lovely walks supplied constant "amusement". Yet there are two literary conventions in this guidebook/tourist brochure kind of promotionalism that stand out - perhaps

${ }^{36}$ John Gershom Greenbough, Towards the sunrising; or, A voyage to the antipodes (London: Arthur H. Stockwell, 1902), p.100.

${ }^{37}$ Roger Collins and Peter Entwisle, Pavilioned in Splendour: George O'Brien's Vision of Colonial New Zealand (Dunedin: Dunedin Public Art Gallery, 1986), p.16. This painting, apart from being seen as a tribute to the designs of L.A. Lawson the architect, could also exhibit a wish-fullfillment theme on the part of the artist. For it could be regarded as a fanciful work depicting a future New Zealand once the country had fully developed and evolved into a prosperous and powerful nation. A similar advertisement was produced for the firm of Massey-Harris in Ontario, Canada. The artist who drew the Canadian lithographic advertisement took all of the plants from Toronto, Woodstock, Hamilton and Brantford, and incorporated them into one huge design, the purpose of which was to show "the power of the company". (See: Rosemary Donegan, Industrial Images (Hamilton: Art Gallery of Hamilton, 1987), p.44. 


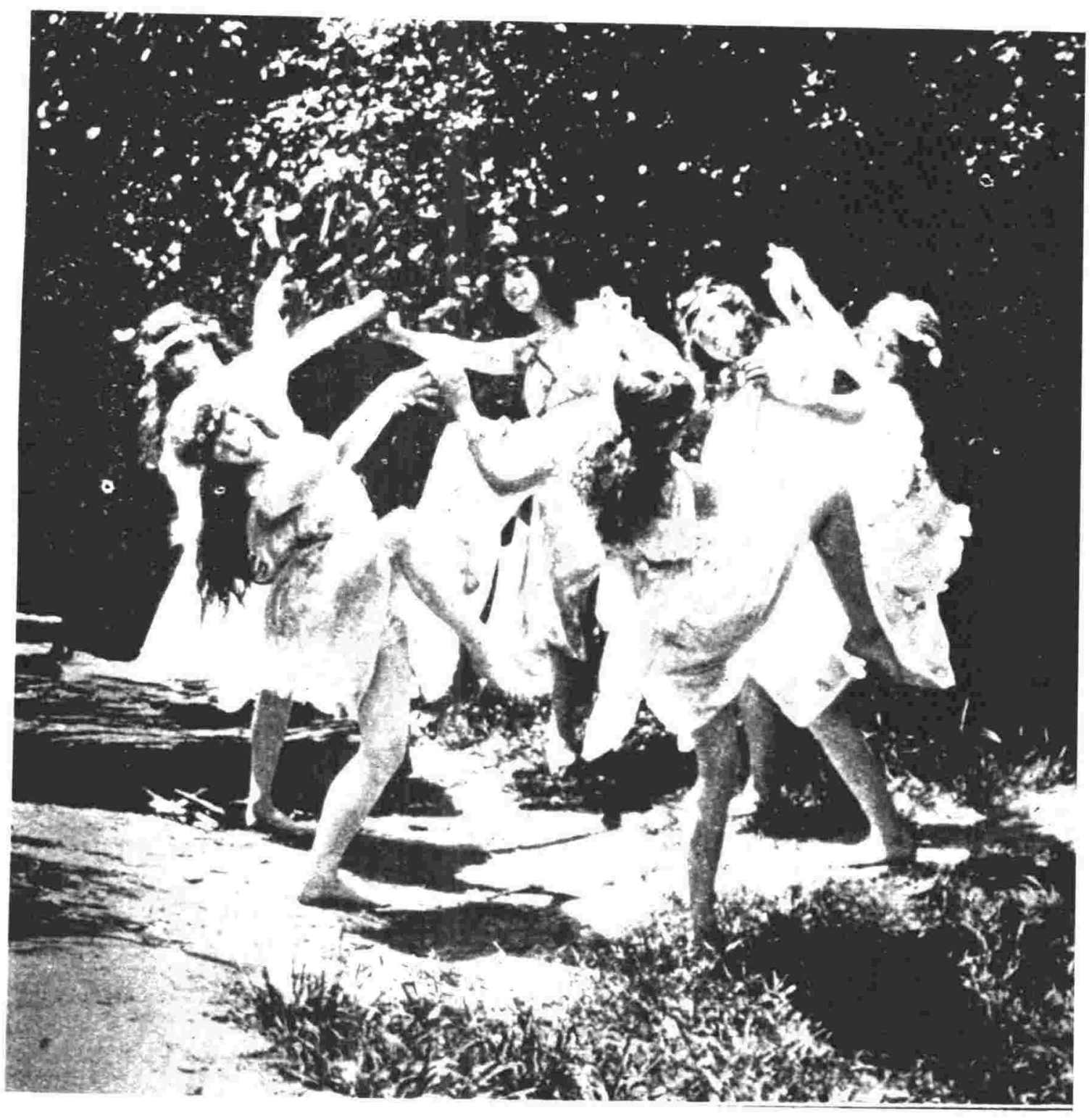


through their sheer repetition or by their comic bravado; they are the booster's use of alliteration and of understatement.

The constant use of alliteration, specifically in the titles of works or in the descriptions of places, dominates the promotional material. Such a technique was in all probability aimed at quickly catching the reader's attention. Alliteration was also undoubtedly a prevalent form of style in the prose and poetry of the day. In fact, when Rudyard Kipling visited New Zealand in 1891 (partly out of curiosity and partly as a means to improve his health), he reportedly praised Dunedin as "First, fairest, finest, fabulously rich..."; he also celebrated the city of Auckland in his poem, "The Song of the Cities" as: "Last, loneliest, loveliest..." ${ }^{138}$ Whether the country's urban promoters were consciously imitating Kipling or not we can never know. Certainly they were aware of his work for much of the booster material regarding Auckland and Dunedin tends to quote Kipling. ${ }^{39}$ Yet regardless of the fact that Rudyard Kipling may well have been culpable for the overwhelming flood of alliterative material, the booster propagandists exploited it for maximum effect.

Wanganui is described as "Pretty, Prosperous and Progressive." ${ }^{110}$ It is also, according to the firm of J. Ilott Ltd., destined to grow because of its "Prudent Policy of Persistent Progress." ${ }^{41}$ The title of one of the Onehunga-Manukau Chamber of

${ }^{38}$ Souvenir of the visit to Dunedin, "The city beautiful", by the American Fleet, August, 1925 (Dunedin: 1925), no page. According to Harry Ricketts, Kipling possibly went on a tour of the colonies as a result of medical advice; for he was suffering from malaria which he had picked up in India and which was infuriated by cold weather in England: "The standard prescription for such a condition was, of course, a sea voyage; which provides the most obvious answer to why Kipling came to New Zealand." See Harry Ricketts introducing Rudyard Kipling's One Lady at Wairakei (Wellington: Mallinson Rendel, 1983), p.10. Kipling's story was first published in The New Zealand Herald on 30 January, 1892.

${ }^{39}$ See the introduction by the Mayor of Dunedin to Souvenir of the Visit to Dunedin. It was a common New Zealand booster tactic to quote prominent literary, political, social or artisitic figures who had responded optimistically to a city or town while visiting. Promoters believed that the reproduction of such positive reactions in the booster material would act as an added incentive for tourists and settlers to come to the colony. A discussion on this particular booster tactic follows later on in the chapter.

${ }^{40}$ John Ball, title.

${ }^{41}$ J. Ilott Ltd., p.4. 
Commerce's booster works reads, "The Matchless Manukau." ${ }^{42}$ The Napier 30000 Club, an organization established in that city to presumably encourage settlement until the population reached the 30000 mark, called their city "The Playground of the Pacific." ${ }^{43}$ Marlborough was described as "SUNNY, SECLUDED, SHELTERED, SERENE."44 "Gisborne the Golden" was the way in which one general tourist and investment book tried to promote that city. ${ }^{45}$ In the promotional booklet Fertile Franklin, The Sunshine Country, the town of Pukekohe was labelled as "Prosperous Progressive Productive." ${ }^{16}$ Christchurch in one 1907 advertising work was described positively in terms of an "English... Episcopalian Eden" that had been founded by "men mighty in mind and muscle. ${ }^{147}$

Another popular and fashionable way to promote New Zealand's urban areas was through the use of understatement. Boosters were often telling their readers that it was only the constraint of space or the restraint of the New Zealander that prevented further booster embellishments. When reporting on Christchurch, John Harvey said that "To describe this beautiful city fully... would require space much greater than which is here at our disposal." ${ }^{48}$ The Mayor of Dunedin in 1925 said that the people of his city "have been inclined to be too reticent about the advantages of their city..." ${ }^{149}$ And the Franklin

\footnotetext{
${ }^{42}$ Onehunga-Manukau Chamber of Commerce, The matchless Manukau, 1877-1927 (Onehunga: Onehunga-Manukau Chamber of Commerce, 1927), title.

${ }^{43}$ Napier 30000 Club, The playground of the Pacific; sunny Napier...The tourist's best way through to New Zealand's thermal wonderland (Napier: G.W. Venables \& Co.
Ltd., ca.1929), title. p.36.

${ }^{44}$ Combined Progress Leagues and Chambers of Commerce of the South Island,
}

${ }^{45}$ Ben Green, ed., New Zealand tourist and commercial guide; a comprehensive illustrated guide to the scenic, sporting, health and commercial advantages of New Zealand with a foreward by Rt. Hon. G.W. Forbes (Wellington: General Publicity
Service Co., 1930), p.115.

${ }^{46}$ Franklin District Advertising Court Committee, p.4.

${ }^{47}$ Christchurch on Avon (Christchurch: Smith and Anthony Ltd., 1907), pp.6-7.

${ }^{48}$ John G. Harvey, Christchurch; the garden city and its industries (Christchurch: 1924?), p.1.

${ }^{49}$ Souvenir of the Visit to Dunedin, p.1. 
District Advertising Court Committee, swore that their little twenty page booklet was "but a meagre index" to their County, and that "an adequate description would fill a volume as large as an encyclopedia." ${ }^{150}$

As mentioned in Chapter 1, New Zealand was competing with Britain's other colonies, as well as America, for a share of the mother country's capital, emigration population and tourist market. Nor was it uncommon, however, for the primary urban areas within New Zealand to compete amongst themselves for this very same lucrative market. This urban rivalry is most evident in the debates which were raging in the Parliament of 1908 over proposed locations for a new capital; nearly every member championed the benefits of his own constituency, and recommendations for future sites included Marlborough, Palmerston North, Greytown, Hamilton, Auckland and Rotorua, to name only a handful. ${ }^{51}$

This rivalry, however, was most prominent amongst the Dominion's four major urban centres, and was commented upon frequently by foreign visitors as well as the country's own inhabitants. In 1901, H. Gaston de Ségur stated that: "Une rivalité pleine d'amertume règne entre Auckland, Wellington, Dunedin, et Christchurch. Chacune veut être, et persuader le monde qu'elle est réellement la cité principale." ${ }^{152}$ Similarly, André Siegfried in 1904 concluded that the country "has no undisputed capital, but four provincial cities which dispute the supremacy between them, and are rivals of each other." ${ }^{53}$ Beatrice Webb noted this inter-city competition when a prominent lawyer from Auckland started to criticise his own city:

Socially Auckland was a nondescript place with no intellectual circles. At Wellington there were the government officials, who formed an intellectual set. At Christchurch the Anglican Church had led the way to another type of culture. At Dunedin, the

${ }^{50}$ Franklin District Advertising Court Committee, p.20.

${ }^{51}$ See: NZPD (June 29 - July 29, 1908), pp.330-365. The issue over a location for a new capital was started with a debate amongst members about the prohibitive costs involved with the erection of new parliament buildings. Eventually, after much discourse and argument, nothing came of the whole issue, and the capital remained at Wellington.

52 "A bitter rivalry exists between Auckland, Wellington, Dunedin, and Christchurch. Each wants to be, and persuade the rest of the world, that she is really the principal
city." In Vicot H. Gaston de Ségur, p.4.

${ }^{53}$ André Siegfried, p.245. 
Presbyterians had done likewise. But Auckland... Football, racing and cricket were the principal subject of conversation. ${ }^{54}$

Even New Zealand's newspapers commented on the competition that existed between the country's urban places: "Town rivals town, and hamlet, hamlet, each one fights to the bitter end..." 55

The inter-city rivalry commented upon by foreign visitors and local inhabitants is readily apparent in the booster literature of the time. T.B. Lamburn, in a lantern slide presentation in 1901, promoted Dunedin at the expense of Auckland and Christchurch: "It has been said that the bustling manners of the business men here are a strong contrast to the languor of Auckland and the gentlemanly deliberation of Christchurch." ${ }^{156}$ Charles Wilson, in promoting Wellington as the most cosmopolitan city in the country because of its busy port, says that the capital is more interesting compared to "The almost stolid gravity of Dunedin, the curiously ecclesiastical and academic atmosphere of Christchurch, [and] the stalwart American-like patriotism, reflected in the very air of Auckland..." ${ }^{57}$ Wellington also promoted itself at the expense of Auckland in another promotional work that used humour to downgrade the intellectual capacity of Auckland's citizenry. The joke revolved around a Wellington man who had entered Auckland's new library:

"Splendid Library, is it not?", said his Auckland friend....

"Yes; What a shame you have not got people here with brains enough to come into it."

Likewise, the Dunedin Expansion League in 1913, tried promoting their city as being the most innovative since "It is the only city in the Dominion supplying electric power for factory purposes..." ${ }^{59}$ The League also tried to induce her citizens to even greater

${ }^{54}$ Beatrice Webb, p.25.

${ }^{55}$ The New Zealand Times (January 25, 1890). Quoted in Graeme Davison, "Cities and Ceremonies: Nationalism and Civic Ritual in Three New Lands", p.113.

${ }^{56}$ T. Lamburn, p.16.

${ }^{57}$ Charles Wilson, pp.13-14.

${ }^{58}$ Wellington, the capital city of New Zealand, p.1.

${ }^{59}$ Dunedin Expansion League, Facts About Dunedin. No.2. Dunedin: A Field for new industries (Dunedin: Dunedin Expansion League, 1913), p.2. 
lengths to promote Dunedin as the three other major centres had overtaken the city, relegating it to fourth position in the country. This concern is nowhere more evident than with the printing of the cartoon entitled "A Spur to Action", which emphasized how prominent the city of Auckland had become by 1911 [ILLUSTRATION 21].

Yet this inter-city competition was not restricted to within New Zealand. The Dominion's cities commonly promoted themselves to the detriment of their two major Australian rivals - Melbourne and Sydney. Such a strategy was particularly suited to mentioning how New Zealand towns, usually because of the climate, resembled those in Great Britain more than their Australian cousins ${ }^{60}$ Emphasis was put on the green trees and gardens which contributed to such a distinct image of New Zealand cities, in contrast to "the depressing monotony of the miles of brick and mortar that line the streets in Sydney and Melbourne." ${ }^{161}$ Sometimes this trans Tasman competition bordered on outright hostility. James Inglis, for example, in trying to attract British investment to New Zealand, vehemently denounces Sydney: "By contrast with the miserable makeshift and primitive arrangements of Sydney, Auckland rises to the rank of a modern city..." Inglis then continues the attack by stating that when Sydney is compared to Auckland, the former "sinks to the level of a medieval fishing village." ${ }^{162}$ The relationship, however, was reciprocal, as testified to by an English visitor: "Victoria in particular likes to crow over New Zealand." ${ }^{63}$

One booster technique that was perhaps not so prevalent as the others mentioned above, but was employed with enough alacrity to comment upon, was the tendency to portray New Zealand's cities and towns as being peopled by attractive women. In all probability, this practice was primarily related to previously mentioned themes about the need to prove that New Zealand was not a backwoods settlement populated by savages, but rather a cosmopolitan nation with a sophisticated and fashionable population. Such appears to be the reason for Alys Adlam's positive comments on female clothing in the
${ }^{60}$ Robert Brown, p.98.
${ }^{61}$ Andrew Garran, pp.648-649.
${ }^{62}$ James Inglis, p.9.
${ }^{63}$ Arthur Vivian Perry, Rough Diary of a Voyage to the Antipodes by a Dartfordian
ford: 1885$)$, p. 168. 


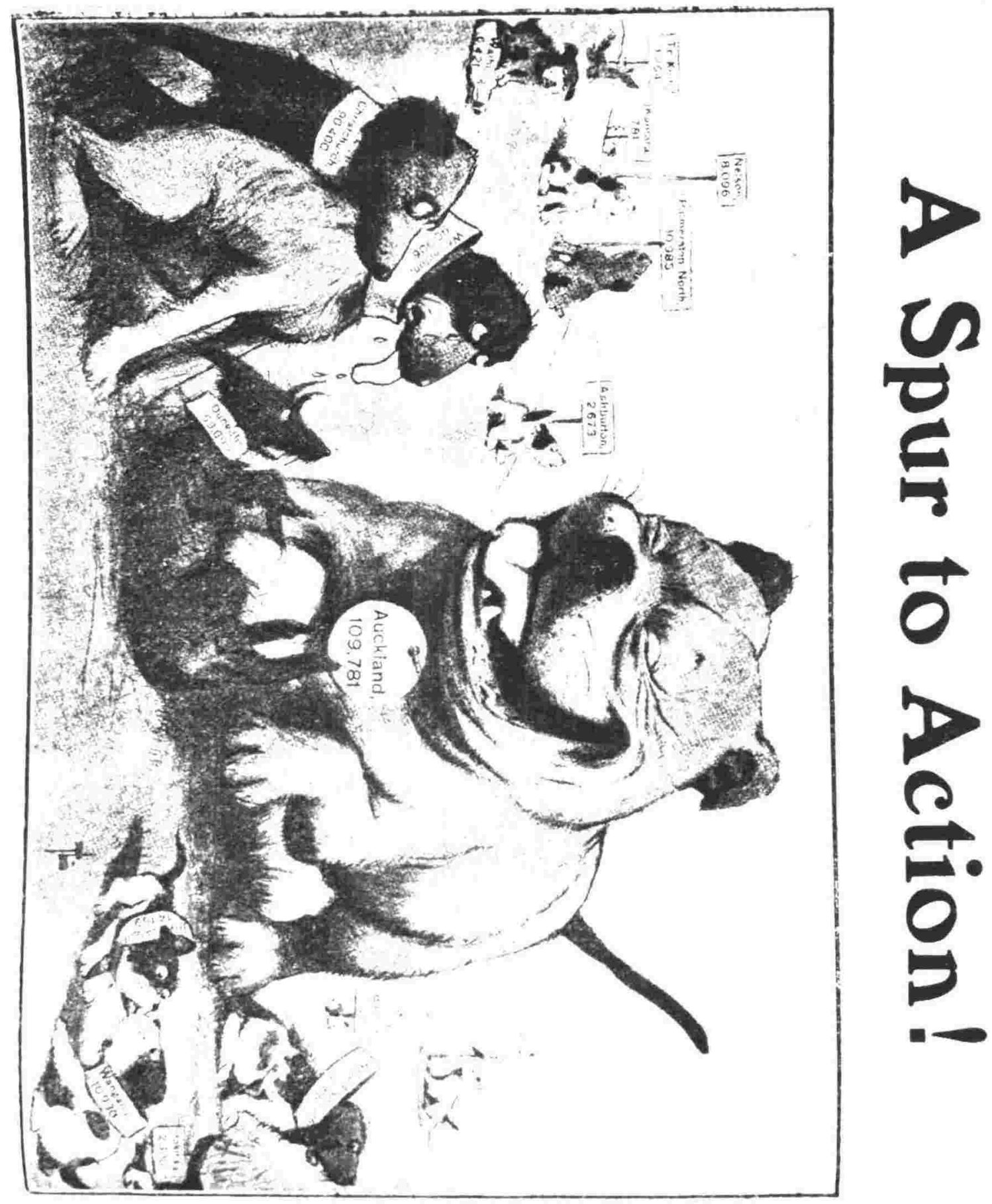

illustration 21 
Dominion: "The first thing that struck me in Auckland was the dress of the women and girls. So smartly were they attired... that I thought it must be a general holiday..." Adlam, after being assured by a local friend that most people in New Zealand are welldressed, concludes that the picture of the general population in the city "is a pleasanter sight than the drab shabbiness that prevails in London." 64 Such a comparison, with New Zealand appearing one-up on the Old World, is reminiscent of the frequent and positive comparisons made to Europe and England as discussed in Chapter 2.

Yet despite Adlam apparently emphasizing the civilised nature of the colony, the desire for sexual pleasure and/or the search for a companion or suitable marriage partner, cannot be ignored as a motive for travel. Certainly male visitors to the colony did not ignore the beauty of New Zealand's women. Stuart Reid, for example, after having arrived by ship from Australia for a tour of Southland, says: "I have seen more pretty girls to the square mile in Invercargill that I ever saw before in my travels. ${ }^{.65}$ However, there is evidence to show that some people deliberately undertook ocean voyages in pursuit of sexual pleasure; nowhere is this more evident than in the many voyages which the New Zealand poet William Hart-Smith, who was nick-named "the gonad nomad", took across the Tasman in 1917 in pursuit of women. ${ }^{66}$

Not surprisingly, the tendency to focus on the beauty and attractiveness of the Dominion's women, was adopted as a promotional device. ${ }^{67}$ This was especially the case in a great deal of the visual booster material. In the Souvenir of the Visit to Dunedin, "The City Beautiful", by the American Fleet (1925), for example, almost a whole page is devoted to the female attractions to be found along Dunedin's seaside [ILLUSTRATION 22]. Were the photographs of local women posing in bathing suits in each corner of the page presumably included to attract American seamen? There is

\footnotetext{
${ }^{64}$ Alys Adlam (Lowth), Emerald hours in New Zealand (Wellington: W \& T, 1907), p.5.
}

${ }^{65}$ Stuart Reid, p.26.

${ }^{66}$ Nelson Wattie, "New Zealand Writers in Australia". Paper presented to the Stout Centre's Eighth Annual Conference, "Australia-New Zealand: Aspects of a Relationship" (6-8 September, 1991). For a discussion of sex in New Zealand society during this time, see Stevan Eldred-Grigg's Pleasures of the Flesh.

${ }^{67}$ Even in today's tourist brochures and television commercials, pictures of beautiful women dining at expensive restaurants, dancing at night clubs, or lying in the sun on a beach, remain an often used promotional device. 


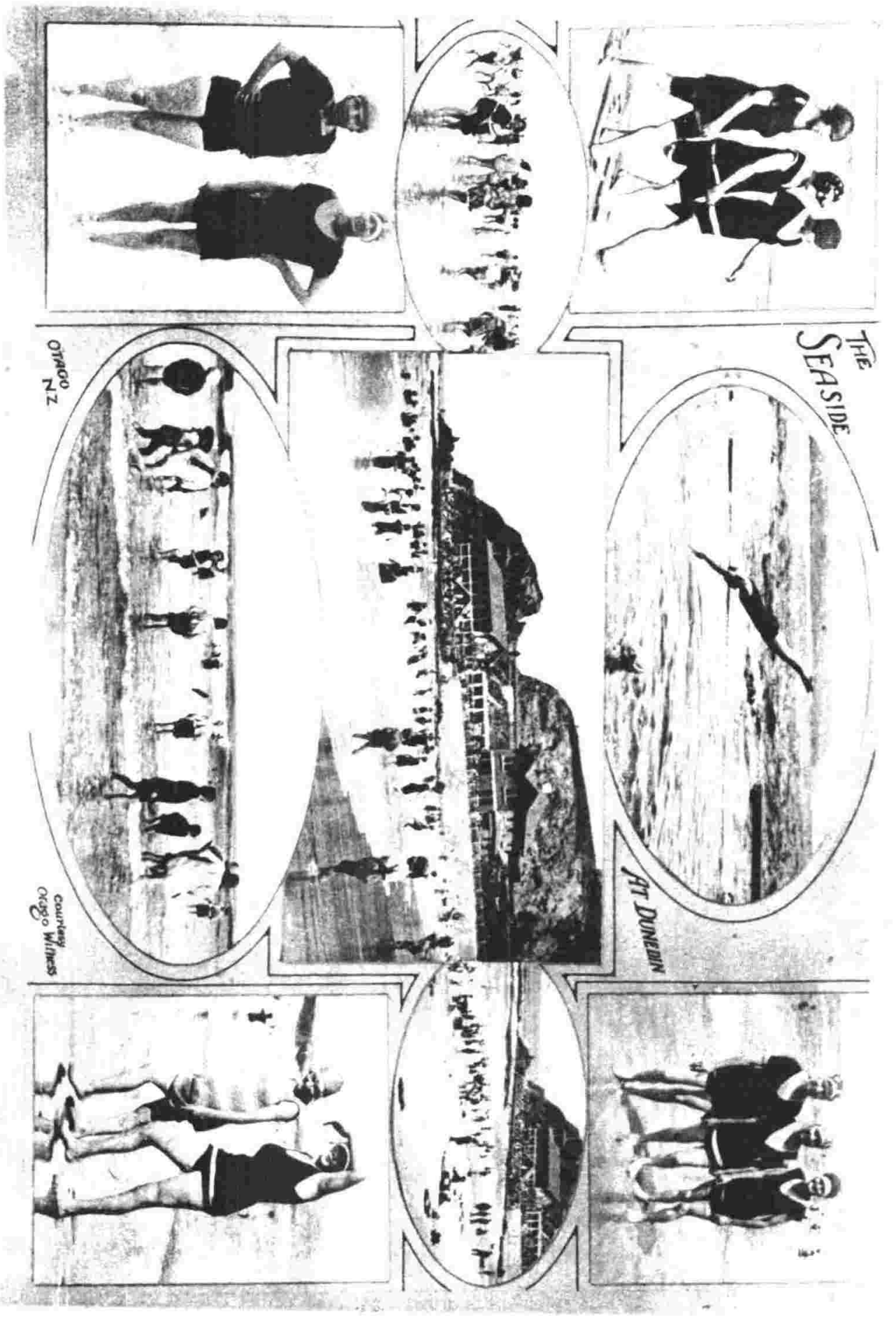

illustration 22 
no doubt, however, about the motives for including a photograph of the "pensive Maori maid" in New Zealand the Wonderland of the Pacific. [ILLUSTRATION 23] The naked woman, posed sensuously amongst the tall grasses, is a deliberate sexual image designed to entice would-be male visitors. ${ }^{68}$ Certainly the market for which such a tactic was specifically designed, the Victorian or Edwardian male tourist or settler, is as obvious to identify as that targetted by a Souvenir of the Visit to Dunedin. In fact, the convention of using native Maori women to advertise the country became the subject of some criticism in Parliament in 1903. John Duthie, a member of the Lower House and representing the City of Wellington, launched an attack on the Tourist Department's promotional literature that made a great deal about the, "handsome dusky daughters" of the Maori:

...he thought it was a mistake and degrading to allow a Government advertisement of that sort to appear. The scenic beauty of New Zealand was quite sufficient in itself to attract tourists. All Asiatic races were jealous of their women being dragged before the public... and such illusions to their daughters would still be offensive to them. ${ }^{69}$

Victorian men, however, were not the only ones in search of pleasures of the flesh or suitable marriage partners. According to evidence presented by Eva-Marie Kröller, British women sometimes embarked on overseas voyages to the colonies in order to get married. Kröller quotes a Canadian on his way to England in 1867 who was commenting on fellow-passengers, particularly:

.... a few elderly virgins who had emigrated from Scotland a few years before... to show their good graces to the Canadian youths; but [they] were also returning disaffected with the country - its bachelors in particular. ${ }^{70}$

$* * *$

A more common means of promoting New Zealand's towns and cities, and one mentioned in Chapter 1 of this thesis, was to celebrate the positive financial state of the

${ }^{68}$ It was frequently the case amongst nineteenth century New Zealand male poets to portray Maori women as nubile and available sexual objects. I owe this point to Harvey McQueen.

${ }^{69}$ John Duthie, NZPD (September 28 - October 23, 1903), p.87.

${ }^{70}$ Kröller, p.43. 


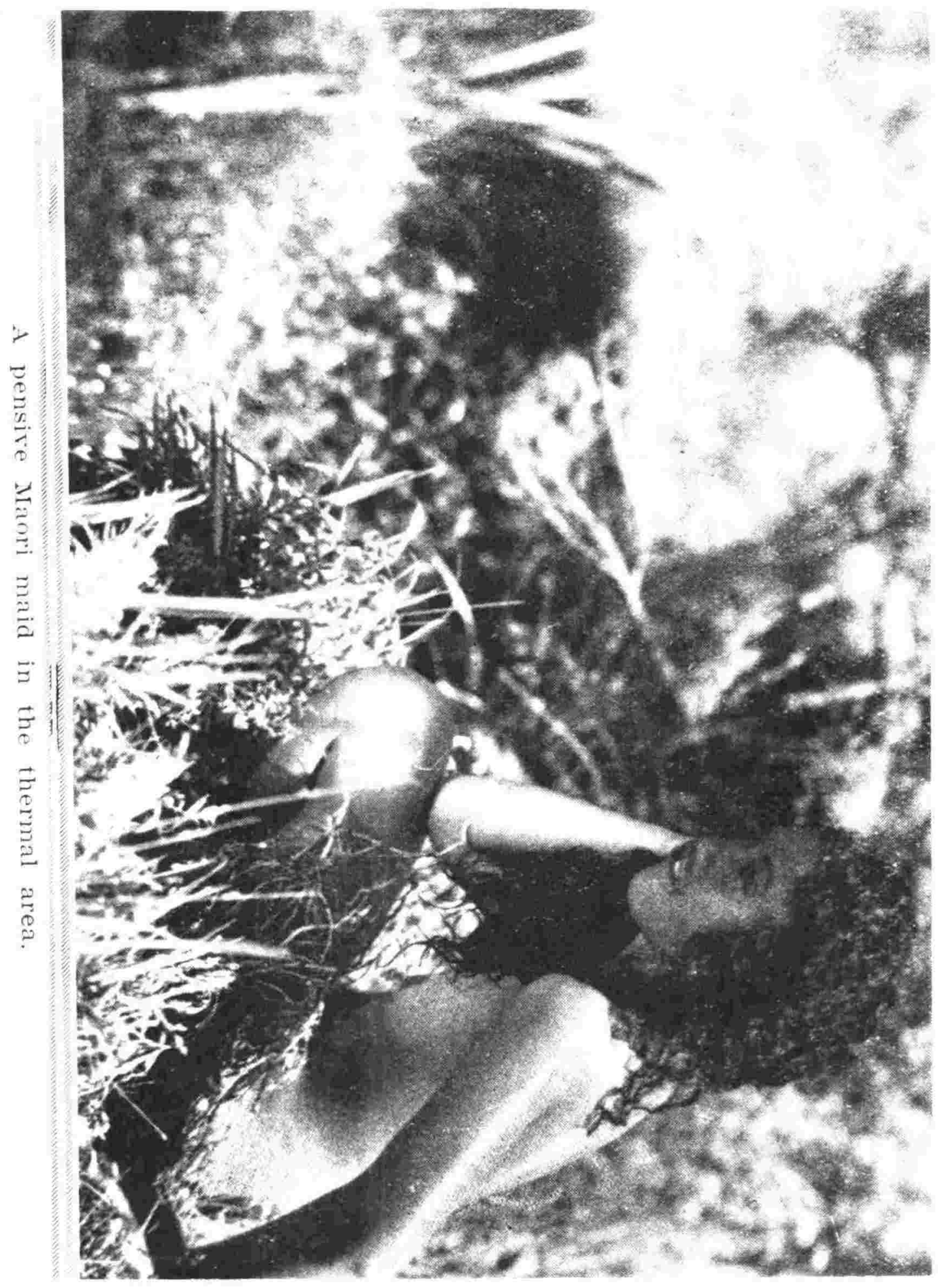

illustration 23 
country and to applaud the business acumen of New Zealanders. Again, this procedure was deliberately undertaken to counter the impression that the colony was suffering economically during the Long Depression years of the $1880 \mathrm{~s} .{ }^{71}$ According to Raewyn Dalziel, news of the poor economic position of the colony had almost succeeded in preventing the country from being granted a loan in $1886 .^{72}$ The art historian Peter Bacon Hales, when talking about the symbolic meaning of the 1893 World's Columbian Exposition, draws attention to this as being one reason for the exposition having been held in Chicago: that it was "An industrial centre sinking into the depression." ${ }^{173}$ This ploy of repeatedly praising the growth of a city's economy during financial hard times is particularly apparent in 1880 s and early 1890s New Zealand.

A common symbol of a city or town's prosperity during the 1880 s, was the number of ships that were berthed in its port. Symbolically, the more ships there were, the more trade that was assumed to be going on. This booster technique is similar to today's tendency to judge the economic well-being of a city by the number of cranes on the skyline. Thus, the more cranes there are, the more buildings that are being put up; for construction was intended to be a symbol that the economy of a city was vibrant and dynamic as it could presumably afford to expand. So in 1889 , when depicting Wellington as a prosperous city, Captain William Ashby did not dare omit the presence of the "six Union Company's steamers lying alongside together... to say nothing of a whole fleet of small coasting vessels."74 Nor did John Bradshaw, responding to criticism of the colony, forget to describe in his promotional work the "steamers of five thousand tons and more", which were berthed in Wellington's harbour. ${ }^{75}$

John Bradshaw was deliberately responding to James A. Froude's Oceana and its negative portrayal of New Zealand. To counter the adverse effects of Froude's economic appraisals, Bradshaw deliberately found evidence of a country not affected by

${ }^{71}$ This strategy of repeatedly emphasising signs of economic recovery in order to encourage business confidence, is also evident in the recession-marred industrialised world of the early 1990s.

${ }^{72}$ Dalziel, Julius Vogel,p.265.

${ }^{73}$ Peter Bacon Hales, "Photography and the World's Columbian Exposition", Journal of Urban History, 15, No.3 (May 1989), 251.

${ }^{74}$ William Ashby, p.28.

${ }^{75}$ John Bradshaw, New Zealand of To-Day (1884-1887), p.35. 
depression; he described the building spree which was going on all over the country with its places of worship:

Timaru could spend 90001. on the fine Early English Church of St. Mary... the Bishop of Waiapau laid the foundation-stone of a church at Napier, which was to cost 160001 ....in the following spring, a new cathedral... was consecrated at Nelson; and, during the same period of depression, the Roman Catholics opened their fine pro-cathedral at Dunedin. No wonder that, under these circumstances, neither Mr. Hoare nor Mr. Sala could find in New Zealand a country depressed beyond other countries of the world. $^{76}$

Like most of the previous boosting methods described above, the tactic of emphasizing the economic well-being of New Zealand's urban centres, is evident in the visual material as well as in the written literature. During the 1880 s a number of works were produced with streetscapes and wharf views as their principal subject matter. According to Graeme Davison, by concentrating on "the city's busy commercial and social life", such a theme "conveyed ideas of commercial vigour and enterprise. It was a favourite image of the merchant and the shopkeeper." ${ }^{177}$

In New Zealand painting this approach is evident with ILUSTRATION 24 Jacques Carabain's "Queen Street, Auckland" (1889). The subject matter of the painting - main street Auckland - exudes a variety of promotional symbols. The stone and brick buildings imply that the city has been built on a solid economic foundation; it seems to tell the viewer that Auckland is no mean town but rather a city of international reputation that is here to stay. The architectural embellishments on these same stone buildings, such as a cupola or crown, mirror this theme; they also serve to indicate that the city has reached a level of cultural maturity akin to European precedents. The well dressed people in the street, the paved sidewalks and the street lamps, serve as further evidence of the prosperity enjoyed by this city. There are no paupers or evidence of a depression here. In fact, a strong light seems to infuse the atmosphere with a sense of optimism by cleansing the scene of any indications of dinginess, despair or torpor.

This same theme of emphasizing progress and commercial enterprise can be seen in two pictures of Auckland's harbour. The first [ILLUSTRATION 25], is a painting by

\footnotetext{
${ }^{76}$ Ibid., p.333.
}

${ }^{77}$ Graeme Davison, "The Picture of Melbourne 1835-1985," in A.G.L. Shaw, ed., Victoria's Heritage (Sydney: Allen and Unwin, 1986), p.18. 


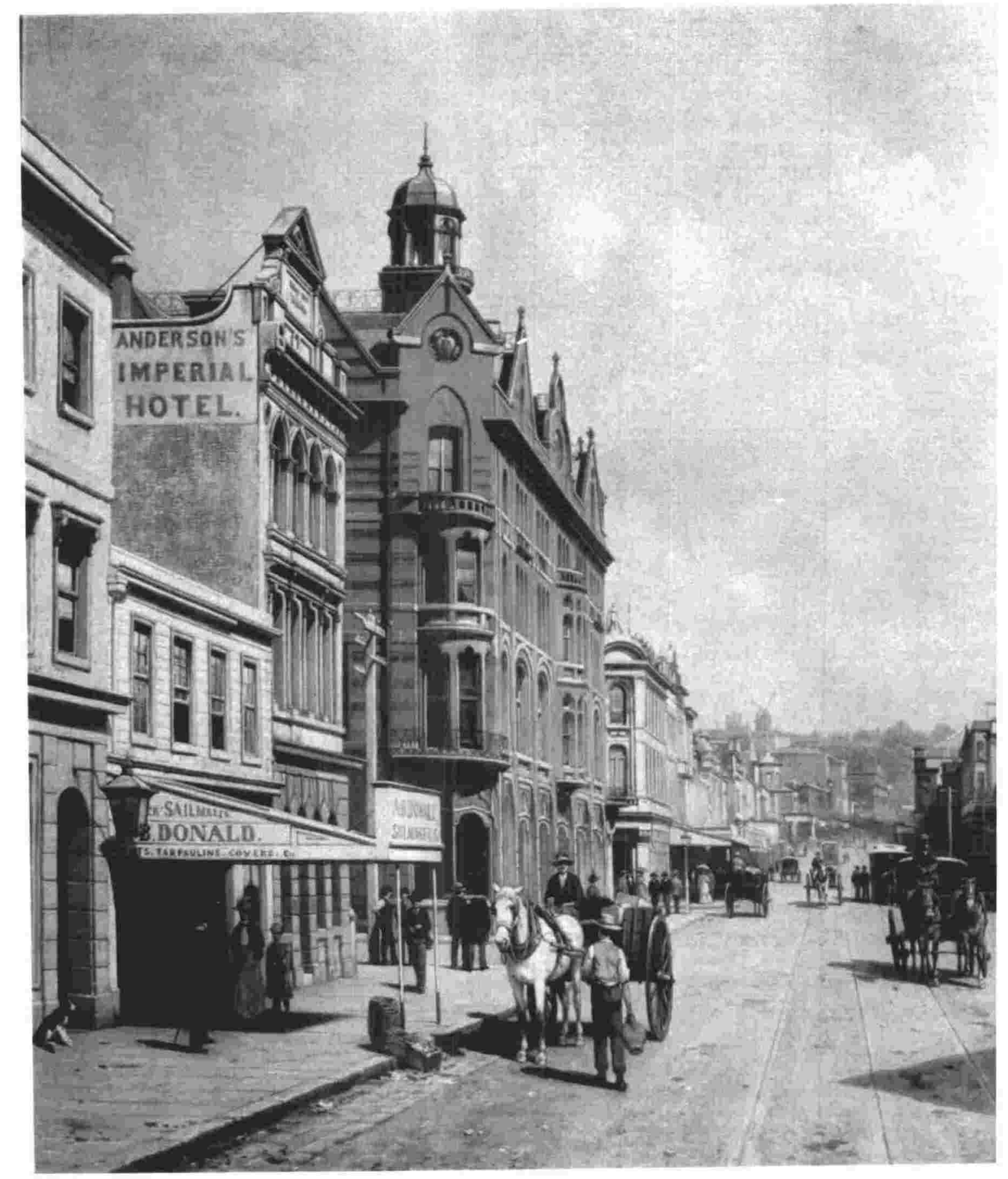

illustration 24 


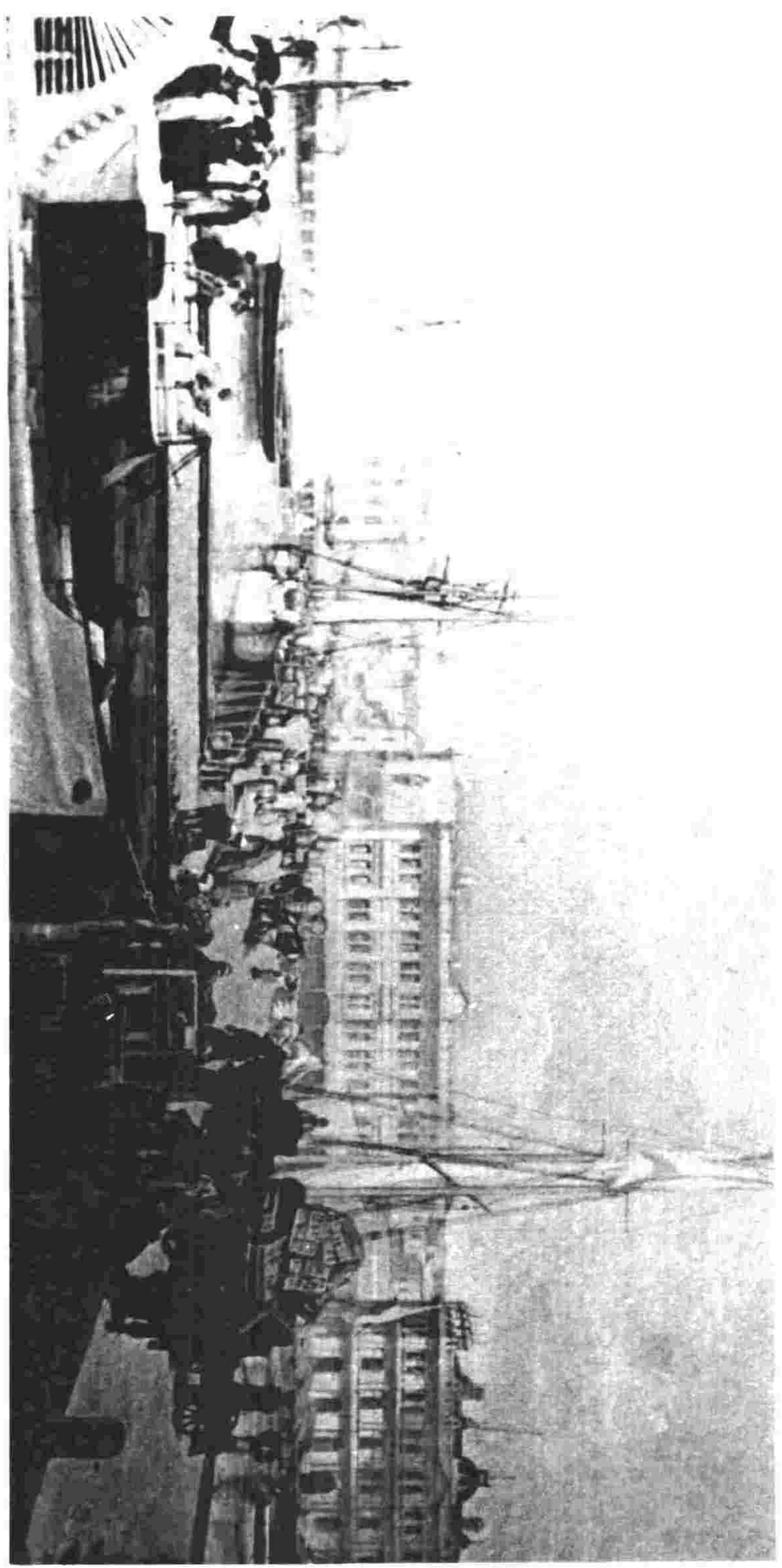

illustration 25 
Edward Augustus Gifford entitled "Auckland From the Wharf" (1887). The subject of this work is a busy port scene. Rich middle class day trippers disembark from a small steamer on the left. Meanwhile, porters are busy running everywhere, moving goods and unloading ships, all the while sailors are preparing their vessels to ply the wide oceans in search of riches and adventure. The general picture is one of a crowded and prosperous scene; such a feeling is furthered by the emphasis on the middle ground in which the presence of smaller coastal vessels is being utilised as proof that the city continues to do a brisk trade. While in the background, the majestic and ennobling stone premises of Auckland city proper, are used yet again to symbolise permanence and sophistication.

The other picture of Auckland's harbour [ILLUSTRATION 26], was prepared for a booster publication in 1889. The theme and the promotional tactics used are similar in nature and method to those in Gifford's work. Again, the spectator can see the rich middle class couples, this time going for strolls along the wharf in the foreground. In the middle ground is a busy pier replete with sailors and labourers; however, unlike Gifford's work that was so crowded and seemed to verge on the chaotic, the harbour in the publication for A.D. Willis seems orderly and efficient, and offers no hint of confusion. In this latter work there are no signs of a probable collision between porters. In fact, the wharf is so big it appears almost to be able to stretch right across the gulf. The theme of affluence is further repeated by the inclusion of numerous smaller craft in the bay, and in the distance, the masts of great ocean-going clippers, presumably bringing new settlers and new money. What makes the entire scene in this lithograph appear even more improbable and yet which contributes to its picturesque quality, is the relatively large sailboat on the left hand side foreground with its spinnaker (or racing sail) up. Normally, a vessel so close to the shore and in the harbour where there are other boats, would not dare raise this extra sail in the event that increased speed might pose a danger. ${ }^{78}$

Auckland was not the only port city to be treated in such a positive manner in the painting of the period. George O'Brien's depiction of Dunedin in 1888 is an excellent example of this kind of promotionalism [ILLUSTRATION 27]. The city occupies the middle ground of the painting, separated from the viewer by a foreground of tamed nature. The hills are gentle and rolling. There are no forests or tall trees, only a few

\footnotetext{
${ }^{78}$ I owe this point to Sarah Williams.
} 


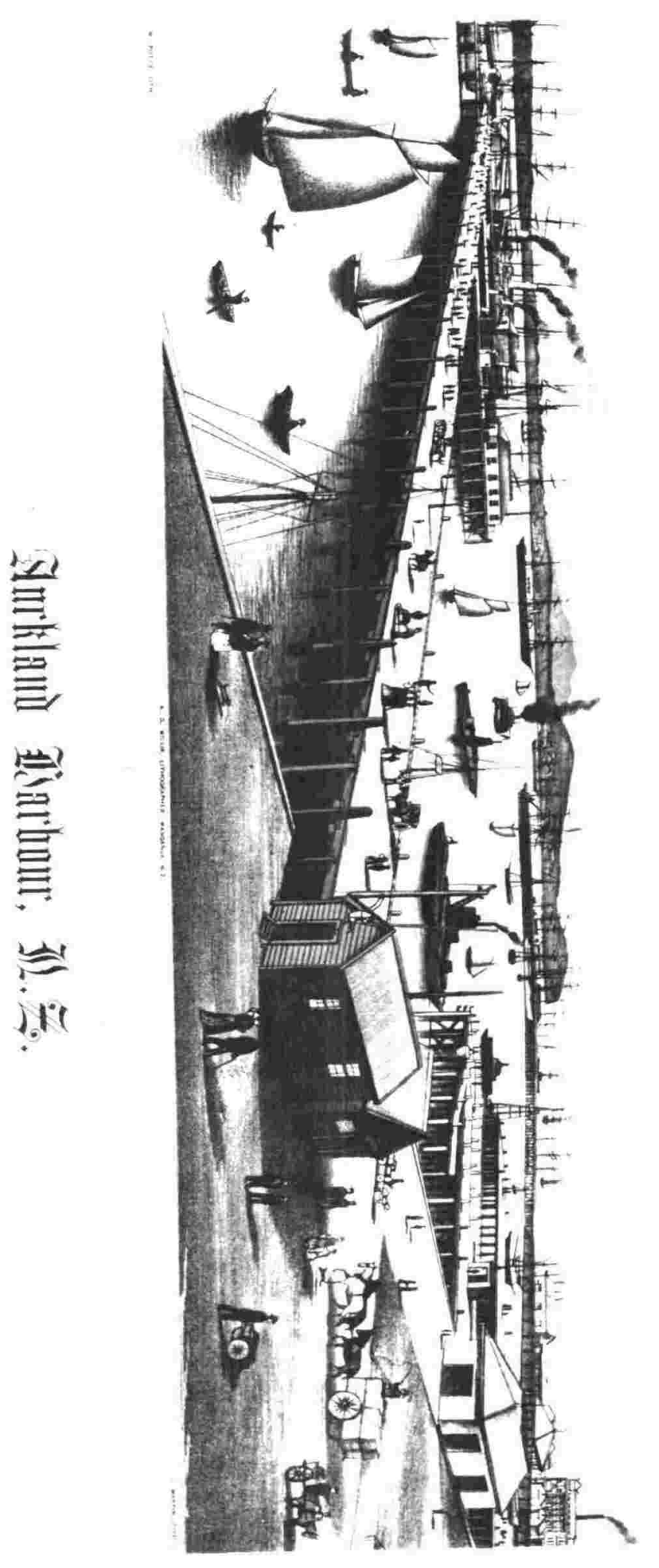

illustration 26 


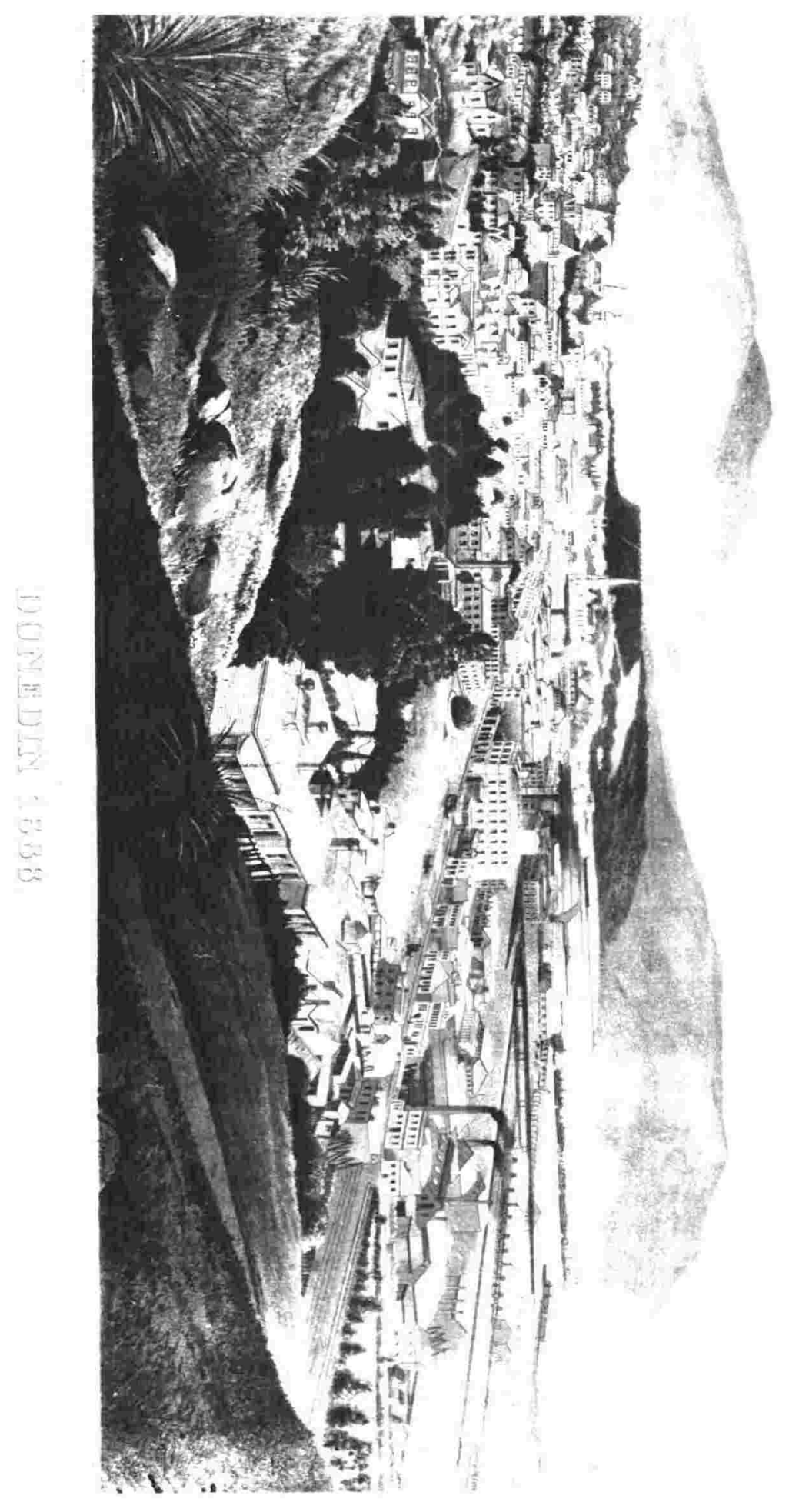

illustration 27 
oversized plants which would be considered exotic enough to the English eye to serve as a locational device, the purpose of which would be to place the picture somewhere in the South Pacific. O'Brien's inclusion of a few New Zealand plants is reminiscent of the marginalisation of the native element which was discussed previously in the section on historical diaromas; it serves to tell the prospective English settler (who was presumably viewing this picture), that the new land had been utterly and completely domesticated.

O'Brien has included in his panorama of Dunedin many symbols of a civilised and prosperous city. The painting is replete with tall church towers, icons of the pious and religious nature of the city's inhabitants. Large stone or brick buildings fill the valley, indicating the high level of affluence which the inhabitants have reached. The city is seen from a distance so no slums or rundown buildings can detract from the ordered and neat scene. Couple all this with the big ships lying moored along the harbour and the smoking stacks of a few industries (not too many that it threatens to recreate Old World industrial evils), then the final image of an ideal and mature urban setting is complete.

The last example to be looked at in this section regarding images of prosperity, is an advertisement that takes the form of a photograph [ILLUSTRATION 28]. The picture is of a freezing works in Christchurch. The photograph has obviously been tampered with by the developer, as seen in the artificial smoke emerging from the lone chimney stack. The smoke in the picture seems to erupt incred with a volcanolike fury, rather than coiling slowly into the atmosphere in a natural manner. The emphasis on the smoke was intended to show the viewer that the factory was operational; for smoking chimneys were meant to be read as favourable symbols of business activity, very much like those images of ships at port or cranes on the skyline.

An additional tactic for boosting a city or town was to stress the safety of a locale. As mentioned in Chapter 2, much was made of the low level of crime in the colony and how the cities and towns were much cleaner and healthier than Old World industrial centres. In keeping with this theme one finds examples of travellers impressed with the advanced fire precautions in Dunedin:

Every precaution is taken here against fire... at various intervals along the streets are fire alarms, connected with the head stations by telegraph. To give the alarm you break the glass font. Then, 


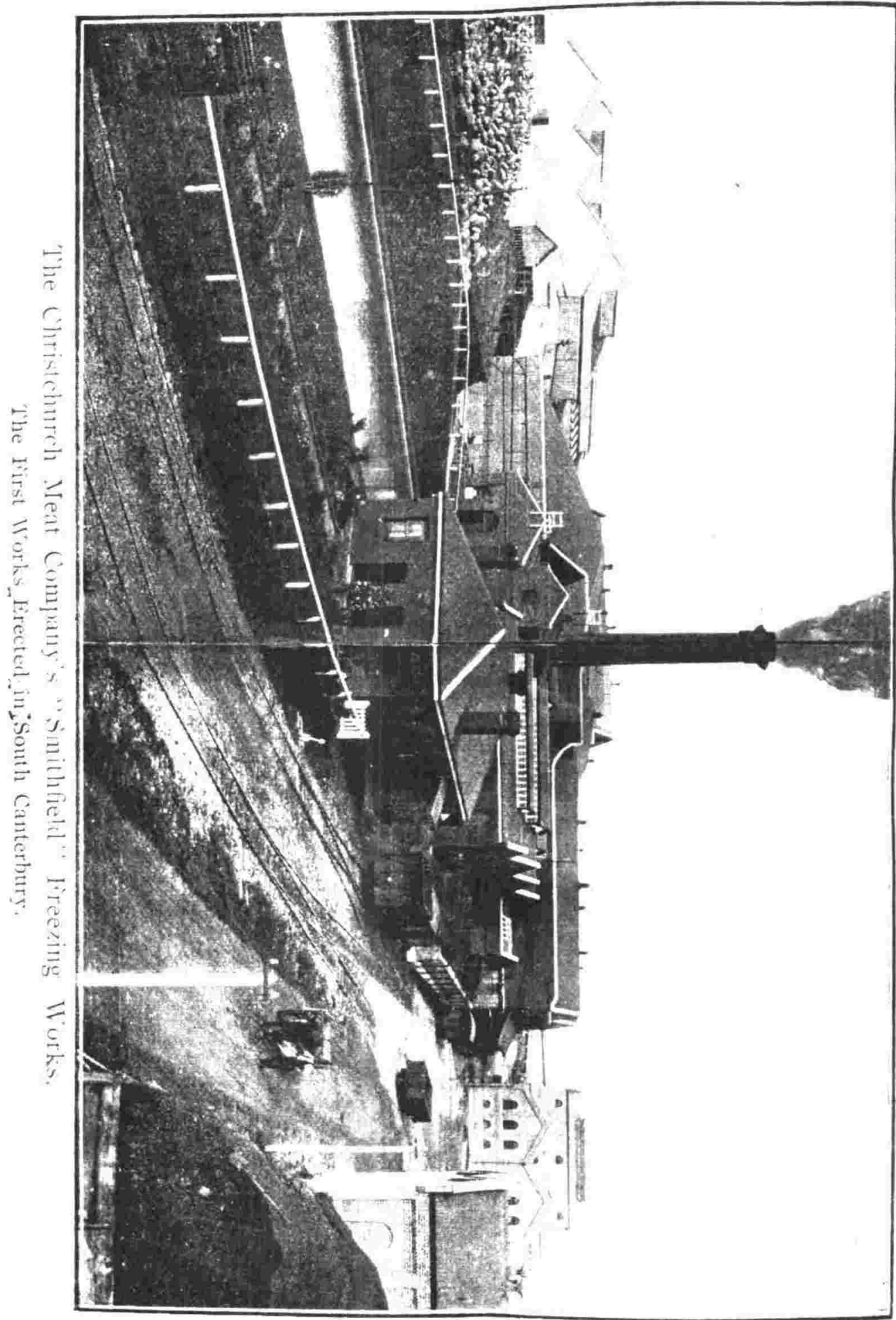

illustration 28 
too, there are the regular fire-escape ladders. This is the only town in the colonies where I have seen any such precautions. ${ }^{79}$

Once again, New Zealand's cities are portrayed as being far ahead of any other urban centres in the world. Related to this theme of safety and health was the emphasis put in booster tracts on places serving as actual health resorts. ${ }^{80}$ Certainly the hot springs at Rotorua dominated the health resort category, that is until the eruption of Mount Tarawera in 1886! However, other locales, such as the town of Akaroa in the South Island, pursued a similar path: "[Akaroa] is a spot that appears especially designed by nature for... the invalid in search of lost health". According to the Akaroa Advancement Committee, a group specifically set up to promote the town, "It is here that the overworked can find rest and variety, the convalescent renewed strength..." ${ }^{11}$

Statistics were commonly used also by boosters to reveal how healthy the country was in comparison to other places. George Potter, writing a booster work designed to attract migrants to New Zealand, included statistics showing the deaths by natural causes per one thousand inhabitants in a multitude of countries. France dominated the list with twenty-four deaths per thousand inhabitants, followed closely by the United States of America with twenty-two deaths for every thousand inhabitants. Yet the Australasian colonies were shown to be the healthiest places in the world, with Australia averaging only fourteen deaths per one thousand people, and New Zealand a mere eleven. ${ }^{82}$

George Potter's inclusion of statistics to prove the healthiness of the climate and country provides evidence of yet another stratagem used by boosters for promotional purposes - the inclusion of statistics from supposedly reliable and scientific sources so as to show the sound economic foundations of a city. According to Alan Artibise and his studies of boosters in Western Canada, "Boosters were constantly measuring their city's progress in quantitative terms - numbers of rail lines, miles of streets, dollars of

${ }^{79}$ James Edge Partington, Random Rot. A journal of three years' wanderings about the world (Guardian Office, 1883), p.318.

${ }^{80}$ Today, the mineral spa town of Hanmer Springs in the central South Island, seems to claim sovereignty in the area of New Zealand health resorts.

${ }^{81}$ Akaroa Advancement Committee, Lovely Akaroa (Akaroa: ca.1891), p.3.

${ }^{82}$ George Potter, Emigrant's guide to New Zealand: With a description of the colony and its provinces... (London: 1889), p.3. 
assessment, size of population, value of manufacturing output... and so on." ${ }^{83}$ Evidence of this latter strategy fills pages of New Zealand's promotional literature; booster works like New Zealand: Its History, Institutions, and Industries (1884), were forever inserting lists of manufactures and factories, numbers of workers employed in each, value of goods produced, etc... ${ }^{84}$ Similarly, the inclusion of statistics showing the low death rate which a city enjoyed, was in constant practice as well. The addition of graphs and numbers in the booster literature also provided boosters with a clever way of promoting a particularly unnattractive aspect of the urban environment, such as a dirty factory complex, without actually including an illustration of the complex itself (see below)!

Another promotional technique similar to that of using statistics, was the repetition of quotations from famous and popular personnages (usually political or literary), who had visited New Zealand and who had responded enthusiastically to what they saw. Boosters, as we have noted, often repeated Rudyard Kipling's lines regarding Auckland and Dunedin. William Pember Reeves uses Keir Hardie's (the British Labour Party agitator) spirited reaction to the colony in order to promote it as the best place for the working man to settle: "Mr. Keir Hardie... after a tour round the Empire, deliberately picks out New Zealand as the most desirable country for a British emigrant workman." 85 Such a promotional device appeared to enjoy the same weight and influence in booster material, as that of including statistical lists; for the comments of well-known and generally well-liked persons seemed to lend an air of authority and learnedness to a publicity campaign, however unjustified. This type of procedure resembles the way in which popular rock bands or film stars endorse political parties or presidential candidates in present-day British and American politics.

When the country's boosters discovered it impossible to wax lyrically over the aesthetic attributes of a place because of some particular eyesore in or near a city or town, they tended to focus instead on the positive benefits to be derived from the functional nature of this eyesore. John Weaver states that such was the case with the

${ }^{83}$ Alan J. Artibise, "Boosterism and the Development of Prairie Cities, 1871-1913," in Alan F.J. Artibise, ed., Town and City: Aspects of Western Canadian Urban Development (Regina: University of Regina Press, 1981), p.213.

${ }^{84}$ Mainwaring, New Zealand: Its history, Institutions, and industries. A narrative with statistics (London: 1884), p.155.

${ }^{85}$ William Pember Reeves, New Zealand Painted, p.27. 
Great Western Railway Yards in Canada; he says that the Canadian Illustrated News in 1863, "turned a blind eye to the collection of very plain buildings and praised the yard solely for size and functions. ${ }^{186}$ Beatrice Webb employed the same tactic when commenting upon the city of Auckland. She found the architecture of the local shops with their iron arcades and asphalt paths "ugly", "mean" and "hideous"; however, she praised the utilitarian features of the overall design as "good" and "useful for wet weather. ${ }^{187}$ Such a practice also provides an alternative reason as to why the country's boosters tended to rely so much on statistics regarding manufacturing instead of actually showing images of the plants and factories themselves.

\section{$* * *$}

It is diverting to hear an Italian expatriate upon the greatness of modern Rome. He will tell you there are above three hundred palaces in the city; that there is scarce a Roman prince, whose revenue does not exceed two hundred thousand crowns; and that Rome produces only the most learned men, but also the most refined politicians in the universe... ${ }^{88}$

Tobias Smollett, the English novelist visiting Rome in 1766, ridiculed the Roman's penchant for exaggeration and was highly critical of what he perceived of as their their unfounded civic pride. Smollett then proceeded to contest the Roman statements by arguing that the people, including the princes, were generally not that well off and that the city itself, despite its Classical and mythical associations, was in fact foul and unhealthy.

As the last two chapters have shown, New Zealand's urban boosters had been deliberately cultivating a certain image of New Zealand. They were so successful in their attempts, that according to some historians, New Zealanders actually believed their own propaganda. Jamie Belich, for example, in a talk given at the National Library regarding myths of settlement, stated that "New Zealanders believed their own paradise myths". ${ }^{89}$ And why not, for it seems that these myths were strong enough to convince

${ }^{86}$ Weaver, Hamilton: An Illustrated History, p.68.

${ }^{87}$ Beatrice Webb, p.26.

${ }^{88}$ Tobias Smollett, Travels Through France and Italy Ed. Frank Felsentein. (Oxford: Oxford University Press, 1981), p.249.

${ }^{89}$ Jamie Belich. Talk given at the National Library on May 6, 1991 regarding the rewriting of New Zealand history. 
people in Britain to leave their family and friends for good, and to look for a new life in a new land far across the sea? Arnoldo Cipolla, an Italian on a tour of the Australias, concluded that "il culto dei neozelandesi per il loro paese è superlativo."190 Consequently, it should come as no wonder to the reader that locals often tended to paint a picture of their cities and towns in an optimistic and favourable light. According to Keith Sinclair, "New Zealanders, we learn, demand 'LOVE ME, LOVE MY LAND'. They were quite intolerant of any criticism of it." ${ }^{191}$ Sinclair later on in A Destiny Apart, makes mention of the people's habit of exaggeration:

It was considered that the colonists were noted for 'blowing', that is, boasting. In the 1880 s New Zealanders claimed to have the biggest water-wheel, the biggest trout, the biggest wooden building and the highest wooden bridge in the world. ${ }^{92}$

Many of the foreign visitors who came to New Zealand became aware of this New Zealand exaggeration. One letter sent to the "Daily Mail" and surprisingly reproduced in a booster work, warned readers that "colonists are such inveterate puffers of their districts that no one ought to be betrayed by them into accepting their descriptions..."93 Baron Joseph Alexander Hubner, a former Austrian Ambassador to England, found that "the enthusiasm of the inhabitants passes all bounds... They compare Auckland with Naples, Nice, Genoa, and Constantinople, and Auckland surpasses all."194 Another tourist, when told that Wellington had the largest wooden building in the world, commented that "One has to take such assurances guardedly in New Zealand, where the people sometimes suffer from megalomania." ${ }^{19}$ An American travel writer writing for an American audience and who is otherwise full of praise for New Zealand, discusses

90 "[T]he cult of New Zealanders for their country is beyond expression." Arnoldo Cipolla, p.51.

${ }^{91}$ Keith Sinclair, A Destiny Apart. New Zealand's Search for National Identity (Wellington: Allen \& Unwin, 1986), p.79.

${ }^{92}$ Ibid., p.109.

${ }^{93}$ Letter reproduced in Arthur Clayden's The England of the Pacific or New Zealand as an English middle-class emigration-field (London: Wyman \& Sons, 1879), p.32.

94 Joseph Alexander von Graf Hubner, Through the British Empire (London: John Murray, 1886), pp.206-207.

${ }_{95}$ Maz Herz, New Zealand; the Country and the people (London: T. Werner Laurie, 1912), p.179. 
the booster's hyperbole: "...some extollers of New Zealand scenery had exaggerated;

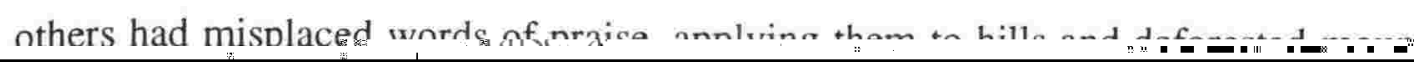

Q In

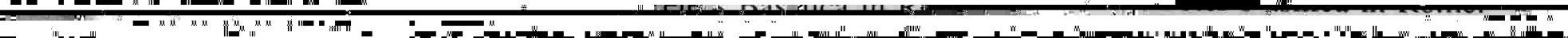
(1)

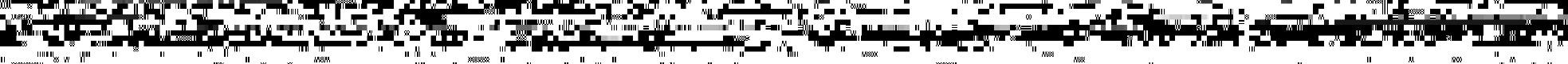

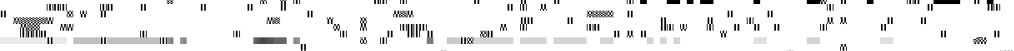

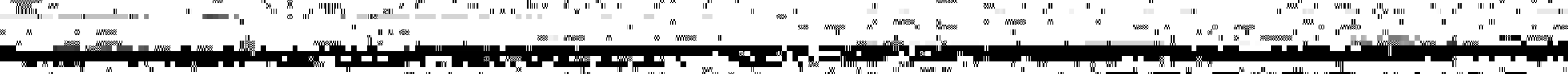

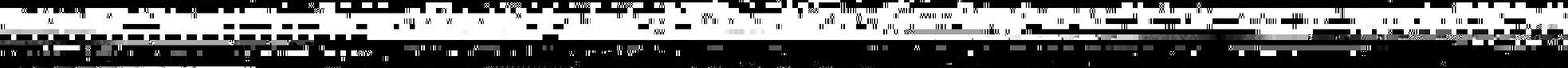
2

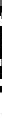

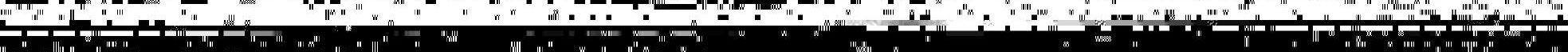

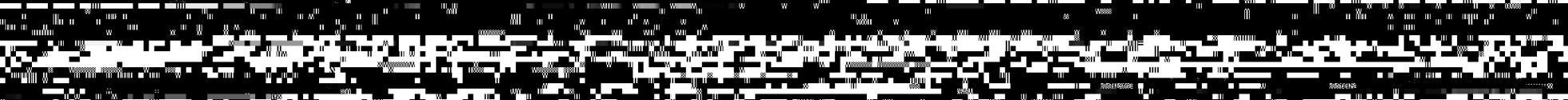

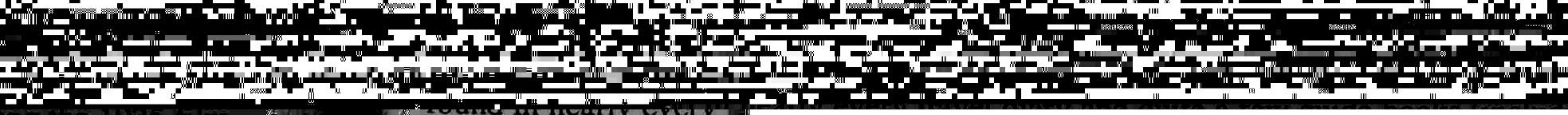

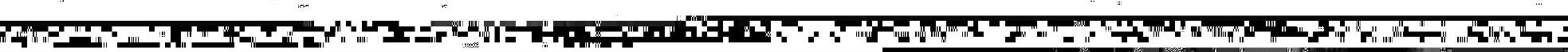

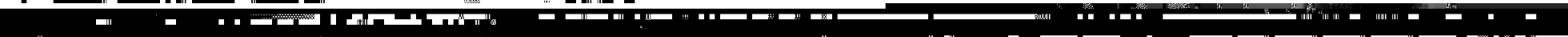

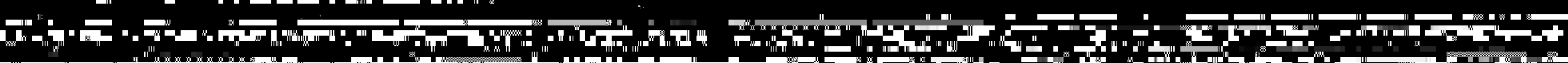

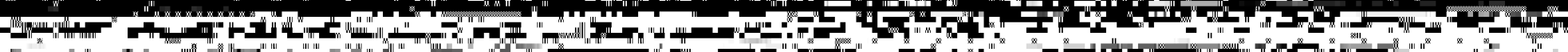

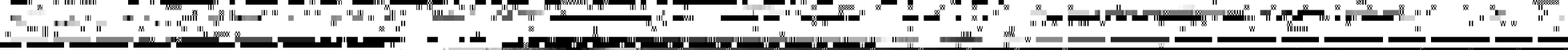
and

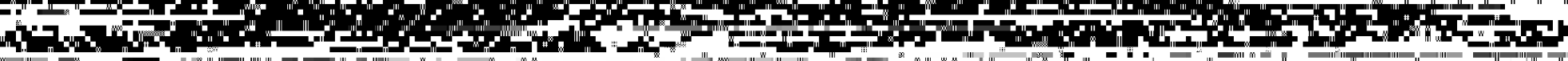

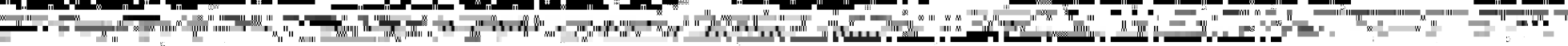

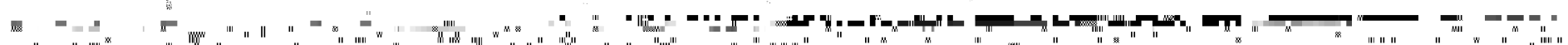

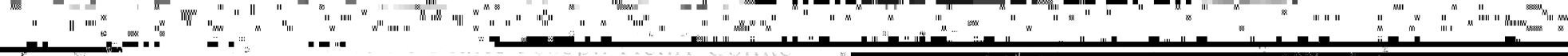

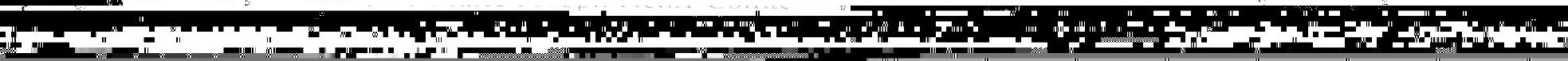

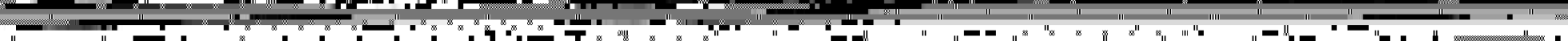

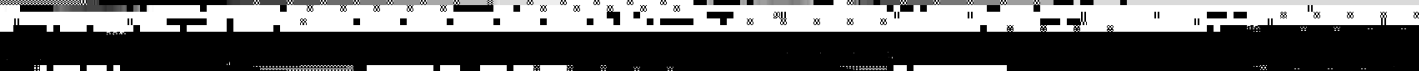


the story of the Wellington man and the wind; I know it." ${ }^{198}$ One would think that the extreme windiness of a place might be the last thing which people would use to promote a city? Yet this was not to prove the case, as the city of Wellington eventually adopted the nickname "The Windy City". 99 Perhaps the association of Wellington with tremendous wind was viewed as a distinctive way of making the city stand out from others?

The town of Invercargill was also the subject of numerous examples of this kind of strange promotionalism. The standard joke revolved around inhabitants having to stop for lunch midway when crossing the streets. ${ }^{100}$ (The wide streets were a legacy of the town fathers who had envisioned tremendous growth). Another booster technique for drawing attention to Invercargill was the series of advertising tactics that revolved around the town's southerly position. Invercargill was in fact promoted as the most southerly city in the world, and much was made about its location. ${ }^{101}$ One American visitor commented:

One of the standing jokes played off upon visitors is that they should avail themselves of beholding here that marvel of marvels, "the southernmost gas-lamp in the world". Of course, I complied with the custom, but... there was no difference that I could see between this and any other gas-lamp... ${ }^{102}$

A common object of much mirth and derision in the country at the time was the slow speed of local trains. James Partington favoured the slow speed as it was a guarantee of safety: "In case of an accident it could not be said that it was the pace that killed, fifteen miles per hour being the most that they are allowed to do."103 The snail-

${ }^{98}$ Maurice Baring, Round the world in any number of days... (London: Chatto and Windus, 1919), no page.

99 The city of Chicago is also known by this title.

${ }^{100}$ Constance McAdam, p.36.

${ }^{101}$ There is a town in Chile which also promotes itself as the most southerly place in the world.

${ }^{102}$ C. MacMurran, p.69.

103 James Partington, p.323. This guarantee of safety was also an important advertising gimmick to promote rail transport in the country; it would have been especially useful to counter negative criticism of the railway after a major disaster, such as the Auckland-Wellington Main Trunk smash which would kill 17 people some forty 
like pace of the trains became so famous (or infamous), that eventually a postcard was actually issued celebrating this peculiar rail transport. ${ }^{104}$ In the postcard a locomotive, ironically called the Flyer, is depicted as progressing so slowly that its conductor is able to umpire a game of cricket, a mule can keep the pace, an engineer assists velocity with the help of a pole, and passengers can sit on the roof reading their papers blessedly unaffected by any wind!

Perhaps the most peculiar advertisement for the country was that found in a letter from a young New Zealander to his cousin in Great Britain. After asking his British relative if he had seen the New Zealand Exhibition at the Empire Exhibition in England, the young lad proudly speaks up in the defense of New Zealand: "In one of your letters you spoke of our little island in rather a disdainful manner. What do you think of it now after reading of the might[y] eruptions?" The young New Zealander actually uses the eruption of Tarawera as a vehicle to promote the country! He goes on to say that "Old Vesuvius is a played out article compared with Tarawera..."105 Although this latter example is not urban in focus, it can be useful in showing the sometimes extreme forms of promotionalism to which boosters frequently went. It also shows the pride and determination to outdo the Old World that is characteristic of many New Zealanders.

The eruption of the volcano and the destruction of Tarawera Village (with the loss of one hundred and fifty lives) were also the cause of much fame for that place as it became a tourist attraction afterwards. ${ }^{106}$ This bizarre turn of events is similar to the story of Pompeii and Herculaneum which, after having been destroyed by Mount Vesuvius, became popular destinations for visitors in Italy. These latter examples are also useful in that they reflect a similar kind of perverse advertising which occurred after a tornado in the town of Vulcan, Canada:

years later in 1923.

104 The postcard entitled: "Our Local Express, Christchurch to Lyttelton" is in the Postcard Collection: ca.1910-1920. (Canterbury Public Library).

105 Derry Family Letters: Canterbury, October 17, 1886. (MS Papers 1043, Alexander Turnbull Library).

${ }^{106}$ According to 75 Years of Tourism, (Wellington: Government Printer, 1977), the site of another volcanic eruption became a popular tourist destination: "Late in 1916 an eruption at Waimangu killed the caretaker's family and ruined the accomodation house. However... the ruins became an added tourist attraction." p.7. 
It uprooted telephone poles... tore buildings apart... and imbedded blades of grass in fence posts. D.C. Jones, local druggist and prominent booster, photographed the tornado and gave the negative to a newspaper friend. When it received wide publication, [including publishing in the Encyclopedia Britannica] residents forgot the destruction and basked in the fame it brought them... Ironically... a worse advertisement would be hard to imagine, yet... for decades residents spoke of "our tornado" with evident pride. ${ }^{107}$

Graeme Davison maintains that such stories of detruction were effective promotional devices for cities. He says that they insinuated that nothing could destroy what these urban pioneers had created, and concludes that it was not surprising to discover that: "The Great Fires of London or Chicago...the earthquakes of San Francisco or Napier would all become the stuff of local legends." ${ }^{108}$

${ }^{107}$ Voisey, p. 166.

${ }^{108}$ Davison, "Cities and Ceremonies", p.100. 


\section{CHAPTER 4: PICTURES AND PAINTINGS}

Chapters 2 and 3 examined the image of the New Zealand city and town formulated by boosters primarily in the written mode, but with pictures and photographs supporting many cases. Chapter 4 will look specifically at the way in which boosters used graphic illustrations and paintings to promote the city and town. It will be seen that artists working for the boosters deliberately nurtured an image of the city that was optimistic and positive, for only images of prosperity and wealth were rendered. The first part of this chapter examines some of the political and cultural dimensions of particular forms of architecture and explains why certain building types, such as churches and civic buildings, received so much attention. It also provides a brief preamble on the merits of visual advertisement over the written word. The second part of the chapter will be devoted to the particular urban images which the artists fashioned and the reasons why they adopted this course. It is hoped that the reader will be given some understanding of the tactics which New Zealand's boosters utilised to promote their cities and towns in this field.

...buildings, indeed the entire built environment, are essentially social and cultural products... Their size, appearance, location and form are governed not simply by physical factors (climate, materials or topography) but by a society's ideas, its forms of economic and social organisation, its distribution of resources and authority, its activities, and the beliefs and values which prevail at any one period of time. ${ }^{1}$

Before commencing a study of the image of the New Zealand city or town rendered in pictures or photographs by the boosters of the period, it is important to understand the political and cultural propaganda inherent in certain forms of architecture. In a study of civic imagery it is imperative to ask questions about certain building types and construction materials, since these very buildings and the bricks and stones used to build them, constituted so much of the thematic focus of the promotional element. Consequently, the answers to three questions must be attempted; one must try to look at why only certain kinds of buildings (such as banks, civic offices and commercial

\footnotetext{
${ }^{1}$ King, Anthony D., "Introduction," in Anthony D. King, ed., Buildings and Society: Essays on the Social Development of the Built Environment (London: Routledge and Kegan Paul, 1980).
} 
agencies) became the predominant subject of promotional material; one must seek to understand why distinct revivalist styles, particularly the Neo-Gothic and the NeoClassical, eclipsed the New Zealand architectural vocabulary of the period; and one must also inquire as to why newer buildings made entirely out of brick or stone were the recipients of so much positive attention in the booster imagery of the period, to the detriment of the earlier wooden edifices which they were usually seen to be replacing.

In response to such demands, we could rightly argue the obvious: that New Zealand's architects had been trained in England and that once they arrived in the new colony they naturally tended to reproduce the prevalent British styles and building materials of the day; such styles and materials would have been more familiar to these transplanted British architects, a result of both their training and their cultural surrounding. We could also argue, and with equal justification, that the reproduction of styles and materials indigenous to or associated with Home, were an effective means of allaying emigrant feelings of homesickness and a way of making settlers feel more comfortable in an otherwise strange landscape. Yet despite the obvious explanations, there is another, more carefully concealed motive for the preponderence of revivalist styles in the booster material of the day: to evoke feelings of solidity and reliability in the colony's financial, business and governmental institutions. The emphasis on solid and enduring Neo-Classical and Neo-Gothic edifices acted as a kind of advertisement for the new colony, encouraging capitalists to invest their wealth in it and emigrants to entrust their fate to it.

One can see much of this confidence-inspiring motivation behind a majority of the commercial, municipal and governmental building designs in the industrialised AngloAmerican world. Such reasoning also lies behind a large number of domestic dwelling types, which were (and still are today) built not entirely for reasons of pure aesthetics or practicality, but rather with the intention of having a psychological effect by fashioning a distinct image of power, confidence or status. In fact, particular forms of architecture can be defined as essentially visual propaganda. Civic or commercial architecture is an ideal form of advertising since it is usually always visible (having been located on prime real estate and being nearly impossible to miss because of its size - a result of its function). It was for these reasons, according to Gordon Cherry's analysis of town planning in England, that Victorian railway stations used Gothic ornaments similar to Middle Age fortifications: "...every effort was made to reflect the 
power and prestige of the Company."2 Similarly, according to Colin Cunningham's analysis of Victorian and Edwardian town hall design in Britain, advertising was an important function of civic buildings: "this explains the determination to build great and costly towers which were by and large without functional justification." ${ }^{3}$ In a study of architectural styles in Toronto, Canada, Alan Gowans adds: "Historic High Architecture at all times and places was made to promote the convictions and interests of whatever Establishments commissioned them." affluence in a building style is also evident in an 1850 s lecture on the need for Leeds Town Hall to have a decorative tower: "The municipal buildings... besides the primary object of furnishing convenient accommodation... are intended to present an appearance worthy of the wealth and prosperity of the town."15

New Zealanders were not immune to these theories on the symbolic meaning of certain kinds of architecture, and the country's promoters would be sure to make the most about particular buildings and design plans when describing the built environment. Linda Tyler declares that the Classical style was employed for commercial buildings in the colony, as it "gave an air of permanence and civilization to the utilitarian and often temporary substance of the buildings." ${ }^{16}$ Likewise, Anne Crighton states why banks in New Zealand preferred Renaissance-inspired architecture: "Its solidity evoked dignity, stability, and security - the more imposing and splendid the facade... the more convincing the impression of power and wealth. ${ }^{17}$ In a similar vein, Robyn Ussher proffers one reason for the use of Venetian Gothic in some of the Dominion's major

\footnotetext{
${ }^{2}$ Gordon E. Cherry, Urban Change and Planning; A History of Urban Development in Britain Since 1750 (Henley-on-Thames: G.T. Foulis \& Co., Ltd., 1972), p.42.

${ }^{3}$ Colin Cunningham, Victorian and Edwardian Town Halls (London: Routledge \& Kegan Paul, 1981), p.166.

${ }^{4}$ Alan Gowans, "The Evolution of Architectural Styles in Toronto," in Gilbert A. Stelter and Alan F.J. Artibise, eds., The Canadian City: Essays in Urban History (Toronto: Macmillan, 1979), p.221.

5 J.D. Heaton in Cunningham, p.39.

${ }^{6}$ Linda Tyler, "Armson's Early Career," in W.B. Armson: A Colonial Architect Rediscovered (Christchurch: Robert McDougall Art Gallery, 1983), p.10.

${ }^{7}$ Anne Crighton, "Armson: Bank Architecture," in W.B. Armson, p.17.
} 
buildings: "it was symbolic of commercial prosperity." ${ }^{18}$ According to Jock Phillips, certain buildings in the colony developed powerful motifs: "The racecourse and grandstand were traditionally among the town's most important symbols of permanence, monuments to the civilising process." ${ }^{19}$ David Hamer says that civic building was a useful indicator of a town's prosperity and of just how far a place had progressed: "there was much play on the concepts of a 'wooden age' and a 'stone age'."10

Such attitudes about the symbolic meanings incorporated into certain forms of architecture are evident in the primary source material as well. When John Wickham arrived in the town of Palmerston North in the late 1880s, he found "an important, business-like front and we've come-to-stay air about the buildings... that is calculated to give confidence to those who have doubts of its stability." ${ }^{11}$ Charles Louisson, a member of the Legislative Council representing Canterbury during the parliamentary debates over construction of a new Parliament house, suggested the erection of a building in Wellington that would make a statement about the country and New Zealanders: "I do hope... the Government will erect a building... that will be worthy of the name... we have to build something that our people can look at and admire something worthy of the position of this country..."12

New Zealand's urban boosters were well aware of the powerful advertising medium which the built environment represented. They were also aware of the tremendous impact of visual advertising as well; for unlike written text which needed time to be digested, pictures were quickly absorbed and the viewer did not need to be literate. The appeal of advertising in the form of pictorial representation, according to experts in the field, is based on the premise that the mode is universal and instantaneous. ${ }^{13}$ The country's promoters employed this knowledge to the full when

${ }^{8}$ Robyn Ussher, "Armson in Christchurch," in W.B. Armson, p.13.

9 Jock Phillips, A Man's Country? The Image of the Pakeha Male - A history (Auckland: Penguin, 1987), p.68.

${ }^{10}$ Hamer, New Towns in the New World,p.115.

11 John Dickson Wickham, Rambling by a Tramp (Auckland: 1888), p.117.

${ }^{12}$ NZPD, 1908, p.39.

${ }^{13}$ Roland Marchand, Advertising the American Dream: Making Way For Modernity (1920-1940)(Berkeley: University of California Press, 1985), p.154. 
boosting their cities and towns overseas for the purposes of attracting migration, money and tourism. Like the verbal descriptions of cities and towns discussed in previous chapters, it will be seen that the visual material was also projecting a promotional message and therefore tended to be coloured or embellished. David Hamer, in New Towns in the New World, discusses at great length the promotional element when examining the ideal perceptions fashioned by New Zealand's emigration and booster agents. ${ }^{14}$ American scholars have also commented on attempts by various illustrators and artists to create more appealing images by exaggerating the positive in their pictures while ignoring the negative. Nancy Anderson, for instance, stated that nineteenth century American landscape artists "rarely addressed" the bleak aspects of indistrialisation and civilisation in the west, preferring instead, "a conciliatory message implying that the natural and technological sublime were compatible..."15 This type of promotionalism in New Zealand is evident in four major visual arenas: illustration, painting, photography and later on in the early twentieth century, motion pictures. This chapter will concentrate on illustration and painting; chapter 5 will examine photography and film.

Illustration is a category which encompasses many aspects of booster propaganda and which includes: bird's eye view maps, the title pages for booster publications, the logos for promotional groups, and lastly, general advertisements themselves (specifically for hotels, factories, small businesses and insurance firms which seem to be represented most frequently in the illustrated material). It becomes obvious after some time that municipal boosters and the artists whom they commissioned followed a common artistic formula for promoting their urban environments which involved a considerable distortion of the truth. Such methods included emphasizing wealth, growth, good planning, a variety of natural assets and resources, and a high degree of culture.

A common and favourite technique amongst boosters for publicizing a city or town was the bird's eye view map. This "map" allowed artists to accentuate selectively what were considered at the time to be the more positive aspects of the city, while simultaneously colouring over any outstanding negative features. The bird's eye map was essentially an artistic rendition of what the city or town was supposed to look like

\footnotetext{
${ }^{14}$ Hamer, New Towns in the New World, p.10.

${ }^{15}$ Nancy K. Anderson, "The Kiss of Enterprise," in The West as America, p.241.
} 
from above, usually from the air but sometimes from a high promontory or mountain. According to George Seddon and David Ravine with their work on images of Perth (Australia), such pictures of a city from an elevated position allowed artists and photographers greater flexibility in depicting the ideal rather than the real: "the detailed city 'on the ground'... may be in contrast with the idealised view from the safe distance and lofty vantage point..."16 The intent of the promotional nature of the bird's eye view map is much more obvious, however, when the focus of the artist is examined:

Artistic license was usually employed to emphasize what were considered at the time to be the more desirable urban attributes grand buildings, thriving industry and bustling commercial areas and transportation facilities. ${ }^{17}$

The 1875 bird's eye view of Dunedin is typical of such booster work [ILLUSTRATION 29]. Note firstly the emphasis on industry and trade in the foreground. The city's harbour is crowded with ocean going vessels of all shapes and sizes, everything from large passenger steamers to cargo clippers and smaller coastal craft. Meanwhile, along the shoreline, a busy rail yard is servicing and refitting trains so that they can send imported goods throughout the city's hinterland and keep Dunedin in constant communication with the rest of the colony. Much has also been made of the impressive stone architecture, the construction of which was financed by Dunedin's newly found prosperity as a rich gold town. To show that the city does not solely rely on its gold output, the artist has included the smoking chimney stacks of several manufacturers. The intent of this emphasis on the city's industry, as mentioned previously in other chapters, was to reveal the prosperity and wealth of a place.

Dunedin's boosters did not wish to appear uncultivated or uncivilised. For this reason the artist has put quite a good deal of effort into depicting the city's cultural attractions, particularly the splendid architecture of many of the buildings. Classical

${ }^{16}$ Seddon and Ravine, p.17.

${ }^{17}$ Walter G. Peace, "Landscapes of Victorian Hamilton: The Use of Visual Materials in Recreating and Interpreting the Past". Unpublished article for the Department of Geography, McMaster University. (Hamilton: 1989), p.3. The promotional intent of American bird's eye view maps in discussed to some extent by John W. Reps in Cities On Stone: Nineteenth Century Lithograph Images of the Urban West (Fort Worth: Amon Carter Museum of Western Art, 1976). Reps believes that the majority of lithographic urban views, particularly in the American West, were subsidized by railroads "in efforts to promote settlement" (p.17). 


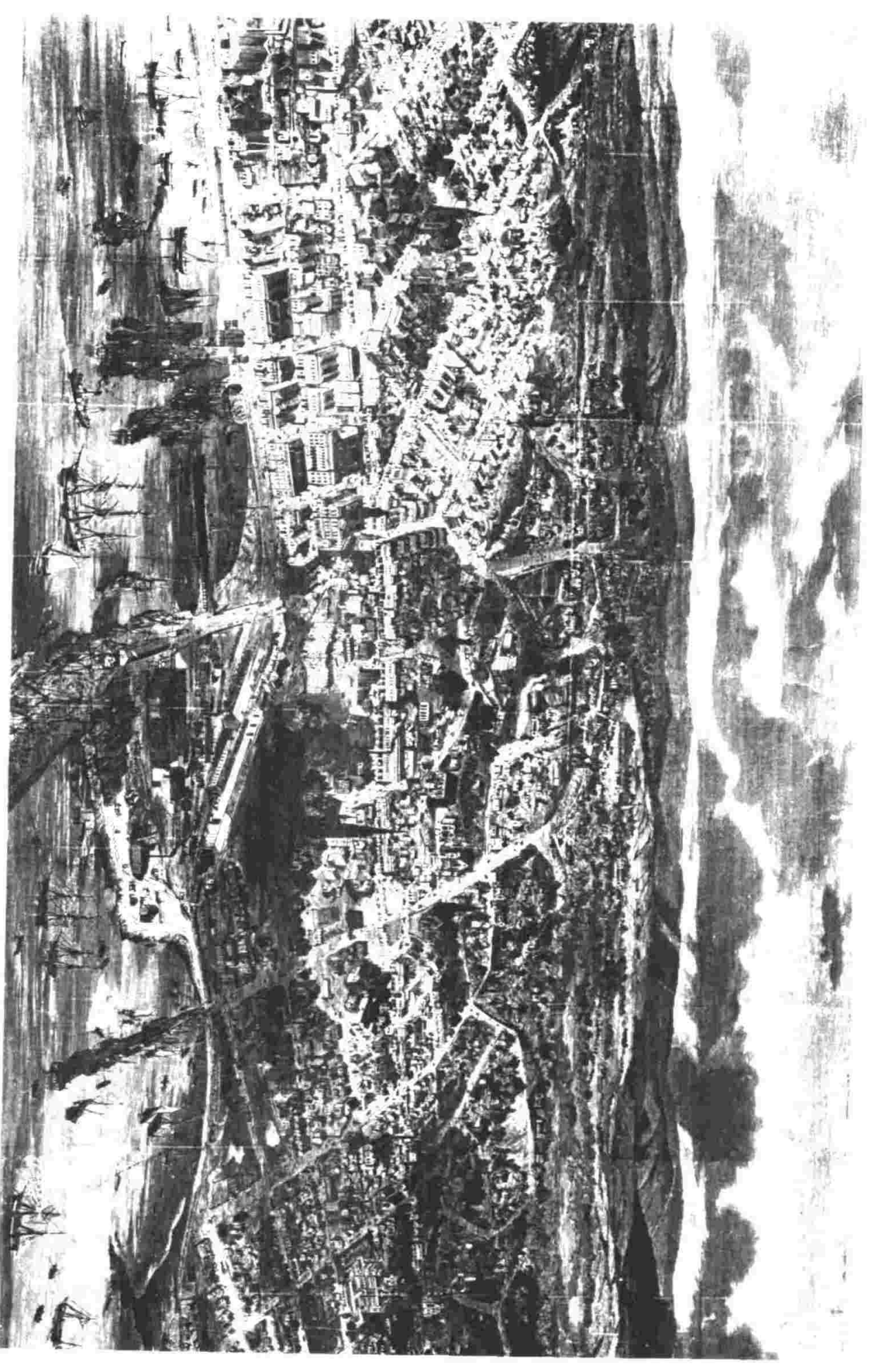

illustration 29 
pediments, fancy towers and cupolas, civic monuments, and the ornate spires of Gothic churches, all serve to catch the spectator's attention. Those particular stone or brick warehouses, banks, and civic or business offices emphasized on the map, and all ornately designed in the Neo-Classical and Neo-Gothic style, stood as further symbols of permanence and prosperity. The emphasis on the churches in the city also reflects the desire of the promoters to develop an image of the inhabitants as moral and religious. This religiosity would be in keeping with the particular denominational origins of the founding pioneers of Dunedin and was also useful for attracting a particular class of immigrant, one that was preferably law abiding and that attended church regularly. ${ }^{18}$

There are no obvious slums in the bird's eye view. Instead, the many homes shown in this map and which testify to the city's development, all appear to belong to the prosperous middle classes. The carefully planted trees, the city's Octagon, the beautiful residences and the well designed factories, were all meant to capture the imagination and to alleviate the oppressive monotony of grid-iron urban planning which was typical of many industrial towns of the period: "The collage of architectural styles and vintages which characterized the urban landscape provides the reader with a sense of architectural order and diversity which... contributed to the quality of life in the city." 19

There are other less obvious booster techniques employed in this illustration. In the distance on Dunedin's hills, for example, are the impressive homes of the upper middle class, a further testament to the success and affluence of the city's inhabitants. The homes of this wealthy upper class are reached on apparently paved roads which have been reduced in grade by the artist to compensate for the actual steepness of the terrain. The city's hills are indeed much higher than the map would suggest and they would have presented a strong impediment to development. Finally, in the background of the picture stretching as far as the eye can see, are rich acres of uncultivated and undeveloped land awaiting settlement, an attractive inducement for intending farmers and settlers.

${ }^{18}$ The Otago Association founded in 1848 had originally been a Wakefieldian colonisation scheme based on the desire to create a community of Free Church of Scotland settlers in New Zealand.

${ }^{19}$ Peace, p. 12 . 


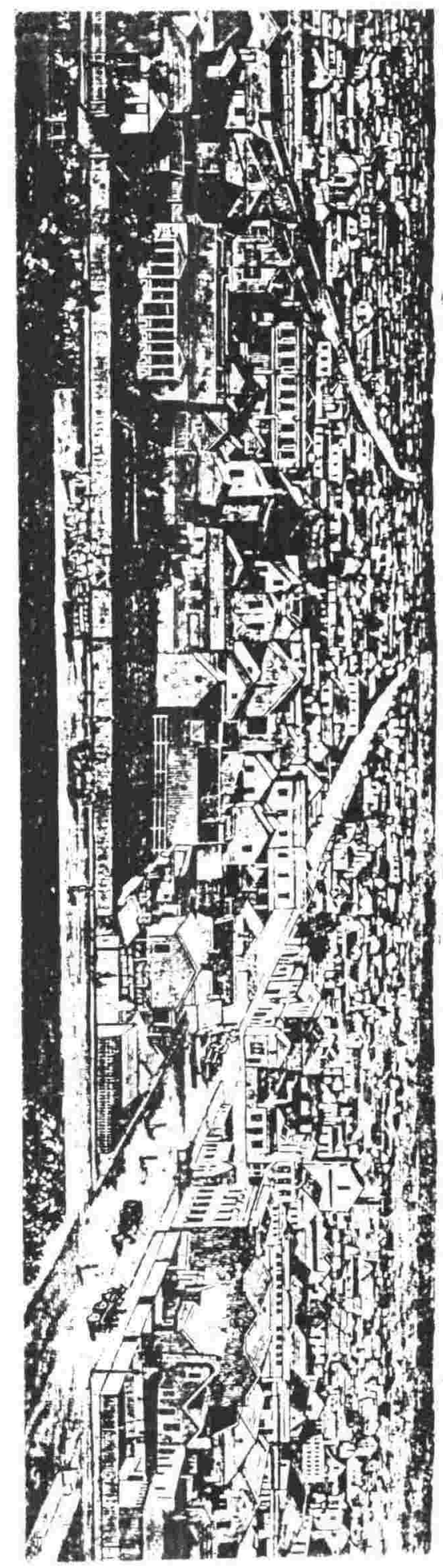


Dunedin was not the only centre to exploit this illustrative procedure. The city of Invercargill in an illustration from the New Zealand Graphic of 1890, also used this method to champion itself [ILLUSTRATION 30]. In the picture the artist has not only drawn the viewer's attention to the well-planned wide streets and the numerous buildings but has succeeded also in making Invercargill appear as an immense metropolis, the skyline of which extends beyond the horizon line! This feeling of enormity echoes Graeme Davison's comments on a bird's eye view of Melbourne which, "was designed to reinforce a sense of urban progress and 'metropolitan vastness'." ${ }^{20}$ This urban immensity, coupled with the artist's attention to the length and depth of the city's streets not to mention its rigid grid pattern layout, suggests that the people of Invercargill have conquered their environment; theirs is a civilised and ordered landscape, (a theme in keeping with Chapter 2). Walter Peace in his work on bird's eye view maps reiterates such a point, saying that such pieces were meant to affirm symbolically the settler's command over the natural landscape. ${ }^{21}$

Advances in photography and aviation meant the illustrated bird's eye view maps were replaced with photographs of the real thing. Photographers not only published various panoramic pictures taken from church steeples or other high locations, but they actually took the camera into the aeroplane and took pictures of the city from above. Again, as with the illustrated bird's eye view maps, distance and height created a vision of the city or town below that appeared highly sanitized and organized. Artists would not only take pictures on a bright sunny day so as to get the best possible result, but they would also be sure to capture only those elements in the city which might be considered constructive for promoting an area, particularly the well laid out public parks and the beautifully designed municipal and religious buildings. In 1930, Sun Newspapers published a booklet entitled Auckland From the Air (See ILLUSTRATION 46, Chapter 5). The work depicted numerous photographs of the city from a aeroplane; those particular views of a spacious and landscaped business district with a bright South Pacific sun reflecting on the stone walls of the buildings, rendered a pristine and

\footnotetext{
${ }^{20}$ Davison, "The Picture of Melbourne 1835-1985", p. 19.

${ }^{21}$ Peace, p.6.
} 
thoroughly optimistic picture of a Renaissance like utopia along the lines of Piero della Franchesca's fifteenth century plans for an ideal city. ${ }^{22}$

Other common forms of illustration which praised New Zealand's towns and cities, and particularly the manufacturing industries which helped support them, were the various title pages of encyclopedias and industrial catalogues, such as the example from the 1902 Cyclopedia of New Zealand [ILLUSTRATION 31]. The country is personified by the female figure of Zealandia, an image comparable to that of Great Britain's Britannia or the United States' America, and one which smacks of British imperial rhetoric. Zealandia is portrayed sitting astride neither a throne of wood like traditional monarchs nor a bed of flowers like mythological characters, but rather on a factory roof! The light which burns in the candle which Zealandia holds is not one symbolizing truth or justice, but rather industry. Her candle conjures up likenesses to the numerous smoking chimneys around her. On her lap rests a ledger, not a codex of laws. What allows her to prosper are urban based industrial networks: the miles of railway lines, the busy ports and wharfs, the numerous manufacturing establishments and the mining companies. Certainly the two pictures on either side of her, one of sheep and of cattle and the other of harvesting, cannot be ignored. But these are insets, smaller than the industrial symbols around her and beginning to fade into the background like the Maori motifs above her. The image of Zealandia presented here resembles Domenico Tojetti's 1875 celebratory painting of America personified; America in Tojetti's painting, according to art historian Patricia Hills, is revealed as being healthy and prosperous because of both the allegorical help of a diverse group of female handmaidens (representing industry and the arts as well as agriculture), and because the forces of socalled civilisation (epitomised by a locomotive) are replacing the savage element (depicted by the fleeing native Americans and buffalo), ${ }^{23}$

The industrial and mining exhibition catalogues not surprisingly show similar themes. The figure of Zealandia personified appears again, this time for Auckland's 1914 Industrial, Agricultural and Mining Exhibition [ILLUSTRATION 32]. Although Zealandia sits on a more traditional throne with a beautiful sunset background behind her, the cornucopia or horn of plenty which she holds and which is meant to affirm the

${ }^{22}$ Auckland from the air, 1930 (Auckland: Sun Newspapers Ltd., 1930).

${ }^{23}$ Patricia Hills, "Picturing Progress in the Era of Westward Expansion," in The West As America, p.136. 


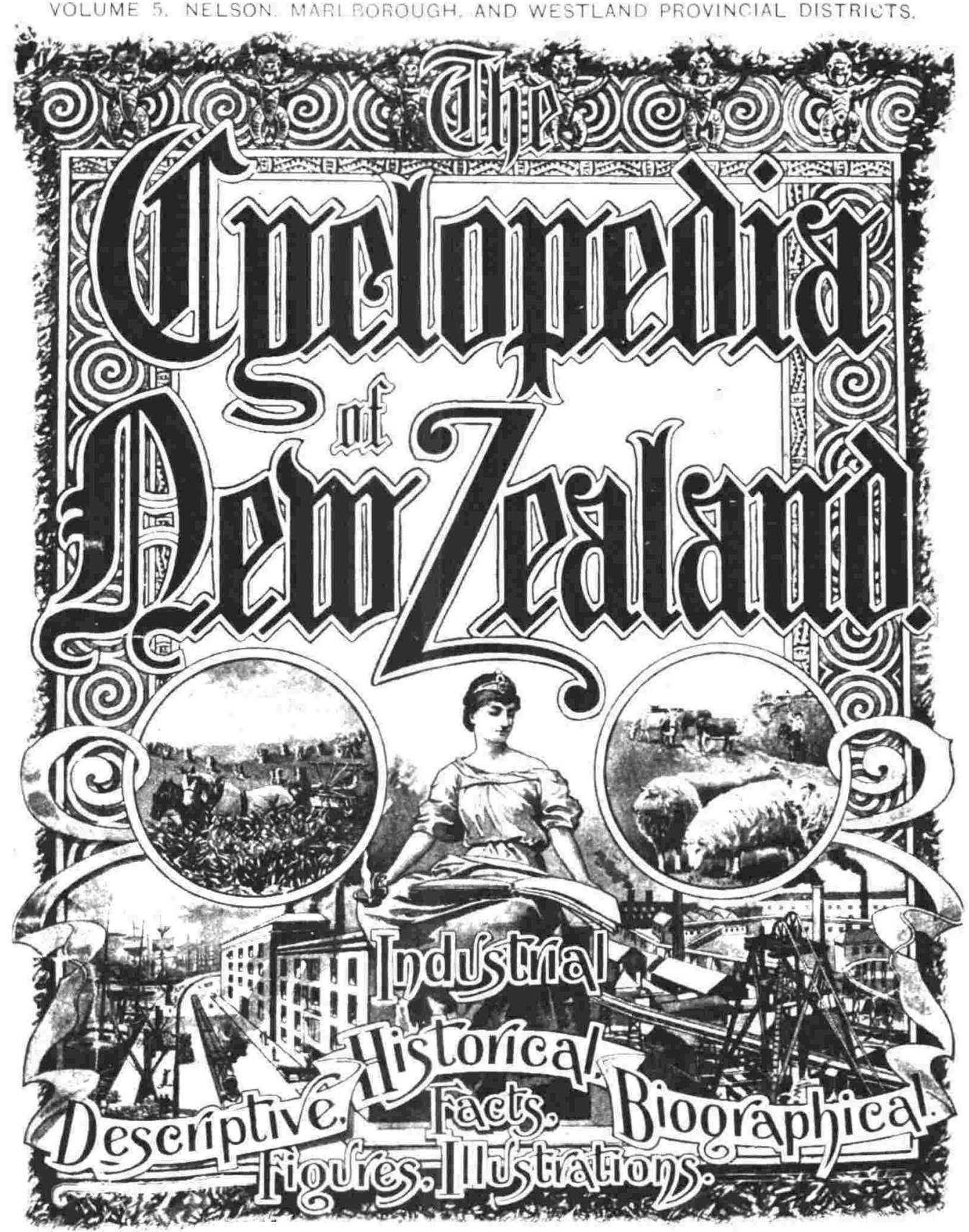

F BLISHED BY THE CYCLOPEDIA COMPANY, LIMITED 


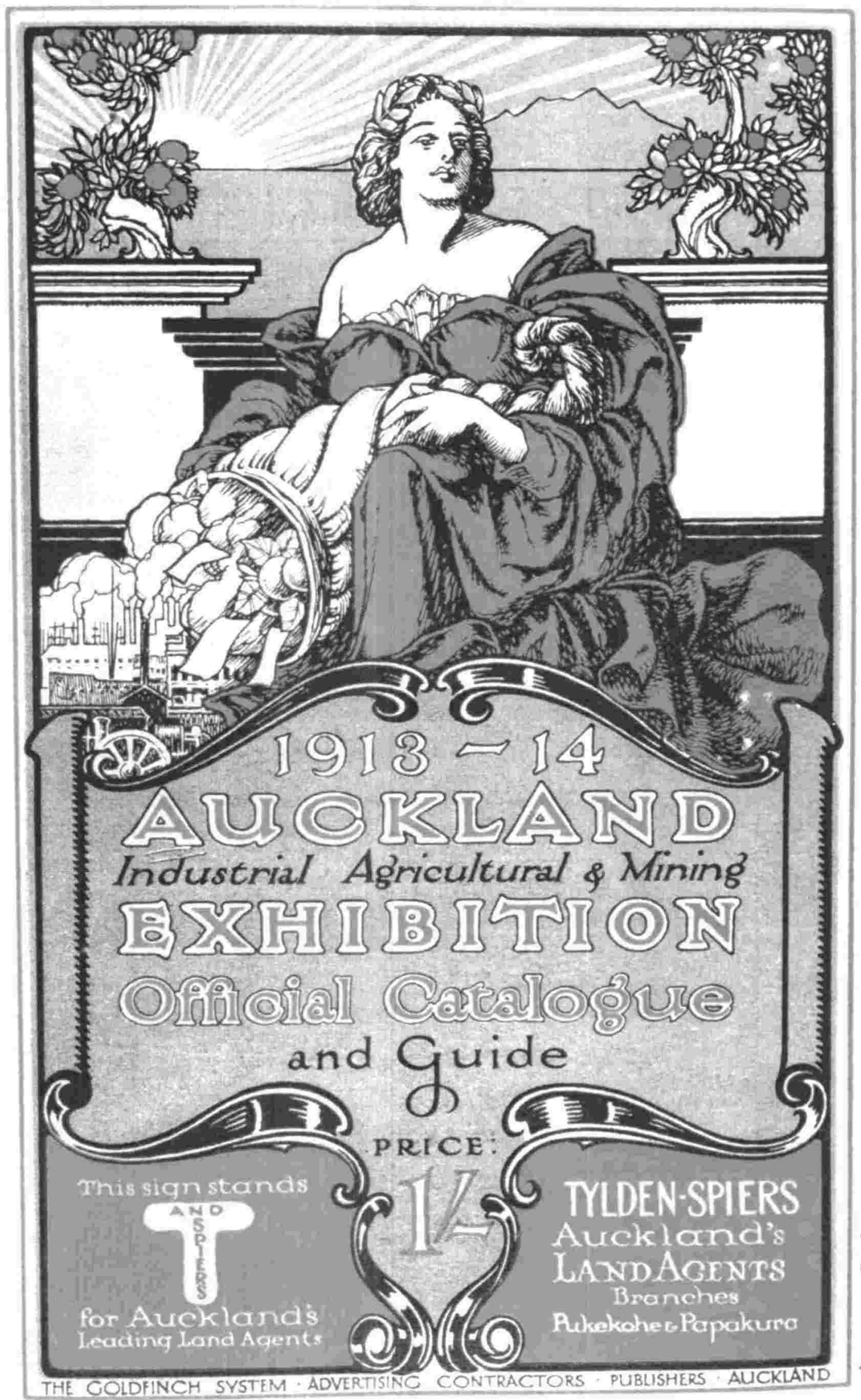

illustration 32 
country's prosperity, does not solely produce agricultural produce. Actually, the fruit and cereal which out of the magical gourd come out last, preceded by pieces of paper which one can presume are bonds, securities and money, and before that, huge smoking factories and large container vessels! The priorities here, as with the other title page from the Encyclopedia, are clearly urban ones based on industry and the machine; agriculture has been seconded.

The Christchurch Art and Industrial Exhibition catalogue cover of 1895, although omitting the figure of Zealandia, also exhibits the same pro industrial and pro urban bias. Christchurch's cathedral is the main subject matter for this title page; however, around the main picture on the left is a paint palette, a musical score and a sculpted bust while on the right are smoking chimneys and huge factories. Both sides of this picture are supported by a base consisting of a picture of a train and a ship. Once again we are familiar with the symbolic meaning of this imagery. The tokens of artistic inspiration are meant to affirm the level of civilisation and maturity which the city of Christchurch has achieved, effective emblems for promoting the city as an attractive destination for migrants wary of coming to a rude and barbarous land. On the other hand, the factories and the transportation networks which support this artistic infrastructure reveal the wealth and prosperity of the place achieved through industry and epitomize ideal conditions for the settler in search of work. ${ }^{24}$

Logo designs were also useful as effective visual propaganda. The Canterbury Chamber of Commerce issued a jubilee logo in the year 1909 to celebrate fifty years of its existence. ${ }^{25}$ Starting at the left and reading towards the right, the bottom third of the design is comprised of a large fleet of trading vessels, followed by bushels of grain and a plough at the centre, and on the right: trains, a smoking factory and a city on a distant hillside (presumably Lyttelton harbour). Although agriculture appears central to Canterbury's economy in this illustration, the importance of industry and the size of urban development does not go unnoticed.

A similar illustration depicting the centrality of industry and the city and meant to represent "STRENGTH \& SECURITY" (to use the words emblazoned in capitals over the picture), can be found towards the back of a booster publication in an advertisement

\footnotetext{
${ }^{24}$ Christchurch Art and Industrial Exhibition, cover.

${ }^{25}$ The logo design was included in the Canterbury Chamber of Commerce Minutes: 1909, Series 1/6. (Canterbury Public Library).
} 
for The United Insurance Company. ${ }^{26}$ Instead of a female mythological figure with connotations of fertility, the artist of this particular advertisement has drawn a Roman gladiator supporting in his left arm numerous factories complete with smoking chimneys, and in his right arm, a steamer and an automobile. One can presume that this male figure represents either the insurance company involved or a collective personification of some kind of urban and industrial New Zealand. Either way, the advertisement suggests that STRENGTH \& SECURITY are to be found in technology and manufacturing, there is no room here for rural or pastoral symbols.

Illustrated advertisements for New Zealand's various manufacturing establishments and service industries epitomized another area where artists consciously boosted the nation's cities and towns; such pictures varied considerably in quality. When a firm wished to advertise its services or products, an artist was often commissioned to draw a picture of the firm; this rendition of the company would then be placed in newspapers, booster pamphlets, and at the top of the firm's stationery (in the form of a letterhead) with the intention of drawing the viewer's notice to the prosperity and the size of the manufacturer. A variety of promotional techniques were introduced by these artists to enhance their subject matter.

One of the most common methods amongst advertisers for promoting aspects of the built environment was by either increasing the size of the building in the illustration or by diminishing the size (and therefore importance) of the people and objects around that particular building. Take the example of the Leviathan Hotel which was doing business in the Dunedin of 1890 and which advertised its services in a local booster publication for the New Zealand and South Seas Exhibition [ILLUSTRATION 33]. The artist has literally translated the Leviathan Hotel into its namesake, creating a monster structure that dwarfs everything around it. The horse and tram in the street outside could actually enter the hotel through one of the structure's windows! And only a giant could open the main doors of this palatial structure, for the people outside seem barely able to reach the window sills let alone the door handle. The Hotel seems built like a Florentine civic palace which was intended to withstand civic revolt for it exudes all the qualities of strength and durability that one would expect of this kind of Renaissance fortress. According to Roland Marchand's analysis of American advertising techniques, this bestowal of heroic proportions upon an object was intended to instil a sense of

${ }^{26}$ Leo Fanning, p.149. 


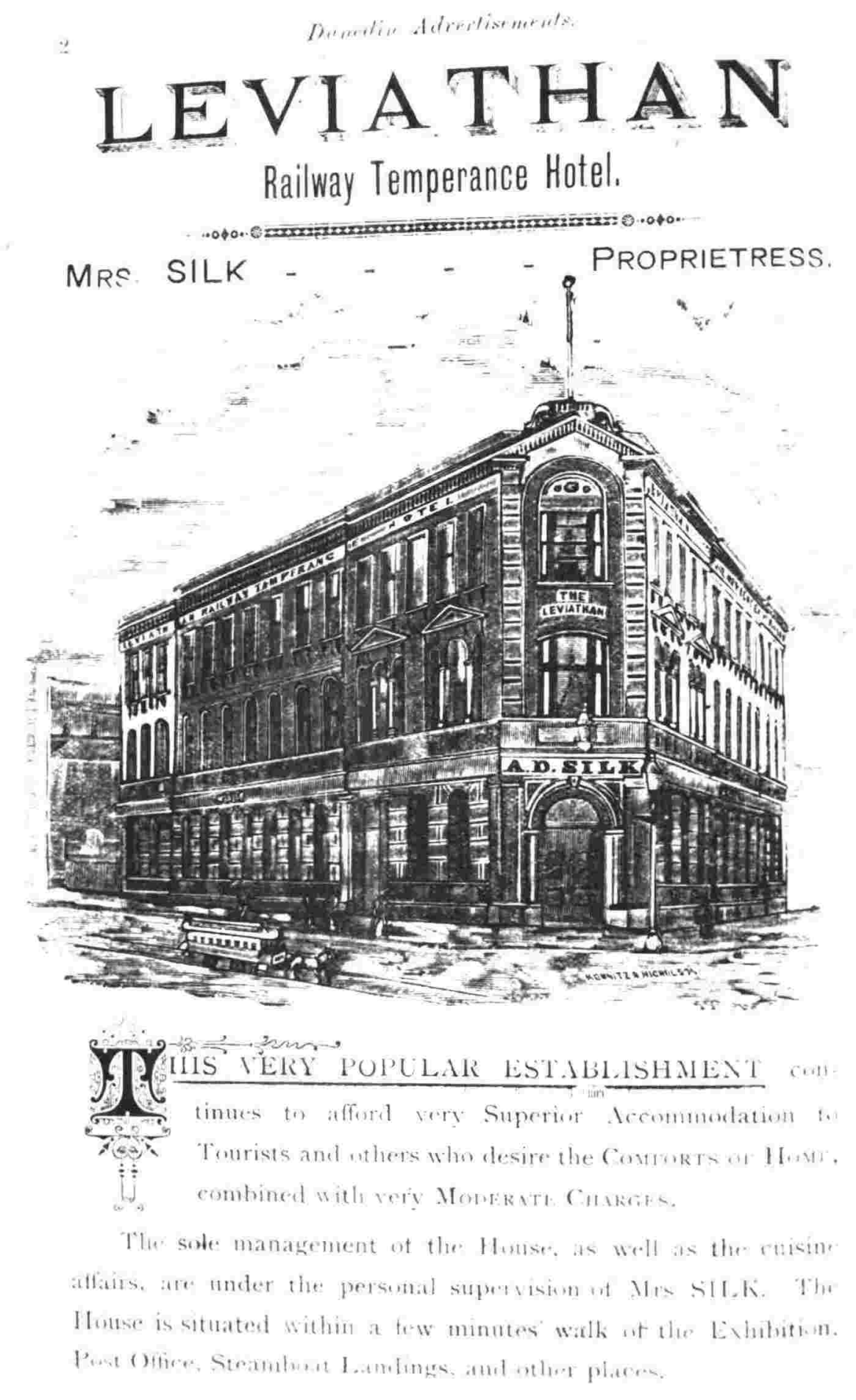

illustration 33 
"confidence and respect." ${ }^{27}$ In the advertisement for the Leviathan Hotel, however, confidence and respect appear to have been seconded by feelings of awe and overbearance!

This technique of altering the size of urban edifices is evident in a great deal of the literature. One can grasp a better idea of just how much these alterations affected the veracity of the image involved when one compares an illustration of the premises with an actual photograph. The Cyclopedia of New Zealand, a thinly veiled business advertisement comprising a history of the leading manufactures and business men in the colony, provides just such an opportunity. On one of its pages there is an artistic reproduction of The Roslyn Woollen Mills near Dunedin [ILLUSTRATION 34]; however, on the next page is a photograph of that same establishment [ILUSTRATION 35]. Despite the fact that the photograph and the illustration are taken from opposite poles, the amount of artistic exaggeration in the graphic depiction is still obvious. This is nowhere more evident than when one compares the height of the chimney stacks and the buildings in the illustration to those of the photograph. Both stacks in the artist's work are raised many stories above the factory buildings below them; comparatively, the smaller chimney stack in the photograph appears barely able to exceed twice the height of the building next to it, let alone three or four times the height! If one takes the nearby trees as an indicator of how much the height of the building has been altered, one perceives the trees in the photograph easily exceeding the height of the buildings around; yet the trees in the artist's picture seem only able to touch the upper parts of the window sills on the first floor, let alone exceeding the height of the two story building. The cumulative effect of the overly tall chimneys and the diminished trees in the graphic illustration makes the woollen mill appear much grander than it really is.

This same phenomenon of artistic distortion is apparent in a comparison of the shop block for the firm of H. E. Shacklock. Just like the illustration for the woollen mill above, this structure has also been considerably expanded in size by the artist responsible for the picture. The illustration itself shows the heads of the pedestrians and workers outside the foundry as only reaching the bottom of the window sills on the first floor of the firm [ILLUSTRATION 36]. When this illustration is compared with an actual photograph [ILLUSTRATION 37] of that same establishment, however, the amount of artistic hyperbole becomes obvious. In the photograph the heads of Mr.

${ }^{27}$ Marchand, p.266. 


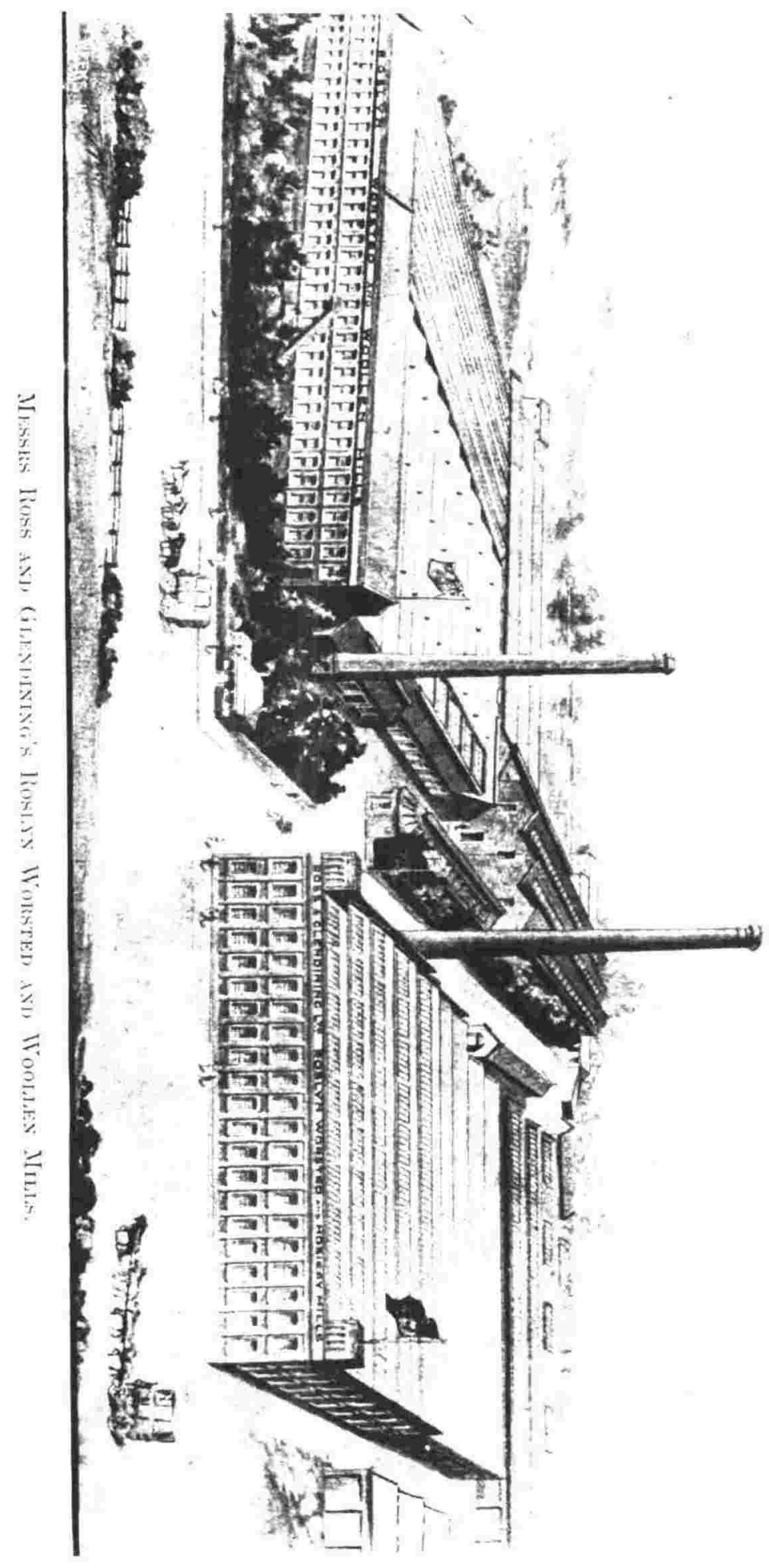

illustration 34 


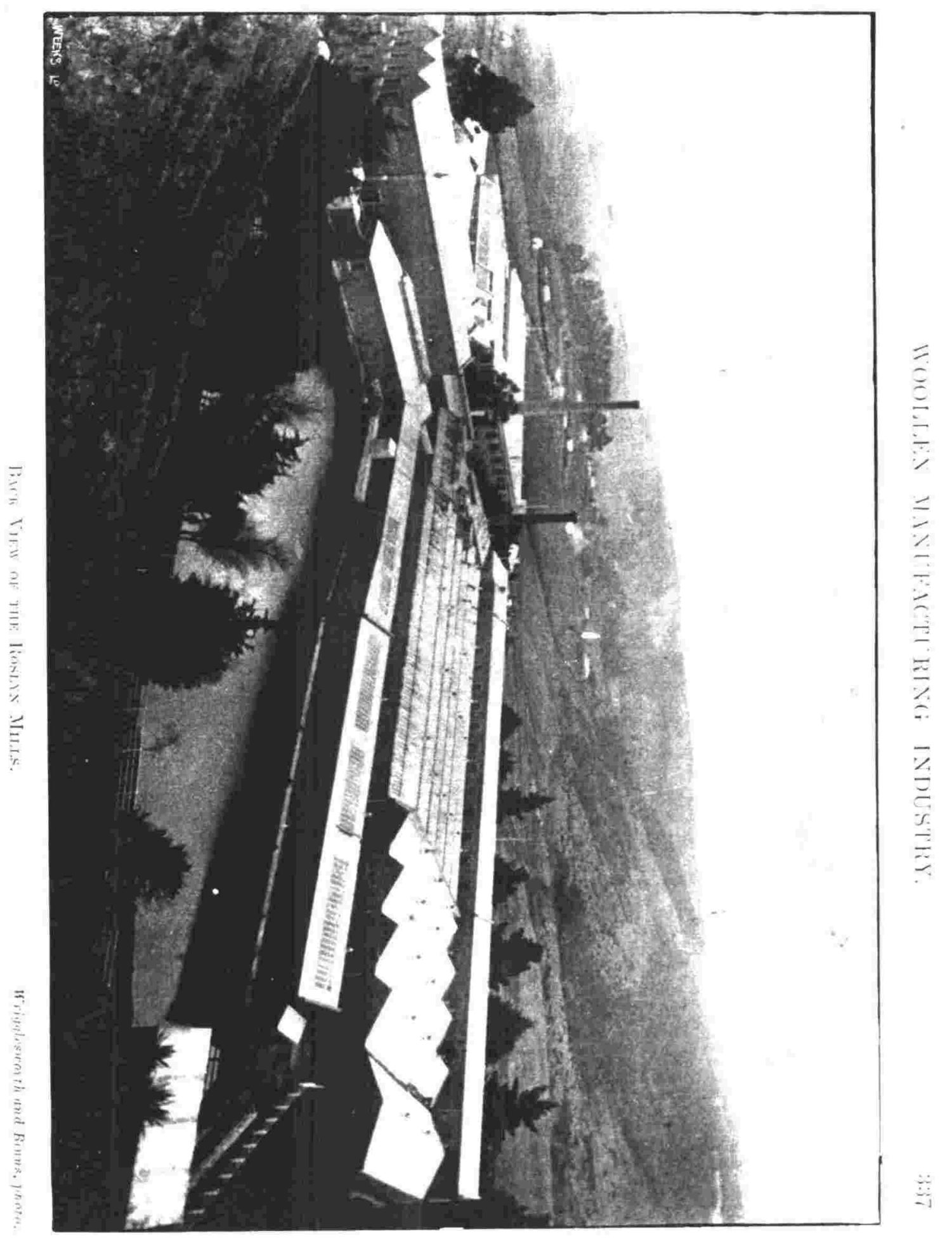

illustration 35 


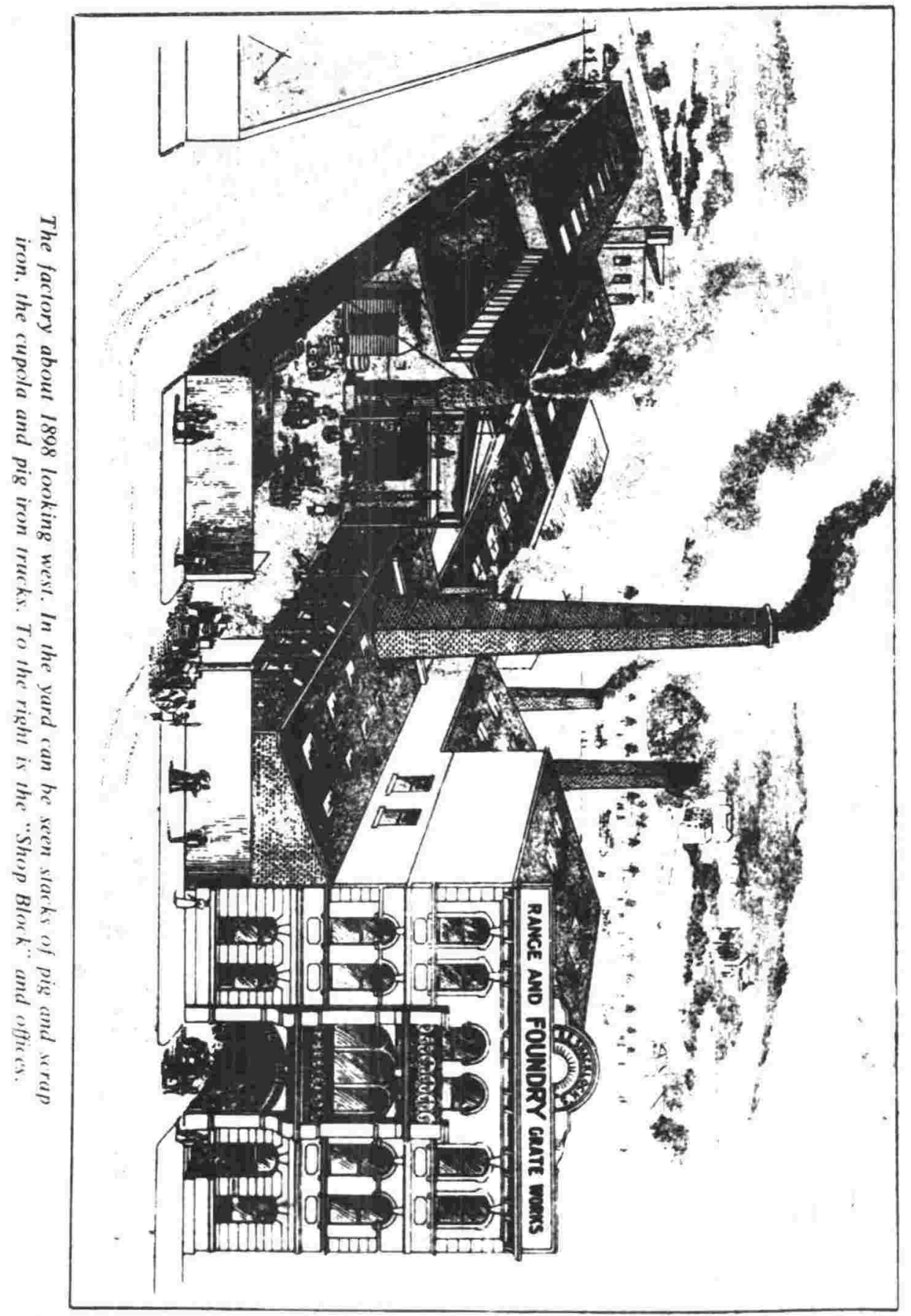

illustration 36 


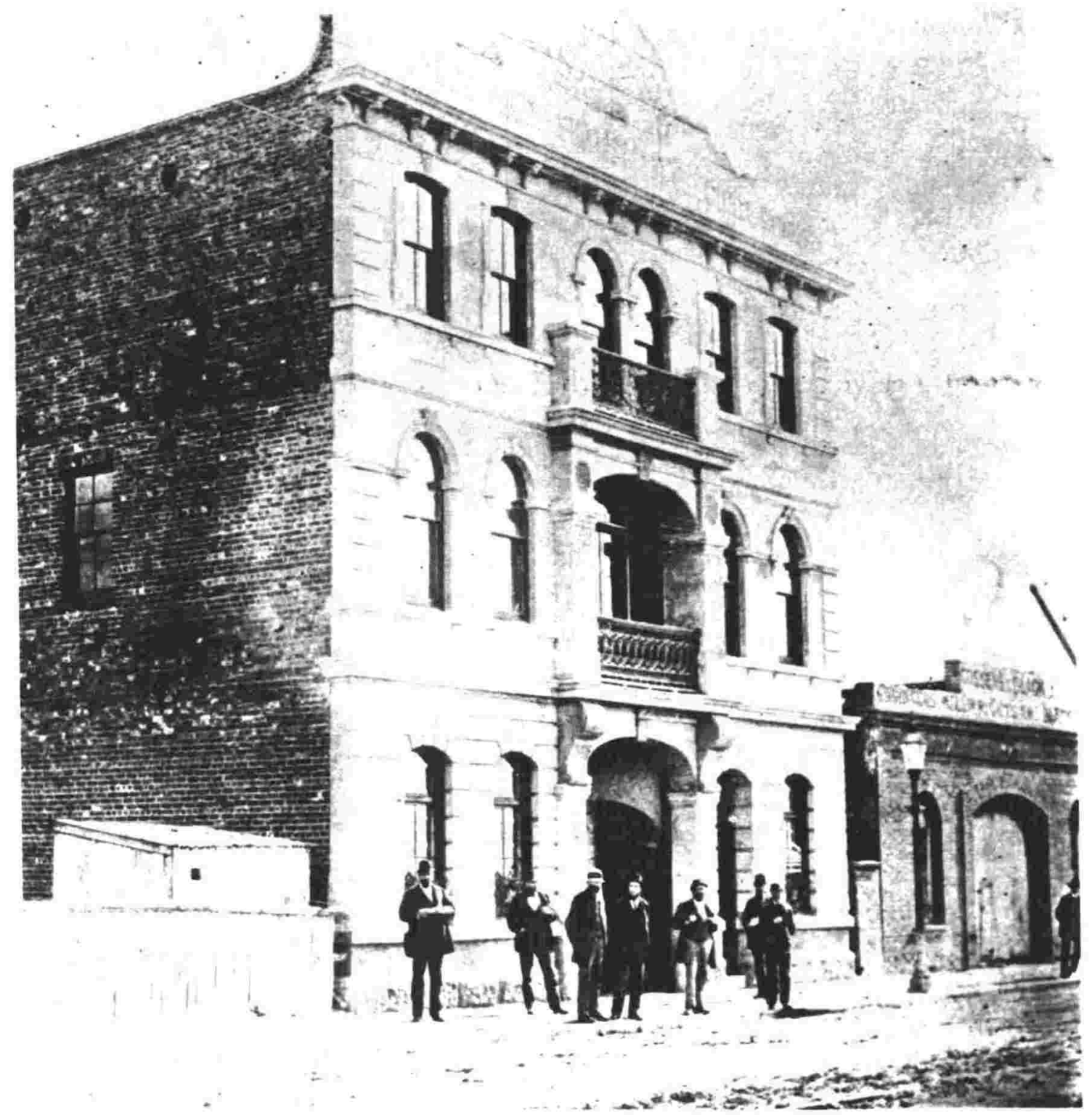

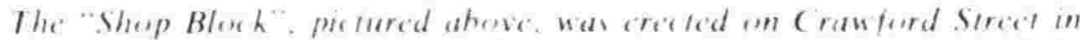

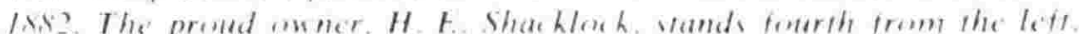


Shacklock and his companions reach almost half way up the windows, not just to the bottom of the window sills as in the drawing! This same alteration in the size of the factory can be seen in another area, this time using the fence at the left of the foundry as a gauge to measure the artist's alterations. Presuming it is the same fence in the two pictures, one sees it only reaching up to the waists of the people in the photograph of the firm while in the drawing it is almost double the height of the people! The firm's dimensions also appear to have been extended horizontally as well as vertically in the graphic illustration for H. E. Shacklock; despite the fact that a cart is able to move freely through the main door of the foundry's entrance with plenty of room to spare in the illustration, the procedure would not appear to be so easy in the actual photograph.

When International Harvester, an American based firm looking to establish a branch plant in Canada so it could avoid import duties decided to move to Hamilton, Ontario, the Company's President said the decision was based on the fact that the city had waterside property, good railway connections and a plentiful supply of cheap electricity. ${ }^{28}$ Not surprisingly, artists liked to make the most of these and any other assets which would assist in the promotion of a particular industry. Therefore, it is common to come across renditions of factories like that for A \& T. Burt, an engineering firm in Auckland, where not only the factory receives the attention but also its surroundings, specifically in this case the port facilities behind the firm. ${ }^{29}$ Water was essential not only for easy and cheap transportation of both the primary material and the finished product, but also for the disposing of waste quickly and efficiently and for the refining of certain products such as steel and iron.

It was also a common booster ploy to leave out surrounding buildings when depicting images of a particular firm. This was done for three reasons: firstly, to give the impression that there was plenty of available surrounding land for the firm to expand later on; secondly, because vacant land was also a useful device for enticing manufacturers since it usually meant that homes for workers could be built nearby the firm so as to provide the factory with a stable and reliable workforce; and thirdly, because the image of the single manufacturer was artistically more appropriate as the viewer's attention could not be distracted by other elements in the picture.

\footnotetext{
${ }^{28}$ Weaver, Hamilton: An Illustrated History, p.88.

${ }^{29}$ Auckland Industrial, Agricultural and Mining Exhibition, p.266.
} 
The illustration for the A \& T Burt engineering firm is useful for revealing other promotional approaches as well; for instance, the two smoking chimney stacks in the graphic depiction were meant to have represented prosperity and acute business activity. A smokeless chimney, on the other hand, might have symbolized closure or a lack of business. Similarly, these graphic illustrations for firms and hotels liked to show pedestrians thronging around the outside of a particular building. Crowds of people were not only used as comparative vehicles with which to make a building appear larger, but also to show the hustle and bustle of a thriving business.

Another booster technique used to promote a particular business was to alter the perspective in a picture. In the case of the Kaiapoi Woollen Mills [ILLUSTRATION 38] where the foreground plane has been lowered, this allowed the spectator to see just how big an establishment was. Instead of only seeing the front of that particular manufacturer or the roofs of the factory sheds disappearing into the background as drawings which used linear or three point perspective would tend to do, here the artist allows us to see a whole series of further buildings and business activity behind the firm, including a rear industrial shed which houses a tall smoking chimney stack. Again, such a technique contributed to an impression of grandeur and enormity.

The more animated activity that was occurring the more trade or business that the place in question was supposedly doing, or so the theory went. Sometimes artists went to the extreme in order to get this message across. The artist of the illustrated advertisement for the Grand Hotel in Dunedin has included as many as eight moving vehicles converging on one corner of the Hotel alone, as if on a collision course. ${ }^{30}$ There are four horse drawn trams, three private carriages and one push cart. Added to the confusion are various other pedestrians all on their own personal errands and trying to cross the street. The artist has been careful to include in this rendition the fact that all the pedestrians are well-off, able to afford private carriages and the latest fashions. The packed trams, the paved road and the ornate decorative facade of the hotel all contribute to the overwhelming impression that Dunedin is a rich, thriving and civilised city. It should be mentioned too that the emphasis on the various trams reveals another factor which artists would have been sure to include in their booster works: the existence

${ }^{30}$ Union Steam Ship Company of New Zealand, Limited, Maoriland - an illustrated handbook - to - New Zealand (Melbourne: George Robertson and Co. Limited, 1884), no page. 


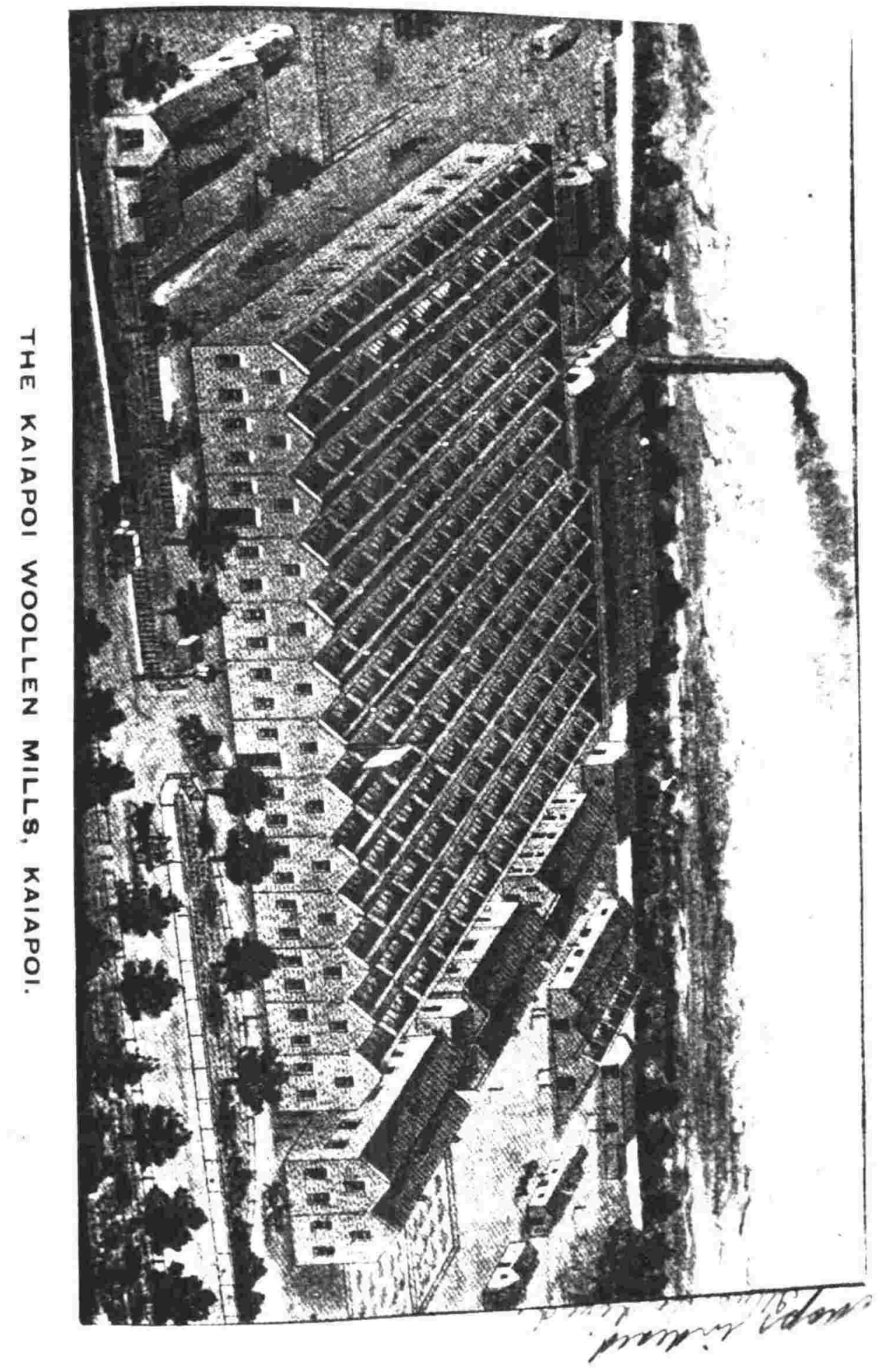

illustration 38 
of extensive public services. Paved roads, streetcars, municipal lighting and covered arcades were all considered of benefit in the struggle to secure investment and settlement. An effective and rapid transportation network was doubly effective for attracting industry and labour for not only was this considered a sign of a city's wealth and a gauge of its maturity, but it also ensured workers that they would be able to commute to and from work easily and relatively cheaply. The three flags flying in the wind at the top of the Grand Hotel complete the scene, acting as a kind of final moral suasion (one founded on nationalism and imperialism) which was used by advertisers to entice patronage.

Marian Minson, the pictorial archivist at the Turnbull Library, Wellington, while discussing the particular Edenic image of the colony depicted by artists from 1770-1870, sees images of British imperialism pervading the visual material:

Permeating the images in this exhibition... is an unanswering belief in the superiority and rightness of the British way of life... We see nothing of the back-breaking labour, the invisible work of women, the dirt, the cold, the poverty and the high mortality rate. $^{31}$

Certainly feelings of nationalism and imperialism were ripe throughout the country during the period of this study, particularly during and after the Boer conflict and the First World War. Images of this militaristic and nationalistic fervour saturate a good part of the art of the period. Walter Bowring's painting "Mafeking Night, Hagley Park" (1900), is a prime example of this celebration of empire with thousands of loyal Christchurch citizens collectively celebrating Britain's victory over the Boers with fireworks at night. So too are those booster publications such as Napier Illustrated(1920), which reveal photographs of white middle class women paying a kind of solemn and quiet tribute to the Empire's heroic soldiers who fell in South Africa. ${ }^{32}$ However, the obvious inclusion of the flags in the illustration for the Grand Hotel, as well as in the advertisements for the Roslyn and Kaiapoi Woollen Mills, exposes imperialism as yet another promotional tactic used by the nation's boosters to fashion a more compelling picture of New Zealand so as to attract money and people. Flags and

\footnotetext{
${ }^{31}$ Marian Minson, Encounter With Eden (1770-1870) (Wellington: National Library of New Zealand, 1990), pp.14-15.

${ }^{32}$ Fergusson Ltd., Napier Illustrated including panoramic views of Napier \& Port Ahuriri (Auckland: ca.1920), p.15.
} 
flagpoles could be drawn so big or so tall that they sometimes appeared to dwarf whole streetcars or to tower many stories above a neighbouring building; oftentimes they could receive as much attention as smoking chimney stacks in some of these graphic advertisements. Evidence of such imperial propaganda has also been seen a little earlier on in this chapter, with the female personification of Zealandia and her association with Britannia. According to John MacKenzie, imperialism was merely another tool to assist in the selling of a particular product:

Until the 1870 s royalty was seen to contain little in the way of opportunities for commercial exploitation. From that date, advertising, bric-a-brac, and packaging all exploited royalty and imperialism, taking symbols of colonial adventures into every home. For imperialism made spectacular theatre... ${ }^{33}$

The desire for order as expressed in the bird's eye view maps is also evident in the advertisements for manufactures. In ILLUSTRATION 38 showing the woollen mills at Kaiapoi, one sees a picture of a mill running at peak efficiency and smoothness. Everything seems to have a place and everything is in that place. On the far right bails of wool are drying, all neatly regimented in sequence. Around the complex itself are the bustling forms of workers and delivery carts all seeing to their appointed tasks. Meanwhile, decorating the entrance of the factory are numerous trees and grassy areas which complete the tidy picture. This concern with visual order is evident elsewhere in the advertisements for the Roslyn Woollen Mill and for H.E. Shacklock. Yet this is not necessarily the correct picture, for factories are usually noisy and dirty places above which hang clouds of poisonous sulfuric smoke. Nevertheless, the smoke from the chimneys in these artistic depictions seems to magically dissipate; nor is one single object that might be considered detrimental to the scene, included in any of these pictures.

The boosters and the artists whom they commissioned were concerned with the visual appearance of a city or a factory for many reasons: Firstly, as mentioned previously, evidence of a controlled environment was helpful in attracting future settlement and investment. Settlers would in all likelihood be a little hesitant about coming to a country which did not show signs of being civilised. Secondly, evidence of a clean and ordered environment would be useful in attracting working class migrants

\footnotetext{
${ }^{33}$ John M. MacKenzie, Propaganda and Empire: the Manipulation of British Public Opinion, 1880-1960 (Manchester: Manchester University Press, 1984), p.5.
} 
who wanted to leave behind the drudgery of slums and of poor economic conditions, the likes of which were to be found particularly in the northern industrial and manufacturing towns of England. Thirdly, a good environment was also good for business; for goods produced in an attractive setting might also impart the consumer with a greater degree of confidence in the product. ${ }^{34}$ Fourthly, the artists and the manufacturers may well have been genuinely influenced by the City Beautiful movement or similar Garden City ideas; the influence of these latter concepts and the degree to which they permeated the thoughts of the individuals involved will be discussed in later chapters.

One of the best examples which can be used to show the amount of artistic distortion and exaggeration that occurred in the illustrated booster works, can be found in the original plates for the Picturesque Atlas of Australasia (1886), a number of which can still be found in the pictorial archives of the Australian National Library at Canberra. ${ }^{35}$ The Atlas was a promotional work designed to celebrate Britain's colonies in the South Pacific; both New Zealand's and Australia's urban centres received a great deal of attention, for according to Australian Art Historian Roger Butler, the Atlas was "primarily concerned with the cities and the growth of a prosperous civilized nation." ${ }^{36}$

The illustrations in the Atlas which accompanied the written text were consciously manipulated to provide readers of the work with the most positive and idealistic image of Antipodean scenes imaginable. Roger Butler says that expert artists and engravers were deliberately brought over from America to oversee production of the Atlas. ${ }^{37}$ The engravings themselves were in fact original photographs touched up by the American artist William Crothers Fitler (1857-1915). The technique was called 'treated photographic image'. Fitler would make additions directly onto the photograph itself which contemporaries considered appropriate for the purposes of promoting the city or

\footnotetext{
${ }^{34}$ Marchand, p.154.
}

${ }^{35}$ A number of original pictures for the Atlas are in the Pictorial Collection of the National Library of Australia at Canberra. However, these are of Australian city scenes and subsequently I have had to base my discussion around Australian scenes and not New Zealand ones. Since the artists responsible for these depictions were the same for both countries I believe that this approach is legitimate.

${ }^{36}$ Roger Butler, Australian Prints in the Australian National Gallery (Canberra: Australian National Gallery, 1985), p.16.

${ }^{37}$ Ibid. 
colony. Engravers would then copy Fitler's manipulated image and the final product would eventually be reproduced in text. Alterations made by Fitler typically included adding smoke to chimneys as well as putting in lots of greenery, as in the engraving of "Sandhurst, From the State School" (page 288 of the Atlas). And as can be seen in the view of St. Patrick's Cathedral in Melbourne, [ILLUSTRATION 39], (page 233 of the Atlas), Fitler has obviously added middle class couples, numerous bushes and trees, a few carriages and an electric tram, all symbols of prosperity and culture, directly onto a photograph of the cathedral. Graeme Davison's work on images of Melbourne points out that alterations of this kind would "underline the sense of urban progress" 138 and be considered valuable in developing a particularly civilised vision of the city.

Paintings as well as graphic illustrations were another effective medium used by boosters to encourage settlement, tourism and investment. There appear to be, however, fewer paintings produced with urban themes as there were engravings or lithographs. Instead, the subject matter for painting tended to remain the traditional landscape primarily until well into the 1930s, as exemplified by artists such as John Gibb (18311909) and his "The Nook on the Avon" (1886). The reasons for this bias towards landscapes rather than cityscapes with the emphasis on fields of wheat, grazing cattle and sheep and quiet cottage scenes, are many and varied. Primarily, this trend must have derived from convention; for the British Government and other settlement associations had commissioned many topographical works in order to record the New Zealand landscape for the benefit of encouraging people back Home to either settle or invest in the colony. As Graeme Davison says: "Their purpose was as much utilitarian as aesthetic. ${ }^{139}$ Typically, according to Gil Docking, such subjects would include: "valleys suitable for farming, forests awaiting milling, harbours calling for townships, and wide expanses of mountains and plains enticing the prospector and squatter." ${ }^{40}$ Marian Minson says that works of this kind:

...were intended to impress those who had remained in England and can be seen therefore as propaganda for the British Empire

\footnotetext{
${ }^{38}$ Davison, "The Picture of Melbourne 1835-1985", p.25.

${ }^{39}$ Ibid., p. 13.

${ }^{40}$ Gil Docking, Two Hundred Years of New Zealand Painting (Wellington: Reed,
} 1971), p.90. 


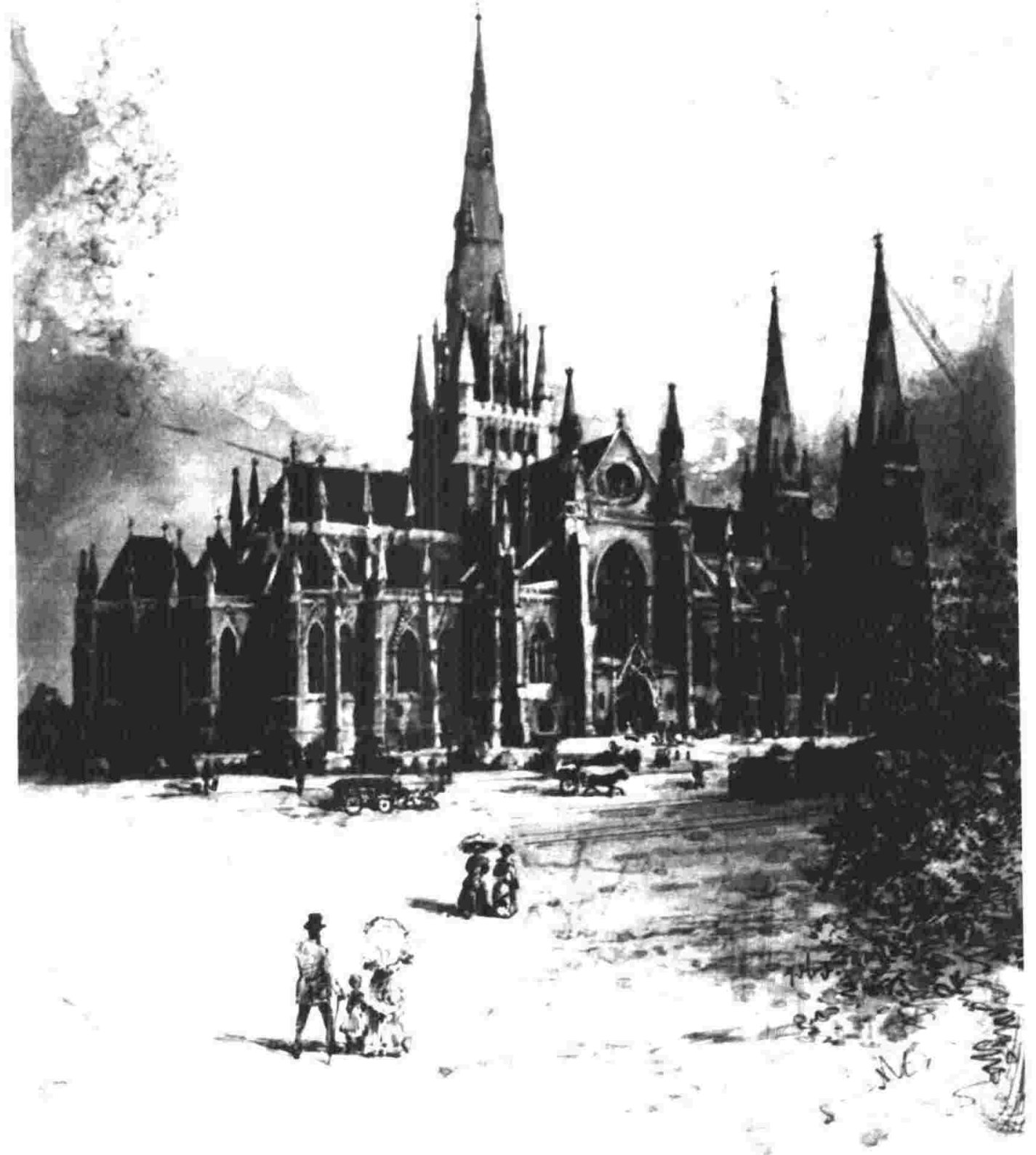

illustration 39 
or as a particularly attractive form of advertising. They are images of what New Zealand could be, rather than what it was. $^{41}$

Another reason for the dearth of cityscapes can be ascribed to a lack of patronage. Those professional artists who came to work in New Zealand during the nineteenth century would have been restricted in their choice of subject by the small domestic market; consequently they would have tended to produce commissioned works for the well off runholders and property owners who were living in the colony. Typical works produced might have included family or personal portraits (as Nerli, the Italian painter who arrived in 1889 was renowned for), or views of the farm and property, with typical emphasis on the animals and the main house. ${ }^{42}$ Such pictures would either be retained by the patrons who commissioned these works or sent Home to England to relatives and friends to show how well the settlers had prospered since arriving in the new land.

There might have been other reasons for this lack of interest in depicting the townscape. As Gil Docking points out, such themes might "not have been acceptable to the hierarchy of the entrenched art societies" of the time. ${ }^{43}$ Graeme Davison, when talking about the want of townscape subject matter in Melbourne for the three decades after 1890 , attributes the phenomena to the onset of the depression which caused that city's artistic and literary circles to seek solace and escape in rural themes. ${ }^{44}$ Another reason for the emphasis on rural subject matter (unlike European contemporary trends), was simply that New Zealand and Australia were behind the times. Evidence of this cultural backwardness in Australia can be seen in the emergence of the avant-garde in Sydney as late as the 1930 s and social realism in Melbourne during that same decade..$^{45}$ Gil Docking supports this statement in reference to New Zealand painting; the argues that by the time James Nairn was painting his impressionistic work "Wellington

\footnotetext{
${ }^{41}$ Minson, p.15.
}

${ }^{42}$ Tim Bonyhady mentions the point about the small domestic market for painters but in relation to Australia; it is, however, in all probability equally valid for New Zealand. The Colonial Image: Australian Painting 1800-1880 (Chippendale: Ellsyd Press, 1987), p.9.
${ }^{43}$ Docking, p. 120.
${ }^{44}$ Davison, "The Picture of Melbourne 1835-1985", p.27.
${ }^{45}$ I owe this point to Tony Bellette. 
Harbour" (1894), impressionism had been replaced in Europe by the post impressionists Van Gogh, Seurat and Gauguin. ${ }^{46}$

Despite the plethora of portraits and landscapes, this is not to say that paintings with urban themes were non-existent in New Zealand; on the contrary, a number of cityscapes were produced during this time period, many of which were used by boosters for the purposes of promoting their towns and cities. There were numerous reasons for this urban genre to develop. Firstly, unlike Australia where Sydney and Melbourne housed most of the colony's population, New Zealand's population was more scattered and much smaller. Its cities, therefore, were not seen to have forced New Zealand painters to seek solace and escape in the country as was the case in Australia amongst certain members of its artistic community, notably the Heidelberg Group. Secondly, painters of specific urban themes may have been commissioned by groups or individuals to promote a manufacturer or a town scene. Consequently, the thought of financial recompense for a work would have certainly provided a strong motive for such subjects. Thirdly, despite the fact that Australasia was behind in the art scene this does not go to say that it was backward either; for Marcel Duchamp's "Nude Descending a Staircase" (1912), when first exhibited in New York in 1913, had also been reproduced in a Sydney paper that same year. ${ }^{47}$ It followed, therefore, that at least a few artists in New Zealand would be influenced by European trends, particularly the demise of the landscape. ${ }^{48}$

There were other reasons for the existence of a few New Zealand cityscapes during these years. Gil Docking comments on the work of "a few rebel painters who recorded and commented on social conditions", particularly during the slump years after $1929 .{ }^{49}$

\footnotetext{
${ }^{46}$ Docking, p.79.

${ }^{47}$ I owe this point to Tony Bellette.
}

${ }^{48}$ Evidence that New Zealand was not too far behind European cultural trends can also be seen in the work of Adrienne Simpson and her studies of opera in the Antipodes. Simpson cites evidence of Gilbert and Sullivan performances being staged in the colony one or two years after first being produced in Great Britain. She also reveals that Verdi was performed in full in New Zealand a mere six years after Europe, no mean feat for a country so far removed from European capitals and with such a small population base. See Adrienne Simpson, "Opera in the Antipodes". Talk delivered at the Eighth Annual Stout Centre Conference: 6 - 8 September, 1991. "Australia - New Zealand: Aspects of a Relationship".

\footnotetext{
${ }^{49}$ Docking, p. 120.
} 
Gil Docking also says that as people moved from the country to the city it was inevitable that urban themes replaced rural ones: "The situation had changed. Most of the country was now settled. More interest was being taken... in the life and pleasures of the growing urban societies." ${ }^{150}$ Robert Hughes accounts for the rise of urban subject matter in Europe for the same reasons: "The master-image of painting was no longer landscape but the metropolis." ${ }^{151}$

Another reason why a number of paintings with urban themes were completed in New Zealand, was that simply many of these New Zealand artists had architectural backgrounds. It was natural, therefore, for people like Christopher Aubrey, James Fitzgerald, Marmaduke Matthews, Rev. John Kinder, George O'Brien, Alfred Sharpe and Charles Nathaniel Worsley, to have an interest in the city. Their architectural backgrounds varied: John Kinder had a personal interest in ecclesiastical architecture, probably the result of his religious vocation; O'Brien was a civil engineer and a draughtsman; and Sharpe was a trained architect. Their training therefore might help explain their preoccupation with urban themes. ${ }^{52}$

Paintings are an extremely valuable source of historical information. Pablo Picasso used to tell his biographers that, "My work is like a diary... It's even dated like a diary." ${ }^{153}$ Yet before beginning an analysis of paintings with urban themes, it is important to qualify the type of cityscape being produced by the artists of the time. For as Picasso's biographer John Richardson warns his readers, "we should remember that diaries are none the less interesting for fantasizing, embroidering and reordering the truth."

By far the majority of pictures produced in New Zealand with an urban subject matter were influenced by the pastoral landscape which had so dominated painting in

${ }^{50}$ Ibid., p.90.

${ }^{51}$ Hughes, p.12.

${ }^{52}$ The biographical information on these various artists was provided by Una Platts.

${ }^{53}$ Richardson, p.3.

54 Ibid. 
England and in its colonies for such a long time..$^{55}$ The pastoral landscape, as defined by Graeme Davison, was a landscape "in which the city was viewed from a distance and framed within a picturesque and often idealised countryside." Davison goes on to argue that "Its underlying values were perhaps not strictly urban at all, but rather the nostalgic longings of a rural upper class. ${ }^{156}$ The definition which Davison uses for Australian pastoral city scenes is equally valid for New Zealand, for its influence saturates work in the colony. This is not surprising since a considerable number of New Zealand and Australian artists regularly criss-crossed the Tasman in search of employment and inspiration. In general, the cityscape subject matter produced at this time in New Zealand was a highly idealised portrait of an Edenic and/or Arcadian scene with a city or town serving as a background in the distance. According to Peter Entwisle, the pastoral genre in New Zealand usually tended to show the viewer "towns growing in the empty landscape and - through the artist's eye - reconciled with it." 57

An early instance of this New Zealand pastoral imagery, and one presumably commissioned by the factory's owners because of the subject matter, can be found in George O'Brien's "Gas Light and Coke Company Works" (1865). This watercolour is in fact not a picture of a city at all but rather a painting of a manufacturer in a rustic setting. In spite of having been painted fifteen years earlier than the starting date for this study, as well as being a picture of a factory and not of a city, this painting does provide an introduction to the stylistic traits of the pastoral landscape for it uses similar booster techniques; it also reveals startling parallels with the graphic illustrations for the other firms discussed previously.

In O'Brien's picture, gentle hills provide a backdrop to the scene while a small creek curves its way gently towards the spectator in the foreground. The setting is sometime shortly before dusk as a warm evening glow bathes the buildings in golden colour. Contented workers rest idly against a doorframe, relaxing after a hard day's work

${ }^{55}$ Other methods of promoting New Zealand's cities and towns in paintings, apart from the pastoral landscape genre, consisted of underlining either an urban centre's civilised qualities (as evidenced in Chapter 2) and/or its economic well-being (as seen in Chapter 3).

${ }^{56}$ Davison, "The Picture of Melbourne 1835-1985", pp.15 and 18.

57 Peter Entwisle, William Matthew Hodgkins and his Circle (Dunedin: Dunedin Public Art Gallery, 1984), p.72. 
stoking the furnace; smoke from the factory chimney coils slowly into the air. A variety of components found in the typical booster advertisements, such as nearby water, plenty of vacant land, symbols of prosperity etc..., have been included in this picture; in the words of Roger Collins, this painting is here "proclaiming that this industrial Eden is found in Southern New Zealand." ${ }^{58}$

In New Zealand, a number of examples of this pastoral genre of cityscape were produced. According to Peter Entwisle's work on some of the colony's late nineteenth century artists, John Kinder, Alfred Sharpe and George O'Brien are the style's bestknown exponents. ${ }^{59}$ However, Henry Grant Lloyd, Charles Nathaniel Worsley, Archibald Duddington Willis, Marmaduke Matthews and Samuel Edwy Green also produced similar pastoral landscape material. In general, New Zealand's four largest urban centres were the focus of much of the work, yet Wanganui, Nelson, Lyttelton Harbour, Gisborne, and other smalller towns, also received their fair share of attention. The images were mostly black and white or coloured lithographs, usually prepared for assorted promotional booklets. Yet despite the prevalence of the lithographic reproductions, a number of "high art" water-colour views were also produced; the latter, however, usually tended to remain concentrated on Auckland, Wellington, Dunedin or Christchurch. Many of these cityscapes varied considerably in quality, from the cheaper productions meant obviously for commercial use and mass distribution, to those one-off and more meticulously detailed works by the more celebrated New Zealand artists of the time. These various cityscape lithographs and watercolours also ranged in dating throughout the period of this study, although none apparently appear after $1920{ }^{60}$ The three examples chosen for analysis in the ensuing pages are by two well-known artsists, Christopher Aubrey and John Kinder, as well as one work by an unknown individual.

\footnotetext{
${ }^{58}$ Collins and Entwisle, p.15.

${ }^{59}$ Entwisle, p.72.
}

${ }^{60}$ Despite the fact that the pastoral image in painting seems to have disappeared by the second decade of the twentieth century, there is still much evidence to suggest that the arcadian image remained an important one. For example, at the New Zealand Town Planning Conference and Exhibition of 1919, organisers of the event asked the general public to lend a hand by donating, "paintings of portions of cities, villages and domestic scenes in rural surroundings." [The competition details for the 1919 Town Planning Conference are in the form of a six page circular which was found inserted in the New Brighton Works Committee Minutes, 1914-1919. (Canterbury Public Library). 
They have been included for analysis because they serve as good examples of many of the promotional techniques adopted by the pastoral cityscape genre. ${ }^{61}$

The first of the works to be examined, Rev. John Kinder's "Dunedin" [ILLUSTRATION 40], which was completed in January 1890, is an excellent example of the pastoral cityscape. A strong light imbues the scene as in George O'Brien's previously mentioned work, serving to mellow the picture. Other elements perform the same tempering function, specifically the hills which have been reduced in scale and the native flora which has been replaced by a landscaped lawn that draws further resemblances to Arcadia. The city of Dunedin appears nestled snugly amongst Otago's highlands, framed by the hills in the background, a small copse of native bush on the left and a gentle park-like lawn in the foreground. In this picture the settlers and nature do not appear to be at odds with one another.

These same Arcadian-like images can be found in another view of Dunedin [ILLUSTRATION 41], this time "Dunedin From North East Valley Above Chingford Homestead Gardens" (ca.1890s), a painting which for some time had been mistakenly attributed to Alfred Sharpe. In this work, the city of Dunedin rests secure in a valley in the distance. Hills on either side of the picture channel the viewer's eye to the far away city. Mountains in the background prevent the viewer's eyes from wandering upwards and away while also reaffirming the city's (one is tempted to say town or village's) cozy and sheltered situation. Fields of cultivated land fill the foreground and middle ground, a testament to the fecundity of the land and to the civilising and ordering hand of the European. The remaining native bush clinging to a hill has been seconded in importance again, this time at the right of the painting rather than on the left as in Kinder's painting.

The third work to be discussed is Christopher Aubrey's 1902 watercolour, "Auckland From Albert Park" [ILLUSTRATION 42]. Unlike the other two paintings where the city itself has been relegated to the background or middle ground, separated from the viewer by distance, Auckland appears much closer to the foreground in this painting. It is, however, still physically isolated from the spectator, not by distance but rather this time by a small forest of trees (mostly exotic). In the foreground, as in Kinder's work, a landscaped park with figures invites the viewer to an exploration of

${ }^{61}$ The only reason that these three works have been chosen is due to personal preference. 


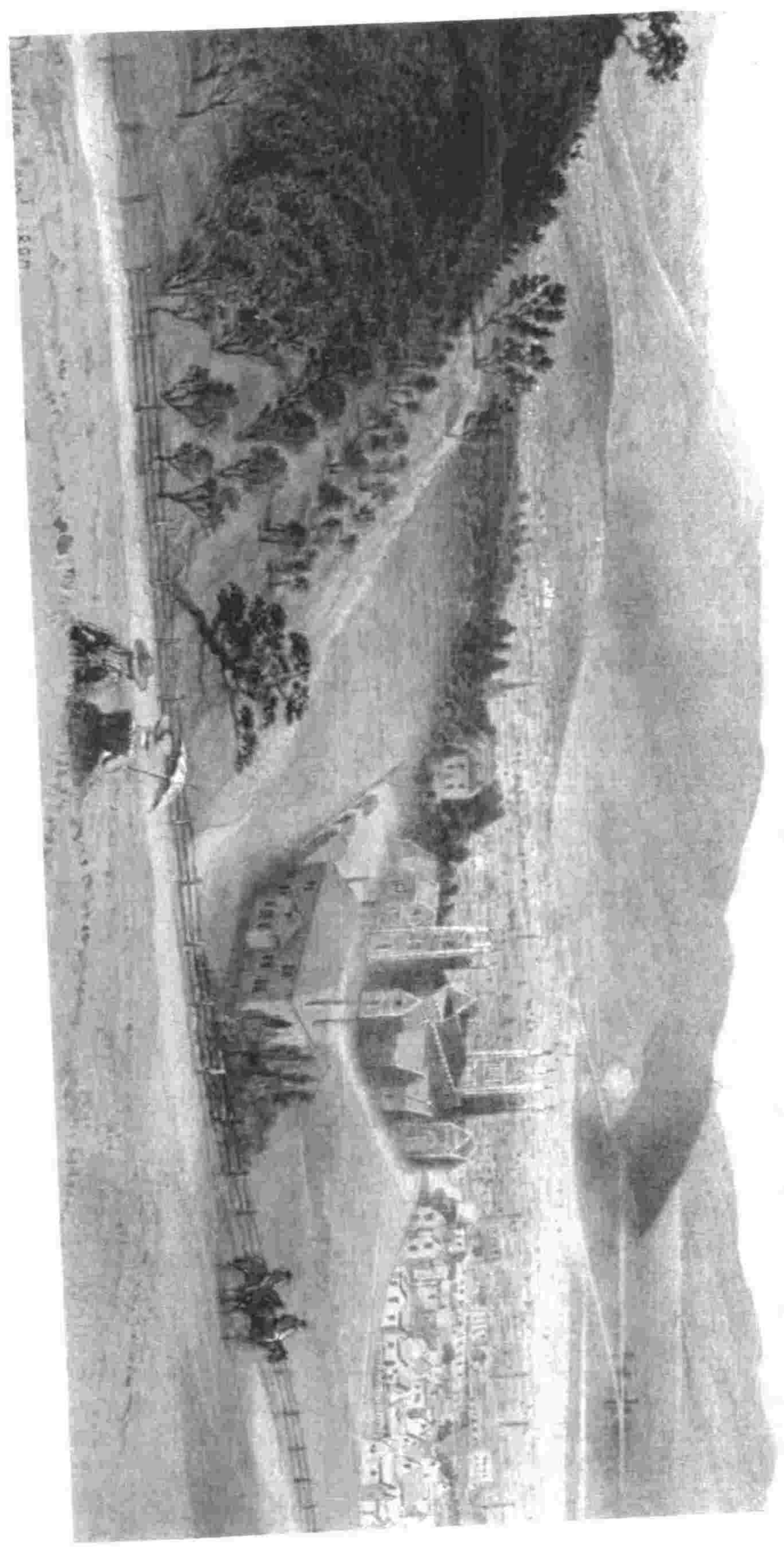

illustration 40 

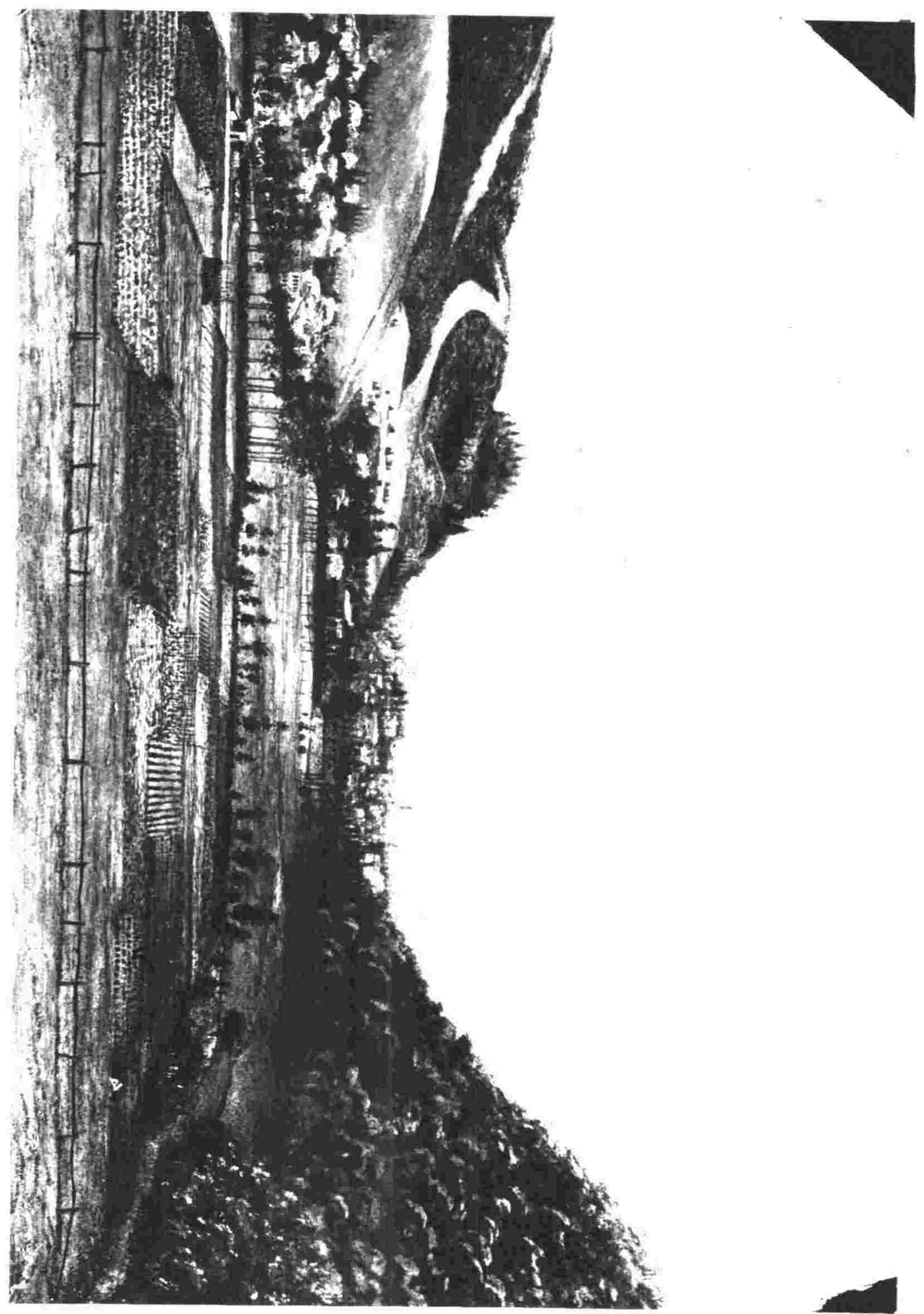

illustration 41 


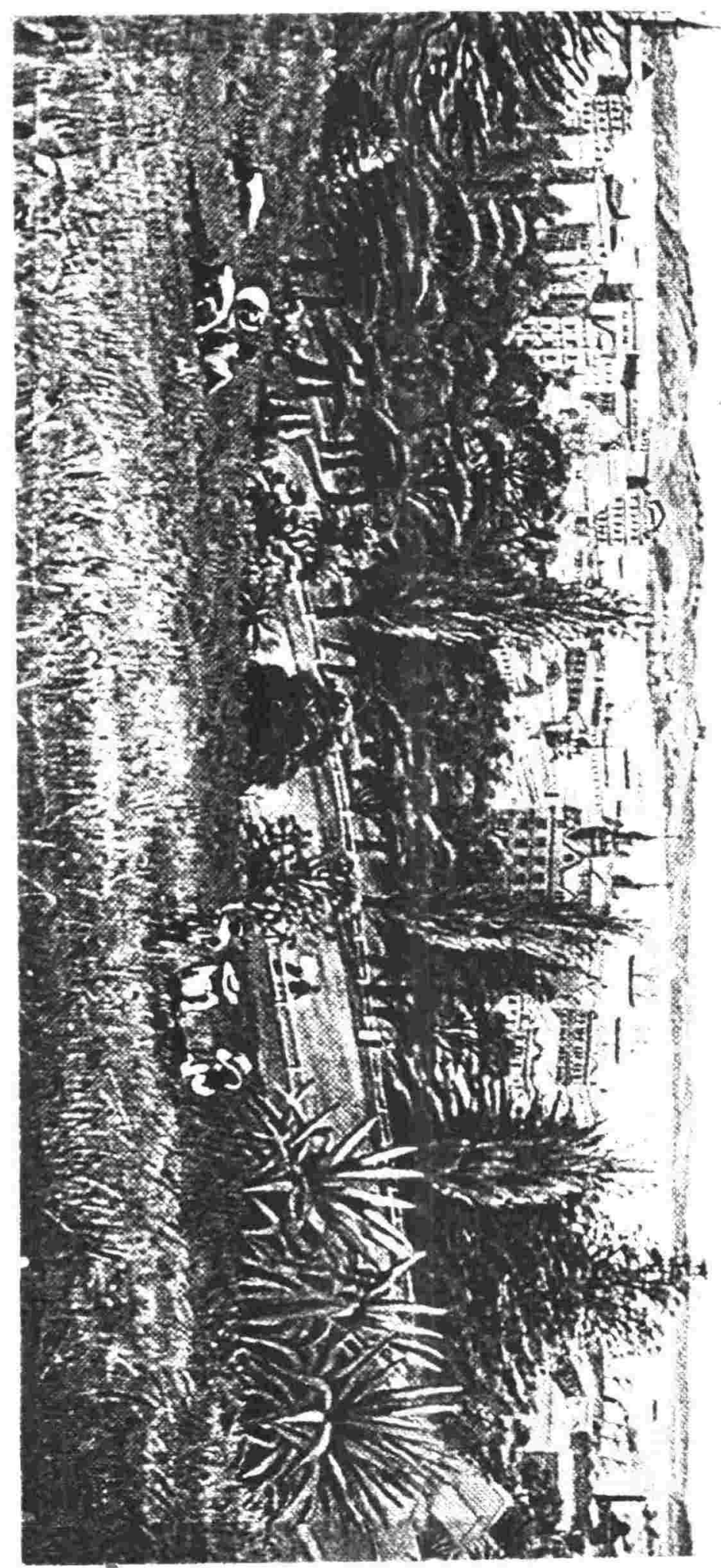

illustration 42 
the scene. The only apparent native bush in this picture are a few toi-toi on the right. Again Auckland is nestled contentedly, this time between the green and rolling hills of the foreground and the bright and warm blue sea of the Pacific in the background. The emphasis on the buildings suggests Aubrey's architectural background. ${ }^{62}$

The three paintings discussed above all have a number of common artistic traits which were used by promoters to develop the pastoralist image of New Zealand's towns and cities. The most important of these was the presence of the city or town itself. Details about the place were not important, although perhaps sometimes the artist would throw in the odd recognisable building or church steeple to identify a particular town or city. What mattered in these paintings though was that the city existed, a symbol of the forces of light and civilisation in a new world only recently settled.

There were other signs which emphasized the European presence. These included relegating the indigenous plants and trees to the sides and accentuating instead symbols of settlement such as cultivated fields, exotic trees, well tended parklands, fences, houses, people, roads and farm animals. In all three works fences play a dominant part in the imagery of the artists. Fences in painting of this genre served two related functions: firstly, they represented a physical means of ordering the new environment by relegating patches of land for cultivation and grazing. Secondly, and perhaps most importantly, fences acted as a kind of pyschological barrier to the unknown; for they could be imagined as keeping at bay the howling wilderness and those forces of darkness and uncertainty in the New World which had not been tamed as yet. Fences in New Zealand painting served the same thematic function as did light in the literature of the Russian novelist Mikhail Bulgakov, who wrote about his experiences as a doctor in Siberia during the early part of the twentieth century. The lights of towns and cities in Bulgakov's work were seen by him as representing the forces of civilisation and reason which were continually being threatend with extinction by "the vast, malevolent, surrounding darkness..." of unknown and elemental powers. ${ }^{63}$

The presence of individual human beings was another more common characteristic of the booster imagery. People could serve as devices to measure scale. They could

${ }^{62}$ Una Platts suggests that Christopher Aubrey may also have been a trained architect (p.28).

${ }^{63}$ Mikhail Bulgakov, A Country Doctor's Notebook. Translated and with an introduction by Michael Glenny. (London: Collins, 1975), p.9. 
function as a compositional purpose by attracting the viewer's gaze or by providing a sense of depth or balance. They could serve to counter feelings of alienation and isolation simply by their physical presence. They could be used as clever promotional devices revealing the prosperity of the colony. (The fact that in Kinder's and Aubrey's work these people are obviously wealthy middle class women would tend to suggest this). The appearance of human beings could also fulfill a thematic function, as stated by Marian Minson: "Such figures could underline the mood of the painting by introducing a pastoral element of rural felicity, with echoes of shepherds and shepherdesses frolicking in Arcadia." ${ }^{164}$ When people were not in the picture, a symbol(s) of their presence replaced them: "But man is usually there in propria persona, usually in the foreground. Both houses and cow announce a common theme, that of domestication." 65

The pastoral landscape proffered a picture of New Zealand that was idealised and sanitized. It was a romantic vision, where there were no dangerous animals, annoying insects, or excesses of weather. ${ }^{66}$ The image was one of eternal spring, where the sun was always shining, the trees and flowers were always in bloom, and where the native presence had been eradicated almost entirely. In the world of the pastoral painting, nature had been manipulated and ordered. Everything had been tidied up. Trees were introduced or taken away where necessary to provide a Classical balanced landscape. The truth was subordinated to the ideal. Maoris, when they were included, assumed Classical poses like figures from Titian. Hills and mountains were reduced and the plains extended to show that the country was suited for settlement. ${ }^{67}$ Such a vision "answered some very real need of the nineteenth century immigrants to find a face of this hostile environment that was not alarming. ${ }^{168}$ It will be seen later that photographs reinforced this notion, capturing only the most beautiful scenes and during the best weather and lighting conditions possible.

\footnotetext{
${ }^{64}$ Minson, p. 15.

${ }^{65}$ Seddon and Ravine, pp.39-40.

${ }^{66}$ Peter J. Schmitt, Back to Nature (New York: Oxford University Press, 1969), pp. 127-147.

${ }^{67}$ I owe these points to Tony Bellette.

${ }^{68}$ Entwisle, p.64.
} 
Such an image was ideal bait with which to entice migrants and tourists, "expecting to escape from [the] dark satanic mills" which they had left behind them in England. ${ }^{69}$ This image was also reflective of similar visual propaganda being produced overseas in America, particularly where the native element was concerned. In the New Zealand town and cityscape, the Maori seem to be missing altogether, and what native bush there is has been marginalised to the sides and reduced in size. The intent of this Europeanization of the countryside was done to celebrate progress and to reassure the settler that the country had been tamed; however, in the words of the entrance plaque at the controversial Smithsonian's "The West As America" exhibition, such a theme also "rarely noted damaging social and environmental change."

${ }^{69}$ Minson, p.13.

${ }^{70}$ Martin Walker, "Westward Oh!," in The Manchester Guardian Weekly, June 30, 1991, p.25. 


\section{CHAPTER 5: PHOTOGRAPHY AND FILM}

Chapter 4 examined the positive images which illustrators and artists fashioned to promote the country's cities and towns. This chapter also examines the positive views of New Zealand's towns and cities in the visual medium, but in this case the modes of photography and film replace those of graphic illustration and painting for purposes of analysis. The section on images in photographs will be discussed first. The beginning of this section, after a brief introduction on the motives of the boosters, will divulge the untrustworthy nature of the camera; the argument will then proceed to show how photographers in New Zealand manipulated their subject matter (both urban and rural) so as to distort the truth by conjuring up only optimistic views of the country and its urban areas. The remaining part of this section on photography will examine the various images which the urban boosters developed, particularly those of stability, orderliness and civilisation, and the rationale behind such actions. The second part of this chapter will concentrate on the tactics utilised by the boosters to advertise the country's towns and cities with moving pictures. It will be argued that in spite of the revolutionary new publicity tool called film, the procedures which the urban promoters used remained analogous to those traditional booster formulas as examined throughout this thesis.

Photography holds a special place in urban history, particularly during the nineteenth century: "Of all the cities of man, the Victorian city was the first to come under the camera's eye." ${ }^{\prime 1}$ Yet despite this new medium, the photographers were just as culpable as the artists in developing a distinct booster image for the purposes of enticing migrants and tourists. This should come as no surprise for the people who commissioned these photographs were the same people who were responsible for promoting the country's cities and towns with paintings and engravings. Therefore, we cannot be shocked at seeing a photographic publication financed by the New Zealand High Commissioner which was trying to convince domestic servants in Britain to emigrate to New Zealand by showing only photographs of prosperous New Zealand homes taken from especially striking angles. ${ }^{2}$ Likewise, one should understand how seductive

${ }^{1}$ G.H. Martin and David Francis, "The Camera's Eye," in H.J. Dyos and Michael Wolf, eds., The Victorian City (London: Routledge and Kegan Paul, 1973), p.227.

${ }^{2}$ New Zealand High Commissioner, Information about New Zealand for domestic servants (London: 1912). 
photographs of rural New Zealand, (along with similar scenes taken of the other Dominions), were placed in British primary schools by colonial governments to be used as emigration propaganda. It was hoped that "...attractive views of seed time and harvest, cattle and sheep stations, fruit cultivation and happy homesteads", might indoctrinate the minds of England's children with sugar plum visions of life in the colonies, thereby infusing in them a desire to emigrate when they grew older. ${ }^{3}$

The camera is not a faultless instrument: its lenses distort, exaggerating some horizontal lines and depressing verticals, and it can be made to utter untruths. ${ }^{4}$

The appeal of the photograph for boosters resided in the fact that photographs were perceived by the public to depict the reality of a situation. Sometimes the boosters stated that such was the case; for instance, an Australian work promoting Victoria in 1893, said that: "The pictures in this work are actual photographs... and as 'the camera cannot lie', these views should carry that conviction with them which 'word painting' might fail to impart." ${ }^{15}$ But before beginning with an investigation of urban booster images, it is vital to understand that the camera was not an unbiased or neutral instrument for recording scenes of cities and towns. On the contrary, photographs could be altered and manipulated to make a scene more aesthetically pleasing. To quote John Kouwenhoven: "We often lose sight of a simple but important truth: that a picture of something is not the thing itself, but somebody's way of looking at it."16

Numerous other people have commented on the photographer's penchant for distorting the truth. The Art Historian H.W. Janson echoes this point while referring to British and American photographers who intentionally posed their figures for effect and who, "composed [their] scenes with the greatest care". ${ }^{7}$ Roland Marchand also says that photographers were guilty of artistic reinterpretation, "via texture, distortion, [and]

${ }^{3}$ Thomas E. Sedgwick, Town lads on imperial farms, with notes on other phases of imperial migration (London: P.S. King \& Son, 1913), p.9.

${ }^{4}$ Martin and Francis, p.227.

${ }^{5}$ E. Jerome Dyer, ed., Victoria and its resources, (Melbourne: F.W. Niven \& Co,, 1893), no page.

${ }^{6}$ John Kouwenhoven, The Columbia Historical Portrait of New York (1953), in Bruce M. Stave, "Introduction", Journal of Urban History, 15, No.3 (May 1989), 243.

${ }^{7}$ H.W. Janson, History of Art (Englewood Cliffs: Prentice - Hall, 1986), p.663. 
unexpected angles of vision", ${ }^{8}$ when using the medium as a vehicle for promoting a commercial product. Peter Bacon Hales, in an essay on the celebrated nineteenth century American photographer William Henry Jackson, says that Jackson carefully prepared the scenes he was going to shoot:

In pictures of Denver, Jackson had assistants clean the streets and public areas before making the photograph, just as - with landscape views during the same years - he had sawed off branches that disrupted the organisation of a "proper" view.?

Stephen Bates in an article for The Guardian Weekly on American Civil War photographs, argued that photographers, to achieve the desired aesthetic and romantic effect, would sometimes pose the corpses of dead soldiers and at other times use live soldiers to pretend that they were dead: "Dead men in one picture often became living soldiers at the same location for the next exposure."10

New Zealand's photographers were not immune to utilizing similar techniques for producing highly idealized views of various scenes. They would take their pictures only when the light suited, as testified to by C.H. Mills, member of the House of Representatives for Waimea-Sounds. Mills stated that photographers of the Dominion's scenery, "very often... had to go to the same place two or three times" to achieve the desired picture. ${ }^{11}$

The country's photographers were also careful to pose their subject matter, as seen in the photograph from The Cyclopedia of New Zealand [ILLUSTRATION 43]. Here one has a unique picture of a photographer meticulously shooting a scene of a town in the South Island during a flood. The setting is Market Street, Blenheim. Wagonloads and boatloads of individuals have carefully halted midstride (or midstream) to be included in the picture. Various people stand up on their canoes or in their carts so that they appear more prominent. The picture has a certain symmetrical quality to it, with the inhabitants crowded together and neatly surrounded by shops on the left and an ornate bank or hotel on the right. The commotion caused by the flood and the people thronging

\footnotetext{
${ }^{8}$ Marchand, p.149.

${ }^{9}$ Hales, "Photography and the World's Columbian Exposition", p. 264.

${ }^{10}$ Stephen Bates, "When the Cameras Went to War," in The Manchester Guardian Weekly, April 7, 1991, p.19.

${ }^{11} N Z P D, 1896$, p.402.
} 


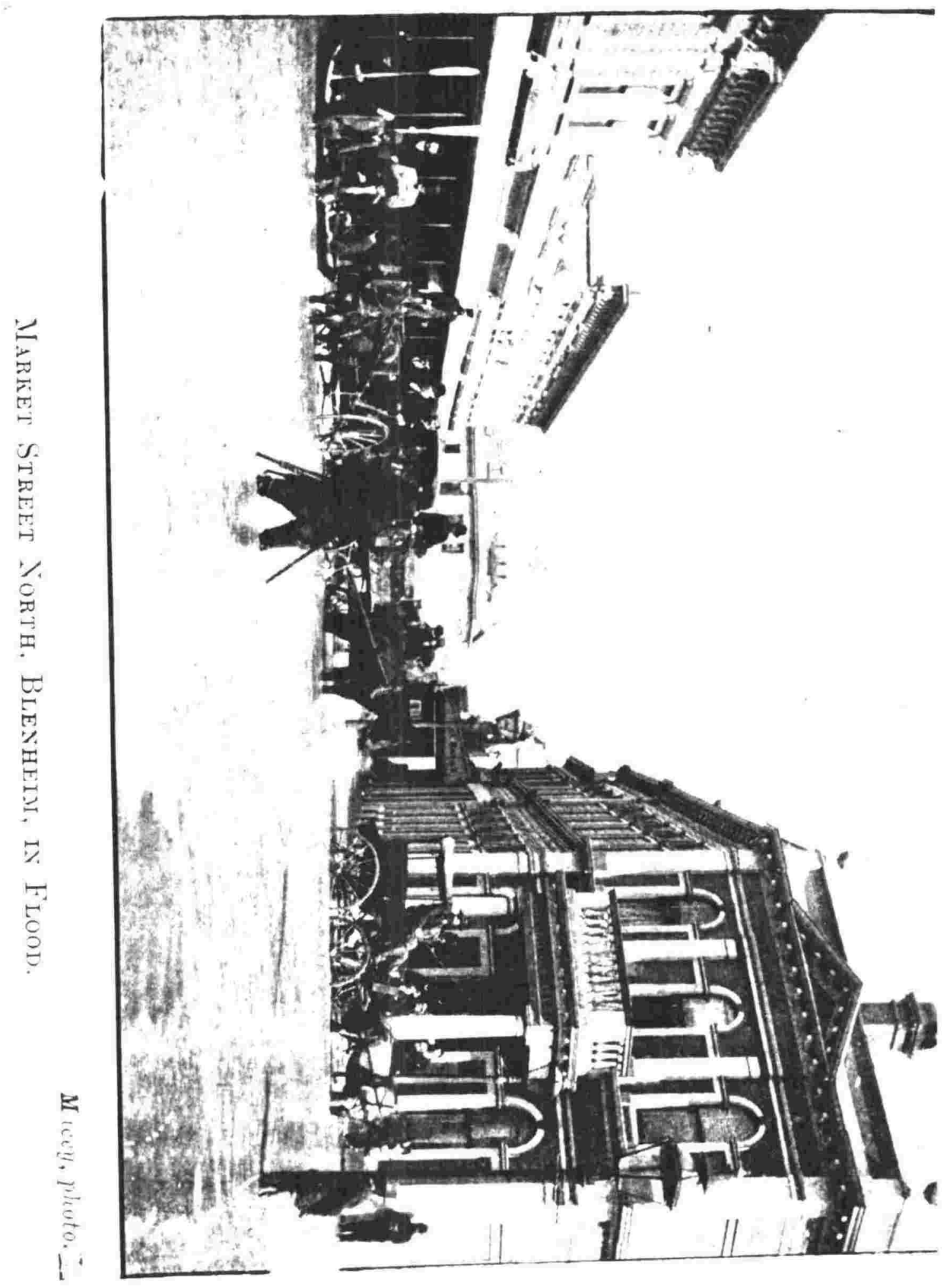

illustration 43 
the street, despite the high level of water, suggests that the city is much more heavily populated than it actually is and hints that even in crisis a brisk business continues to be conducted. The theme of this picture might very well be that "nothing seems able to stop the progress of this little town"! Outside of the photographer's lens, however, there are far fewer people indeed. When examining this photograph, one must also wonder why a picture of Blenheim in flood was included in the Cyclopedia in the first place. It is highly likely that this strange photograph was meant to be conducive to advertising by calling attention to the town, similar in intent and method to those booster works which advertised the effects of tornados, volcanoes and other peculiar like as discussed at the end of Chapter 3.

There is a great deal more evidence than just those few examples used above, which testifies to the outright maneuvering of urban boosters. For instance, a letter to the New Brighton Town Council from the Canterbury Progress League, attests to boosters arranging their subject matter. The Canterbury Progress League was a body set up for the purposes of promoting the city of Christchurch as well as the other towns in that province. New Brighton was a small town that regularly contributed to the League's funds and that wished to advertise itself as a tourist resort. The town was particularly suited to such a role as it was on a fine stretch of sandy beach and was near the city of Christchurch, where it found a convenient and steady population from which to draw summer visitors. The Government Publicity Department had previously visited the town so as to take photographs of New Brighton's attractions. However, the weather had not co-operated during that visit and the pictures had not turned out too well. The Government photographers, therefore, were going to try again; so the Canterbury Progress League wrote to New Brighton's Town Council telling them to advertise the event in the local papers so as to attract great crowds to the beaches that day. It was believed that should the pictures be taken on a bright sunny day and should a healthy crowd be seen enjoying the amenities which New Brighton offered, then the resulting effect would convince people (both in New Zealand and abroad) that New Brighton was a destination worthy of a visit. The following is a segment of the letter written to New Brighton's Town Clerk from the Organiser of the Canterbury Progress League:

...This is to advise you that we have arranged for the Government photographers to visit New Brighton next Saturday afternoon for the purpose of taking both cinematograph and 'still' pictures of the foreshore. On the last occasion photographs were taken of New Brighton, the day was overcast, and the 
attendances on the beaches were rather disappointing. Thus the reason why we have deemed it advisable to procure fresh photographs. May I suggest that you invite the co-operation of the public in making these pictures a success, as without their attendance in large numbers, the foreshore will look very deserted... ${ }^{12}$

There were numerous other ways by which photographers could manipulate their subject matter to make it more aesthetically appealing; many of these methods went beyond merely posing the subject matter or taking the picture on a fine sunny day. The following examples are not ones used to promote urban areas, yet they do reveal the amount of artistic exaggeration that did occur within the ranks of New Zealand's photographers as well as showing the sometimes extreme means that some photographers took to meet these ends.

The first example of photographic manipulation comes from an obituary written by the Editor of The Otago Daily Times. He was a good friend of Sydney Taylor who was the first photographer and cinematographer for the Government Tourist Department. According to the article, Taylor sometimes took drastic actions to get the perfect picture:

One concerned a publicity photograph of Lake Manapouri... It showed the lake framed by a distinctive tree. A beautiful shot it was displayed throughout New Zealand and overseas... Many other photographers have tried to find the very spot from whence Syd took that photograph. They never will though - he cut the tree down straight afterwards. ${ }^{13}$

Sometimes the artistic tampering with a photograph is so obvious that it does not require a written confession on the behalf of the artist or publicity group involved. Instead, the viewer is easily able to identify the amount of artistic hyperbole with his or her own eyes. Taking the example of Diamond Lake at Wakatipu [ILLUSTRATION 44], one cannot help but see how the photographer has carefully planned the final product. The setting is a picturesque South Island evening, with wisps of artificial cloud painted in by a developer circling lazily about the moon. A small boat rocks gently in

${ }^{12}$ Letter addressed to the Town Clerk of New Brighton from the Organiser of the Canterbury Progress League, March 3, 1925. From the New Brighton Records: 2/9 Inwards Correspodence (1921-1925). (Canterbury Public Library).

${ }^{13}$ E.A. Aubin, The Otago Daily Times (Dunedin: November 29, 1973), p.12. The Burton Brothers, photographers who had emigrated from Leicester to Dunedin in 1868 , went so far as to successfully call for the demolition of an entire building in Leicester which they had considered an eyesore! I owe this point to John Turner. 


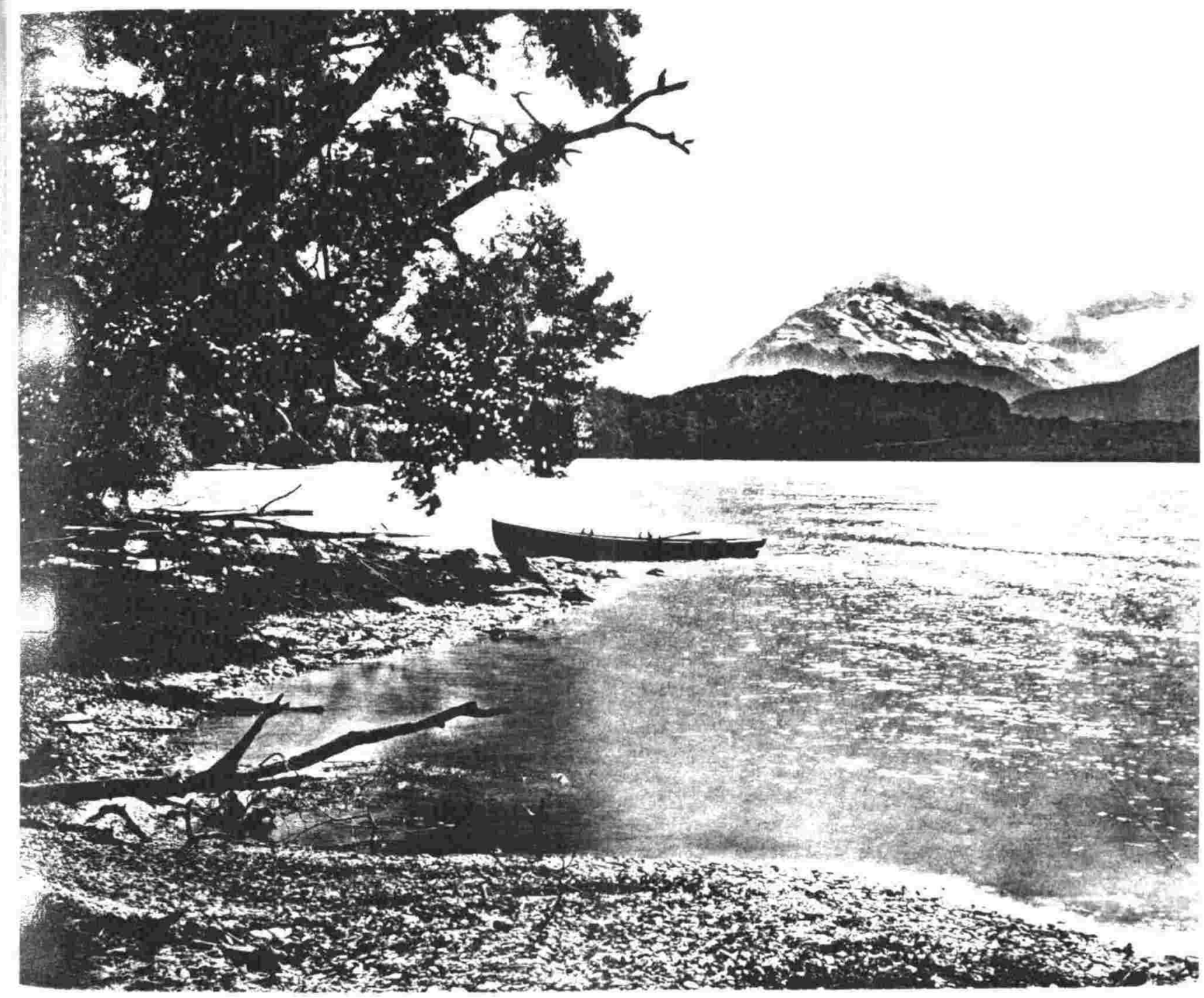

Diamond Lake, Wakatipu N.Z 
the wind, moored to a quiet bit of beach. The tree on the left and the log in the foreground frame this enchanted scene. The light from the resplendent full moon, (which has been obviously added to the picture so as to achieve a romantic effect), reflects on the placid surface of the lake and serves to highlight the snow-capped peaks in the distance (which like the moon and the clouds, also appears heavily accented). Roland Marchand, when examining the techniques which American advertising used to orchestrate a particular photographic image, says that similar results could have all been brought about by the discriminate use of "pen, brush, or super-imposed photo." ${ }^{14}$

The picture of Diamond Lake, despite the feigned sky and lighting, shows a judicious amount of artistic license on behalf of the developer and/or photographer. The picture of "A Youthful Canoeist" along the Wanganui River, however, epitomizes the contrived and the spurious [ILLUSTRATION 45]. One almost does not know where to begin when discussing the technical errors in this promotional work. The picture is supposed to be one of a young Maori girl peacefully rowing down a river. Yet a number of mistakes, which are blatant to even the untrained eye, reveal the photograph as a promotional work and a poor one at that.

It is only too obvious that the central subject of this photograph, the girl on the canoe, comes from an entirely different picture. It is as though the developer cut her image out of another photograph and hastily added it straight onto this one. This artistic manipulation can be seen in two instances: firstly, the canoe has been carelessly superimposed onto some rocks rather than onto the water; secondly, the girl is out of scale with the passengers in the other much smaller canoe behind her. Even allowing for the effects which distance has on scale, the tallest of the three men in the boat behind her could only reach the bottom of the Maori girl's knees at best!

The most astounding faux pas on the behalf on the printers of this book, though, remains the inexplicable and incorrect drawing of New Zealand which appears on the side of every page of this work. A picture of New Zealand is not so hard to explain in itself; perhaps it was a laudable attempt at giving the reader of the work a good grounding in the colony's geography, which as the evidence has shown previously in Chapter 1, was severely lacking. But what is so hard to account for is the fact that the country has been drawn upside down. Considering that the book was published in

${ }^{14}$ Marchand, p.152. 


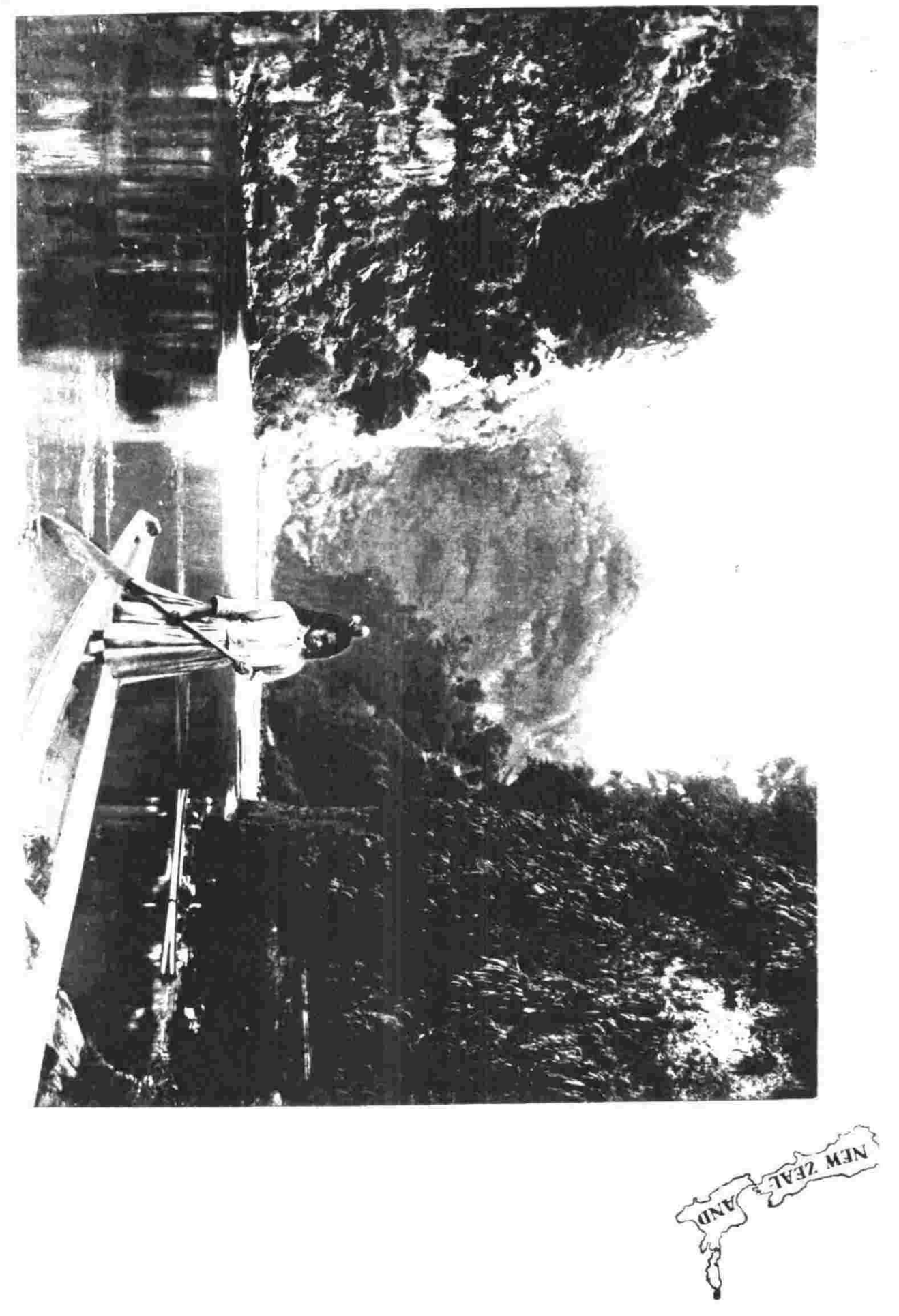

illustration 45 
Wellington, the only excuse for this mistake (as well as for the poor quality of the artistic additions), appears to be shoddy workmanship.

One can see a number of ways in which photographers could alter their pictures so as to make the finished product more appealing visually. Sometimes these techniques ranged from simply posing figures and taking advantage of the best lighting conditions, to effecting alterations in the developing process itself. As can be seen also in the evidence, the quality of these booster photographs varied greatly. Some were well crafted photographs with few discernible traces of artistic tampering, while others still were cheap products presumably aimed at rapid turnover and for quick profit. Let us return now to images of towns and cities and to those specific procedures which were used by the photographers to boost the country's urban locales. It can be seen that photographers employed similar techniques to those of artists when depicting images of urban New Zealand. The primary evidence from this study reveals that such techniques included showing only chosen views of the best that a city had to offer and usually taking these views only on a bright sunny day and from a distance.

Turning to the example of [ILLUSTRATION 46], "Auckland From the Air" (1930), we are able to discern a number of these booster characteristics. Firstly, the view of the city from quite some distance (in this case a photograph taken from an aeroplane) allows the spectator only a glimpse of the urban environment, and one that has been carefully selected by the photographer. We are so far away and so removed from the scene that we can not see the little details which might otherwise detract from the general impression of a highly civilised and highly ordered urban centre which this photo was trying to present. Those inevitable darker and sadder characteristics which accompany urban living: the homeless, the unemployed, the sick, the lonely, the criminal element, the dirt, the disease, the dilapidation and the rubbish on the street, have all been excluded from this picture. The setting is demonstrably more pristine with the addition of the strong midday light which saturates the entire photograph with an air of optimism and which hides any trace of the nefarious and the ugly. Consequently, Auckland appears to the viewer as a shining city of light exhibiting all the characteristics of a prosperous New World utopia. Such panoramas and bird's eye view photographs taken from a distance would have also served to make Auckland and other cities 


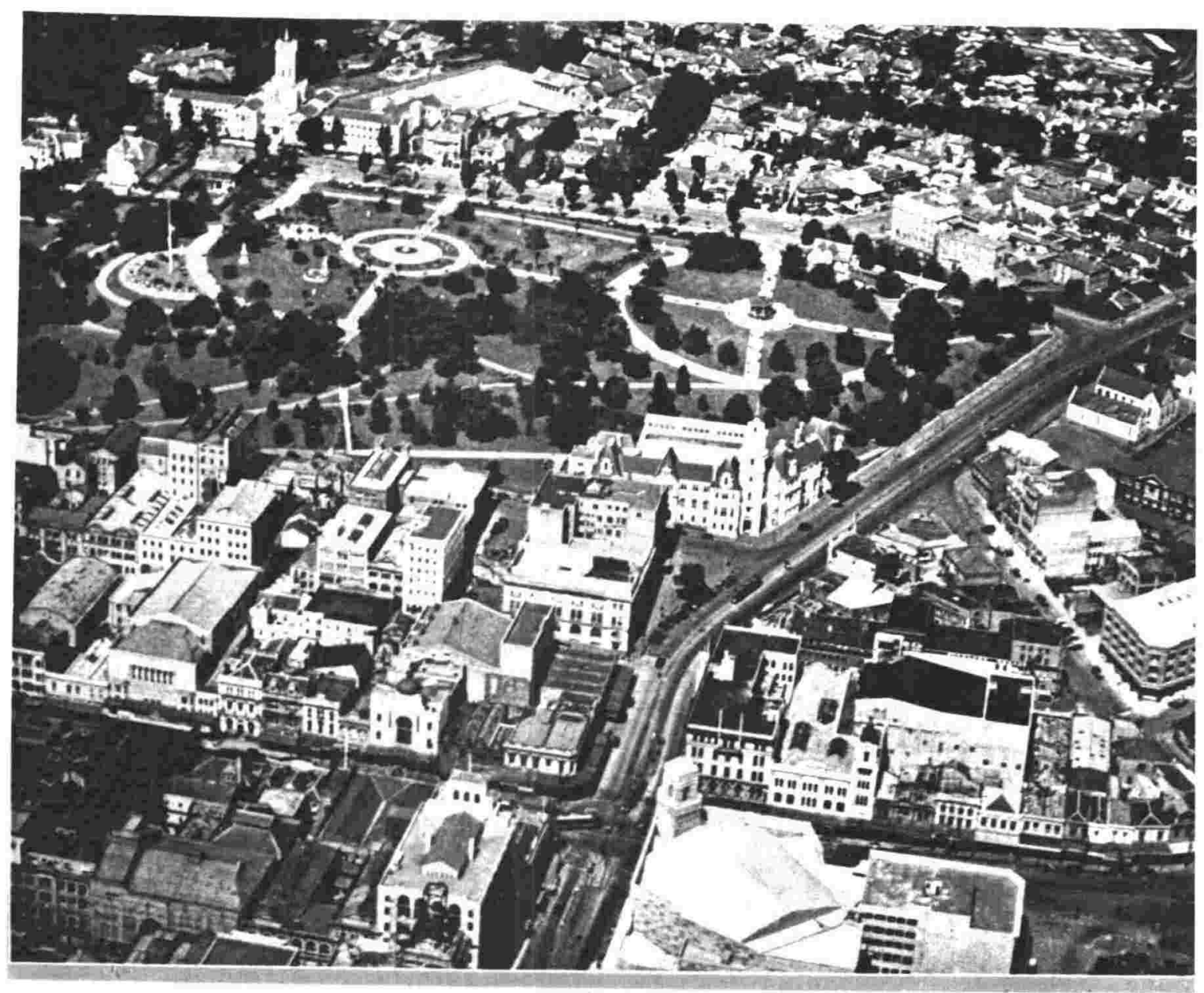

BIFINESS AND BEATTY TIRIVE SIDE: BY SILE.

A eity liberally eadowed with parks, Auckland tas nene nore beatiful than Albert Park which liw within a fuw Fards of the main lusiness area. Beyond it, to the left, is the Auckland Cniversity follege. Year the junetion

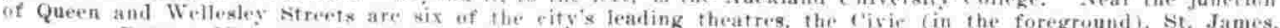
Regent. Mrjestic, stratul, and Plaza. In the centre of the picture is the Public Lilirary. 
understandable for both their inhabitants and their visitors; for according to Peter B. Hales, "By enclosing and encapsulating the city, they gave it holistic identity."15

The second major method by which this picture of Auckland reflects the booster's ambitions is that it selects the subject matter for the viewer. It is highly unlikely that photographers wishing to boost Auckland would have taken pictures of the city's slums, derelict houses or run down wharfs. On the contrary, as can be seen in this photograph, only images of culture and business are rendered. Notice the emphasis on the planned parks, the roadways, the university and the library, all symbols of "the achievement of civilization." 16 New Zealand's cities, like many of those of South America, preferred to concentrate on the cultured European image so as to deliberately foster notions of enlightenment and progress. ${ }^{17}$ Hence the emphasis on one of Auckland's more attractive sites, and the marble and limestone building materials which dominate the city's centre and which conjure up comparisons to Rome, Paris or London.

The emphasis on Albert Park in this photograph represents a third promotional technique commonly utilised by the urban boosters. The accent laid on the park's manicured lawns, its classical fountains and tempiettos and its Renaissance - inspired paths, helps in invoking an image of nature domesticated. This image is similar to American photographs of the period, specifically those taken of New York city's skyline emerging from copses of trees in Central Park; the latter image was meant to be a strong message symbolising "the preeminence of man over nature in the urban environment." ${ }^{18}$ Urban parks, therefore, acted as agents by which to reveal the colonial's firm control over a new environment. Pictures of parks and woodlands in or nearby cities would have also appealed to British emigrants desiring to escape from the Wigan Piers and Coketowns of industrialised England.

Other New Zealand cities had similarly arranged photographs taken of their downtown cores, particularly Wellington's Lambton Quay, Dunedin's Princes Street and p.73.

\footnotetext{
${ }^{15}$ Peter Bacon Hales, Silver Cities (Philadelphia: Temple University Press, 1984),
}

${ }^{16}$ Hales, "Photography and the World's Columbian Exposition", p.252.

${ }^{17}$ Robert M. Levine, "Images of Progress in Nineteenth-Century Latin America", Journal of Urban History, 15, No.3 (May 1989), 310.

${ }^{18}$ Hales, Silver Cities, p.95. 
Christchurch's Cathedral Square. The overall aim of such photographs was to draw likenesses with fashionable and cultured European centres. Such photographs were typically taken from an elevated position and would tend to highlight a city's paved roads, tree-lined boulevards, electric trams, and high rise stone buildings, all signs of wealth and prosperity. When the pictures were taken at street level, the subject matter remained focused on objects intended to affirm a city's progress and cultural maturity: the ornate facades of stone hotels and banks, the paved sidewalks and roads, the fashionable middle class crowds, the rich carriages thronging the streets, the gas lamps or later - electric lighting, and the myriad rows of electric and telephone wires which seemed to cling precariously to wooden poles. ${ }^{19}$ The latter was meant to reveal the technical prowess and advanced standard of living which the colony enjoyed, further good promotional propaganda.

Another favourite subject in the promotional stockpile of photographic material included local amenities; particularly popular were pictures of beaches, zoos, libraries, parks, gardens, art galleries, decorative rustic bridges, promenades, amusements (Wellington's water chute), local fairs and international exhibitions (especially pictures of the entrance to the 1906 Christchurch exhibition and some of the amusement rides open to the public during that event).

To add to the appeal of these pictures, artists usually tidied up the streets and the backgrounds, as seen in the photograph of Wellington's Lambton Quay [ILLUSTRATION 47]. The spectator can hardly ignore the changes introduced into this picture in the middle scape and in the background. It appears as though the developer has brushed over with paint or ink those areas which either did not turn out so well in the finished picture or which were unpleasing to the aesthetics of the day; foliage has been added where necessary, the lines on buildings have been sharpened and other rougher patches have been smoothed over, particularly the hills in the background. It even appears as though the odd cottage or house in the middle ground has been entirely drawn onto the photograph. In a way the photographers of that time period were very much like the town councillors or mayors who greeted the important visitors at the railway station or at the local harbour upon arrival. For just like those visitors who were

${ }^{19}$ For a good example of a photograph showing a complicated morass of electrical wiring, see the picture of the power poles in front of Victoria Arcade, Auckland, in 53 views illustrating Auckland city and suburbs (Auckland: Fergusson Ltd., ca.1920), no page. 


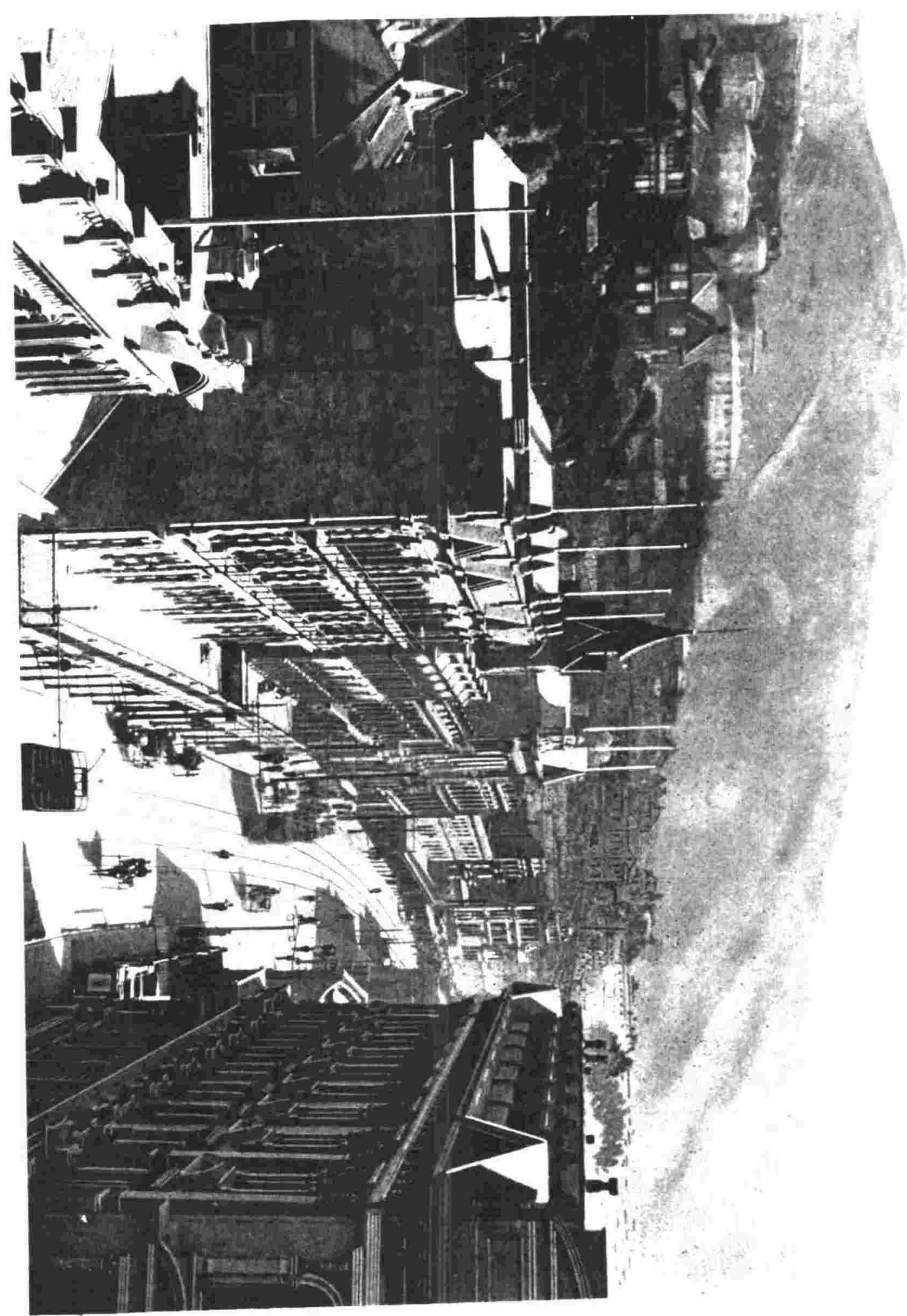

illustration 47 
shown only the positive and optimistic images of the urban locale, we are shown by the photographers only those selective aspects of the city or town which would produce upon the mind a favourable impression. David Hamer echoes many of the above points when he comments on the ordered appearance of early towns and cities in images of the day: "...artistic depictions of frontier towns were obviously highly sanitized and betray an obsession with fences and neatness and order..." ${ }^{20}$

The booster's concern with fostering only a certain sanitised and civilised image is made all the more acute when one considers the debate which surrounded the Photographic Copyright Bill that was proposed in the New Zealand Parliament of 1896. The motion to introduce a copyright law had been originally suggested by Samuel Carnell, a member of the Lower House representing Napier and also a professional photographer by occupation. Carnell wanted to curb the indiscriminate pirating of photographs of New Zealand scenery which was occurring abroad, particularly in Germany. Pirated copies of New Zealand photographs were being reproduced in great numbers and being sold at prices which were much cheaper than their New Zealand produced counterparts. Carnell argued that "it was very unfair to the photographers" in New Zealand who had gone to so much trouble to take those pictures. ${ }^{21}$ Carnell also complained that the quality of the copied photographs was not very high. Prime Minister Richard Seddon, on the other hand, opposed any attempts to stop the pirating of pictures of New Zealand scenery on the justifiable grounds that it might lessen the country's overseas publicity. Nevertheless, despite Seddon's opposition, Carnell's motion was passed in the House by a considerable majority.

This debate, however, goes beyond a simple case of protecting one's own. On the contrary, it mirrors a similar controversy that had erupted with Charles D. Arnold's photographic monopoly over the world's fair in Chicago some years earlier. According to Peter B. Hales, the organisers of the International Exposition had given Arnold the monopoly for photographing the exhibition because his "vision fit the conception of his sponsors perfectly, and it seems highly likely... that indiscriminate output would damage the force and integrity" of the model ideal city. ${ }^{22}$ New Zealand's politicians, therefore,

\footnotetext{
${ }^{20}$ Hamer, New Towns in the New World, p.206.

${ }^{21}$ NZPD, 1896, p.400.

${ }^{22}$ Hales, Silver Cities, p. 140.
} 
might have also been concerned that a flood of poorly produced literature on the country would adversely tarnish the image of the colony overseas. Certainly should a photograph like that of the young Maori girl along the Wanganui make its way into people's homes, then the net results might not be too favourable.

Such an ulterior motive was not improbable, for according to David Hamer, New Zealand's Liberal Government of the 1890 s had been deliberately cultivating a distinct image of the colony as a model democracy by advertising its radical legislation. ${ }^{23}$ Such propaganda was effective advertising both for the country in general and for its exported products. Why, therefore, would the government not hesitate to fashion an equally effective campaign of visual propaganda for the purposes of advertising the country? Keeping in mind how important a good image of the country was in the minds of New Zealand's Liberal politicians, this point does not seem so far-fetched. The proof supporting this case about the need for the government to control the quality of New Zealand's image abroad, however, comes from another member of the Lower House $\mathrm{T}$ MacKenzie, who represented Clutha; according to MacKenzie, the pictures pirated overseas: "...were the most villainous reproductions, and got up in the cheapest manner... anybody who saw these photographs would never come near the country at all."24

New Zealand's urban photographers, in keeping with the civilised and Europeanised image as discussed above, liked to cultivate parallels to England and the Continent when promoting their cities and towns. Such visual techniques are similar to those verbal comparisons mentioned earlier in the written booster literature. Taking the example of the square in Palmerston North [ILLUSTRATION 48], a picture taken by a Government Publicity Department photographer, the image rendered is one straight out of Gray's "Elegy in a Country Churchyard" or any number of typically sentimentalised English poems and drawings. The Palmerston North photograph has been carefully staged; the pond covered in waterlillies, the rustic bridge, the English trees and the Gothic church in the near background, was all meant to affirm a likeness to the Cathedral Cities of Great Britain, like that of Llandalf in Cardiff for instance. The fact that there are no visible signs of a city evident at all, despite this picture having been taken in the heart of Palmerston North, underscores this point. Christchurch's promoters

\footnotetext{
${ }^{23}$ Hamer, The New Zealand Liberals, p.63.

${ }^{24} N Z P D, 1896$, p.401.
} 


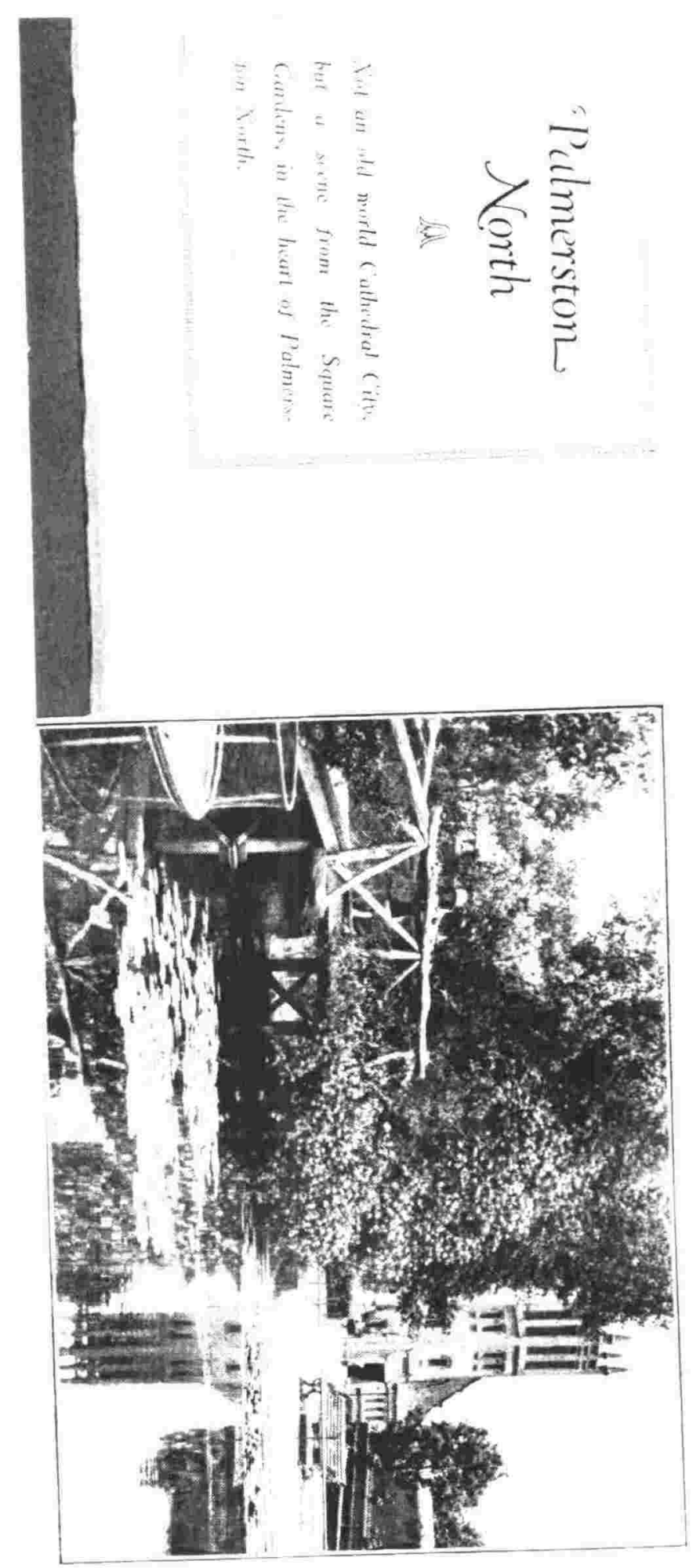

illustration 48 
with their pictures of Cathedral Square, also attempted to develop similar analogies to Cathedral towns in England. The plethora of photographs either taken from the cathedral's tower or of the cathedral proper, emphasize this point by seeming to evoke comparisons to Salisbury, Canterbury or York.

Numerous examples of this kind of boosterism, drawing likenesses to Old World towns and cities, permeate the visual literature. A comparable photograph of picnickers along the River Avon in Christchurch [ILLUSTRATION 49] elicits an impression of Stratford (England) and of punting along the river of that same name. This last photograph of middle class families refreshing themselves from New Zealand's summer heat along the River Avon, is also highly reminiscent of the French artist Georges Seurat (1859-1891) and his paintings "Une Baignade"(1883-84) and "La Grande Jatte"(1884-86) [ILLUSTRATIONS 50 and 51]. In both paintings as well as in the photograph, not only is the arcadian subject matter the same but the poses of the figures are also remarkably similar. These images also share a number of other common features, notably the dappled late afternoon sun reflecting on the placid surface of the water and the broad sun hats with their decorative black ribbons. The photographer of the New Zealand picture may have been aware of Seurat's work, consciously evoking a comparison with Paris itself and suggesting that Christchurch was New Zealand's historical and cultural equivalent of the French capital. Likewise, the photographer may have merely been including picturesque views of urban parkscapes as valuable additions in the arsenal of booster propaganda.

Accordingly, numerous comparable booster elements in other towns and cities receive a great deal of attention in the promotional literature, particularly the repeated pictures of Hamilton's Railway Bridge or those of Auckland's Grafton Bridge. These great engineering feats, with their trains and road traffic racing topside and their magnificent arches spanning rivers and rocky gullies, epitomized the modern and were saturated with symbolic meaning. Not only were they physical icons representing development, growth and technical advancement, but they also exemplified colonial energy and willpower. They were iron, steel and concrete monuments testifying to the presence of the settler in the country and to the European's firm control of the environment, particularly of the colonial's ability to overcome wild terrain and to unify the nation with a modern, efficient and effective communications and transportation network. 


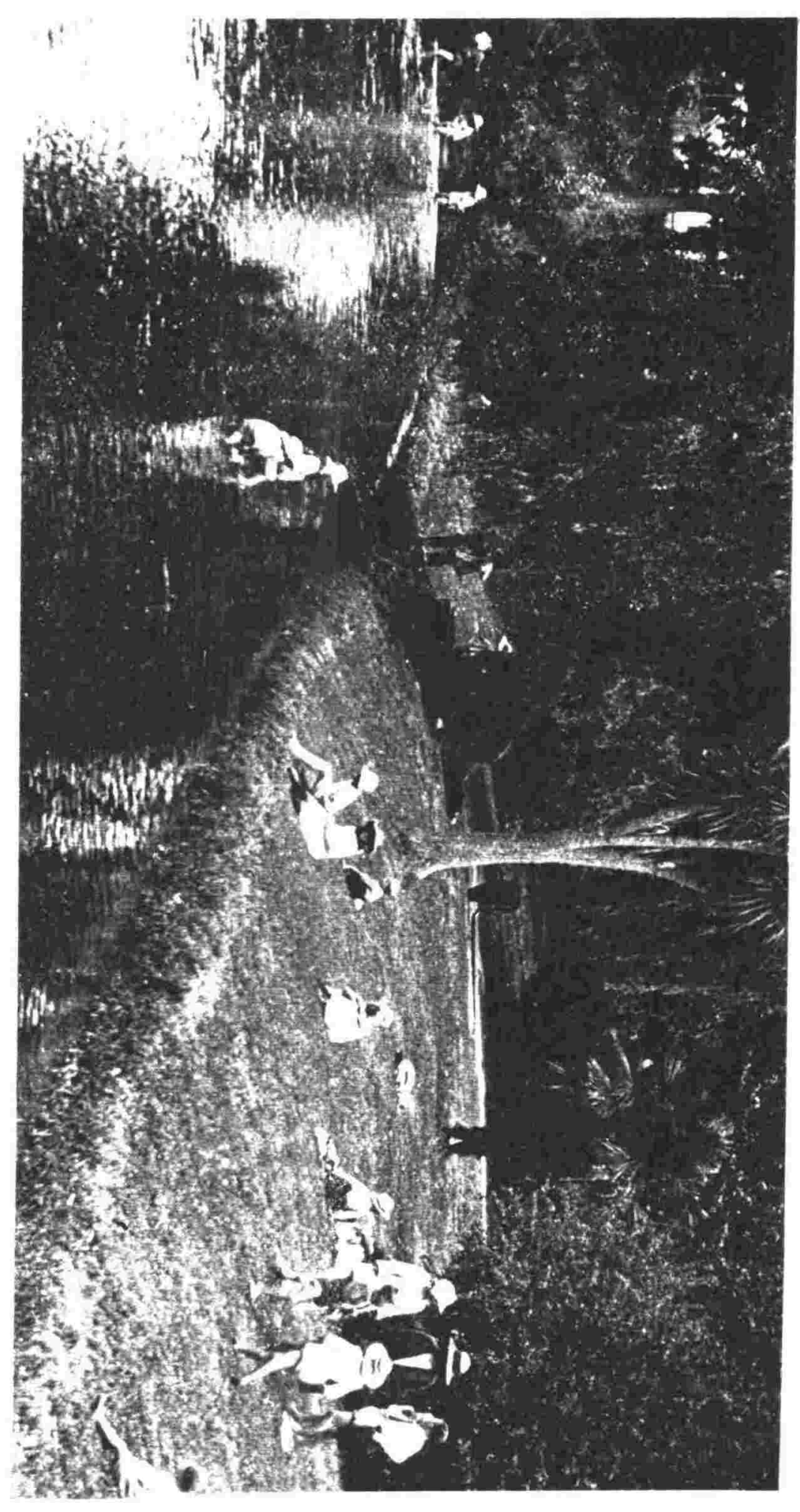

illuctration 4 요. 


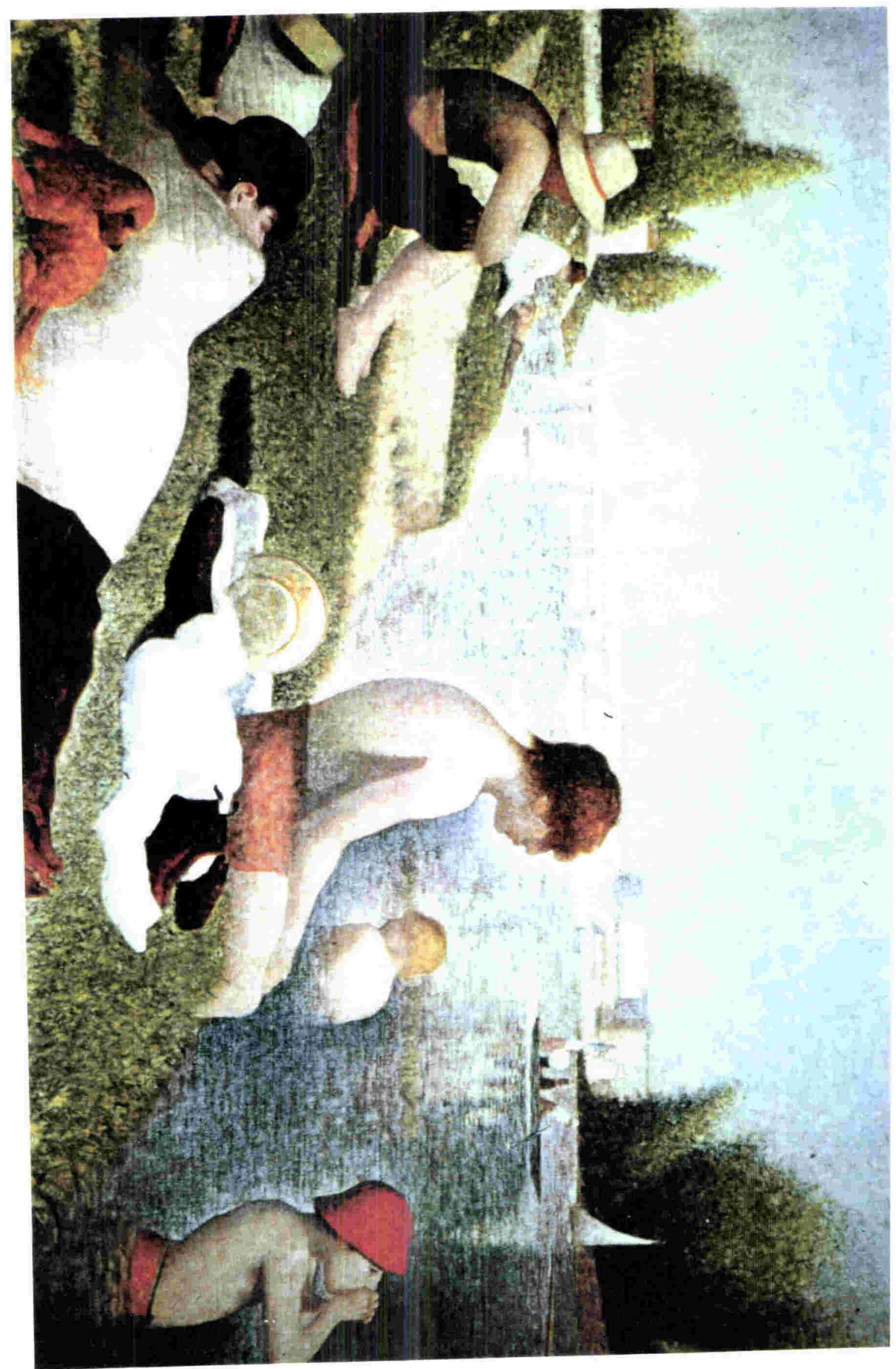

illustration 50 


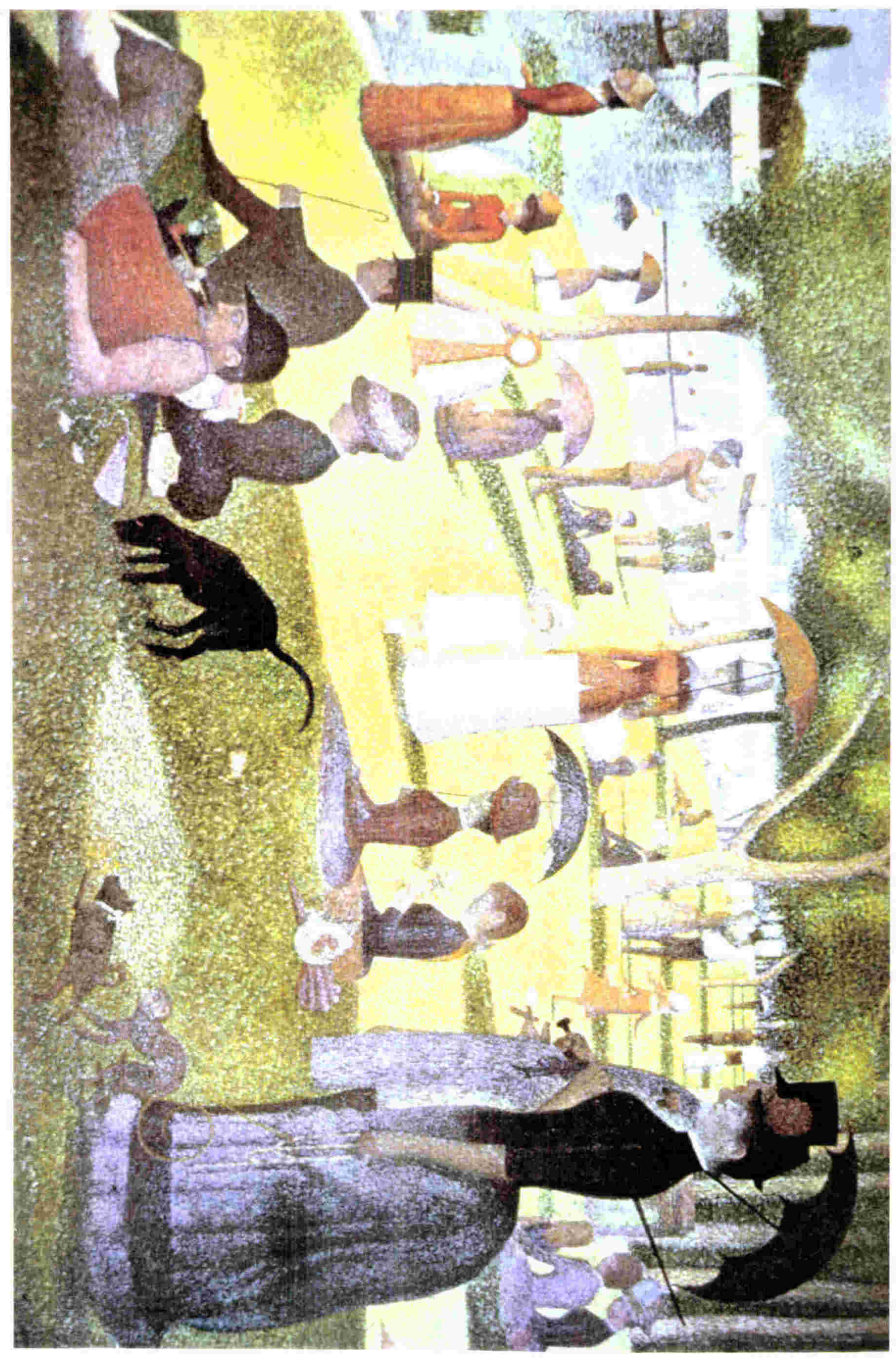


All these pictures with their assorted promotional techniques call to mind Peter B. Hales's work on photographic images in American urban history, and the manner of photographing cities between 1870 and 1900 which he dubbed The Urban Grand Style. According to Hales, the urban grand style:

....acted to present as fact the developing mythos of urban health by editing out the undesirable elements and by treating the ideal aspects of the city in a way which gave them the maximum of persuasive power. Communicating by a variety of stylistic devices the qualities of monumentality, order, and civilization... the urban grand style gave the authority of fact to what was, and would remain, an unrealized ideal. ${ }^{25}$

Before leaving the section on booster photography, it is necessary to discuss the reasons why pedestrians were either included or excluded from certain promotional photographs. Usually the reason was either an intentional promotional device on behalf of the artist or simple technical difficulties. If we turn to Hales yet again, he tells us that many photographs of American cities, particularly those of mid nineteenth century San Francisco by George R. Fardon, omitted including the presence of human beings. Their aim, rather, was to depict the ideal city. By inserting a human presence the photographer threatened to undermine the ideal of stability and order, for the human element included a measure of risk - a potentially disharmonious and subversive presence in an otherwise uniform arrangement and plan. ${ }^{26}$ Accordingly, William Main argues that many of the earlier street and city scenes in New Zealand were devoid of human life simply because photographers were not able to convince pedestrians to keep still for the time period required for wet plate photography. ${ }^{27}$ Hence the ghosting that is common in many photographs.

Nevertheless, a pedestrian was often included in photographs for a variety of reasons, depending on the intent of the booster. As addressed previously, if the promoters wanted to show a bustling and busy city scene, one would be almost sure to see crowds included in promotional pictures. Likewise, if a manufacturer wanted to show a thriving business, it would often be the practice to include people milling around

\footnotetext{
${ }^{25}$ Hales, Silver Cities, p.72.

${ }^{26}$ Ibid., pp.55-57.

${ }^{27}$ William Main, Wellington Through a Victorian Lens (Wellington: Millwood Press, 1980), p.15.
} 
a particular business enterprise. Also, if an artist wanted to reveal the wealth of the colony, it was common for the photographer to include fashionable middle class couples parading the streets of a city or town. However, pedestrians could also be included in a photograph for aesthetic reasons, as mentioned in an article on British photography by G.H. Martin and David Francis: "A human presence gives scale and a sympathetic interest to a picture..." ${ }^{128}$

$$
* * * k
$$

In the closing years of the nineteenth century New Zealanders were introduced to the wonders of moving pictures. In 1896 they had their first public screening of a film, the subject of which was a vaudeville performance. In 1898 the first film footage ever was taken in the country, that of the opening of the Auckland Exhibition. ${ }^{29}$ The country's boosters quickly took advantage of this new medium as a promotional weapon. In 1901 the Government had already commissioned its first film, footage commemorating the Royal Visit by the Duke and Duchess of Cornwall and York. Twenty two years later, by 1923 , the Government Tourist and Publicity Department was producing publicity films on a regular basis. ${ }^{30}$ Other non-governmental booster groups were also getting into the practice of advertising by film, including private individuals and other assorted promotional organizations. Despite this new medium, however, the methods of advertising the country's cities and towns were remarkably similar to those booster procedures discussed previously in both the written and visual promotional material. The quality, quantity and popularity of the booster films depicting urban images will be discussed first, followed by an examination of the assorted advertising techniques themselves.

Although this section on motion pictures purports to analyze a variety of urban promotional films, the desired end is hindered by the quantity of material available for study. Firstly, although an almost complete list of films produced by the Government Publicity Department does exist from which to examine moving picture productions with urban themes, there appears to be no similar method for cataloguing those films

${ }^{28}$ Martin and Francis, p.242.

${ }^{29}$ The information about the early years of New Zealand's film industry comes from "Film Pioneers," On Film vol.7, no.2, (February/March 1990), p.24.

${ }^{30}$ Jonathan Dennis, Ed. and Clive Sowry, "The Tin Shed": The origins of the National Film Unit (Wellington: New Zealand Film Archive, 1981), p.8. 
commissioned by otherwise non-governmental agencies, such as those by private individuals or local publicity bodies. Therefore, the evidence tends to focus more on the government's productions rather than on those by any other organisations or individuals. Secondly, the availability of this same primary evidence which comes from the government and which is documented is limited; of a list of two hundred and fifty-five films known to have been completed by the Government Publicity Department between 1922 and 1930, only sixty survive today. This small list is primarily a result of the films being made on nitrate, a material which starts to decay the minute that it is made. The remaining minute quantity of those films available for analysis is even more hindered by the fact that of those sixty surviving films, the majority are of a general subject matter having very little to do with cities. Instead, they tend to be films taken of scenic and sporting wonders. Typical of such themes are titles like "New Zealand Fiordlands" (1924), "Lakeland" (1926) or "Sword Fishing"(1930). Consequently, of the sixty films that do remain and which are available for study, only eighteen listed by titles such as "Christchurch The Cathedral City" (1925), "Sunshine City" (1928) or "River City Wanganui" (1929), appear to have urban scenes as their primary focus.

Technically, the quality of the motion pictures in general is quite advanced. Innovative filming techniques like irising in or out, fading, and speeding up the pictures or making them go backwards (done for comic effect), are all put to good use. In 1928 'talkie' films are introduced and the government make quick use of this added gimmick. Not only were entirely new productions made with sound, but old films were brought "up to date" by having sound added. ${ }^{31}$

There is a good deal of evidence to show that all these films received a great deal of exposure, both in New Zealand and overseas. The government's promotional films were viewed at the New Zealand and South Seas Exhibition held in Dunedin in 1925: "The Government Publicity Office runs a free cinema... where its films are seen by over half a million visitors..." ${ }^{32}$ A photograph of an audience gathered upon one of these occasions at the Exhibition also attests to the popularity of these screenings within the Dominion (See ILLUSTRATION 4). Although from the bored looks to be seen on the faces of the children in the cinema and from the fact that nobody except the odd overtly

\footnotetext{
${ }^{31} N Z P D, 1929$, p.655.

${ }^{32}$ Dennis, p.8.
} 
curious child stares directly at the camera, it appears as though the crowd in this photograph has been posed by the photographer like so many of the other pictures we have seen before.

Data from civic booster organizations attest both to their involvement in producing motion pictures for promotional purposes and to the point that these very same films were screened abroad. For instance, the minutes of the Wellington Chamber of Commerce reveal that they awarded the sum of eight pound (later raised to ten pound) to a certain F.E. Tomlinson to take a film of Wellington with him when he went overseas. ${ }^{33}$ It was common practice at the time for individuals who were travelling abroad to be awarded financial assistance by either the national government or local booster groups (particularly chambers of commerce and expansion leagues), on the condition that the said individuals promoted these groups' interests when touring. Initially this was accomplished through lectures and lantern slide shows; however, with the advent of moving pictures the lantern slide shows appear to have lost their popularity and were soon replaced with the new medium of film.

The Dunedin Expansion League were also ardent believers in the power of film as a promotional device. In a publication addressed to the city's inhabitants and which was aimed at showing the populace just what the organization was accomplishing with their tax money, the League expounded on the national and international attention which the city was going to arouse with its own booster film:

The League possesses a film called 'Picturesque Dunedin', of nearly one thousand feet, in which is included many beautiful views of the business and residential parts of the city. This film is now being shown at moving pictures theatres throughout the Dominion, and when this circuit is completed it will be despatched to Australia, where arrangements have been made for its being shown in some 450 theatres throughout Australia. ${ }^{34}$

${ }^{33}$ General Minute Books: the Wellington Chamber of Commerce, March 24, 1926, p.23. (Manuscripts: Alexander Turnbull Library). Archivists at the New Zealand Film Archive believe that Tomlinson actually produced this film as the title reads: "F.E. Tomlinson presents Bigger and Better Wellington". However, if this film is the same one as that mentioned in the Chamber of Commerce records, it may instead have been especially prepared for Tomlinson. For the records reveal that the Chamber asked their Publicity Office to "furnish him with a film they had."

${ }^{34}$ Dunedin Expansion League, What Are We Doing!, p.7. 
In the films themselves, we see evidence of many of the promotional methods seen before. In some cases the titles of films have been alliterated as an attention-grabbing technique, such as "Fernland Forests (1926), "Summer Sands" (1926), "Golden Grain" (1928), "Summit Seekers" (1929), and "New Zealand's River of Romance" (1930), all produced by the Government Publicity Department. Similarly, many of these same Government produced films have also attempted to introduce a romantic or fantasy element into their product, in keeping with the fashion of the day. Typical of such titles are: "Isle of Enchantment" (1927), "Storied Isles" (1927), "Portals of the Underworld" (1927), "Magic Playgrounds" (1928) and "Valley of Enchantments" (1930). ${ }^{35}$

The content of these motion pictures as well as their titles reflects the prevailing booster fashions of the day. The subject matter of the films which concentrate on promoting the urban aspects of the Dominion remain similar to those booster photographs discussed previously. There is much emphasis on the civilised and cultured nature of New Zealand's urban places, for busy wharfs, smoking industrial stacks, public buildings such as the Houses of Parliament, Government House, various museums and libraries etc..., all receive a great deal of attention. Comparisons are frequently proffered with Old World counterparts too; for instance, in the film "Beautiful Avon" (1928) produced by the Government Publicity Department, views of rusticated Tudor mansions, graceful swans and quiet punting along the river Avon, were meant to evoke parallels of Christchurch with England. These pictures of an arcadia or utopia realized also assisted in the forging of a New Zealand urban image that was superior to its European counterpart in that it was free of Old World problems.

These moving pictures also accentuated the progressive nature of the Dominion's towns. In the Government film "Christchurch Scenes" (1928), the bustling lifestyle and fast pace of urban living in the city of Christchurch is stressed with a comic scene of a policeman directing traffic while the film speed has been increased and motorized vehicles go racing past him; the superscript at the bottom of the screen reads: "The traffic is so quick and dangerous that the 'traffic cops' wear crash helmets."

These promotional films were also used as an effective advertising tool for destroying negative preconceptions about New Zealand. In the Government film "The

${ }^{35}$ All the films in the following section, including any produced by private bodies as well as the Government Publicity Department, are located at the National Film Archive, Wellington. 
Maritime City" (1930), for instance, the many shots of Wellington's bustling port with goods being depicted loading and unloading, were meant to affirm the prosperous economic position of the city despite the downcycle of a depression. Likewise, the motion picture "The Adventures of Algy" (1925), produced by Beaumont Smith Films and which tells the story of a bungling Englishman in New Zealand, renders a picture of the country's cities as civilised places and not the wild haunts of cannibal natives as many people overseas believed them to be (see Chapter 2). This aspect can be seen when the hero of the motion picture - Algy, is initially afraid to disembark in Auckland as he was fearful of the Maoris and that, "he would be risking his life if he ventured into the wilds of Queen Street alone." ${ }^{136}$ However, once Algy arrives in the city, he sees only a very progressive and advanced metropolis complete with all the civilised amenities of Home. The discovery of a culturally mature city in the Antipodes would assuage not only whatever anxieties Algy was suffering, but also by implication those of moviegoers in Great Britain watching the film and who might have been considering emigration.

Motion pictures also used a number of other not-so-conventional booster techniques while promoting the country, all of which have been seen previously in other chapters, yet which must be mentioned before ending this chapter. For example, the peculiar receives attention in "The Adventures of Algy", during an episode in the film when Wellington's windy weather was repeatedly being underscored by Algy always having his hat blown off whenever he rounded one of the corners of Windy Wellington. The comic effect (and by ramification the promotional consequence) was even further heightened when at the same time other pedestrians would clutch their hats vigorously to their heads whenever they turned a corner!

Likewise, another lesser used promotional device - sex appeal, played a part in motion picture propaganda. In the film "Magic Playground" (1928), produced by the Government Publicity Department and later dubbed with sound in 1935, a number of attractive Maori women are given a great deal of attention. The climax of the sexual promotionalism in this picture, however, comes when a blonde European woman is shown fully naked in daylight while preparing a bath on a hot water beach. The title of

${ }^{36}$ English fears about the Maori are evident even as late as the 1950s! Harvey McQueen told me a story about one particular migrant coming from Britain during that period who brought a handgun with him just to be safe. 
the film - "Magic Playground", is itself suggestive with sexual innuendo, especially after having viewed the subject content. ${ }^{37}$ The title and the subject matter of the film with its underscoring of sex, also evokes comparisons of New Zealand with the mythical land of Cockaygne. Such a connotation with Cockaygne, a magical land where "men's appetites" could be given free reign and yet be fully satisfied, ${ }^{38}$ added to the promotional nature of the film by evoking an impression of the country which was as appealing to some (presumably the rich white male tourist) as the image of utopia or arcadia was to others.

${ }^{37}$ Although "Magic Playground" was a film aimed at promoting the attractions of Rotorua and was not specifically aimed at creating a particular urban image, the film still cannot be ignored. The reasons for this are many: firstly, because it was promoting an amenity located near an urban development; secondly, because of the blatant sexual nature of the images themselves; and thirdly, because no other examples of this kind of sexual promotionalism can be found in the surviving Government films, it is not to say that there were not other instances of this in Government films with urban themes which have been either destroyed or still not found. 1981), p.21.

${ }^{38}$ J.C. Davis, Utopia and the Ideal Society (Sydney: Cambridge University Press, 


\section{CHAPTER 6: COLONIAL COMPARISONS}

Having examined the methods used by New Zealand's urban promoters to boost their cities and towns, both in the verbal and visual mediums, we can now extend the analysis to compare the ways in which urban boosters in two other British colonies promoted their towns and cities, specifically Australia and Canada. After providing the reasons for justifying an examination of these two colonies in particular, it will be seen from only a small fraction of the primary evidence available, that promoters in both places pursued remarkably similar strategies to those of their New Zealand urban counterparts.

The intentions of the Australian and Canadian promoters (like their New Zealand relatives) were mainly to attract settlement, capital and tourism. Yet they too were influenced by a degree of pride in their towns and cities and an optimism about their future. In the promotional literature methods of boosting included: likening a city to Europe or England; reproducing favourable quotations; drawing parallels to fairyland; using a town or city's rapid growth as a symbol of its prosperity; denigrating a rival town or city; and celebrating the entrepreneurial talents of a place's citizens. In the visual material, colonial booster practices also stayed consistent: the pastoral cityscape remained the most common style to depict the city and town in painting; commercial letterheads and bird's eye view maps were the typical means endorsed by engravers and lithographers; and photographers revealed a distinct bias towards certain elements of the urban infrastructure and a suspicious penchant for posing their subjects.

There are many reasons for examining Australia and Canada. Canada seemed a natural choice because of my familiarity with the country. ${ }^{1}$ In addition to this, there has been much study on boosterism in Canada (paying particular attention to the country's Western Prairies). ${ }^{2}$ Australia was chosen primarily for the reason that much of the early literature published before the country federated in 190 , included a great deal of

${ }^{1}$ This familiarity is a result of my having been brought up in Canada and having already undertaken research of a similar nature on boosterism in Hamilton, Ontario. See: Dominic T. Alessio, "Capitalist Realist Art: Industrial Images of Hamilton, Ontario, 1884-1910", Journal of Urban History, 18, No.4 (August 1992), 442-469.

${ }^{2}$ See the work of Alan F.J. Artibise, ed., Town and City: Aspects of Western Canadian Urban Development (Regina: University of Regina, 1981). 
information about New Zealand as it did on the other two principal Australian colonies, Victoria and New South Wales. Australia was also chosen for comparative purposes since like New Zealand, it too suffered from distance from Great Britain. Consequently the two colonies tended to pursue a similar advertising strategy to rectify their isolation. Australia and Canada were also chosen for analysis since they were both populated by Europeans of primarily British descent and were both considered by contemporaries to be new worlds where their populations could start afresh and avoid the mistakes of older European urban centres. As stated in the introduction and by David Hamer in New Towns in the New World and Asa Briggs in Victorian Cities, ${ }^{3}$ it is hoped that this comparative method affords the reader with a methodology for understanding the process of urbanization in general. For as Clyde Griffen points out:

[The] British colonies which began as new frontiers separated by great distances, such as Canada and Australia or the United States and New Zealand, seem peculiarly useful laboratories for investigation with an eye to comparison... [allowing us to discover] how much our nations seem to have shared and also obvious and crucial differences. ${ }^{4}$

Before beginning with an analysis of how Canadian and Australian boosters promoted their towns and cities, it is first necessary to understand why the boosters wanted to advertise these settlements initially. Paul Linteau states that boosters in the industrial suburb of Maisonneuve, Montreal, wanted to attract further manufacturing and investment to that area. ${ }^{5}$ The city of Hamilton, Ontario, also underwent a process of municipal boosterism and for the same reasons. ${ }^{6}$ Similarly, the aims of Australian boosters were congruent with their Canadian colleagues; one Victorian promotional

\footnotetext{
${ }^{3}$ See: Hamer, New Towns in the New World, p.vii and Asa Briggs, Victorian Cities (Auckland: Penguin, 1987), p.50. Hamer and Briggs are not the only urban historians, however, who advocate the comparative method in order to understand the "historical process" while avoiding the "antiquarian" or the "parochial"; other historians who have pursued such a course of study include: the South African A.J. Christopher, The British Empire at its Zenith (Sydney: Croom Helm, 1988); the Australian Lionel Frost, The New Urban Frontier (1991); and the Canadian Alan F.J. Artibise, Town and City (1981).

${ }^{4}$ Clyde Griffen, "Towards an Urban Social History for New Zealand", New Zealand Journal of History, 20, No.2 (1986), 111.

${ }^{5}$ Paul André Linteau, The Promoter's City (Toronto: Lorimer and Co., 1985) p.70.

${ }^{6}$ Alessio, "Capitalist Realist Art", p.443.
} 
booklet attested that its main objective was "the advancement of the Producing, Manufacturing, Shipping and Export Trade of the State. ${ }^{17}$

The need to increase capital investment and trade was coupled with the desire to induce further settlement: "Australia is remote, and therefore special effort must be made to induce settlers to go to that country, otherwise many will simply drift to Canada because it is the nearest land to go to." ${ }^{18}$ Attempts at attracting tourists also played a significant part in the promotional basis for advertising a particular town or city; According to Charles Forward, it was for this reason that the city of Victoria, British Columbia, established a Tourist Development Association in 1901 and why that city's Board of Trade published its first tourist brochure in the same year. ${ }^{9}$ And the desire to increase tourism in Australia was also the reason why the Australian National Travel Association was formed in 1929.

The quotation from Turnor about Australia's remoteness brings up a point which is vital to underline in regards to understanding the Australian booster mentality - its isolation. Australia, like New Zealand, was off the beaten track and people at Home showed a remarkable ignorance about the colony of which Australia's boosters were only too aware. ${ }^{10}$ James Ballantyne in the preface of his booster work admits that this desire to inform people about the country is one of his primary motives in writing the book:

We find, moreover, that the Colony is not so well known as it ought to be in the Old Country... There is field for effort in

${ }^{7}$ Victoria of to-day (Melbourne: The Daily Australasian News, 1902), p.7.

${ }^{8}$ Christopher Hatton Turnor, Land settlement for ex-service men in the oversea dominions. Report to the Royal Colonial Institute (London: Saint Catherine Press, 1920), p.6.

${ }^{9}$ Charles N. Forward, "The Evolution of Victoria's Functional Character," in Alan F.J. Artibise, ed., Town and City: Aspects of Western Canadian Urban Development (Regina: University of Regina, 1981), p.357.

${ }^{10}$ This ignorance about Australia can still be found today. John Pilger in A Secret Country (London: Jonathan Cape, 1989), illustrates this point when he tells the story of a Turkish migrant who lands in Sydney tired and jet-lagged, unable to understand why it took so long to get to Austria. (p.1). 
making people in England better acquainted with our history and resources. ${ }^{11}$

Likewise, the editor of a promotional work advertising the state of Victoria, admitted that the "raison d'etre" of his work was, "to convey to the people of the mother-country a more perfect knowledge... of one of the noblest provinces of the British Empire, than they at present possess..."12

The desire for financial recompense from increased capital, migration and tourism was not the sole motive for producing booster works, quite the contrary; the boosters were also concerned with encouraging notions of civic pride. Paul André Linteau maintains that this was the case with Maisonneuve's promoters. He states that they wanted to nurture civic pride as much as they coveted attracting increased investment through industry. Linteau also believes that the enthusiasm which promoters revealed for their cities was genuine. He states that the bourgeoisie in French Canada really assumed that their municipalities would continue to expand and to develop. ${ }^{13}$ Proof of a similar sense of civic duty and patriotism, like that seen with Maisonneuve's boosters, can be found in Australian propaganda:

A native-born and therefore thoroughly Australian population is growing up in our midst, and it is desirable that they should be inspired with patriotic feeling, with warm attachment to the land which has given them birth, and with a sterling interest in all that pertains to its advancement. ${ }^{14}$

There were other motives too than just civic pride, which were responsible for so much celebratory propaganda. Some boosters - particularly the illustrators - were also trying to introduce a new technological and industrial aesthetic into their work. While discussing the image of the railway depicted by artists between 1880 and 1935 in America, John Stilgoe contends that their intent was as much to celebrate the

${ }^{11}$ Rev. James Ballantyne, Our Colony in 1880 (Melbourne: M.L. Hutchinson, 1880), no page.

12 Jerome Dyer, no page.

${ }^{13}$ Paul André Linteau, "The Development and Beautification of an Industrial City: Maisonneuve, 1883-1918," in Gilbert A. Stelter and Alan F.J. Artibise, eds., Shaping the Urban Landscape: Aspects of the Canadian City-Building Process (Ottawa: Carelton University Press, 1982), p.320.

${ }^{14}$ James Ballantyne, no page. 
mechanised and industrialised environment as a whole as it was to promote a particular industry. ${ }^{15}$ My work on images of industrial Hamilton also reiterates such a point; I argue that graphic artists focusing on factories and industrial scenes in the city were introducing a new image of Hamilton that was based on power, technology and efficiency, one that foreshadowed the work of the Futurists. ${ }^{16}$

$$
* * *
$$

Having looked at the motives of the promoters, it is time to examine the means by which boosters advertised their city or town, and also to look at the question of whether or not the boosters were successful in promulgating their information to readers and viewers abroad. It seems immediately apparent that the Australian and Canadian boosters used the same promotional tactics to promote their towns and cities as did the New Zealanders and to the same effect. They held International Exhibitions, such as the 1882 Canadian National Exhibition in Toronto (the first fair to be lit by electricity) ${ }^{17}$, and the 1880 Melbourne Exhibition. It was the intention of the organisers of these events to provide "opportunities for diffusing intelligence" about the country to a "large influx of strangers."18 The boosters also published a great deal of literature, copies of which were "sent out to all public bodies connected with Trade and Commerce throughout the Commonwealth, New Zealand, Great Britain, America, The East and South Africa..." ${ }^{19}$ Records in the Christchurch Civic Offices indicate that the Canadian National Railways sent pictures of Canadian scenes to the Christchurch Council, with the design of having them hung in the city's Chambers as a promotional device. ${ }^{20}$ Australasian boosters commissioned European writers, like Belgium's Emile de Harven,

15 John R. Stilgoe, Metropolitan Corridor (New Haven: Yale University Press, 1983), p.78.

${ }^{16}$ Alessio, "Capitalist Realist Art", p.467. These "other motives", such as civic pride and a genuine optimistic outlook for the future of the city, will be discussed in Chapter 10.

17 J.M.S. Careless, Toronto to 1918: An Illustrated History (Toronto: Lorimer and Company/National Museum of Man, 1984), p.112.

${ }^{18}$ James Ballantyne, p.1.

${ }^{19}$ Victoria of to-day, p.7.

${ }^{20}$ Christchurch Bylaws: Financial and Departmental Committee Minutes, December 9, 1926, p.2955. (Christchurch Civic Offices). 
to produce optimistic French-language promotional booklets that were intended to appeal to "jeunes gens, intelligents" considering emigration. ${ }^{21}$ The Australian National Travel Association, a private group formed in the late 1920 s to promote tourism in the country, commissioned Australia's poster artists to produce advertisements which were "distributed widely both in Australia and overseas..." 22

Australian and Canadian booster material frequently resembled that of New Zealand's. ${ }^{23}$ The technique used most often to emphasize how civilized and technically advanced a colonial city or town was, consisted of drawing likenesses with other wellknown and established urban precedents, particularly European ones. Accordingly, Maisonneuve was called "Le Pittsburg du Canada" by its promoters, ${ }^{24}$ while Hamilton was labelled "the Birmingham of Canada" and later "The Electric City."125 Melbourne was depicted "as both the Birmingham and Manchester of Victoria", ${ }^{26}$ as well as "the Paris of the Antipodes." ${ }^{12}$ Sometimes these European comparisons were given catchy titles for effect; for example, the present day city of Kitchener-Waterloo, Ontario, was once promoted alliteratively as "Bigger, better, beautiful, busy Berlin."28 (The name Berlin had been changed to Kitchener-Waterloo as a result of anti-German sentiment

21 "[Y]oung, intelligent men". Émile de Harven, L'Australasie. Esquisse sur ses Ressources Mercantiles, Industrielles, Agricoles et Minières (Anvers: 1881), p.5.

22 Roger Butler, Australian Travel Posters (Josef Lebovic Gallery Exhibition Catalogue: June 16 - July 14, 1990), p.8.

${ }^{23}$ It would be difficult, if not impossible, to state which country initiated a particular booster strategy. In one particular case, however - the establishment of government tourist agencies overseas, New Zealand led the way. For the Australian papers advised their government to copy the New Zealand precedent. Australian Star (August 22, 1906).

${ }^{24}$ Linteau, The Promoter's City, p.70.

${ }^{25}$ C.M. Johnston, The Head of the Lake (Hamilton: Robert Duncan and Company, 1958), p.243.

${ }^{26}$ Jubilee history of the city of South Melbourne and illustrated handbook (Periodicals Publishing Co., 1905), no page.

${ }^{27}$ Briggs, p. 278 .

${ }^{28}$ Elizabeth Bloomfield, "Reshaping the Urban Landscape? Town Planning Efforts in Kitchener-Waterloo, 1912-1925," in Gilbert A. Stelter and Alan F.J. Artibise, eds., Shaping the Urban Landscape: Aspects of the Canadian City-Building Process (Ottawa: Carleton University Press, 1982), p.266. 
during World War 1). Likewise, the city of Melbourne was advertised not only with the well-known expression "Marvelous Melbourne",29 but it was also called "Musical Melbourne" (as well as the "Italy of the South"), because of its inhabitant's'supposed penchant for singing and music. ${ }^{30}$ The city of Victoria, British Columbia, because its promoters believed the countryside similar to that found in England, said that their town "had the appearance of an English city..." ${ }^{31}$ Akin to these European comparisons were attempts by promoters at favourably equating Melbourne's climate with that of a compromise between Lisbon and Algeria; ${ }^{32}$ and there were also ventures by Melbourne's boosters to liken their city's architecture to that found in Europe:

First visitors to Melbourne must be apprehensive of considerable astonishment when, instead of the ordinary colonial town, they find themselves in a city of great extent, covered with magnificent buildings, and boasting of many advanced institutions which are yet strange to several European capitals. ${ }^{33}$

This last point emphasizing how Melbourne was actually more advanced in some ways than its Old World precedents recalls a similar discussion on booster tactics used by New Zealanders: that of boasting how colonial towns and cities were actually better places to live than their older urban cousins. Further proof of this element of colonial superiority in the promotional material can be seen in boosters celebrating the lack of rigid class barriers in Australian cities: "A marked general equality in matters of society and education renders social intercourse in the colony much more attractive. ${ }^{134}$

There existed a plethora of techniques used by boosters to promote their towns and cities, all of which have been seen before with the New Zealand material. Visitors to Sydney and Melbourne who commented favourably on that which they saw were often

${ }^{29}$ Numerous urban historians have commented on the alliterative description of the city attributed to G.A. Sala during the 1880 s, including Asa Briggs, Graeme Davison (who adopted the expression in the title of his 1978 book on Melbourne), and Lionel Frost.
${ }^{30}$ Jerome Dyer, p.26.
${ }^{31}$ Forward, p.357.
32 Émile de Harven, L'Australasie., p.13.
${ }^{33}$ Jerome Dyer, p.26.
${ }^{34}$ Ibid. 
quoted, such as the American who (after being surprised by the progress of the colony's cities), imagined himself "in fairy land. ${ }^{135}$ Praise was lavished upon the colony for the rapidity of its urban progress, the intent of which was to provide an endorsement for continued wealth and prosperity: "The rapid progress which Victoria has made during the short period of her history is the best guarantee of a prosperous future..." ${ }^{136}$ And much stress was placed on how civilised a place was and on the fact that all this growth and prosperity had occurred over a very short period of time in comparison to European urban development:

Though only forty-two years old, Melbourne has attained goodly dimensions... Its growth in that brief time from the rude home of the savage, to the position of a city which can vie in magnificence with cities in older countries, must be to any thoughtful mind a marvel, ${ }^{37}$

Numerous other techniques for promoting a city or town included praising one place at the expense of another and acclaiming the unique business skills of a certain urban population. Inter-city rivalry was common, with Australia's two largest cities Melbourne and Sydney - repeatedly disparaging the other: "The Melbourne man is always on the look-out for business, the Sydney man waits for business to come to him." ${ }^{138}$ This same urban competitiveness was evident in Canada too, particularly between the cities of Hamilton and Toronto which were located at the head of Lake Ontario. According to Michael Katz, rival newspaper editors from these two cities waged long and prolific editorial campaigns to praise the virtues of their own city while simultaneously criticizing its commercial rival. ${ }^{39}$

The emphasis on the character of an urban centre's population also received much attention, presumably to placate readers overseas who might have been hesitant about a city's growth, believing that it was due solely to good luck which could end at any moment. It was common, therefore, to find booster works exalting the "exceptionally

\footnotetext{
${ }^{35}$ James Ballantyne, p.95.

${ }^{36}$ Victoria of to-day, p. 17.

${ }^{37}$ James Ballantyne, p.95.

${ }^{38}$ Quoted from Richard E.N. Twopenny, Town Life in Australia (1883) in Davison, The Rise and Fall of Marvelous Melbourne, p.231.
}

$39 \mathrm{Katz}$, pp. 1-2. 
enterprising population" of Victorians, ${ }^{40}$ and heaping praise upon the Tasmanian's business acumen as well as their hospitable nature. ${ }^{41}$

Paintings were an often used medium for promoting the urban environment and the civilising hand of the European settler [ILLUSTRATION 52]. Taking the example of Samuel T. Gill's Australian painting, "The Henderson Factory" (1876), one can see a host of booster clichés in the pastoral cityscape tradition which are analogous to those used by George O'Brien in his New Zealand work, "Gas Light and Coke Company Works" (1865). The subject matter of Gill's work is familiar: an industrial firm in a rural setting. ${ }^{42}$ In the Australian case, however, the painting is a depiction of an abattoir in Footscray, a manufacturing suburb on the outskirts of Melbourne.

There are numerous promotional devices evident in "The Henderson Factory": the smoking chimney stacks indicate prosperity; the nearby river with its flotilla of small vessels provides ideal transport and a convenient place to discharge the abattoir's waste; in the distance are two steaming trains whose presence not only reveals that the abattoir has thriving commercial links with the rest of the country, but also that Australia is a civilised country with a sophisticated transportation network; the white picket fences around the front of the factory, (which along with the ornate gardens and carefully planted cypresses that they protect, presumably from wandering animals), symbolize the European's mastery over nature and the new environment; lastly, the crowds of people around the abattoir and along the road indicate that this is not a sparsely inhabited land, but rather a bustling and prosperous commercial centre where migrants are wealthy, can find steady employment, and can enjoy a healthy life.

There is nothing to detract from the ideal pastoral vision which Gill has prepared for the viewer. There is no dirt, no commotion, not unpleasantness of any kind. Not

${ }^{40}$ Victoria of to-day, p. 17.

${ }^{41}$ Émile de Harven, L'Australasie, p.38.

${ }^{42}$ Industrial images remain an important aspect of urban iconography, for "They reflect the evolving of a society from rural to urban, and from agricultural to industrial". (Donegan, p.vi). It is for this reason that pictures of factories in rural or quasi-rural settings, like those by Samuel T. Gill or George O'Brien, have been included in this study. Such works have also been included as they serve as good examples of how such artists modified the Antipodean landscape and cityscape to make it appear more condusive and attractive to the European settler. 


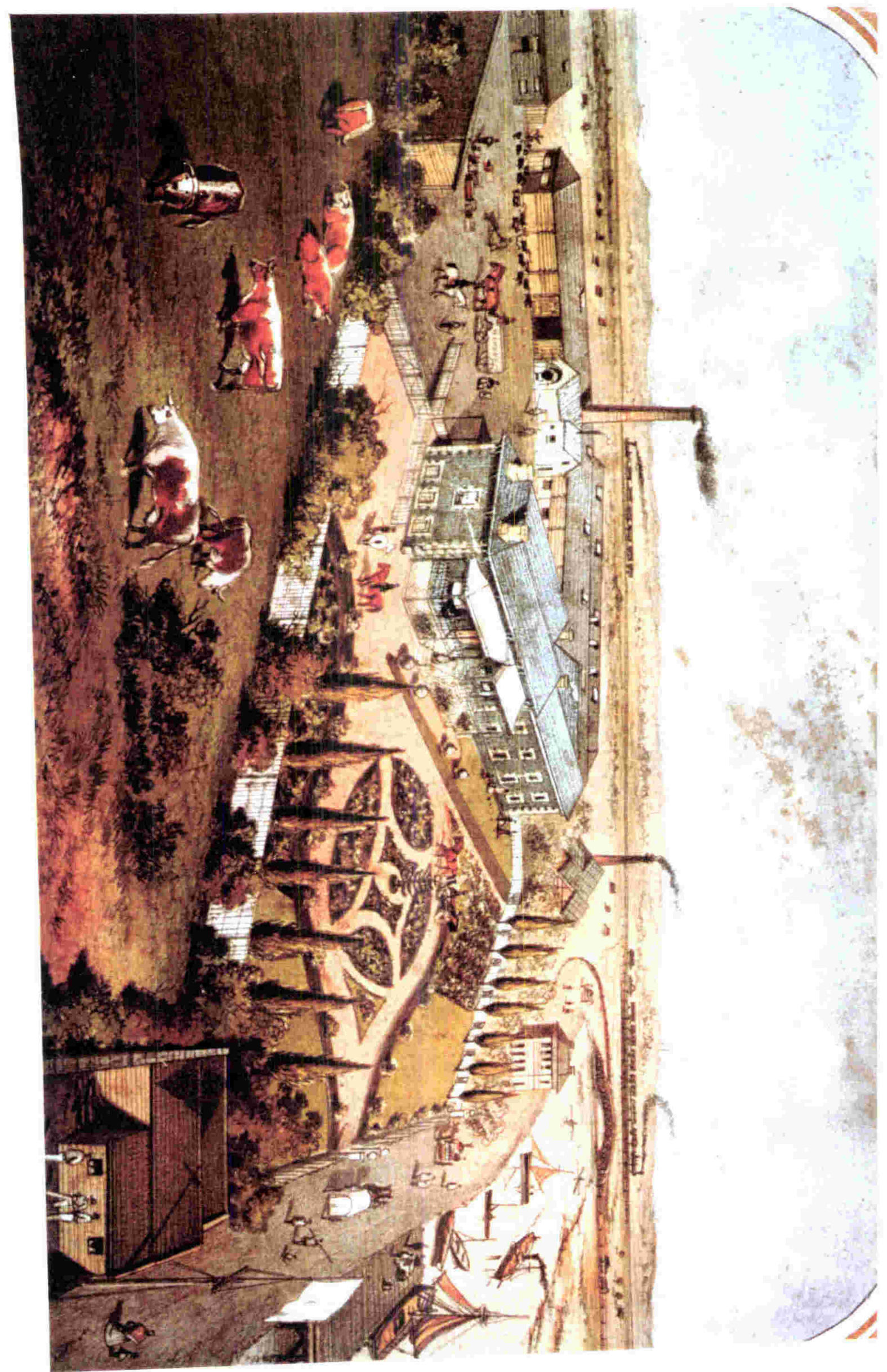

illustration 52 
even the animals grazing in the foreground show any signs of discomfort. Remarkably in fact, the opposite seems true; the cattle in the foreground graze contentedly outside, unaware of their impending doom, all the while their more unfortunate cousins are led seemingly without any opposition on their behalf to be slaughtered in the background! Pictures of cattle and horses would have also represented a symbol of settlement and the domesticating hand of the settler. The seemingly endless expanses of green and fertile fields which are seen surrounding the factory in this picture, would have also represented enticing symbols of untapped wealth to the prospective emigrant.

The presence of a fort in the foreground at the bottom right hand side of the painting, would have been interpreted as the ultimate of civilising tools, a paramount symbol of order and power. According to Richard Hill, police in colonial society were one of the most important symbols of stability, and were needed if industry and agriculture were to flourish. ${ }^{43}$ It should come as no surprise, therefore, to see their presence in promotional material. Bernard Smith is more than aware of similar promotional themes while discussing the work of Gill's contemporary, the Australian painter George French Angas (1822-1886):

... it is quite clear that the purposes which his paintings came to serve were considerably wider than those normally served by picturesque paintings... The landscapes were used to illustrate the nature of the country awaiting settlement in the new colonies and so to promote migration...44

Australian poster art commissioned to promote tourism was another vehicle used by boosters to show how civilised and how technically advanced the country was. In the colour lithograph [ILLUSTRATION 53] by Percy Trompf called the "Trans AustralianRailway" (ca.1935), one sees a speeding train racing at night; the train's lights illuminate the darkness and steam pours forth from the funnel. The lights may well symbolize the supposedly civilising forces of the white settler brightening the contrasting ignorance of the black savage in a dark land, ${ }^{45}$ while the steam was an indication of the mighty

${ }^{43}$ Richard S Hill, Policing the Colonial Frontier (Wellington: Historical Publications Branch, Department of Internal Affairs, 1986), pp.1-2.

${ }^{44}$ Bernard Smith, European Vision and the South Pacific (Auckland: Oxford University Press, 1989), p.303.

${ }^{45}$ The adjective 'Dark' is traditionally associated with the colour black and has connotations of ignorance, death, ugliness, the unknown, night, etc... See: Howard Zinn, 


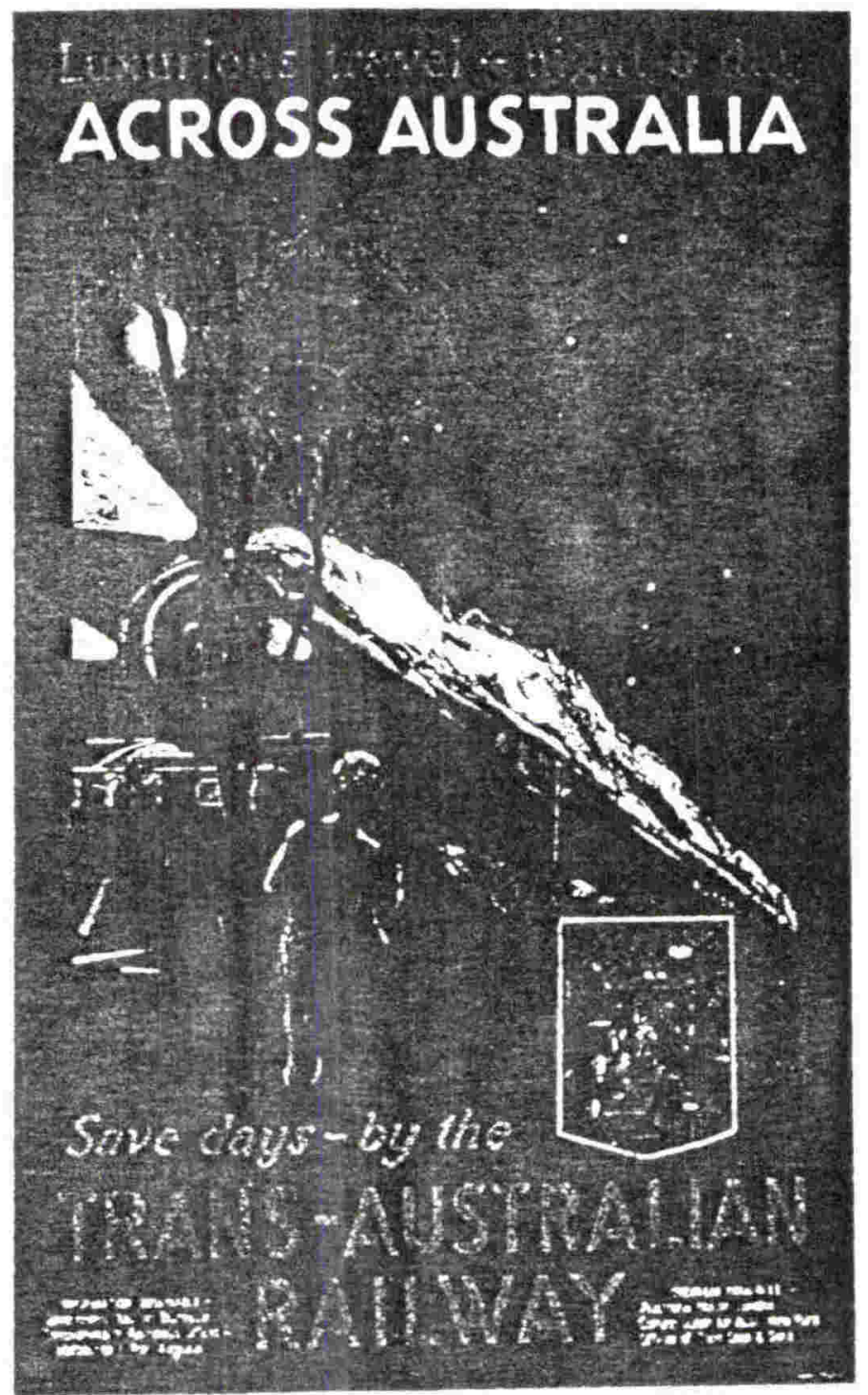


forces of technology being unleashed on the new continent. The railway lines themselves and the sleek and speeding train running on them, serve as a powerful Mumfordian-like symbol of tentacular urban encroachment. The railway seems to reach out beyond the metropolis, and like those pictures of factories and industry discussed previously, the railway line represents an important step in the evolution of urban development in the country; for it is a constant reminder that there have to exist at least two urban centres along the line which function either as a terminus and/or a departure point. The lone bushman looking on with awe at the train and appearing to be almost run over by the locomotive, underscores the notion about the power of industry and of the dominating presence of European settlement; like the pictures of the Maori discussed previously, the natives in Australian booster art have no option but to appear to die out (knocked down by the train perhaps?), or to be dislocated by further urban encroachment which is sure to follow in the train's wake. The Australian Aborigines and the Maori were not the only native peoples to be displaced in this manner by images of European technology. Patricia Hills in her article on western expansion in the United States, includes a similar 1867 frontispiece of a mighty train charging towards a Native American family, subsequently forcing them to flee (perhaps to the supposed safety of the reservation?) if they are to avoid imminent annihilation. ${ }^{46}$

Canadian painting was also very much like Australian and New Zealand art in that industry and progress were the focus of much work, exemplifying the rise of an urban society. Taking the example of Sir William C. Van Horne's "The Steel Mills, Sydney, Cape Breton" (1907), one is shown a picture of a fiery steel mill at night, the blazing fires of which reflect gloriously and magically on the waters of the foreground bay; it is a vision both of power and of beauty. Van Horne, however, was also Director of that same steel company which he depicted in his painting, and such a positive rendition of the firm would have been "consistent with his own personal economic interests as a major shareholder... [yet] also symbolized his personal belief in the industrial age as progressive, enterprising and profitable." ${ }^{47}$ Charles Comfort (born 1900) was another

A People's History of the United States (London: Longman, 1980), p.31. The inherent symbolism present in just such a poster would not have been lost on viewers of the period.

${ }^{46}$ Hills, pp. 128 and 130.

${ }^{47}$ Donegan, p.1. 


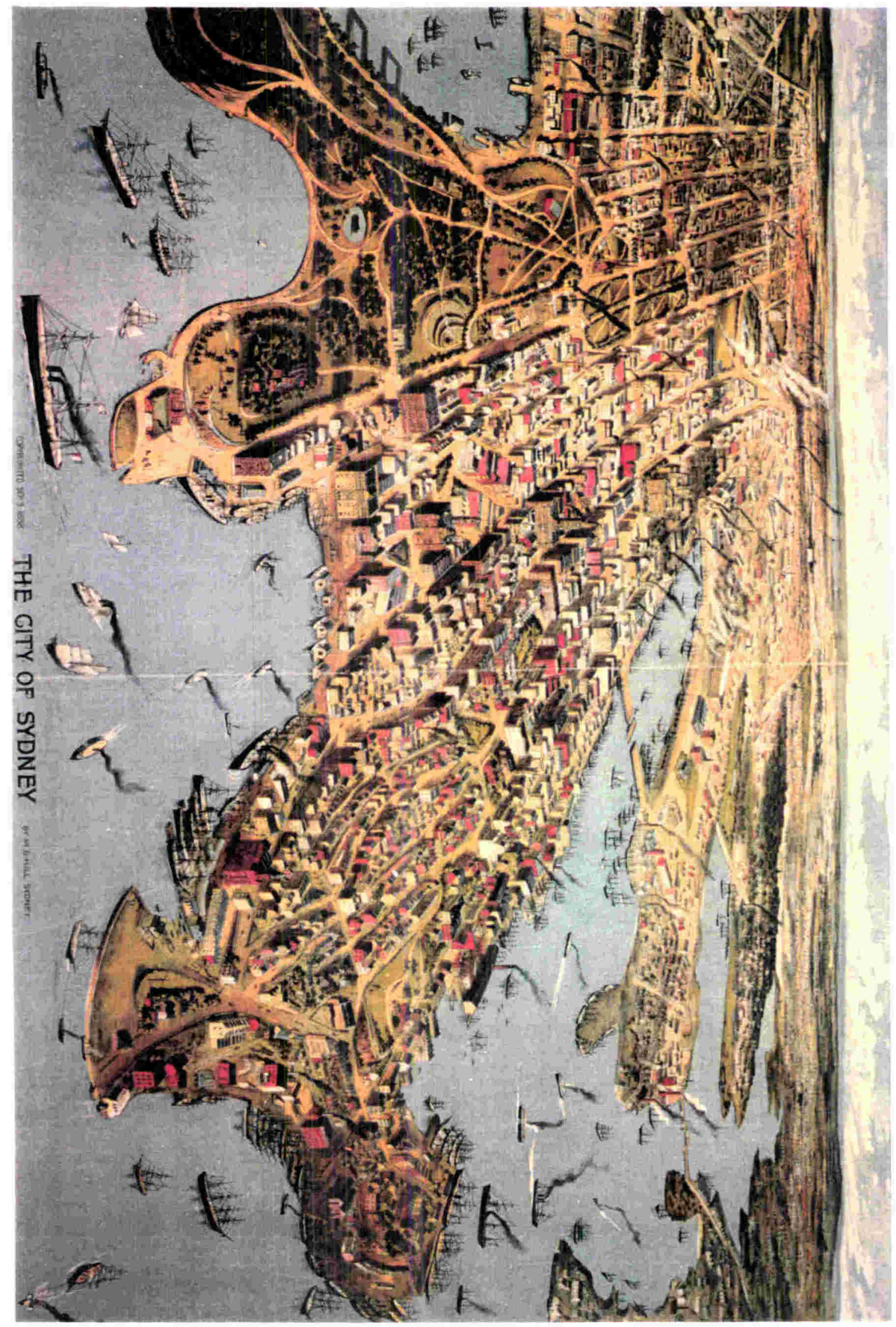


Canadian artist who celebrated industry and the city. Having worked for a nickel mining company in Sudbury, Ontario, he was commissioned to paint a mural at the Canadian pavilion of the 1937 Paris Exposition. Behind and around the central figure of a miner whose strength and pose "invokes the heroism usually associated with Social Realism", ${ }^{48}$ are a horde of symbols for the modern, including: a racing train, a fast plane, test tubes and even some planets in outer space! Yet the symbols used twice in this mural to indicate modernity and progress are the two cities located on either side of the worker, one at the far right and the other on the middleground at his left. The positive image of the city as it was represented here stood as a potent icon of what great urban metropolises awaited Canada in the near future.

Bird's eye view maps were yet another frequently used means for urban promoters both in Australia and Canada to celebrate and to publicize their cities. In the 1888 chromolithograph map of "The City of Sydney" [ILLUSTRATION 54], there exists a profusion of booster devices. The smoking chimney stacks from thirty-eight factories (not to mention the countless other ones from trains and ships), reveals the thriving business which the port of Sydney enjoys. Underscoring this vitality in the city's industry are the numerous vessels of all shapes and sizes and from all nations (such as the steamer flying the French tricoleur in the left foreground), which crowd Sydney harbour. Coupled to these images of wealth is a view of the city itself which appears so expansive that is stretches to the horizon line! The well planned parks and lovely municipal gardens, not to mention the ornate edifices of various administrative or ecclesiastical buildings, give an overall feeling of a cultured and civilised city akin to European examples. And lastly, the inclusion of assorted bridges, trains, railway tracks, roads and factories, divulges a profound urban infrastructure which would have appealed to capitalists contemplating investment. The 1893 bird's eye view map of Hamilton, Canada, mirrors many of the same promotional artifices found in the Sydney example. There are crowded and busy harbour scenes, well-planned streets and an impressive railyard. Yet in the Hamilton map there are as many as one hundred and fifty smoking stacks, ${ }^{49}$ the probable result of Hamilton's claim to fame as an industrial and manufacturing centre.

\footnotetext{
${ }^{48}$ Ibid., p.76.

${ }^{49}$ Peace, p.3.
} 
The work of Australian and Canadian lithographic artists had many parallels with the promotional stratagems found in New Zealand's advertisements. As in the New Zealand examples, increasing the size of an edifice or diminishing the size of objects around an edifice, was the most common tactic used to make a firm appear more important that it really was. This can be seen in the advertisement for the Sydney plant of the Whybrow Shoe Company. ${ }^{50}$ The firm's main plant has been made to appear so big that the steaming passenger train which races in front of it could easily go through one of the building's many windows! A Canadian instance of this penchant for artistic exaggeration can be seen with the illustration for the Sanford Clothing Company in Hamilton. When this illustration of a seven story building is compared with a photograph of the same company, it becomes apparent that the artist has added two whole floors to the engraving to make the firm seem larger! $!^{51}$ Another frequently adopted plan, and one which has been addressed previously also, was to make a company appear prosperous by showing chimney stacks smoking. In the Hugo Wertheim letterhead, the sewing machine factory near Melbourne has four large stacks. To add to the sense of prosperity in this letterhead, the artist has also included numerous people going into or coming out of the firm. The overall aesthetic effect is heightened by rows of trees, large roads, and ornate fencing. Such a well-planned appearance was more than reflective of the influences of City Beautiful ideals; it was also a shrewd merchandising scheme. For the viewer of the illustrated advertisement may well have equated the welldesigned firm with a well-designed product which the company had manufactured! ${ }^{52}$

Having seen evidence of Canadian, Australian and New Zealand artists all imitating one another's urban propaganda, it should come as no surprise to find that photographers in Australia and Canada also pursued similar boosting practices with their medium. In photographs of industrial firms in Hamilton, Ontario, it was often the case to see photographs of buildings taken on bright sunny days and with their surroundings selectively arranged. Blue skies and trees in full bloom were often painted in for effect, and it also tended to be the case that few or no pedestrians were included for fear that

${ }^{50}$ Australia To-Day and New Zealand (Melbourne: The United Commercial Travellers' Association of Australasia Ltd., 1906), p.28.

${ }^{51}$ Alessio, "Capitalist Realist Art", pp.445 and 452.

${ }^{52}$ The letterhead can be found in the Crabb Collection, PA 576: LaTrobe. (State Library of Victoria, Melbourne). 
they might distract the viewer's attention from the factory. ${ }^{53}$ In Australia, when people were included in photographs they were often posed, and photographers usually employed a number of manipulative techniques to create a better effect. For example, The Peterson and Larsen Box Factory photograph not only had its workers and carriages posed stiffly in the foreground, but the developer of the picture also had some all too obvious whiffs of smoke added to the firm's chimney stack to show that the company was doing a good business. ${ }^{54}$

${ }^{53}$ Alessio, "Capitalist Realist Art", p.462.

${ }^{54}$ The photograph can be found in the Jubilee history of the city of South Melbourne and illustrated handbook, p.111. 


\section{CHAPTER 7: A CHRISTCHURCH CASE-STUDY}

Thus far we have examined the methods used by urban promoters, both in New Zealand and in two other British colonies, to boost their cities and towns. Chapter 7 proposes to take a closer look at the means and the grounds for boosting one New Zealand city in particular - Christchurch, and that of one of its neighbouring boroughs, New Brighton. It will be seen that both municipalities undertook a vigorous campaign to promote the interests of their respective communities so as to foster increased investment, settlement and tourism. It will also be argued that the motives of these boosters, despite their entrepreneurial class backgrounds and the economic benefits which many amongst this group stood to reap from increased advertisement, were also at least partly based on a genuine desire to reform their city and town so as to avoid the industrial evils of the Old World. ${ }^{1}$ The latter part of Chapter 7, with its emphasis on utopian prophecy and other altruistic influences on perceptions of urban life in Christchurch, provides an introduction to the second half of this thesis, which will show that utopian imagery provided not only a well-spring of ideas for booster propaganda but was also responsible for inculcating many boosters with a optimistic vision of the future,

\section{$* * *$}

Christchurch and New Brighton were chosen for this case-study analysis because they had been forced to take animated measures to promote themselves; for according to organisers of the Canterbury Progress League, the province "was a long way behind the North Island in regard to boosting its attractions..." Such action appeared especially imperative on account of the declining growth rate of the city and its borough, and the North/South population imbalance which was favouring Auckland and Wellington at the expense of South Island urban centres like Christchurch and Dunedin. In the last years of the nineteenth century, Christchurch's European population stood at 51,330 inhabitants and was second only to that of Auckland which had a population of $57,616 .^{3}$

${ }^{1}$ According to Tipples (p.6), "the initial membership of the committee of the Christchurch Beautifying Association was from the Christchurch establishment."

${ }^{2}$ The Times (July 16, 1918), p.22.

${ }^{3}$ Erik Olssen, "Towards a New Society," in W.H. Oliver and B.R. Williams, eds., The Oxford History of New Zealand (Auckland: Oxford University Press, 1988), p.254. 
Yet despite continual growth throughout the early decades of this century, Christchurch's population growth was overtaken by that of New Zealand's capital Wellington in the early 1920s, and the South Island centre dropped to third most populous city in the country. To rectify the situation, groups like the Canterbury Chamber of Commerce made a tremendous effort to "increase the population of New Zealand" and to encourage many of these same immigrants to settle in the Christchurch area. ${ }^{4}$ To add to the sense of discomfort and unease which Christchurch's leaders and business community must have been experiencing at the declining growth rate of their city, was the fact that Auckland's population stood at 50,000 more than Christchurch in 1921, and 70,000 more in $1926 .^{5}$

Yet the city of Christchurch and its neighbouring borough New Brighton, were also selected for two other important reasons: one, because of the quantity and quality of surviving municipal records located predominantly at the Canterbury Public Library; and two, because both municipalities belonged to the Canterbury Progress League, which along with the Dunedin Expansion League, was one of the most active promotional bodies in the country and which left a treasure trove of promotional material.

Christchurch is located on the Canterbury Plain, almost at the mid centre of the South Island and only a few kilometres from its Eastern coast. The city is served by the port of Lyttelton, and although connected to Lyttelton by rail transport in the nineteenth century, there was talk until well into the twentieth century of connecting the city and its port with a canal scheme. Notwithstanding the substantial promotional measures which civic groups like the Christchurch Chamber of Commerce or private individuals such as Richard Wedderspoon, ${ }^{6}$ had taken to promote that city throughout the last two decades of the nineteenth century and the first two decades of the twentieth, a more concerted effort was needed. This led directly to leading citizens in Christchurch forming the Canterbury Progress League in 1918, the aim of which was "to promote and

${ }^{4}$ Canterbury Chamber of Commerce Records: Series 1 - Minutes, February 27, 1890, p.101. (Canterbury Public Library).

${ }^{5}$ Olssen, p.254.

${ }^{6}$ The Canterbury promoter Richard Wedderspoon was an active booster for his area and the author of a number of promotional works. He stated that his work was addressed "Not only to the New Zealand traveller and holiday-maker", but also to "business men overseas, to introduce them to South Canterbury as a field for investment..." See: Pictorial South Canterbury, no page. 
assist any movement for the advancement of Canterbury, and by united public action, or by other means to secure the co-operation of Town and Country to that end." [ILLUSTRATION 55]

The borough of New Brighton also undertook extensive promotional measures and for many of the same reasons as that of Christchurch. For this reason New Brighton's local council immediately joined with the Canterbury Chamber of Commerce and the Christchurch City Council, as well as all the other town councils in Canterbury, in associating with the Canterbury Progress League and contributing regularly to the League's funds. New Brightonians were particularly concerned with attracting tourists to the borough's beaches during the summer months, especially from Christchurch. To succeed at this task the borough council had to undertake an effective advertising strategy aimed at removing the negative image of drunkeness and dilapidation with which New Brighton was regarded, for according to librarians at the Canterbury Public Library:

...the New Brighton Borough Council was very much one of the down-at-heel local bodies of the Christchurch metropolitan area... Drunken parties were a blight... [and] certainly frequent enough to lead to the coining of the phrase: 'are you married or do you live at Brighton?"7

By far one of the most prominent groups to promote Christchurch throughout the fifty year period of this study was the Chamber of Commerce. The Chamber was started in 1859 in Lyttelton and transferred to Christchurch in 1863. One of the major objectives of the organization was to "increase the population of New Zealand"; and the best means to achieve this end, according to the Chamber, was by establishing offices "in Great Britain for disseminating information." ${ }^{8}$ Yet Chambers of Commerce were also concerned with a barrage of other promotional ambitions which included:

...advancing the interest of a chamber's town and city; encouraging its development and prosperity; improving and extending its trade facilities; encouraging the growth of local

\footnotetext{
${ }^{7}$ Richard Greenaway and Gary Clover on the New Brighton Records, p.89. (Canterbury Public Library).

${ }^{8}$ Canterbury Chamber of Commerce Records: Series 1, Minutes (February 27, 1890), p.101. (Canterbury Public Library).
} 


\section{Canterlutry}

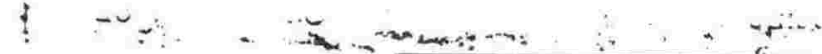 \\ Aims and Objects.}

The League shall be an entirely non-party organisation to promote and "assist any môvement for" the advancement of Canterbury, and by united :-public action,-or by other means, to secure the co-operation of Town and Country to that end.

(a) In the matter of railways, roads, and other means of communication.

(b) In the derelopment of shipping, commercial, and general business facilities.

(c) In the promotion of the industrial, agricultural, and pastoral interests of the Province.

(d) In the encouragement of education.

(e) In the extension generally-and especially to all-country districts-of the hydro-electric scheme.

(f) In the improvement and extension of parks and scenic reserves, and in the promotion of town-planning schemes.

(g) In the advertisement within New Zealand and abroad of the advantages of Canterbury. as a field for business activity and as a place; of residence.

(h) In making more widely known the attractions of Canterbury to tourists, anglers and sportsmen generally.

(i) In collecting and publishing reliable up-to-date information of the industries, trade, commerce, exports, imports, agriculture, modes of investments; climate, health, cost of living, natural conditions, markets, holiday and pleasure resorts, sport, etc., of the Province; and generally in whatever direction the League may decide to take action for the advancement of Canterbury. 
industry; and making its area healthy in the field of business and culturally and educationally progressive. ${ }^{9}$

The Canterbury Chamber actively pursued these goals. In the late 1880 s the Chamber was urging Parliament to make amends for New Zealand's poor showing at the Melbourne Exhibition by "having a thorough exhibit" at the Paris Exhibition of 1889. ${ }^{10}$ This was followed up a year later with a resolution calling upon the Government to appoint a special commissioner to represent New Zealand in Paris, "in conjunction with Sir Dillon Bell." ${ }^{11}$ Sir Dillon Bell was at the time New Zealand's Agent-General in London and had been asked by Parliament to go to Paris to represent the colony there; the Canterbury Chamber of Commerce, however, felt that another agent was needed if the colony was to be advertised adequately as there appeared to be so much work to do.

The Chamber of Commerce was also involved with directly boosting Christchurch itself. To this end it was responsible for distributing promotional literature overseas, such as the "1888 Report on Immigration" which had been published by the Government, the statistical conclusions of which proved favourable to Christchurch. Consequently, up to ten thousand copies of this report were ordered by the Chamber and sent overseas to "all the leading English and Colonial newspapers, London Banks, Colonial Chambers and Public Institutions etc...", where they could be read by potential investors. ${ }^{12}$ The Chamber also forwarded relevant promotional literature about the city to agents of the Government Tourist and Health Department. ${ }^{13}$ To finance these booster publications for attracting tourists and settlers, the Chamber approached local business men in the Christchurch community for financial contributions. ${ }^{14}$ Another method endorsed by the Chamber to promote the city and which has been discussed previously,

9 Canterbury Chamber of Commerce Records: Introduction to the Archives. (Canterbury Public Library).

${ }^{10}$ Canterbury Chamber of Commerce Records: Series 1 - Minutes, November 28, 1888, p.58. (Canterbury Public Library).

${ }^{11}$ Ibid., November 28, 1889, p.64.

${ }^{12}$ Ibid., January 13, 1888, p.24.

${ }^{13}$ Ibid., April 7, 1924, p.223.

${ }^{14}$ Ibid., February 6, 1930. 
was to greet and entertain important visitors. During the 1906 Christchurch Exhibition, for instance, a wine and biscuit function was planned for "the accredited overseas representatives." 15 The purpose of holding this function was to leave these visitors with a good impression of Christchurch so that once they returned home they would be a source of positive free publicity for the city.

The evidence shows that the Canterbury Chamber of Commerce often co-operated with other chambers of commerce throughout New Zealand, and particularly the South Island, with the intention of promoting the country as well as their own local interests. This co-operation amongst South Islanders would have been primarily the result of an attempt to redress the population imbalance that was favouring the North Island. ${ }^{16}$ Records in the Minute Books reveal that the South Island Chambers worked together to encourage tourism "by the publication and distribution of suitable literature."17 Annual conferences of the chambers were also held to discuss promotional means. During one such conference it was concluded that the term 'Australasia' should be avoided where possible in boosting New Zealand, as it "involved a loss of identity" for the colony by drawing connotations with Australia next door. ${ }^{18}$

This determination to create a particular identity for New Zealand could also be seen a few years later, during a call in Parliament to avoid conjuring likenesses to overseas places when boosting the colony: "...we should not call our scenic beauties by the names of well-known scenic areas of other countries." ${ }^{19}$ Presumably it was the intention of these nationalistic exclamations to ensure that New Zealand (and by implication her cities) was not associated with the Old World; rather, the endeavour of such proclamations, in keeping with the booster literature and visual material discussed before, was to secure a unique image of the colony that was utopian and without the

${ }^{15}$ Ibid., October 8, 1906, p.226.

${ }^{16}$ In 1901 the combined population of Auckland and Wellington was just over 7000 more persons than the combined populations of Christchurch and Dunedin; by the year 1926 , this number had increased to 87,000 . Olssen, p. 254 .

${ }^{17}$ Canterbury Chamber of Commerce Records: Series 1 - Minutes, March 5, 1928, 1/10. (Canterbury Public Library).

${ }^{18}$ Canterbury Chamber of Commerce Records: Annual Report of New Zealand Chamber's of Commerce 1922, p.19. (Canterbury Public Library).

${ }^{19}$ Thomas Mason Wilford, NZPD (July 28 - September 9, 1927), p.311. 
dubious connotations associated with European (and perhaps even Australian) urban centres. $^{20}$

In 1923, the Canterbury Chamber of Commerce received a letter from the Wellington Chamber suggesting that a 'Postcard Day' be held across New Zealand in conjunction with the forthcoming 1924 British Empire Exhibition. The idea was to send out a battery of postcards from the country so as to draw attention to the New Zealand Court at the Exhibition; the Canterbury Chamber agreed to the motion and forwarded a resolution calling for, "postcards referring to New Zealand scenery, etc. be sent to friends in England..." 21 The Chamber's decision to agree to the Wellington motion not only illustrates the co-operation that occurred between various promotional groups and chambers of commerce, but also provides an introduction to the promotional nature of postcards and greeting cards from Christchurch.

The collection of postcards and greeting cards from 1900-1920 located at the Canterbury Public Library exposes a number of visual images which were used to promote the city of Christchurch. The collection includes a variety of different pictures yet they all express a similar theme, that of demonstrating that Christchurch was a civilised and cultured metropolitan centre. There are shots of municipal improvements, such as the Muir and Moodie Company picture of the corner of Bealey Avenue and Papanui Road, with its asphalted road surface and tram track lines; there are photographs of local amenities and cultural attractions, such as the Clarendon Hotel, the "New Catholic Cathedral", Cathedral Square and the "Hospital Buildings taken from the Boatsheds"; there are colour photographs of prosperous upper middle class homes in tudor designs and set in rustic surroundings along the River Avon, such as those taken by the Government Publicity Department [ILLUSTRATION 56]. There are photographs of wealthy middle class families going for promenades along tree-lined boulevards

${ }^{20}$ Perhaps this attempt on the part of New Zealanders to dissassociate themselves from their Australian cousins could be blamed in part on the prevalence of the myth that New Zealand was a land peopled by the best of the British; for if British people believed Australians and New Zealanders were one in the same, then were supposedly racially superior New Zealanders in danger of being identified with the convict blood and the criminal legacy of the Botany Bay settlers? If they were, it would certainly result in the loss of an extremely effective and exclusively New Zealand promotional argument.

${ }^{21}$ Canterbury Chamber of Commerce Records: Series 1 - Minutes, February 4, 1924, p.216. (Canterbury Public Library). 


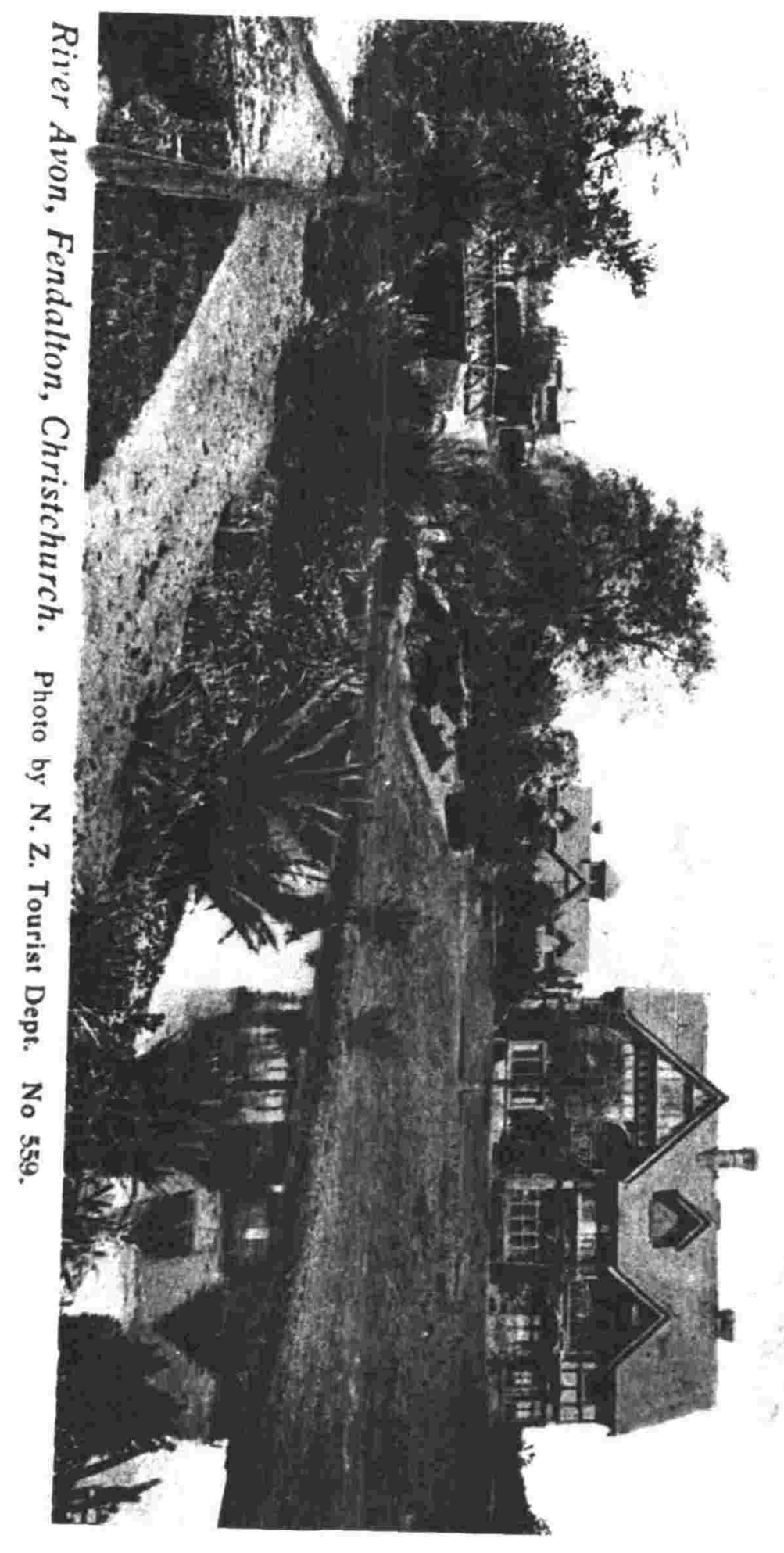

illustration 56 
which draw likenesses to European capitals; there are painted images, such as the romantic view of the Supreme Court taken from near a bridge over the River Avon. There is even a postcard showing a crowded beach scene in New Brighton. In all of these postcards and the many others not mentioned, the vision being rendered by the photographers and artists is of an ideal world; for the emphasis is placed upon the stone and brick buildings which give an air of permanence and prosperity, while the lovely surroundings and park-like lawns give an impression of a brighter and happier world than that left behind in England.

Christchurch's promoters pursued a similar advertising strategy with their greeting cards and souvenir booklets. There were Christmas and New Year's greeting cards which opened up like contemporary cards but whose covers had photographs of general views of the city and modernist hand drawn pictures of the city's monuments, rather than the more traditionalist yuletide images of sleighbells and typical religious subject matter. On the cover of one of these Christmas cards, Christchurch was even labelled as "The Garden City", (the title by which the city is still promoted today), implying that Christchurch enjoyed a relaxed and healthy lifestyle that was more than up-to-date with contemporary English Garden City designs. The garden city notion would have appealed to people living in older industrial centres in Great Britain and who were considering emigrating so as to be able to find a new and better life overseas. One greeting card had a painting of the New Zealand flag on its back cover. Such an image would have served as a nationalistic device ensuring that New Zealand's notions of separateness from European and Australian urban centres were emphasized. One particular souvenir card from the 1906-1907 Christchurch International Exhibition had a clever cover picture of the exhibition itself which had a cut away area that when opened, revealed a miniature album inside containing a series of ten photographs of promotional municipal scenes. [ILLUSTRATION 57]

The Christchurch City Council was also active in promoting the city, both at home and overseas. During the Melbourne International Exhibition, for example, a motion was carried "suggesting that a panoramic view of Christchurch" be published and sent to the Exhibition, the intent of which was to advertise the city abroad. ${ }^{22}$ Likewise, the City Council was also responsible for boosting the image of the city at home. For this reason

\footnotetext{
${ }^{22}$ Christchurch City Council Minutes: March 19, 1888, p.172. (Christchurch Civic Offices).
} 


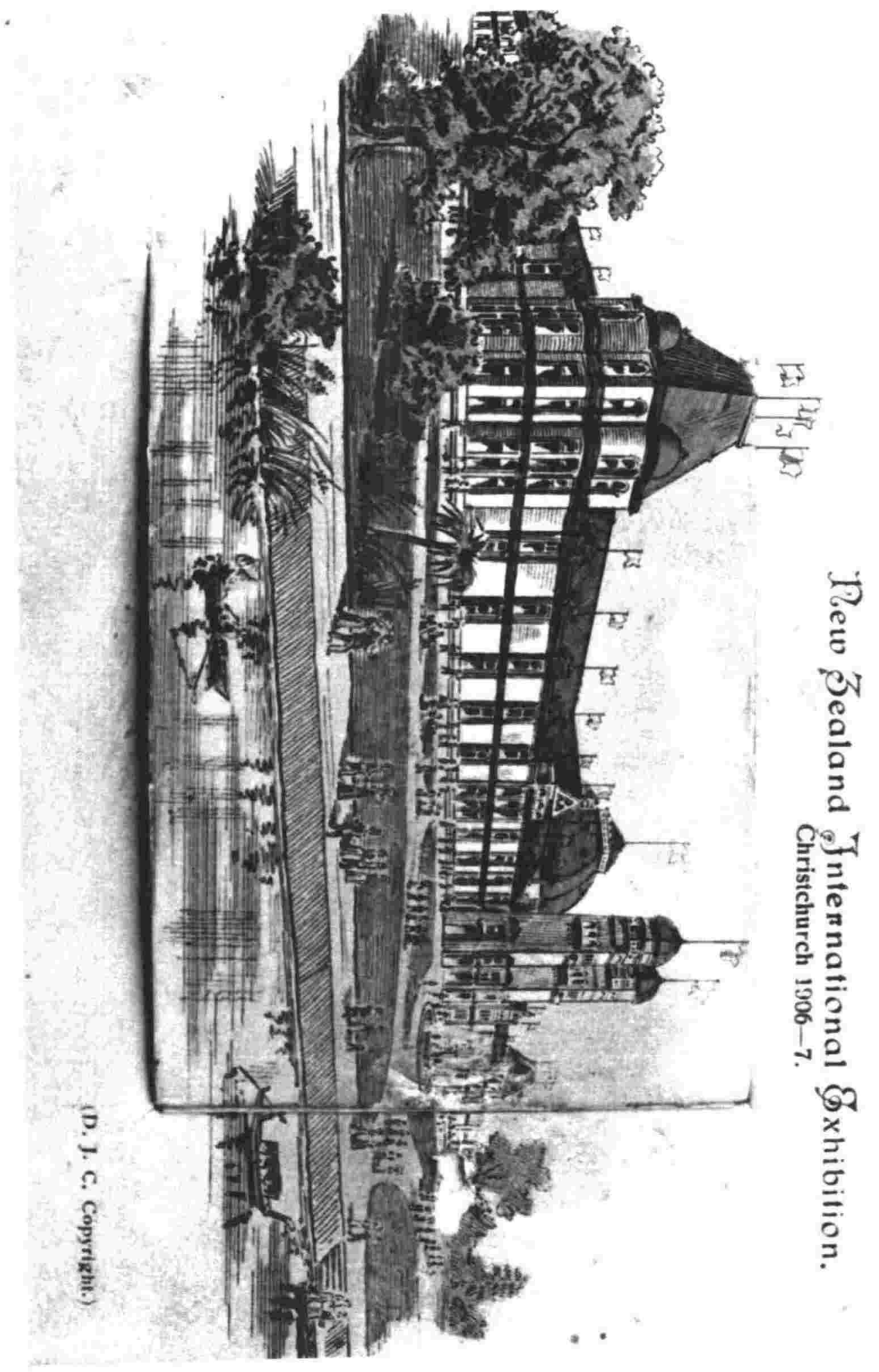

illustration 57 
the Port and City League, a civic committee designed to facilitate better transport between Christchurch and Lyttelton Harbour, used promotional motion pictures at a local cinema to advertise harbour improvement propaganda before the major film attraction was shown. ${ }^{23}$ By far one of the Council's most active promotional bodies was its Publicity Committee. One of the committee's primary functions was to prepare promotional works for the New Zealand High Commissioner in Great Britain for distribution in that country. An extract from the "1919 Report of the Publicity Committee", serves as an excellent indicator of just how diverse and complex the ambitions of the Christchurch council were for the procurement of settlers and investment. Such a plan included stressing the financial security of the city, its industrial growth and the existence of at least the trappings of a civilised lifestyle:

You will explain the advantages Canterbury offers and state what has already been accomplished, which can be ascertained by an analysis of the statistics relating to Canterbury. Say that he can be sure, if he puts money into Canterbury... that he has an absolutely gilt-edged security. The figures if extracted from the Official Year Book will prove the absolute security on that point... Figures relating to the growth of Canterbury's industries should be given. Another booklet should give pictures of Canterbury's magnificent educational institutions, so that the men with families will know that he can come here and find art galleries, colleges, and museums. These are the things that will lead people with fixed incomes to come and settle here. ${ }^{24}$

Perhaps the most innovative and successful of the City Council's advertising strategies was the financial support given to the publication of the monthly magazine The City Beautiful. The journal, a high quality glossy publication with numerous articles and excellent photographs, reached a wide audience and appeared to concern itself solely with promoting "the interests of City Beautifying and Improvement."25 Yet because of

${ }^{23}$ Canterbury Chamber of Commerce Records: Minutes of the Port and City Committee, September 16, 1929. (Canterbury Public Library).

${ }^{24}$ Report of the Publicity Committee as quoted in The Press (March 27, 1919), p.48.

${ }^{25}$ Charles Chilton Papers: Report of Directors, October 9, 1925. (Canterbury Museum). The publication's orientation was devoted to city beautiful and town planning improvements. The magazine retained this orientation until the late 1920 s when horticultural sections grew increasingly dominant. By 1929 the journal had completely switched its focus to gardens, flowers and the like, and in that same year the Canterbury Horticultural Society took over publication from the Christchurch Beautifying Association. 
its popularity, the Council sanctioned two issues in the year to be used as Official Civic Numbers, the purpose of which was to promote the City Council's improvements. Consequently, despite appearing in the guise of a publication aimed at creating an ideal city, the testimony of the director's report alludes to the fact that the magazine was also in part a vehicle for boosting Christchurch throughout the country and overseas; for the report states that the Journal drew "appreciative comment not only from Christchurch and many parts of New Zealand but also from prominent authorities on Town-Planning in England and America." 26

The borough council of New Brighton was also responsible for attracting tourism and settlement to its district. Yet as mentioned before, the area did not enjoy a respectable reputation; in the eyes of many people living in Christchurch, New Brighton was more renowned for its sandy tracks which tried to pass for roads and for its makeshift shacks which provided accommodation for the poor and the transitory. According to Bruce F. Ferrand, the borough attempted to attract tourists with a variety of civic improvements. To achieve these ends a host of different societies were formed, including: the New Brighton Improvement Association (after 1891), the two Improvement societies which were active in the central and southern parts of the borough respectively (between 1920 and 1936), and the Beautifying Association which was formed in 1902 and whose contributions included a promenade, swings and a surf club. $^{27}$

Apart from these local civic improvements, the methods used by the borough to boost their community were analogous to many of those mentioned before for other towns and cities in the country. The New Brighton Greater Progress League for example, a group set up to promote the borough, lobbied the municipal council to send a deputation to the Minister in charge of the Department of Publicity in order to ensure that New Brighton received greater publicity in the Department's tourist brochures. ${ }^{28}$ The New Brighton Borough Council, in order to advertise the borough's amenities,

\section{${ }^{26}$ Ibid.}

27 Bruce F. Ferrand, "The Borough of New Brighton. An Experiment in Local Government in the Years 1897-1941", M.A. thesis (Canterbury University, 1951), pp.4860. Library).

${ }^{28}$ New Brighton Committee Minutes: June 6, 1929, p.287. (Canterbury Public 
considered taking out full page advertisements in forthcoming Cantabrian tourist guides. $^{29}$

By far the most prolific of all these promotional groups in the Christchurch/New Brighton area, however, remained the Canterbury Progress League. This is not surprising since, according to the organiser of the League - P.R. Climie, it seemed to enjoy the membership of every civic council in the province of Canterbury. ${ }^{30}$ The League was very vigorous in boosting Canterbury since one of its most important functions was "the advertisement of Canterbury in New Zealand and abroad." ${ }^{131}$ The League used every available means to achieve the promotion of the province and especially its city and town districts. ${ }^{32}$ It attempted to "improve in every possible manner the means employed to advertise the trade and scenic beauties of the South Island", by proposing the setting up of a South Island Trade Commissioner in London. ${ }^{33}$ (Nothing came of the proposal as it was deemed financially impossible to support). The League also pressed for further photographic publicity in overseas newspapers; for a New Zealand Publicity Officer had written from London, "stressing the value of photographs in the English newspapers" as a promotional device. ${ }^{34}$ The League was also busy raising funds to help finance the

29 New Brighton Borough Council Records: 1/28 Rough Council/Committee Minutes, August 15, 1929. (Canterbury Public Library).

${ }^{30}$ Lyttelton Times (September 26, 1918), p.13.

${ }^{31}$ Canterbury Progress League Minutes: pamphlet distributed to all local bodies which were members of the League. (Canterbury Public Library).

${ }^{32}$ There was a degree of hesitation amongst the country districts which joined the Canterbury Progress League in that they felt only Christchurch and the larger urban areas would receive any benefit from the League's activities. The organisers of the League assured the country districts that this was not the case. See: the Lyttelton Times (January 27, 1919), p.30. Yet the majority of the booster literature, despite the guarantees of the League's Organiser, does appear to promote Christchurch at the expense of smaller areas in the county.

${ }^{33}$ Canterbury Chamber of Commerce Records: Special Committee Minutes, January 29, 1929. (Canterbury Public Library).

${ }^{34}$ Canterbury Progress League: March 6, 1929, p.207. The same publicity officer, while discussing photographic subjects for English newspapers, emphasized the need for these photographs to also "have some special feature of appeal." Perhaps such an accent on extraordinary subject matter accounts for the likes of New Zealand pictures showing towns in flood or Canadian photographs of tornado damage? Such peculiar images would have tended to attract public attention in the United Kingdom, and this would 
publication and distribution of booster propaganda at home and abroad, such as the booklet: New Brighton, New Zealand. Canterbury's Playground. In this booster tract the Canterbury Progress League in association with the New Brighton Publicity Committee, promoted the borough district in typical booster style by focusing on wealth and stability in the verbal description of the area: "...the township and district are substantial and progressive, and present all the elements of permanence and prosperity. ${ }^{135}$ Lastly, the League was also involved in promoting Christchurch with motion pictures; for the minutes of the League reveal that it co-operated with the Government Publicity Department, in as much as it showed its appreciation for the Department's production of a new film entitled "City on Wheels."

Businesses were also dynamic propagandists in Christchurch, primarily motivated though with thoughts of increased sales and profit. In the visual material a number of booster techniques are readily evident. There are illustrations in booster tracts, such as that for the Thomas Crompton Iron Works in Armagh Street, with a surfeit of smoking chimney stacks (16 in fact), to say nothing of the bustling crowds of workers and customers rushing around the premises. ${ }^{37}$ The intention of such artistic devices was to reveal a thriving and profitable business. There are photographs of factories, like that of the boot manufacturers Suckling Brothers, which have been obviously tampered with. In this case a flag has been added, the promotional writing advertising the name of the manufacturer has been emphasized with a pen or a brush, and a fence and the rear sheds have all been painted over by an artist and given a neat and tidy appearance [ILLUSTRATION 58]. Where photographs have not been tampered with by an artist, photographers have used other promotional methods. For instance, in the 1909 letterhead for Rotherfield's Hotel on Cashel Street, the picture of the establishment reveals crowds of patrons gathered on the balcony and on the ground level. It is obvious to even the untrained eye that the stiff postures of the customers, not to mention the existence of

account for their publication. Refer to Chapter 3.

${ }^{35}$ The Canterbury Progress League and the New Brighton Publicity Committee, p.2.

${ }^{36}$ Canterbury Progress League: May 2, 1928, p.141. (Canterbury Public Library).

37 Montague Mosley, Illustrated guide to Christchurch and Neighbourhood (Christchurch: 1885), no page. 


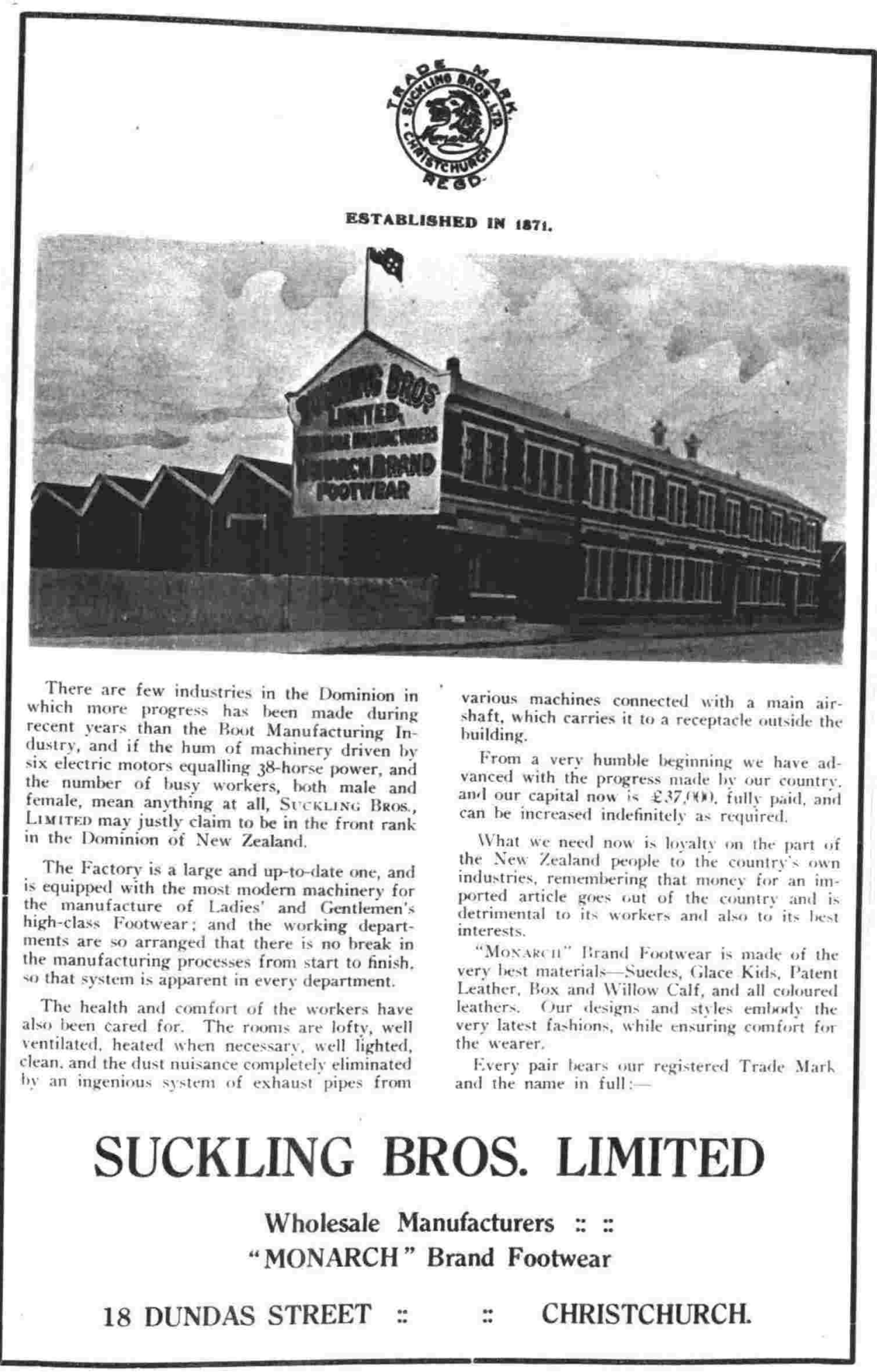


such a crowd at all, are the result of a photographer consciously posing the subject matter for the greatest possible effect [ILLUSTRATION 59].

The best indicator of the amount of artistic exaggeration in an illustration remains a comparison with a photograph. Two obvious examples of artistic hyperbole from Christchurch are those of the Shipping Agents J.M. Heywood \& Co. and the offices of the Lyttelton Times newspaper. In the example from the Lyttelton Times building, the photograph reveals a stone establishment of three stories in height with a sub-basement of smaller arched windows on ground level below a cap above the pediment [ILLUSTRATION 60]. In the photograph, the heads of two pedestrians near the entrance of the building are level with the cap. Yet, when one looks at the letterhead illustration for the newspaper, one sees that the artist has drawn the heads of the people outside the establishment as barely reaching half way up the arched basement windows [ILLUSTRATION 61]! The intention of this engraving was to give the newspaper building a greater appearance of authority by increasing its size. Another promotional device for making a building look larger, and for the same reason, has been used in the letterhead example for J.M. Heywood [ILLUSTRATION 62]. In this case, the firm's height appears to have been increased by altering the perspective; by both drawing the structure from ground level looking up and by condensing the sides of the building, the resulting image is of an edifice that appears much more grandiose that it really is. When one compares the artist's engraving with a modern photograph of the building [ILLUSTRATION 63], the artist's intention of creating an illusion of majesty is immediately apparent.

$$
* * *
$$

There is promise in the sky of a new day... There is coming a new city - the City Beautiful - ... The transformation that Nero made of Rome will be as nothing in contrast with the city that is appearing as with a new birth. As John saw the heavens rolled away, and beheld the new Jerusalem, so also unto us who gaze comes a vision of the new city that breaks with the morning's sunshine upon the discomfort and baseness of the dingy city of the nineteenth century. And with the new dream comes a new hope. $^{38}$

Christchurch's promoters were forging an image of the city that was positive mainly for reasons of attracting tourists, capital and settlement. Yet the city's boosters

38 The City Beautiful, 1, No.8 (1925), 10. 

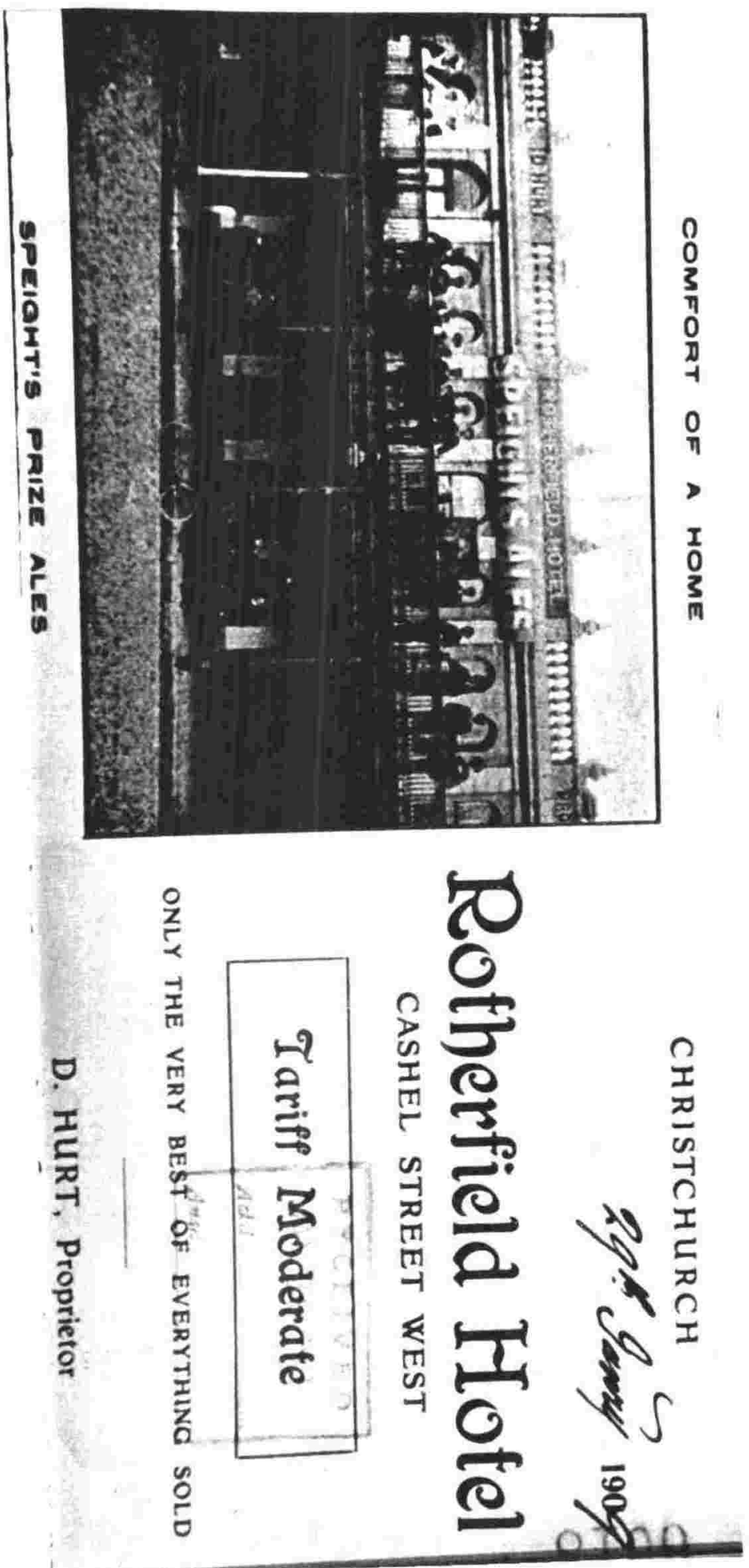

illustration 59 


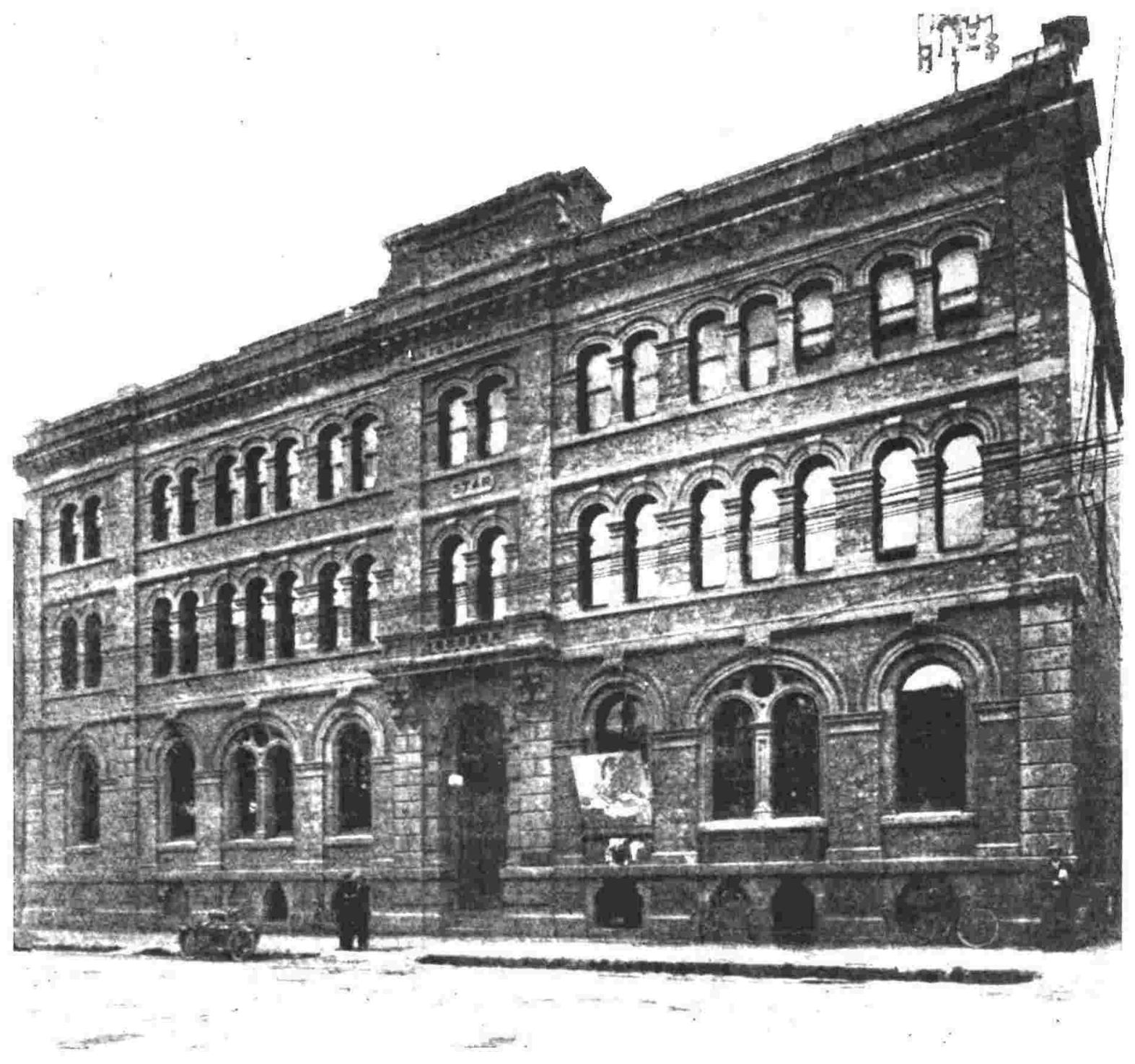

illustration 60 


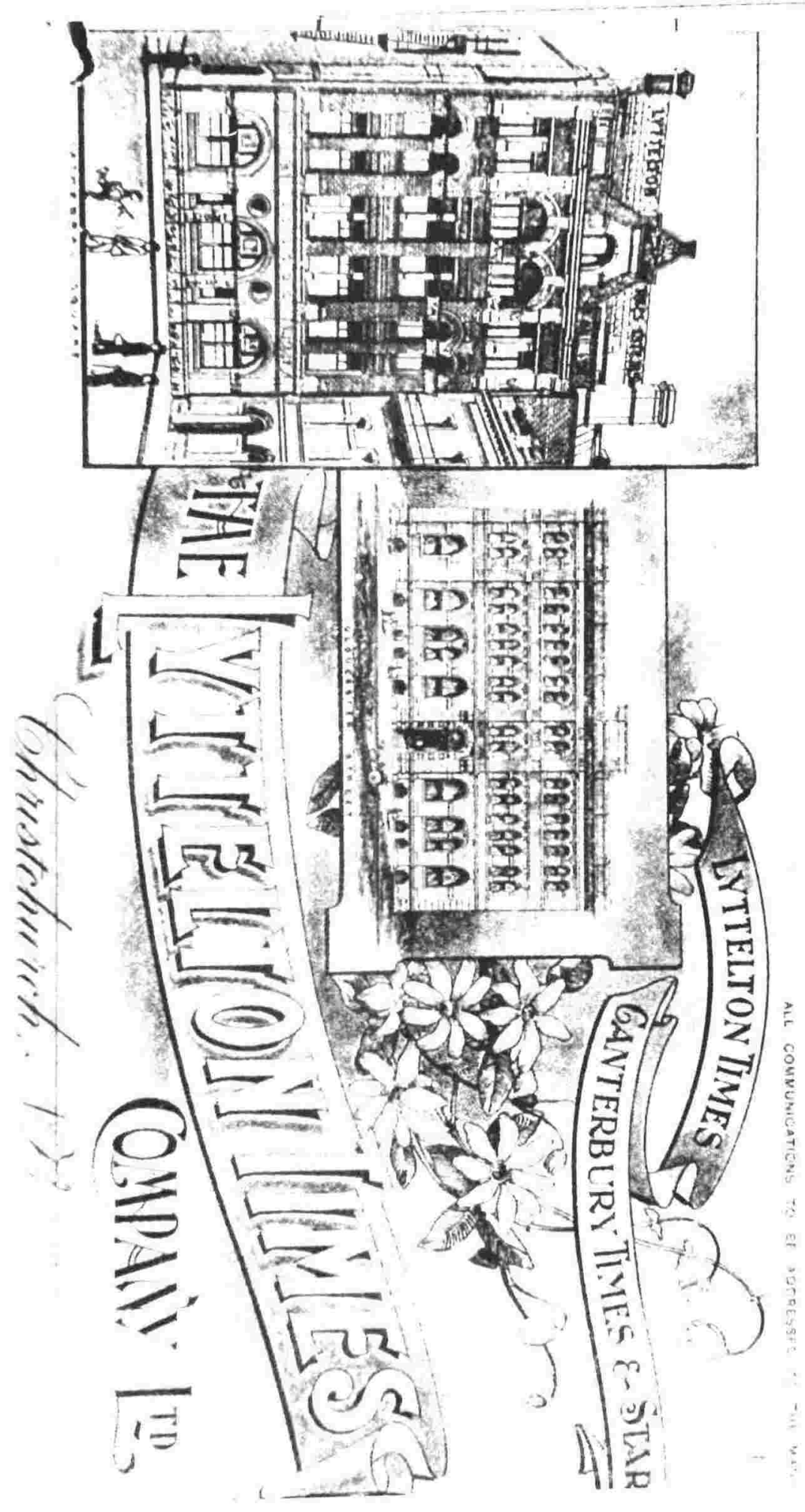

illustration 61 


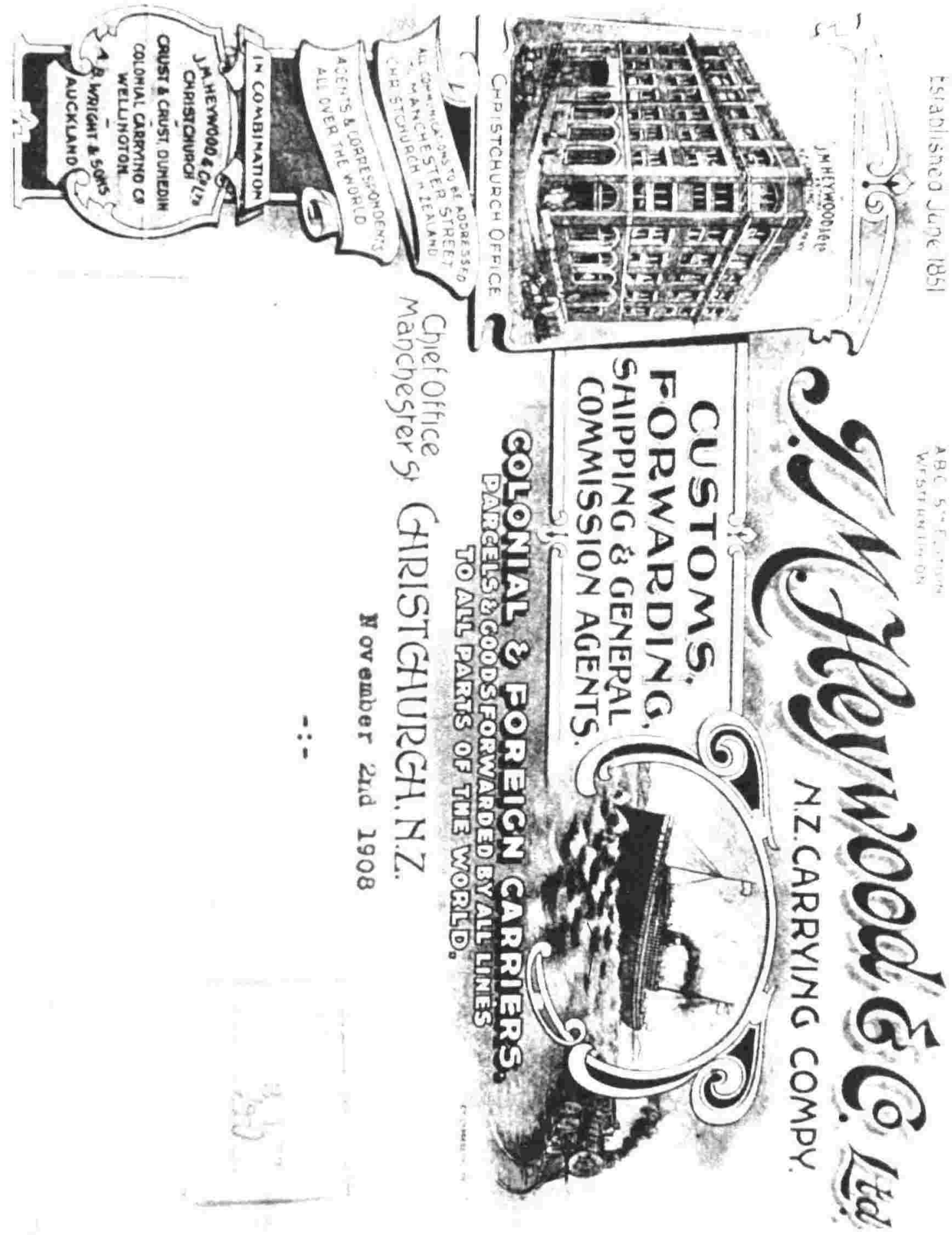

illustration 62 


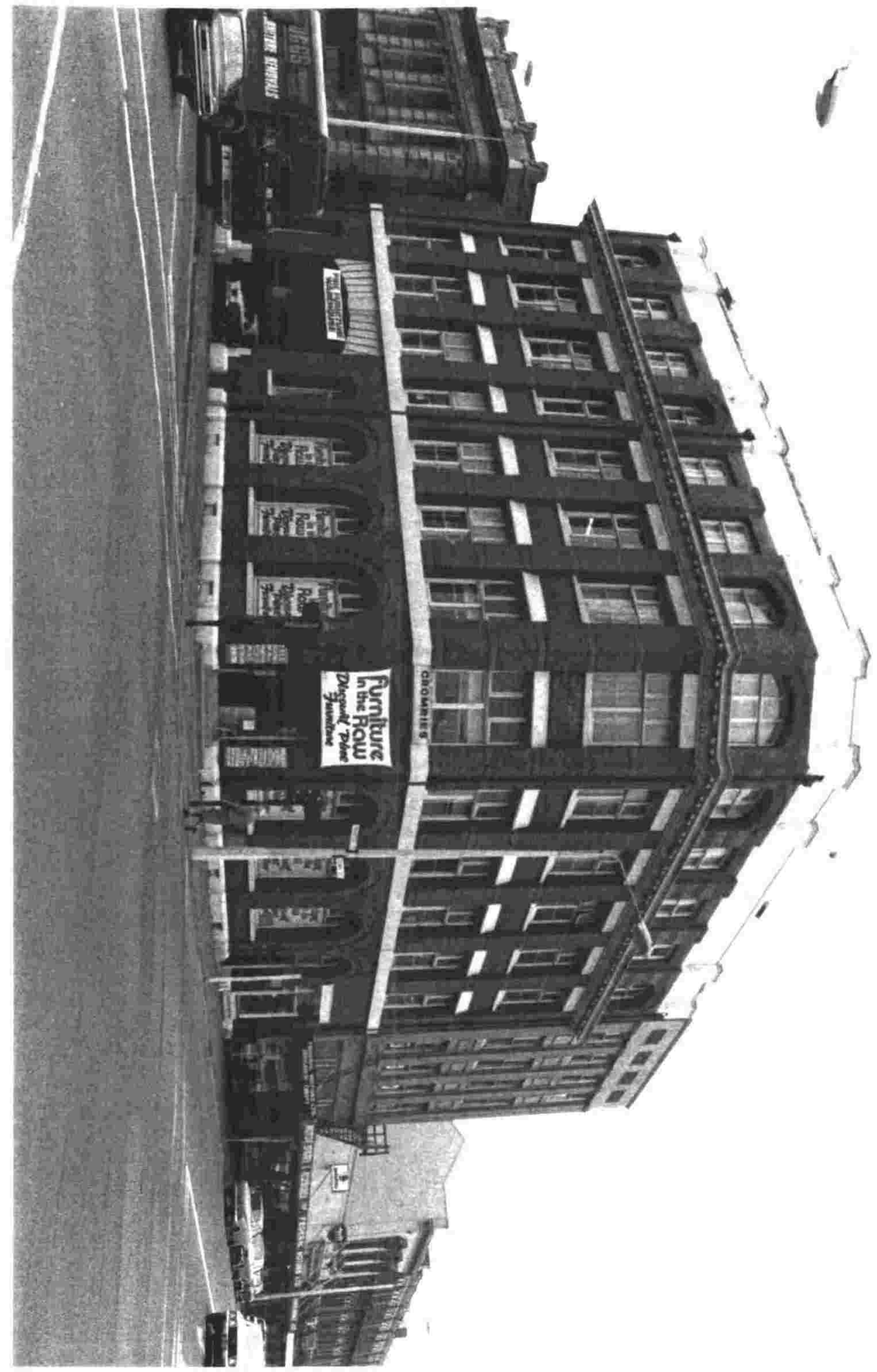

illustration 63 
were influenced by a variety of other motives in addition to those of material gain, namely: civic pride, a desire to improve their city and an attempt to avoid repeating the mistakes of Old World urban centres. The above passage from The City Beautiful magazine is perhaps the best vehicle to introduce these other motives. It could be argued that this passage was another prophetic advertising technique similar to those booster tracts which foretold how prosperous and stable certain urban communities in New Zealand would grow (See Chapter 3); yet the emotionally charged language of the excerpt and the religious optimism of the millennial text, in addition to the very reformorientated nature of the magazine from which the quote was taken, suggests that the author was genuinely instilled with a utopian vision of what Christchurch could become. ${ }^{39}$ It was a dream of a biblical New Jerusalem and of a 'Heaven upon Earth' realised, one that might have had its origins in the Book of Revelation $\$$. Perhaps not all of the urban boosters in Christchurch, not to mention the country, were instilled with these utopian visions of New Zealand's towns and cities; and an accurate assessment of the percentage that were would be impossible to attain. However, when one is looking at the primary source material for Christchurch, these utopian and reformist elements cannot be ignored.

It seems that this desire to improve Christchurch and its environs owed much to the influence of new ideas from abroad, such as the City Beautiful, the Garden City, suburbs and Town-Planning. This can be seen in a number of areas: with the local projects of the numerous improvement societies, the amount of space devoted to city beautifying activities in the civic records and local newspapers, the publication of periodicals such as The City Beautiful and Christchurch's adaptation of the title 'Garden City' itself. The influences and pervasiveness of such ideas are best expressed, however, in the concern shown over improving the health of the city's inhabitants as well as their living and working conditions. Before initiating a discussion on these ideal notions it is important to recognise two things. Firstly, that there might have been varying degrees of influence which these utopian and reformist considerations had on the people at the

${ }^{39}$ Davis develops distinct definitions for five ideal societies: Arcadia, Utopia, the Land of Cockaygne, the Millennium and the Perfect Moral Commonwealth. In using the term 'utopia' I am aware of these differences in definition, but am skeptical about whether or not most of the authors of the evidence which I am studying were. For this reason I hold with Fairburn's point that after the 1890 s, these definitions tended to shift and become less clear. See The Ideal Society and its Enemies, p.27. 
time; and secondly, and perhaps most importantly, that the City Beautiful, the Garden City, suburban and Town Planning initiatives were not mutually exclusive of booster aims. Such idealistic motivation was potentially also of financial benefit to the communities which were influenced by them; for not only was a good image of the city an attractive promotional bonus in the stockpile of booster propaganda (exemplified in publications such as The City Beautiful magazine), but improved and beautified areas were also of value to the propertied classes in that they helped elevate real estate values.

One of the most forceful arguments for supporting the thesis that some of the booster propaganda was genuinely concerned with creating an ideal society by avoiding old world evils, can be seen with the consideration expressed in the literature regarding the health of the city's citizenry. This concern was the result of a desire amongst the inhabitants of Christchurch and of New Brighton to avoid the appearance of Old World urban problems. This anxiety is epitomized in the Christchurch Beautifying Association's call to lessen pollution levels before the city's smog condition began to resemble that of London, England: "Prevention is better than cure and before the city grows larger... care should be taken to provide an atmosphere free from smoke and dust." ${ }^{140}$ This worry over clean air and a healthy environment is mirrored in the concern shown over the spread of disease; local anxiety about curbing such contagion can be seen in the construction of open schools in which whole sides of a classroom could be opened with giant sliding doors so as to avoid unnecessary stuffiness and the potential for infection [ILLUSTRATION 64]. ${ }^{41}$ In New Brighton the borough council's regard for sanitation led it to obtain possession, for purposes of improvement, "of what is commonly known as the Old River Bed... [which was] a menace to the Public Health. ${ }^{142}$ And this concern over health and sanitation can also be seen in an invitation

40 The City Beautiful, 1, No.4 (1924), 2.

${ }^{41}$ One can see evidence of this belief in the recuperative properties of fresh air in New Zealand's'sanitoriums, whereby tuberculosis patients were placed in open air camps so as to supposedly benefit from exposure to clean air. I owe this point to Linda Bryder.

42 New Brighton Work's Committee: September 29, 1902. (Canterbury Public Library). The Committee's report went on the explain that apart from reasons of health, the river bed also represented an ugly blot on the local landscape, one that might detract from creating a positive image of the borough as "a place of popular resort". So once again one can see evidence here of dual motives (material and reformist) for some town 


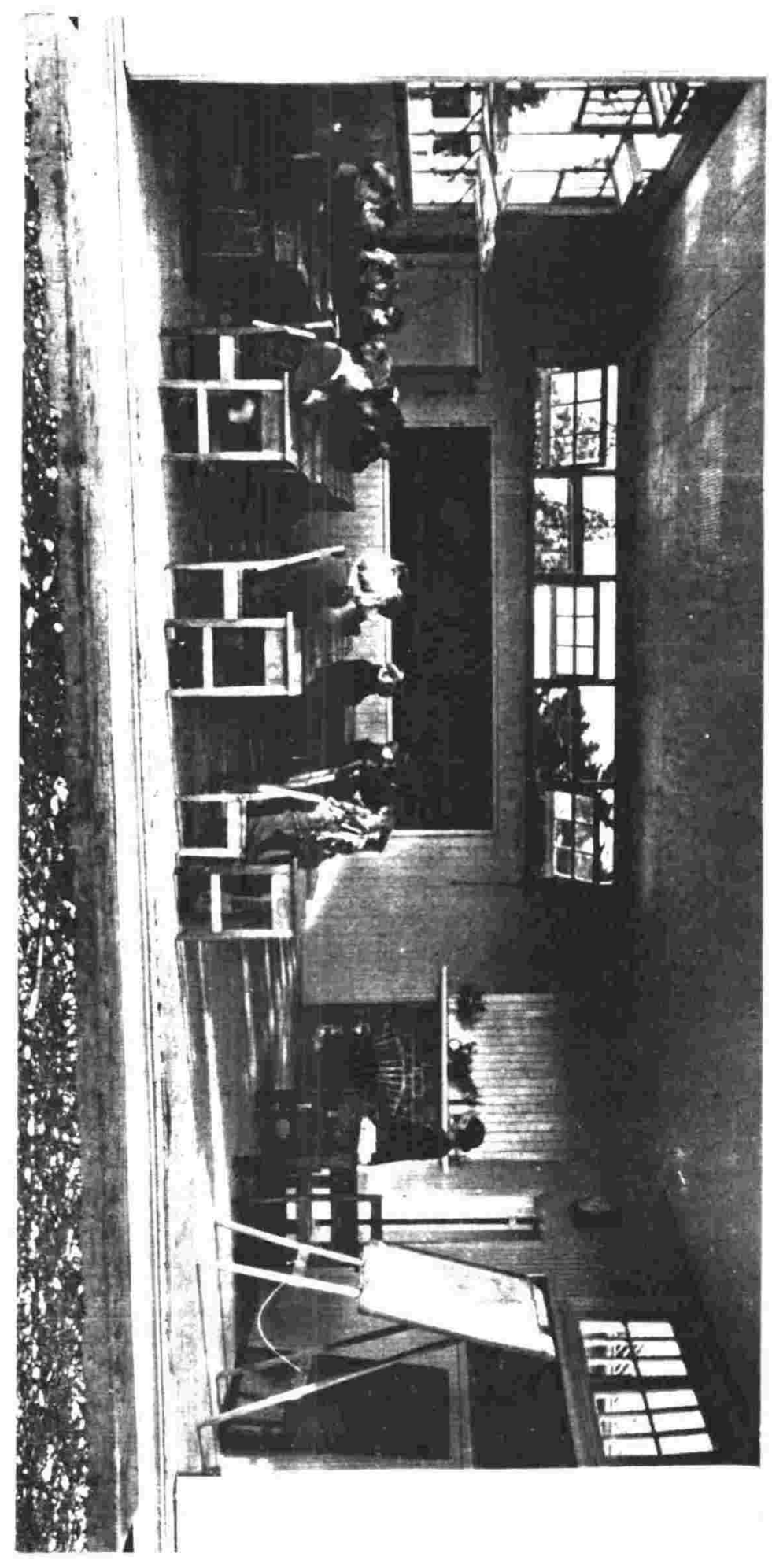

illustration 64 
from the Christchurch Beautifying Association to make the city more spacious: "...so that none shall be forced to live in cramped, air-less slum areas, where diseases can walk abroad..." ${ }^{43}$ Interestingly enough, this concern with disease in this passage should be qualified; for the quotation goes on to talk about the need to avoid another kind of old world peril: the "disease of the mind...[that] leads to the dark thoughts of revolution and revolt." ${ }^{14}$

Evidence of trying to foster civic pride and of avoiding old world threats (in this case those of a biological nature rather than those of the revolutionary kind), can also be found in bids to improve the living and working conditions of the city's residents, particularly with the work of the Christchurch Beautifying Association. According to its First Annual Report, the Association was concerned with beautifying the surrounding landscape primarily for reasons of aesthetics and improved health, ${ }^{45}$ but civic pride was also a factor not to be ignored: "The strength of a city must rest on the pride its citizens take in it..." ${ }^{46}$ Consequently, efforts at improving the environment for artistic effect usually involved planting flowers and trees, weeding, removing rubbish, improving waste or vacant lots, campaigning for the eradication of placards covering walls of factories and homes, deciding on decorative elements of the urban cityscape (such as fountains and types of streetlamp), building rustic bridges and pretty promenades and awarding prizes for the best kept gardens. Likewise, the concern shown over health can be evidenced with the Association pushing for industrial firms to relocate out of town

improvements.

43 The City Beautiful, 1, No.8 (1925), 11.

${ }^{44}$ Ibid. The presence of slums in New Zealand was viewed pessimistically by many in the Garden City Movement and the government in New Zealand. Slums were believed to result not only in the spread of disease and physical and moral degeneracy, but the existence of slums was also envisioned as leading to increased worker militancy. See: B. Schrader, "A Peaceful Path to Reform", research paper presented for B.A. (Hons) in History, (Victoria University of Wellington, 1991), p.16.

45 Christchurch Beautifying Association, First Annual Report (Christchurch: Christchurch Press, 1898?), p.2.

46 The City Beautiful, 1, No.11 (1925), 1. 
so as to avoid crowding, ${ }^{47}$ and to turn to hydro electric power which was cleaner than coal burning power sources. ${ }^{48}$

There is strong evidence to suggest that other groups than just the Christchurch Beautifying Association, such as the Canterbury Chamber of Commerce and the Canterbury Progress League, were also affected by such altruistic and philanthropic motives. For such a reason the Christchurch Chamber of Commerce began discussing Esperanto classes, ${ }^{49}$ this being reflective of a utopian vision of the future where one language could unify an educated and technologically advanced world. Likewise, one sees the Canterbury Progress League concerned with improving the situation of the city's labour force by not only recommending that City Council "initiate a housing scheme for the better housing of the workers of Christchurch", 50 but also that manufacturers improve "as far as possible the material conditions under which workers carry on their occupations." ${ }^{51}$ The League's concern with encouraging civic pride can also be seen in the "1919 Report of the Publicity Committee". For the first objective of the committee, before that of advertising the province abroad even, was to stimulate:

... the interest of Canterbury people in Canterbury affairs... They should be educated to have faith in their province, to believe in it, to foster its interests, to support its industries and to help actively in the development of its magnificent resources... ${ }^{52}$

47 "...there is now no need for our factories to be located in crowded surroundings." The City Beautiful, 1, No.7 (1925), 4.

48 "Yet because the use of coal steadily is being superseded by hydro-electric power, the manufacturing development has not meant a forest of hideous chimney stacks or districts given over to smoke-grimed factories." The City Beautiful, 1, No.12 (1925), 7.

${ }^{49}$ Canterbury Chamber of Commerce Records: Special Committee Minutes, May 1, 1930. (Canterbury Public Library).

${ }^{50}$ Canterbury Progress League Minutes: March 19, 1919, p.6. (Canterbury Public Library).

${ }^{51}$ Ibid.

${ }^{52}$ Lyttelton Times (March 27, 1919), p.51. 


\section{CHAPTER 8: THE BAD AND THE UGLY}

A sight of marvelous beauty held me rigid for a moment. Marble palaces, margined with gleaming gardens, flecked the length of the river as far as my eye could reach... Boats with brilliant covered awnings plied from bank to bank, like swarms of tropical butterflies... Great temples and public buildings broke the outline with their sky-pricking spires... I dared not approach such noble purity so begrimed as I then was. I sought the outskirts of the city, for I knew that every town, however beautiful and rich, draggles off in some direction into meanness and filth and penury. I marvelled at the extent of the squalor here... A reeking human quagmire stretched for miles over the flood-soaked borders of this noble city... ${ }^{1}$

As seen in the last chapter on Christchurch and in previous chapters on the New Zealand boosters, the country's promoters were forging a positive image of their towns and cities for reasons of publicity. Yet despite the optimistic propaganda which was emanating from promoter and reformist literature, it is important to realize that the country's urban centres were not entirely the utopian places some were making them out to be and others were hoping they might develop into. There exists also a great deal of information relating to the darker side of the colony's cities and towns. The bulk of such material comes from commentators who were not boosters, but rather travellers touring the country, politicians trying to initiate reform, and authors looking for fame and/or fortune. Instead of an optimistic vision of a new world free from the evils of industrial urban life, we are greeted with a depiction of old world problems re-emerging, especially drunkenness, gambling, prostitution, disease and violent crime. Rather than the ideal picture of civilised settlement which the boosters created for overseas consumption, we see towns and cities as uncivilised places: badly planned, ugly and peopled by savages and hooligans. Nor do the country's cities appear as the prosperous or thriving centres which the boosters made many of them out to be. Alternatively, according to some reports, New Zealand's cities and towns were places suffering economically and at no time was the financial plight more acute than during the depression years of the 1880 s and the recession years of the 1920 s.

The intent of this chapter is not to prove that the positive image of New Zealand's towns and cities, carefully nurtured by its urban boosters, was incorrect; on the contrary,

\footnotetext{
${ }^{1}$ John Macmillan Brown, p.24.
} 
as stated before in the Introduction to this thesis, the validity of the material is of no consequence to a discussion of images. What is important, however, is the actual mental picture itself held in sway by an individual or group of individuals, and the reason(s) such a view was espoused. A chapter on the negative descriptions of the colony's cities and towns is important for three reasons: firstly, the quantity of negative statements to be found is a fact in itself which requires at least some comment. Secondly, an examination of negative imagery reveals why many reformist and utopianist New Zealanders turned to City Beautiful, Garden City, suburban, and town planning movements as a solution to what they perceived of as an urban dilemma. ${ }^{2}$ And thirdly, such negative criticism was actually in part responsible for booster propaganda, as it led to New Zealanders cultivating a positive image of their cities and towns in order to counteract any pessimistic impressions which might have proven detrimental to securing investment, settlement and tourism.

In this chapter, the profusion of motives for negative reactions to aspects of urban life on the part of colonials and overseas writers will be discussed first. It will be seen that the reasons for a writer's description of a locale varied accordingly. For many authors, an adverse depiction of a place was entirely due to artistic license, primarily conceived for its entertainment value. For others, particularly politicians or reformers, negative portraits could be used as effective evidence in convincing people of the need for change. For others still, their reactions to a town or city could depend upon the circumstances when they arrived, such as the weather and their own physical and mental well-being. The first section on the reasons why people criticised the country's urban locales will be followed by an actual description of some of the pessimistic portraits of the nation's cities and towns themselves. The majority of criticisms tended to rest on the fact that the colony's settlements were beginning to show signs of old world evils, such as the "description found in John Macmillan Brown's Riallaro which introduced this chapter. Yet the nation's cities and towns also received a great deal of censure on account of their lamentable state of civilisation and culture, and the belief that they were parasitic bodies draining the life blood of the country's economy and contributing to depression and recession.

$$
* * *
$$

${ }^{2}$ The urban/rural conflict will be examined in Chapter 9 and the utopian theme will be discussed in Chapter 10. 
For some, mention of the nefarious side of New Zealand urban life and of the fact that much of the country was uncivilised, was simply of good entertainment value in a story or description. Peter Gibbons reiterates just such a point during a discussion on local histories: "When the less savoury aspects of life are recounted, they are presented as colourful incidents." ${ }^{13}$ Nelson Wattie makes a similar comment on the reasons why authors included nefarious descriptions of the country in fiction. He concludes that unbelievable episodes about people committing suicide by jumping into geysers or tales of slum conditions in the colony's cities, were either "manufactured for foreign consumption" by New Zealand authors or related by visitors to the country deliberately to incite scandal. ${ }^{4}$

Graphic details about the seedy side of life in the big city (as well as terrible tales of savagery and cannibalism), were considered by many authors as an excellent device for increasing the popularity of a work, not to mention its sales potential. Consequently, Oscar Alpers (a lawyer and a supreme court judge), left room in his memoirs for the convicted murderer Thomas Hill, whom he described as one of "the very greatest criminals of the nineteenth century." ${ }^{5}$ Likewise, Jules Verne who had never even been near New Zealand, portrayed the North Island as an uncivilised and geologically unstable land peopled by cannibal natives who went to great lengths to make a meal of a ship-wrecked party of Europeans. ${ }^{6}$ Sensationalist public speakers such as Lottie Wilmot told their audiences horror stories about prostitutes and brothels throughout the country so as to provide material for controversial, and thus well-frequented, public lectures. ${ }^{7}$ Mark Kershaw, in a travel history about his visit to New Zealand, used his

${ }^{3}$ Gibbons, p.66.

${ }^{4}$ Nelson Wattie, "New Zealand Writers in Australia". Paper delivered to the Eighth Annual Stout Centre Conference, "Australia-New Zealand: Aspects of a Relationship"
(6-8 September, 1991). (6-8 September, 1991).
${ }^{5}$ Oscar Thorwald Johan Alpers, Cheerful Yesterdays...With a preface by the Earl of Birkenhead (London: John Murray, 1928), p.315. 1876?).

${ }^{6}$ Jules Verne, A voyage round the world (London: George Routledge \& Sons,

${ }^{7}$ Lottie Wilmot, New Zealand beds a sequel to Beds I have slept in...being the experience of a celebrated lecturess and advanced Progressionist while on a New Zealand tour. This history is truthful...and the various characters, although disguised by
a non de plume, are still...easily recognised... (Christchurch: 1882). 
adverse criticism of the rude state of civilisation in Invercargill, specifically the town's attempts at a museum, for comic effect:

...[a] skull... two frowsy deer... [and] a mangy marsupial... When I meet the gentleman who sent me through the rain to interview these treasures, it would be well if he had either a suit of armour, or else a bottle of arnica, or other preparation for the relief of bruises. ${ }^{8}$

Unlike the travel writers, public speakers and fiction authors who used pessimistic descriptions of towns and cities for their stylistic appeal or their comic effect, politicians and reformers were concerned with practical results. It was by way of presenting evidence to support an argument that many of the latter repeated tales of the horrors of urban life in the colony so as to win over popular agreement for a specific reform or proposal. According to Richard Hill, proponents of the temperance movement repeatedly drew attention to instances of drunkenness in cities and towns so as to provide adequate grounds for increasing numbers in the police force who could in turn enforce anti-liquor regulations. ${ }^{9}$ It was also usual for members of parliament to relate details about the horrendous conditions of some slum areas of Wellington so as to press for Town Planning initiatives: "There are portions of Wellington which compare as slum areas with the worst in Europe". ${ }^{10}$ There were political pamphlets issued by people campaigning for municipal office that condemned the high levels of unemployment to be found in the towns and cities and which were intended to convince people of the need to place a check on unrestricted immigration: "We owe much of our trouble to a policy that has wrought extravagantly on public works, and put no adequate check on immigration when bad times were threatening." ${ }^{11}$ Science fiction authors would relate horror stories about the deadly consequences of unchecked industrial expansion so as

${ }^{8}$ Mark Kershaw, Colonial Facts and fictions Humourous Sketches (London: Chatto and Windus, 1886), pp.203-204.

'Richard Hill, "Policing the Colonial Frontier". Paper presented to the Department of Sociology at Victoria University of Wellington. (Wednesday, August 14, 1991).

${ }^{10}$ Daniel G. Sullivan, NZPD(August 3 - August 28, 1926), p.716.

11 Rev. Joseph Upton Davis, Plain talks on "Being Out of Work","Business is Business", "Push","Gambling","Doing Well For Oneself." (Dunedin: James Horsburgh, 1880), p.5. 
to gain urban reform of some sort. ${ }^{12}$ Members of Parliament representing rural constituencies frequently complained about the economic drain cities and towns wielded on the country, arguing instead that money should go to their own locales:

I have previously stated, although the Government have no money available for roading or for loans to local bodies, we find they can provide money for almost every other purpose, for buildings in cities... The people in the cities are only, as it were, a parasite hanging on to those who are living in the country... it is the country that maintains the towns, and therefore the country people should be the first consideration of any Government... ${ }^{13}$

In addition to various people describing the more negative aspects of urban life solely as a successful narrative formula or for political expediency, there were also many visitors to the colony's towns and cities who were genuinely critical of the rude state of affairs which they had encountered upon their arrival. Such reactions in most cases were due to personal circumstances of the time. For instance, the Maori prophet Te Whiti and his companion Tohu, who had both encouraged passive resistance amongst the tribes in Taranaki against the Government's attempts to open up confiscated land to European settlement, had christened Dunedin the "Town in the Swamp."14 This antagonism to Dunedin on their behalf, as well as to certain other settlements in the South Island, should come as no surprise. The two prophets had been arrested by the Government on account of their actions and subsequently forced to spend a period of exile in the South, away from their homes and families, in a colder climate and under strict confinement.

Others too had adverse reactions to a locale because of bad experiences. James Coutts and his wife came to detest Invercargill because of the execrable state of the city's water which had adversely affected their health; according to Mr. Coutts, the drinking water was "saturated with organic matter, from which we suffered untold

${ }^{12}$ In William Delisle Hay's The Doom of the great city. being The Narrative of a Survivor, written A.D.1942 (London: Newman \& Co., 1880), the narrator recounts the story of his lucky escape from London in 1882 after a poisonous fog, the result of unchecked industrial pollution, decimates the city's population.

${ }^{13}$ Francis Mander, NZPD (June 28 - July 28, 1904), p.736.

${ }^{14}$ As quoted by John P. Ward in Wanderings With the Maori Prophets, Te Whiti \& Tohu: Being reminiscences of a twelve months' Companionship with them, from their arrival in Christchurch in April, 1882, until their return to Pari-haka in March, 1883 (Nelson: Bond, Finney \& Co., 1883), p.63. 
agonies..."15 James Anthony Froude lamented the fact that all the world appeared to abandon tradition and seemed to prefer modern urban and industrial living instead, where "obedience and truth and simplicity do not flourish..."16 Marianne North, a member of the English aristocracy spending a holiday in New Zealand, also responded harshly to the country. She had come to New Zealand to paint pictures of the flora, but during her visit condemned the whole colony for what she believed was its inability to adequately emulate the civilised amenities to be found in Great Britain:

I was quite glad when the Governor came, and I moved into his house and heard him abuse the island and all belonging to it with as much heartiness as I did. He said, justly, something must be wrong with a country which required so much laudation. Everyone was asserting its supreme beauty and superiority wherever I went. Every blade of grass was to be especially admired, and was different from anything anywhere else. ${ }^{17}$

Sometimes a person's reaction to a place could depend upon something as variable as the weather. In Chapter 1 we saw evidence that visitors arriving on a sunny day and after a long and difficult sea journey, tended to react favourably to a place. The reverse was true too, however, and tourists who had the bad luck to be repeatedly greeted by rain or wind on their visits were often vehement in their denunciations of a city or town. For instance, a German Count after experiencing Wellington's infamous winds, concluded that living there "would be... equal to criminal exile to the leadmines of Siberia." ${ }^{18}$ On a more humorous note, an English visitor's sarcastic comments on the type of business which he would open up should he live in Invercargill, aptly sum up his ill-feeling for the place after repeatedly experiencing bad weather there: "If ever I purchase a store at Invercargill I shall sell rubber boots, mackintoshes and umbrellas. ${ }^{19}$

. James Coutts, Vacation Tours in New Zealand \& Tasmania (Sydney: George Robertson, 1880), p.26.

${ }^{16}$ James Anthony Froude, Oceana or England and her colonies (London: Longmans, Green, and Co., 1886), p.246.

${ }^{17}$ Marianne North, Recollections of a happy life, II, (London: MacMillan and Co., 1893), pp.189-190.

${ }^{18}$ Fritz Hochberg, An eastern voyage. A journal of the travels of Count Fritz Hochberg through the British Empire, in the east and Japan (London: J.M. Dent \& Sons Ltd., 1910), p.91.

${ }^{19}$ Mark Kershaw, p.202. 
Having examined a few of the reasons for the negative reactions to the country's cities and towns, we can now turn to a study of the images themselves. The most severe charge levelled against the New Zealand city is that it was beginning to emulate many of the adverse conditions found in Old World centres. Stevan Eldred-Grigg argues that the contemporary Puritan image of colonial New Zealanders, "as dour folk who denied their bodies and crippled their souls", did not match the statistics for cases of prostitution, incest, rape, drugs, illegitimate births, infanticide, abortion and alcoholism. ${ }^{20}$ Instead, as one of the more down to earth and honest booster works was also careful to make note of, the country's image was being tarnished by a number of "conspicuous blemishes." 21 The most endemic of these blots on the country's record and those that appear most frequently in the literature of the period, appear to be: drunkenness, gambling, slums, sexual immorality and physical violence.

Jock Phillips in his work on the male image in New Zealand, stated that drunkenness was a grave problem in the nineteenth century, and that "convictions for drunkenness" were "considerably greater than in Britain". ${ }^{22}$ The English author Anthony Trollope made a similar comment about drinking and the colonial's ability to better others in this field, when he visited New Zealand in the early 1870s: "...one point as to which the New Zealand colonist imitates his brethren and ancestors at home, - and far surpasses his Australian rival. He is very fond of getting drunk." ${ }^{23}$ Trollope seemed to be using the penchant for drinking amongst New Zealanders as a vehicle to poke fun at Australians in a roguish manner, (similar to the fraternal comradeship of inter-city and inter-colonial rivalry which we have observed previously), while at the same time making his observation for a general comic effect. It is this propensity to chastise colonial drinking habits humourously, particularly amongst wealthy male tourists, that appears to dominate the motives for making remarks about drink in the literature.
${ }^{20}$ Eldred-Grigg, Pleasures of the Flesh, p.1.
${ }^{21}$ John Moore, p.215.
${ }^{22}$ Phillips, p.59.
23 Anthony Trollope, Australia and New Zealand (London: Chapman and Hall, 1873), p.458. 
Sir Charles Wentworth Dilke (1810-1869), for instance, an English baronet and politician who was touring in Hokitika in the late 1860s, commented ironically on the naming of saloons: "When I reached that particular gin palace which was known as a hotel..." ${ }^{124}$ Apparently the people of Hokitika were renowned for their zealous drinking as the town also received a critical and somewhat humourous jibe at the hands of William Towers Brown a few decades later: "Every other house seemed literally to be a public-house... The inspector of police told me in this one street there were over ninety!"25 A German Count's perplexed experiences upon visiting Queenstown during a tour of New Zealand and his encounter with a drunk who was also a fellow national, border on the slapstick: "The hotel proprietor, a German, was absolutely drunk (at first I thought he was dotty), and insisted upon addressing me as 'Doctor'..."26

Closely associated with the vice of excessive drinking in the cities and towns was that of gambling. According to David Grant, gambling was widespread throughout colonial New Zealand and to some, like the Women's Christian Temperance Movement, it was seen as even more degrading than prostitution. ${ }^{27}$ Gambling receives quite a bit of attention in the travel diaries of the time. For some, such as the Auckland lawyer in conversation with Beatrice Webb, gambling was a serious bone of contention in the

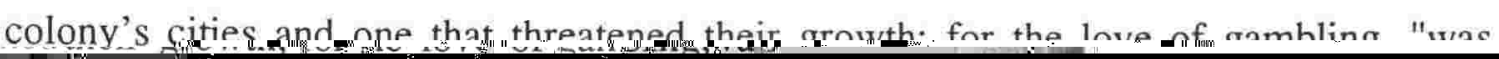

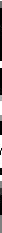


in port and its crew presented their own bird for a fight. According to Pallander, the Chilean bird resembled more a peculiar looking turkey than a rooster. Never-the-less, a fight ensued and after a few seconds Tewtox was ripped asunder by its Chilean contender. It was soon discovered, however, that the Chilean bird was a bald eagle in disguise and a terrible fight erupted between the two crews! ${ }^{29}$

One could be sure that reformers (particularly teetotalers), would use this very kind of disruptive behaviour for purposes of illustrating the need to introduce social legislation. They would argue that reform was needed to curb conduct such as drinking and gambling and the ensuing fights which usually resulted from indulging in such excesses. Many reformers believed that such performances interfered with the smooth running of the work routine and affected productivity. ${ }^{30}$ Congruent to this teetotaler logic about the need for reform were calls for the introduction of legislation to ameliorate living and working conditions, especially in the areas of town planning and factory reform. Such calls were not only based on a desire to increase manufacturing productivity, however. On the contrary, they were also based on a genuine fear about the appearance of old world evils in the colony, evils which many European and British migrants had hoped to avoid or escape from by settling in New Zealand. The 1889 Sweating scandal which illustrated the extent of the poor working conditions for women and children in factories and the 1918 influenza epidemic in which some six thousand seven hundred people died (primarily the result of unhealthy living conditions), ${ }^{31}$ were but two examples which revealed the extent of the nation's urban predicament and which showed that the colony was not immune to these old world perils. Such an awareness about old world hazards making their presence felt in the colony prompted reformers to give a series of warnings about the need for the nation's cities and towns

29 Edwin Pallander, The log notes of an island wanderer; notes of travel in the eastern Pacific (London: C. Arthur Pearson Ltd., 1901), pp.10-15.

${ }^{30}$ See Richard Hill's paper "Policing the Colonial Frontier". According to George Brown Tindall and David E. Shi, American drinking habits also raised the ire of reformers and leading industrialists, for drunkeness was seen to affect worker productivity: "The dynamic new economy, with factories and railroads moving on strict schedules, made tippling by the labor force a far greater problem that it had been in a simple agrarian economy." America: A Narrative History (New York: W.W. Norton \& Co., 1989), p.321.

${ }^{31}$ Laurie Barber, New Zealand. A Short History (Auckland: Century Hutchinson, 1989), p.116. 
to take preventative action before the situation grew out of hand: "the reproduction in New Zealand of the miseries of the old world must be prevented." ${ }^{32}$ Various publications echoed these feelings about the need for reforms. Consequently, the prevalence of diseases such as typhoid and diphtheria received much space in the literature of the period; their presence was explained by "the insanitary state of most of the New Zealand cities and towns." ${ }^{133}$ Likewise, there were also warnings about the rising dangers of pollution levels and the resulting ugliness that threatened the country's natural beauty: "By day... the city [Wellington] is too often wreathed in smoke to afford a coup d'oeil as attractive as might be desired. ${ }^{134}$

Immorality was another of the great evils to receive attention in the literature attacking New Zealand's cities and towns. Yet again, as in the criticism expressed by some over drunkenness, gambling and the need to introduce planning legislation, such condemnations also served a dual function. On the one hand these condemnations might have been sincere, yet on the other hand, they might have also served the interests of whatever parties were bringing them to the forum for public debate. Such questionable motivation can be evidenced in the example of the American spiritualist and public orator Lottie Wilmot, who had come to visit New Zealand for a year and a half in the 1880s. Certainly it appears as though Ms. Wilmot was legitimately concerned with the need to improve urban conditions for she cites numerous examples of the unsavoury and immoral cases which she uncovered during her travels round the colony. In Wellington, Wilmot related descriptions of "women... in men's clothes, the men vice versa..."; ${ }^{35}$ and in Christchurch she visited bordellos and was shocked at seeing prostitutes, "some mere children in years." ${ }^{136}$ But she saved her most vehement denunciation for Auckland:

The back of Queen Street is an abomination and a disgrace. In full sight of the Police Station there are women... living in cellars not fit for pigs... [In one particular pub] a Maori woman - was dancing on the counter for the edification of a crowd of

32 "Report of Public Meeting Re. Sweating" in the Otago Daily Times (June 8, 1889), p. 24.

\footnotetext{
${ }^{33}$ John Moore, p.206.

${ }^{34}$ Charles Wilson, p. 10.

${ }^{35}$ Lottie Wilmot, p.24.

${ }^{36}$ Ibid., p. 18.
} 
wretched men and women. She had scarcely any clothes on, a hat being the principle article of clothing, and that was just borrowed from a friend to collect money after the performance. $^{37}$

Yet Lottie Wilmot's accounts of trips into the shadowy realms of the city at night, accompanied by a private detective for her personal protection, also appear sensationalised. They reveal her going out of the way to gain sordid material for her public lectures so as to gain the largest potential audience. She was so successful at achieving publicity that not only were her lectures the subject of much debate in the press, but her life was also threatened and certain prominent figures in the Christchurch establishment (some of whom she had recognised as frequenters of bordellos), sought to have her expelled from the city and sought a ban on her speaking further! ${ }^{38}$

Lottie Wilmot was not the only person to question colonial morality. One anonymous individual whose first name we know was Maggie and who went by the pseudonym of 'Hopeful', was also very critical of life in New Zealand. She found the living conditions of the town in which she was staying primitive, and in writing to her brother in Canada, warned him never to come and settle in New Zealand. In a booklet entitled Taken In, Hopeful lamented the day she had ever come to the country and seemed to almost curse those who had duped her through false advertising into thinking that New Zealand was an Arcadia realized. Some of Hopeful's worst criticisms, however, were saved for groups like the Salvation Army whom she suspected of lax morality. She felt that behind their mantle of piety and religiosity, the Salvation Army were guilty of a great deal of improper and irreligious behaviour:

From all accounts the prayer meetings given in the dark... are not productive of noble results: sometimes some one not in the show manages to turn on the lights unexpectedly, and then there is found quite a transformation scene, all have changed places;

- the girls who were kneeling together devoutly are now quite scattered... smooth faces are kissing rough ones, and rough ones are kissing smooth ones... But putting joking aside, I hear from many quarters that the young girls are not in good hands... ${ }^{39}$

${ }^{37}$ Ibid., p.39.

${ }^{38}$ According to Wilmot, the ban on her speaking in Christchurch was the result of established religious opposition to spiritualism.

39 'Hopeful', p.139. 
The last of the old world vices to be addressed in this section on the perceived image of the city and town is the threat of physical violence and disorder. According to Jock Phillips, while cities in New Zealand "brought new expectations of order, routine and public decorum", they also bred fears about anarchy and disorder. ${ }^{40}$ Such worries were responsible for an assortment of comments on the part of politicians about the physical threat to persons residing in the major centres and the subsequent need for new laws against vagrancy and vandalism. George Waterhouse, for example, told members that "it was certainly dangerous for females to go along the streets at an advanced hour of the night." ${ }^{141}$ Colonel De Renzie, the member representing Canterbury, stated that "the residents of Christchurch were afraid to send their children out to take exercise in the beautiful gardens and parks..." ${ }^{142}$ Monetary awards were offered by local civic councils for information leading to the arrest of vandals. ${ }^{43}$ There were even fears expressed amongst members of Parliament regarding the trustworthiness of police officers, as two had been caught pilfering at the Christchurch Exhibition while on duty! ${ }^{44}$

Apart from reasons of political expediency, tales of violence, death and upheavals in the cities were surprisingly used also for comic effect. One Auckland circus owner in his memoirs loved to include stories of the highjinks caused by his employees, particularly rowdy Indians and drunk cowboys whom he had imported from America: "..the Indians drunk as well... a free fight occurred. Bowie knives and revolvers were freely used, and so we had to call in the police..." ${ }^{45}$ Another booster of New Zealand even dismissed the high suicide rate in the country in a humourous vein:

Strange, but the books show seventy-nine suicides to have been committed in one year in Zelandia, though it seems incredible that any person in Zelandia should voluntarily retire.

\footnotetext{
${ }^{40}$ Phillips, p.49.y

${ }^{41}$ George M. Waterhouse, NZPD (Volume 38: June 9 - July 21, 1881), p.309.

${ }^{42}$ J. Brett De Renzie, NZPD (June 9 - July 21, 1881), p.308.

${ }^{43}$ New Brighton Borough Council Records: 1/16 Works Committee Minutes, July, 1915, no page. (Canterbury Public Library).

${ }^{44}$ NZPD (July 31 - September 15, 1882), p.343.

${ }^{45}$ George Wirth, Round the world with a circus; memories of trials, triumphs and tribulations (Melbourne: 1925), p.50.
} 
Of course, they may have desired to get to heaven ahead of some of their neighbours, for in Zelandia they like to be considered a little advanced. ${ }^{46}$

So far we have examined how and why some people reacted negatively to New Zealand's cities and towns. For a few, especially the writers, a negative portayal was either a stylistic device used to provide an exciting setting or else it tended to be a humourous sketch of colonial living included for amusement's sake. For the reformers and the politicians, descriptions of urban blight were a popular vote-catcher and useful evidence to support their calls for reform. While for others, particularly travellers, adverse criticism seemed simply to reflect the moods of those visitors at that time. In all the examples mentioned it is important to note that the fears expressed about cities and towns in the colony were primarily those voiced about recreating old world evils, especially worries over drunkenness, gambling, disease, immorality and anarchy. Yet there existed a whole barrage of criticisms which took issue with New Zealand's urban centres for just the opposite reason; these other arguments stated that the country was in fact too little civilised. Criticisms of this sort abounded. The primary concern over the colony's cities and towns was that they had only reached a pioneer stage of development. There was, however, a number of comparable criticisms which reflected similar anxieties over the state of New Zealand's urban centres, namely: their ugliness, the presence of Maori inhabitants, larrikinism and a general lack of cultural or recreational pastimes.

Perhaps the most disparaging attacks regarding comments about the uncivilised state of the country were those that insinuated or actually stated that New Zealand's cities and towns were still in their infancy and could not in fact be called urban settlements at all. Instead, the nation's cities and towns were often portrayed as struggling between the pioneer stage and one of civilisation. Ethel Vincent declared that Hamilton, "By courtesy... is called a town, but it consists of one short street, with the hotel facing the bank, above which is the office of the local paper." ${ }^{147}$ Reverend James Couper, writing almost thirty years later, came to a similar conclusion: "A mile, or even

\footnotetext{
${ }^{46}$ George Bell, p.178.

${ }^{47}$ Ethel Vincent, p.161.
} 
less, is sometimes enough to change the centre of a town to the centre of the bush." ${ }^{148}$ Count Hochberg was even more vehement in his denunciation of the country's cities and towns along these lines than most other visitors; he was particularly critical of Wellington:

I do not mind camping out in the Arabian desert for weeks with Arabs, but this European, rough, rude, uncivilized, pretentious and uncomfortable sort of existence I could not like. Give me either civilisation and comfort, or nature and simplicity... but not an uncomfortable go-between, giving itself airs. ${ }^{49}$

Travellers found similar faults with many of the country's roads and railways. For example, Oscar Vojnich and his party when touring in Dunedin, were "obliged to wade up to their ankles in mud. ${ }^{150}$ Emily Bates, a wealthy tourist holidaying in the country, told a comical anecdote to illustrate her substantial frustration with the slow velocity of the colony's trains:

...the wearisome pace made one easily believe the story of the man only lately arrived in New Zealand who, being asked to take a train, declined with thanks on the plea that "he was in a hurry", and preferred walking. ${ }^{51}$

Often these reproaches, as mentioned above, were deliberately humorous. For instance, James Inglis poked fun at the colonial mentality of imitating out-dated European fashion while describing a violin performance in Auckland. According to Inglis, the ladies in the audience insisted on decorating their head dress with huge ostrich feathers "in the Queen Anne style". And when these ladies nodded their heads to the music, "the effect was really ludicrous in the extreme." 52 Inglis was writing an otherwise promotional work and his comments tended to be usually constructive. Such censures on New Zealand's pretentiousness were, however, more often than not outright hostile. For example, Emily Bates was highly critical of Dunedin's Grand Hotel for not living up to its namesake:

${ }^{48}$ Rev. William James Couper, A voyage to New Zealand (Edinburgh, 1911), p.38.

${ }^{49}$ Fritz Hochberg, pp.90-91.

${ }^{50}$ Oscar Vojnich, p.74.

${ }^{51}$ Emily Katherine Bates, Kaleidoscope: Shifting scenes from east to west (London: Ward and Downey, 1889), p.63.

${ }^{52}$ James Inglis, p.11. 
Every one had spoken to me of the "Grand Hotel" at Dunedin as the finest in the Colonies. That may be, but it leaves much to be desired. It is built on a very large scale, somewhat resembling a baby American hotel. The food is pretentious but not well served, and the service generally is deficient. ${ }^{53}$

These inimical reactions to New Zealand's cities and towns by foreign travellers and people come to settle, were primarily aimed at attacking the country's urban pretense. The gist of their arguments resided in the fact that many of the urban settlements and symbols of civilisation had been falsely described. Hopeful admits that such was the reason why she had chosen the title Taken In to describe what she encountered, "because there is a great deal of false information afloat respecting Colonial facts." ${ }^{54}$ For other tourists, however, their unfavorable comments were the result of personal experiences. Some may have simply been tired after a long journey where they may have encountered unforseen delays; others may have been upset at having lost their luggage, been swindled by what they believed were excessive prices, or been sold poor quality goods and inferior merchandise. ${ }^{55}$ While other visitors, after having arrived directly from America or Europe, in contrasting old world cities with their new world counterparts, may well have genuinely found New Zealand's settlements as sadly lacking in any comparison.

Travellers and migrants were not the only ones to deride the uncivilised state of affairs in New Zealand's cities and towns. Many of the colony's politicians frequently proffered similar critiques. Members of Parliament often complained about the poor conditions of a city's amenities, particularly sewage disposal, poor street lighting and inferior or slow road transport. J.C. Buckland, for instance, the member representing Waikouaiti, complained of "noisome odours" and "offensive matter" which exuded from one particular Wellington cemetery; he went on to state "that in wet weather parts of

\footnotetext{
${ }^{53}$ Emily Bates, p.71.

54 'Hopeful', p.xii.
}

${ }^{55}$ A common complaint of this nature was directed at oyster merchants at the Bluff; as people were embarking for a voyage to Australia or America, they were usually offered free samples of shellfish by cunning salespeople. Unweary tourists were then convinced to buy sacs full of these oysters, believing them all to be of the same superior quality as those already tasted by the dock. It was only at sea, too late to do anything about it, that the passengers discovered to their shock that the sacs were filled with inferior produce. 
coffins and even skeletons were exposed to public view." ${ }^{156}$ Local politicians, citizen complaints and newspaper editorials and cartoons, also frequently condemned the paucity of civilised amenities in the nation's urban centres. Not surprisingly though, political expediency was the motive behind many of these complaints for most of these criticisms were aimed at obtaining some kind of political reform or municipal by-law while others were intended for denouncing either a political opponent or a rival city or town.

There were, however, many other images which were used to show the apparently uncivilised nature of the country's cities and towns. Perhaps the supreme symbol of this state of affairs, for some critics at least, was the presence of Maori in the colony's urban centres. The Maori came to represent an all too recent reminder of the colony's stained history and a rude intrusion on an otherwise European-dominated landscape. David Hamer suggests that in New World towns such criticisms about natives were common, and subsequently many natives "came to feel that they did not 'belong'...[and] were treated as oddities, essentially as 'foreigners'." ${ }^{57}$ Hamer goes on to argue that aboriginal peoples "were expected to don disguise, in effect to look like Europeans. ${ }^{\text {"58 }}$ Sherman Denton, an American visiting Auckland in 1889, comments humourously (and also warily), on the presence of a group of Maori in Auckland and this propensity on their behalf to try to imitate European customs:

The Maori King and his tattooed retinue were boarding next door, and 'doing' the city. They were a terrible-looking lot of men... The day being warm they did not trouble to dress themselves, but, robed only in the sheets of their beds, strutted about the streets, reminding one of Second Adventists in their white robes, prepared for ascension to the New Jerusalem... ${ }^{59}$

A larrikin, according to A Dictionary of Kiwi Slang, is a "rowdy [or] mischievous youth. ${ }^{160}$ The presence of larrikins was another often cited criticism used as proof

\footnotetext{
${ }^{56}$ J.C. Buckland, NZPD (August 12 - September 22, 1885), p.213.

${ }^{57}$ Hamer, New Towns in the New World, pp.217-222.

${ }^{58}$ Ibid., p.222.
}

59 Sherman Foote Denton, Incidents of a collector's rambles in Australia, New Zealand and New Guinea (Boston: Lee and Shepard, 1889), p.61.

${ }^{60}$ David McGill, A Dictionary of Kiwi Slang (Lower Hutt: Mills, 1988), p.68. 
regarding the unruly state of New Zealand's cities and towns. According to some reports, larrikins in the street could make more noise and incite greater fear and disruption in many a New Zealander's life than a group of North American Indians could with "their blood-curdling yells." ${ }^{161}$ James A. Froude commented negatively on the presence of this disruptive group in New Zealand society: "an idle set at the lower end of the scale: noisy, riotous scamps..." ${ }^{12}$ Yet the majority of talk about such disorderly behaviour seemed to be used mainly for comic effect in travel journals and works of non-fiction. Edward Payton, who spent four years touring around New Zealand, wrote about larrikin activities in the crater of Mount Eden, Auckland: "In the deep crater the juveniles are fond of lighting fires, possibly with the idea of frightening timid people by giving them the impression that the volcano is going to 'erupt' once more."63 Likewise, George Wirth the circus owner, related tales intended for amusement's sake about the depravity of Palmerston North's youth:

Lassoing became the craze after seeing our cowboys at work. Every boy and 50 per cent of the young men could be seen with a rope, practising the art. The boys were the worst danger, for they soon learnt, and would lasso anything and anybody. I've seen Chinamen lassoed and hauled head first from their carts, one being seriously hurt... ${ }^{64}$

When an incident of larrikinism was debated in Parliament, that surrounding the snowballing "of the respectable class" coming out of the Opera House, that also was seen in a "humorous" light and quickly dismissed. ${ }^{65}$

One of the most common criticisms of towns and cities in the colony was their ugliness. The Reverend James Couper, for instance, drew a not so favourable Old World comparison: "Like Naples, Auckland looks best from a distance." ${ }^{166}$ Similarly, Robert Irvine called the city of Wellington "the ugliest in the world", and said that it resembled

\footnotetext{
${ }^{61}$ George Wirth, p.52.

${ }^{62}$ James Froude, p.138.

${ }^{63}$ Edward Payton, p.65.

${ }^{64}$ George Wirth, p.53.

${ }^{65}$ James McGowan, NZPD (July 30 - September 9, 1908), p.112.

${ }^{66}$ William Couper, p.44.
} 
"nothing so much as a collection of derelict kerosine tins. ${ }^{167}$ Robert Loughnan in a more honest booster handbook, stated that after the well-planned and well-designed central business districts of many a New Zealand town, "Gradually everything degenerates into the style known as 'Carpenter's Gothic'."68

Foreign visitors trotted out similar critiques regarding the poor aesthetic appeal of many of the colony's cityscapes and much of its urban architecture. The Frenchwoman Anna Vickers believed that New Zealand houses were sadly wanting when compared to their Australian counterparts which had verandas and balconies; she stated that the houses in Dunedin, "sont roides, sévères, comme celle d'une ville manufacturière anglaise." ${ }^{169}$ Likewise, the Italian travel writer Arnoldo Cipolla commented: "Ma qui bisogna accontentarsi di ammirare le bellezze della natura, perchè quelle erette dagli uomini sono ancora troppo modeste. ${ }^{170}$ And Cassell's Picturesque Australasia commented sarcastically on the state of New Zealand's buildings when discussing the architectural magnificence of Dunedin's lunatic asylum: "In the old world palaces are built for kings: in the new, for idiots." ${ }^{11}$

Another frequent criticism of New Zealand's cities and towns was that they were boring and that there was absolutely nothing to do or to see in one's spare time. Each of the colony's four largest cities were subjected to such complaints, and by both overseas visitors and migrants alike. William Strange-Muir in an 1884 letter described Wellington as "a small place and terribly slow [sic] no excitement of any sort." ${ }^{172} \mathrm{~A}$ Roman Catholic priest living in India and visiting New Zealand on a holiday for the

\footnotetext{
${ }^{67}$ Irvine and Alpers, p.383.

${ }^{68}$ Robert Andrew Loughnan, New Zealand at Home (London: George Newnes, Limited, 1908), p.40.

- 69 "... they are stiff, severe, like those found in an English industrial centre." Anna Vickers, Voyage en Australie et en Nouvelle-Zélande (Paris: Librarie Ch. Delagrave, 1883), pp.309-310.

70 "But here you have to be content to admire the beauties of nature, for those created by the hand of man are still too modest". Arnoldo Cipolla, p.51.

${ }^{71}$ Edward Morris, ed., Cassell's Picturesque Australasia, p.290.

${ }^{72}$ William T.H. Strange-Muir: 1884 letter in "Letterbooks 1874-1897". (Volume 4, M.S. Sequence, Alexander Turnbull Library).
} 
purposes of improving his health, ascribed the want of entertainment in Dunedin to that city's predominantly Scottish population: "they are not given to much amusements, all their attention being occupied how to make money. ${ }^{173}$ Hopeful found fault with Christchurch's flat topography and the resulting monotony of its streetscape; she described the effect as being "dismal in the extreme." ${ }^{174}$ Arnoldo Cipolla concluded that Auckland was a very restful place, "perchè alle sette di sera non c'e anima viva per la strada." 75

Such critical judgments regarding the tediousness of the colony's towns and cities were made for a wide assortment of reasons. Some, like the French Viscount Gaston Ségur, reacted adversely to a particular city because he found the place simply boring. ${ }^{76}$ Others, like C.F.R. Schwartze, could dismiss a city like Christchurch for personal reasons, such as the unattractiveness of its women: "the young ladies of Christchurch are spoken of with scant courtesy as the 'Canterbury Plains'."77 Others still, like the mariner and globe trotter Edwin Pallander, castigated Auckland for what he believed was that city's ultra-conservative nature and puritanical Victorianism:

Auckland is the most respectable city in the world... The long, prim, soberly ugly streets scarifying the pale heavens with their network of telephone wire... the innocently temperate suggestions of those ever-recurring "Coffee" Palaces; the rows of painted villas moulding themselves so persuasively to the curve of the hills - as beautifully uniform in style and feeling as no doubt are the souls and political convictions of the occupants... the sombre copses of pine and cypress, and the endless frivolity-rebuking cemetery. $^{78}$

Such complaints sometimes served a political function; they expressed the need for the government to provide alternative amusements to the pub. For it was believed that many

\footnotetext{
${ }^{73}$ C. Cesary, p. 235 .

- 74 'Hopeful', p.75.

75 "because at seven in the evening there is not a living soul to be seen in the street". Arnoldo Cipolla, p.51.
}

${ }^{76}$ Vicot de Ségur, pp.26-27.

${ }^{77}$ C.E.R. Schwartze, Travels in Greater Britain (Melbourne: Cassell \& Co. Limited, 1885), p.136.

${ }^{78}$ Edwin Pallander, pp.7-8. 
a frustrated or bored young man would resort to drink in lieu of an acceptable alternative. One member of Parliament, therefore, called for the building of public libraries: "if the people had not the library to go to there was only the hotel..."

$$
* * *
$$

Thus far we have witnessed the country's cities and towns as having been criticised on two levels: firstly, for reproducing in New Zealand many of the problems and terrible conditions of old world cities; and secondly, at the other end of the scale, for being undercivilised and showing signs of backwardness and coarseness. There was, however, another criticism laid at the feet of New Zealand's urban image - that of an economically backward and depressed place where unemployment was rife and investment negligible. Such criticisms flourished particularly during the Long Depression years of the 1880 s and early 1890s, and also somewhat during a period of sharp economic recession in the 1920 s.

The greater part of such pessimistic description came from Members of Parliament who were defending their urban constituencies and protecting their political records; these members countered attacks on their person or policies by arguing that the depressed economic scene was not the fault of their particular city or town, but rather was the result of factors beyond their control. For example, George Smith the member representing Christchurch pointed out, it was "the unemployed... coming in from the country districts" and in turn flooding the urban labour market who were responsible for his constituency's predicament. ${ }^{80}$ F.J. Moss representing Parnell echoed such sentiments while defending Auckland:

... for a long time it has been receiving large additions to the population from the southern parts of the colony. There have been prosperous times there, and large numbers of people have been attracted to the place. They are now without the means of obtaining employment, and therefore the suffering must be greater than in any other town in New Zealand. ${ }^{81}$

National politicians were not the only ones aware of the acute economic state of the country. In 1927 The Auckland Sun was circulating stories about emaciated vagrants

\footnotetext{
${ }^{79}$ William Cowper Smith, NZPD (August 15 - September 8, 1883), p.6.

${ }^{80}$ George J. Smith, NZPD (August 13 - September 3, 1895), p.287.

${ }^{81}$ F.J. Moss, NZPD (July 20 - August 18, 1886), p.229.
} 
having to remain in prison in order to remain fed and clothed. ${ }^{82}$ Likewise, many overseas visitors were commenting on the poor state of affairs which they envisioned some areas of the colony to be suffering from. Emily Bates believed that Invercargill's large stone buildings, "suggesting unlimited financial possibilities [were]... scarcely justified by the present condition of affairs in New Zealand." ${ }^{83}$ Samuel Pipkin visiting from England saw evidence of poor economic performance in Auckland city's quiet and neglected appearance:

The bitterness of their trouble is evidenced by empty docks, empty shops, empty houses, empty factories, and empty pockets. Faces are long, and speech is mournful, whichever way one turns... The streets, however, are very busy with idling loafers, and quays are alive with men but little life of hope within them. ${ }^{84}$

New Zealand artists in the late 1920s also appear somewhat influenced by the economic downturn which was affecting the country. Sydney Hamlet Higgs (1884-1978), for example, in his watercolour paintings of "Old Custom House St., Wellington" (ca.1930) and "Farish St., Wellington" (192-), reveals a landscape which is sinister and depressed [ILLUSTRATIONS 65 AND 66]. In both works the streets are almost deserted, peopled by one or two figures which cling to the shadows and call to mind the eerie and ominous subjects of a De Chirico painting. The walls of tall and sinister buildings, apparently abandoned and dilapadated, also conjure up these comparisons to the early works of the Italian painter. Whether or not Higgs was drawing on the precedent of De Chirico might be hard to prove; but certainly the haunting quality of the work and the time when they were produced, suggests that the troubling effects of the recession bore some impact on perceptions of the cityscape in art.

${ }^{82}$ Auckland Sun of July 26, 1927. Quoted by William Edward Parry in NZPD (June 23 - July 27, 1927), p.933.

${ }^{83}$ Emily Bates, pp.62-63.

${ }^{84}$ Samuel J. Pipkin, A run round the world. Through Canada, New Zealand, Australia, and India (London: King, Sell \& Railton Ltd., 1890), p.92. 


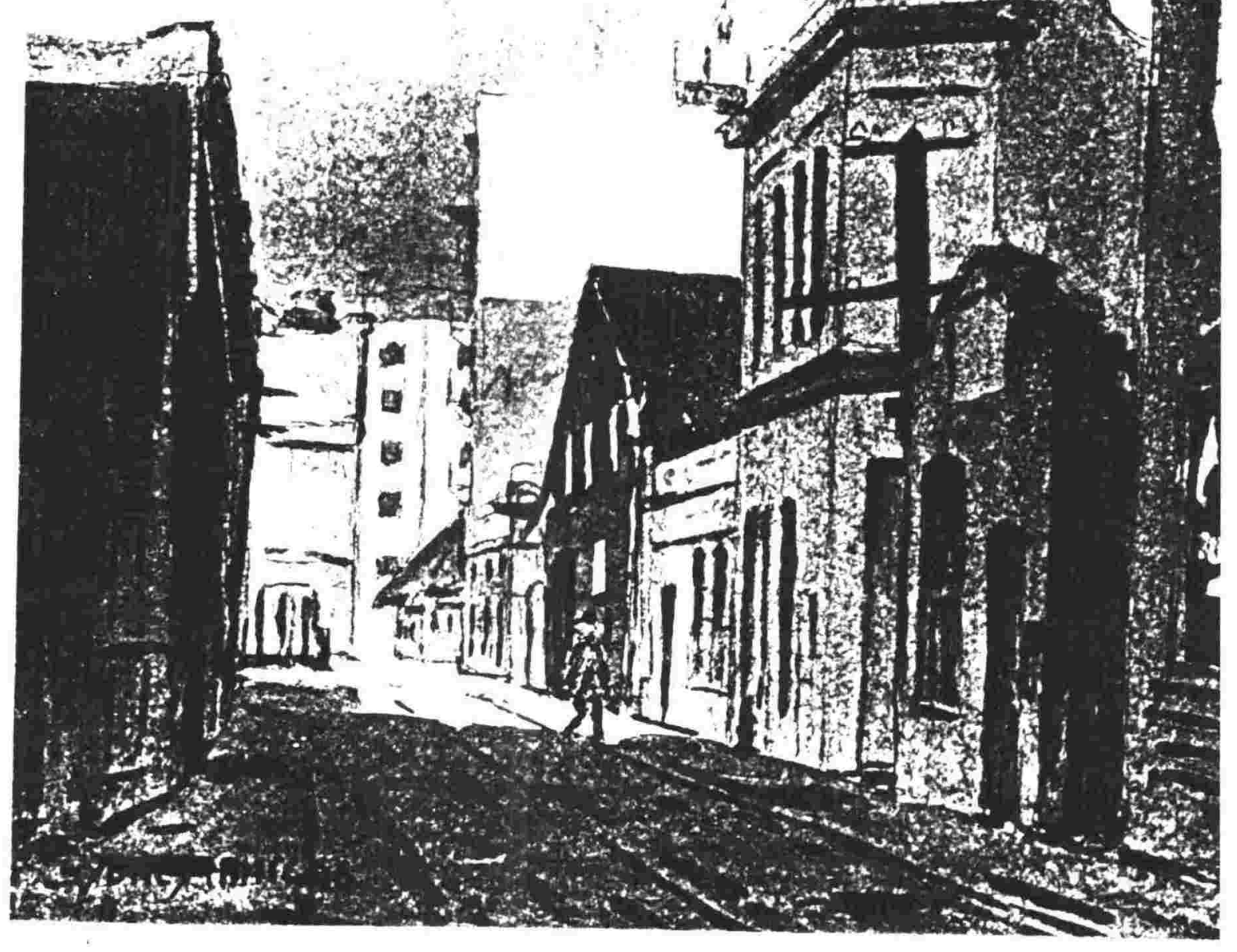

illustration 65 


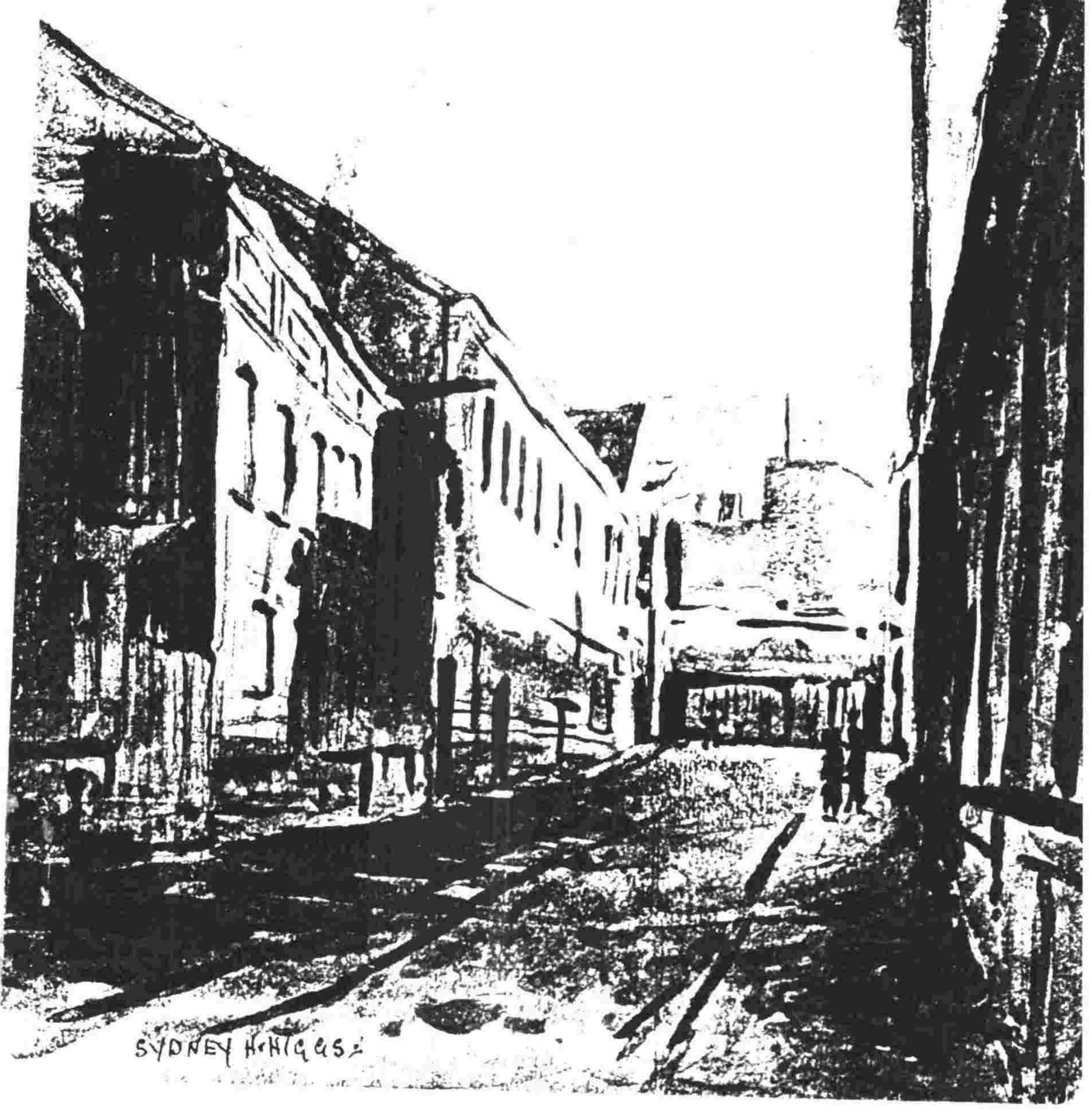




\section{CHAPTER 9: BACK TO THE LAND}

Chapter 8 revealed that there existed a great deal of dissatisfaction with the state of New Zealand's cities and towns. ${ }^{1}$ This in turn led to much discussion on the nature of future settlement patterns in the country, with many individuals and groups advocating a return to the land. This subsequent debate on the 'Back to the Land' movement and the urban/rural conflict which precipitated it, is the subject of Chapter 9. Emphasis is placed upon attempts to restrict urban growth and on the significant number of people in favour of a predominantly rural way of life. Such an examination is vital if one is to comprehend fully the motivation of boosters trying to foster an optimistic urban image for purposes of attracting settlement, tourism and capital, as well as for ensuring that people already settled in New Zealand's towns and cities did not leave; for in the eyes of the promoters, a prevalent anti-urban bias may very well have jeapordised further city and town development. The first part of Chapter 9 will discuss the reasons why some New Zealanders spurned the urban lifestyle (particularly the negative connotations associated with city life), while the second part will deal with the methods by which certain individuals and groups in New Zealand sought to induce people onto the land and away from towns or cities. These same persons who so vehemently denounced urbanism believed that cities were the cause of the colony's economic and social dilemmas while simultaneously assuming that a return to the land would offer New Zealanders a panacea to all of their problems, especially unemployment.

The reasons why people turned to the country as a solution to economic and social ills are many and varied. Primarily, the greatest cause of concern in New Zealand was the appearance of old world evils such as crime, slums, disease, overcrowding, pollution, etc... Yet there was a number of other contributing factors, all varying in their impact and significance, which also played a role in this Back to the Land movement. Listed in ascending order of importance, they are: the perceived threat of urban inhabitants to the social order; urban life becoming envisioned as weak and effeminate; the impact of an historical diet of anti-urban literature and art which contributed to moulding such prorural attitudes; the viewpoint that towns and cities were parasitic and speculative; the

\footnotetext{
'Many of these negative images are also discussed in R.B. Lyon's chapter on cities in "The Principles of New Zealand Liberal Political Thinking in the late Nineteenth Century", Ph.D. thesis (University of Auckland, 1982). pp.275-308.
} 
fact that land in general was seen as an indicator of status and wealth which many sought to emulate; a fear of technology and industrialization (epitomized by the city) and a resulting desire to seek reassurance in a traditional way of life; and ultimately, the influence of notions of arcadia on immigrants to the colony.

W.H. Oliver asserts that many leading figures in New Zealand politics in the 1880 s, such as Stout, Atkinson and Reeves, believed that the country "was endangered by the possible growth... of the social tensions of the old world... that the new start would prove to be a false start." ${ }^{12}$ Such fears about the emergence of old world evils in the country would also appear after the 1880 s and well into the 1920s. Charles Reade in 1901 published a booklet entitled The Revelation of Britain, in which he showed a photograph of poisonous black smoke billowing out of a factory in England and warned that if town planning legislation was not introduced in New Zealand, the country would face similar problems [ILLUSTRATION 67]. Likewise, Willis Airey in 1925 warned his fellow countrymen and women that they were, "in danger of repeating the mistakes of the Old World... [and] of developing cities like those of the Old World with their slums and smoke." ${ }^{13}$ Airey concluded his gloomy prophecies by stating that New Zealand and the other British Dominions, unlike America which had lost its chance, still had an opportunity to ameliorate the situation before it got out of hand. ${ }^{4}$

According to Graeme Davison, such anxieties about old world evils appearing in Australia (particularly "a revulsion from the enforced communalism of the industrial wens"), contributed to the development of suburbs in that country and to a move away from industrial tenements and row housing. ${ }^{5}$ In Canada, Canadian historians are also aware of the influence of a similar Back to the Land movement. Paul Rutherford states that the increase of the urban population in Canada between 1881 and 1921 accounted

${ }^{2}$ W.H. Oliver, "Reeves, Sinclair and the Social Pattern," in Peter Munz, ed., The Feel of Truth (Wellington: A.H. \& A.W. Reed, 1969), p.165.

${ }^{3}$ Willis Thomas Goodwin Airey, New Zealand a nation (Christchurch: The New Zealand Student Christian Movement, ca.1925), pp.6-7.

${ }^{4}$ Ibid., p. 10.

${ }^{5}$ Davison, The Rise and Fall of Marvelous Melbourne, p.141. 


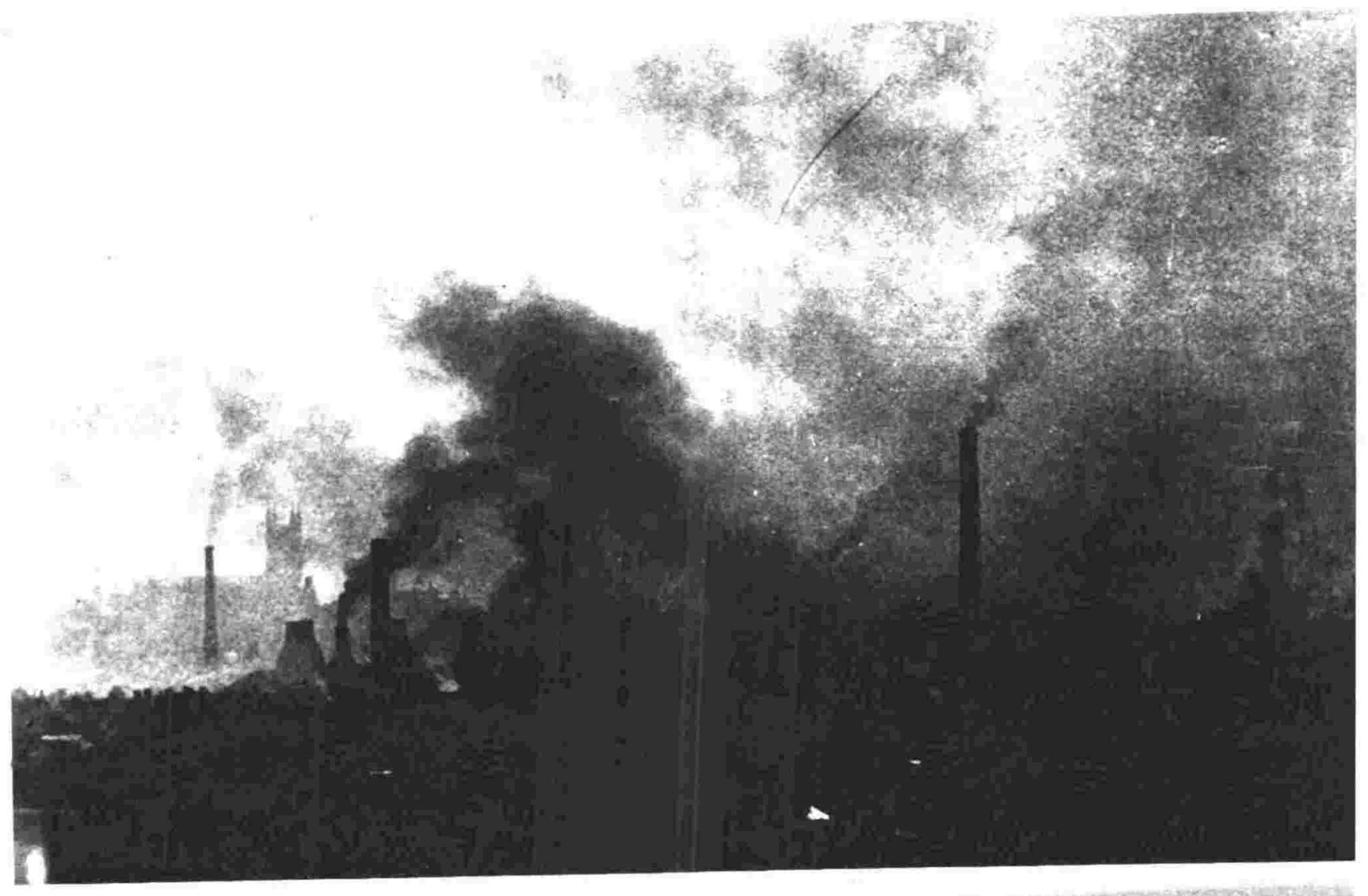

A TYPICAL DAY IN A BRITISH MANUFACTURING TOWN. STOKE-ON-TRENT, STAFFORDSHIR

illustration 67 
for many public leaders advocating "a new wave of agricultural development [that] would direct the city dweller back to the farm."

Correspondingly, expressions of dissatisfaction to living in industrial towns and cities on the part of a few settlers are evident in the New Zealand material as well, especially in the plans for garden cities and the designs for detached homes. ${ }^{7}$ This antipathy towards the urban and industrial lifestyle in the colony led some to seek a solution by also escaping into the country. Frederick Morgan, for instance, expressed his views on the subject in an 1884 lecture. Morgan believed that the over-population of the towns and cities in the colony had caused unemployment and untold agonies upon the settlers in New Zealand. He argued, instead, that people should become farmers:

The colonists have been diverted from the purpose for which they left the old country: instead of being distributed equably throughout the country, and being producers, they have been driven into towns, where they lead a life which is a servile imitation of life in an old country. ${ }^{8}$

Another motive for getting settlers onto the land and owning tracts of property was to reduce the threat of social disorder and revolution, for towns were seen as "peculiarly exposed to adverse foreign influences." ${ }^{\text {9 }}$ Miles Fairburn places great emphasis on this point in relation to owning land in The Ideal Society and its Enemies. He claims that William Rolleston in 1879 was advocating greater property ownership to the House of Representatives as an inducement for immigrants, "to act in ways which did not upset the tranquility of society and so imperil their investments. ${ }^{10} \mathrm{He}$ also quotes the Prime Minister William Massey who was speaking in 1924 and wanted every person to own the house they occupied so that they would have "VERY MUCH LESS OF THIS

${ }^{6}$ Paul Rutherford, "Tomorrow's Metropolis: The Urban Reform Movement in Canada, 1880-1920," in Gilbert A. Stelter and Alan F.J. Artibise, eds., The Canadian City: Essays in Urban History (Toronto: Macmillan, 1979), p.369.

${ }^{7}$ George William Phillips, Designs for New Zealand homes and residences comprising over 100 plans, elevations of from 4 to 20 roomed residences (Christchurch:

\footnotetext{
${ }^{8}$ Frederick George Morgan, An Enquiry into the Causes preventing the settlement of the youth of New Zealand upon the country lands, with Suggestions for their removal (Invercargill: 1884), p.2.

${ }^{9}$ Frederick George Morgan, Agricola \& Mercator (Invercargill: 1887), p.10.

${ }^{10}$ Fairburn, The Ideal Society and its Enemies, p.65.
} 
BOLSHEVISTIC NONSENSE."11 New Zealand's politicians and landowners were not the only ones to advocate home ownership so as to reduce the threat of social unrest; in Vancouver, Canada, the Real Estate Exchange ran a home-ownership campaign to exterminate "that prey of unrest and radicalism - discontented rent-payers." ${ }^{2}$

A further reason proffered for emigration to New Zealand, and taken up by advocates of the Back to the Land movement, was that of providing people with an antidote to what perceived as the feebleness and effeminacy of urban living. For people living in towns and cities were visualised as "parasites hanging on to those who are living in the country." ${ }^{13}$ Further proof of the supposed weakness of city dwellers was evidenced in England by the large number deemed unfit for active service during the Boer War. Congruently, a sort of cult of rural virility developed amongst New Zealand's writers and politicians in which the farming life of a New Zealander was portrayed as "healthy labour", in stark contrast to "those ailments... [secured by living] in the great metropolis...", namely London. ${ }^{14}$ According to Jock Phillips, such anti-urban sentiment was especially suited to emigration literature which enticed at least a few lower middleclass men by thoughts of abandoning their sterile urban lifestyles in Britain and replacing them in the colonies with a new and richer life: "In the colonies a man could feel a man once more." 15

Apart from threatening to undermine the social fabric as well as the vigour and virility of the English man, another reason for many in New Zealand standing opposed to further urban settlement and seeking instead a return to the land, was "the rejection

${ }^{11}$ Ibid, p.260. Schrader also states that fear of worker militancy was a contributing factor to attempts at introducing town planning in New Zealand; he paraphrases the Minister of Internal Affairs - G.W. Russell, who in 1919 implied that "revolution and anarchy were not a product of people who had 'happy homes and delightful gardens', but were bred in the 'crowded tenement, the squalid environment and the slum'." (p.33)

12 Quoted in the British Columbia Record (April 16, 1920) in Deryck W. Holdsworth, "House and Home in Vancouver: Images of West Coast Urbanism, 18861929," in Gilbert A. Stelter and Alan F.J. Artibise, eds., The Canadian City: Essays in Urban History (Toronto: Macmillan, 1979), p.193.

${ }^{13}$ Francis Mander, NZPD (June 28 - July 28, 1904), p.736.

${ }^{14}$ William Ashby, p.99.

${ }^{15}$ Phillips, p.5. 
of the industrial metropolis" in English literature and art of the period. ${ }^{16}$ A number of historians have commented on this factor as contributing to the evolution of a country or rural myth. The celebrated English urban historian H.J. Dyos stated this fact in his essay "Urbanity and Suburbanity":

If, once upon a time, you brought him up on a diet of the Bible, Pilgrim's Progress, Shakespeare, and the pastoral poets, what (as David Eversley once asked) do you expect? Such habits of mind die hard." 17

Coral Lansbury answers the Dyos question in reference to the growth of the Australian bush legend; she states that it is very unlikely that the country myth would have taken such a hold on Australians had not rural themes so dominated English culture: "Australians of the nineties [the 1890s] unconsciously lived in the imagined Arcadia past of England furnished for them in books." ${ }^{18}$ Leigh Astbury, in an examination of the Heidelberg artists in late nineteenth century Australia, also argues that their conservative pastoral subject matter developed as a result of the popularity of rural imagery, particularly that found "in black-and-white illustration and photography." ${ }^{19}$ Tony Bellette says that prophetic Old Testament Biblical passages bore considerable influence on Australian artists such as Sydney Nolan, who concentrated on the wilderness in their work rather than on urban themes. ${ }^{20}$

Urban critics in New Zealand were often fervent in accusing towns and cities of being over-speculative and parasitic. This was particularly the case during the depression years of the 1880s. Frederick Morgan perceived the colony as "an invertebrate land", in

${ }^{16}$ Seddon and Ravine, p.23.

${ }^{17}$ H.J. Dyos, "Urbanity and Suburbanity," in David Cannadine and David Reeder, eds., Exploring the Urban Past: Essays in Urban History (Sydney: Cambridge University Press, 1982), p.28.

${ }^{18}$ Coral Lansbury, Arcady in Australia (Melbourne: Melbourne University Press, 1970), p.163.

${ }^{19}$ Astbury, p.2.

${ }^{20}$ Tony Bellette, "The Voice From the Wilderness: Strains of Prophecy in Australian and New Zealand Art". Paper presented to the Stout Centre's Eighth Annual Conference, "Australia - New Zealand: Aspects of a Relationship" (6-8 September, 1991). 
which there were too many towns but too few farmers to support them. ${ }^{21}$ Morgan was calling for the large tracts of land occupied by runholders or absentee landowners living overseas to be broken up and distributed amongst the newly arrived settlers so as to provide homes and employment. Similarly, James Froude was highly critical of the New Zealand Government's borrowing schemes and "the high wages" offered in the towns and the overseas loans raised to maintain this way of life. ${ }^{22}$ Froude denounced living beyond one's means as extravagant and accused the government of being naive in thinking that it would be able to repay the loans. Instead, he urged the English settlers to move to the country and to produce their own crops without having to borrow from anyone. William Ashby was also critical of town life and for the same reasons as Morgan and Froude. Ashby believed that there were too many "allurements" in towns that threatened to separate the immigrant from his or her money. Ashby argued alternatively that settlers should go immediately to the country where they could save their hard earned cash and enjoy a healthy and prosperous way of life. ${ }^{23}$

The Back to the Land movement, seen in the break up of the larger estates or in migration into the suburbs, also exhibits a desire to emulate the landed gentry as much as it reveals a sense of antipathy for the city. The Reverend Joseph Upton Davis, a candidate for parliament from Dunedin, was very aware of this fact while speaking about one of the reasons for people wanting to own their own land in the country: "Land gives social position... we are children of feudalism."24 Numerous New Zealand historians are also aware of this factor when debating colonial motives regarding the desire for land. Miles Fairburn states that the attraction of suburban living rested primarily on the fact, "that it created the possibility of imitating... the exclusive older country house culture of the landed aristocracy..."25 R.C.J. Stone believes that one of

\footnotetext{
${ }^{21}$ Frederick George Morgan, "Land Settlement." Speech delivered to the Southland Institute (August 12, 1884) (Invercargill: 1887), p.3.

${ }^{22}$ James Froude, p.245.

${ }^{23}$ William Ashby, p.10.

${ }^{24}$ Rev. Joseph Upton Davis, Dunedin City East. An address to the Electors (Dunedin: November, 1881), p.4.

${ }^{25}$ Miles Fairburn, "The Rural Myth and the New Urban Frontier: An Approach to New Zealand Social History, 1870-1940", New Zealand Journal of History, 9, No.1 (1975), 6.
} 
the arguments proffered for escape into the country, was "the social prestige attached to suburban life." ${ }^{126}$ Stevan Eldred-Grigg declares that the desire for land in Canterbury, "was reinforced by the overpowering example of the runholders. So long as the province regarded wool kings as the ne plus ultra, land would remain the most potent symbol of status and power." 27 Likewise, Roberta Nicholls concludes that "the purchase of country lands" by successful businessmen, "was also a means of elevating one's status in New Zealand." 28 This tendency amongst certain groups to model themselves on patrician archetypes was not unique to New Zealand; on the contrary, as Robert Fishman points out, it also existed markedly in the United States and was evidenced with the move to the suburbs by "the industrial bourgeoisie." 29

... as urban society became more industrialised, sophisticated and complex it was perhaps inevitable that artists and writers should turn with nostalgia towards the 'simpler' life of the bush. When the economic depression of the 1890 s brought widespread poverty and serious social dislocation to the cities, this imaginative identification with rural life and its vicissitudes became even more pronounced in art and literature. ${ }^{30}$

One of the more profound reasons for some in New Zealand rejecting the city and turning instead to the country, as Leigh Astbury pointed out above regarding late nineteenth century Australia, was a distinct distrust and fear of technology. By the 1880s the city for many had come to epitomize a mechanical and modern existence. The country, on the other hand, remained in stark contrast by representing an alternative and reassuring way of life rooted in tradition and familiar values. ${ }^{31}$ The anxiety felt by a

${ }^{26}$ Stone, p. 120 .

${ }^{27}$ Stevan Eldred-Grigg, A New History of Canterbury (Dunedin: John McIndoe, 1982), p.39.

${ }^{28}$ Roberta Nicholls, "Elite Society in Victorian and Edwardian Wellington," in David Hamer and Roberta Nicholls, eds., The Making of Wellington, (18001914)(Wellington: Victoria University Press, 1990), p.199.

${ }^{29}$ Robert Fishman, Bourgeois Utopias (New York: Basic Books, 1987), p.95.

${ }^{30}$ Astbury, p.3.

${ }^{31}$ Escape into the country as a solution to the urban dilemma has been a constant theme of the British Victorian novel and modern American literature, especially science fiction. See: Dominic T. Alessio, "A Tale of Twenty Cities: The Urban Environment in American Science Fiction of the 1950s and 1960s", Journal of Unconventional History, 
few over the unprecedented growth of the city and the fast pace of technological change can be evidenced in architectural design, particularly with the return to traditional classic and Gothic forms. ${ }^{32}$ This uncertainty and uneasiness over technology can also be seen with the dramatic rise of the science fiction genre in literature. The fact that science fiction works like Bulwer Lytton's The Coming Race, Karel Capek's R.U.R.(1923), Thea von Harbore's Metropolis (1927) and H.G. Wells Time Machine (1895) were read by at least a few New Zealanders, ${ }^{33}$ indicates that themes about a wariness of the machine and of the unchecked growth of the city did exist in the society of the time. There were even a significant number of science fiction and utopian works which were written by New Zealanders during this time period and which also reflected similar themes regarding the threatening nature of technology and accelerated urban growth. William Hay's The Doom of the Great City (A.D.1942) reflects just such a fear. The novella was written in 1880 but was set two years in the future in the London of 1882 . It told the story of a deadly fog which proved so poisonous after being polluted by untold quantities of industrial gases and chemicals, that it killed nearly all the inhabitants of London. Henry Holland, a member of the New Zealand parliament who had read many of the above-mentioned European and American science fiction authors and the father of Sidney Holland (National Party Prime Minister from 1949 to 1957), voiced similar fears about the dangers of unbridled technological growth:

\begin{abstract}
...we can see the mechanical marvels of the Twentieth Century unfolding themselves in fulfilment of many of the prophecies and forecasts of the writers I have named... To-day... Bellamy's all-electric house has arrived well in advance of the year 2000, and the radio broadcasting stations are flooding the homes with music... the flying machine has long since played the part cast for it by Ignatius Donnelly... the robot... may not be the dreaded
\end{abstract}

2, No. 2 (Winter 1991), 69-72.

${ }^{32}$ Leland M Roth, A Concise History of American Architecture (New York: Harper and Row, 1979) states that the rise of traditional styles of architecture emerged as a direct result of rapid change: "As the pace of technological and cultural change quickened and intensified, so the need for security through historical associationalism in architecture became more insistent. Thus, in the turbulent years in which modern American society emerged, and in the two decades which followed from 1915-1935, there flowered a traditional architecture, both classic and Gothic." (p.174).

${ }^{33}$ Henry Edmund Holland makes mention of these novels in his pamphlet The Machine: friend of man - or rival (Wellington: Clarte Book Shop, 1931), p.6. 
creation of Karel Capek, but he is with us, threatening... to become a Frankenstein monster.. ${ }^{34}$

This uneasiness over cities and the new machine age was grounded in the fear that one day, "man's creations could rise against him and eventually destroy him", to use the words of the art historian Robert Hughes. ${ }^{35}$ This fear proved to be a prevalent theme in New Zealand literature of the time. For instance, Robert Loughnan in a booster handbook, discussed not only the hostility to technological change exhibited by a few people but also the sometimes fatal effects of rapid change on these same persons:

...the "bus has now receded... The electric tram... reigns in its place... But there is a solid minority which dislikes the noise and push of the new system... There are even some of the older members of this party of natural conservatism who find it less difficult to accept the electric system than to get out of the way of trams. The results are sometimes sad. ${ }^{36}$

The opposition to mechanical progress was sometimes so extreme that it resulted in a Luddite-like violence against the new machines, or at least a desire to turn the clock back. For example, this hostility to machines and a destructive reaction against them, is seen in New Zealand as early as Samuel Butler's utopian work Erewhon (1872), and is interestingly enough commented upon by Aldous Huxley in the 1934 introduction to Butler's work:

The results... of our misplaced zeal for 'progress' are disastrously visible throughout the contemporary world. Butler's Erewhonians foresaw the dangers into which they were running. Fearful of becoming the slaves and parasites of their own inventions, they destroyed all machinery more elaborate than that which was necessary to support a late-mediaeval mode of life. ${ }^{37}$

Examples abound exposing a severe animosity for the new machine age and a subsequent desire to return to a simpler way of life, one based on the cultivation of the

${ }^{34}$ Henry Holland, p.6.

${ }^{35}$ Hughes, p.48.

${ }^{36}$ Robert Loughnan, p.39.

${ }^{37}$ Butler, Samuel. Erewhon, or, Over the range. With special introduction by Aldous Huxley and the illustrations and a special design for each chapter made by Rockwell Kent(New York: 1934), p.xxi. Huxley may have also been influenced by the publication of James Hilton's Lost Horizon (1933), which epitomized the ideal escapist society. 
land and a return to home crafts. In early nineteenth century America, for instance, religious groups such as the Shakers and Mormons epitomized just such a reaction with their desire to found and farm a new Promised Land. In England, the Pre-Raphaelites and the Arts and Crafts Movement attempted to "reform the ills of modern civilization" and to "displace the shoddy products of the machine age by reviving the handicrafts of the pre-industrial past."138 In New Zealand, an Arts and Crafts Club was eventually formed in Auckland in 1912, and an exhibition was produced complete with a catalogue of works displayed. In 1925, the Christchurch Beautifying Association lamented the fact that the urban man was no longer interested in traditional pursuits such as gardening, but preferred instead to pass the time by "cleaning and grooming his Ford or Chevrolet" and wasting "his spare cash... in benzino or in paying instalments on purchase money." ${ }^{39}$ Yet one of the best New Zealand examples of opposition to things mechanical can be found when the eccentric J.J. Mann arrived in Hamilton for the New Zealand leg of his world tour by automobile. His vehicle frightened the horses of the cabmen in the town who were as yet unused to motorized traffic. Consequently, Mann was not only physically threatened in front of his hotel, but he discovered the next morning to his chagrin that the tires on his car had been slashed through with a knife. ${ }^{40}$

This enmity towards the machine was increased by two further important factors. The first was the advent of the First World War in which "machinery was turned on its inventors and their children." ${ }^{141}$ According to Aldous Huxley, nineteenth century man was so caught up in his love of the machine and of progress that no sacrifice seemed too great. ${ }^{42}$ However, the aerial bombings, the horrors of gas, the tanks, the minefields, the barbed wire, the beaches of Gallipoli, and the disabled returning veterans, nearly destroyed all the faith in technology displayed previously by groups such as The Futurists. J.B. Waters, the President of the New Zealand Chamber of Commerce,

${ }^{38}$ Janson, pp.624 and 633.

39 The City Beautiful, 2, No.1 (1925), p.7.

${ }^{40}$ J.J. Mann, Round the world in a motor car (London: G. Bell and Sons Ltd., 1914), p.218.

${ }^{41}$ Hughes, p.56.

${ }^{42}$ Huxley in Erewhon, p.xx. 
commented in 1922 on just how overwhelmingly the world had been changed for the worse after that war:

We live and trade to-day during a period of transition and uncertainty. The great war which 'ploughed European society to the roots' has overthrown or depreciated all conventional standards of value, social and material, and civilised humanity stands upon the brink of the unknown confronted by tremendous problems. ${ }^{43}$

The second major factor which contributed towards the animosity for the machine and to a subsequent desire for the simple rural existence, was a nineteenth century fear of the future which had been heightened as the end of the nineteenth century approached and the twentieth century loomed. Kenneth Roemer in writing about nineteenth century American society, argues that rapid technological change and rapid urbanisation, accompanied by such things as violent strikes and an inability to attain cheap land, were more than likely to have caused a sense of "future shock' long before Alvin Toffler popularized the term." ${ }^{14}$ Similarly, Julie Wheelwright writes: "The final decades of a century often spawn apocalyptic fantasies, doomsayers and outlandish prophets." ${ }^{15}$ These same fears about the uncertainty of the future were true of New Zealanders as well as of Americans and Europeans. A number of prophetic religious tracts were written in the colony about the end of the world and the arrival of the millennium. ${ }^{46}$ They were full of tales of invasions, famines, pestilence, earthquakes, volcanic eruptions, etc..., all of which symbolised decline. ${ }^{47}$ In A. O'Brien's The Coming Day (1892), for

${ }^{43}$ J.B. Waters, Annual Report of the New Zealand Chamber of Commerce (Dunedin: November 1, 1922). Located in the Canterbury Chamber of Commerce Records. (Canterbury Public Library).

${ }^{44}$ Roemer, p.5.

45 Julie Wheelwright reviewing Elaine Showalter's Sexual Anarchy: Gender and Culture at the Fin-de-Siecle in The New Statesman, 4, No.144 (29 March, 1991), 29.

${ }^{46}$ Millenarianism, as defined by Norman Cohn and repeated by Davis, is "any religious movement with a phantasy of salvation which is to be collective (enjoyed by the faithful as a group), terrestrial, imminent, total (utterly transforming life on earth, not merely to improve but to perfect) and accompanied by agencies which are consciously regarded as supernatural." (p.32).

47 Roemer (p.23) argues that volcanic imagery was a common precedent for symbolizing the end of the world, and he mentions the eruptions of Vesuvius in 1872 and Krakatoa in 1883 as contributing to the "late nineteenth century volcano vogue." In 
example, a great war occurs which culminates in the end of the world as we know it and the appearance of a heavenly Jerusalem on earth. ${ }^{48}$ Charles J. Stone's History of the Decline and Fall of the British Empire by Edwarda Gibbon (Auckland, AD 2884) (1884), on the other hand, tells the story of the end of the British Empire after a severe climactic change; the novella itself is set in a strange new world where the method of dating has changed: "In the nineteenth century of the Christian era, and the first age of Spiritualism..."49

Thus far in this chapter we have examined a number of reasons why a strong prorural element was to be noticed in contemporary New Zealand literature and art. By far the reason which seemed to receive the most attention, after fears over a repetition of old world conditions in the new colony, was the not so insignificant misgivings amongst colonials regarding unprecedented technological development. This technophobia was furthered considerably by the calamitous events of World War One and fears over an ensuing apocalypse or millennium which might accompany the advent of the twentieth century. Yet in spite of these concerns, the most persistent and frequently proffered reason for the Back to the Land movement in New Zealand, was a shared vision amongst the colony's immigrants of founding a Garden of Eden or arcadia.

Before discussing this arcadian image in New Zealand history, it is important to define the term and to emphasize its rural and natural appeal as opposed to its utopian cousin which is urban-orientated and with which it is often associated. An arcadian vision is traditionally one in which shepherds and shepherdesses (as well as other assorted Classical or mythological figures) are often seen to frolic or relax amongst golden fields of wheat, nearby sparkling streams and under trellises of ripe grape vines or the boughs of wild conifers. It is a tamed landscape where the beasts of the field are fat and healthy and where the fish are always biting. It is a picture of a benign natural world where people's wants are met by the land and where there is no poverty or disease. In European art this arcadian image is traditionally affiliated with the Classical and Neo-Classical works of Titian during the High Renaissance and Nicolas Poussin and

\footnotetext{
geologically unstable New Zealand, such imagery would have had a particularly strong message, especially after the eruption of Tarawera in the North Island in 1886.

${ }^{48}$ A. O'Brien, The Coming Day (Nelson: Bible \& Tract Depot, 1892). The author was a farmer from Ngatimoti, Taranaki.

${ }^{49}$ Charles Stone, p.3.
} 
Claude Lorraine during the seventeenth century. ${ }^{50}$ In England during the early nineteenth century a variation of this ideal is often identified with the works of John Constable. Constable's paintings tend to differ somewhat from their heavily accented classical counterparts in that Roman ruins and Classical figures receive much less attention than do farms, villages and hamlets. This English arcadian landscape is quintessentially a romantic one, epitomized by church steeples, thatched roofs and smoking chimneys. Martin Weiner says that descriptions such as "quaint" or "oldfashioned" are usually associated with it. ${ }^{51}$ In Australasian art William Hodges, Nicholas Chevalier, Thomas Clark and John Gully epitomize the arcadian ideal in varying degrees. J.C. Davis in Utopia and the Ideal Society, draws on the work of Northrop Frye to come to terms with a definition of arcadia in order to underscore its distinctiveness from utopianism:

...arcadia has two characteristics which distinguish it from utopia. First, arcadia emphasizes the integration of man and nature. Utopia, on the other hand, seeks to illustrate man's capacity to dominate nature. Secondly, the arcadian simplifies human desires and at the same time throws great stress on their satisfaction. Utopia, by contrast, seeks to act out a pattern of restraint. In addition, it might be said that the arcadian tradition is much more radical than the utopian. It not only rejects, as here, the institutions of an acquisitive society, but it rejects all institutions whatsoever and so highlights the institutional preoccupations of the utopian. ${ }^{52}$

Arcadian themes are prevalent in a great deal of Australasian art and literature. As we have seen before in Chapter 4, they were particularly suited to topographical landscapes which were aimed at attracting settlement, as well as making an appearance in the New Zealand pastoral cityscapes of artists such as John Kinder, Alfred Sharpe and Christopher Aubrey. The arcadian image was also often used in promotional pictures for real estate advertisements for suburbs. For example, the photograph of wealthy middle

${ }^{50}$ According to Honour (p.161), this arcadian landscape goes back much further than the eighteenth century; Honour states that its origins lie in the "literary landscape $[s]$ " of Homer and Virgil, as well as the "Later European poets - notably Dante, Ariosto, Tasso,
Shakespeare and Milton..."

${ }^{51}$ Martin Weiner, English Culture and the Decline of the Industrial Spirit, 18501980 (Markham: Penguin, 1985), p.51.

${ }^{52}$ Davis, p.24. 
class families relaxing along the banks of the River Avon in Christchurch [ILLUSTRATION 49) or that of the square in Palmerston North [ILLUSTRATION 48], conjure up allusions to subjects or settings which one would expect to read about in the poetry of the English romantics. Such images would have been especially attractive for English labourers desiring to leave their working class tenements in London, Birmingham, Manchester or Liverpool. Taking the example of the real estate flier for the Glen Aplin Estate in Queensland, Australia, one comes across just such a typically arcadian vision aimed at the urban working class [ILLUSTRATION 68]. The illustration reveals a happy father sharing the fruits of his labour with a beautiful wife and a healthy daughter. Ripe apples, fields of wheat, fat chickens and a cosy bungalow, reveal all the elements needed to contribute to an image of abundance and security. The illustration seems to be telling viewers that such a lifestyle can be theirs if only they leave the city and move to this suburban paradise. Similarly, New Zealand builders and developers would use the same imagery to promote their homes. O.W. Clayton of Wellington, for example, used poetic advertisements full of arcadian and rustic imagery to draw the attention of buyers:

Just look at his cottages neat,

While bright children are swinging the gate on;

He has fifty which you may chose,

So hasten to O.W. Clayton. ${ }^{53}$

Such images were also readily apparent in the New Zealand literature of the day. Thomas G. Leech, for example, tried to establish in the late 1890 s a co-operative village settlement in New Zealand that was based on the ideas of John Ruskin, the English professor of Fine Art in 1860s Oxford who so vehemently denounced industrial cities and the materialistic/mechanical age which fostered them. ${ }^{54}$ Henry Lloyd, the prominent American reformer writing at the same time as Leech and an "ardent advocate" of New Zealand, emphasized the rustic nature of New Zealand and its

${ }^{53}$ Walter K. Bishop, Guide to Wellington \& District (Wellington: Walter Bishop, 1882), p.41.

${ }^{54}$ Thomas Green Leech, Co-operative colony of Ruskin. The most contented people in the world. Why not one in New Zealand? (Patea: 1898), p.1. 


\section{BUY AN INCOME}

on our GLEN APLIN ESTATE in the Stanthorpe

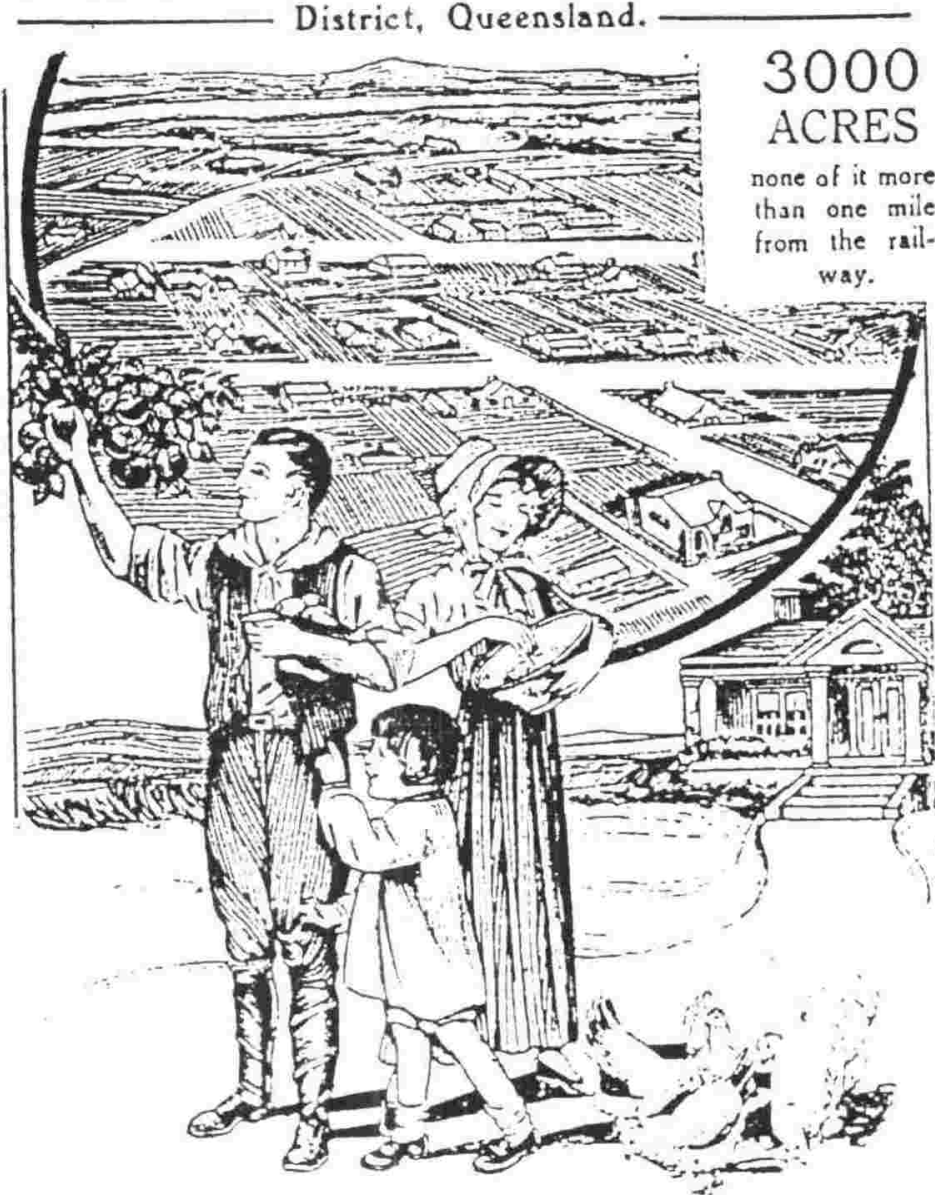

The Blue Mountains of Queensland.

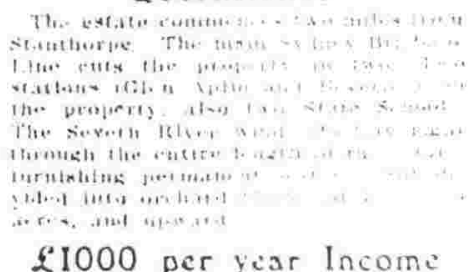

$£ 1000$ per year Incom
from Five Acres.

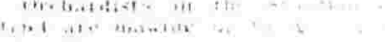

Water. Water. Wath

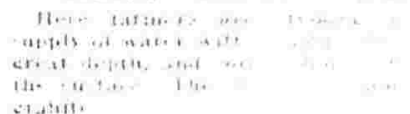

REALTY DEVELOPMENT CO..
Exceptionslly Low Terms.

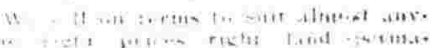

Cash Income Monthly.

START ONE OF THESE ORCHARDS WORKING FOR YOU TO-DAY. 
people..$^{55} \mathrm{He}$ stated that the colony was not to all intents and purposes "a citified country", like the colonies of Victoria or New South Wales, but rather that it had an "unmetropolitanised" quality which he greatly admired. ${ }^{56}$ Lloyd also approvingly concluded that the average New Zealand man resembled more the "English country gentleman" in his good manners and sincerity than his city-slicker and presumably Australian counterparts. ${ }^{57}$ Robert Irvine and O.T.J. Alpers also commended the arcadian development which New Zealand seemed to follow. Instead of congested cities, flats and unhealthy slums, they argued that the people in the colony tended to live, "in cottages and villas with plenty of open space and garden-ground around them..." ${ }^{n 8}$

The impact of this rustic and arcadian imagery can be seen in the titles which some cities adopted to advertise themselves, such as Christchurch which chose the phrase "The Garden City". According to the American historian Anselm L. Strauss, such sentiments suggested qualities attributed to "outdoor life... [and] close contact with the soil." ${ }^{59}$ New Zealand's historians have also commented on the importance of this arcadian imagery to the country's settlers. Keith Sinclair devotes a great deal of space to the influence of literature about ideal societies on William Pember Reeves, in particular "the experimental settlements in the United States... [and] the ideas of Robert Owen..." ${ }^{60}$ Miles Fairburn, writing about the origins of the rural myth in the country

${ }^{55}$ According to Howe (p.93), Lloyd's enthusiasm for New Zealand was in part due to his friendship and correspondence with Edward Tregear, the first secretary of the Labour Department.

${ }^{56}$ Henry Demarest Lloyd, Newest England; notes of a democratic traveller in New Zealand, with some Australian comparisons (New York: Doubleday, Page \& Co., 1900), p.244.

${ }^{57}$ Ibid.

${ }^{58}$ Robert Irvine and Oscar Alpers, p.423.

59 Strauss, p.23.

${ }^{60}$ Keith Sinclair, William Pember Reeves (Oxford: Clarendon Press, 1965), p.101. Robert Owen was a British capitalist who attempted to establish a co-operative settlement in the town of New Harmony, Indiana, in the early nineteenth century. 
and the rejection of the town and city, identifies three different types of arcadian vision. $^{61}$

\section{$* * * *$}

Settlers came to the colonies during the nineteenth century for two important reasons: firstly, because they disliked urban and industrialized Britain; and secondly, because they had romantic arcadian visions of an unspoiled and prosperous land across the seas to where they could escape and start anew: "Many overseas settlements were established with the express aim of avoiding industrialisation and recreating an agrarian society free from the perceived evils of urbanisation..." ${ }^{162}$ According to Gordon E. Cherry, an authority on town planning, this "setting up of communities in new settlements", was a common nineteenth century formula for avoiding urban problems and one that was derived from the Owenite tradition. ${ }^{63}$ Rollo Arnold, in relation to New Zealand settlement in particular, suggests that this ideal image "of an alternative promised land in the virgin countryside beyond the seas", was picked up by emigration agents and used deliberately as valuable propaganda in enticing English labourers. ${ }^{64}$

Yet once these colonists arrived in New Zealand the arcadian dream maintained its appeal. Essentially, the reason for the prevalence of the rural myth, was that for many of the new settlers the reality of their new situation failed to satisfy the arcadian vision which they had brought over with them; for many of these same people had established themselves in towns and cities and once these new settlements had begun to expand and to grow, they revealed several of the urban and industrial problems which the colonists had emigrated to avoid. Miles Fairburn attributes the perserverance of the rural myth in New Zealand to the rapid growth of the city:

...the New Zealander was confronted with a terrible dilemma: his ethos was rigidly rural while his social structure became urban. Although he believed everything connected with the city was

${ }^{61}$ According to Fairburn's "The Rural Myth and the New Urban Frontier", the "three visions of arcadia - the suburban middle class, the middleclass Dickensian, and the lower class yeoman - merged together into an almost perfect harmony, to create the common rural myth: all rejected the city..." (p.8).

${ }^{62}$ Christopher, p.4.

${ }^{63}$ Gordon E. Cherry, Town Planning in its Social Context (London: Leonard Hill, 1970), pp.22-23.

${ }^{64}$ Arnold, p.354. 
bad, it was there increasingly that he searched for security and opportunities... His spiritual home was in the country whereas his physical nourishment came from the city. ${ }^{65}$

George Seddon and David Ravine argue that it was this antipathy to the city which led to the emergence of the bush legend in Australian historiography. ${ }^{66}$ Graeme Davison states that the development of village settlement schemes in the Australia of the $1890 \mathrm{~s}$ as well as the frequent nostalgic reminiscences for the early pioneers, also reflects this arcadian vision. ${ }^{67}$ Another possible motive for the perserverance of the aracdian myth in New Zealand, was that many urban colonials may well have been the sons and daughters of farmers who were unable to farm because of restricted land. They and their children, therefore, having been forced to look for employment in the towns and cities, may well have retained idyllic memories of a happy and carefree childhood in the country. ${ }^{68}$

Images of old world evils, of the threat of revolutionary anarchists, of moral and physical weakness, of parasitic townies, of arcadian forests, and of glimpses of a paradise lost or an Eden found, all contributed to fueling a strong anti-urban consciousness in New Zealand. Having examined the reasons why certain New Zealanders were distrustful of urban living and desired instead a return to the country, we can now leave the images themselves and turn to another part of the rural/urban debate: the methods by which people were induced to actually go back to the land. These attempts at turning back the clock on urban development and living the rural myth, must also be examined; for such beliefs and actions would have seemed a real threat to city and town promoters looking to expand their urban dominions. These apparent threats to urban growth are important for they resulted not only in further booster propaganda aimed at counterring anti-urban feeling, but also in attempts to ameliorate urban conditions through various improvement schemes. These schemes,

${ }^{65}$ Fairburn, "The Rural Myth and the New Urban Frontier", pp.9-10.

${ }^{66}$ Seddon and Ravine, p.23.

${ }^{67}$ Davison The Rise and Fall of Marvelous Melbourne, p.251, and "The Picture of Melbourne 1835-1985", p.25.

${ }^{68}$ I owe this point to Rollo Arnold. White (p.42), however, makes a similar point regarding the invalidity of certain Australian myths, especially those based on "hearsay [and] parents' memories". 
particularly City Beautiful, Garden City, suburb, and town planning ideas, will be discussed in the next chapter.

One of the most frequent methods used to achieve rural settlement, and one which we have seen before, was to utter gloomy prophecies about the dire consequences of urban over-development. Sometimes these warnings were merely predictions about old world evils reasserting themselves in the new world if some kind of precautions were not taken to check city growth. At other times, such cautioning bordered on the extreme. William Ashby, for instance, advised his readers to: "Avoid the large cities as you would avoid mad dogs. ${ }^{169}$ Such advice usually proved ineffective, however; so a number of attempts were made on the behalf of different individuals and groups to either restrict city expansion altogether or to compel people to "leave the large towns" for a life on the farm where they could be more productive and where their endeavours would prove more fruitful. ${ }^{70}$ Such proposals are listed chronologically and included: opposing all further emigration to New Zealand; restricting what emigration there was to farmers only and introducing town lads on farm schemes and other educational programmes to foster agriculture; subdividing the large runholdings and estates into smaller holdings so as to provide more land for settlement; and lastly, settling returning soldiers on farms.

Perhaps one of the most radical solutions of the time to the perceived urban dilemma, was to restrict all further emigration to the colony. This was particularly the case during the years of the Long Depression when the urban unemployed were highly visible in city and town centres. Walter Hazell, in a report on colonisation to the Australian colonies, was just such an advocate; he concluded that "any large scheme of assisted emigration from England... did not appear to us to be favourable." ${ }^{71}$ His decision was based on the premise that most settlers arriving in New Zealand were unproductive as they tended to stay in the towns and so compete for jobs. He also argteed that where there were assisted emigration schemes for farmers, many incorrectly

${ }^{69}$ William Ashby, p.80.

${ }^{70}$ Eugene J. O'Conor, NZPD (July 31 - August 25, 1891), p.430.

${ }^{71}$ Walter Hazell, The Australian Colonies: Emigration and colonisation. Report of inquiries made by Walter Hazell and Howard Hodgkin...during a visit to Australia, Tasmania and New Zealand, December 1886-April 1887 (London: 1887), p.46. 
described themselves as belonging to this category in order to get free or subsidised passage over from England. ${ }^{72}$

Another solution put forth to prevent further increases in the urban population, and one which received attention throughout the time-frame of this study, was to encourage farming practices. As William Hazell had previously mentioned, the New Zealand government had established assisted passage schemes for farmers from the United Kingdom for just such a reason. These pro-farming policies were also given a good deal of attention by the politicians and bureaucrats of the time. James Thomson, the member for Clutha in the House of Representatives, stated that the government "should induce young men to become tillers of the soil", rather than encouraging them to lead unproductive lives as clerks and shopkeepers. ${ }^{73}$ In 1888 Launcelot Walker in the Legislative Council, expressed his desire that New Zealand's pavilion at the Paris Exhibition might "induce people from that country to settle in this colony for the purpose of establishing such industries as the production of wines, the growth of olives, and industries of a kindred character..." ${ }^{74}$ According to Miles Fairburn, George Hogben (the head of the Education Department from 1898 to 1915), attempted to institute changes in the curriculum of primary schools so as to emphasize non-academic subjects such as "gardening and practical agriculture."75 Other educationists pursued similar strategies. For example, James E. Strachan (1883-1973), the President of the Canterbury Progress League and a principal in a country school, "downplayed the formal academic nature of the official education curriculum to emphasize practical farming..." ${ }^{76}$ And Donald McLeod, the Minister of Lands in 1928, discussed the government's schemes for increasing incentives to farm. He talked about the Ruakura Farm, a government funded training school set up to give young men, "practical and elementary scientific training [in farming techniques] over a period of eighteen months." 77

${ }^{72}$ Ibid., p.30.

${ }^{73}$ James William Thomson, NZPD (July 6 - July 29, 1880), p.86.

${ }^{74}$ Launcelot Walker, NZPD (August 8 - August 30, 1888), p.47.

${ }^{75}$ Fairburn, "The Rural Myth and the New Urban Frontier", p.13.

${ }^{76}$ James E. Strachan Papers. (Canterbury Public Library).

${ }^{77}$ Donald Alexander McLeod, NZPD (August 7 - September 4, 1928), p.232. 
Another suggested method for encouraging people to leave the cities for a new life in the country, was the 'Town Lads on Farm' scheme formulated around 1910. The crux of this strategy was to convince young urban men in England, who were single and who were either unemployed or without good prospects for steady employment, to emigrate to New Zealand where they could take up farming. Each of these town lads would be apprenticed to successful farmers already settled in the colony for a period up to three years; after learning their trade, these ruralised urbanites were then expected to take up their own sections of land and begin farming. According to Thomas E. Sedgwick, the plan's progenitor, such a scheme offered a solution to both the problem of poverty in Great Britain and to that of under-settlement in New Zealand:

The migration of town lads provides the Dominion with the exact type of labour they require, without depopulating the country districts at home where poverty is less prevalent than that in the towns. ${ }^{78}$

Town lads on farm schemes were still the subject of some debate nearly fifteen years later. Both the Christchurch Chamber of Commerce and the Taranaki Chamber of Commerce had shown interest in the notion. According to the records in the minute books of the Christchurch Chamber, the Taranaki Chamber had even gone so far as to offer financial assistance for the scheme. ${ }^{79}$ The majority of those fifty English urbanites who did join with the Sedgwick program, seem to have been moderately successful. ${ }^{80}$ For the following results were published in a 1914 report which Sedgwick produced:

...forty or eighty percent, were still in the country districts, two lads had gone up to towns, three had gone to Australia, one had died, two had come home, and two had disappeared. ${ }^{81}$

The most vocal group of individuals in New Zealand clamouring for a return to the land were the Liberals who assumed office in 1891 under John Ballance. The reason for theirpro-rural attitude was that they blamed the rapid increase in the colony's urban

\footnotetext{
${ }^{78}$ Thomas Sedgwick, p.3.

79 Christchurch Chamber of Commerce Records: Special Committee Minutes, November 30, 1928. (Canterbury Public Library).

${ }^{80}$ The scheme initiated by Thomas Sedgwick appears to have been run only once.

${ }^{81}$ Thomas E. Sedgwick, Lads For The empire; with notes on other phases of imperial migration (London: P.S. King \& Son, 1914), p.19.
} 
population for its poor economic performance and for the appearance of old world evils such as slums, disease and crime. They were of the opinion that the only way to amend the situation was to get people back onto the land and the only way to achieve this was to break up the large land monopolies: "Land settlement was seen as a cure for unemployment and a means of eliminating... such evils consequent upon unemployment as workhouses, relief workers, social and political unrest, and heavy rates and taxes to pay for the relief of the unemployed..." ${ }^{182}$ According to Raewyn Dalziel, the Liberal Government used a variety of tactics to accomplish such an end:

They intended to re-purchase large estates for subdivision and to introduce a graduated land tax that would force the great landowners to sub-divide. They proposed to alienate crown lands only to genuine settlers and later made cheap loans available to them to start farming. ${ }^{83}$

This tendency to see land settlement as the solution to all the colony's economic problems, held common sway at the time. John Ballance, Prime Minister from 1891 to 1893, advocated just such a resolution in his first year of office; he argued that New Zealand would soon be going the way of Great Britain in using the workhouse to alleviate unemployment unless the poor were given land to settle on and to farm. ${ }^{84}$ Likewise, a political treatise written anonymously in 1894, argued for the huge estates to be broken up in order to provide land for settlement and an answer to the country's growing economic predicament:

Land settlement is looked to by the people as a whole, and by their political leaders, as the best way of preventing land monopoly, and as the best way of increasing our exports. It is hoped, also, that many of the present unemployed will find profitable work on the land. ${ }^{85}$

David Hamer states that the Liberals were so "obsessed... with the view that land reform could cure all urban ills that they were unenthusiastic about policies for dealing

${ }^{82}$ Hamer, The New Zealand Liberals, p.66.

${ }^{83}$ Dalziel, The Origins of New Zealand Diplomacy, p.148.

${ }^{84}$ John Ballance, NZPD (July 31 - August 25, 1891), p.432.

85 'Ensign Grace', Land settlement. In relation to labour as a solution of the unemployment difficulty (Wellington: 1894), p.3. 
Etrecty with those ills." ${ }^{186}$ For this reason, Hamer argues, the Worker's Dwelling Bill If 195 was criticised by Alexander Hogg (the member for Masterton) on the grounds tha- it was not right to do something that would attract people into the cities. ${ }^{187}$ Miles Fatiourn comes to the same conclusion in his paper on the rural myth in New Zealand. He suggests that if the New Zealand government was so concerned with the housing Ssice Juring the 1898-1910 period, why were "flats, tenements or multi-unit dwellings 江 Ore an ascertain this same myopic and anti-urban Liberal reasoning in Richard Seticn's response to a proposal for a national exhibition in order to stimulate New Zaziarad's industry:

... the Government were of the opinion that one of the safest ways of providing for the arts, manufactures, and industries of the colony was by making the country progress by placing the people upon the land. If they found the country prosperous and land-settlement going on, the arts, industries, and manufacturers would progress also in the towns... ${ }^{89}$

The last procedure in the Dominion to be discussed for getting people out into the county and away from the towns or cities, were the soldier-settlement schemes initiated ¿y the New Zealand government after World War One. According to William

\section{ss Hamer, The New Zealand Liberals ,p.66.}

Ibid. Alexander Hogg (as the member for Masterton) did, however, urge the government some ten years earlier "to attend to the demands of the towns... as well as the Eemands of the country", by introducing a tariff on imported goods so as to secure the expansion of a domestic industry. See NZPD (August 16 - September 14, 1894), p.165.

s Fairburn, "The Rural Myth and the New Urban Frontier", p.15. Another reason gut corth by two sociologists for the popularity of "single-storey, detached [homes]... on their own large block of land... [is] the cheapness of land in relation to incomes and the relazive cheapness of building materials." See: Leslie Kilmartin and David C. Thorns, Ciries Unlimited: the Sociology on Urban Development of the Built Environment Sydney: George Allen \& Unwin, 1978), p.40. Yet despite price being a important factor to ake into consideration regarding the prevalence of suburban development in the country, it is not the prime motive for immigrants from Great Britain crossing the sea and serting in the country or suburban areas of New Zealand; for such a voyage in itself would have constituted a considerable expense on the settler's behalf. Rather, the wealth of arcadian imagery evident, suggests that the cheapness of the land appeared more as an added bonus contributing to the appeal of the arcadian dream.

\footnotetext{
Richard Seddon, NZPD (September 17 - October 24, 1894), p.4.
} 
Nosworthy, Minister of Agriculture from 1919-1925, these schemes were primarily aimed at assisting returning New Zealand soldiers onto the land. ${ }^{90}$ Yet a 1920 report to the Colonial Institute for British Soldiers, also states that soldier-settlers from the United Kingdom were invited to settle in New Zealand. ${ }^{91}$ From all accounts these schemes were not too successful for a variety of reasons. Primarily, and perhaps most importantly, many returning veterans had no experience of farming and were just abandoned to fend for themselves once settled; these returning servicemen were not helped by the 1920s slump which resulted in lower prices for their products and increased hostility to the whole programme. ${ }^{92}$ Yet another reason for their failure is that the best sections of land were already occupied by settlers who had arrived in the late nineteenth century, and consequently that land which remained uninhabited and which the soldiers did receive, was either of a poor quality or had not as yet been cleared. $^{93}$

Such conservative responses about the need to open up land for settlement in order to rectify the nation's urban and economic dilemmas, are apparent even as late as 1930. In an over-simplified diagram, Frederick Alley repeated the old Liberal message that the best panacea for the country's ills was a return to the land [ILLUSTRATION 69].

${ }^{90}$ William Nosworthy, NZPD (June 30 - August 2, 1922), p.756.

${ }^{91}$ Christopher Turnor, introduction.

92 For a precise discussion of soldier settlement schemes, see P.B. Hurricks, "Reactions to Urbanisation in New Zealand During the Nineteen Twenties", M.A. Thesis, (University of Canterbury, 1975), pp.79-81.

${ }^{93}$ According to Hurricks, soldier settlement schemes were not too successful because soldiers were not interested in farming their land, but rather in making a profit through speculation on high land prices (p.79). 


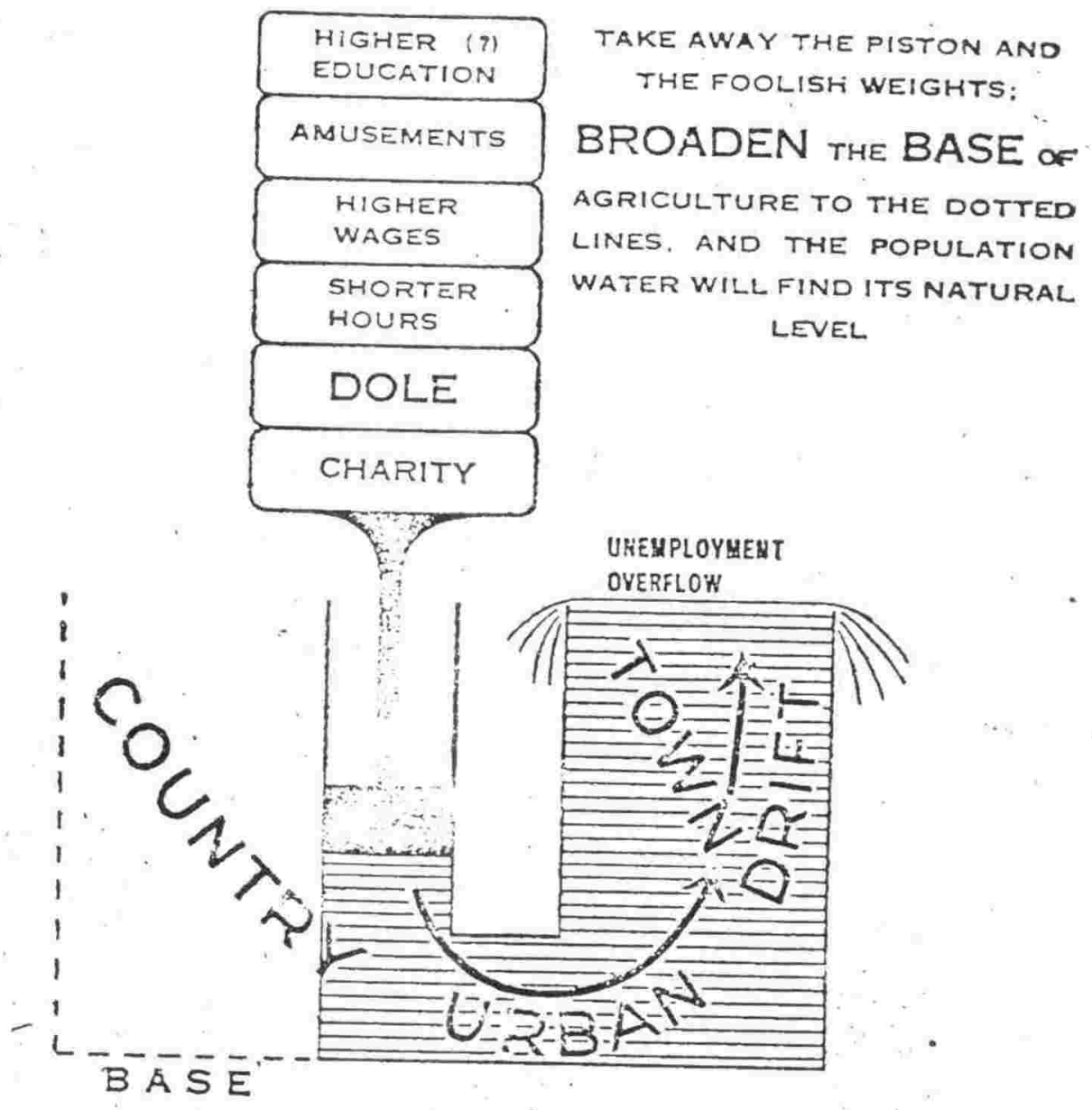

illustration 69 


\section{CHAPTER 10: \\ 'AN ATLANTIS OF THE ANTIPODES': THE INFLUENCE OF UTOPIA}

Thus far this thesis has examined the booster images used by New Zealanders to attract settlement, tourism and investment to their cities and towns. For the most part the images have been positive and this is consistent with the promotional nature of the material. Yet as Chapters 8 and 9 revealed, there was a significant amount of genuine anti-urban feeling in the country expressed by various groups and individuals and for a variety of reasons. The most persistent criticism amongst this group, was the appearance of old world evils and a feeling that New Zealand might follow the path of decline and ruin which its Old World parents were seen to have taken. Such criticism appeared well-founded when in 1911 it was understood that the country's urban population had excee dits rural population. Chapter 10 moves beyond the area of boosterism and documents the response to these deep-seated anti-urban and pro-rural attitudes. It argues that urban promoters in the country were aware of these issues and ready to take steps to alleviate the situation before it got out of hand. Such steps involved looking to Europe and the United States for solutions to the perceived urban dilemma, and included: City Beautiful and Garden City schemes, the creation of suburbs and the introduction of town planning legislation. It will be argued that the defenders of the colony's towns and cities were sincere in their conviction that they could still build a new and better world in New Zealand. Unlike their technophobic counterparts mentioned in the previous chapter, these boosters believed that technology could help, rather than hinder, in the building of their dream cities. Such optimistic visions of the future of the New Zealand city and town are an integral aspect of booster propaganda which cannot be ignored; for they were in part responsible for manufacturing booster pride and for moulding the booster image, especially in regard to contributing to promoter rhetoric about how civilized, advanced or prosperous a city would become. However, as has been documented beforehand in preceding chapters, not all these reformist and utopian motives were idealistic; on the contrary, there was a considerable amount of self-interest involved amongst a few at least who stood to gain from municipal improvements. 
According to "Kenneth M. Roemer's study of utopias and utopian authors, Americans had repeatedly imagined that their society was untroubled by old world problems. Roemer states that American people had frequently believed that theirs was an earthly paradise, far removed from the conflicts and scourges of old world time; for Roemer, however, all this was to change with the coming of the 1890s: "Anyone could see that America was no longer "new and original'."1 He goes on to conclude that American reformers were of the opinion that if actions were not taken to halt the nation's decline, then "all the New World would become as corrupted as the Old; and this would be a 'final failure'."2

Immigrants who had come to settle in New Zealand in the nineteenth century echoed many of these same American sentiments. They had also perceived their new home as a new world which had heretofore been untainted by old world evils. Yet in the last decades of the nineteenth century and the first decade of the twentieth, New Zealanders too saw their arcadian and utopian dreams apparently crumbling before their very eyes. Like the American reformists, many asserted a need to rectify the situation before it became too late and the decline proved irreversible. According to David Hamer, many Liberal politicians of English origin may well have become involved in government as a direct result "of the appearance in New Zealand in the late 1880s of evils associated with English industrial cities. ${ }^{13}$ Evidence of such ill feeling regarding the emergence of Old World evils abounds in the literature of the period. Robert Irvine and Oscar Alpers warned of the need for New Zealanders to introduce radical labour legislation, thereby "preventing the installation of abuses before such abuses attain formidable dimensions." ${ }^{44}$ The English journalist and town planning enthusiast Charles Reade advised New Zealanders to learn from England's example and enact town planning legislation before the urban crisis in their colony got out of hand. ${ }^{5}$ Arthur Myers in 1910, the member for Auckland East and later Mayor of the city, asked the

${ }^{1}$ Roemer, p.42.

${ }^{2}$ Ibid., p.43.

${ }^{3}$ Hamer, The New Zealand Liberals. p.49.

${ }^{4}$ Robert Irvine and Oscar Alpers, p.332.

${ }^{5}$ Charles Reade, The revelation of Britain. A book for colonials (Wellington: Gordon and Gotch Proprietary Ltd., 1909). 
Prime Minister Sir Joseph Ward whether or not the Government intended, "avoiding the evils that arise when cities grow up without any definite plan", by proposing some sort of town-planning mandate. ${ }^{6}$ The Greater Wellington Town Planning and Municipal Electors' Association in 1912 called for town planning measures to prevent "Slum Conditions." ${ }^{17}$ The New Zealand historian R.M. Burdon, writing in the early 1960s, comments on similar exhortations. He concludes that it was these very fears about unbridled city and town growth that led directly to town planning initiatives in the colony at the turn of the century. ${ }^{8}$ Peter Coleman also discusses the perceived threat of the Old World to New Zealand, which he believes was heightened as a result of economic depression:

Many colonists concluded that the Old World was about to overtake the New... Alarmists drew the obvious conclusion: that the increase in poverty, slums, disease, unemployment, sweated labour, and violent industrial disputes in the towns... provided clear proof that the colony was slipping back toward Old World conditions. ${ }^{9}$

Attempts at finding solutions to unrestricted urban growth and the problems which accompanied them were, however, compounded by the fact that New Zealanders had always considered themselves much more advanced than their overseas contemporaries (See Chapter 2). The colony's cities and towns had been variously described in booster literature as healthier, more beautiful, better planned and not subject to barriers of class or birth, unlike their European and sometimes even American counterparts with which they were frequently compared. Such feeling abounded elsewhere in New Zealand circles at the time. According to David Hamer, the colony's innovative labour and social legislation had been envisioned by the Liberal government of the 1890 s as a symbol of just how much more advanced New Zealand was than any other nation on the earth. ${ }^{10}$

${ }^{6}$ Arthur M. Myers, NZPD (June 28 - July 22, 1910), p.683.

${ }^{7}$ Greater Wellington Town Planning \& Municipal Electors' Association, A brief outline of town planning aims (Wellington: Wellington Publg. Co. Ltd., ca.1912), p.7.

${ }^{8}$ R.M. Burdon, The New Dominion (Wellington: A.H. \& A.W. Reed, 1965), p.112.

${ }^{9}$ Coleman, pp.22-23.

${ }^{10}$ Hamer, The New Zealand Liberals, p.63. 
Yet from the period from about 1911 onwards, when the country's urban European population was fast approaching fifty percent of the entire population of the nation and when the colony's urban issues were becoming ever more acute, New Zealand's planners began to fear that their nation was beginning to lag behind the Old World. There existed a feeling that New Zealand was no longer the progressive and advanced nation which its boosters had made it out to be. So New Zealanders began turning to England and the United States for answers. Sir Arthur Myers, arguably one of the country's strongest advocates of town planning, summed up the feeling in the country at the time:

We are apt to pride ourselves in New Zealand on being in the van of social reform and progress; but in this matter we have allowed ourselves to be left behind by the countries of the old world... It may be the question is not so urgent here as it is in older countries; but if we are wise we shall profit by the experience of others. ${ }^{11}$

A number of voices made similar calls for New Zealand to turn to European and American precedents in order to allay the urban crisis. George Fowlds, the Acting Minister of Public Health in 1911, believed that "the time is coming when we in New Zealand shall be compelled, whether we like it or not, to follow more on the lines of legislation in the Old Country." ${ }^{12}$ Likewise, S. Hurst Seagar, formerly Vice-President of the New Zealand Institute of Architects, in a 1911 lecture to the Christchurch Beautifying Association on ugly placard advertising, stated that New Zealand should learn from American examples and introduce some sort of municipal act to preserve some notions of beauty and propriety in the nation's cities and towns:

It is pleasing to find that America, with which we are unfortunately often compelled to associate all that is worst in modern commercialism, has among its citizens an ardent band of workers striving to prevent the further disfigurement of their towns and rural scenery. ${ }^{13}$

11 Sir Anthony Mielziner Myers, Proposed Town Planning Bill submitted to conference of local bodies, Auckland, 1st March 1911 (Auckland: Brett Publg. Co.,
1911), p.1.

${ }^{12}$ George Fowlds, NZPD (July 22 - August 25, 1911), p.263.

${ }^{13}$ Samuel Hurst Seagar, Our Beautiful World. Man's work in the making and marring of it. A lecture delivered to the Christchurch Beautifying Association (Wellington: Harry Tombs, 1911), p.19. 
Cries to follow European and American examples abounded well into the 1920s. Advocates of town planning from England such as Charles Reade and W.R. Davidge, gave illustrated lecture tours throughout New Zealand and under the patronage of local bodies as well as the national parliament, in order to preach the merits of preventative municipal legislation. ${ }^{14}$ The Canterbury Progress League entertained the idea of publishing a pamphlet advancing the idea that Canterbury might learn from other places and enact town planning measures: "Other countries have shown us the way, and there is no reason why we should not follow their excellent lead." ${ }^{15}$ The Government sponsored a New Zealand Town-Planning Conference and Exhibition in 1919, which included a competition for designing a garden city (the British solution to urban and industrial sprawl put forth by Ebenezer Howard in the closing years of the nineteenth century). ${ }^{16}$ The Christchurch Beautifying Association in 1925 championed the merits of industrial estates based on Garden City designs like those of Port Sunlight and Bourneville in Great Britain, and encouraged New Zealand manufacturers to follow their examples. ${ }^{17}$ George Fowlds in 1925 repeated the need for New Zealand to commence some form of town planning provision as he argued that the country's cities were quickly falling behind the times:

\footnotetext{
${ }^{14}$ Letter from Charles Reade (January 14,1914$)$ to the Christchurch City Council: Christchurch City Council Inwards Correspondence. (Canterbury Public Library). Library).

15 Pamphlet: Canterbury Progress League Minutes, 1918. (Canterbury Public

16 The Garden City, as originally conceived by Howard, was designed as a selfcontained and scientifically planned community which was aimed at providing both a practical and picturesque solution to urban sprawl. It was to be based on concentric circles and Germanic medieval village patterns, with a surrounding band of agricultural or park land to prevent further urban encroachment. In also gave priority to the health and welfare of what was intended to be its primarily working class inhabitants by emphasising such things as sanitation and convenience. The City Beautiful movement, which was also a reaction to the urban "disease" and which will be discussed later, differed from the Garden City in that the former was concerned first and foremost with the aesthetic and consequently lacked Howard's social agenda. The City Beautiful also placed greater emphasis on the Classical ideal; it is synonymous with long and regular boulevards and stands in contrast to its organically based Garden City counterpart which deliberately incorporated curved streets into its design to prevent monotony.
}

17 The City Beautiful, 1, No.7 (1925), p.3. 
No provision is being made for broad imposing avenues, boulevards, or main arterial streets; but, on the contrary, we find little, blind, crooked alleys leading nowhere... I stated that after a trip to Europe... the cities of Great Britain were 25 years behind Continental cities in town-planning, and that New Zealand cities were 25 years behind those of Great Britain... ${ }^{18}$

Like the calls from the Christchurch Beautifying Association mentioned above for local manufacturers to specifically emulate Port Sunlight and Bourneville in England, sometimes these proposals went beyond the general and argued instead that New Zealanders should follow a particular Old World route. As early as 1896 the member of Parliament for Inangahua requested that the Minister of Lands allow waste land in the cities and towns to be used by the poor to grow vegetables in order to supplement their diet: he stated that such a method, "had been adopted in one of the many American cities recently [Detroit]". ${ }^{19} \mathrm{~S}$. Hurst Seager proposed in a little pamphlet printed around 1911 that the American capital of Washington, D.C., was the epitome of ideal townplanning and he implied that New Zealand planners would do well to copy its precedent. ${ }^{20}$ After 1900 New Zealand architects such as Chapman-Taylor in Wellington began showing signs of being influenced by British architects such as Charles Francis Voysey (1857-1941), Charles Rennie Mackintosh (1868-1928) and Philip Webb (18311915) and by American architects like Henry Hobson Richardson (1838-1886), Louis Sullivan (1856-1924) and Frank Lloyd Wright (1867-1959). ${ }^{21}$ S.V. Irwin, a rather eccentric lady living in Auckland in 1912, proposed that Auckland's urban planners copy Prefect Baron Georges-Eugéne Haussman's (1809-1891) early nineteenth century plans for the modernization of Paris by following a grand plan for the city replete with boulevardes and places. Irwin stated that the inspiration for this idea had come to her in a vision from the French civil servant himself! She published a small tract to let her ideas.be known which included an illustrated map of the city complete with a proposed

${ }^{18}$ Sir George Fowlds, Planning Auckland for tomorrow (Auckland: 1925), p.2.

${ }^{19}$ NZPD, (June 11 - July 7, 1896), no page.

${ }^{20}$ Samuel Hurst Seager, Washington: America's pre-planned federal capital (Letchworth: ca.1911), p.3. Charles Chilton Papers. (Canterbury Museum).

${ }^{21}$ Martin Hill, New Zealand Architecture (Wellington: School Publications Branch, Department of Internal Affairs, 1986), p.25. 
route for a grand boulevard. This publication also included the transcript of a conversation between herself and the Baron:

I have come to Auckland... for the purpose of designing your city... A city of such great future as Auckland, and still in an embryonic stage of development, is eminently suited for laying out according to artistic lines and avoiding the huge indemnities for expropriation that the town of Paris had to pay for the improvements I effected there. ${ }^{22}$

New Zealand was not alone in turning to the Old World for solutions to its urban predicament. Canadian urban historians are aware of similar town-planning influences from Great Britain and America on the Canadian urban scene. Elizabeth Bloomfield concludes that, "the growing knowledge of city planning ideas and organizations in larger cities of the day", was one of the factors that led directly to Kitchener-Waterloo's municipal self-improvement schemes. ${ }^{23}$ Paul Linteau discusses the impact of foreign ideas on Quebec's development: "through their journals and specialized publications, architects were rapidly informed of new designs... Quebec was not isolated and architects followed with interest what was going on in the rest of the world."24 Linteau cites the influence of Frank Lloyd Wright in the plans for Maisonneuve's fire-station as an example of Canadian architects borrowing from the United States. Gilbert A. Stelter and Alan F.J. Artibise talk about the inspiration which the City Beautiful movement and then the Garden-City idea had on Canadian urban development between the 1890s and World War One:

From the late 1890 s, urban leaders began to call for solutions to the threat which rapid growth seemed to pose for the future of the nation. Contemporary planning concepts from the United States and Britain were proposed for adaptation to the Canadian scene. From the 1890 s to before 1914 , the dominating theme was the City Beautiful movement with its grand designs for aesthetic improvement, but most of these plans never left the drawing board. For a short time before 1914 the emphasis switched to the British-inspired Garden City idea with its concerns for the health

${ }^{22}$ Mrs. S.V. Irwin, What Auckland might be or, A tribute from France (Auckland: 1912), no page.

${ }^{23}$ Bloomfield, p.260.

${ }^{24}$ Linteau, "The Development and Beautification of an Industrial City: Maisonneuve, 1883-1918", p.315. 
and housing of workers... The hopes for "master" plans in most cities fared no better. ${ }^{25}$

Having examined the reasons why urban reform was believed to be imperative in New Zealand, we can now turn to the solutions that were being proffered in Europe and America and which the colony was seeking to implement. City Beautiful and Garden City ideas were some of the initial schemes adapted as a solution for the New Zealand environment. According to Leland Roth's A Concise History of American Architecture (1979), such plans were introduced to the American public by way of the nation's numerous world fairs: "such fairs... brought the City Beautiful movement to thousands of people who delighted in their bright order and the conveyed associations. "26 New Zealand's fairs and exhibitions, particularly the 1906-07 Christchurch Exhibition and the 1925-26 Dunedin Exhibition, would have provided similar opportunities for the colony's citizens to experience such notions first hand. Visitors to the exhibitions would have been sure to see the Nash-inspired grand entrance to the Christchurch exhibition as well as the splendid pavilion grounds of the Dunedin fair. Nor could they have failed to be impressed by the town planning exhibits at the Dunedin venue, with its detailed Garden City model made to scale. [ILLUSTRATION 70] The 1919 New Zealand TownPlanning Conference and Exhibition held in Wellington would have also contributed significantly to popularizing such ideas. Its competition for a Garden City of four thousand people complete with recreational facilities, a library, schools, churches and parks, would have appealed to many New Zealanders who had emigrated from Britain in search of a brighter and better future. ${ }^{27}$

City Beautiful and Garden City schemes in the country were also propagated by way of utopian works like Edward Bellamy's Looking Backwards; 2000-1887 (1887) or

${ }^{25}$ Gilbert A. Stelter, "The City-Building Process in Canada," in Gilbert A. Stelter and Alan F.J. Artibise, eds., Shaping the Urban Landscape: Aspects of the Canadian City-Building Process (Ottawa: Carleton University Press, 1982), p.27.

${ }^{26}$ Roth, p. 216.

${ }^{27}$ A copy of the New Zealand Town Planning Conference and Exhibition Competition can be found in the New Brighton Works Committee Minutes: March 1914 - August 1919. (Canterbury Public Library). 


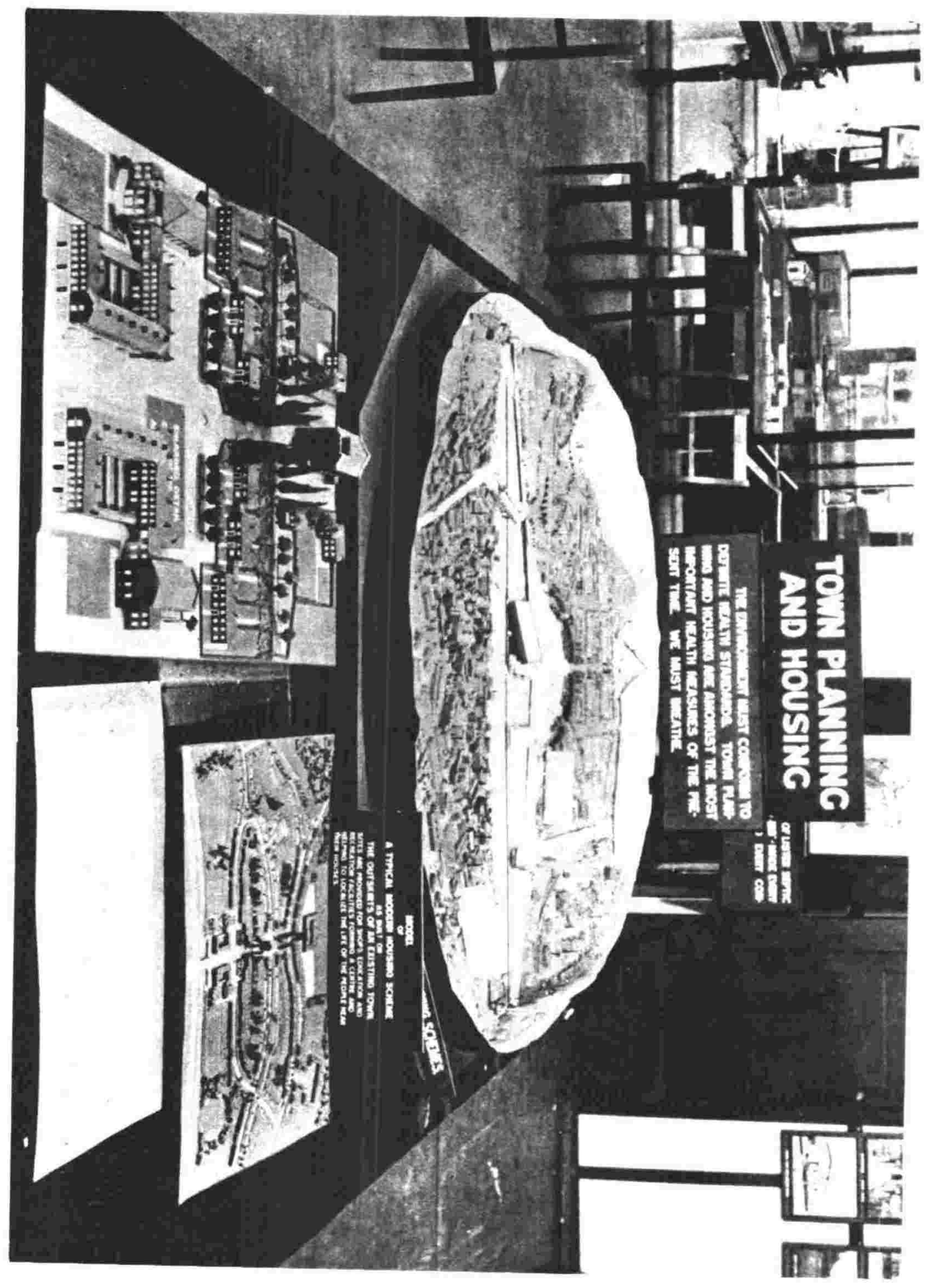

illustration 70 
'The Inhabitant's' The great Romance (1881). ${ }^{28}$ Copies of Bellamy's work sold prolifically throughout New Zealand. ${ }^{29}$ Such urban improvement concepts were spread too by the work of local groups such as the Christchurch Beautifying Association, which as mentioned in Chapter 6, published their own magazine throughout the 1920s called The City Beautiful . This publication contained photographs of tranquil and landscaped worker homes from Garden Cities in England such as Letchworth, which were then contrasted with fenced-up New Zealand bungalows which were located on narrow and crowded lots. The positive images of Letchworth were used as propaganda in order to idealise the British Garden City plan.

The Garden City Movement failed to take hold in New Zealand before 1930 as it had also failed in Canada during this same period. ${ }^{30}$ In New Zealand it was the City Beautiful schemes that received the most attention, but they remained much more

${ }^{28}$ The plot of The great Romance (Ashburton: 1881) involves a man in 1950 taking a sleeping drug only to awaken in a wondrous future in the year 2143 . The protagonist (John Brenton Hope) finds himself wandering around, "an immense city... thickly peopled as the Old London Streets, but... four times their width, and planted with trees along either side." (p.13) However, soon after waking up, Hope leaves the Earth and sets out for an amazing adventure in outer space (including a journey to the planet Venus). The storyline of the New Zealand work is remarkably similar in parts to Edward Bellamy's much more famous Looking backwards; 2000-1887; the latter was published in America six years after the New Zealand novella.

Startling parallels between the two novels abound: firstly, both works are set in a future where crime and violence have been eradicated; secondly, they involve their protaganists sleeping over a hundred years and awaking to find an advanced "golden age"; thirdly, Hope and Julian West (Bellamy's central character) are greeted by friendly guides and given tours of their new world; fourthly, Hope and West were sent to sleep by doctors, one by a potion the other by hypnosis; and lastly, both protaganists fall in love with girls called Edith!

Although The great Romance was published in Ashburton and had presumably limited circulation, could it be that Bellamy had somehow heard of it or even obtained a copy of it? Did Bellamy then borrow the plot of the New Zealand novella for his own work? According to Kenneth Roemer (p.6), such borrowing was not unique to the period, for Bellamy went on to inspire the publication of a number of similar utopian works, such as: Looking Ahead, Looking Beyond, Looking Within, etc...

${ }^{29}$ According to an interview with Lyman Tower Sargent, Bellamy's work sold out the first day it arrived in New Zealand in 1888: "Within 24 hours a pirated edition was on the market... Sales amounted to over 100,000 copies." The Listener (January 27 February 2, 1992), p.27.

${ }^{30}$ See Schraedder (pp.40-45) for a discussion on the impact and influence of the Garden City Movement in New Zealand. 
mundane in their concerns; they tended to stay focused on such every day controversies as deciding on what pattern of ornamental street-lamp the municipal government should choose, where to plant flowers or where to build a commemorative monument or decorative fountain. Utopian works such as Charles Wilson's New Zealand in 1980; a glimpse forward (1919) reflected such City Beautiful anxieties, particularly attempts to beautify the local urban environment by tearing down domestic fences and cleaning refuse from the streets. ${ }^{31}$

A great deal of the debate amongst those of the City Beautiful movement in New Zealand was dominated by a furore over ugly placard advertisements. S. Hurst Seagar, President of the Christchurch Beautifying Association, published pictures of the gruesome future which awaited the city "unless the placarding mania is checked." ${ }^{32}$ John Torrens in a science-fiction/utopian story about an Aucklander's trip to Mars in a home-made rocket, showed the Aucklander's horror at discovering that Martians could understand English, "having acquired it through studying our large placard hoardings with their potent telescopes." 33 Such anxiety over the visual pollution created by commercial advertisements may have stemmed directly from the criticisms of nineteenth century Boston found in Edward Bellamy's work and which proved so popular with New Zealand readers:

Another feature of the real Boston.. was the prevalence of advertising. There had been no personal advertising in the Boston of the twentieth century... but here the walls of the buildings, the windows, the broadsides of the newspapers in every hand, the very pavements, everything in fact in sight, save the sky, were covered with the appeals of individuals who

${ }^{31}$ Charles August Wilson, New Zealand in 1980; a glimpse forward (Auckland: 1919), p.10. The story revolves around a man born in 1920 to shipwrecked parents on a Pacific Island. When he is eventually rescued after sixty years of isolation, he discovers a world very different to that which his Victorian parents described to him. For he finds a positive new world in New Zealand replete with air travel, landscape gardening, skyscrapers no higher than 5 stories in height and traffic control.

${ }^{32}$ Samuel Seager, Our Beautiful World, p.25.

${ }^{33}$ John M. Torrens, A trip to Mars: An "awful venture", a curious message. Being a copy of a circular addressed to the inhabitants of this world, by Mr. H.V. Mundo, the late visitor to the planet Mars (Auckland: Wilson and Horton, 1901), p.11. 
sought, under innumerable pretexts, to attract the contributions of others to their support. ${ }^{34}$

In addition to City Beautiful and Garden City plans, another response to what was perceived by some boosters as an unpleasant urban and industrial environment, was the creation of suburbs: "worker's dwellings in country districts and in the suburban areas of the principal cities... [with] an area of land attached." ${ }^{35}$ The suburb appeared to the city dweller as an ideal "middle landscape", ${ }^{36}$ offering the best of both worlds. For it was in the suburb that the urban worker could find "all of the advantages of 'country' living while at the same time the worker would remain available for urban employment." ${ }^{37}$ Suburban dwellings with their supplementary "garden produce" also had the added attraction of making the "rent most reasonable." 38 The latter was considered of particular advantage during times of severe economic hardship. The optimistic picture of suburban development held by contemporaries of the period is best expressed in a utopian work by G. Warren Russell, New Zealand's Minister of Internal Affairs and Public Health. The story is set in heaven, and Russell's positive depiction of city life there strongly suggests that the same utopian existence is possible in New Zealand should the country's government only introduce a means to secure suburban allotments:

The diversity of the architecture was wonderful... Nor were the streets formed on that pattern of straight lines and right angles which gives so ugly and barren an appearance to most cities of Earth. Here, there was a delightful variety in crescent, curve, and semicircle, which charmed the eye, and gave the homes we passed the appearance of distance, accompanied by privacy... they resembled rather houses in parks, than in a great city. ${ }^{39}$

${ }^{34}$ Edward Bellamy, Looking backwards; 2000-1887 (Dunedin: James Horsburgh, ca.1895), p.92.

${ }^{35}$ Arthur Myers, NZPD (June 27 - August 14, 1912), p.623.

${ }^{36}$ Hamer, New Towns in the New World, p.192.

${ }^{37}$ Hamer, The New Zealand Liberals, p.179.

${ }^{38}$ William Ashby, pp.12-13.

${ }^{39}$ George W. Russell, A new heaven (London: Metheun \& Co. Ltd., 1919), pp.48-49. 
In order to secure this heavenly Jerusalem on Earth by way of City Beautiful, Garden City and various suburban schemes, it was necessary for the government at both the national and the local level to introduce town planning legislation. The United Labour Party of New Zealand called for town planning initiatives to improve city life in its 1912 Municipal Platform. Such measures included: the "erection of worker's homes, and the clearing of slum areas... [the] Improvement of streets, sanitation, and lighting; and strict attention to the general requirements of public health." ${ }^{40}$ In 1911 and 1917 there were attempts by members of Parliament to introduce town planning legislation, although such efforts came to naught. There were calls at various municipal levels for similar legislation. The Town Planning Association in Wellington demanded "The immediate passage of an up-to-date Town Planning Act... providing for Garden City principles being applied to... towns." ${ }^{11}$ These requests also included provisions for financing such schemes, the creation of a Town Planning Department "free from political influence", and the introduction of zoning. ${ }^{42}$ In 1916 a Town Planning Branch was formed in Dunedin. In Christchurch, as a direct result of the 1918 flu epidemic, the city's mayor stated "the necessity for doing something to improve the housing of the poor... he was convinced that much could be done by a Town Planning Association." ${ }^{43}$

Yet despite all the rhetoric about town planning and the apparent support which it seemed to receive amongst most individuals and local bodies, town planning legislation was only eventually passed in Parliament in 1926. It passed in the house by a majority of fifty members and only three stood opposed. According to R.M. Burdon, the Act itself, "appointed a town planning director, set up a town planning board, and required every borough with a population of not less than 1,000 to prepare and submit a town planning scheme before 1 January 1930." ${ }^{44}$ Yet with the onset of the

${ }^{40}$ United Labour Party of New Zealand, Constitution and platform; as adopted April $6-12,1912$, by the Unity Conference and the annual conferences of the Trades and Labour Councils' Federation of Labour and the Labour Party, both of which are now incorporated in the United Labour Party (Wellington: 1912), p.19.

${ }^{41}$ Greater Wellington Town Planning and Municipal Electors' Association, p.2.

${ }^{42}$ Ibid., pp.2-3.

${ }^{43}$ The Lyttleton Times (December 21, 1918), p.10.

${ }^{44}$ Burdon, p. 113. 
Depression, Burdon states that the Bill remained useless as it was subject to continuous delay in implementation. ${ }^{45}$$$
* * *
$$

Yes, they were distraught, but they were also enthralled by their Age of Energy and Age of Reform... Machines threatened the agrarian world view and chained children to factory life, but they also held the promise of less drudgery and more inexpensive goods for farmhand and factory worker alike. Cities were dirty and crime-ridden, but they were also exciting... and a whole world of music, art, and theatre were close at hand. Furthermore, there were indications that many old and new reform battalions were preparing for a full-scale onslaught against the evils of the era... purity crusaders attacked prostitution; powerful temperance groups assailed the triumvirate of alcohol manufacturer, saloon keeper, and politician; it seemed as if there were a cleanup campaign raging against every speck of dastardliness in sight. ${ }^{46}$
\end{abstract}

As Roemer's depiction of the mood in the United States at the turn of the century suggests, utopian idealism saturated the minds of a large number of Americans and was the inspiration behind City Beautiful, Garden City, suburban and town planning ideas. Roemer suggests that given recent technological innovation and a reformist zeal, many Americans were of the opinion that it was still possible to create an ideal society in their country. Gordon Cherry believes that such utopian ideals were also the basis of British town planning; for Cherry envisions town planning as the realization of the myth of the Renaissance utopia in a faraway place: "the ideal state was now possible by social revolution and projects of social experiment..." ${ }^{147}$ This same utopian idealism held true for the motives of many a New Zealand town planner during this time frame. This section of the chapter will focus on the prevalence of utopian thought in New Zealand, and will also include a discussion on the settler's infatuation with recent technological innovation, the likes of which fueled their utopian dreams. The prevalence of Christian evangelicism in the country will also be addressed, in as much as it motivated certain groups and individuals to support town planning initiatives along with other turn-of-thecentury social reforms such as prohibition.
45 Ibid.
${ }^{46}$ Roemer, pp.5-6.
${ }^{47}$ Cherry, Town Planning in its Social Context, p.16. 
Before launching into a discussion on utopian thought in colonial society, it is necessary to clarify the term 'utopia'. As J.C. Davis underscores, the notion of Utopia must be first isolated from four other types of ideal societies with which it is frequently associated, namely: Cockaygne, Arcadia, the Perfect Moral Commonwealth and the Millennium. ${ }^{48}$ According to Davis, utopians appear more "realistic" than their other ideal-society counterparts. Utopians understand that human desires can never be satisfied in this world. And so, unlike the other ideal societies which ignore these desires or which assume either that they can be met or eradicated, the utopian seeks to control by way of organisation, "the social problems that the collective problem can lead to - crime, instability, poverty, rioting, war, exploitation and vice." ${ }^{19}$ Northrop Frye, to whom Davis returns regularly as a source of elucidation on the meaning of utopia, also distinguishes the utopian tradition from the pastoral or arcadian type. He states that, "The utopia is a city, and it expresses rather the human ascendancy over nature, the domination of the environment by abstract and conceptual mental patterns. ${ }^{150}$ Consequently, one of the most important aspects of utopia that allowed it to differ from its other ideal society counterparts, was that the image it presented of an imaginary world, "ought to or might be reached by the young reader's generation within their own lifetime... Without the support of such an idea utopias had a weakened impact..."51 Utopian ideas, subsequently, were intended as an actual guide to social reform. ${ }^{52}$

Gordon E. Cherry underlines the reformist nature of utopian thought with his comments on its prevalence in English society at the close of the century. Cherry says

${ }^{48}$ Arcadia, Cockaygne and the Millennium have been discussed previously in this thesis; only the Perfect Moral Commonwealth tradition remains to be addressed. According to Davis (p.37), the latter tradition assumes a change in the nature of humanity, whereby "Men's desires become limited; limited, in fact, to the satisfactions, both material and sociological, that exist, as a whole and for particular groups or classes." Such a definition stands opposite Cockaygne wherein man's appetites are seen to be given full reign.

49 Ibid.

${ }^{50}$ Northrop Frye, "Varieties of Literary Utopias," in Frank E. Manuel, ed., Utopias and Utopian Thought (Boston: Souvenir Press, 1973), p.41.

${ }^{51}$ Richard Gerber, Utopian Fantasy (London: Routledge and Kegan Paul Ltd., 1955), p. 45 .

52 M. Dupont's L'Utopie et le Roman Utopique dans la Littérature Anglaise (1941) quoted in Gerber, p.xi. 
that it was these very same visions of an ideal city that could actually be attained through enlightened legislation that led to various attempts at city improvement schemes in Great Britain, the most notable of these initiatives being the town planning movement. ${ }^{53}$ Frank Manuel, by pointing out that turbulent times produce utopias to "reflect their economic dislocations and social upheavals", suggests that such visions were also meant to offer a solution to a particular social dilemma. ${ }^{54}$

The reformist intentions of New Zealand's utopian authors are evident by the comments of critics of this genre of literature. Desmond MacCarthy, for instance, brings this point up in the introduction to Samuel Butler's Erewhon and Erewhon Revisited. MacCarthy states that the book's function was the same as that of Gulliver's Travels, whereby "an imaginary civilization is used as a device for criticizing our own." 55 Likewise, A.G. Bagnall says that the inhabitants of the mysterious islands of John Macmillan Brown's Riallaro (1901), "provide a foil for the author's comments on social customs and politics." ${ }^{156}$ It was the intention of Butler and Brown to point out the foibles of society and then provide an alternative vision to the present situation. Lyman Tower Sargent, in an interview with the New Zealand Listener, also comments on the fact that New Zealanders thought it was possible to actually fashion some sort of utopia in their country:

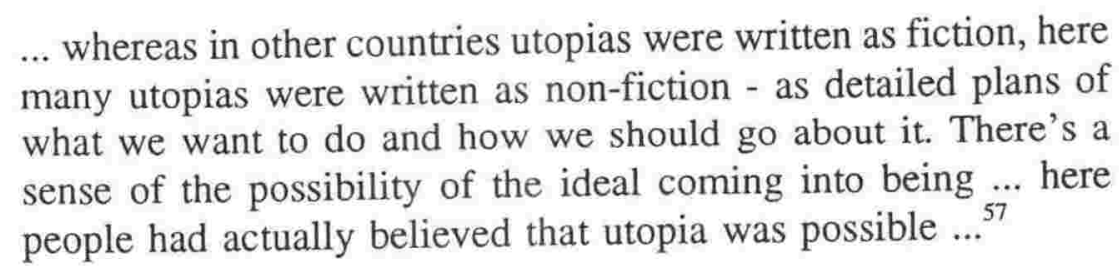

Even Charles Chilton, the President of the Christchurch Beautifying Association, conceived of City Beautiful plans as a vehicle for implementing reformst utopian

${ }^{53}$ Cherry, Town Planning in its Social Context, pp.9-10.

${ }^{54}$ Frank E. Manuel, ed. Utopias and Utopian Thought (Boston: Souvenir Press, 1973), p.xii.

55 Desmond MacCarthy introducing Samuel Butler's Erewhon and Erewhon Revisited (Toronto: J.M. Dent \& Sons, 1932), p.vi.

${ }^{56}$ Bagnall, vol.II, p. 173.

57 Sargent, p.27. 
schemes: "The City Beautiful' is not the name of any existing city. It is the city of our dreams; the city as we would have it to be..$^{158}$

Utopian thought permeated New Zealand thinking throughout the period of this study. As early as 1890 Sir Julius Vogel was describing his fantastic vision of New Zealand in the year 2000, replete with enfranchised women, wave power, anti-magnetic fields, air-cruisers and laser guns. ${ }^{59}$ Edwin Harrow in that same year envisioned a future republic of the English-speaking races, whose "Supreme President" would reside on "a most magnificent floating palace [that] should make tours round all the states throughout the world." 160 In 1901 John Macmillan Brown, professor of Classics and English at Canterbury College, depicted his image of utopia; Brown portrayed it as an island which he called Limanora, whose inhabitants were advanced not only technically with such transportation devices as airships, but who were also spiritually evolved and who did not believe in killing. Brown was concerned mostly with the spiritual dimensions of the Limanorians but he did envision their architecture as being resplendent and grandiose. In 1913 Marshall Hudson published his view of the ideal settlement, one which was directed at abolishing urban problems such as disease, poverty, crime and over-population by creating communities consisting only of young and healthy atheists who were free to marry every year. ${ }^{61}$ Also in 1901, John Torrens's depiction of Mars and its advanced citizenry reflected his vision of a future New Zealand. According to Torrens, Martians were healthy and creative people, the result of a six hour work week four days a week. Torrens also describes Martian city planning as decentralized, and his vision of future habitation patterns calls to mind the ideas of Frank Lloyd Wright's Broadacre City:

Cities on Mars are a thing of the past. What were once cities and towns are now, if favourably situated, the sites of museums, art galleries, music halls, schools etc... Their dwellings... are as

${ }^{58}$ Charles Chilton, The place and function of water in the city beautiful...with photographs... (Christchurch: 1929), cover.

59 Sir Julius Vogel, Anno Domini 2000; or Woman's destiny (London: Hutchinson and Co., 1889).

${ }^{60}$ Edwin Harrow, New Zealand as I have found it, or, The harrowing experiences of a settler at the Lake, Auckland, New Zealand (Auckland: 1890), p.15.

${ }^{61}$ Marshall H. Hudson, Reintribement, or, Proposals for a new departure for the human race (Auckland: Wright \& Jaques, 1913). 
nearly equidistant as the nature of the country will permit, and are models of exquisite design, combining the picturesque with the commodious and healthful... ${ }^{62}$

Contemporaries were aware of the strong vein of utopian thought influencing New Zealand society, particularly urban improvement schemes and social legislation. Robert Irvine and Oscar Alpers in their booster work, note that "There seems to have existed in New Zealand at one time a taste for books depicting 'ideal commonwealths'." Alpers and Irvine go on to state that, "The same taste exists today... but finds expression in utopian legislation rather than in utopian literature."63 Stevan Eldred-Grigg makes mention of utopian tendencies in the ideas of groups such as the eugenists, who proposed to solve urban issues such as over-crowding with 'eugenic garden cities'. Eldred-Grigg states that such cities with their spacious and relaxing grounds, "would provide a fitting environment for sexual intercourse among the 'racially fit'". ${ }^{64}$ According to Peter Coleman, the famous American author Edward Bellamy was a great influence on utopian thinking in New Zealand:

Bellamy's ideas shaped the thinking of labor leaders, politicians, and reformers; crept into parliamentary debates and the editorial pages of liberal newspapers; and brought an entire generation of settlers to new ways of viewing the role of the state in the modern world. ${ }^{65}$

Evidence of utopian planning can also be found in the visual material. In the early 1900s a French visitor to the British colonies in the Antipodes who was caught up in the grand rhetoric over Australian unification, envisioned New Zealand as eventually joining with the Australian federation to create a powerful South Seas

${ }^{62}$ Torrens, p.17. Wright's Broadacres, "took decentralization beyond the small community... to the individual family home. In Broadacres all cities larger than a county seat have disappeared. The center of society has moved to the thousands of homesteads which cover the countryside... Most people work part-time on their farms and part-time in the small factories, offices, or shops that are nestled among the farms. A network of superhighways joins together the scattered elements of society." Robert Fishman, Urban Utopias in the Twentieth Century (New York: Basic Books, 1977), p.9.

\footnotetext{
${ }^{63}$ Robert Irvine and Oscar Alpers, p.391.

${ }^{64}$ Eldred-Grigg, Pleasures of the Flesh, p.151.

${ }^{65}$ Coleman, p. 25 .
} 
Commonwealth. ${ }^{66}$ This Frenchman included in his travel history a painted vision of this imaginary Commonwealth's new capital, the work of another Frenchman, - G. Massias [ILLUSTRATION 71]. The romantic image of this new Australasian capital is comprised of an amalgam of varying architectural styles. In the foreground to the left, the column with the lion resembles a similar decorative feature in the piazza of St. Mark's Square in Venice. To the extreme right, also in the foreground, a Gothic mansion complete with crenellations and conical towers, resembles either a French chateau of the late Medieval period or an English country house of the same time frame. In the distance are a number of Greco-Roman features including columned temples and domed basilicas. Florentine campaniles have also been included in this Classical vision. Landscaped gardens amidst which wealthy upper middle class pedestrians wander on their promenades and golden vistas with pleasure boats drifting serenely on a calm sea, all contribute to the usual optimistic booster panoply. The overall impression which the spectator gets after viewing the painting in its entirety, is that should New Zealand unify with Australia, then the new federation's capital is sure to be a fantastic cultural centre, an Atlantis of the Antipodes.

Utopian idealism, as expressed in attempts at controlling and ameliorating society by way of improving architecture, can also be seen in the comments of New Zealand's planners and politicians. In 1912 there were calls amongst certain municipal groups in Wellington for town planning, which they believed "Makes Better Citizens. ${ }^{167}$ In 1913 architects trying to introduce a Bill to register and provide official qualifications for their profession, based their argument on the fact that good buildings were necessary to preserve social harmony: "...improved and beautified surroundings... exercise an elevating and refining influence upon a people. ${ }^{468}$ Five years later, Sir Robert Stout the former Prime Minister, gave a talk on the need for art in New Zealand society; he based his speech on the premise that: "the environment... has a great influence on our social life. If one is trained in a beautifully-kept city, we expect greater things from the citizen

${ }^{66}$ Comte de Courte, p. 121.

${ }^{67}$ Greater Wellington Town Planning and Municipal Electors' Association, p.8.

${ }^{68}$ New Zealand Institute of Architects, Memorandum on the New Zealand Institute of Architects Bill. A bill to provide for the statutory qualification and registration of architects practising in New Zealand (Wellington: Watkins, Tyer \& Tolan Ltd., 1913), no page. 


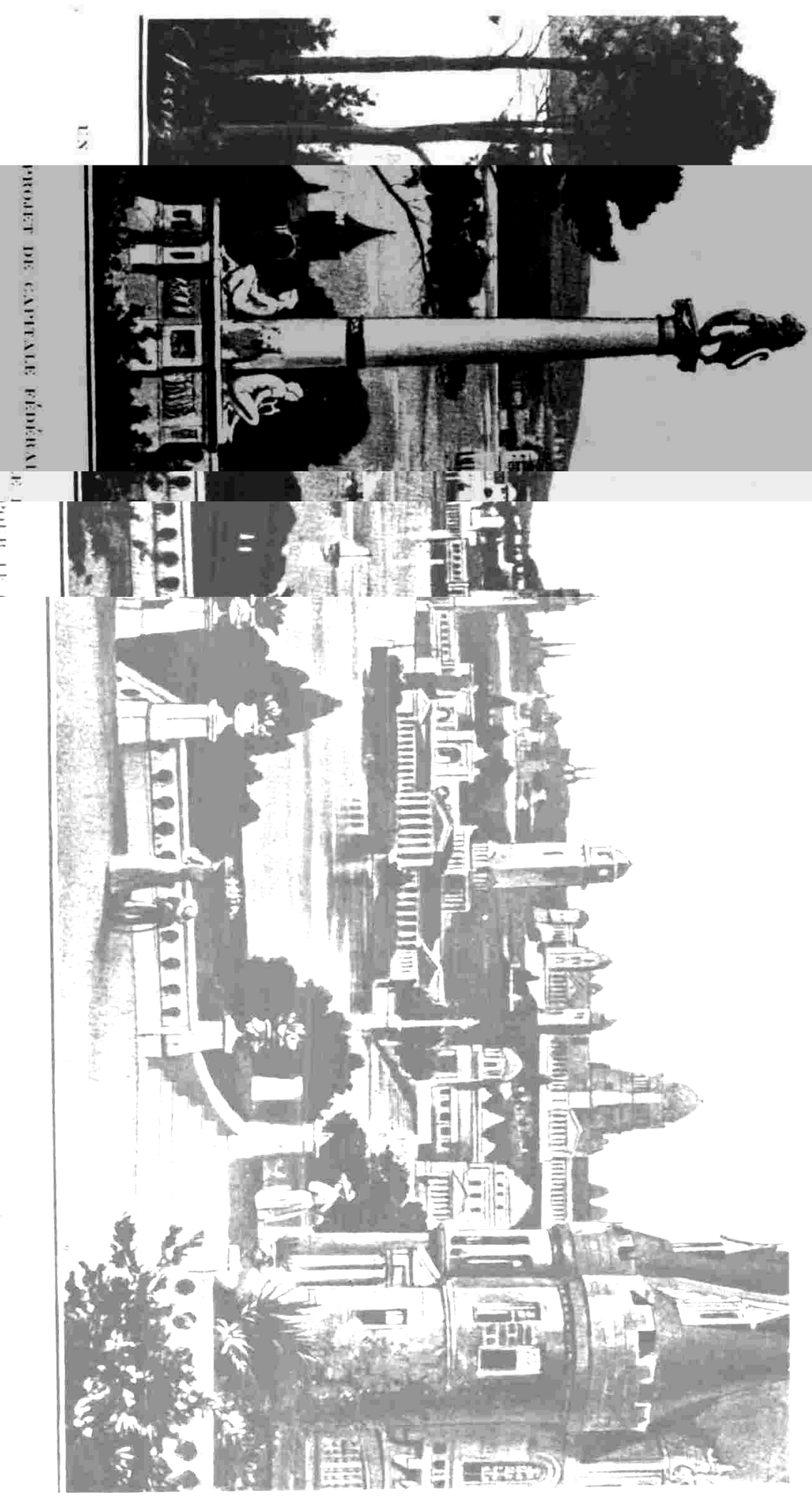


than from one brought up in a slum." ${ }^{169}$ In 1926, during the seemingly endless debates in Parliament over introducing a Town Planning Bill, the then leader of the Opposition Henry Holland, suggested that town planning improved people physically and morally. ${ }^{70}$ According to the art historian Robert Hughes, "the ideal of social transformation through architecture and design was one of the driving forces of modernist culture" between 1880 and $1930 .{ }^{71}$ Hughes quotes the architectural historians Philip Johnson and Henry Russell Hitchcock, who summarized the idealistic motivation behind the International Style of this 1920s: "We were thoroughly of the opinion that if you had good architecture the lives of people would be improved; that architecture would improve people..."172

These utopian aspirations, as mentioned previously, were not unique to New Zealand. Anselm L. Strauss, in writing about the last years of the nineteenth century and the growth of American cities, concludes that "urbanized utopias as a form of idealized planning" were frequently read about by large audiences. ${ }^{73}$ Kenneth M. Roemer argues that the large quantities of utopian literature published from the 1880 s onwards in America, testify to their popularity in that country. ${ }^{74}$ The enormous success of works like Bellamy's Looking Backwards; 2000-1887, would seem to lend credence to such statements. Utopian ideas also greatly affected England. According to Robert Fishman, Bellamy's work "fairly carried away" the English town planner Ebenezer Howard. ${ }^{75}$ The prevalence of such utopian thought in the British Isles can be seen elsewhere too, in the ideas of H.G. Wells, for example; his vision of an urban region in the year 2000 consisted of secluded villages with "small homes and factories set in the open fields, yet

${ }^{69}$ Sir Robert Stout, Art and society; their true relation. Address delivered at the opening of the annual exhibition of the New Zealand Academy of Fine Arts, on Saturday, October 5th, 1918(Wellington, 1918).

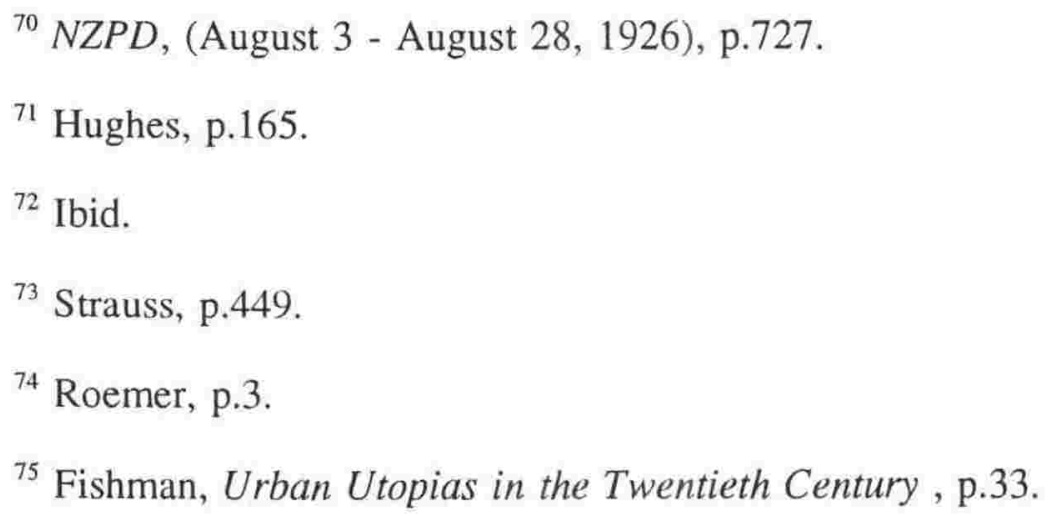


connected by high speed rail transportation..."176 These fantastic utopian ambitions are also evident in Canada. They can be seen in the dreams of wealthy settlers who strove to build a new Troy of one thousand acres on swampland in Beverly County, Ontario, but who succeeded only in creating a hotel and a store; and they are also visible in Thomas Baker McQuesten's (1882-1948) ideal plans for the city of Hamilton. ${ }^{77}$

The realization of such utopian dreams throughout Europe and the English speaking countries appeared all the more possible as the nineteenth century closed and the twentieth century dawned:

The achievements of science and technology obviously had a powerful influence on interventionist thought. It was not difficult to suppose that if men could devise ways to vulcanize rubber, perform surgery under anesthesia, mass-produce steel or transmit messages by undersea cable, they could deal effectively with social and economic questions. ${ }^{78}$

The inventions and theorems which the 1900s introduced seemed to herald a brave new world in as much as they provided a technological impetus to fabricate such ideal visions: "the myth of the Future was born in the atmosphere of millennarian optimism that surrounded the high machine age..." ${ }^{179}$ Maren Lockwood in writing about American utopianism at the turn of the century, expresses a similar view about the boost given to utopian thinkers by the new technology: "For some, this paradise was not a distant hope, but an immediate expectation. Recent technological discoveries and theoretical reformulations seemed to have increased dramatically the pace of social change. ${ }^{180}$ The

${ }^{76}$ Fishman, Bourgeois Utopias, p.187.

.77 The Hamilton Spectator (December 7, 1991), p.C2. Thomas Baker McQuesten was a Hamilton alderman responsible for a variety of civic improvements, including: the creation of the botanical gardens and the building of new roads, parks, and fountains. He also had grand plans (which remained unseen) for the Hamilton escarpment, which included a great boulevard which bordered a scenic canal decorated with Venetianinspired bridges. The whole canal/road complex terminated in a monumental series of steps resembling Rome's monument to Vittorio Emanuelle II.

${ }^{78}$ Coleman, p. 167.

${ }^{79}$ Hughes, p.6.

${ }^{80}$ Maren Lockwood, "The Experimental Utopia in America," in Frank E. Manuel, ed., Utopias and Utopian Thought (Boston: Souvenir Press, 1973), p.184. 
town planner Martin Auster concludes that during the 1920s, "A respect for technical expertise, combined with an essentially mechanical or industrial vision", gave rise to the Technocracy movement and the belief that government by science could positively influence the world. ${ }^{81}$ In Australia and Canada there were comparable optimistic responses to technological change. Graeme Davison states that technological innovations such as the lighting of Melbourne's streets by gas at night, "symbolised the disappearance of the frontier town and the arrival" of a new era in that city's history, one that was "highly civilized'," ${ }^{82}$ In Canada, "the blessings of technology...", were seen by some to usher in "the Millenium... the Summer Time of the World... [and] the New Jerusalem." 183

The new machine age appeared to proclaim that utopias were no longer the stuff of fantasy. The Wright brothers' flight (1903) had made visions of Sir Julius Vogel's air-ships seem a reality; theories on rocket propulsion propounded in 1895 allowed for Torrens's voyage to Mars; the Dunlop pneumatic tyre (1888), the diesel engine (1892) and the Ford car (1893) constrained readers of H.G. Wells to quell their doubts over his vision of the future; and Marconi's invention of radio telegraphy in 1903 even caused Bellamy's Boston to look dated, one hundred years before it was forecast to be conceived! The fact that utopian works began to be confused with the science fiction genre as Northrop Frye pointed out, would seem to substantiate the claim that technology was often indispensable in creating these new optimistic cities of tomorrow. ${ }^{84}$

New Zealanders were not unaffected by this belief in the ability of science to vastly improve the world, and they were vocal about such opinions. Utopian writers such as Marshall H. Hudson believed that, "the discoveries of science" would help humanity on its "slow but irresistible movement upward." ${ }^{85}$ John Torrens asserted that Earth people would soon follow the path of their superior Martian neighbours: "We talk about

${ }^{81}$ Martin Auster, "Construction of the Planning Idea: Britain, the USA and Australia 1929-1939", Planning Perspectives 4 (1989), 211.

${ }^{82}$ Davison, "The Picture of Melbourne 1835-1985", p.17.

${ }^{83}$ Kröller, p. 104.

${ }^{84}$ Frye, pp. 27-28.

${ }^{85}$ Marshall Hudson, p.6. 
living in an advanced age. We are only on the eve of advancement." ${ }^{186}$ The City Beautiful magazine envisioned the new hydro-electric power source as a clean alernative to coal. ${ }^{87}$ Advertisements for promoting gas proclaimed gas pipes as "the perfection of civilization... elements... to refine, elevate, and bless mankind." ${ }^{188}$ Even an epidemic of UFO sightings across New Zealand in 1909 reflected "a public awareness of the coming age of 'Ariel Navigation'" 189 and thus may very well have made the imaginative visions of Torrens and other science fiction and utopian writers seem all the more possible.

The hyperbole expressing so much hype and optimism in the new machine age in New Zealand, can best be ascertained by examining the literature describing incredible transportation and construction feats, a direct result of mechanical innovation. As stated previously in the "Introduction" to this work, railways are an integral part of the urban landscape; they not only represent a visible sign of an urban presence and a powerful force in shaping cities and towns, but they also share similar promotional tactics to those found in the urban booster material, particularly when it comes to optimistic visions of the future. In the transportation field there are a variety of positive pictures depicting a wonderful future awaiting a technologically advanced nation. One Wellingtonian imagined a huge united empire of Great Britain connected by a vast rail network that included a Channel tunnel (a dream nearing completion some one hundred and ten years later) and a tunnel under the Strait of Gibraltar. Although admitting that the notion was "somewhat of a Jules Verne idea", the author believed that the technology to create such a scheme did exist; for according to this person, "Nothing should daunt the engineers of these times." 90 'The Inhabitant', presumably from Ashburton, wrote about space flight to other worlds, specifically Mars and Venus. He asked the reader whether it was possible to "reach them and inhabit them?"91 Shipping agents such as William Ashby

${ }^{86}$ John Torrens, p.22.

87 The City Beautiful, 1, No.12 (1925), p.7.

${ }^{88}$ John Rees George, Gas and some of its uses (Wellington: 1884), inset. p. 15 .

${ }^{89}$ Brian Mackrell, "Epidemic of 1909" in The Christchurch Press (July 8, 1978),

${ }^{90}$ A Wellington Resident, The Federation of the British Empire; or From London to New Zealand in a week (Wellington: 1880), pp.14-15.

91 'The Inhabitant', p.6. 
proclaimed that Jules Verne's Round the World in Eighty Days, which was once "looked on as a satire on locomotion [and]...associated with fairy-tales... is now accomplished by our great ocean liners." ${ }^{192}$ Mark Twain in 1897 praised the New Zealand railway sincerely, yet somewhat ironically, for having a lavatory in each car: "This is progress; this is nineteenth-century spirit." ${ }^{193}$ Canadians were also very enthusiastic about the potential of rail travel; Sanford Fleming, a travel writer in the 1880 s, "declared the railway equal in cultural importance to the discovery of America, the development of the Gutenberg press, and the Reformation." 194

The praises heaped upon New Zealand building techniques in the literature of the period, also reflect a captivation with this new technology and a subsequent unbridled optimism in its potential. In 1882 tribute was showered upon the builders of the Christchurch Exhibition for their speedy erection of the fair grounds in only forty-eight hours, "a marvelous short space of time. ${ }^{195}$ The rapidity of the exhibition's construction and the acclaim which it received in New Zealand resembled the phenomenally quick erection of, and positive reaction to, the 1851 Crystal Palace Exhibition in London. An 1887 description of the Timaru breakwater defying "the fury of the angry surf", reveals a similar optimism in the genius of man, whose technology "has completely conquered some of the mightiest forces in nature. ${ }^{196}$ Visitors to the 1906 Christchurch Exhibition were startled by "the surprising advance made in the Colony in industries, in manufactures..."197 According to James Cowan, these same visitors could not help but be impressed by the same exhibition's fourteen acre pavilion, as it was the "largest

${ }^{92}$ William Ashby, p.59.

${ }^{93}$ Samuel Longhorne Clemens, p.303.

${ }^{94}$ Kröller, p.31.

${ }^{95}$ Christchurch New Zealand International Exhibition, 1882. Record containing Retrospect of the colony, Sketch of exhibitions, complete description of exhibits, compiled by M. Mosley (Christchurch: James Caygill, 1882), p.xcv.

${ }^{96}$ James Inglis, p. 156.

${ }^{97}$ Christchurch New Zealand International Exhibition, 1906-1907, Official Catalogue of the New Zealand International Exhibition, 1906-1907 (Christchurch: Christchurch Press Co. Ltd., 1906), p.65. 
building that has ever been erected in New Zealand." 198 In 1913 reclamation work in ferro-concrete at Auckland's port was being called "the most ambitious scheme in the world of such material..."99 In 1922 Auckland's Grafton Bridge was praised "as having the longest three-hinged arch in the world..." ${ }^{100}$ A few years later Auckland's downtown was being celebrated on account of its skyscrapers: "Modern buildings, up to eight stories in height, are rapidly replacing the older structures." ${ }^{101}$ And in 1919 the Organiser of the Canterbury Progress League was urging Christchurch to switch to electrical power on the grounds that such innovation was necessary for the city's survival:

Yet history is a record of the rise and fall of cities far greater in their day than any New Zealand towns. Babylon, Athens, Rome, Florence, Pompeii, should teach us the folly of depending wholly upon the material forces to maintain communities. It is mankind that builds cities... A community should therefore think progress... ${ }^{102}$

Such positive and quasi-utopian images, a result of an infusion of technological know-how, are also apparent in the visual material of the period. An engraving of Invercargill's railway station in 1895 by William Beverell (ca.1854-ca.1920), is a prime example of the excitement exhibited in this new age [ILLUSTRATION 72]. Approaching storm clouds create an underlining feeling of agitation, of one's hair beginning to stand on end. The clouds seem to absorb all the natural light leaving the darkened silhouette of the town to resemble some sort of mammoth fortification. In the foreground are a number of trains, also darkened. Their blackened bodies look like the battle armour that crusaders' horses might have worn in preparing for a conflict. Some of the trains carry freight goods, others people. The buildings and the locomotives seem

${ }^{98}$ James Cowan, Official Record of the New Zealand International Exhibition...19061907, p.74.

${ }^{99}$ Souvenir of Auckland; a new view album illustrating the queen city of the north (Auckland: ca.1912), p.20.

100 John Barr, The City of Auckland, New Zealand, 1840-1920...Prepared by direction of the Auckland City Council (Auckland: W \& T, 1922), p.200.

${ }^{101}$ Auckland the Beautiful, no page.

${ }^{102}$ P.R. Climie in The Ellesmere Guardian (July 2, 1919), p.66. 


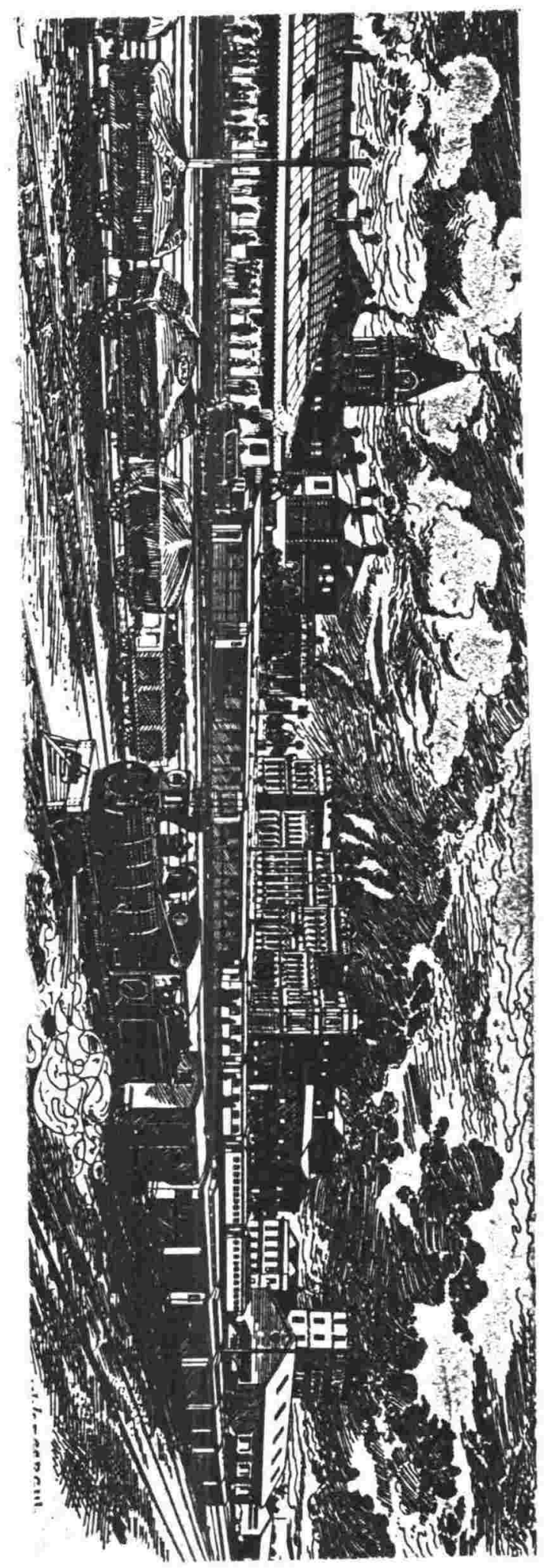

illustration 72 
to stand as powerful icons representing human forces of endurance, speed or steam. The underlying theme of Beverell's etching is one of approaching conflict, a battle between man and nature. In this imminent battle, those mechanical forces mastered by humanity are going to win over nature. For the crowds of people taking shelter from the elements on the train station's platform attest to the fact that they are not going to be driven away by the storm. It appears as though nothing is going to stop business being transacted or the trains from running on time in Invercargill.

According to John R. Stilgoe, trains were envisioned by American contemporaries as representing "powerful [and] romantic" symbols. ${ }^{103}$ Certainly trains (or at least some hint of their presence) are repeated in the booster visual material over and over again. A train overtakes the Australian aborigine in the tourism poster, a train is present in every bird's eye view map, and trains were forever being depicted in photographs and films. E.J. Hobsbawn states that the railway was the symbol of the new age in the nineteenth century: "'railway' became a sort of synonym for ultra-modernity in the 1840 s, as 'atomic' was to be after the Second World War." 104 The railway (or at least a symbol of its presence, - tram tracks), is also apparent in ILLUSTRATION 73: James Fitzgerald's (1869-1945) "High Street, Christchurch; Relaying the tram track" (undated). In Fitzgerald's work, however, there are numerous other symbols of progress and optimism in the future of the city apart from the tram tracks. Substantial granite and brick buildings in the background underscore the feeling that Christchurch is a financially solid city, one that is here to stay. An ornamental fountain in the middleground reveals that the town is not a blackened industrial wen full of repetitive and uninteresting brick tenements, but rather an enlightened city with cultural and artistic taste. Muscle bound workers toiling in the noon heat and surrounded by clouds of dust, underscore the theme that the city is prosperous and expanding. Rosemary Donegan, a Canadian art historian writing about urban images in Canada, substantiates the claim that the urban worker represented progress and action; she says that "The muscle bound male worker was... a traditional image of work."105

\footnotetext{
${ }^{103}$ Stilgoe, p.3. p.89.

${ }^{104}$ E.J. Hobsbawn, Industry and Empire (London: Weidenfeld and Nicolson, 1968),
}

${ }^{105}$ Donegan, p.viii. 


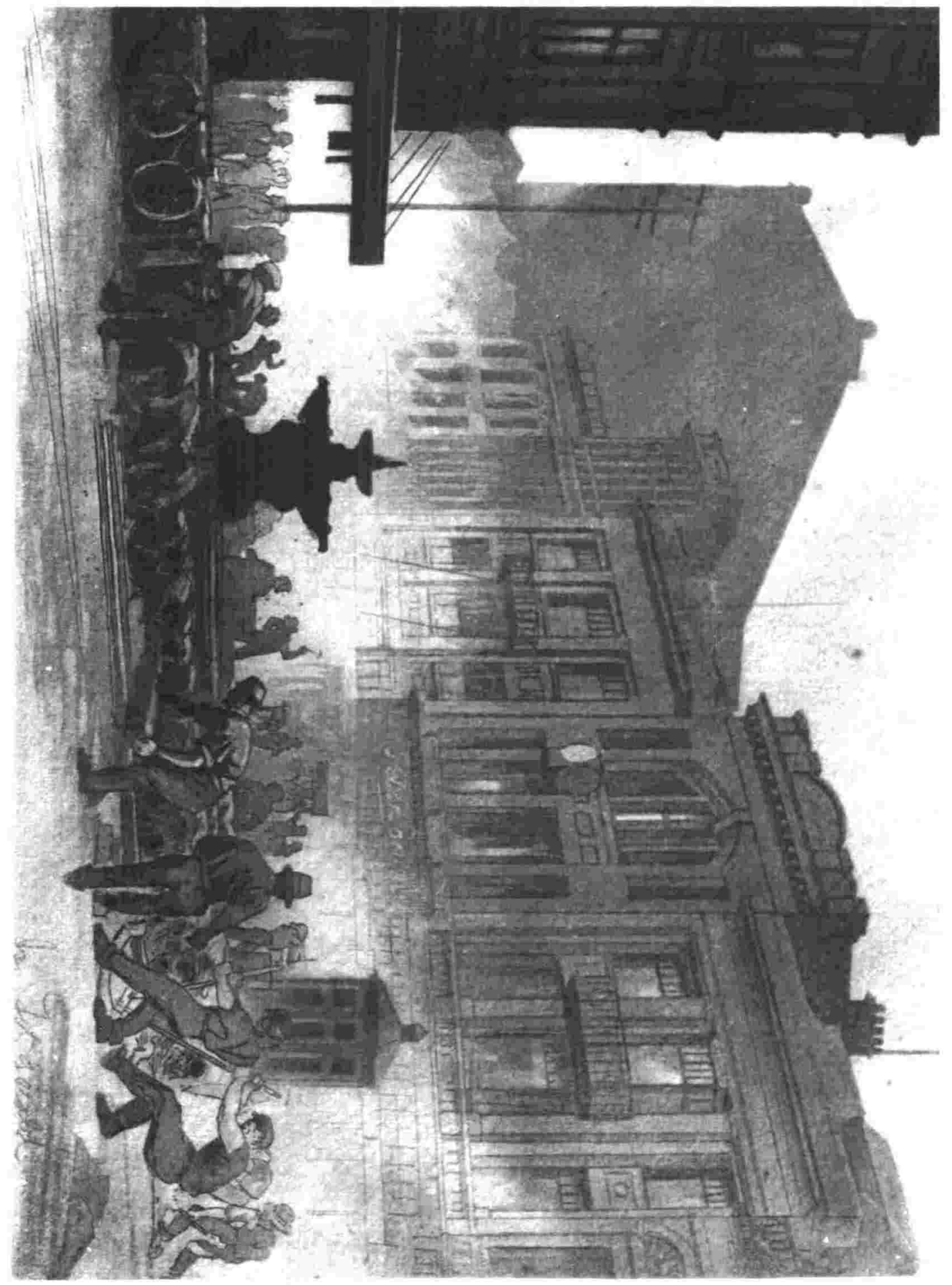

illustration 73 
The last depiction to be discussed in relation to utopian idealism being positively influenced by technological innovation, is also the most fantastic and the most obvious. It is the Auckland Electric Power Board's 1930 advertisement for the tremendous electrical city of the future [ILLUSTRATION 74]. The portrait presented by the Board of a future Auckland is of a magnificent and fabulous skyline resembling that of New York's. Skyscrapers countless stories in height, floating dirigibles, mammoth spotlights, and strange and wonderful aircraft, fill up the view creating an image comparable to that found in an H.G. Wells novel or on a Flash Gordon filmset. In the foreground, however, are typical booster images including some greenery, a well-off couple and a number of automobiles, all symbols of progress, wealth and aesthetic beauty.

\section{***⿰冫⿰亅⿱丿丶丶}

Closely allied with the utopian camp and a group that deserves mention before leaving the section on the idealistic motives of the reformers, were the Christian evangelists. They viewed town planning and other municipal improvement schemes as part and parcel of their campaign for moral reform. This group's desire to build "Christ's kingdom on earth", resembled the perfect moral commonwealth tradition in which "Society is to be made harmonic by the moral reformation of every individual..." ${ }^{106}$ According to Stevan Eldred-Grigg, the Puritan reformers in New Zealand were drawn primarily from the middle classes of European society and exerted a political pressure, "out of all proportion to their numbers..." ${ }^{107}$ Eldred-Grigg states that the urban reformers belonged to the same category as those who "fought against gambling, opium, prostitution and secular education." ${ }^{108}$ Eldred-Grigg's point about the multifaceted concerns of the reformers is substantiated when one realizes that a person like George Fowlds who led the temperance movement in the country was also one of the most vehement advocates of town planning reform. Gordon E. Cherry, in referring to British evangelical philanthropists, points out that such groups were not unique to New Zealand in their support for urban reform; on the contrary, in Great Britain they were responsible for giving "a particular stimulus to the activities of

\footnotetext{
${ }^{106}$ Davis, p.27.

${ }^{107}$ Eldred-Grigg, Pleasures of the Flesh, p.132.

${ }^{108}$ Ibid., p. 2.
} 


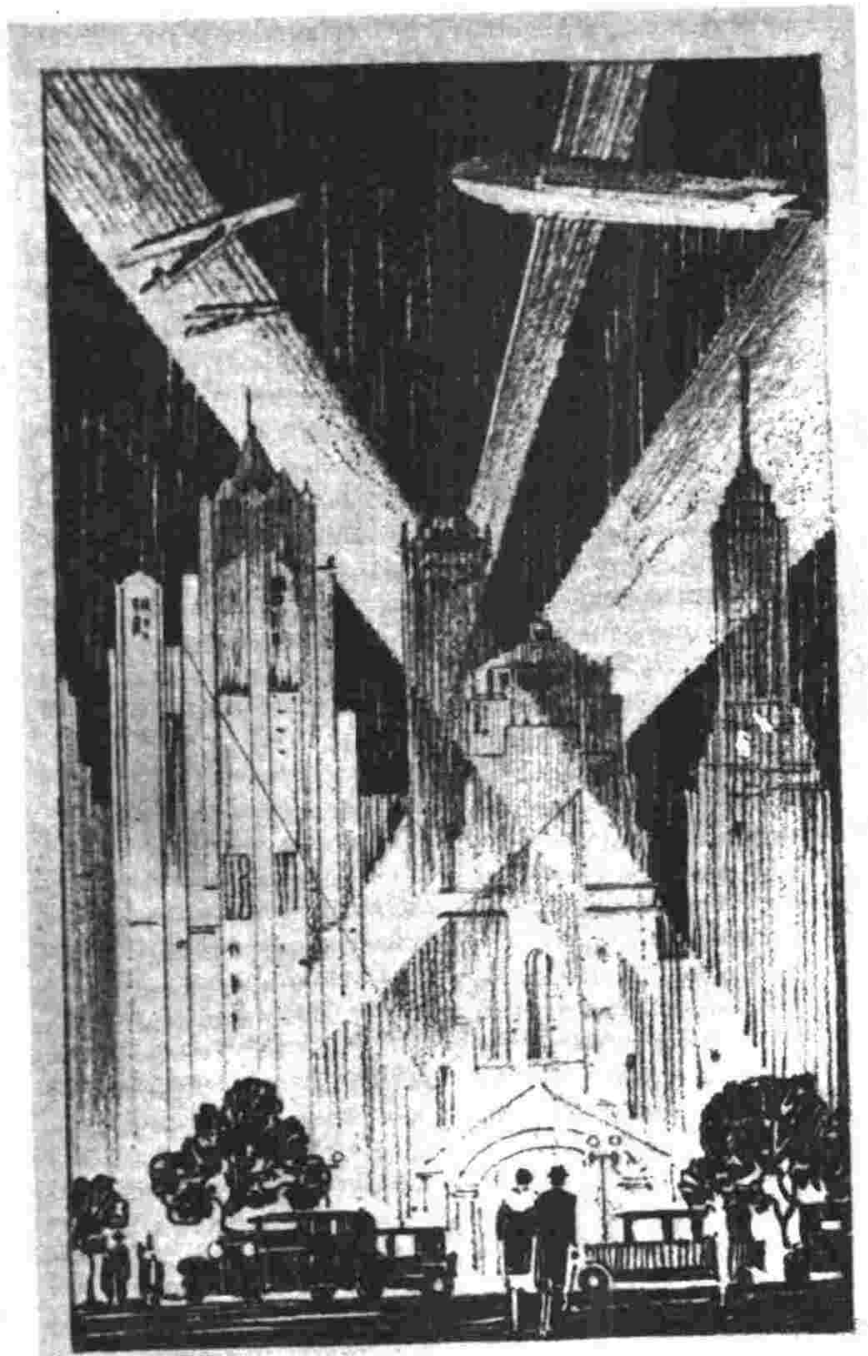

\section{A CITY DE IICUT ఠ POWEI}

illustration 74 
philanthropists in housing reform, manufacturers in improving living and working conditions, and reformers in exposing various social evils..."109

According to Stevan Eldred-Grigg, "Male puritans were often suspected of obscure personal vices." ${ }^{110}$ Urban reformists were also hiding other motives, particularly when it came to town planning or City Beautiful measures. Despite the magnitude of utopian feeling evident throughout New Zealand during this period and the optimism in the new machine age which accompanied it and which was envisioned as providing the impetus for reformers to create their ideal societies, there is a good deal of evidence suggesting that not everybody was motivated by altruistic or philanthropic idealism. Martin Auster states that aesthetics and economics played equal roles in debates over town planning. ${ }^{111}$ According to Patricia Hills, railroad developers and financiers in the United States shared not only a common dream of the train "as a national unifier", but also saw the railroad as a source of "immense profits." ${ }^{112}$ In New Zealand, a number of reform measures also appear to have been implemented or opposed for reasons of self-interest, namely: to enhance property values; and secondly, to create a stable workforce and contented populace so as to reduce the threat of anarchy and to encourage further investment.

Richard E. Foglesong, in writing about the motives of Baron Haussman's redevelopment of Paris in the 1840 s, states that the French planner's primary ambitions were to increase property values and to secure further tourism and investment in the city. ${ }^{113}$ John Weaver, in discussing Western Canadian attitudes towards reform, concludes that reforms were not always initiated for idealistic reasons: "If western cities were "laboratories of reform," they were also real estate casinos and the two features

${ }^{109}$ Cherry, Town Planning in its Social Context, p.18.

${ }^{110}$ Eldred-Grigg, Pleasures of the Flesh, p.132.

111 Auster, p.213.

${ }^{112}$ Hills, p. 127.

113 Richard E. Foglesong, Planning the Capitalist City (Princeton: Princeton University Press, 1986), p.140. 
proved complementary."114 Paul A. Linteau, in writing about the motives of Maisonneuve's boosters, also emphasizes their strong incentive to realize a profit. He cites the example of a Jesuit community in that city that was refused tax exemptions whereas manufacturers were given twenty-five year exemptions! $!^{115}$

In New Zealand, evidence of attempts at profiteering is expressed not in support for reforms but rather in the resistance shown to such improving measures. Evidence of this kind of antagonism to town planning can be seen in the 1926 parliamentary debates over the proposed Town Planning Bill. According to Richard Francis Bollard, the then Minister of Internal Affairs, "A number of local bodies think it [the Town Planning Bill] will take away some part of their powers..."116 Likewise, the member for Wellington South concluded: "We know that on many local bodies there are men whose private interests are opposed to it, such as land speculators... such men usually allow their personal interests to dominate their actions..."117 The Wellington Chamber of Commerce was just such a local body which opposed one aspect of the Town Planning Bill. Although professing to support the main principles of the Bill, the Wellington Chamber of Commerce remained hostile to the Betterment Provision which stated that the value of property would increase with improvement so it should be taxed. ${ }^{118}$ R.M. Burdon concludes that this sort of self-interest was responsible for the continual delays in implementing a Town Planning Bill in the country:

...in 1911 and 1917 bills to establish a central town planning authority were brought before Parliament. Neither became law, mainly because of the pressure brought to bear on members by their constituents, for, fashionable though it might be to pay lip service to the principle of town planning, the fear that its practical application would in some way damage their interests

114 John Weaver, "'Tomorrow's Metropolis' Revisited: A Critical Assessment of Urban Reform in Canada, 1880-1920," in Gilbert A. Stelter and Alan F.J. Artibise, eds., The Canadian City: Essays in Urban History (Toronto: Macmillan, 1979), p.395.

115 Linteau, "The Development and Beautification of an Industrial City: Maisonneuve, 1883-1918", pp.308-309.

${ }^{116}$ NZPD, (August 3 - August 28, 1926), p.699.

${ }^{117}$ NZPD, (August 3 - August 28, 1926), p.710.

${ }^{118}$ Wellington Chamber of Commerce Records: General Minute Books, August 17, 1926, p.78. (Manuscripts, Alexander Turnbull Library). 
was shared by local bodies, associations and individuals alike.
119

Numerous historians and critics of utopian literature, also believe that reforms were not always initiated for their professed idealistic purposes. Instead, they argue that town planning and other city betterment schemes were introduced to ensure a contented workforce and a productive use of land. Northrop Frye in discussing utopian literature, states that its popularity was a result of "the distrust and dismay aroused by extreme laissez-faire versions of capitalism" which in turn threatened anarchy. ${ }^{120}$ According to Paul André Linteau, Maisonneuve's land promoters beautified the city so as to realize a profit on their property investments by securing residents and industry. ${ }^{121}$ Leland Roth states that worker homes were built "to induce skilled labour to stay put." 122 Richard Foglesong concludes that City Beautiful schemes, particularly attempts at beautifying municipal environments with landscaped parks, were started to reduce the threat of violent social unrest by a discontented populace: "[the] overriding objective was the socialization and control of the new urban working class... Public parks were seen by reformers as a way of diverting workers' attention from the world of work..."123

${ }^{119}$ Burdon, p.112.

${ }^{120}$ Frye, p.27.

121 Linteau, "The Development and Beautification of an Industrial City: Maisonneuve, 1883-1918", p.320.

122 Roth, p. 138.

${ }^{123}$ Foglesong, p.91. New Zealand concerns about social unrest have already been discussed (Chapter 9). 


\section{CONCLUSION}

As stated in the "Preface" and the "Introduction", an examination of the booster images of the New Zealand city and town and the surrounding debate on the metropolis and the rate of technological change, is as pertinent today as it was one hundred or so years ago. Having examined the coloured views of New Zealand's cities and towns from 1880 to 1930 , we now turn to the coloured views depicted in the $1980 \mathrm{~s}$ and early $1990 \mathrm{~s}$. However, the relevance of the material is not the only feature of the thesis which requires further comment. A summary of the key points will also follow. This is justified not only for a stylistically correct ending and to underscore the continuity of the images themselves; it is also necessary to emphasize the need for further urban studies in New Zealand, especially those using the multi-disciplinary and comparative methods.

Urban boosters of the 1880-1930 period were concerned with attracting settlement, investment and tourism to their cities and towns, as well as with fostering civic pride in order to keep those immigrants who had already settled down from moving away, particularly during economic hard times. These boosters were comprised of a wide array of peoples and organisations; they included the New Zealand government, local town and city councillors, members of the business community, foreign visitors, and individual New Zealanders who were fond of "blowing". New Zealanders, and to a certain extent Australians, were especially fervent boosters for they had to counter the considerable ignorance expressed at Home and elsewhere about their countries. The geographical distance between the Antipodes, Europe and America, as well as the fact that other nations closer to the mother country (such as America and Canada) were competing for a piece of the booster pie, only underlined the need for further advertising.

In order to promote their cities and towns, New Zealand's boosters undertook a variety of advertising strategies. These included: making representations at international expositions, as well as having their own exhibitions; publishing tourist brochures, city and town guides, and a variety of promotional literature of a similar ilk; compiling civic histories and utopian tracts which were in reality nothing more than thinly disguised promotional pieces; setting up the world's first Department of Tourism and Publicity, with overseas and domestic agencies; and making a great fuss of important foreign visitors to ensure that these people were left with a good impression of their visit, so that they in turn would act as good publicity agents when they returned home. 
. The actual promotional image itself varied. By far the most common tactic consisted of making New Zealand's cities and towns appear as civilised and as attractive (or even more so), than their urban counterparts at Home or elsewhere in Europe and America. Emphasis was placed on such things as: the aesthetic qualities of a particular city or town; its healthy climate; its various cultural attractions such as its museums, art galleries, universities, etc...; the fact that the country's cities and towns were especially cosmopolitan or dynamic; or that they were advanced technically and not just another colonial backwater. Other methods of advertising in the written mode included making grand prophecies of a prosperous future awaiting a particular place, drawing parallels with fairy worlds to describe a place's beauty, and using literary conventions such as alliteration and understatement to attract attention, to name only a few.

In the visual mediums of illustration, painting, photography and film, boosters employed various similar promotional strategies. Critics have developed different labels for these methods of depicting towns and cities. Graeme Davison uses the term 'pastoral landscape' to describe paintings of Australian cities and towns which were usually placed in attractive arcadian surroundings. Peter Bacon Hales calls the American method of photographing cities that contemporaries of the period would have found appealing, the 'Urban Grand Style'. I have utilised the phrase 'Capitalist Realist Art' to describe the optimistic and heroic method of illustrating certain urban and industrial scenes in turn of the century Canada. Yet despite the different labels, the emphasis on stability, orderliness and civilisation in all the images remains constant.

In investigating present-day boosting techniques, we still see the New Zealand Tourism Board, as well as city and regional councils, promoting the country's cities and towns as tourist destinations. ${ }^{1} \quad$ However, groups like Chambers of Commerce are

${ }^{1}$ The New Zealand Tourism Board was established in 1992 by the National Party government. It is an entirely government funded and appointed body created to promote tourism. It replaces the old Department of Tourism and its primary function is to attract tourists to New Zealand. Once in the country, it is the responsibility of city and regional councils, as well as private business, to move visitors around. No longer does the New Zealand Tourism Board have domestic offices that function like travel agents by selling tickets, providing accommodation, etc... Most of the Board's overseas offices are now operated solely to generate travel and interest in New Zealand; they are particularly concerned with educating the travel trade. Like the Department of Tourism and Publicity in 1902, the 1992 New Zealand Tourism Board remains one of the most ardent promoters of the country, with overseas offices in Los Angeles, Vancouver, Chicago, New York, London, Frankfurt, Hong Kong, Taiwan, Tokyo, Singapore, Brisbane, Melbourne and Sydney. 
now almost entirely devoted to promoting business and trade within a region. ${ }^{2}$ No longer are attempts at attracting settlement an issue with any body, although civic pride is still a factor. This emphasis on civic pride features predominantly in Wellington's 1992 "Absolutely Positively" television campaign, whereby pictures of the capital city's many attractions, accompanied by a catchy version of a Neil Diamond song, are meant to instill enthusiasm for the city amongst its inhabitants. According to Alison Corich, Promotions Officer at Wellington City Council, this enthusiasm is intended to be infectious; for it is hoped that local residents praising the virtues of their home town (blowing) will in turn instill a subsequent optimistic response from visitors to the city: "If someone's proud of it [the city] they'll talk about it... it results in a positive perception of Wellington from visitors." ${ }^{3}$

Today tourism remains the sine qua non of the urban boosters. ${ }^{4}$ Tourism has been New Zealand's top foreign exchange earning sector since $1988 .{ }^{5}$ From the first recorded tally of 5,233 visitors to the country in 1903-04, the New Zealand Tourism Board expects some 3 million visitors by the year $2000 .^{6}$ Yet according to various sources, New Zealand still suffers from its geographical isolation and a general level of ignorance

${ }^{2}$ I owe this point to Mike Gilbert, Project Manager with the Wellington Chamber of Commerce. Interview date: 03/06/92.

${ }^{3}$ I owe this point to Alison Corich, Promotions Officer at Wellington City Council. Interview date: 20/05/92.

${ }^{4}$ Although the majority of modern promotional images of New Zealand are directed towards the rural aspects of the country, particularly mountains, beaches, forests, lakes, etc..., there is considerable attention given to the major cities. According to Charles Williams, Market Co-ordinator for the New Zealand Tourism Board, recent emphasis has been on the nation's three "gateway" cities of Auckland, Wellington and Christchurch. Williams states that tourists typically, once they arrive, make their way straight out of the cities to explore the country. The Tourism Board now wants these visitors to spend some time in the cities discovering the cultural advantages offered by them. Interview date: 11/06/92.

${ }^{5}$ Brief leaflet produced by the Ministry of Tourism stating its role and functions. (The Ministry of Commerce, October 1991).

${ }^{6}$ See: 75 Years of Tourism (Wellington: Government Printer, 1977), p.2., and Tourism New Zealand: A Strategy for Growth, a twenty four page booklet published by the New Zealand Tourism Board (1992), p.13. Foreign visitors are not the only tourists in New Zealand, however. There is also an extremely large internal market comprised of New Zealanders who are visiting other parts of the country for recreation, business and family reasons. 
abroad about the country. The special one hour television documentary prepared by Television New Zealand on the New Zealand Pavilion at Seville's 1992 Expo, illustrates this point admirably. New Zealand's journalists revealed that New Zealand itself could not be seen on Spanish television news maps which were used as studio backdrops. Nor were these journalists able to find many people in Seville who knew New Zealand's geographical location; the journalists were informed by two old Spanish women that New Zealand was somewhere way up in the Northern hemisphere, a land of ice and snow. ${ }^{7}$

To counter this present-day international ignorance about the country, booster techniques remain remarkably similar to those used last century. New Zealand devoted a great deal of time and money to a pavilion at Seville's 1992 Expo. Various theatres within this pavilion screened promotional films about "contemporary New Zealand, including... tourist spots and cities." ${ }^{18}$ The New Zealand Tourism Department in the late 1980s and early 1990s produced a number of glossy brochures and magazines meant to attract tourists from destinations such as America, Japan, the United Kingdom, Germany, Canada, Scandinavia, and Hong Kong. In this literature New Zealand's cities and towns are often compared with European capitals. Dunedin is labelled the "Edinburgh of the South" and Christchurch is called "the most English piece of the world not actually in England." ${ }^{19}$ Alliteration is still used as a promotional device, with Wellington being described as a "Culture Capital. ${ }^{10}$ Even comparisons to fairy worlds are also still in vogue. Christchurch and the Canterbury Plains are described as "spellbinding" in one work, while Larnach Castle in Dunedin is depicted as something out of a "fairytale"; ${ }^{11}$

${ }^{7}$ Moment of Truth (Television 1: screened - 26/04/92). The emphasis on the country's isolation is also underlined in National's abridged version of its tourism policy paper, released 23/06/90. Spaniards are not the only ones to be confused about New Zealand's geographical location; an old Canadian school friend believed that New Zealand was a country somewhere up in Northern Europe near Scandinavia!

${ }^{8}$ The Christchurch Press (26/04/92), p.9.

${ }^{9}$ See: The New Zealand Book (New Zealand Tourism Department: 1991/2), p.55; and the New Zealand Tourism Board film New Zealand A World of its Own (ca.1990).

${ }^{10}$ The New Zealand Book, p.38.

${ }^{11}$ Ibid., pp.52 and 55. 
and films produced by the New Zealand Tourism Board retain their fairytale titles such as "New Zealand: The Magic Season".

The comparative booster techniques do not end here. Today, a great deal of emphasis is placed upon New Zealand's urban centres as being dynamic and exciting places full of culture and entertainment. This is evidenced in the New Zealand Tourism Department booklet describing cities such as Auckland, Christchurch and Wellington as "Sophisticated... modern and cosmopolitan, offering world-class hotels, restaurants, cafes, theatres, art galleries and museums, and well-stocked shopping complexes." ${ }^{12}$ Famous or important visitors to the country who responded favourably to what they saw are also mentioned in the tourist literature, the likes of which include: "royalty, presidents and figures like novelist Wilbur Smith, golfer Jack Nicklaus and actor Larry Hagman..."13 New Zealanders travelling abroad are actively encouraged by the New Zealand Tourism Board to act as "unofficial ambassadors" for their country by boasting to foreigners about New Zealand's attributes. In a specially compiled pamphlet designed with this in mind, New Zealanders are asked:

...to talk to them [foreigners] about our country... tell them about picturesque towns and cities... arts and music... The Commonwealth Games... The Wellington International Arts Festival... ${ }^{14}$

According to Charles Williams, visiting media are very important to the Tourism Board. Like those distinguished visitors of old who were escorted about the country and greeted at the ports and railway stations by civic and government officials, journalists, film-makers, and television crews are today waited on hand, foot and finger by the Board when they visit the country; for they are seen as providing a source of valuable publicity for New Zealand when they return home. Even the bizarre or outrageous is still used to promote the country! Wellington is advertised as "the world's most southerly

\footnotetext{
${ }^{12}$ New Zealand (Wellington: New Zealand Tourism Department, January 1991), p.9.
}

${ }^{13}$ Assignment Abroad (Wellington: New Zealand Tourist and Publicity Department, no date), no page.

${ }^{14}$ Ibid., no page. Although this pamphlet was designed by the old New Zealand Tourist and Publicity Department, it is still in use today and a great deal of emphasis is placed upon this programme by the Tourism Board. 
capital"15 in some of the Tourist Department literature, while Napier's Art Deco architecture, a result of the 1931 Hawke's Bay earthquake, is underscored as an interesting tourist destination in the Department's films. ${ }^{16}$

Even the visual booster images of today remain strikingly similar to those employed at the beginning of this century. According to Graeme Davison's work on images of Melbourne, this should come as no surprise to the reader, for "the picture postcards of the $1980 \mathrm{~s} .$. [and other] popular modern views... also have their nineteenthcentury counterparts." ${ }^{17}$ Consequently, present-day bird's eye view postcards of "Wellington's City Centre" taken from an aeroplane or helicopter on a bright sunny day reveal a prosperous and shining South Pacific capital, the envy of any nation. Modern freeways and skyscrapers are seen to rest contentedly alongside a pretty landscaped waterfront and a shining blue sea [ILLUSTRATION 75]. In 1992 the New Zealand Tourism Board, in association with New Zealand Post, even effected a deal whereby some postcards were subsidised or given away free of charge. Despite video replacing nitrate, the promotional images rendered on television screens in the 1990s seem remarkably analogous to those shown on the movie screens of theatres so many years ago. Modern films released by the New Zealand Tourism Board to tourist operators, such as "New Zealand A World of its Own" (ca.1990), are replete with enticing pictures of an English Christchurch full of flower gardens, young boys in school uniforms, and punting along the river Avon; in the same film, Wellington is described as "exciting" and "energetic" when shots of government buildings, the city's night-life, and the Nissan 500 car race accompany the narrator's description.

As seen previously in Chapter 5, the government was not the only organisation to produce publicity films. In the late 1980 s the Wellington City Council also produced a film to promote the city: "Wellington Taking Centre Stage". Although of an inferior quality to the government production, the same municipal attractions receive coverage, albeit in greater detail. ${ }^{18}$

${ }^{15}$ Ibid.

${ }^{16}$ New Zealand A World of its Own.

${ }^{17}$ Graeme Davison, "The Picture of Melbourne 1835-1985", p. 12.

${ }^{18}$ The videos discussed in this section can be located either at the offices of the Zealand Tourism Board or the Wellington City Council. No production information accompanied the cassettes. 


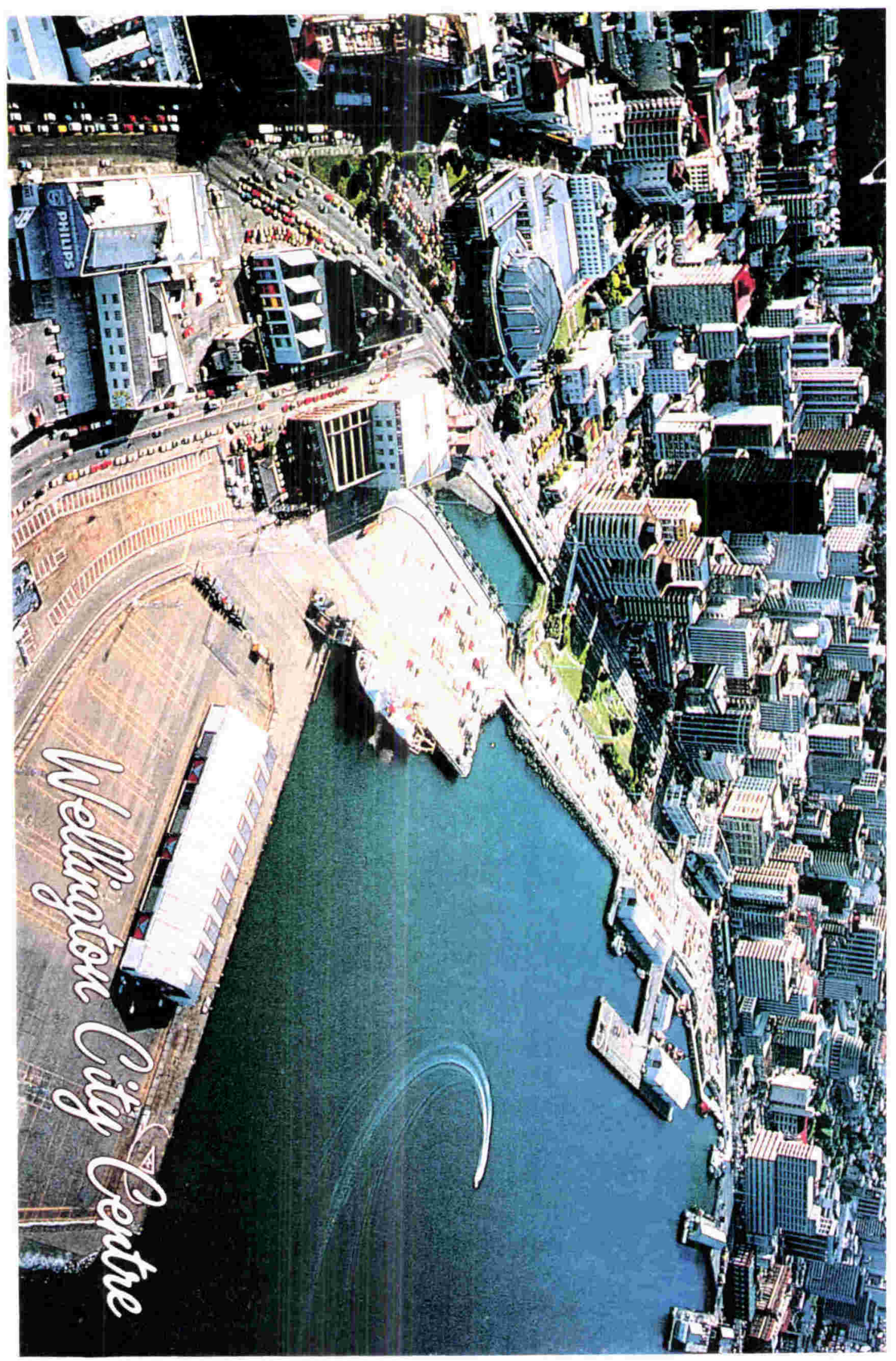


This study of booster propaganda, however, is valuable not only for its topicality. It also serves to illustrate the fact that there exists a much greater volume of discussion on towns and cities than New Zealand historiography in general would have us believe, and that the influence of the country or arcadian myth in attracting settlement and tourism to New Zealand has been decidedly over-emphasized. ${ }^{19}$ This should come as no surprise to the reader considering the fact that the colony's urban population exceeded its rural one by 1911. Nor can defenders of the country myth argue that Garden Cities and various other attempts at bringing the rus in urbe represent a victory for their side; for while nature was certainly brought into the towns and cities through the use of botanic gardens, tree-lined boulevards, public parks and the like, it was always controlled and confined within strict borders. "Coloured Views", therefore, attempts to revise the assumption that "no strong lobby in favour of urbanisation emerged in opposition to the strident claims of those who advocated rural virtues", ${ }^{20}$ or that "There existed no clear, positive endorsement of the city for its contribution to the civilising influences..."21

Although primarily aimed at reverting the imbalance in New Zealand historiography, this study does not go so far as to say which image, the rural or urban one, proved more attractive. It does, however, while recognising the fact that towns and cities have been ignored by New Zealand historians, at least acknowledge the pervasiveness of the rural myth by devoting a whole chapter to the subject (something which similar studies of rural images have failed to do for their urban counterparts). ${ }^{22}$ Nor does this thesis attempt an examination of the effectiveness of the booster material.

${ }^{19}$ The volume of discussion about towns and cities in New Zealand is particularly evident when one looks at the number of booster works listed in A.G. Bagnall's New Zealand National Bibliography. Of the nearly one thousand titles published between 1880 and 1930 which were examined for this thesis, nearly all made some mention of the country's urban centres; many of these concentrated almost exclusively on cities and towns! Emphasis should also be made here on the value of Bagnall as an historical research tool.

${ }^{20}$ Hurricks, p.72.

${ }^{21}$ Lyon, p.308.

${ }^{22}$ Discussion of the urban/rural conflict in New Zealand has automatically assumed that "much of the thinking about the [New Zealand] town was overwhelmingly negative." Lyon, p.308. 
This would have been not only more difficult to gauge but would have also involved a great deal more work than present time or space allow. But the fact that many visitors to the country today are attracted by its nuclear free and clean and green image would go some way towards arguing that those who saw the booster material one hundred years ago would not have remained entirely unaffected by it. David Hamer suggests that such is the case when in his Introduction to New Towns in the New World, he states that: "[the] 'urban frontier' had a substantial influence over the process of settlement..."23

At the same time this thesis does not say that New Zealand scholars have been entirely negligent in examining cities and towns. Geographers, sociologists, town planners, architects and historians have written a substantial body of literature on aspects of urban history, particularly: inter-urban structures, planning, housing, class, manufacturing, business, municipal government, transport, and local studies, to name a few. With the exception of a few individuals in the discipline of History and the recently established (June 1992) Urban History Working Group, however, urban studies per se ("making the town or city itself the object of perception and commentary") ${ }^{24}$ have been virtually ignored.

The fact that the pervasiveness of the rural myth has frustrated a fairer analysis of colonial New Zealand begs the question as to why such a situation occurred in the first place. Primarily the reason lies with historians having ignored certain sources or only having used them in traditional ways. Booster works, for example, have often been frowned upon by urban historians for their non-academic approach and for their uncritical celebration of a particular locality. ${ }^{25}$ Instead, historians, sociologists, demographers and economists, have all tended to prefer more scientific, and hence what they have assumed, were more accurate methods of investigation. Yet if promotional materials are examined with booster biases in mind and with the realisation that they represent not 'reality' but rather "contemporary perceptions", ${ }^{26}$ then local histories,

\footnotetext{
${ }^{23}$ Hamer, New Towns in the New World, p.1.

${ }^{24}$ Ibid., p.4.

${ }^{25}$ Briggs, p.52.

${ }^{26}$ Hamer, New Towns in the New World, p.1.
} 
tourist pamphlets, travel guides, utopian novels, photographic albums, postcards and the like, acquire a new historical validity all their own.

Keeping this in mind, a variety of other largely heretofore ignored sources attain an newly-found accuracy and authenticity as historical documents. Paintings and illustrations by professional artists, for instance, are no longer the demesne of aesthetes admired solely for their visual appeal. Now they begin to assume an important historical significance in their own right. The reinterpretation of American frontier images in art and published in book form as The West As America, highlights such an exercise with its troubling story of westward expansion displayed through pictorial sources. Likewise, such an experiment is equally appropriate for New Zealand pictorial sources. In the case of New Zealand, moreover, the analysis in this thesis does not stop with high art and photography. It goes on to include commercial advertisements, letterheads for industrial firms, bird's eye view maps, and even publicity films produced by the government, the latter being a source which as far as I am aware, has been completed overlooked by historians in New Zealand and yet one which holds a startling array of new research possibilities.

Further new sources of documentation utilised in this thesis (albeit to a much smaller extent) yet which require some comment before moving onto the need for further comparative approaches, are foreign language texts. New Zealand historians of primarily British descent have generally tended to rely only on English language sources for their evidence. ${ }^{27}$ Although a few individuals have examined French texts, there still exists a wealth of untapped and untranslated French material, not to mention Italian, German, Dutch and Spanish works. All of this untouched material presents historians in New Zealand with new and exciting perspectives on their culture, society and history.

After having summarised some of the various urban promotional techniques (both past and present), as well as having underlined the new multidisciplinary approach taken in examining certain sources (notably art and literature), only the use of comparative

${ }^{27}$ This reliance on English language texts was particularly emphasized during the Friends of the Turnbull Library Seminar, "European Sources of New Zealand Culture" (Wellington: June 26-28, 1992). With the exception of a Swedish speaker who was talking about the "Northern rim" of Europe, the contributions from the rest of Europe (Britain aside) remained largely forgotten. The need for further comparative and interdisciplinary studies (with emphasis on gender and race relations) was highlighted during a particularly stimulating debate at the conclusion of the conference. 
studies remains to be discussed. Two key points emerge in this comparative context: firstly, that New Zealand cities and towns were promoted in a similar way and for comparable reasons as their Australian, Canadian and American twins; and secondly, that New Zealand boosters were unique in the degree to which they believed it was possible to actually build a utopia in the Antipodes.

Regarding the first point about New Zealand's similarity to new societies, "Coloured Views" provides a companion text to other studies about boosterism. ${ }^{28}$ It reveals that a common denominator existed in the thinking about cities and towns amongst the promoters in the new world. The intentions of the boosters throughout New Zealand and the rest of the Anglo-American world are seen to have remained firmly fixed on attracting settlement, capital and tourism to their urban centres, although varying amounts of utopian thinking did permeate the ideals of these boosters at different stages in their histories. This study also goes some way in proving that New Zealand was not isolated or alone from events and trends elsewhere in Europe or North America. Rather, there was a phenomenal amount of communication and exchange of ideas and information between Kipling's "Last [and] loneliest" colony and the rest of the industrialised and modern world.

Regarding the second key point about utopianism, the fact that the ideal society image promoted today attracted me to New Zealand in the first place, as it did a great many other fellow travellers with whom I have spoken, speaks volumes for supporting the case that New Zealand had a particularly strong utopian image abroad and one which remains to this day. As mentioned in Chapter 3, the theme of the Antipodes as a kind of haven from Old World threats is prevalent in modern science fiction too. It would appear then that this present day utopian perception of New Zealand is a continuation of the ideal image that was fostered a century before by the nation's urban promoters, and that some or most of the urban boosters between 1880 and 1930 were genuinely influenced by the dream of creating (or having already created!) a utopia in New Zealand.

From the extent of the evidence presented, it would also seem apparent that New Zealand's promoters were unique in the degree to which the utopian spirit pervaded their

${ }^{28}$ Refer particularly to the works of Artibise, Davison, Hales, Hamer and Stelter, as well as my work on Hamilton (Canada), all of which has been cited in the urban history section of the bibliography. 
thinking. Certainly it would appear that Australia, Canada and the United States were not affected to such an extent by notions of utopia during this period. Lyman Tower Sargent, in a discussion of utopian literature written by people in power, echoes this point: "New Zealand is unique in that utopian imagery played a powerful role in directly influencing politics... here people actually believed that utopia was possible." 29 The reason(s) for the pervasiveness of utopian thinking in New Zealand and the extent to which the colony differed from other places, remains to be explored in detail. The question of whether or not this utopia was ever realised in New Zealand, also remains another story. But perhaps as Willis Airey hinted at in the 1920s, in a world threatened by war, pollution, and anarchy, New Zealand was humanity's last hope - the youngest, most blessed, and most distant of the colonies? ${ }^{30}$ The image of the country as a utopian haven, for some at least, has not changed much today. People continue to believe in the paradise myth.

\footnotetext{
${ }^{29}$ Sargent, p. 27.

${ }^{30}$ Willis Airey, p. 10.
} 


\section{BIBLIOGRAPHY}

Primary Sources:

(i) Contemporary books, brochures and papers

(ii) Unpublished official records

(iii) Contemporary newspapers and periodicals

(iv) Manuscripts

(v) Interviews

(vi) Official publications

(vii) Contemporary films and lantern slides

(viii)Modern promotional material

Secondary Sources:

(i) Urban history

(ii) Utopian literature

(iii) Art and architecture

(iv) General

(v) Newspapers

Primary Sources:

(i) Contemporary books, brochures and papers

Acton, R. Our Colonial Empire. London: Cassel, Petter, Galpin and Co., 1881.

Album of Christchurch and Dunedin N.Z. ca.1885.

Adlam, Alys (Lowth). Emerald hours in New Zealand. Wellington: W \& T., 1907.

Airey, Willis Thomas Goodwin. New Zealand a nation. Christchurch: New Zealand Student Christian Movement, ca.1925.

Akaroa Advancement Committee. Lovely Akaroa. Akaroa: ca.1891.

Alley, Frederick James. Back to the Land! Now and how. Auckland: 1930.

Alpers, Oscar Thorwald Johan. Cheerful Yesterdays...With a preface by the Earl of Birkenhead. London: John Murray, 1928.

Ashby, William. New Zealand The Land of Health, Wealth and Prosperity. Its present position and future prospects. 1889

Auckland Advertising Club. Handbook and Programme [of] New Zealand Advertising Exhibition inaugurated...under the direction of the Auckland Advertising Club to be opened...on Tuesday, June 28, at 2 p.m., Town Hall, Auckland... Auckland: 1927.

Auckland Arts and Crafts Club. Catalogue of the first annual exhibition held at Coburg Street, Auckland. Open 1st November 1912... Auckland: 1912.

Auckland from the air, 1930. Auckland: Sun Newspapers Ltd., 1930.

Auckland Electric-Power Board. A city of light \& power. Auckland: Carlton-Carruthers Ltd., 1930.

Auckland Industrial, Agricultural and Mining Exhibition, 1913-14 Official Accomodation Directory. Auckland: 1913. 
Auckland Industrial, Agricultural \& Mining Exhibition, official catalogue and guide.

Auckland: Brett Ptg and Publg Co. Ltd., 1913.

Auckland the Beautiful. Auckland: Frank Duncan \& Co., 1926.

Australia To-Day and New Zealand. Melbourne: The United Commercial Travellers'

Association of Australasia Ltd., 1906.

Ball, John. Wanganui, pretty, prosperous and progressive. Christchurch: 1901.

Ballantyne, Rev. James. Our Colony in 1880. Melbourne: M.L. Hutchinson, 1880.

Ballou, Maturin Murray. Foot-prints of travel; or, Journeyings in many lands. London: Ginn \& Company, (1888?),85-104.

Bandmann, Daniel E. An actor's tour or Seventy Thousand Miles with Shakespeare. Boston: Cupples, Upham and Company, 1885.

Baring, Maurice. Round the world in any number of days... London: Chatto \& Windus, (1919),96-109.

Barr, John. The City of Auckland, New Zealand, 1840-1920...Prepared by direction of the Auckland City Council. Auckland: W \& T, 1922.

---- Municipal and official handbook of the city of Auckland, New Zealand. Prepared by direction of the Auckland City Council. Auckland: Wilson \& Horton, 1922.

Bates, Emily Katharine. Kaleidoscope: Shifting scenes from east to west. London: Ward and Downey, 1889.

Bathgate, John. New Zealand its resources and prospects. London: W \& R Chambers, 1880.

Beattie (W.) \& Co. From city to city; Views of the North Island main trunk railway. Auckland: W. Beattie \& Co., ca.1910.

Beautiful Napier. (Hawke's Bay, N.Z.) From a visitor's point of view. Napier: 1900.

Beautiful New Zealand; cities, townships and beauty spots; the scenic paradise of the world, the home of the Maori. Wellington: C.B. \& Co. Ltd., ca.1905.

Bell, George W. Mr. Oseba's last discovery. Wellington: The New Zealand Times Co. Ltd., 1904.

Bellamy, Edward. Looking backward; 2000-1887. Dunedin: James Horsburgh, ca.1895.

Bishop, Walter K. Guide to Wellington \& District. Wellington: Walter Bishop, 1882.

Bolitho, Henry Hector. The New Zealanders...illustrated by Harry Rountree. London: J.M. Dent \& Sons Ltd, 1928.

Boyce, William Dickson. Australia and New Zealand Illustrated. New York: Rand McNally \& Co., 1922.

Bracken, Thomas. The New Zealand Tourist. Dunedin: Union Steam Ship Company of New Zealand (Limited), 1879.

Bradshaw, John. New Zealand as it is. London: Sampson Low, Marston, Searle, \& Rivington, 1883.

---- New Zealand of to-day (1884-1887). London: Sampson, Low, Marston, Searle, \& Rivington, 1888.

Brown, John Macmillan. Riallaro, the archipelago of exiles, by Godfrey Sweven. London: G.P. Putman's, 1901.

Brown, Robert. The Countries of the World: Being A popular description of the various continents, islands, rivers, seas, and people of the globe. London: Cassell, Petter, Gilpin \& Co., 1880.

Brown, William Towers. Notes of Travel Extracts from home letters written during a two years' tour round the world, 1879-1881. London: R. Clay, Sons, and Taylor, (1882), $73-132$. 
Butler, Samuel. Erewhon, or, Over the range. With special introduction by Aldous Huxley and the illustrations and a special design for each chapter made by Rockwell Kent. New York, 1934.

Capra, Giuseppe. La Nuova Zelanda (una Italia australe). Rome: La Società Geografica Italiana, 1911.

Caroline Bay Association, Timaru. Official guide; Timaru and surrounding districts. Timaru: Timaru Post Newspaper Co. Ltd., 1912.

----- Visitors' guide to Timaru and Victoria Cross records. Timaru: The Association, 1929.

Cesary, C. Rev. The beautiful countries or Travels In Australia, New Zealand and Tasmania, through Madras, Colombo and Candy. Calcutta: Cones and Co., (1884),203-236.

Chilton, Charles. The place and function of water in the city beautiful...with photographs... Christchurch: 1929.

Christchurch Art and Industrial Exhibition, 1895. Catalogue of exhibits. Christchurch: 1895.

Christchurch Beautifying Association. First Annual Report 1897-1898. Christchurch: Christchurch Press Co., 1898.

----- The City Beautiful. Christchurch: 1924-1929.

Christchurch New Zealand International Exhibition, 1882. Record, containing Retrospect of the colony, Sketch of exhibitions, complete description of exhibits, compiled by M. Mosley. Christchurch: James Caygill, 1882.

Christchurch New Zealand International Exhibition, 1906-1907. Official Catalogue of the New Zealand International Exhibition, 1906-1907. Christchurch: Christchurch Press Co. Ltd., 1906.

Christchurch on Avon. Christchurch: Smith and Anthony Ltd., 1907.

Cipolla, Arnaldo. Il Mio Viaggio in Oceania, Australia e Insullindia...Disegni originalli di Umberto Zimelli. Milano: Casa editrice Giacomo Agnelli, (1928),45-99.

Clayden, Arthur. The England of the Pacific or New Zealand as an English middle-class emigration-field. London: Wyman \& Sons, 1879.

---- A Popular handbook to New Zealand, its resources and industries. London: Wyman \& Sons, 1885.

The Colony of New Zealand, in two parts. Part I - The North Island. Westminster: 1882 ?

Clemens, Samuel Langhorne. Following the equator; a journey round the world by Mark Twain. London: Harper and Brothers, 1899.

Combined Progress Leagues and Chambers of Commerce of the South Island. The South Island of New Zealand; a tourist guide. Christchurch: New Zealand Newspapers, 1929-30.

Cottrell, Horace Spence. Napier, NZ; sunshine and sea breezes. Napier, 1920.

Couper, William James. A voyage to New Zealand. Edinburgh, (1911),34-47.

Courte, Louis Antoine Marie Joseph Henri, Comte de. La Nouvelle-Zélande. Préface de N. le Baron Hulot. Paris: Librarie Hachette et cie., 1904.

Coutts, James. Vacation Tours in New Zealand \& Tasmania. Sydney: George Robertson, 1880.

Cowan, James. Official Record of the New Zealand International Exhibition of Arts and Industries, held at Christchurch, 1906-7. A descriptive and historical account. Wellington: Government Print, 1910. 
-- The dominion of New Zealand; its characteristics, resources and scenery. Wellington: Government Print, 1911.

The Cyclopedia of New Zealand. Industrial, descriptive, historical, biographical. Christchurch: Cyclopedia Co. Ltd., 1897-1908.

D'Avigdor, Elim Henry. Antipodean Notes collected on a nine months' tour round the world. London: Sampson Low, Marston, Searle \& Rivington Limited, (1888),55200.

Davie, Mort. Tourists' guide to Canterbury. Christchurch: 1902.

Davis, Joseph Upton. Plain talks on "Being Out of Work," "Business is Business,"'Push,"'Gambling,"'Doing Well For Oneself." Dunedin: James Horsburgh, 1880.

-..-- Dunedin City East. An address to the Electors. Dunedin: November, 1881.

Dawson, Edward Walter. The Isles of the Sea; being an entertaining narrative of $A$ Voyage to the Pacific and Indian Oceans... Hartford: Betts \& Co., (1886),510-523.

De Harven, Émile. L'Australasie. Esquisse sur ses Ressources Mercantiles, Industrielles, Agricoles et Minières. Anvers: 1881.

----- La Nouvelle Zélande Histoire, géologie, climat, Gouvernement, institutions, agriculture, Etc... Anvers: 1883.

De Ségur, Vicot H. Gaston. Au Bout du Monde. Une Saison en Nouvelle Zélande. Paris: Librairie Plon, 1901.

Denton, Sherman Foote. Incidents of a collector's rambles in Australia, New Zealand, and New Guinea. Boston: Lee and Shepard, (1889),56-98.

The Descriptive Handbook to the Waikato: Its condition and resources. To which is added A short guide to the Hot Lakes, Province of Auckland, New Zealand. Hamilton: E.M. Edgcumbe \& Co., 1880.

Dilke, Sir Charles Wentforth. Greater Britain: a record of travel in English-speaking Countries. London: Macmillan and Co., (1890),231-282.

Douglas, Sir Arthur Percy. The Dominion of New Zealand. London: Sir Isaac Pitman \& Sons, 1909.

Dunedin Expansion League. An appeal to the loyal citizens of Dunedin and the residents of Otago. Dunedin: Mills, Dick \& Co., 1911.

---- Facts About Dunedin. No.2. Dunedin: a Field for new industries. Dunedin: Dunedin Expansion League, 1913.

-.--- What are we doing! A short resume of work undertaken. Dunedin: The League, 1914.

Dyer, E. Jerome, ed. Victoria and its resources. Melbourne: F.W. Niven \& Co., 1893.

Europa's fate; or The coming struggle A history lesson in New Zealand, A.D. 2076. London: Griffith and Farran, 1875.

Fanning, Leo Stephen, ed. New Zealand today; an authentic illustrated description of the industries \& commerce of New Zealand and the government's policy for the development of the Dominion's rich resources, scenery, sport \& other attractions of the "Brighter Britain of the south". Dunedin: Vivian E. Page, 1925.

Fergusson Ltd. Napier Illustrated including panoramic views of Napier \& Port Ahuriri. Auckland: ca.1920.

53 views illustrating Auckland city and suburbs. Auckland: Fergusson Ltd., ca.1920.

Floyd, John F. Our tour around the world containing a description in brief letters of a tour...through America, Hawaiian Islands, New Zealand...including ten years' residence in New Zealand and Australia. Chicago: Charles H. Kerr \& Co., (1896).

Fowlds, Sir George. Planning Auckland for tomorrow. Auckland, ca.1925. 
Fox, Sir Frank. Oceania...containing...illustrations in colour... London: Adam and Charles Black, (1911),135-199.

Franklin District Advertising Court Committee. Fertile Franklin, the sunshine county; a brief description of the district, its progress and products. Pukekohe, 1929.

Froude, James Anthony. Oceana or England and her colonies. London: Longmans, Green, and Co., 1886.

Garran, Andrew, ed. Picturesque Atlas of Australasia. Sydney: Picturesque Atlas Publishing Company, Limited, (1889), III:531-660.

George, John Rees. Gas, and some of its uses. Wellington: 1881.

Gisborne, William. The Colony of New Zealand its history, vicissitudes and progress. London: E.A. Petherick \& Co., 1888.

Glimpses of New Zealand; being a collection of high class and perfectly finished views of the "Beautiful Britain of the south". Christchurch: New Zealand Publg. Co., 1896.

The Golden North of the South Island; Golden Bay, sunny Nelson, Marlborough the golden. Christchurch: H.W. Bullivant \& Co., ca.1925.

Goldman, Charles Sydney, ed. The Empire and the century; a series of essays on imperial problems and possibilities by various writers. London: John Murray, (1905),462-477.

Gooding, David Paul. Picturesque New Zealand. New York: Houghton Mifflin Co., 1913.

'Grace, Ensign'. Land settlement. In relation to labour, as a solution of the unemployment difficulty. Wellington: 1894.

Grant, James Gordon Stuart. Twenty-five years in Dunein. Dunedin: 1880.

Greater Wellington Town Planning \& Municipal Electors' Association. A brief outline of town planning aims. Wellington: Wellington Publg. Co. Ltd., ca.1928.

Green, Benn, ed. New Zealand tourist and commercial guide; a comprehensive illustrated guide to the scenic, sporting, health and commercial advantages of New Zealand with a foreword by Rt. Hon. G.W. Forbes. Wellington: General Publicity Service Co., 1930.

Greenhough, John Gershom. Towards the sunrising; or, A voyage to the antipodes. London: Arthur H. Stockwell, (1902),99-133.

Grey, James Grattan. Australasia, old and new. London: Hodder and Stoughton, (1901),227-385.

Hall-Jones, Frederick George. Souvenir of Invercargill and Southland (scenic and historical). Invercargill: The Southland Historical Committee, 1949.

Hamer, David, ed. The Webbs in New Zealand 1898: Beatrice Webb's Diary with Entries by Sydney Webb. Wellington: Price Milburn for Victoria University Press, 1974.

Harrow, Edwin. New Zealand as I have found it, or, The harrowing experiences of a settler at the Lake, Auckland, New Zealand. Auckland: 1890.

Harvey, John G. Christchurch; the garden city and its industries. Christchurch: 1924 ?

Haweiss, Hugh Reginald. Travel and Talk; 1885-93-95. My hundred thousand miles of travel through America, Canada, Australia, New Zealand, Tasmania, Ceylon and the paradises of the Pacific. London, (1897), II:110-147.

Hay, William Delisle. The Doom of the great city; being The Narrative of a Survivor, written A.D. 1942. London: Newman \& Co., 1880. 
Hazell, Waltar. The Australian Colonies: Emigration and colonisation. Report of inquiries made by Walter Hazell and Howard Hodgkin...during a visit to Australia, Tasmania and New Zealand, December I886-April 1887. London: 1887.

Herz, Max. New Zealand; the Country and the people. London: T. Werner Laurie, 1912. Hochberg, Fritz. An eastern voyage. A journal of the travels of Count Fritz Hochberg through the British Empire, in the east and Japan. London: J.M. Dent \& Sons Ltd., (1910), I:59-117.

Holland, Henry Edmund. The Machine; friend of man - or rival. Wellington: Clarte Book Shop, 1931.

'Hopeful'. "Taken in;" being, A sketch of New Zealand life. London: W.H. Allen \& Co., 1887.

Houghton, John. Rural New Zealand. The Britain of the south. Auckland: Henry Brett, 1893.

Hubner, Joseph Alexander, Graf von. Through the British Empire. London: John Murray, (1886), I:169-247.

Hudson, Marshall H. Reintribement, or, Proposals for a new departure for the human race. Auckland: Wright \& Jaques, 1913.

Ilott, J. Ltd. Wanganui, New Zealand's river city. Wanganui: Wanganui Chronicle Co. Ltd., 1924.

The imperial album of New Zealand scenery depicting scenes, cities, industries and interesting phases of New Zealand life. Preface by Sir Robert Stout. Wellington: McKee \& Gamble and Wheeler \& Son, 1899.

The immigrants prospects in New Zealand. Handbook of Information, Resources, Advantages and Attractions, Soil, Climate, Products, Trade \& Wages. London: F.W. Hetherington, 1883?

Industrial Corporation of New Zealand. Exhibition of New Zealand industries, Christchurch 1922. Christchurch: 1922.

Inglis, James. Our New Zealand cousins. London: Sampson Low, Marston, Searle, and Rivington, 1887.

'The Inhabitant'. The great Romance. Ashburton: 1881.

Irvine, Robert Francis and Alpers, O.T.J. The progress of New Zealand in the century. London: Linscott Publg. Co., 1902.

Irwin, Mrs. S.V. What Auckland might be or, A tribute from France. Auckland: 1912. Jones, Fred W. The Monarch of Utopia. Wellington, 1893.

Jubilee history of the city of South Melbourne and illustrated handbook. Periodicals Publishing Co., 1905.

Kelly, John Stuart. Christchurch, the garden city of New Zealand. Compiled from information supplied by the Christchurch City Council, the Chamber of Commerce, the Progress League, Industrial Association, Beautifying Association and the Canterbury Pilgrims' Association. Christchurch: Andrews, Baty \& Co. Ltd., 1925.

Kershaw, Mark. Colonial Facts and fictions Humorous Sketches. London: Chatto and Windus, (1886),192-297.

Lamburn, T.B. New Zealand, North and South Islands. London? 1901 ?

Leech, Thomas Green. Co-operative colony of Ruskin. The most contented people in the world. Why not one in New Zealand? Patea: 1898.

Lloyd, Henry Demarest. Newest England; notes of a democratic traveller in New Zealand, with some Australian comparisons. New York: Doubleday, Page \& Co., 1900. 
Loughnan, Robert Andrew. New Zealand at Home. London: George Newnes, Limited, 1908.

McAdam, Constance. New Zealand; country and people. Christchurch: W \& T, 1925.

MacMurran, C.W. From New York to New Zealand; or, The new century trip... Introduction by His Honour Sir Robert Stout. Wellington: Government Print, 1904.

Mackie, Charles Strickland. A half-century's personal reminiscences of New Zealand, and Garden of South Africa. London: Gould \& Co., 1901.

Mainwaring. New Zealand: Its history, Institutions, and industries. A narrative with statistics. London: 1884.

Mann, J.J. Round the world in a motor car. London: G.Bell and Sons Ltd., (1914),215227.

Maskell, W.M. A Discussion on Earthquakes and Architecture before the Philosophical Society, Wellington. Wellington: 1889.

Mason, George Edward. Round the round world on a church mission. London: S.P.C.K., (1892),51-190.

Michel, Ernest. A travers l'hemisphère sud ou mon second voyage autour du monde. Paris: Librairie Vicor Palme, (1888), 221-347.

Moore, John Murray. New Zealand for the emigrant, invalid, and tourist. London: Sampson Low, Marston, Searle \& Rivington, 1890.

Morgan, Frederick George. An Enquiry into the Causes preventing the settlement of the youth of New Zealand upon the country lands, with Suggestions for their removal. Invercargill: 1884.

---- Agricola \& Mercator. Invercargill: 1887.

---- Land Settlement. Invercargill: 1887.

Morris, Edward Ellis. Pictorial New Zealand With Preface by Sir W.B. Perceval. London: Cassell \& Co. Ltd., 1895.

Morris, Edward Ellis, ed. Cassell's Picturesque Australasia. Melbourne: Cassell \& Co. Ltd., 1889-1890.

Mosley, Montague. Illustrated guide to Christchurch and Neighbourhood. Christchurch: 1885.

Myers, Sir Arthur Mielziner. Proposed Town Planning Bill submitted to conference of local bodies, Auckland, 1st March 1911. Auckland: Brett Publg. Co., 1911.

Napier: a bright and prosperous city. Auckland: The Brett Ptg. and Publg. Co. Ltd., 1907 ?

Napier 30000 Club. The playground of the Pacific; sunny Napier...The tourist's best way through to New Zealand's thermal wonderland. Napier: G.W. Venables \& Co. Ltd., ca.1929.

New Brighton Publicity Committee and the Canterbury Progress League. New Brighton, New Zealand, Canterbury's playground. Christchurch: 1923.

New Plymouth Tourist and Expansion League. New Plymouth, New Zealand. New Plymouth: 1922.

New Zealand and South Seas Exhibition, 1889-90. Official catalogue of the exhibits, preceded by historical introduction and statistics by the editor. Dunedin: The Exhibition Commissioners, 1889.

New Zealand High Commissioner. Information about New Zealand for domestic servants. London: 1912.

New Zealand Institute of Architects. Memorandum on the New Zealand Institute of Architects Bill. A bill to provide for the statutory qualification and registration of 
architects practising in New Zealand. Wellington: Watkins, Tyer \& Tolan Ltd., 1913.

North, Marianne. Recollections of a happy life. London: Macmillan and Co., (1893), II:177-190.

Northcliffe, Alfred Charles William Harmsworth, 1st Viscount. My journey round the world (16 July 1921 - 26 Feb. 1922). London: The Bodley Head Ltd., (1923),2234.

O'Brien, A. The Coming Day. Nelson: Bible and Tract Depot, 1892.

O'Brien, Conor. Across three oceans; a colonial voyage in the yacht "Saorise". London: Edward Arnold \& Co., (1926),127-145.

Onehunga-Manukau Chamber of Commerce. Onehunga, the future industrial town. Auckland: Onehunga-Manukau Chamber of Commerce, 1913.

---- The matchless Manukau, 1877-1927; jubilee souvenir. Onehunga: OnehungaManukau Chamber of Commerce, 1927.

Pallander, Edwin. The log notes of an island wanderer; notes of travel in the eastern Pacific. London: C. Arthur Pearson Ltd., (1901),7-16.

Palmerston North City Council. Highways, railways and seaways lead you to Palmerston North, New Zealand. Palmerston North: H.L. Young Ltd., 1925.

Parsons, Frank. The story of New Zealand. A history of New Zealand from the earliest times to the present with special reference to the political, industrial, and social development of the island commonwealth... Philadelphia: C.F. Taylor, 1904.

Partington, James Edge. Random Rot. A journal of three years' wanderings about the world. Altrincham: (1883),286-375.

Payton, Edward William. Round about New Zealand being Notes from a journal of three years' wanderings in the antipodes. London: Chapman \& Hall Limited, 1888.

Perry, Arthur Vivian. Rough Diary of a Voyage to the Antipodes by a Dartfordian. Dartford: 1885.

Peterson, C.B. and Guy, E.G. New Zealand the wonderland of the Pacific. Rotorua: Combined Motor Transport Companies of Rotorua, 1930?

Phillips, George William. Designs for New Zealand homes and residences comprising over 100 plans, elevations of from 4 to 20 roomed residences. Christchurch: 1909.

Pipkin, Samuel J. A run round the world. Through Canada, New Zealand, Australia, and India. London: King, Sell \& Railton Ltd., (1890),87-128.

Podmore, Percy St. Michael. Rambles and adventures in Australasia, Canada, India, etc... London: L. Upcott Gill, (1909),230-245.

Potter, George. Emigrant's guide to New Zealand: With a description of the colony and its provinces... London: 1889.

Randle, Marie R. Lilts and Lyrics of New Zealand. Dunedin: James Horsborough, 1893.

Reade, Charles Compton. The revelation of Britain. A book for colonials. Wellington: Gordon and Gotch Proprietary Ltd., 1909.

Reeves, William Pember. The fortunate isles (picturesque New Zealand). A paper contributed to the Proceedings of the Colonial Institute, May 12, 1896. Wellington: Government Print, 1897.

---- "New Zealand today". In Charles Sydney Goldman, ed. The Empire and the century; a series of essays on imperial problems and possibilities by various writers. London: John Murray, (1905),462-477.

---- New Zealand painted, by F. and W. Wright, described by Hon. William Pember Reeves, High Commissioner for New Zealand. London: Adam and Charles Black, 1908. 
Reid, Stuart. Three weeks in Southland being the account of a trip to New Zealand partly for pleasure and partly for profit... Melbourne: 1885.

Ringland, W. In Southern Seas. A Trip to the Antipodes. London: Simpkin, Marshall, \& Co., (1888),77-122.

Roberts, J. Herbert. A World-Tour: Being A Year's Diary, written 1884-'85. Liberpool: (1886),460-532.

Russell, George W. A new heaven. London: Metheun \& Co. Ltd., 1919.

Sanderson, Edgar. The British Empire in the nineteenth century; its progress and expansion at home and abroad, comprising a description and history of the British colonies and dependencies. London: Blackie \& Son Ltd., (1899), 6:247-309.

Scholefield, Guy Hardy. New Zealand in evolution, industrial, economic and political...With an introduction by the Hon. W. Pember Reeves. London: T.Fisher Unwin, 1909.

Scenes in New Zealand. Wellington: Tanner Bros. Ltd., ca.1905.

Schwartze, C.E.R. Travels in Greater Britain. Melbourne: Cassell \& Company, Limited, (1885), 117-142.

Seager, Samuel Hurst. Washington; America's pre-planned federal capital. Letchworth: 1911.

----Our Beautiful World. Man's work in the making and marring of it. A lecture delivered to the Christchurch Beautifying Association. Wellington: Harry Tombs, 1911.

Sedgwick, Thomas E. Town lads on imperial farms, with notes on other phases of imperial migration. London: P.S. King \& Son, 1913.

---- Lads for the empire; with notes on other phases of imperial migration. London: P.S. King \& Son, 1914.

Ségur, Victor-Henri-Gaston, Comte de. Au bout du monde: Une Saison en NouvelleZelande. Paris: Librairie Plon, 1901.

Siegfried, André. Democrary in New Zealand. Translated from the 1904 original by E.V. Burns and with introductions by David Hamer and William Downie Stewart. Wellington: Victoria University Press with Price Milburn, 1982.

Smollett, Tobias. Travels Through France and Italy. Frank Felsentein, ed. Oxford: Oxford University Press, 1981.

Souvenir album of 36 postcards, each one different; coloured views of Wellington \& district and West Coast of New Zealand, faithfully reproduced from original photographs. London: G.D. \& D., Co., ca.1910.

Souvenir of Auckland; a new view album illustrating the queen city of the north. Auckland: ca.1912.

Souvenir of the visit to Dunedin, "The city beautiful", by the American Fleet, August, 1925. Dunedin: C.S.W., 1925.

Special pictorial history, New Zealand and South Seas Exhibition 1925-6. Wellington: Coulls Somerville Wilkie Ltd., ca.1926.

Stone, Charles John. History of the Decline and fall of the British Empire by Edwarda Gibbon...Auckland, A.D. 2884. London: Field \& Tuer, 1884.

Stout, Sir Robert. Art and society; their true relation. Address delivered at the opening of the annual exhibition of the New Zealand Academy of Fine Arts, on Saturday, October 5th, 1918. Wellington: 1918.

Taranaki: the garden of New Zealand. Compiled by W. Courtney. London: Howard \& Jones, 1887. 
Thompson, George Edward. Official record of the New Zealand and South Seas International Exhibition, Dunedin, 1925-26. Dunedin: The New Zealand and South Seas Exhibition Company Limited, 1926.

Torrens, John M. A trip to Mars: An "awful venture", a curious message. Being a copy of a circular addressed to the inhabitants of this world, by Mr. H.V. Mundo, the late visitor to the planet Mars. Auckland: Wilson and Horton, 1901.

Trollope, Anthony. Australia and New Zealand. London: Chapman and Hall, (1873), I:143-327.

Turnor, Christopher Hatton. Land settlement for ex-service men in the oversea [sic] dominions. Report to the Royal Colonial Institute. London: Saint Catherine Press, (1920),22-31.

Union Steam Ship Company of New Zealand, Limited. Maoriliand - an - illustrated handbook - to - New Zealand. Melbourne: George Robertson and Co. (Limited), 1884.

---- New Zealand the wonderland of the world. Dunedin: The Union Steam Ship Co. of New Zealand, Limited, 1886 ?

United Labour Party of New Zealand. Constitution and platform; as adopted April 6 12, 1912, by the Unity Conference and the annual conferences of the Trades and Labour Councils' Federation of Labour and the Labour Party, both of which are now incorporated in the United Labour Party. Wellington, 1912.

Unity Press Ltd. Auckland, 1850-1929. Auckland: 1929.

Verne, Jules. A voyage round the world. London: George Routledge and Sons, 1876?

Vickers, Anna. Voyage en Australie et en Nouvelle-Zelande. Paris: Librairie Ch. Delagrave, 1883.

Victoria of to-day. Melbourne: The Daily Australasian Shipping News, 1902.

Vincent, Ethel Gwendoline (Moffat). Forty thousand miles over Land and water The journal of a tour through the British Empire and America. London: Sampson Low, Marston, Searle, \& Rivington, (1885), I:147-238.

Vogel, Sir Julius. The official handbook of New Zealand edited by the Agent-General Parts I and II. London: Edward Stanford, 1883.

Vogel, Sir Julius. Anno Domini 2000; or Woman's destiny. London: Hutchinson and Co., 1889.

Vojnich, Oscar. The island-world of the Pacific; journey notes. Translated from the Hungarian by Arthur B. Yolland. Budapest: Pallas Literary Publg. Co., (1909),46158.

Wakefield, Edward. New Zealand Illustrated. The story of New Zealand and Descriptions of its cities and towns. Wanganui: A.D. Willis, 1889.

---- New Zealand after fifty years. London: Cassell \& Co., 1889.

Ward, John P. Wanderings with the Maori Prophets, Te Whiti \& Tohu: Being reminiscences of a twelve month' Companionship with them, from their arrival in Christchurch in April, 1882, until their return to Pari-haka in March, 1883. Nelson: Bond, Finney \& Co., 1883.

Waters, J.B. Annual Report of the New Zealand Chamber of Commerce. Dunedin: November 1, 1922, Canterbury Museum Library.

Wedderspoon, Richard. The Dominion of New Zealand, Britain's El Dorado of the southern hemisphere. Produced under the auspices of the Government Tourist and Health Resorts Department. Christchurch: Simpson and Williams, 1927. 
---- Pictorial South Canterbury; being a description of the four counties of South Canterbury, the port of Timaru and other principal towns. Christchurch: Simpson \& Williams Ltd., 1924.

Wellington; the capital city of New Zealand. Christchurch: Christchurch Press Co. Ltd., ca.1901.

A Wellington Resident. The Federation of the British Empire; or From London to New Zealand in a week. Wellington: 1880.

Wheeler, William Webb. A glimpse of the isles of the Pacific. St. Joseph, Mo.: Hardman Press, 1907.

Wickham, John Dickson. Ramblings By A Tramp. Auckland: 1888.

Wigram, Sir Henry Francis. The story of Christchurch, New Zealand. Christchurch: Lyttelton Times Co. Ltd., 1916.

Wilmot, Lotti. ...New Zealand beds a sequel to Beds I have slept in...being the experience of a celebrated lecturess and advanced Progressionist while on a New Zealand tour. This history is truthful...and the various characters, although disguised by a non de plume, are still...easily recognised.... Christchurch: 1882.

Wilson, Charles. New Zealand cities. Wellington. Auckland: W \& T, 1919.

Wilson, Charles August. New Zealand in 1980; a glimpse forward. Auckland: 1919.

Wirth, George. Round the world with a circus; memories of trials, triumphs and tribulations. Melbourne: (1925),44-57.

(ii) Unpublished official records

Canterbury Chamber of Commerce: Annual Report of New Zealand's Chambers of Commerce (1922). Canterbury Public Library.

Canterbury Chamber of Commerce: Minutes of the Port and City Committee. Canterbury Public Library.

Canterbury Chamber of Commerce: Special Committee Minutes. Canterbury Public Library.

Canterbury Chamber of Commerce Minutes. Canterbury Public Library.

Canterbury Progress League Minutes. Canterbury Public Library.

Christchurch Bylaws: Financial and Departmental Committee Minutes. Christchurch Civic Offices.

Christchurch City Council Minutes. Christchurch Civic Offices.

Department of Tourism and Publicity Records. National Archives of New Zealand, Wellington.

New Brighton Borough Council Records: 1/28 Rough Council/Committee Minutes. Canterbury Public Library.

New Brighton Borough Council Records: 1/16 Works Committee Minutes. Canterbury Public Library.

New Brighton Committee Minutes. Canterbury Public Library.

New Brighton Inwards Correspondence. Canterbury Public Library.

New Brighton Works Committee Minutes. Canterbury Public Library.

Report of Directors. Christchurch Beautifying Association (1925). Charles Chilton Papers, Canterbury Museum Library.

Wellington Chamber of Commerce Records: General Minute Books. Manuscripts, Alexander Turnbull Library.

(iii) Contemporary newspapers and periodicals 
Australasian Sketcher

Australian Star

Lyttelton Times

New Zealand Graphic

New Zealand Times

Press (Christchurch)

Sydney Mail

(iv) Manuscripts

Charles Chilton Papers. Canterbury Museum.

Derry Family Letters 1879-1937. MS Papers 1043, Alexander Turnbull Library.

Sprackman Papers 1891-1900. Volume 4. MS Sequence, Alexander Turnull Library.

James E. Strachan Papers. Canterbury Public Library.

(v) Official Publications

New Zealand Parliamentary Debates (referred to as NZPD in text).

(vi) Interviews

Alison Corich, 20/05/92.

Mike Gilbert, 03/06/92.

Charles Williams, 11/06/92.

(vii) Contemporary films and lantern slides

All the Government Tourism and Publicity Department films used for this study, such as: "Beautiful Avon" (1928), "Christchurch Scenes" (1928), "Christchurch The Cathedral City" (1925), "Fernland Forests" (1926), "Golden Grain" (1928), "Isle of Enchantment" (1927), "Lakeland" (1926), "Magic Playground" (1935), "Magic Playgrounds" (1927), "The Maritime City" (1930), "New Zealand Fiordlands" (1924), "New Zealand's River of Romance" (1930), "Portals of the Underworld" (1927), "River City - Wanganui" (1929), "Storied Isles" (1927), "Summer Sands" (1926), "Summit Seekers" (1929), "Sunshine City" (1928), "Sword Fishing" (1930), and "Valley of Enchantments" (1930), are in the New Zealand Film Archive, Wellington.

Beaumont Smith Films, "The Adventures of Algy", (1925), New Zealand Film Archive. Henry Thompson lantern slide collection, Canterbury Public Library.

Wellington Chamber of Commerce, "F.E. Tomlinson presents Bigger and Better Wellington" (ca.1926), New Zealand Film Archive.

(viii) Modern promotional material

Assignment Abroad. Wellington: New Zealand Tourism and Publicity Department, ca.1990. 
National Party Tourism Policy Paper. 23/06/90.

The New Zealand Book. New Zealand Tourism Department, ca.1991.

New Zealand Tourism Board film, "New Zealand A World of its Own", (ca.1990).

75 Years of Tourism. Wellington: Government Print, 1977.

Television New Zealand documentary, "Moment of Truth", 1992.

Tourism New Zealand: A Strategy for Growth. New Zealand Tourism Board, 1992.

Wellington City Council film, "Wellington Taking Centre Stage", (ca.1990).

Secondary Sources:

\section{(i) Urban History}

Alessio, Dominic. "A Tale of Twenty Cities: The Urban Environment in American Science Fiction of the 1950s and 1960s." The Journal of Unconventional History (Winter, 1991), 2(2):59-74.

---- "Capitalist Realist Art: Industrial Images of Hamilton, Ontario, 1884-1910." The Journal of Urban History (August, 1992), 18(4):442-469.

Artibise, Alan F.J. "Introduction." In Alan F.J. Artibise, ed., Town and City: Aspects of Western Canadian Urban Development, pp.xvii-xviv, Regina: University of Regina, 1981.

"Boosterism and the Development of Prairie Cities, 1871-1913." In Alan F,J. Artibise, ed., Town and City: Aspects of Western Canadian Urban Development, pp.209-235, Regina: University of Regina Press, 1981.

Auster, Martin. "Construction of the Planning Idea: Britian, the USA and Australia 1929-1939." Planning Perspectives (1989), 4: 207-223.

Bloomfield, Elizabeth. "Reshaping the Urban Landscape? Town Planning Efforts in Kitchener-Waterloo, 1912-1925." In Gilbert A. Stelter and Alan F.J. Artibise, eds., Shaping the Urban Landscape: Aspects of the Canadian City-Building Process,pp.256-303, Ottawa: Carleton University Press, 1982.

Briggs, Asa. Victorian Cities. Auckland: Penguin, 1987.

Cant, R.G. and R.J. Johnston "Regional Development Patterns." In R.J. Johnston, ed., Urbanisation in New Zealand, pp.15-40, Wellington: Reed, 1973.

Careless, J.M.S. Toronto to 1918: An Illustrated History. Toronto: Lorimer and Company/National Museum of Man, 1984.

Cherry, Gordon E. Town Planning in its Social Context. London: Leonard Hill, 1970.

---- Urban Change and Planning; A History of Urban Development in Britain Since 1750. Henley-on-Thames: Foulis \& Co. Ltd., 1972.

Christopher, A.J. The British Empire at its Zenith. Sydney: Croom Helm, 1988.

Cunningham, Colin. Victorian and Edwardian Town Halls. London: Routledge \& Kegan Paul, 1981.

Davison, Graeme. The Rise and Fall of Marvelous Melbourne. Melbourne: Melbourne University Press, 1978.

---- "The Picture of Melbourne 1835-1985." In A.G.L. Shaw, ed., Victoria's Heritage: Lectures to Celebrate the 150th Anniversary of European Settlement in Victoria, pp.12-36. Sydney: Allen \& Unwin, 1986.

----- "Cities and Ceremonies: Nationalism and Civic Ritual in Three New Lands." New Zealand Journal of History (October 1990), 24(2):97-117.

Dyos, H.J. Exploring the Urban Past: Essays in Urban History. David Cannadine and David Reeder, eds. Sydney: Cambridge University Press, 1982. 
Ferrand, Bruce F. "The Borough of New Brighton. An Experiment in Local Government in the Years 1897-1941." M.A., Canterbury University, (1951).

Fishman, Robert. Urban Utopias in the Twentieth Century. New York: Basic Books, 1977.

---- Bourgeois Utopias. New York: Basic Books, 1987.

Foglesong, Richard E. Planning the Capitalist City. Princeton: Princeton University Press, 1986.

Forward, Charles N. "The Evolution of Victoria's Functional Character." In Alan F.J. Artibise, ed., Town and City: Aspects of Western Canadian Urban Development, pp.347-370, Regina: University of Regina, 1981.

Frost, Lionel. The New Urban Frontier. Kensington: New South Wales University Press, 1991.

Gowans, Alan. "The Evolution of Architectural Styles in Toronto." In Gilbert A. Steler and Alan F.J. Artibise, The Canadian City: Essays in Urban History, pp.212-226, Toronto: Macmillan, 1979.

Griffen, Clyde. "Towards an Urban Social History for New Zealand." The New Zealand Journal of History (1986), 20(2):111-131.

Hales, Peter Bacon. Silver Cities. Philadelphia: Temple University Press, 1986.

---- "Photography and the World's Columbian Exposition: A Case Study." The Journal of Urban History (May 1989), 15(3):247-273.

Hamer, David. "Towns in Nineteenth-Century New Zealand." The New Zealand Journal of History (April, 1979), 13(1):5-24.

---- New Towns in the New World: Images and Perceptions of the Nineteenth-Century Urban Frontier. New York: Columbia University Press, 1990.

Holdsworth, Deryck W. "House and Home in Vancouver: Images of West Coast Urbanism, 1886-1929." In Gilbert A. Stelter and Alan F.J. Artibise, The Canadian City: Essays in Urban History, pp.186-211, Toronto: Macmillan, 1979.

Hurricks, P.B. "Reactions to Urbanisation in New Zealand During the Nineteen Twenties." M.A., University of Canterbury, (1975).

Johnston, C.M. The Head of the Lake. Hamilton: Robert Duncan and Company, 1958.

Katz, Michael B. The Peoples of Hamilton, Canada West. Cambridge: Harvard University Press, 1975.

Kilmartin, Leslie and Thorns, David C. Cities Unlimited: the Sociology of Urban Development in Australia and New Zealand. Sydney: George Allen \& Unwin, 1978.

King, Anthony D., ed. Buildings and Society: Essays on the Social Development of the Built Environment. London: Routledge and Kegan Paul, 1980.

Levine, Robert M. "Images of Progress in Nineteenth-Century America."The Journal of Urban History (May 1989), 15(3):304-323.

Linteau, Paul André. "The Development and Beautification of an Industrial City: Maisonneuve, 1883-1918." In Gilbert A. Stelter and Alan F.J. Artibise, eds., Shaping the Urban Landscape: Aspects of the Canadian City-Building Process pp.304-329, Ottawa: Carelton University Press, 1982,

---- The Promoter's City. Toronto: Lorimer and Co., 1985.

Main, William. Wellington Through a Victorian Lens. Wellington: Millwood Press, 1980.

McDonald, R.C. City of Dunedin. Dunedin: Dunedin City Corporation, 1965.

Mumford, Lewis. The Culture of Cities. London: Secker and Warburg, 1938.

Peace, Walter G. "Landscapes of Victorian Hamilton: The Use of Visual Materials in Recreating and Interpreting the Past", McMaster University, (1989). 
Reps, John W. Cities On Stone: Nineteenth Century Lithograph Images of the Urban West. Fort Worth: Amon Carter Museum of Western Art, 1976.

Rider, Nick. Urban History Yearbook, pp.229-232, Leicester: Leicester University Press, 1990.

Rutherford, Paul. "Tomorrow's Metropolis: The Urban Reform Movement in Canada, 1880-1920." In Gilbert A. Stelter and Alan F.J. Artibise, eds., The Canadian City: Essays in Urban History, pp.368-392, Toronto: Macmillan, 1979.

Schmitt, Peter J. Back to Nature. New York: Oxford University Press, 1969.

Schraeder, Ben. "A Peaceful Path to Reform: The Garden City/Suburb Movement in New Zealand/Aotearoa 1900-1930." B.A., Victoria University of Wellington, (1991).

Stange, Maren. "Jacob Riis and Urban Visual Culture: The Lantern Slide Exhibition as Entertainment and Ideology." The Journal of Urban History (May 1989), 15(3):274-303.

Stave, Bruce M. "Introduction." The Journal of Urban History (May, 1989), 15(3):243245.

Stelter, Gilbert A and Alan F.J. Artibise, eds. The Canadian City: Essays in Urban History. Toronto: Macmillan, 1979.

Stelter, Gilbert A. "The City Building Process in Canada." In Gilbert A. Stelter and Alan F.J. Artibise, eds., Shaping the Urban Landscape: Aspects of the Canadian CityBuilding Process, pp.1-29, Ottawa: Carleton University Press, 1982.

Stelter, Gilbert A. and Alan F.J. Artibise, eds. Shaping the Urban Landscape: Aspects of the Canadian City-Building Provess. Ottawa: Carleton University Press, 1982,

Strauss, Anselm L. The American City: A Sourcebook of Urban Imagery. London: Penguin, 1968.

Tipples, Rupert. "Christchurch - The First Garden City." Paper presented to the New Zealand Historical Conference, (1991).

Voisey, Paul. "Boosting the Small Prairie Town, 1904-1931: An Example From Southern Alberta." In Alan F.J. Artibise, ed., Town and City: Aspects of Western Canadian Urban Development, pp.147-176, Regina: University of Regina, 1981.

Weaver, John, "'Tomorrow's Metropolis' Revisited: A Critical Assessment of Urban Reform in Canada, 1880-1920." In Gilbert A. Stelter and Alan F.J. Artibise, eds., The Canadian City: Essays in Urban History, pp.393-418, Toronto: Macmillan, 1979.

---- Hamilton: An Illustrated History. Toronto: James Lorimar \& Co., 1982.

(ii) Utopian literature

Davis, J.C. Utopia and the Ideal Society. Sydney: Cambridge University Press, 1981. Frye, Northrop. "Varieties of Literary Utopias." In Frank E. Manuel, ed., Utopias and Utopian Thought, pp.25-49, Boston: Houghton Mifflin Co., 1966.

Gerber, Richard. Utopian Fantasy (London: Routledge and Kegan Paul Ltd., 1955.

Lockwood, Maren. "The Experimental Utopia in America." In Frank E. Manuel, ed., Utopias and Utopian Thought, pp.183-200, Boston: Houghton Mifflin Co., 1966. Manuel, Frank E., ed. Utopias and Utopian Thought. Boston: Souvenir Press, 1973. Roemer, Kenneth M. The Obsolete Necessity: America in Utopian Writings, 1888-1900. Kent State University Press, 1976.

(iii) Art and architecture 
Anderson, Nancy K. "The Kiss of Enterprise." In William H. Truettner, ed.,The West as America, pp.237-284. Washington: The Smithsonian Institute Press, 1991.

Astbury, Leigh. City Bushmen: The Heidelberg School and the Rural Mythology. Melbourne: Oxford University Press, 1986.

Bonyhady, Tim. The Colonial Image: Australian Painting 1800-1880. Chippendale: Ellsyd Press, 1987.

Broun, Elizabeth. "Foreward." In William H. Truettner, ed.,The West As America, pp.viiix. Washington: The Smithsonian Institute Press, 1991.

Brown, Gordon H. Visions of New Zealand: artists in a new land. Auckland: Bateman, 1988.

Butler, Roger. Australian Prints in the Australian National Gallery. Canberra: Australian National Gallery, 1985.

----- Australian Travel Posters. Josef Lebovic Gallery, 1990.

Collins, Roger and Peter Entwisle. Pavilioned in Splendour: George O'Brien's Vision of Colonial New Zealand. Dunedin: Dunedin Public Art Gallery, 1986.

Crighton, Anne. "Armson and Bank Architecture". In W.B. Armson: A Colonial Architect Rediscovered, pp.17-20. Christchurch: Robert McDougal Art Gallery, 1981.

Docking, Gil. Two Hundred Years of New Zealand Painting. Wellington: Reed, 1971.

Donegan, Rosemary. Industrial Images. Hamilton: Art Gallery of Hamilton, 1987.

Entwisle, Peter. William Matthew Hodgkins and his Circle. Dunedin: Dunedin Public Art Gallery, 1984.

Hill, Martin. New Zealand Architecture. Wellington: School Publications Branch, Department of Internal Affairs, 1986.

Hills, Patricia. "Picturing Progress in the Era of Westward Expansion." In William H. Truettner, ed.,The West as Amercia, pp.97-148. Washington: The Smithsonian Institute Press, 1991.

Honour, Hugh. Neo-Classicism. Auckland: Penguin, 1977.

Hughes, Robert. The Shock of the New. London: BBC Publications, 1981.

Janson, H.W. History of Art. Englewood Cliffs: Prentice-Hall, 1986.

Marchand, Roland. Advertising the American Dream: Making Way for Modernity (19201940). Berkeley: University of California Press, 1985.

Martin, G.H. and Francis, David. "The Camera's Eye." In H.J. Dyos and Michael Wolf, eds., The Victorian City. London: Routledge and Kegan Paul, 1973.

Minson, Marian. Encounter with Eden. (1770-1870). Wellington: National Library of New Zealand, 1990.

Onfilm (February/March, 1990), 7(2):24.

Platts, Una. Nineteenth Century New Zealand Artists. Christchurch: Avon, 1979.

Richardson, John. A Life of Picasso. New York: Random House, 1991.

Roth, Leland M. A Concise History of American Architecture. New York: Harper and Row, 1979.

Seddon, George and David Ravine. A City and its Setting: Images of Perth, Western Australia. Fremantle: Fremantle Arts Centre Press, 1986.

Smith, Bernard. European Vision and the South Pacific. Auckland: Oxford University Press, 1989.

Timms, Edward. "Unreal City - Theme and Variations." In Edward Timms and David Kelley, eds., Unreal City, pp.1-12. New York: St. Martin's Press, 1985. 
Tyler, Linda. "Armson's Early Career: Melbourne, Dunedin, Hokitika." In W.B. Armson: A Colonial Architect Rediscovered, pp. 7-12, Christchurch: Robert McDougal Art Gallery, 1983.

Usher, Robyn. "Armson in Christchurch". In W.B. Armson: A Colonial Architect Rediscovered, pp. 13-16, Christchurch: Robert McDougal Art Gallery, 1983.

Whitford, Frank. "The City in Painting." In Edward Timms and David Kelley, eds., Unreal City, pp.45-64. New York: St. Martin's Press, 1985.

(iv) General

Angus, John. The Ironmasters: the first one hundred years of H.E. Shacklock Limited. Dunedin: H.E. Shacklock Limited, 1973.

Arnold, Rollo. The Farthest Promised Land. Wellington: Victoria University Press, 1981.

Bagnall, A.G., ed. New Zealand National Bibliography to the Year 1960. Wellington: A.R. Shearer, 1969.

Barber, Laurie. New Zealand A Short History. Auckland: Century Hutchinson, 1989.

Belich, James. The New Zealand Wars. Auckland: Auckland University Press, 1986.

Bettelheim, Bruno. "The Child's Perception of the City." In Michael C. Jaye and Anna

Chalmers Watts, eds., Literature and the Urban Experience: Essays on the City and Literature, pp.219-231, New Brunswick: Rutgers University Press, 1981.

Bulgakov, Mikhail. A Country Doctor's Notebook. Translation and introduction by Michael Glenny. London: Collins, 1975.

Burdon, R.M. The New Dominion. Wellington: A.H. \& A.W. Reed, 1965.

Butler, Samuel. Erewhon Revisited. Introduction by Desmond MacCarthy. Toronto: J.M. Dent \& Sons, 1932.

Coleman, Peter J. Progressivism and the World of Reform. Lawrence: University Press of Kansas, 1987.

Condliffe, J.B. New Zealand in the Making. London: George Allen \& Unwin Ltd., 1959.

Dalziel, Raewyn M. The Origins of New Zealand Diplomacy. Wellington: Victoria University Press, 1975.

---- Julius Vogel. Auckland: Auckland University Press, 1986.

Dennis, Jonathan, ed. and Sowry, Clive. "The Tin Shed": The origins of the National Film Unit. Wellington: New Zealand Film Archive, 1981.

Department of Tourism and Publicity. Seventy Five Years of Tourism. Wellington: Government Printer, 1977.

Eldred-Grigg, Stevan. A New History of Canterbury. Dunedin: John McIndoe, 1982.

---- Pleasures of the Flesh. Wellington: Reed, 1984.

Fairburn, Miles. "The Rural Myth and the New Urban Frontier: An Approach to New Zealand Social History, 1870-1940." The New Zealand Journal of History (1975), 9(1):3-21.

----- The Ideal Society and its Enemies. Auckland: Auckland University Press, 1989.

----- "The Farmers Take Over." In Keith Sinclair, ed., The Oxford Illustrated History of New Zealand,pp.185-210. Auckland: Oxford University Press, 1990.

Gibbons, Peter. "Non-fiction." In Terry Sturm, ed., The Oxford History of New Zealand Literature, pp.25-104, Auckland: Oxford University Press, 1991.

Graham, B.D. "The Country Party Idea in New Zealand Politics, 1901-1935." In Robert Chapman and Keith Sinclair, eds., Studies of a Small Democracy, pp.175-198, Auckland: University of Auckland, 1965. 
Hamer, David. "Newest America? Comments on the Perception of New Zealand by American Visitors." In Malcolm McKinnon,,ed., The American Connection: Essays from the Stout Centre Conference, pp.12-24, Wellington: Allen and Unwin, 1988.

---- The New Zealand Liberals. The Years of Power, 1891-1912. Auckland: Auckland University Press, 1988.

---- "Centralisation and Nationalism." In Keith Sinclair, The Oxford Illustrated History of New Zealand, pp.125-152, Auckland: Oxford University Press, 1990.

Hargreaves, R.P. and T.J. Hearn. New Zealand in the Mid-Victorian Era. Dunedin: John McIndoe, 1977.

Hill, Richard S. Policing the Colonial Frontier. Wellington: Historical Publications Branch, Department of Internal Affairs, 1986.

Hobsbawn, E.J. Industry and Empire. London: Wedidenfeld and Nicolson, 1968.

Howe, K.R. Singer in a Songless Land: A Life of Edward Tregear (1846-1931). Auckland: Auckland University Press, 1991.

Kipling, Rudyard. One Lady at Wairakei. Introduction by Harry Ricketts. Wellington: Mallinson Rendel, 1983.

Kröller, Eva-Marie. Canadian Travellers in Europe 1851-1900. Vancouver: University of British Columbia Press, 1987.

Lansbury, Coral. Arcady in Australia: The Evocation of Australia in Nineteenth Century English Literature. Melbourne: Melbourne University Press, 1970.

The Listener. (January 27-February 2, 1992):26-27.

Low, Alan. "An Economic Review." In Ian Wards, ed., Thirteen Facets: Essays to Celebrate the Silver Jubilee of Queen Elizabeth the Second 1952-1977, pp.99-132, Wellington: Government Printer, 1978.

Lyon, R.B. "The Principles of New Zealand Liberal Political Thinking in the Late Nineteenth Century." Ph.D., University of Auckland, (1982).

MacKenzie, John M. Propaganda and Empire: the Manipulation of British Public Opinion, 1880-1960. Manchester: Manchester University Press, 1984.

Marx, Leo. "The Puzzle of Anti-Urbanism in Classic American Literature." In Michael C. Jaye and Ann Chalmers Watts, eds., Literature and the Urban Experience: Essays on the City and Literature, pp.63-80, New Brunswick: Rutgers University Press, 1980.

McGill, David. A Dictionary of Kiwi Slang. Lower Hutt: Mills, 1988.

Millar, J. Halket, The Merchants Paved the Way. Wellington: A.H. and A.W. Reed, 1956.

Nicholls, Roberta. "Elite Society in Victorian and Edwardian Wellington." In David Hamer and Roberta Nicholls, eds., The Making of Wellington, 1800-1914, pp.195225, Wellington: Victoria University Press, 1990.

Oliver, W.H. "Reeves, Sinclair and the Social Pattern." In Peter Munz, ed., The Feel of Truth, pp.163-178, Wellington: A.H. \& A.W. Reed, 1969.

Oliver, W.H. and B.R. Williams, eds., The Oxford History of New Zealand. Auckland: Oxford University Press, 1988.

Olssen, Erik. "Towards a New Society." In W.H. Oliver and B.R. Williams, eds., The Oxford History of New Zealand, pp.250-278, Auckland: Oxford University Press, 1988.

Phillips, Jock. A Man's Country? The Image of the Pakeha Male - A History - . Auckland: Penguin, 1987.

Pilger, John. A Secret Country. London: Jonathan Cape, 1989. 
Shillingsburg, Miriam Jones. At home abroad: Mark Twain in Australasia. University Press of Mississippi, 1988.

Sinclair, Keith. William Pember Reeves. Oxford: Clarendon Press, 1965.

---- A History of New Zealand. Ringwood: Penguin, 1969.

---- A Destiny Apart. New Zealand's Search for National Identity. Wellington: Allen \& Unwin, 1986.

Sinclair, Keith, ed. The Oxford Illustrated History of New Zealand. Auckland: Oxford University Press, 1990.

Stilgoe, John R. Metropolitan Corridor. New Haven: Yale University Press, 1983.

Stone, R.C.J. Makers of Fortune: A Colonial Business Community

and its Fall. Auckland: Auckland University Press, 1973.

Sutch, W.B. Poverty and Progress in New Zealand; a reassessment. Wellington: A.H. \& A.W. Reed, 1969.

Tindall, George Brown and David E. Shi, America: A Narrative History. New York: W.W. Norton \& Co., 1989.

Weiner, Martin. English Culture and the Decline of the Industrial Spirit, 1850-1980. Markham: Penguin, 1985.

Wheelwright, Julie. The New Statesman (March 29, 1991),4(144):29.

White, Richard. Inventing Australia: Images and Identity, 1688-1980. Sydney: Allen \& Unwin, 1981.

Wilkes, G.A. A Dictionary of Australian Colloquialisms. Sydney: Sydney University Press, 1985.

Zinn, Howard. A People's History of the United States. London: Longman, 1980.

(vi) Newspapers

Aubin, E.A. The Otago Daily Times (November 29, 1973).

Bates, Stephen. "When the Cameras Went to War." The Guardian Weekly (June 30, 1991), 144(14):19.

Mackrell, Brian. "UFO Epidemic of 1909." The Press (July 8, 1978):15.

Walker, Martin. "Westward, Oh!." The Guardian Weekly(June 30, 1991), 144(14):25.

Ward, Tessa. "Seville '92." The Press (January 17, 1992):9.

Wesley, David. The Hamilton Spectator (December 7, 1991):C2. 